Nevada

Environmental

Restoration

Project

Corrective Action Decision Document for Corrective Action Unit 562:

Waste Systems

Nevada Test Site, Nevada

Controlled Copy No.:

Revision No.: 0

August 2010

Approved for public release; further dissemination unlimited.

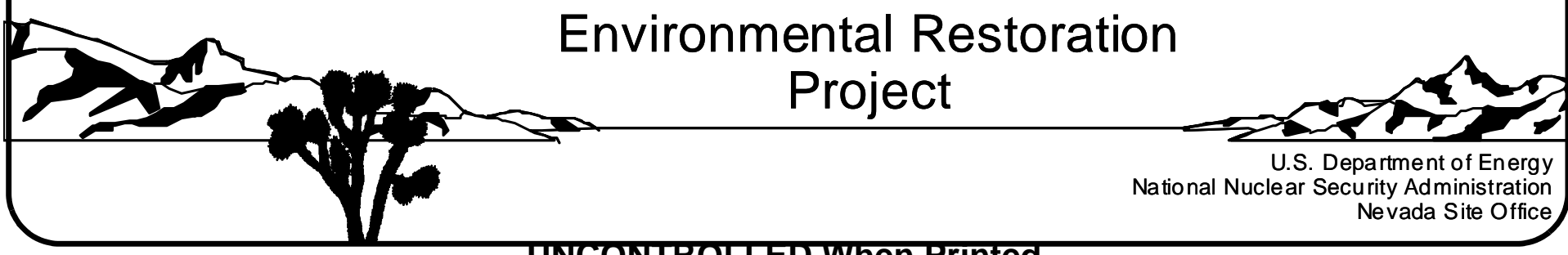


Available for sale to the public from:

U.S. Department of Commerce

National Technical Information Service

5301 Shawnee Road

Alexandria, VA 22312

Telephone: 800.553.6847

Fax: 703.605.6900

E-mail: orders@ntis.gov

Online Ordering: http://www.ntis.gov/help/ordermethods.aspx

Available electronically at http://www.osti.gov/bridge

Available for a processing fee to U.S. Department of Energy and its contractors, in paper, from:

U.S. Department of Energy

Office of Scientific and Technical Information

P.O. Box 62

Oak Ridge, TN 37831-0062

Phone: 865.576.8401

Fax: 865.576.5728

Email: reports@adonis.osti.gov

Reference herein to any specific commercial product, process, or service by trade name, trademark, manufacturer, or otherwise, does not necessarily constitute or imply its endorsement, recommendation, or favoring by the United States Government or any agency thereof or its contractors or subcontractors. 


\title{
CORRECTIVE ACTION DECISION DOCUMENT FOR CORRECTIVE ACTION UNIT 562: WASTE SYSTEMS NEVADA TEST SITE, NEVADA
}

\author{
U.S. Department of Energy \\ National Nuclear Security Administration \\ Nevada Site Office \\ Las Vegas, Nevada
}

Controlled Copy No.:

Revision No.: 0

August 2010

Approved for public release; further dissemination unlimited.

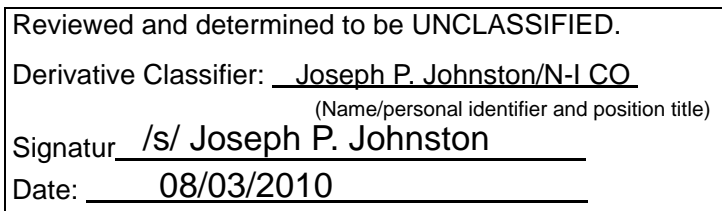




\section{CORRECTIVE ACTION DECISION DOCUMENT FOR \\ CORRECTIVE ACTION UNIT 562: \\ WASTE SYSTEMS \\ NEVADA TEST SITE, NEVADA}

Approved by: _ /s/ Kevin J. Cabble

Date: $08 / 03 / 2010$

Kevin J. Cabble

Federal Sub-Project Director

Industrial Sites Sub-Project

Approved by: _ _ _ _ / Robert F. Boehlecke

Date: $\underline{08 / 03 / 2010}$

Robert F. Boehlecke

Federal Project Director

Environmental Restoration Project 


\section{Table of Contents}

List of Figures xii

List of Tables xiii

List of Acronyms and Abbreviations xxii Executive Summary ES-1

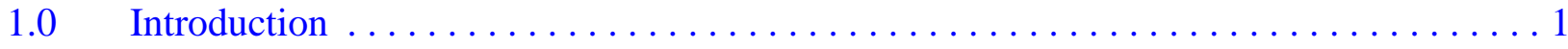

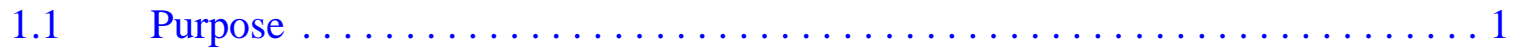

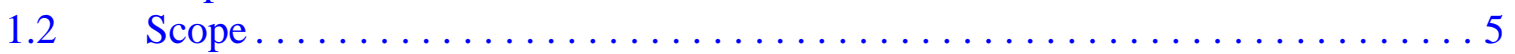

1.3 Corrective Action Decision Document Contents . . . . . . . . . . . . . 5

1.4 Applicable Programmatic Plans and Documents . . . . . . . . . . . . . 7

2.0 Corrective Action Investigation Summary $\ldots \ldots \ldots \ldots \ldots \ldots \ldots \ldots \ldots$

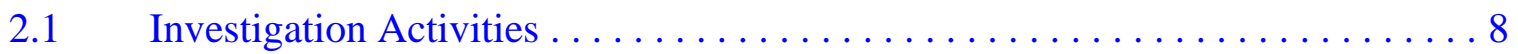

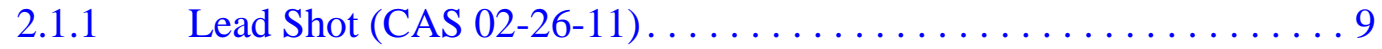

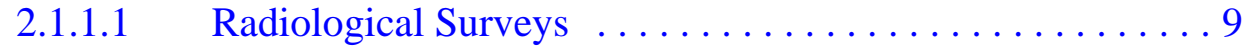

2.1.1.2 Visual Inspections . . . . . . . . . . . . . . . . 9

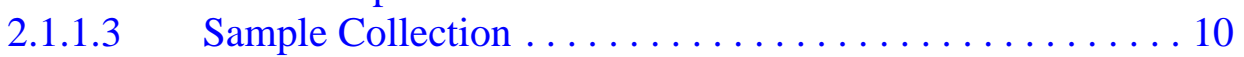

2.1.1.4 Conceptual Site Model Validation . . . . . . . . . . . 11

2.1.2 Paint Spills and French Drain (CAS 02-44-02) . . . . . . . . . 11

2.1.2.1 Radiological Surveys . . . . . . . . . . . . . 11

2.1.2.2 Visual Inspections . . . . . . . . . . . . . . . . . . 11

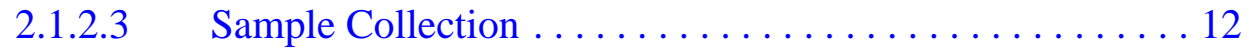

2.1.2.4 Conceptual Site Model Validation . . . . . . . . . . . . . . 14

2.1.3 Septic System (CAS 02-59-01) . . . . . . . . . . . . . . . . 14

2.1.3.1 Radiological Surveys .................. 14

2.1.3.2 Visual Inspections . . . . . . . . . . . . . . . 15

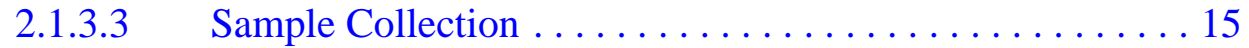

2.1.3.4 Conceptual Site Model Validation ............... 16

2.1.4 Concrete Drain (CAS 02-60-01) . . . . . . . . . . . . . . . 17

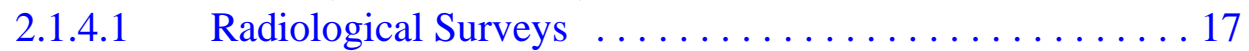

2.1.4.2 Geophysical Surveys ................... 17

2.1.4.3 Visual Inspections . . . . . . . . . . . . . . . . . 17

2.1.4.4 Sample Collection ................... 18

2.1.4.5 Conceptual Site Model Validation . . . . . . . . . . . . 19

2.1.5 French Drain (CAS 02-60-02) . . . . . . . . . . . . . . . 19

2.1.5.1 Radiological Surveys ..................... 19

2.1.5.2 Geophysical Surveys . . . . . . . . . . . . . . 19

2.1.5.3 Visual Inspections . . . . . . . . . . . . . . . . 20

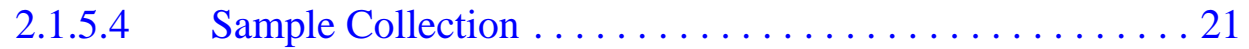

2.1.5.5 Conceptual Site Model Validation . . . . . . . . . . . 21

2.1.6 Steam Cleaning Drain (CAS 02-60-03) . . . . . . . . . . . . 22 


\section{Table of Contents (Continued)}

\begin{tabular}{|c|c|c|c|}
\hline & & 2.1.6.1 & Radiological Surveys . . . . . . . . . . \\
\hline & & 2.1.6.2 & Visual Inspections $\ldots \ldots \ldots \ldots \ldots \ldots \ldots \ldots$ \\
\hline & & 2.1.6.3 & Sample Collection $\ldots \ldots \ldots \ldots \ldots \ldots \ldots \ldots$ \\
\hline & & 2.1.6.4 & Conceptual Site Model Validation $\ldots \ldots \ldots \ldots \ldots \ldots$ \\
\hline & \multirow[t]{5}{*}{2.1 .7} & \multicolumn{2}{|c|}{ French Drain (CAS 02-60-04) . . . . . . . . . } \\
\hline & & 2.1.7.1 & Radiological Surveys . . . . . . . . . . . . . . . . . . 24 \\
\hline & & 2.1.7.2 & Visual Inspections . . . . . . . . . . . . . . . . . . . . . . . . 24 \\
\hline & & 2.1.7.3 & Sample Collection . . . . . . . . . . . . . . . . . . . . . . 25 \\
\hline & & 2.1.7.4 & Conceptual Site Model Validation . . . . . . . . . . . . . 26 \\
\hline & \multirow[t]{5}{*}{2.1 .8} & \multicolumn{2}{|c|}{ French Drain (CAS 02-60-05) . . . . . . . . . . } \\
\hline & & 2.1.8.1 & Radiological Surveys . . . . . . . . . . . . . . . . . \\
\hline & & 2.1.8.2 & Visual Inspections $\ldots \ldots \ldots \ldots \ldots \ldots \ldots \ldots$ \\
\hline & & 2.1.8.3 & Sample Collection . . . . . . . . . . . . . . . . . . . . . . . 27 \\
\hline & & 2.1.8.4 & Conceptual Site Model Validation ....... \\
\hline & \multirow[t]{5}{*}{2.1 .9} & \multicolumn{2}{|c|}{ French Drain (CAS 02-60-06) . . . . . . . . . . . } \\
\hline & & 2.1.9.1 & Geophysical Surveys . . . . . . . . . . . . . . . . . . . . . . . 29 \\
\hline & & 2.1.9.2 & Visual Inspections $\ldots \ldots \ldots \ldots \ldots \ldots \ldots \ldots$ \\
\hline & & 2.1.9.3 & Sample Collection . . . . . . . . . . . . . . . . . . . . . . . . 29 \\
\hline & & 2.1.9.4 & Conceptual Site Model Validation $\ldots . \ldots \ldots \ldots \ldots \ldots$ \\
\hline & 2.1.10 & \multicolumn{2}{|c|}{ French Drain $($ CAS $02-60-07) \ldots \ldots \ldots \ldots \ldots$} \\
\hline & \multirow[t]{4}{*}{ 2.1.11 } & \multicolumn{2}{|c|}{ Mud Trap Drain and Outfall (CAS 23-60-01) . . . . . . . . . . . . 31} \\
\hline & & 2.1.11.1 & Visual Inspections $\ldots \ldots \ldots \ldots \ldots \ldots \ldots \ldots$ \\
\hline & & 2.1.11.2 & Sample Collection . . . . . . . . . . . . . . . . \\
\hline & & 2.1.11.3 & Conceptual Site Model Validation $\ldots \ldots \ldots \ldots \ldots \ldots$ \\
\hline & \multirow[t]{4}{*}{2.1 .12} & \multicolumn{2}{|c|}{ Grease Trap (CAS 23-99-06) . . . . . . . . . . . } \\
\hline & & 2.1.12.1 & Visual Inspections $\ldots \ldots \ldots \ldots \ldots \ldots \ldots$ \\
\hline & & 2.1.12.2 & Sample Collection . . . . . . . . . . . . . . . \\
\hline & & 2.1.12.3 & Conceptual Site Model Validation $\ldots \ldots \ldots \ldots \ldots \ldots$ \\
\hline & \multirow[t]{4}{*}{2.1 .13} & \multicolumn{2}{|c|}{ Building 3123 Outfalls (CAS 25-60-04) ... } \\
\hline & & 2.1.13.1 & Visual Inspections $\ldots \ldots \ldots \ldots \ldots \ldots \ldots$ \\
\hline & & 2.1.13.2 & Sample Collection . . . . . . . . . . . . . . . . \\
\hline & & 2.1.13.3 & Conceptual Site Model Validation . . . . . . . . . . . 36 \\
\hline & \multicolumn{3}{|c|}{ 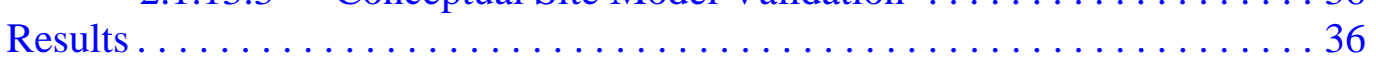 } \\
\hline & \multirow[t]{7}{*}{2.2 .1} & \multicolumn{2}{|c|}{ 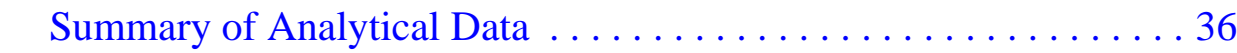 } \\
\hline & & \multirow{3}{*}{ 2.2.1.1 } & 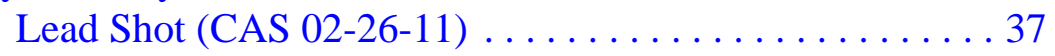 \\
\hline & & & 2.2.1.1.1 Environmental Sample Results ......... \\
\hline & & & 2.2.1.1.2 Potential Source Material Sample Results . . . . 37 \\
\hline & & \multirow[t]{3}{*}{ 2.2.1.2 } & Paint Spills and French Drain (CAS 02-44-02) . . . . . . . 39 \\
\hline & & & 2.2.1.2.1 Environmental Sample Results . . . . . . . . . . \\
\hline & & & 2.2.1.2.2 Potential Source Material Sample Results . . . 41 \\
\hline
\end{tabular}




\section{Table of Contents (Continued)}

2.2.1.3 Septic System (CAS 02-59-01) ................... 41

2.2.1.3.1 Environmental Sample Results ........... . 44

2.2.1.3.2 Potential Source Material Sample Results ... . 44

2.2.1.4 Concrete Drain (CAS 02-60-01) . . . . . . . . . . . . . . . . 47

2.2.1.5 French Drain (CAS 02-60-02) . ............... 50

2.2.1.6 Steam Cleaning Drain (CAS 02-60-03) . . . . . . . . . . 50

2.2.1.7 French Drain (CAS 02-60-04) . . . . . . . . . . . . 53

2.2.1.7.1 Environmental Sample Results ............ 54

2.2.1.7.2 Potential Source Material Sample Results ....54

2.2.1.8 French Drain (CAS 02-60-05) ................. 56

2.2.1.8.1 Environmental Sample Results ........... 56

2.2.1.8.2 Potential Source Material Sample Results . . . . 58

2.2.1.9 French Drain (CAS 02-60-06) . . . . . . . . . . . . 58

2.2.1.10 French Drain (CAS 02-60-07) ................. 59

2.2.1.11 Mud Trap Drain and Outfall (CAS 23-60-01) . . . . . . . . 59

2.2.1.11.1 Environmental Sample Results .......... 59

2.2.1.11.2 Potential Source Material Sample Results ....662

2.2.1.12 Grease Trap (CAS 23-99-06) .................6 63

2.2.1.13 Building 3123 Outfalls (CAS 25-60-04) ..........665

2.2.1.13.1 Environmental Sample Results ..........665

2.2.1.13.2 Potential Source Material Sample Results . . . . 67

2.2.2 Data Assessment Summary . . . . . . . . . . . . . . . . 67

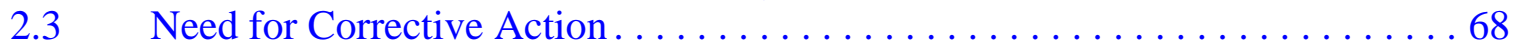

2.3.1 Lead Shot (CAS 02-26-11) ...................... 70

2.3.2 Paint Spills and French Drain (CAS 02-44-02) . . . . . . . . 70

2.3.3 Septic System (CAS 02-59-01) . . . . . . . . . . . . . . . 71

2.3.4 Concrete Drain (CAS 02-60-01) ..................... 71

2.3.5 French Drain (CAS 02-60-02) .................... 71

2.3.6 Steam Cleaning Drain (CAS 02-60-03) . . . . . . . . . . . 71

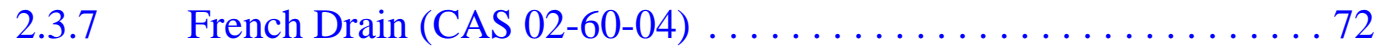

2.3.8 French Drain (CAS 02-60-05) . . . . . . . . . . . . . . 72

2.3.9 French Drain (CAS 02-60-06) . . . . . . . . . . . . . . . . 72

2.3.10 French Drain (CAS 02-60-07) ...................... 72

2.3.11 Mud Trap Drain and Outfall (CAS 23-60-01) ............ 73

2.3.12 Grease Trap (CAS 23-99-06) ..................... 73

2.3.13 Building 3123 Outfalls (CAS 25-60-04) .............. 73

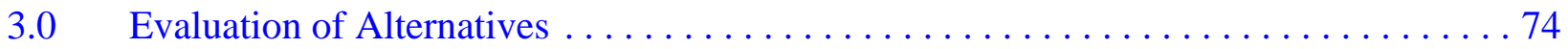

$3.1 \quad$ Corrective Action Objectives $\ldots \ldots \ldots \ldots \ldots \ldots \ldots \ldots \ldots \ldots \ldots \ldots \ldots$

$3.2 \quad$ Screening Criteria . . . . . . . . . . . . . . . . . . . . . . . 76

3.2.1 Corrective Action Standards . . . . . . . . . . . . . . 77 


\section{Table of Contents (Continued)}

3.2.2 Remedy Selection Decision Factors . . . . . . . . . . . . 78

3.3 Development of Corrective Action Alternatives.................. . 79

3.3.1 Alternative 1 - No Further Action ................... 79

3.3.2 Alternative 2 - Clean Closure. ..................... 80

3.3.3 Alternative 3 - Closure in Place with Administrative Controls . . . . . 80

3.4 Evaluation and Comparison of Alternatives .................... 81

4.0 Recommended Alternatives . . . . . . . . . . . . . . . . . . . . . . . . 85

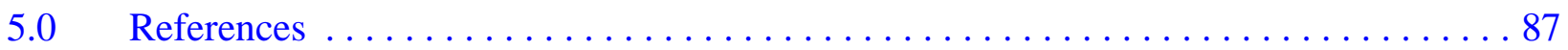

\section{Appendix A - Corrective Action Investigation Results}

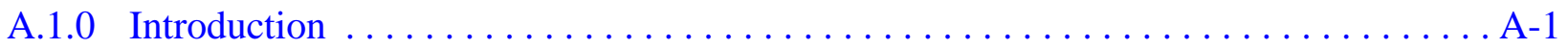

A.1.1 Project Objectives . . . . . . . . . . . . . . . . . . . . . . . . A 4

A.1.2 Contents....................................... A-4

A.2.0 Investigation Overview $\ldots \ldots \ldots \ldots \ldots \ldots \ldots \ldots \ldots \ldots \ldots \ldots \ldots \ldots \ldots \ldots \ldots \ldots \ldots \ldots$

A.2.1 Sample Locations $\ldots \ldots \ldots \ldots \ldots \ldots \ldots \ldots \ldots \ldots \ldots \ldots \ldots \ldots \ldots \ldots \ldots \ldots$

A.2.2 Investigation Activities $\ldots \ldots \ldots \ldots \ldots \ldots \ldots \ldots \ldots \ldots \ldots \ldots \ldots \ldots \ldots \ldots \ldots \ldots \ldots \ldots$

A.2.2.1 Radiological Surveys ...................... A-7

A.2.2.2 Piping and Septic Tank Inspections ................ A

A.2.2.3 Surface and Subsurface Soil Sampling. . . . . . . . . . . A-8

A.2.2.4 Waste Characterization Sampling. .................. A-9

A.2.3 Laboratory Analytical Information $\ldots \ldots \ldots \ldots \ldots \ldots \ldots \ldots \ldots \ldots$ A-10

A.2.4 Comparison to Action Levels . ........................ A-10

A.3.0 CAS 02-26-11, Lead Shot, Investigation Results. . . . . . . . . . . . . . . . A-13

A.3.1 Corrective Action Investigation Activities . . . . . . . . . . . . . A -13

A.3.1.1 Radiological Surveys . . . . . . . . . . . . . . . . . A

A.3.1.2 Visual Inspections......................... A-13

A.3.1.3 Sample Collection.......................... A-16

A.3.1.4 Deviations ............................. A-16

A.3.2 Investigation Results . .......................... A-17

A.3.2.1 Volatile Organic Compounds .................. A-17

A.3.2.2 Semivolatile Organic Compounds ................... A-18

A.3.2.3 Total Petroleum Hydrocarbons........................ A-18

A.3.2.4 Resource Conservative and Recovery Act Metals

A.3.2.5 Polychlorinated Biphenyls . . . . . . . . . . . . . . . A-18

A.3.2.6 Pesticides ................................. A-18 


\section{Table of Contents (Continued)}

A.3.2.7 Gamma-Emitting Radionuclides. . . . . . . . . . . . . . . . A-22

A.3.3 Potential Source Material Sample Results . . . . . . . . . . . . . . . . A-22

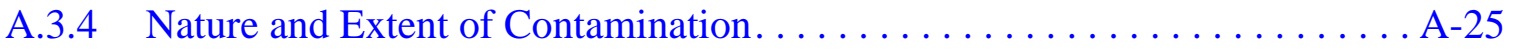

A.3.5 Revised Conceptual Site Model . . . . . . . . . . . . . . . A-26

A.4.0 CAS 02-44-02, Paint Spills and French Drain, Investigation Results . . . . . . . . . A-27

A.4.1 Corrective Action Investigation Activities . . . . . . . . . . . . . . . . A-27

A.4.1.1 Radiological Surveys . . . . . . . . . . . . . . . A-27

A.4.1.2 Visual Inspections. . . . . . . . . . . . . . . . . A-27

A.4.1.3 Sample Collection. ......................... A-31

A.4.1.4 Deviations.......................... A-32

A.4.2 Investigation Results . . . . . . . . . . . . . . . . . A-32

A.4.2.1 Volatile Organic Compounds ..................... A-33

A.4.2.2 Semivolatile Organic Compounds . .................. A-33

A.4.2.3 Total Petroleum Hydrocarbons. . . . . . . . . . . . . . . . . . A-33

A.4.2.4 Resource Conservation and Recovery Act Metals . . . . . . . . . . A-36

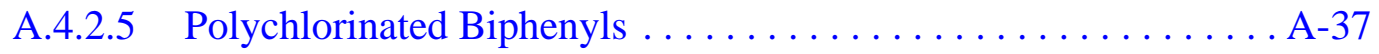

A.4.2.6 Gamma-Emitting Radionuclides. . . . . . . . . . . . . . . . A-38

A.4.3 Potential Source Material Sample Results . . . . . . . . . . . . . . . A-38

A.4.4 Nature and Extent of Contamination. . . . . . . . . . . . . . A-39

A.4.5 Revised Conceptual Site Model . . . . . . . . . . . . . . A-41

A.5.0 CAS 02-59-01, Septic System, Investigation Results . . . . . . . . . . . . . . A-42

A.5.1 Corrective Action Investigation Activities . . . . . . . . . . . . . A-42

A.5.1.1 Radiological Surveys . . . . . . . . . . . . . . . . A A-42

A.5.1.2 Visual Inspections. . . . . . . . . . . . . . . . . . A-42

A.5.1.3 Sample Collection....................... A-46

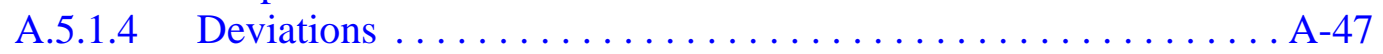

A.5.2 Investigation Results . . . . . . . . . . . . . . . . . . . . . A

A.5.2.1 Volatile Organic Compounds . . . . . . . . . . . . . . . A-48

A.5.2.2 Semivolatile Organic Compounds . . . . . . . . . . . . . . . . A-48

A.5.2.3 Total Petroleum Hydrocarbons. . . . . . . . . . . . . . . . . A A-48

A.5.2.4 Resource Conservation and Recovery Act Metals . . . . . . . . . . A A-48

A.5.2.5 Polychlorinated Biphenyls . . . . . . . . . . . . . . . A-48

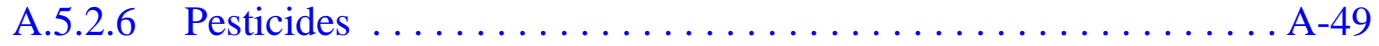

A.5.2.7 Herbicides. . . . . . . . . . . . . . . . . . . . . . . . . . . . A-49

A.5.2.8 Gamma-Emitting Radionuclides. . . . . . . . . . . . . . . . . . . . A-50

A.5.3 Potential Source Material Sample Results . . . . . . . . . . . . . . . A A-50

A.5.4 Nature and Extent of Contamination. . . . . . . . . . . . . . . A-53

A.5.5 Revised Conceptual Site Model ..................... A-53 


\section{Table of Contents (Continued)}

A.6.0 CAS 02-60-01, Concrete Drain, Investigation Results. . . . . . . . . . . . . . . . . A-54

A.6.1 Corrective Action Investigation Activities . . . . . . . . . . . . . . A-54

A.6.1.1 Radiological Surveys . . . . . . . . . . . . . . . . . .

A.6.1.2 Geophysical Surveys...................... A-54

A.6.1.3 Visual Inspections........................ A-54

A.6.1.4 Sample Collection. ....................... A-57

A.6.1.5 Deviations .............................. A-58

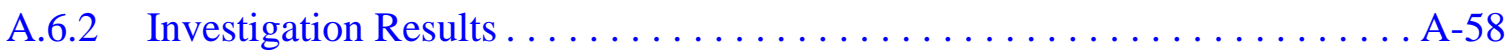

A.6.2.1 Volatile Organic Compounds .................. A-58

A.6.2.2 Semivolatile Organic Compounds . . . . . . . . . . . . . A-58

A.6.2.3 Total Petroleum Hydrocarbons. . . . . . . . . . . . . . . A-59

A.6.2.4 Resource Conservation and Recovery Act Metals . . . . . . . . . . A-59

A.6.2.5 Polychlorinated Biphenyls .................... A-61

A.6.2.6 Gamma-Emitting Radionuclides .................... A-62

A.6.3 Nature and Extent of Contamination. . . . . . . . . . . . . . . . . A-62

A.6.4 Revised Conceptual Site Model . . . . . . . . . . . . . . . . . . . A-63

A.7.0 CAS 02-60-02, French Drain, Investigation Results . . . . . . . . . . . . . . . . A-64

A.7.1 Corrective Action Investigation Activities . . . . . . . . . . . . . A-64

A.7.1.1 Geophysical Surveys....................... A-64

A.7.1.2 Radiological Surveys .......................... A-64

A.7.1.3 Visual Inspections.......................... A-66

A.7.1.4 Sample Collection. ....................... A-67

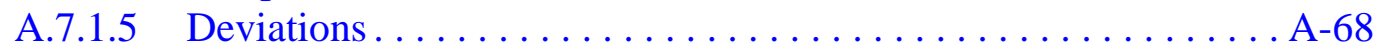

A.7.2 Investigation Results ........................... A-68

A.7.2.1 Volatile Organic Compounds ..................... A-69

A.7.2.2 Semivolatile Organic Compounds ................ A-69

A.7.2.3 Total Petroleum Hydrocarbons. . . . . . . . . . . . . . A-69

A.7.2.4 Resource Conservation and Recovery Act Metals ............ A-69

A.7.2.5 Polychlorinated Biphenyls ..................... A-69

A.7.2.6 Gamma-Emitting Radionuclides. . . . . . . . . . . . . . A-72

A.7.3 Nature and Extent of Contamination. . . . . . . . . . . . . . . . A-73

A.7.4 Revised Conceptual Site Model . . . . . . . . . . . . . . . . . . . . A-73

A.8.0 CAS 02-60-03, Steam Cleaning Drain, Investigation Results . . . . . . . . . . . A-74

A.8.1 Corrective Action Investigation Activities . . . . . . . . . . . . . . . A-74

A.8.1.1 Radiological Surveys . . . . . . . . . . . . . . . . . A-74

A.8.1.2 Visual Inspections.......................... A-74

A.8.1.3 Sample Collection........................ A-77

A.8.1.4 Deviations................................. A-78 


\section{Table of Contents (Continued)}

A.8.2 Investigation Results . ............................ A-78

A.8.2.1 Volatile Organic Compounds ..................... A-78

A.8.2.2 Semivolatile Organic Compounds .................. A-79

A.8.2.3 Total Petroleum Hydrocarbons. . . . . . . . . . . . . . A-79

A.8.2.4 Resource Conservation and Recovery Act Metals ............ A-79

A.8.2.5 Polychlorinated Biphenyls ............................ A-79

A.8.2.6 Pesticides . . . . . . . . . . . . . . . . . . . . . . . . . A-83

A.8.2.7 Gamma-Emitting Radionuclides .................. A-84

A.8.3 Nature and Extent of Contamination. ...................... A-84

A.8.4 Revised Conceptual Site Model ............................ A-85

A.9.0 CAS 02-60-04, French Drain, Investigation Results . . . . . . . . . . . . . . A-86

A.9.1 Corrective Action Investigation Activities . . . . . . . . . . . . . . . A-86

A.9.1.1 Radiological Surveys ........................ A-86

A.9.1.2 Visual Inspections. . . . . . . . . . . . . . . . . . A-86

A.9.1.3 Sample Collection. ....................... A-89

A.9.1.4 Deviations .............................. A-89

A.9.2 Investigation Results ............................. A-89

A.9.2.1 Volatile Organic Compounds ................... A-90

A.9.2.2 Semivolatile Organic Compounds ................. A-90

A.9.2.3 Total Petroleum Hydrocarbons. ................. A-90

A.9.2.4 Resource Conservation and Recovery Act Metals ............ A-91

A.9.2.5 Polychlorinated Biphenyls ..................... A-92

A.9.2.6 Gamma-Emitting Radionuclides. ................. A-92

A.9.3 Potential Source Material Sample Results . . . . . . . . . . . . . . A-93

A.9.4 Nature and Extent of Contamination. . . . . . . . . . . . . . . . . . A-94

A.9.5 Revised Conceptual Site Model ......................... A-94

A.10.0 CAS 02-60-05, French Drain, Investigation Results . . . . . . . . . . . . . . . A-95

A.10.1 Corrective Action Investigation Activities . . . . . . . . . . . . . . . A-95

A.10.1.1 Radiological Surveys . . . . . . . . . . . . . . . . . . . A-95

A.10.1.2 Visual Inspections. . . . . . . . . . . . . . . . . . . A-95

A.10.1.3 Sample Collection. ........................ A-99

A.10.1.4 Deviations .............................. A-100

A.10.2 Investigation Results .............................. A-100

A.10.2.1 Volatile Organic Compounds ................... A-100

A.10.2.2 Semivolatile Organic Compounds .................. A-100

A.10.2.3 Total Petroleum Hydrocarbons. . . . . . . . . . . . . . . . . A-101

A.10.2.4 Resource Conservation and Recovery Act Metals ............ A-101

A.10.2.5 Polychlorinated Biphenyls ....................... A-101

A.10.2.6 Gamma-Emitting Radionuclides .................. A-103 


\section{Table of Contents (Continued)}

A.10.2.7 Potential Source Material Sample Results . . . . . . . . . . . . . A-104

A.10.3 Nature and Extent of Contamination. . . . . . . . . . . . . . . . . . . . A-104

A.10.4 Revised Conceptual Site Model . . . . . . . . . . . . . . . . . . A-106

A.11.0 CAS 02-60-06, French Drain, Investigation Results . . . . . . . . . . . . . . . A-107

A.11.1 Corrective Action Investigation Activities . . . . . . . . . . . . . . . A-107

A.11.1.1 Geophysical Surveys. . . . . . . . . . . . . . . . . A-107

A.11.1.2 Visual Inspections. . . . . . . . . . . . . . . . . A-107

A.11.1.3 Sample Collection. ............................. A-109

A.11.1.4 Deviations................................... . . . . . . . . . . .

A.11.2 Investigation Results . . . . . . . . . . . . . . . . . . A-110

A.11.2.1 Volatile Organic Compounds . . . . . . . . . . . . . . A-110

A.11.2.2 Semivolatile Organic Compounds . . . . . . . . . . . . . . . . A A-110

A.11.2.3 Total Petroleum Hydrocarbons. . . . . . . . . . . . . . . . . . A-111

A.11.2.4 Resource Conservation and Recovery Act Metals . . . . . . . . . . A-111

A.11.2.5 Polychlorinated Biphenyls . . . . . . . . . . . . . A-111

A.11.2.6 Gamma-Emitting Radionuclides. . . . . . . . . . . . . . A-112

A.11.3 Nature and Extent of Contamination. . . . . . . . . . . . . . . . . . A-112

A.11.4 Revised Conceptual Site Model . . . . . . . . . . . . . . . . A-113

A.12.0 CAS 02-60-07, French Drain, Investigation Results . . . . . . . . . . . . . . A-114

A.13.0 CAS 23-60-01, Mud Trap Drain and Outfall, Investigation Results. . . . . . . . . . A-115

A.13.1 Corrective Action Investigation Activities . . . . . . . . . . . . . A-115

A.13.1.1 Visual Inspections. . . . . . . . . . . . . . . . . A-115

A.13.1.2 Sample Collection. ....................... A-118

A.13.1.3 Deviations............................... . . . . . . . .

A.13.2 Investigation Results . . . . . . . . . . . . . . . . . . A-119

A.13.2.1 Volatile Organic Compounds . . . . . . . . . . . . . . . . . A-119

A.13.2.2 Semivolatile Organic Compounds . . . . . . . . . . . . . . . . A-119

A.13.2.3 Total Petroleum Hydrocarbons. . . . . . . . . . . . . . . . . . A-120

A.13.2.4 Resource Conservation and Recovery Act Metals . . . . . . . . . . . A-120

A.13.2.5 Polychlorinated Biphenyls . . . . . . . . . . . . . . A-123

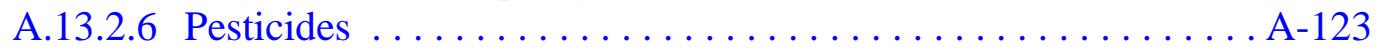

A.13.2.7 Gamma-Emitting Radionuclides. . . . . . . . . . . . . . . . A-123

A.13.3 Potential Source Material Sample Results . . . . . . . . . . . . . . . . A-124

A.13.4 Nature and Extent of Contamination. . . . . . . . . . . . . . . . A-125

A.13.5 Revised Conceptual Site Model . . . . . . . . . . . . . . . . . . A-125 


\section{Table of Contents (Continued)}

A.14.0 CAS 23-99-06, Grease Trap, Investigation Results . . . . . . . . . . . . . . . . A-128

A.14.1 Corrective Action Investigation Activities . . . . . . . . . . . . . A-128

A.14.1.1 Visual Inspections. . . . . . . . . . . . . . . . . . A

A.14.1.2 Sample Collection. ....................... A-128

A.14.1.3 Deviations ............................ A-130

A.14.2 Investigation Results ........................... A-130

A.14.3 Potential Source Material Sample Results . . . . . . . . . . . . . . A-131

A.14.4 Nature and Extent of Contamination. . . . . . . . . . . . . . . . . A-131

A.14.5 Revised Conceptual Site Model ....................... A-135

A.15.0 CAS 25-60-04, Building 3123 Outfalls, Investigation Results . . . . . . . . . . . A-136

A.15.1 Corrective Action Investigation Activities . . . . . . . . . . . . . . A-136

A.15.1.1 Visual Inspections......................... A-136

A.15.1.2 Sample Collection............................ A-140

A.15.1.3 Deviations............................. A-141

A.15.2 Investigation Results ............................... A-141

A.15.2.1 Volatile Organic Compounds ...................... A-142

A.15.2.2 Semivolatile Organic Compounds ................... A-143

A.15.2.3 Total Petroleum Hydrocarbons. . . . . . . . . . . . . . . A-143

A.15.2.4 Resource Conservation and Recovery Act Metals .......... A-143

A.15.2.5 Polychlorinated Biphenyls .................... A-145

A.15.2.6 Gamma-Emitting Radionuclides. ................... A-147

A.15.3 Potential Source Material Sample Results . . . . . . . . . . . . . . . A-147

A.15.4 Nature and Extent of Contamination. . . . . . . . . . . . . . . . A-148

A.15.5 Revised Conceptual Site Model ....................... A-149

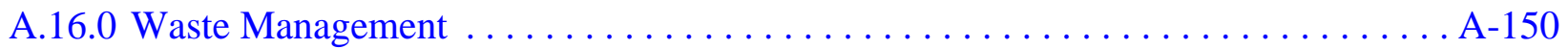

A.16.1 Investigation-Derived Waste. . . . . . . . . . . . . . . . . . A-150

A.16.1.1 Waste Streams........................... A-150

A.16.1.2 Waste Generated.......................... A-150

A.16.2 Waste Characterization ............................ A-152

A.16.2.1 CAS 02-26-11, Lead Shot.................... A-152

A.16.2.2 CAS 02-44-02, Paint Spills and French Drain . . . . . . . . . . A-152

A.16.2.3 CAS 02-59-01, Septic System . . . . . . . . . . . . . . . . . . A-154

A.16.2.4 CAS 02-60-01, Concrete Drain ..................... A-154

A.16.2.5 CAS 02-60-02, French Drain ...................... A-155

A.16.2.6 CAS 02-60-03, Steam Cleaning Drain . . . . . . . . . . . A-155

A.16.2.7 CAS 02-60-04, French Drain ....................... A-156

A.16.2.8 CAS 02-60-05, French Drain . . . . . . . . . . . . . . A-156

A.16.2.9 CAS 02-60-06, French Drain . ................... A-157 


\section{Table of Contents (Continued)}

A.16.2.10 CAS 23-60-01, Mud Trap Drain and Outfall . . . . . . . . . . . A-157

A.16.2.11 CAS 23-99-06, Grease Trap . . . . . . . . . . . . . . . . . A-157

A.16.2.12 CAS 25-60-04, Building 3123 Outfalls . . . . . . . . . . A-157

A.17.0 Quality Assurance. . . . . . . . . . . . . . . . . . . . . . . . . A-159

A.17.1 Data Validation . . . . . . . . . . . . . . . . . . . A-159

A.17.1.1 Tier I Evaluation . . . . . . . . . . . . . . . . . . . . . A-159

A.17.1.2 Tier II Evaluation $\ldots \ldots \ldots \ldots \ldots \ldots \ldots \ldots \ldots \ldots \ldots$ A $\ldots \ldots \ldots$

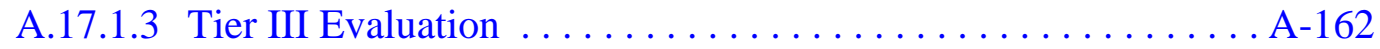

A.17.2 Field Quality Control Samples........................ A-163

A.17.2.1 Laboratory Quality Control Samples . . . . . . . . . . . . . . . A-164

A.17.3 Field Nonconformances . . . . . . . . . . . . . . . . . . A-164

A.17.4 Laboratory Nonconformances...................... A-164

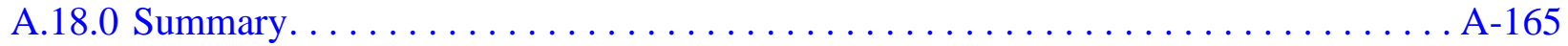

A.19.0 References . . . . . . . . . . . . . . . . . . . . . . A-168

\section{Appendix B - Data Assessment}

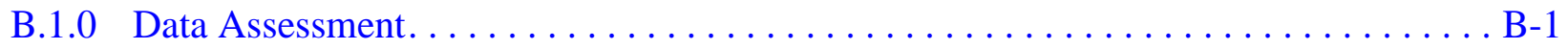

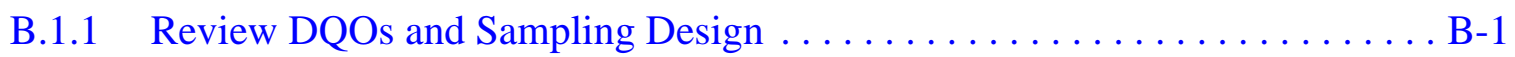

B.1.1.1 Decision I . . . . . . . . . . . . . . . . . . B-2

B.1.1.1.1 DQO Provisions To Limit False Negative

Decision Error ....................... B-2

B.1.1.1.2 DQO Provisions To Limit False Positive

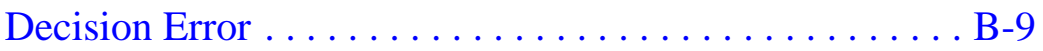

B.1.1.2 Decision II. . . . . . . . . . . . . . . . . . . B-10

B.1.1.2.1 DQO Provisions To Limit False Negative

Decision Error . . . . . . . . . . . . . . B-10

B.1.1.2.2 DQO Provisions To Limit False Positive

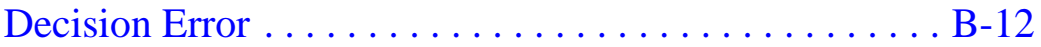

B.1.1.3 Sampling Design. ..........................

B.1.2 Conduct a Preliminary Data Review. . . . . . . . . . . . . . . B-13

B.1.3 Select the Test and Identify Key Assumptions . . . . . . . . . . . . . B-13

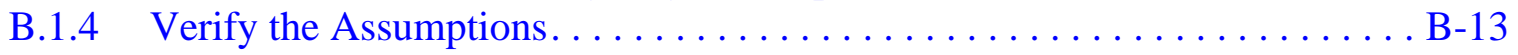

B.1.5 Draw Conclusions from the Data $\ldots \ldots \ldots \ldots \ldots \ldots \ldots \ldots \ldots \ldots . \ldots \ldots$

B.1.5.1 Decision Rules for Decision I. . . . . . . . . . . . . . . B-14

B.1.5.2 Decision Rules for Decision II . . . . . . . . . . . . . B-16

B.2.0 References $\ldots \ldots \ldots \ldots \ldots \ldots \ldots \ldots \ldots \ldots \ldots \ldots \ldots \ldots \ldots \ldots \ldots \ldots \ldots$ 


\section{Table of Contents (Continued)}

\section{Appendix C - Cost Estimates}

\section{Appendix D - Evaluation of Risk}

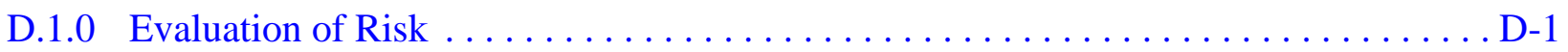

D.1.1 A. Scenario . . . . . . . . . . . . . . . . . . . . .

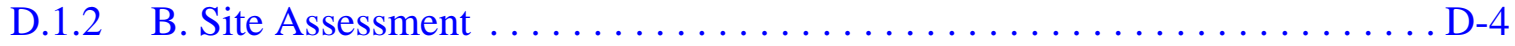

D.1.3 C. Site Classification and Initial Response Action . . . . . . . . . . . . D-13

D.1.4 D. Development of Tier 1 Lookup Table of RBSLs . . . . . . . . . . . . . . D-13

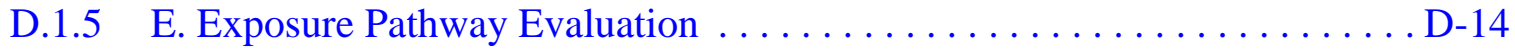

D.1.6 F. Comparison of Site Conditions with Tier 1 RBSLs . . . . . . . . . . . . . D-15

D.1.7 G. Evaluation of Tier 1 Results. . . . . . . . . . . . . . . . . . . . . . D-15

D.1.8 H. Tier 1 Remedial Action Evaluation . . . . . . . . . . . . . . . . . D-15

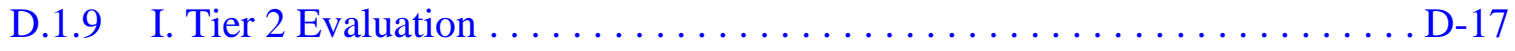

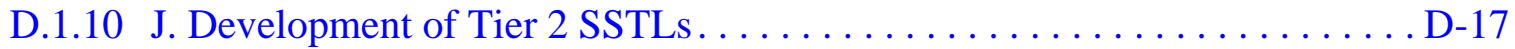

D.1.11 K. Comparison of Site Conditions with Tier 2 SSTLs . . . . . . . . . . . D-20

D.1.12 L. Tier 2 Remedial Action Evaluation .................. D-20

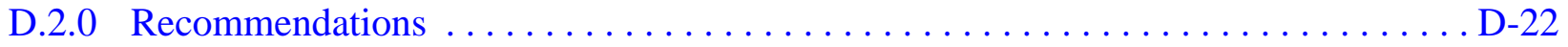

D.3.0 References ................................. D-25

\section{Appendix E - Project Organization}

E.1.0 Project Organization. . . . . . . . . . . . . .

Appendix F - Sample Location Coordinates

F.1.0 Sample Location Coordinates. . . . . . . . . . . . . . . . . . . F-1

Appendix G - Waste Disposal Documentation

Appendix H - Nevada Division of Environmental Protection Comments 


\section{List of Figures}

Number

Title

Page

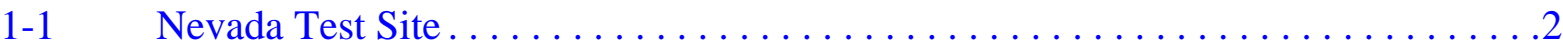

1-2 CAU 562, CAS Location Map ................................

A.3-1 Sample Locations at CAS 02-26-11, Lead Shot................. A-14

A.4-1 Sample Locations at CAS 02-44-02, Paint Spills and French Drain ........ A-28

A.5-1 Sample Locations at CAS 02-59-01, Septic System................ A-43

A.6-1 Sample Locations at CAS 02-60-01, Concrete Drain. ............. A-55

A.7-1 Sample Locations at CAS 02-60-02, French Drain $\ldots \ldots \ldots \ldots \ldots \ldots$ A-65

A.8-1 Sample Locations at CAS 02-60-03, Steam Cleaning Drain . . . . . . . . . . A-75

A.9-1 Sample Locations at CAS 02-60-04, French Drain $\ldots \ldots \ldots \ldots \ldots \ldots$ A-87

A.10-1 Sample Locations at CAS 02-60-05, French Drain $\ldots \ldots \ldots \ldots \ldots \ldots \ldots$ A-96

A.11-1 Sample Locations at CAS 02-60-06, French Drain ............... A-108

A.13-1 Sample Locations at CAS 23-60-01, Mud Trap Drain and Outfall . . . . . . . A-116

A.14-1 Sample Locations at CAS 23-99-06, Grease Trap . . . . . . . . . . . . . A-129

A.15-1 Sample Locations at CAS 25-60-04, Building 3123 Outfalls . . . . . . . . A A-137

D.1-1 Risk-Based Corrective Action Decision Process $\ldots \ldots \ldots \ldots \ldots \ldots \ldots$ D-3 


\section{List of Tables}

Number

Title

Page

ES-1 Summary of COCs and PSM by CAS

2-1 Maximum Concentration of Detected Contaminants

for CAS 02-26-11, Lead Shot . . . . . . . . . . . . . . . . . . . 38

2-2 Maximum Concentration of Detected Contaminants

in PSM Samples from CAS 02-26-11, Lead Shot . . . . . . . . . . . . . 40

2-3 Maximum Concentration of Detected Contaminants for Environmental

Sample Results at CAS 02-44-02, Paint Spills and French Drain . . . . . . . . . . 42

2-4 Maximum Concentration of Detected Contaminants in PSM

Samples from CAS 02-44-02, Paint Spills and French Drain . . . . . . . . . . 43

2-5 Maximum Concentration of Detected Contaminants for Environmental

Samples Results at CAS 02-59-01, Septic System. . . . . . . . . . . . . . 45

2-6 Maximum Concentration of Detected Contaminants in PSM

Sludge Samples from CAS 02-59-01, Septic System. . . . . . . . . . . . . . . . 45

2-7 Maximum Concentration of Detected Contaminants in PSM

Liquid Samples from CAS 02-59-01, Septic System . . . . . . . . . . . . . 48

2-8 Maximum Concentration of Detected Contaminants

for CAS 02-60-01, Concrete Drain. . . . . . . . . . . . . . . . . . . 48

2-9 Maximum Concentration of Detected Contaminants

for CAS 02-60-02, French Drain . . . . . . . . . . . . . . . . 51

2-10 Maximum Concentration of Detected Contaminants

for CAS 02-60-03, Steam Cleaning Drain . . . . . . . . . . . . . . . . . . 52

2-11 Maximum Concentration of Detected Contaminants

for CAS 02-60-04, French Drain . . . . . . . . . . . . . . . . . . 54

2-12 Maximum Concentration of Detected Contaminants in PSM Samples

from CAS 02-60-04, French Drain . . . . . . . . . . . . . . . . . . . 55 


\section{List of Tables (Continued)}

Number

Title

Page

2-13 Maximum Concentration of Detected Contaminants for CAS 02-60-05, French Drain . . . . . . . . . . . . . . . . . . . . 57

2-14 Maximum Concentration of Detected Contaminants in PSM Samples from for CAS 02-60-05, French Drain. ............. 59

2-15 Maximum Concentration of Detected Contaminants for CAS 02-60-06, French Drain . . . . . . . . . . . . . . . . . . . 60

2-16 Maximum Concentration of Detected Contaminants for CAS 23-60-01, Mud Trap Drain and Outfall................. 61

2-17 Maximum Concentrations of Detected Contaminants in PSM Samples from for CAS 23-60-01, Mud Trap Drain and Outfall ........... 62

2-18 Maximum Concentration of Detected Contaminants for PSM at CAS 23-99-06, Grease Trap . .......................... 64

2-19 Maximum Concentration of Detected Contaminants for CAS 25-60-04, Building 3123 Outfalls . . . . . . . . . . . . . . 66

2-20 Maximum Concentration of Detected Contaminants in PSM Samples from for CAS 25-60-04, Building 3123 Outfalls . . . . . . . . . 68

$2-21$ Summary of COCs and PSM by CAS $\ldots \ldots \ldots \ldots \ldots \ldots \ldots \ldots \ldots \ldots \ldots \ldots \ldots$

3-1 Definition of FALs for CAU 562 COPCs $\ldots \ldots \ldots \ldots \ldots \ldots \ldots$

3-2 Evaluation of General Corrective Action Standards . . . . . . . . . . . 82

3-3 Evaluation of General Corrective Action Standards . . . . . . . . . . . 83

3-4 Evaluation of Remedy Selection Decision Factors ................. 84

A.2-1 CAI Activities Conducted at Each CAS To Meet CAIP

Requirements for CAU $562 \ldots \ldots \ldots \ldots \ldots \ldots \ldots \ldots \ldots \ldots \ldots \ldots \ldots \ldots \ldots \ldots$

A.2-2 Laboratory Analyses and Methods, CAU 562 Investigation Samples ....................... A-11 


\section{List of Tables (Continued)}

Number

Title

Page

A.3-1 Samples Collected at CAS 02-26-11, Lead Shot................. A-15

A.3-2 Sample Results for Total VOCs Detected above MDCs

at CAS 02-26-11, Lead Shot ........................ A-17

A.3-3 Sample Results for Total SVOCs Detected above MDCs

at CAS 02-26-11, Lead Shot ......................... A-19

A.3-4 Sample Results for TPH-DRO Detected above MDCs

at CAS 02-26-11, Lead Shot ...

A.3-5 Sample Results for Metals Detected above MDCs

at CAS 02-26-11, Lead Shot ......................... A-21

A.3-6 Sample Results for PCBs Detected above MDCs

at CAS 02-26-11, Lead Shot ......................... A-22

A.3-7 Sample Results for Pesticides Detected above MDCs

at CAS 02-26-11, Lead Shot ......................... A-22

A.3-8 Sample Results for Gamma-Emitting Radionuclides Detected

above MDCs at CAS 02-26-11, Lead Shot . . . . . . . . . . . . . A-23

A.3-9 PSM Results Detected above MDCs for CAS 02-26-11, Lead Shot. . . . . . . . A-24

A.4-1 Samples Collected at CAS 02-44-02, Paint Spills and French Drain . . . . . . A-29

A.4-2 Sample Results for Total VOCs Detected above MDCs

at CAS 02-44-02, Paint Spills and French Drain.................. A-33

A.4-3 Sample Results for Total SVOCs Detected above MDCs

at CAS 02-44-02, Paint Spills and French Drain............... A-34

A.4-4 Sample Results for TPH-DRO Detected above MDCs

at CAS 02-44-02, Paint Spills and French Drain................. A-36

A.4-5 Sample Results for Metals Detected above MDCs at CAS 02-44-02,

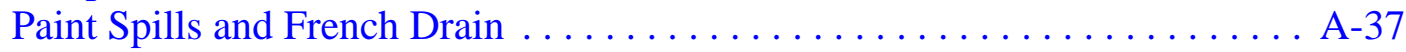




\section{List of Tables (Continued)}

Number

Title

Page

A.4-6 Sample Results for PCBs Detected above MDCs at CAS 02-44-02, Paint Spills and French Drain................ A-38

A.4-7 Sample Results for Gamma-Emitting Radionuclides Detected above MDCs at CAS 02-44-02, Paint Spills and French Drain. .......... A-39

A.4-8 PSM Results Detected above MDCs for CAS 02-44-02, Paint Spills and French Drain ......................... A-40

A.5-1 Samples Collected at CAS 02-59-01, Septic System . . . . . . . . . . . . . A-44

A.5-2 Sample Results for TPH-DRO Detected above MDCs at CAS 02-59-01, Septic System . . . . . . . . . . . . . . . . . . A-48

A.5-3 Sample Results for Metals Detected above MDCs at CAS 02-59-01, Septic System . . . . . . . . . . . . . . . . . A-49

A.5-4 Sample Results for Gamma-Emitting Radionuclides Detected above MDCs at CAS 02-59-01, Septic System . . . . . . . . . . . . . . . A-50

A.5-5 PSM Results Detected above MDCs for CAS 02-59-01, Septic System . . . . . . . . . . . . . . . . A-51

A.6-1 Samples Collected at CAS 02-60-01, Concrete Drain. . . . . . . . . . . . A A-56

A.6-2 Sample Results for Total VOCs Detected above MDCs at CAS 02-60-01, Concrete Drain . . . . . . . . . . . . . . . . . . . . . A-59

A.6-3 Sample Results for Total SVOCs Detected above MDCs at CAS 02-60-01, Concrete Drain . . . . . . . . . . . . . . . . A-60

A.6-4 Sample Results for TPH-DRO Detected above MDCs at CAS 02-60-01, Concrete Drain . . . . . . . . . . . . . . . . A-61

A.6-5 Sample Results for Metals Detected above MDCs at CAS 02-60-01, Concrete Drain . . . . . . . . . . . . . . . . . A-61

A.6-6 Sample Results for PCBs Detected above MDCs at CAS 02-60-01, Concrete Drain . . . . . . . . . . . . . . . . A A-62 


\section{List of Tables (Continued)}

Number

Title

Page

A.6-7 Sample Results for Gamma-Emitting Radionuclides Detected above MDCs at CAS 02-60-01, Concrete Drain ................ A-62

A.7-1 Samples Collected at CAS 02-60-02, French Drain $\ldots \ldots \ldots \ldots \ldots \ldots$ A-66

A.7-2 Sample Results for Total SVOCs Detected above MDCs at CAS 02-60-02, French Drain......................... A-70

A.7-3 Sample Results for TPH-DRO Detected above MDCs at CAS 02-60-02, French Drain. .......................... A-71

A.7-4 Sample Results for Metals Detected above MDCs at CAS 02-60-02, French Drain......................... A-71

A.7-5 Sample Results for PCBs Detected above MDCs at CAS 02-60-02, French Drain........................ A-72

A.7-6 Sample Results for Gamma-Emitting Radionuclides Detected above MDCs at CAS 02-60-02, French Drain. ................ A-73

A.8-1 Samples Collected at CAS 02-60-03, Steam Cleaning Drain . . . . . . . . A-76

A.8-2 Sample Results for Total SVOCs Detected above MDCs at CAS 02-60-03, Steam Cleaning Drain. .................... A-80

A.8-3 Sample Results for TPH-DRO Detected above MDCs at CAS 02-60-03, Steam Cleaning Drain.

A.8-4 Sample Results for Metals Detected above MDCs at CAS 02-60-03, Steam Cleaning Drain. .................... A-81

A.8-5 Sample Results for PCBs Detected above MDCs at CAS 02-60-03, Steam Cleaning Drain. ................... A-82

A.8-6 Sample Results for Pesticides Detected above MDCs at CAS 02-60-03, Steam Cleaning Drain.

A.8-7 Sample Results for Gamma-Emitting Radionuclides Detected above MDCs at CAS 02-60-03, Steam Cleaning Drain 


\section{List of Tables (Continued)}

Number

Title

Page

A.9-1 Samples Collected at CAS 02-60-04, French Drain . . . . . . . . . . . . . A-88

A.9-2 Sample Results for Total SVOCs Detected above MDCs at CAS 02-60-04, French Drain....................... A-90

A.9-3 Sample Results for TPH-DRO Detected above MDCs at CAS 02-60-04, French Drain.......................... A-91

A.9-4 Sample Results for Metals Detected above MDCs at CAS 02-60-04, French Drain. ....................... A-91

A.9-5 Sample Results for PCBs Detected above MDCs at CAS 02-60-04, French Drain........................ A-92

A.9-6 Sample Results for Gamma-Emitting Radionuclides Detected above MDCs at CAS 02-60-04, French Drain. ................ A-92

A.9-7 PSM Results Detected above MDCs for CAS 02-60-04, French Drain ..... A-93

A.10-1 Samples Collected at CAS 02-60-05, French Drain . . . . . . . . . . . . A-97

A.10-2 Sample Results for Total VOCs Detected above MDCs at CAS 02-60-05, French Drain.......................... A-101

A.10-3 Sample Results for Total SVOCs Detected above MDCs at CAS 02-60-05, French Drain........................ A-102

A.10-4 Sample Results for TPH-DRO Detected above MDCs at CAS 02-60-05, French Drain......................... A-103

A.10-5 Sample Results for Metals Detected above MDCs at CAS 02-60-05, French Drain........................ A-103

A.10-6 Sample Results for PCBs Detected above MDCs at CAS 02-60-05, French Drain........................ A-104

A.10-7 Sample Results for Gamma-Emitting Radionuclides Detected above MDCs at CAS 02-60-05, French Drain. .................. A-104 


\section{List of Tables (Continued)}

Number

Title

Page

A.10-8 PSM Results Detected above MDCs

for CAS 02-60-05, French Drain . . . . . . . . . . . . . . . . . .

A.11-1 Samples Collected at CAS 02-60-06, French Drain . . . . . . . . . . . . A-109

A.11-2 Sample Results for Total SVOCs Detected above MDCs

at CAS 02-60-06, French Drain........................ A-110

A.11-3 Sample Results for TPH-DRO Detected above MDCs

at CAS 02-60-06, French Drain. . . . . . . . . . . . . . . . . . . . . . . A-111

A.11-4 Sample Results for Metals Detected above MDCs

at CAS 02-60-06, French Drain........................ A-112

A.11-5 Sample Results for PCBs Detected above MDCs

at CAS 02-60-06, French Drain........................ A-112

A.11-6 Sample Results for Gamma-Emitting Radionuclides Detected

above MDCs at CAS 02-60-06, French Drain. .................. A-113

A.13-1 Samples Collected at CAS 23-60-01, Mud Trap Drain and Outfall . . . . . . A-117

A.13-2 Sample Results for Total VOCs Detected above MDCs

at CAS 23-60-01, Mud Trap Drain and Outfall................. A-120

A.13-3 Sample Results for Total SVOCs Detected above MDCs

at CAS 23-60-01, Mud Trap Drain and Outfall................ A-121

A.13-4 Sample Results for TPH-DRO Detected above MDCs

at CAS 23-60-01, Mud Trap Drain and Outfall. ................ A-122

A.13-5 Sample Results for Metals Detected above MDCs

at CAS 23-60-01, Mud Trap Drain and Outfall................. A-122

A.13-6 Sample Results for PCBs Detected above MDCs at CAS 23-60-01, Mud Trap Drain and Outfall............... A-124

A.13-7 Sample Results for Pesticides Detected above MDCs at CAS 23-60-01, Mud Trap Drain and Outfall. ................. A-124 


\section{List of Tables (Continued)}

Number

Title

Page

A.13-8 Sample Results for Gamma-Emitting Radionuclides Detected above MDCs at CAS 23-60-01, Mud Trap Drain and Outfall. .......... A-125

A.13-9 PSM Results Detected above MDCs for CAS 23-60-01, Mud Trap Drain and Outfall . ....................... A-126

A.14-1 Samples Collected at CAS 23-99-06, Grease Trap . . . . . . . . . . . . . A-130

A.14-2 PSM Results Detected above MDCs for CAS 23-99-06, Grease Trap . . . . . A A-132

A.15-1 Samples Collected at CAS 25-60-04, Building 3123 Outfalls ......... A-138

A.15-2 Sample Results for Total VOCs Detected above MDCs at CAS 25-60-04, Building 3123 Outfalls .................... A-142

A.15-3 Sample Results for Total SVOCs Detected above MDCs at CAS 25-60-04, Building 3123 Outfalls .................. A-143

A.15-4 Sample Results for TPH-DRO Detected above MDCs at CAS 25-60-04, Building 3123 Outfalls ...

A.15-5 Sample Results for Metals Detected above MDCs at CAS 25-60-04, Building 3123 Outfalls

A.15-6 Sample Results for PCBs Detected above MDCs at CAS 25-60-04, Building 3123 Outfalls ...

A.15-7 Sample Results for Gamma-Emitting Radionuclides Detected above MDCs at CAS 25-60-04, Building 3123 Outfalls............. A-147

A.15-8 PSM Results Detected above MDCs for CAS 25-60-04, Building 3123 Outfalls.......................... A-148

A.16-1 Waste Summary Table......................... A-151

A.16-2 Waste Characterization Results Detected at CAS 02-26-11, Lead Shot ... 


\section{List of Tables (Continued)}

Number

A.16-3 Waste Characterization Results Detected at CAS 02-59-01, Septic System . . . . . . . . . . . . . . . . . . A-154

A.16-4 Waste Characterization Results Detected at CAS 02-60-02, French Drain.

A.16-5 Waste Characterization Results Detected at CAS 02-60-04, French Drain. .

A.16-6 Waste Characterization Results Detected at CAS 25-60-04, Building 3123 Outfalls .................. A-158

B.1-1 CAU 562 Analyses Performed $\ldots \ldots \ldots \ldots \ldots \ldots \ldots \ldots \ldots \ldots \ldots . \ldots \ldots$

B.1-2 Analytes Failing Sensitivity Criteria $\ldots \ldots \ldots \ldots \ldots \ldots \ldots \ldots$ B-4

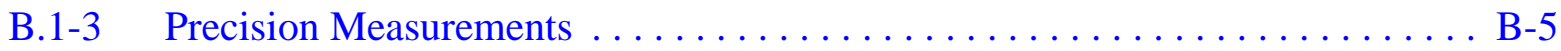

B.1-4 Accuracy Measurements $\ldots \ldots \ldots \ldots \ldots \ldots \ldots \ldots \ldots \ldots$ B-6

B.1-5 Rejected Measurements ......................... B-8

B.1-6 Key Assumptions............................... B-14

B.1-7 Summary of COCs and PSM by CAS $\ldots \ldots \ldots \ldots \ldots \ldots \ldots \ldots \ldots \ldots$

D.1-1 Summary of COCs and PSM by CAS $\ldots \ldots \ldots \ldots \ldots \ldots \ldots \ldots \ldots \ldots \ldots$

D.1-2 Maximum Reported Soil Sample Results for Tier I Comparison ........... D-7

D.1-3 Maximum Reported PSM Sample Results for Tier I Comparison ........ D-10

D.1-4 Contaminants Exceeding PALs $\ldots \ldots \ldots \ldots \ldots \ldots \ldots \ldots \ldots \ldots \ldots \ldots \ldots \ldots$

D.1-5 Tier 2 SSTLs and CAU 562 Results for Hazardous Constituents of Diesel ............................. D-18

F.1-1 Sample Location Coordinates and Locations of Interest for CAU 562.........F-1 


\section{List of Acronyms and Abbreviations}

Ac

ALM

Am

ASTM

bgs

BMP

CAA

CADD

CAI

CAIP

CAS

CAU

CFR

CLP

COC

COLIWASA

COPC

Cs

CSM

DNA

DOE

DQA

DQI

DQO

DRO

EERF
Actinium

Adult Lead Methodology

Americium

American Society for Testing and Materials

Below ground surface

Best management practice

Corrective action alternative

Corrective action decision document

Corrective action investigation

Corrective action investigation plan

Corrective action site

Corrective action unit

Code of Federal Regulations

Contract Laboratory Program

Contaminant of concern

Composite liquid waste sampler

Contaminant of potential concern

Cesium

Conceptual site model

Defense Nuclear Agency

U.S. Department of Energy

Data quality assessment

Data quality indicator

Data quality objective

Diesel-range organics

Eastern Environmental Radiation Facility 


\section{List of Acronyms and Abbreviations (Continued)}

\begin{tabular}{|c|c|}
\hline EML & Environmental Measurements Laboratory \\
\hline EPA & U.S. Environmental Protection Agency \\
\hline FADL & Field activity daily log \\
\hline FAL & Final action level \\
\hline FD & Field duplicate \\
\hline FFACO & Federal Facility Agreement and Consent Order \\
\hline FSR & Field-screening result \\
\hline $\mathrm{ft}$ & Foot \\
\hline gal & Gallon \\
\hline GPS & Global Positioning System \\
\hline GRO & Gasoline-range organics \\
\hline HASL & Health and Safety Laboratory \\
\hline ID & Identification \\
\hline IDW & Investigation-derived waste \\
\hline in. & Inch \\
\hline $\mathrm{kg} / \mathrm{kg}$ & Kilograms per kilogram \\
\hline $\mathrm{kg} / \mathrm{L}$ & Kilograms per liter \\
\hline LCS & Laboratory control sample \\
\hline LLNL & Lawrence Livermore National Laboratory \\
\hline LVF & Load Verification Form \\
\hline MDC & Minimum detectable concentration \\
\hline $\mathrm{mg} / \mathrm{kg}$ & Milligrams per kilogram \\
\hline $\mathrm{mg} / \mathrm{L}$ & Milligrams per liter \\
\hline $\mathrm{mi}$ & Mile \\
\hline $\mathrm{mm}$ & Millimeter \\
\hline MS & Matrix spike \\
\hline
\end{tabular}




\section{List of Acronyms and Abbreviations (Continued)}

\begin{tabular}{|c|c|}
\hline MSD & Matrix spike duplicate \\
\hline N/A & Not applicable \\
\hline NAC & Nevada Administrative Code \\
\hline NAD & North American Datum \\
\hline NCRP & National Council on Radiation Protection and Measurements \\
\hline NDEP & Nevada Division of Environmental Protection \\
\hline ND & Nondetect \\
\hline $\mathrm{NIOSH}$ & National Institute for Occupational Safety and Health \\
\hline NIST & National Institute of Standards and Technology \\
\hline NNES & Navarro Nevada Environmental Services, LLC \\
\hline NNSA/NSO & $\begin{array}{l}\text { U.S. Department of Energy, National Nuclear Security Administration } \\
\text { Nevada Site Office }\end{array}$ \\
\hline NTS & Nevada Test Site \\
\hline PAH & Polyaromatic hydrocarbon \\
\hline PAL & Preliminary action level \\
\hline PB & Preparation blank \\
\hline PCB & Polychlorinated biphenyl \\
\hline $\mathrm{pCi} / \mathrm{g}$ & Picocuries per gram \\
\hline $\mathrm{pCi} / \mathrm{L}$ & Picocuries per liter \\
\hline POC & Performance objective criteria \\
\hline PPE & Personal protective equipment \\
\hline PRG & Preliminary Remediation Goal \\
\hline PSM & Potential source material \\
\hline PVC & Polyvinyl chloride \\
\hline QA & Quality assurance \\
\hline QAPP & Quality Assurance Project Plan \\
\hline QC & Quality control \\
\hline
\end{tabular}




\section{List of Acronyms and Abbreviations (Continued)}

$\begin{array}{ll}\text { RBCA } & \text { Risk-based corrective action } \\ \text { RBSL } & \text { Risk-based screening level } \\ \text { RCP } & \text { Reactor Control Point } \\ \text { RCRA } & \text { Resource Conservation and Recovery Act } \\ \text { RESL } & \text { Radiological and Environmental Sciences Laboratory } \\ \text { RPD } & \text { Relative percent difference } \\ \text { SCL } & \text { Sample collection log } \\ \text { SDG } & \text { Sample delivery group } \\ \text { SNJV } & \text { Stoller-Navarro Joint Venture } \\ \text { SSTL } & \text { Site-specific target level } \\ \text { SVOC } & \text { Semivolatile organic compound } \\ \text { TC } & \text { Toxicity characteristic } \\ \text { TCLP } & \text { Toxicity Characteristic Leaching Procedure } \\ \text { Th } & \text { Thorium } \\ \text { TPH } & \text { Total petroleum hydrocarbons } \\ \text { TSCA } & \text { Toxic Substances Control Act } \\ \text { UR } & \text { Use restriction } \\ \text { UTM } & \text { Universal Transverse Mercator } \\ \text { VOC } & \text { Cubic yard } \\ \text { \% } & \end{array}$




\section{Executive Summary}

This Corrective Action Decision Document (CADD) presents information supporting the selection of corrective action alternatives (CAAs) leading to the closure of Corrective Action Unit (CAU) 562, Waste Systems, in Areas 2, 23, and 25 of the Nevada Test Site, Nevada. This complies with the requirements of the Federal Facility Agreement and Consent Order (FFACO) that was agreed to by the State of Nevada; U.S. Department of Energy (DOE), Environmental Management; U.S. Department of Defense; and DOE, Legacy Management. Corrective Action Unit 562 comprises the following corrective action sites (CASs):

- 02-26-11, Lead Shot

- 02-44-02, Paint Spills and French Drain

- 02-59-01, Septic System

- 02-60-01, Concrete Drain

- 02-60-02, French Drain

- 02-60-03, Steam Cleaning Drain

- 02-60-04, French Drain

- 02-60-05, French Drain

- 02-60-06, French Drain

- 02-60-07, French Drain

- 23-60-01, Mud Trap Drain and Outfall

- 23-99-06, Grease Trap

- 25-60-04, Building 3123 Outfalls

The purpose of this CADD is to identify and provide the rationale for the recommendation of CAAs for the 13 CASs within CAU 562. Corrective action investigation (CAI) activities were performed from July 27, 2009, through May 12, 2010, as set forth in the CAU 562 Corrective Action Investigation Plan.

The purpose of the CAI was to fulfill the following data needs as defined during the data quality objective (DQO) process:

- Determine whether COCs are present.

- If COCs are present, determine their nature and extent.

- Provide sufficient information and data to complete appropriate corrective actions.

A data quality assessment (DQA) performed on the CAU 562 data demonstrated the quality and acceptability of the data for use in fulfilling the DQO data needs. 
Analytes detected during the CAI were evaluated against appropriate final action levels (FALs) to identify the COCs for each CAS. The results of the CAI identified COCs at 10 of the 13 CASs in CAU 562, and thus corrective action is required. Assessment of the data generated from investigation activities conducted at CAU 562 is shown in Table ES-1.

Based on the evaluation of analytical data from the CAI, review of future and current operations at the 13 CASs, and the detailed and comparative analysis of the potential CAAs, the following corrective actions are recommended for CAU 562.

- No further action is the preferred corrective action for CASs 02-60-01, 02-60-06, and 02-60-07.

- Clean closure is the preferred corrective action for CASs 02-26-11, 02-44-02, 02-59-01, 02-60-02, 02-60-03, 02-60-04, 02-60-05, 23-60-01, 23-99-06, and 25-60-04.

The preferred CAAs were evaluated on technical merit focusing on performance, reliability, feasibility, safety, and cost. The alternatives were judged to meet all requirements for the technical components evaluated. The alternatives meet all applicable federal and state regulations for closure of the site and will reduce potential exposures to contaminated media to acceptable levels.

The DOE, National Nuclear Security Administration Nevada Site Office provides the following recommendations:

- No further corrective action is required at CASs 02-60-01, 02-60-06, and 02-60-07.

- Clean closure is recommended for the remaining 10 CASs in CAU 562.

- A Corrective Action Plan will be submitted to the Nevada Division of Environmental Protection that contains a detailed description of the proposed actions that will be taken to implement the selected corrective actions. 
Table ES-1

Summary of COCs and PSM by CAS

\begin{tabular}{|c|c|c|c|}
\hline CAS & Media & Contaminant(s) & PSM or COC \\
\hline \multirow[t]{2}{*}{$02-26-11$} & Rusted and non-rusted shot & $\begin{array}{l}\text { Antimony } \\
\text { Arsenic } \\
\text { Lead } \\
\text { Chromium }\end{array}$ & PSM \\
\hline & Soil & None & N/A \\
\hline \multirow[t]{2}{*}{$02-44-02$} & Paint chips & $\begin{array}{c}\text { Chromium } \\
\text { Benzo(a)pyrene } \\
\text { Benzo(b)fluoranthene } \\
\text { Bis(2-ethylhexyl)phthalate } \\
\text { Lead }\end{array}$ & PSM \\
\hline & Soil & Benzo(a)pyrene & $\mathrm{COC}$ \\
\hline \multirow{3}{*}{ 02-59-01 } & Sludge & $\begin{array}{l}\text { 1,4-dichlorobenzene } \\
\text { Naphthalene }\end{array}$ & PSM \\
\hline & Liquid & None & $N / A$ \\
\hline & Soil & None & $\mathrm{N} / \mathrm{A}$ \\
\hline $02-60-01$ & Soil & None & $\mathrm{N} / \mathrm{A}$ \\
\hline $02-60-02$ & Soil & Aroclor 1260 & $\mathrm{COC}$ \\
\hline $02-60-03$ & Soil & $\begin{array}{c}\text { Aroclor } 1260 \\
\text { Benzo(a)pyrene }\end{array}$ & $\mathrm{COC}$ \\
\hline \multirow[t]{2}{*}{$02-60-04$} & Sediment & $\begin{array}{c}\text { Aroclor } 1260 \\
\text { Aroclor } 1268 \\
\text { Benzo(a)pyrene }\end{array}$ & PSM \\
\hline & Soil & None & $\mathrm{N} / \mathrm{A}$ \\
\hline \multirow[b]{2}{*}{$02-60-05$} & Asphalt & None & N/A \\
\hline & Soil & $\begin{array}{c}\text { Benzo(a)pyrene } \\
\text { Benzo(a)anthracene } \\
\text { Benzo(b)fluoranthene } \\
\text { Benzo(k)fluoranthene } \\
\text { Dibenzo(a,h)anthracene } \\
\text { Indeno(1,2,3-cd)pyrene }\end{array}$ & $\mathrm{COC}$ \\
\hline $02-60-06$ & Soil & None & $\mathrm{N} / \mathrm{A}$ \\
\hline $02-60-07$ & $\mathrm{~N} / \mathrm{A}$ & None & $\mathrm{N} / \mathrm{A}$ \\
\hline \multirow{2}{*}{$23-60-01$} & Sediment & Lead & PSM \\
\hline & Soil & None & $\mathrm{N} / \mathrm{A}$ \\
\hline 23-99-06 & Sediment & $\begin{array}{c}\text { Arsenic } \\
\text { Aroclor } 1260 \\
\text { Chlordane }\end{array}$ & PSM \\
\hline \multirow[t]{2}{*}{$25-60-04$} & Sludge & $\begin{array}{l}\text { Aroclor } 1254 \\
\text { Lead }\end{array}$ & PSM \\
\hline & Soil & Aroclor 1254 & $\mathrm{COC}$ \\
\hline
\end{tabular}

N/A = Not applicable

$\mathrm{PSM}=$ Potential source material 
This Corrective Action Decision Document (CADD) has been prepared for Corrective Action Unit (CAU) 562, Waste Systems, Nevada Test Site (NTS), Nevada. The corrective actions proposed in this document are in accordance with the Federal Facility Agreement and Consent Order (FFACO) that was agreed to by the State of Nevada; U.S. Department of Energy (DOE), Environmental Management; U.S. Department of Defense; and DOE, Legacy Management (FFACO, 1996; as amended March 2010). The NTS is approximately 65 miles (mi) northwest of Las Vegas, Nevada (Figure 1-1).

Corrective Action Unit 562 comprises the 13 corrective action sites (CASs) that are shown on Figure 1-2 and listed below:

- 02-26-11, Lead Shot

- 02-44-02, Paint Spills and French Drain

- 02-59-01, Septic System

- 02-60-01, Concrete Drain

- 02-60-02, French Drain

- 02-60-03, Steam Cleaning Drain

- 02-60-04, French Drain

- 02-60-05, French Drain

- 02-60-06, French Drain

- 02-60-07, French Drain

- 23-60-01, Mud Trap Drain and Outfall

- 23-99-06, Grease Trap

- 25-60-04, Building 3123 Outfalls

A detailed discussion of the history of this CAU is presented in the Corrective Action Investigation Plan (CAIP) for Corrective Action Unit 562: Waste Systems, Nevada Test Site, Nevada (NNSA/NSO, 2009).

\subsection{Purpose}

This CADD summarizes the corrective action investigation (CAI), develops and evaluates potential corrective action alternatives (CAAs), and provides the rationale for the selection of recommended CAAs for the CASs in CAU 562. 


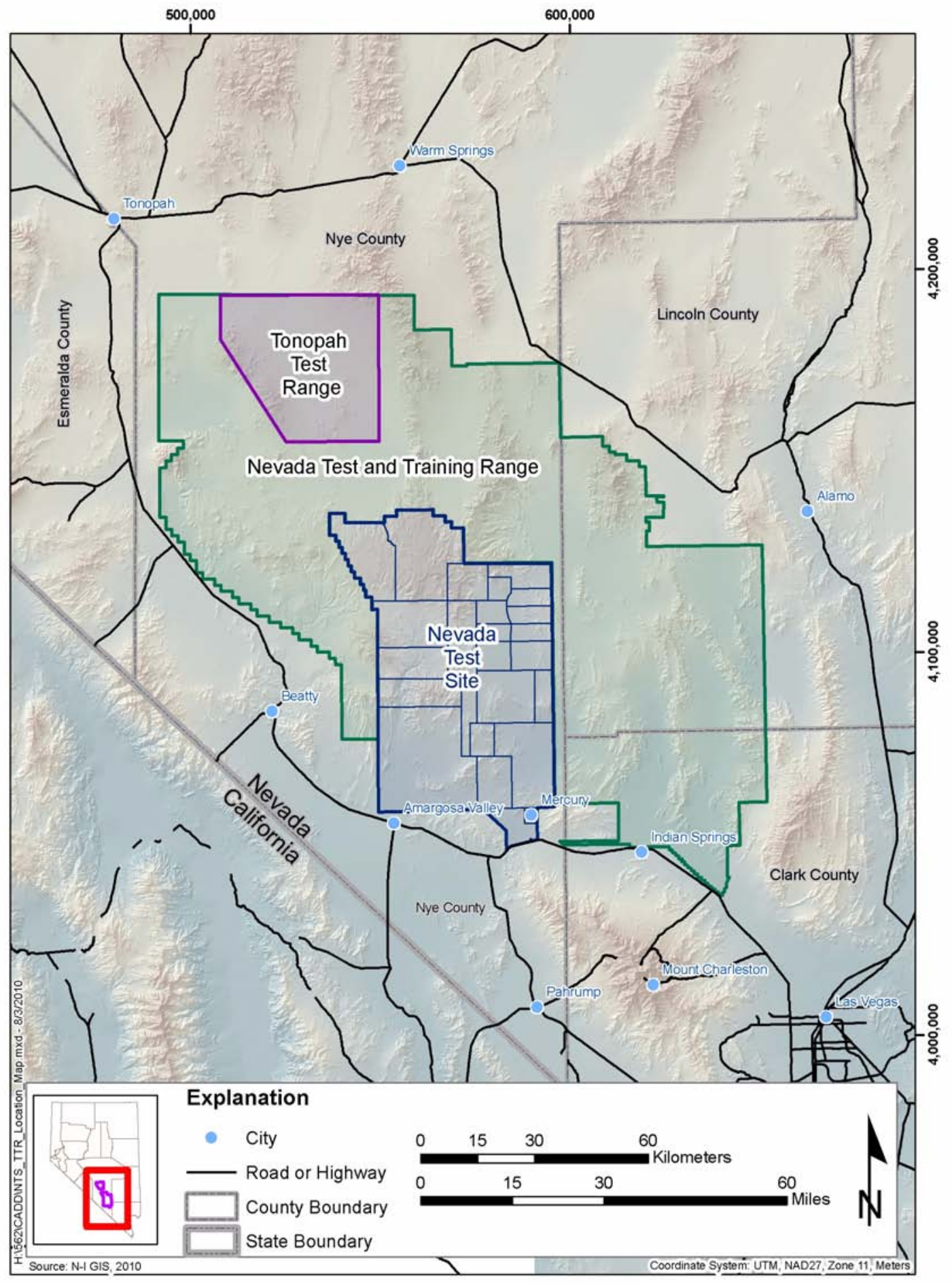

Figure 1-1

Nevada Test Site 


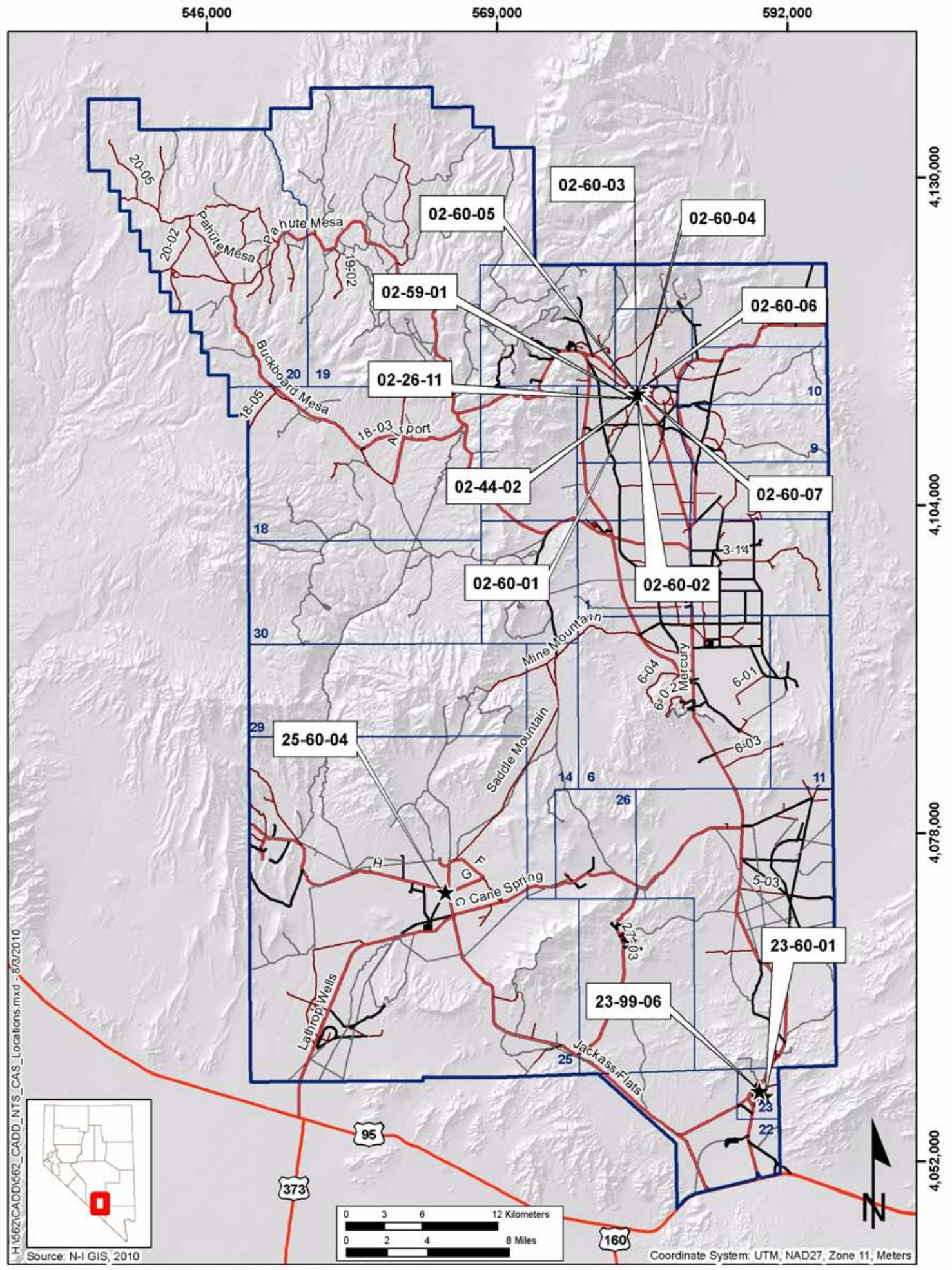

Figure 1-2

CAU 562, CAS Location Map 
Corrective Action Unit 562, Waste Systems, consists of 13 inactive and abandoned sites. Ten CASs are located in the Area 2 Camp, two CASs are located in Mercury in Area 23, and one CAS is located in the Reactor Control Point in Area 25. The components identified in the CAS descriptions as french drains are more aptly constructed like dry wells. A true french drain is designed to remove liquid from the soil while the dry well is designed for disposing of liquids into the soil. However, to be consistent with the FFACO nomenclature (FFACO, 1996; as amended March 2010), the CAS components constructed as dry wells will be referred to as french drains.

The Area 2 Camp operated between the mid-1950s and the mid-1990s. The camp was used by Lawrence Livermore National Laboratory (LLNL) to support construction and drilling operations that took place in the Yucca Flat area. There were numerous facilities in the Area 2 Camp, such as linemen, refrigeration, painter, and electrician shops as well as various storage yards. There were french drains, a concrete drain, a septic system, and a steam cleaning sump in CAU 562 that supported activities associated with these types of shops and storage yards. There were also spills or releases of lead shot and paint as a result of the activities in the area.

The two CASs located in Mercury are associated with a former commercial gas service station and a wash-down facility. The former gas station discharged wastes generated during operations to a grease trap located outside the building that ultimately released to the sanitary sewer system. The wash-down facility consisted of a wash shed and a grease rack. Waste from inside the wash shed flowed into a mud trap and then eventually to a wash via an outfall pipe. It is assumed that the grease rack was used for vehicle maintenance and that there could have been inadvertent releases to the environment.

The remaining CAS is associated with Building 3123 located at the Reactor Control Point (RCP) in Area 25. The building originally housed a laboratory, shop, and office space. The two outfalls associated with this CAS originally discharged to daylight. The outfalls are no longer active. 


\subsection{Scope}

The scope of the activities used to identify, evaluate, and recommend preferred CAAs for CAU 562 included the following:

- Removing surface debris and/or materials to facilitate sampling

- Performing radiological surveys

- $\quad$ Performing field screening

- Collecting Decision I environmental samples for laboratory analysis to determine the nature of suspected contamination

- Collecting step-out (Decision II) samples to define the lateral and vertical extent of the contamination

- Collecting samples of potential source material (PSM) to determine the potential to generate contaminants of concern (COCs) if released to the environment

- Collecting samples to determine the proper disposal of wastes

- Collecting quality control (QC) samples

- Evaluating corrective action objectives based on the results of the CAI and the CAA screening criteria

- $\quad$ Recommending and justifying preferred CAAs

\subsection{Corrective Action Decision Document Contents}

This CADD is divided into the following sections and appendices:

Section 1.0, “Introduction,” summarizes the purpose, scope, and contents of this CADD.

Section 2.0, "Corrective Action Investigation Summary,” summarizes the investigation field activities, the results of the CAI, and the need for corrective action.

Section 3.0, "Evaluation of Alternatives," describes, identifies, and evaluates the steps taken to determine preferred CAAs. 
Section 4.0, "Recommended Alternatives," presents the preferred CAAs for each CAS and the rationale based on the corrective action objectives and screening criteria.

Section 5.0, "References," provides a list of all referenced documents used in the preparation of this CADD.

Appendix A, Corrective Action Investigation Results, provides a description of the project objectives, field investigation and sampling activities, CAI results, waste management, and quality assurance (QA). Sections A.3.0 through A.15.0 provide specific information regarding field activities, sampling methods, and laboratory analytical results from the CAI.

Appendix B, Data Assessment, provides a data quality assessment (DQA) that reconciles data quality objective (DQO) assumptions and requirements to the CAI results.

Appendix C, Cost Estimates, presents cost estimates for the construction, operation, and maintenance of the CAAs evaluated for each CAS.

Appendix D, Evaluation of Risk, provides documentation of the chemical and radiological risk-based corrective action processes as applied to CAU 562.

Appendix E, Project Organization, identifies the DOE Federal Sub-Project Director and other appropriate personnel involved with the CAU 562 characterization and closure activities.

Appendix F, Sample Location Coordinates, provides CAI sample locations coordinates.

Appendix G, Waste Disposal Documentation, provides load verification and shipping documentation for CAU 562.

Appendix H, Nevada Division of Environmental Protection (NDEP) Comments, contains NDEP comments on the draft version of this document. 


\subsection{Applicable Programmatic Plans and Documents}

All CAI activities were performed in accordance with the following documents:

- $\quad$ CAIP for CAU 562, Waste Systems (NNSA/NSO, 2009)

- Industrial Sites Quality Assurance Project Plan (QAPP) (NNSA/NV, 2002)

- $\quad$ FFACO (1996, as amended March 2010)

- Approved procedures 


\subsection{Corrective Action Investigation Summary}

The following sections summarize the CAI activities and investigation results, and identify the necessity for corrective action at CAU 562. Detailed CAI activities and results for individual CAU 562 CASs are presented in Appendix A of this document.

\section{$2.1 \quad$ Investigation Activities}

Corrective action investigation activities were performed as set forth in the CAU 562 CAIP (NNSA/NSO, 2009) from July 27, 2009, through May 12, 2010. The purpose of the CAU 562 CAI was to address the decision statements in the project-specific DQOs by (1) determining whether COCs are present in the soils associated with CAU 562; (2) determining the lateral and vertical extent of identified COCs; and (3) ensuring adequate data have been collected to close the sites under NDEP, Resource Conservation and Recovery Act (RCRA) (CFR, 2008a), Toxic Substances Control Act (TSCA) (CFR, 2008b), and DOE requirements.

The scope of the CAI included the following activities:

- Performing radiological surveys (i.e., static, scanning, and swipe collection)

- Field-screening soil samples for total alpha and beta/gamma radiation

- Collecting environmental samples for laboratory analyses to determine the presence of COCs and to define the vertical and lateral extent of COCs, if present

- Collecting QC samples for laboratory analyses to ensure that the data generated from the analysis of investigation samples meet the requirements of the data quality indicators (DQIs)

- Collecting liquid and solid waste samples from septic system and trap components to identify whether the wastes contained in these structures are potential sources of environmental contamination and to support future waste disposal activities

A judgmental sampling scheme was implemented to select sample locations as outlined in the CAU 562 CAIP (NNSA/NSO, 2009). Judgmental sampling allows the methodical selection of sample locations that targets the populations of interest (defined in the DQOs) rather than nonselective random locations. Individual sample results (rather than average concentrations) are used to compare to final action levels (FALs). Therefore, statistical methods to generate site 
characteristics (averages) are not necessary. If prior information is available on the target site of interest, then the sampling may be designed to collect samples only from areas known to have the highest concentration levels on the target site. If the observed concentrations from these samples are below the action level, then a decision can be made that the site contains safe levels of the contaminant without the samples being truly representative of the entire area (EPA, 2006).

The judgmental sampling design was used to confirm the existence of contamination at specific locations and provide information, such as the extent of contamination, about specific areas of the site. Confidence in judgmental sampling scheme decisions was established qualitatively by validation of the conceptual site model (CSM) and justification that sampling locations are the most likely locations to contain a COC, if a COC exists.

Waste characterization activities were conducted to gather sufficient information and data to support waste disposal decisions. Information regarding waste characterization is presented in Appendix A.

The following sections describe specific CAI activities conducted at each CAS. Additional information regarding the CAI is presented in Appendix A.

\subsubsection{Lead Shot (CAS 02-26-11)}

Corrective Action Site 02-26-11 consists of potential releases to the soil from rusted and non-rusted shot. The following sections summarize the field activities conducted at this CAS.

\subsubsection{Radiological Surveys}

A radiological walkover survey was completed within the boundary of CAS 02-26-11. The results of the survey did not show radiological contaminants at activities statistically distinguishable from background activities (more than twice background levels). The survey results did not indicate the need for additional biased samples.

\subsubsection{Visual Inspections}

At CAS 02-26-11, both rusted and non-rusted shot is scattered throughout the area and is not uniformly distributed. Therefore, a visual survey was performed to identify one area with a high 
concentration of rusted shot and one area with a high concentration of non-rusted shot. As a result of this survey, two biased sample locations were selected at each area. A visual survey was also performed to determine the lateral extent in all directions of shot present on the ground surface. As a result of this survey, four biased sample locations were selected on the north, south, east, and west sides of the square-shaped area to confirm the lateral extent of the area potentially impacted by the shot.

No additional biased samples were identified other than those proposed in the CAU 562 CAIP (NNSA/NSO, 2009).

\subsubsection{Sample Collection}

Sampling included the collection of 13 (including 1 field duplicate [FD]) environmental surface and subsurface soil samples and 2 PSM samples from the 8 locations shown in Figure A.3-1. The sampling activities are discussed below.

Two sample locations, A05 and A06, were selected in an area of concentrated non-rusted shot. At sample location A05, one PSM sample (562A006) that included non-rusted shot was collected from 0.0 to 0.5 foot (ft) below ground surface (bgs), and one soil sample (562A015) that did not contain shot was collected at a depth of 1.0 to $1.5 \mathrm{ft}$ bgs. At sample location A06, directly adjacent to A05, the shot was brushed away from the sample location and three samples excluding shot were collected at 2.0-inch (in.) intervals. Samples 562A007, 562A008, and 562A009 were collected at 0.0 to $2.0,2.0$ to 4.0 , and 4.0 to 6.0 in. bgs, respectively.

Sample locations A07 and A08 were selected in an area of concentrated rusted shot. At sample location A07, one PSM sample (562A010) that included rusted shot was collected from 0.0 to $0.5 \mathrm{ft}$ bgs, and one soil sample (562A014) that did not include shot was collected at a depth of 1.0 to $1.5 \mathrm{ft}$ bgs. At sample location A08, directly adjacent to A07, the shot was brushed away from the sample location and three samples excluding shot were collected at 2.0-in. intervals. Samples 562A011, 562A012, and 562A013 were collected at 0.0 to 2.0, 2.0 to 4.0, and 4.0 to $6.0 \mathrm{in.}$ bgs, respectively.

Samples 562A001 through 562A005 were collected from 0.0 to $0.5 \mathrm{ft}$ bgs at locations A01 through A04 in an attempt to define the lateral extent of the shot. 


\subsubsection{Conceptual Site Model Validation}

A CSM was developed to represent the release mechanisms and potential migration pathways for contaminant releases at CAU 562 CASs. The CSM and associated discussion for this CAS are provided in the CAU 562 CAIP (NNSA/NSO, 2009).

The migration pathway and release mechanism information gathered during the CAI was consistent with the CSM. Based on the results of the DQA (presented in Appendix B), all information gathered during the CAI supports and validates the CSM as presented in the CAIP. Therefore, revision of the CSM was not necessary.

\subsubsection{Paint Spills and French Drain (CAS 02-44-02)}

Corrective Action Site 02-44-02 consists of potential releases to the soil from two french drains, paint spills, and a historical spill. The following sections summarize the field activities conducted at this CAS.

\subsubsection{Radiological Surveys}

A radiological walkover survey was completed within the boundary of CAS 02-44-02. The results of the survey did not show radiological contaminants at activities statistically distinguishable from background activities (more than twice background levels). Therefore, the survey results did not indicate the need for additional biased samples.

\subsubsection{Visual Inspections}

The following features were visually inspected before and/or during sampling activities at CAS 02-44-02:

French Drains - Inspection of the original french drain discussed in the CAIP revealed that it consisted of a bottomless 55-gallon (gal) drum with a removable lid and approximately $2.0 \mathrm{ft}$ of void space between the ground surface and the soil in the french drain. The bottom of the drum contained about 6.0 in. of soil with a thin layer of paint-like material on top. The drain was underlain by leach rock that extended to approximately $7.0 \mathrm{ft}$ bgs to the native soil interface. A small diameter pipe was 
visible in the sidewall that was closest to the Painters Shop pad. It is believed that the pipe connected to the new french drain and the two french drains worked as an overflow system.

During the CAI, a new french drain was identified. This french drain consisted of a bottomless 55-gal drum with a lid that was embedded in the foundation of the former Painters Shed. There was approximately $2.0 \mathrm{ft}$ of void space above the leach rock that extends to a depth of approximately $8.5 \mathrm{ft}$ bgs. A small diameter pipe was also present in the sidewall that was closest to the Painters Shed pad. It is believed that this pipe connected the new french drain with the original french drain.

Paint Spills - Two areas consisting of multiple layers of dried paint were identified on the foundations of the former Paint Storage Rack and Painters Shed; these areas were selected as biased locations B05 and B09, respectively. A third paint spill was identified on the northeast side of the Paint Storage Rack foundation and was selected as biased location B01. The soil underlying the dried layers of paint at location B01 was mixed with pea gravel and slightly discolored.

Historical Spill - The area on the southeastern side of the former Painters Shed was inspected to identify the reported historical spill of a resin-like material; however, no soil discoloration or other visual evidence of a release was observed. The biased sample location (B06) representing the historical spill was, therefore, determined using Global Positioning System (GPS) coordinates provided in the document that first identified the spill (REECo, 1995).

No additional biased sample locations were identified other than those proposed in the CAU 562 CAIP (NNSA/NSO, 2009).

\subsubsection{Sample Collection}

Sampling included the collection of 18 (including 1 FD) environmental surface and subsurface soil samples and 2 PSM samples from 14 locations. All sample locations are shown on Figure A.4-1. The sampling activities are discussed below.

French Drains - Sampling activities at the original french drain discussed in the CAIP included the collection of two environmental samples from location B10. Sample 562B013 was collected from a depth of 2.0 to $2.5 \mathrm{ft}$ bgs and consisted of soil mixed with possible paint chips and other miscellaneous debris. This sample was collected from the 6.0 in. of material on top of the leach rock. 
Leach rock extended from the base of the french drain to $7.0 \mathrm{ft}$ bgs. Sample 562B014 was collected at a depth of 7.5 to $8.0 \mathrm{ft}$ bgs and represents the native soil below the french drain and leach rock.

Sampling activities at the french drain identified in the Painters Shed foundation during the field investigation included the collection of two environmental samples from location B14. Sample 562B020 was collected from a depth of 3.0 to $3.5 \mathrm{ft}$ bgs, from the sidewall of the excavation directly below the base of the french drain. The french drain was emplaced in a bed of leach rock that extended $8.5 \mathrm{ft}$ bgs to the native soil interface. Sample 562B019 was collected from 8.5 to $9.0 \mathrm{ft}$ bgs and represents the native soil below the leach rock.

Paint Spills - Sampling activities at the Paint Storage Rack included the collection of one PSM sample and six environmental soil samples. Potential source material sample 562B006 (location B05) consisted of 1.0- to 3.0-millimeter (mm)-thick paint chips of various colors. Environmental samples 562B001 and 562B012 were collected from the paint spill location (B01) northeast of the Paint Storage Rack. Sample 562B001 was collected from 0.0 to $0.5 \mathrm{ft}$ bgs and consisted of soil and the surface layer of paint. Sample 562B012 was collected from 1.0 to $1.5 \mathrm{ft}$ bgs, directly below sample 562B001, and consisted of native soil. Environmental surface soil samples (562B002 through 562B005) were collected from each of the remaining sides of the Paint Storage Rack (location B02, northwest; location B03, southwest; and location B04, southeast).

Sampling activities at the Painters Shed foundation included the collection of one PSM sample and two environmental soil samples. Potential source material sample 562B010 was collected from the Painters Shed foundation (location B09) and consisted of 1.0- to 3.0-mm-thick paint chips. Surface samples 562B008 and 562B009 were collected from the southwestern and northeastern sides of the Painters Shed foundation at locations B07 and B08, respectively.

Because a COC was identified in sample 562B009, four Decision II environmental soil samples were collected to define the extent of contamination. One sample (562B015) was collected at 1.0 to $1.5 \mathrm{ft}$ bgs at sample location B08, which contained a COC. Three additional sample locations (B11 through B13) were selected approximately $3.0 \mathrm{ft}$ laterally in three directions from location B08. Sample location B12 was altered slightly because there was asphalt present in the area. 
Historical Spill - Sampling activities at the historical spill included the collection of two environmental soil samples from location B06 on the southeastern side of the Painters Shed foundation. Sample 562B007 was collected from 0.0 to $0.5 \mathrm{ft}$ bgs and consisted of surface soil. Sample 562B011 was collected from 1.0 to $1.5 \mathrm{ft}$ bgs at the same location and consisted of native soil.

\subsubsection{Conceptual Site Model Validation}

A CSM was developed to represent the release mechanisms and potential migration pathways for contaminant releases at CAU 562 CASs. The CSM and associated discussion for this CAS are provided in the CAU 562 CAIP (NNSA/NSO, 2009).

The semivolatile organic compound (SVOC) contamination adjacent to the Painters Shed foundation is consistent with the CSM in that if activities resulted in a release of contaminants directly to the surface soil, the concentration of the contaminants would decrease from the source. The contamination is limited in vertical and lateral migration. The information gathered during the CAI supports and validates the CSM as presented in the CAIP.

\subsubsection{Septic System (CAS 02-59-01)}

Corrective Action Site 02-59-01 consists of potential releases to the soil from the septic system, which includes a septic tank and leachfield. The following sections summarize the field activities conducted at this CAS.

\subsubsection{Radiological Surveys}

A radiological walkover survey was completed within the boundary of CAS 02-59-01. The results of the survey did not show radiological contaminants at activities statistically distinguishable from background activities (more than twice background levels). The survey results did not indicate the need for additional biased samples. 


\subsubsection{Visual Inspections}

At CAS 02-59-01, the following features were visually inspected before and/or during sampling activities:

Septic Tank - The surface components of the septic tank include two access lids aligned in a northwest to southwest direction with a distribution box on each end. Each access lid sits $2.0 \mathrm{ft}$ above ground surface and is attached to a 3.0-ft-diameter steel pipe that extends $7.5 \mathrm{ft}$ to the top of the septic tank. Removal of the northwest and southeast access lids revealed a wire cable that is used to lift and remove a secondary lid on top of the septic tank. The septic tank is an approximately 30.0-ft-long, 6.0-ft-diameter concrete tank with a 6.0-in. polyvinyl chloride (PVC) inlet pipe that enters the northwest side of the tank and a 6.0-in. PVC outlet pipe that exits the southeast side of the tank leading to the leachfield. The tank is situated in a gravel envelope and the leach lines are surrounded with leach rock. The tank contained approximately $1.5 \mathrm{ft}$ of air space, $4.0 \mathrm{ft}$ of liquid, and $0.5 \mathrm{ft}$ of sludge (based on measurements from the northwest tank access). It could not be determined if the tank design is a single or double chamber; however, the southeast end appeared to contain less sludge than the northwest end. Therefore, it is speculated that the tank has two chambers. Both the tank and the inlet and outlet pipes appeared to be in excellent condition.

Leachfield - The PVC outlet pipe of the septic tank leads to a distribution box accessed through a manhole cover. Removal of the manhole cover revealed three outlet distributions to the leachfield. The leachfield piping is 7.0 to $8.0 \mathrm{ft}$ bgs and consists of 9 leach pipes oriented in a northwest-southeast direction. The proximal and distal ends of each pipe tie-in to a north-south oriented pipe via T-joints, or 90-degree elbows. The leach pipe consists of a 4.0-in. PVC pipe with perforations set in a bed of leach rock that extends 9.0 to $10.0 \mathrm{ft}$ bgs to the native soil interface.

No biasing factors were identified during the excavation and visual survey that resulted in the selection of additional sampling locations.

\subsubsection{Sample Collection}

Sampling activities included the collection of 11 (including 1 FD) environmental subsurface soil samples and 4 PSM samples from the 12 locations shown in Figure A.5-1. The sampling activities are discussed below. 
Septic Tank - Four PSM samples were collected from inside the septic tank at locations C07 and C09. Because the tank was suspected to have two chambers, liquid and sludge samples were collected from each end of the tank (northwest and southeast). Samples 562C008 (liquid) and 562C011 (sludge) were collected from the northwest side of the tank (location C07). The liquid sample had a slight septic odor and consisted of clear fluid with some suspended black particles. An oil sheen was observed on the surface of the liquid in the tank. The sludge sample had a strong, septic-like odor, and consisted of black, muddy sludge with abundant miscellaneous debris. Samples 562C010 (liquid) and 562C012 (sludge) were collected from the southeast side of the tank (location C09) and resembled the samples from the northwest side, but less sludge was present at this location.

Environmental sampling outside the septic tank included the collection of subsurface soil samples 562C001 from directly below the inlet pipe connection (location C01) and 562C004 from below the outlet pipe connection (location C03). Samples 562C002 and FD 562C003 were collected directly below the base of the tank at the northwest end (location C02); and sample 562C005 was collected directly below the base of the tank at the southeast end (location C04). Samples were collected at depths ranging from 7.5 to $13.5 \mathrm{ft}$ bgs.

Leachfield - Sampling activities at the leachfield included the collection of six soil samples at the native soil interface below leach rock at the proximal and distal ends of the middle and outer leach pipes. The three leach pipes from which samples were collected are referred to as the middle, north, and south leach pipes. From the middle leach pipe, sample 562C006 was collected at the proximal end (location C05) and sample 562C013 was collected at the distal end (location C10). From the north leach pipe, sample 562C007 was collected at the proximal end (location C06) and sample 562C009 was collected at the distal end (location C08). From the south leach pipe, sample 562C015 was collected at the proximal end (location C12) and sample 562C014 was collected at the distal end (location C11). Samples were collected at depths ranging from 9.0 to $12.0 \mathrm{ft}$ bgs.

\subsubsection{Conceptual Site Model Validation}

A CSM was developed to represent the release mechanisms and potential migration pathways for contaminant releases at CAU 562 CASs. The CSM and associated discussion for this CAS are provided in the CAU 562 CAIP (NNSA/NSO, 2009). 
The migration pathway and release mechanism information gathered during the CAI was consistent with the CSM, and all information gathered during the CAI supports and validates the CSM as presented in the CAIP.

\subsubsection{Concrete Drain (CAS 02-60-01)}

Corrective Action Site 02-60-01 consists of potential releases to the soil from activities associated with the concrete drain. The following sections summarize the field activities conducted at this CAS.

\subsubsection{Radiological Surveys}

A radiological walkover survey was completed within the boundary of CAS 02-60-01. The results of the survey did not show radiological contaminants at activities statistically distinguishable from background activities (more than twice background levels). The survey results did not indicate the need for additional biased samples.

\subsubsection{Geophysical Surveys}

A geophysical survey was conducted to identify the location of the concrete drain. The geophysical survey results indicated that there were no linear anomalies representing possible inlets or outlets from the concrete drain; however, two anomalies were identified directly outside the drain. It was noted that the anomalies were possibly a result of buried metal because the area had been previously disturbed (Weston, 2007).

\subsubsection{Visual Inspections}

Surface soils were removed from the area surrounding the concrete drain to fully uncover the drain and determine its configuration. The drain consists of a shallow concrete basin that is approximately $4.0 \mathrm{ft}$ long, $2.5 \mathrm{ft}$ wide, and $1.0 \mathrm{ft}$ deep. A 3.0-in.-diameter metal drain pipe that is no longer connected to the concrete foundation discharged to the drain. The drain contained $8.0 \mathrm{in}$. of soil that was likely backfill material. No staining or other biasing factors indicative of a release were observed. However, it should be noted that there is broken asphalt of various sizes and compositions surrounding the concrete drain, former building foundation, and throughout the storage yard. It appears that the storage yard was previously paved but the asphalt has deteriorated. 
An area measuring 7.0 by $8.0 \mathrm{ft}$ adjacent to the southwest corner of the concrete drain was excavated to $2.0 \mathrm{ft}$ bgs to investigate the two anomalies identified in the geophysical survey. It was determined that the anomalies were associated with buried metal debris. The entire area surrounding CAS 02-60-01 was littered with other metal debris (e.g., pipe pieces, bolts, nuts, nails, scrap sheet metal). Because there was no evidence of a release associated with these anomalies, no samples were collected. No additional biased samples were identified other than those proposed in the CAU 562 CAIP (NNSA/NSO, 2009).

\subsubsection{Sample Collection}

Sampling activities included the collection of 18 (including 1 FD) environmental surface and subsurface soil samples from 17 sample locations. All sample locations are shown in Figure A.6-1. The sampling activities are discussed below.

Sample 562D001 was collected at location D01 from the bottom of the 8.0-in.-deep concrete drain directly adjacent to the opening of the drain pipe. This sample consisted of silty sand with miscellaneous debris (e.g., plastic, wood, paper); however, no staining was observed. Samples 562D002 and FD 562D003 were collected from 1.5 to $2.0 \mathrm{ft}$ bgs at the native soil interface directly below the concrete drain (location D02).

The Decision I analytical results showed that concentrations of various polyaromatic hydrocarbons (PAHs) in sample 562D001 exceeded the preliminary action levels (PALs), and it was determined that Decision II sampling was necessary. Decision II sampling was conducted from November 3, 2009, to January 20, 2010. Samples (562D004 through 562D018) were collected at a depth of 0.0 to $0.5 \mathrm{ft}$ bgs from 15 sample locations (D03 through D17) ranging from approximately 1.0 to $35.0 \mathrm{ft}$ laterally from the concrete drain, the suspected source of contamination. These locations were positioned in a radial pattern moving outward from the concrete drain and adjacent former building foundation. Pieces of asphalt ranging in size from large chunks to small particles were observed throughout the storage yard. It was noted that much of the deteriorated asphalt was so small that it could not be distinguished from soil. Attempts were made to exclude visible pieces of asphalt from the samples, but it was impossible to know whether a sample contained grains of asphalt. 


\subsubsection{Conceptual Site Model Validation}

A CSM was developed to represent the release mechanisms and potential migration pathways for contaminant releases at CAU 562 CASs. The CSM and associated discussion for this CAS are provided in the CAU 562 CAIP (NNSA/NSO, 2009).

The PAH contamination within the area of CAS 02-60-01 is not consistent with the CSM in that the concentrations of PAHs do not decrease with increasing distance from the suspected source as would be expected. The data show that the PAH concentrations tend to increase with distance from the drain. It was also observed that the samples with the highest concentration of PAHs were collected at the locations where the density of the asphalt was the greatest. This suggests that the reported PAH contamination is not a result of a release from CAS 02-60-01 but is associated with the deteriorated asphalt in the area. Therefore, the PAHs reported in the surface samples are not considered to be associated with CAS 02-60-01, and revision of the CSM was not necessary.

\subsubsection{French Drain (CAS 02-60-02)}

Corrective Action Site 02-60-02 consists of potential releases to the soil from activities associated with two french drains and two elongated drains. The following sections summarize the field activities conducted at this CAS.

\subsubsection{Radiological Surveys}

A radiological walkover survey was completed within the boundary of CAS 02-60-02. The results of the survey did not show radiological contaminants at activities statistically distinguishable from background activities (more than twice background levels). The survey results did not indicate the need for additional biased samples.

\subsubsection{Geophysical Surveys}

A geophysical survey was conducted on the western side of the pad near the elongated drains to determine the presence of piping and a termination point for effluent. The geophysical survey results indicated that there were no linear anomalies originating from or terminating at the "drains on the west side” (Weston, 2007). Although the geophysical survey did not detect the presence of piping or 
a french drain, piping and a french drain were identified during excavation. It is believed that the presence of heavy vegetation prevented the survey team from identifying the structures.

\subsubsection{Visual Inspections}

At CAS 02-60-02, the following features were visually inspected before and/or during sampling activities:

French Drains - Visual inspection of the original french drain on the east side of the concrete foundation revealed that it consisted of a rusted 55-gal drum with holes drilled through the walls and bottom. The top of the drum was flush with the ground surface, and it was approximately half full of soil/sediment, which left a void space between the ground surface and the material in the bottom of the drain.

While investigating the north elongated drain, the inspection team identified a second french drain with a metal cover under several inches of soil. This drain, referred to as the north french drain, was approximately two-thirds full of soil/sediment, which left a void space between the ground surface and the material in the drain. The casing was a rusted and significantly corroded 55-gal drum with large holes punched though the bottom. No leach rock associated with this drain was identified. Instead, a metal screen was observed at the center, and two plastic vertical pipes, which were most likely installed to promote infiltration, were identified. The north french drain served as a discharge point for the two elongated drains.

Elongated Drains - Two elongated drains (north and south) consisting of a steel rectangular trough with a metal grate cover are located on the west side of the concrete foundation. Both drains were nearly full of soil/sediment and measured $7.0 \mathrm{ft}$ long by $11.0 \mathrm{in}$. wide and $15.0 \mathrm{in}$. deep. The south drain discharged to the north drain and ultimately to the adjacent north french drain via a small diameter metal drain pipe.

As a result of the visual inspection of the CAS, a new french drain was identified and additional samples were collected at this component. Because the north french drain was newly identified during the field investigation, biased samples were collected that were not discussed in the CAIP (NNSA/NSO, 2009). 


\subsubsection{Sample Collection}

Sampling activities included the collection of nine (including one FD) environmental subsurface soil samples from six locations. All sample locations are shown on Figure A.7-1. The sampling activities are discussed below.

French Drains - At the original french drain (location E03), sample 562E004 was collected at 2.5 to $3.0 \mathrm{ft}$ bgs from the bottom interior of the 55-gal drum. This sample consisted of well-sorted sand with small miscellaneous debris and dark black (potentially organic-rich) material. Sample 562E005 was collected at 4.5 to $5.0 \mathrm{ft}$ bgs from the native soil interface directly below the original french drain. At the north french drain (location E04), sample 562E006 was collected from 2.5 to $3.0 \mathrm{ft}$ bgs from the bottom interior of the 55-gal drum. This sample consisted of moist, dark brown, silty sand with miscellaneous debris (e.g., metal, plastic, wood). Sample 562E007 was collected at 4.0 to $4.5 \mathrm{ft}$ bgs from the native soil interface directly below the north french drain.

Elongated Drains - A sample was collected from the contents of each of the two elongated drains. Sample 562E001 was collected from 1.0 to $1.5 \mathrm{ft}$ bgs inside the north elongated drain (location E01) directly adjacent to the drain pipe that discharges to the north french drain. Samples 562E002 and FD 562E003 were collected from 1.0 to $1.5 \mathrm{ft}$ bgs inside the south elongated drain (location E02) directly adjacent to the drain pipe that discharged to the north elongated drain. Each of these samples consisted of medium sand with miscellaneous debris (e.g., plant material, glass, possible paint chips). No staining was observed.

Decision I sampling results from the interior of the original french drain (sample 562E004) indicated the need for Decision II sampling because polychlorinated biphenyls (PCBs) were detected at concentrations exceeding the FAL. Decision II sampling included collecting two soil samples (562E008 and 562E009) in two locations (E05 and E06) approximately $2.0 \mathrm{ft}$ laterally from the french drain at the same depth interval (2.5 to $3.0 \mathrm{ft}$ bgs) as the location of the PCBs.

\subsubsection{Conceptual Site Model Validation}

A CSM was developed to represent the release mechanisms and potential migration pathways for contaminant releases at CAU 562 CASs. The CSM and associated discussion for this CAS are provided in the CAU 562 CAIP (NNSA/NSO, 2009). 
The PCB contamination identified within the french drain is consistent with the CSM in that if discharge to the drain resulted in a release of contaminants, the concentration of the contaminants would decrease from the area most likely to contain a COC. The Decision II soil samples show that the PCBs are limited to the subsurface interval where concentrations decrease to below the FALs within $2.0 \mathrm{ft}$ laterally and $1.5 \mathrm{ft}$ vertically of the base of the french drain.

The information gathered during the CAI supports and validates the CSM as presented in the CAIP.

\subsubsection{Steam Cleaning Drain (CAS 02-60-03)}

Corrective Action Site 02-60-03 consists of potential releases to the soil from a steam cleaning sump and outfall. The following sections summarize the field activities conducted at this CAS.

\subsubsection{Radiological Surveys}

A radiological walkover survey was completed within the boundary of CAS 02-60-03. The results of the survey did not show radiological contaminants at activities statistically distinguishable from background activities (more than twice background levels). The survey results did not indicate the need for additional biased samples.

\subsubsection{Visual Inspections}

At CAS 02-60-03, the following components were visually inspected before and/or during sampling activities:

Steam Cleaning Sump - Visual inspection of the steam cleaning sump revealed that it consists of a shallow earthen pit with a fabricated steel grate cover designed to allow for vehicles to drive over it and waste water to drain to the subsurface soil. No liners or associated drain pipes were identified in the sump. The base of the sump consisted of a thin layer of silty sand underlain by leach rock. The native soil interface with the leach rock was identified at approximately $3.0 \mathrm{ft}$ bgs. No soil staining was identified; therefore, sample locations F06 through F09 were selected at the midpoint of each side of the sump. Location F10 was selected at the lowest point in the middle of the sump. 
Steam Cleaning Pad and Outfall - A metal outfall pipe extending from $3.0 \mathrm{ft}$ east from the steam cleaning pad was identified under several inches of soil as a result of an underground utility survey. The end of the outfall (3.0 in. diameter) was covered with a mesh screen and was mostly filled with soil. The location of the outfall was selected as biased sample location F05. Sample locations F01 through F04 were selected along the midpoint of each of the four sides of the steam cleaning pad.

No additional biased samples were identified other than those proposed in the CAU 562 CAIP (NNSA/NSO, 2009).

\subsubsection{Sample Collection}

Sampling activities included the collection of 17 (including 1 FD) environmental surface and subsurface soil samples from 14 locations. All sample locations are shown in Figure A.8-1. The sampling activities are discussed below.

Steam Cleaning Sump - Because no biasing factors were identified, one environmental sample, including one FD (location F06), was collected from the midpoint of each side of the sump (locations F06 through F09). These samples (562F006 through 562F010) were collected at a depth of 0.0 to $0.5 \mathrm{ft}$ bgs. The steel grate was then removed and surface sample 562F011 was collected from the lowest point in the middle of the sump at location F10. This sample consisted of silty sand with some consolidated clumps, organics, and possible rusted metal debris. An additional sample (562F012) was collected at location F10. This sample was collected at the native soil interface directly below the leach rock from a depth of 3.0 to $3.5 \mathrm{ft}$ bgs.

Based on sample results from surface sample 562F008 at sample location F07, Decision II environmental samples were required at the steam cleaning sump. Sample 562F013 was collected at a depth of 1.0 to 1.5 bgs at sample location F07. A surface sample (562F015) was collected at location F12, approximately $2.0 \mathrm{ft}$ west from location F07. Three additional surface samples (562F014 through 562F017) were collected from locations F11, F13, and F14, approximately $2.0 \mathrm{ft}$ laterally from the original sample locations (F06, F08, and F09) on the other three sides of the steam cleaning sump. 
Steam Cleaning Pad and Outfall - Because no biasing factors were identified, one sample was collected from the midpoint of each side of the concrete steam cleaning pad (locations F01 through F04). These samples (562F001 through 562F004) were collected at a depth of 0.0 to $0.5 \mathrm{ft}$ bgs. Surface sample 562F005 was collected directly adjacent to the open end of the outfall pipe at location F05.

\subsubsection{Conceptual Site Model Validation}

A CSM was developed to represent the release mechanisms and potential migration pathways for contaminant releases at CAU 562 CASs. The CSM and associated discussion for this CAS are provided in the CAU 562 CAIP (NNSA/NSO, 2009).

The PCB contamination within and adjacent to the steam cleaning sump is consistent with the CSM in that discharge from the decontamination activities would release contaminants directly to the surface and decrease in concentration from the source. The contamination migration is limited vertically to $1.0 \mathrm{ft}$ and laterally to $5.0 \mathrm{ft}$ from the sump.

The information gathered during the CAI supports and validates the CSM as presented in the CAIP.

\subsubsection{French Drain (CAS 02-60-04)}

Corrective Action Site 02-60-04 consists of potential releases to the soil from a french drain. The following sections summarize the field activities conducted at this CAS.

\subsubsection{Radiological Surveys}

A radiological walkover survey was completed within the boundary of CAS 02-60-04. The results of the survey did not show radiological contaminants at activities statistically distinguishable from background activities (more than twice background levels). The survey results did not indicate the need for additional biased samples.

\subsubsection{Visual Inspections}

Inspection of the french drain revealed that it consisted of a 10.0-in.-diameter, 9.0-ft-long perforated steel casing without an end cap. The casing, which was filled with pea gravel and PSM, was set in an 
18.0-in.-diameter borehole. The drain was located in the center of an 18-in.-thick reinforced concrete foundation. An area of the concrete foundation approximately 22.0 by $20.0 \mathrm{ft}$ was removed to allow for access to the drain. The drain casing was full of material that consisted of mottled (dark brown, black, and orange stained) sediment with a mud-like consistency and abundant debris (e.g., plastic, wood, metal). Because of the presence of waste and the visual appearance of the sample, three more sample locations were identified to gather additional characterization information.

\subsubsection{Sample Collection}

Sampling activities included the collection of six (including one FD) environmental subsurface soil samples and one PSM sample from the five locations shown in Figure A.9-1. The sampling activities are discussed below.

At the french drain, sample 562G001 was collected from the bottom interior of the drain casing (location G01) at a depth of 8.5 to $9.0 \mathrm{ft}$ bgs. The sample consisted of a moist, mottled sediment with a mud-like consistency and was presumed to be PSM. Miscellaneous debris was present in the sample, and orange staining, possibly from rust, was visible. Samples 562G002 and FD 562G003 were collected from location G02 at 10.0 to $11.0 \mathrm{ft}$ bgs from the native soil interface directly below the french drain casing. An additional sample, 562G006, was collected at location G02 from 11.0 to $12.0 \mathrm{ft}$ bgs. The french drain casing was removed from the ground and the PSM was placed in a 55-gal drum staged on site at a satellite accumulation area.

Due to the presence of PSM in the french drain, additional sample locations G03, G04, and G05 were selected on the north, east, and west sides of the former french drain location, respectively. The locations could not be equally spaced around the drain due to the presence of the reinforced concrete pad that the drain was located in. Samples from each of these locations were collected from 8.5 to $9.0 \mathrm{ft}$ bgs, which represent the depth of the PSM collected from the interior of the french drain. Sample 562G004 was collected at location G03, $10.0 \mathrm{ft}$ north of the former french drain location (G01). Sample 562G005 was collected at location G04, $10.0 \mathrm{ft}$ east of location G01. Sample 562G007 was collected at location G05, $18.0 \mathrm{ft}$ west of location G01. 


\subsubsection{Conceptual Site Model Validation}

A CSM was developed to represent the release mechanisms and potential migration pathways for contaminant releases at CAU 562 CASs. The CSM and associated discussion for this CAS are provided in the CAU 562 CAIP (NNSA/NSO, 2009).

The migration pathway and release mechanism information gathered during the CAI was consistent with the CSM, and all information gathered during the CAI supports and validates the CSM as presented in the CAIP.

\subsubsection{French Drain (CAS 02-60-05)}

Corrective Action Site 02-60-05 consists of potential releases to the soil from a french drain. The following sections summarize the field activities conducted at this CAS.

\subsubsection{Radiological Surveys}

A radiological walkover survey was completed within the boundary of CAS 02-60-05. The results of the survey did not show radiological contaminants at activities statistically distinguishable from background activities (more than twice background levels). The survey results did not indicate the need for additional biased samples.

\subsubsection{Visual Inspections}

Inspection of the french drain revealed that it consisted of a bottomless 55-gal drum that was rusted and corroded. The top 6.0 in. of the drum contained accumulated soil that was likely windblown or backfill material. The rest of the drum was filled with leach rock with very little soil and was set in a bed of leach rock that extended to $5.5 \mathrm{ft}$ bgs to the native soil interface. It was noted during surface sampling (with the exception of the surface sample collected at the french drain) that there was a layer of black material present throughout the area sampled. The thickness of the layer varied from barely visible to 1 in.; the depth of the layer was from less than $1 \mathrm{in.} \mathrm{to} 7.0 \mathrm{in.} \mathrm{bgs.} \mathrm{In} \mathrm{places,} \mathrm{the} \mathrm{material}$ appeared to be consolidated but was easily broken up and would become granular. This material was identified to be chip seal, which is a type of sprayed asphalt. Based on the presence of the chip seal, additional samples were collected. 


\subsubsection{Sample Collection}

Sampling activities included the collection of 32 (including 2 FDs) environmental surface and subsurface soil samples and 2 PSM samples from the 17 locations shown in Figure A.10-1. The sampling activities are discussed below.

Sample 562H001 was collected from the top 6.0 in. of soil in the drum because the remainder of the drum was filled with leach rock. It is suspected that this sample represents an accumulation of windblown soil over the top of the drum. Subsequent to the removal of the drum, samples 562H002 and FD 562H003 were collected in the sidewall directly below the drum at a depth of 2.5 to $3.0 \mathrm{ft}$ bgs. The fourth Decision I sample was collected from location $\mathrm{H} 01$ at 5.5 to $6.0 \mathrm{ft}$ bgs from the native soil interface just below the leach rock. The analytical results from the Decision I sampling identified benzo(a)pyrene at concentrations exceeding the FALs extending from the surface to a depth of $6.0 \mathrm{ft}$ bgs, which necessitated Decision II sampling.

A total of 28 Decision II samples (including 1 FD) and 2 PSM samples were collected in a radial pattern at 16 locations ranging from 3.0 to $45.0 \mathrm{ft}$ laterally from the drain. Decision II subsurface samples were collected from the original location (H01) at three intervals below the deepest Decision I samples to a depth of $20.0 \mathrm{ft}$ bgs. Subsurface soil samples were also collected at various intervals at location H10 to a depth of $20.0 \mathrm{ft}$ bgs. Subsurface soil samples were also collected at intervals between 2.0 and $3.0 \mathrm{ft}$ bgs at eight locations and to a depth of $6.0 \mathrm{ft}$ bgs at two locations. Evaluation of the analytical results identified five additional PAHs [benzo(a)anthracene, benzo(b)fluoranthene, benzo(k)fluoranthene, dibenzo(a,h)anthracene, and indeno(1,2,3-cd)pyrene] that exceeded the FALs in various samples at various depths throughout the area sampled. Benzo(a)pyrene was the PAH that was detected most consistency and was the only PAH that exceeded the FALs within the Decision I samples. Based on the distribution and location of the PAHs identified beyond the immediate area of the drain, those contaminants could not have originated from CAS 02-60-05 (see Section 2.1.8.4). The additional PAHs identified beyond the immediate area of the french drain are not considered to result from a release from the drain but reflect the presence of a tar-like material identified as chip seal. 


\subsubsection{Conceptual Site Model Validation}

A CSM was developed to represent the release mechanisms and potential migration pathways for contaminant releases at CAU 562 CASs. The CSM and associated discussion for this CAS are provided in the CAIP (NNSA/NSO, 2009).

The migration pathway and release mechanism information gathered during the CAI was consistent with the CSM, and all information gathered during the CAI supports and validates the CSM as presented in the CAIP.

Evaluation of the data showed that the vertical extent of the contamination extends to at least $8.5 \mathrm{ft}$ bgs but no deeper than $15.0 \mathrm{ft}$ bgs in the immediate area of the drain. Samples collected at deeper depth at this location did not show the presence of any COCs. Benzo(a)pyrene was reported at a concentration exceeding the FALs at one location (H10) at a depth of 3.0 to $3.5 \mathrm{ft}$ bgs approximately $13.0 \mathrm{ft}$ laterally from the drain. Samples collected at deeper depths did not identify any COCs. The distribution of the PAHs as well as the concentration is not consistent with what would be expected if the french drain were the only source of the release. The CSM suggests that the concentration of contamination should decrease as the distance from the source increases. Further evaluation of the data indicates that the concentrations in the surface samples generally increase with distance from the drain. However, the concentrations do decrease with increasing depth, which is consistent with the CSM. During the sampling, a layer of black tar-like material identified as chip seal was present within the surface intervals that were sampled. This material ranged from 1.0 to 7.0 in. bgs and is considered the other source of the PAHs. The area around the CAS was once managed as an access road, and the chip seal was present in the area. The SVOC contamination in the outlying area is not considered to originate from this CAS.

The contamination associated with this CAS is limited to the area encompassed by sample locations $\mathrm{H01}, \mathrm{H} 02, \mathrm{H} 03$, and H10. The evaluation of the data from these locations is consistent with the CSM and supports and validates the CSM as presented in the CAIP. The contamination identified at the other locations is not considered to be related to a release form CAS 02-60-05 and is considered to be related to the tar-like material identified as chip seal. 


\subsubsection{French Drain (CAS 02-60-06)}

Corrective Action Site 02-60-06 consists of potential releases to the soil from a french drain. The following sections summarize the field activities conducted at this CAS.

\subsubsection{Geophysical Surveys}

A geophysical survey was conducted to identify the location of the french drain. The southwest corner of the former building foundation for the Electricians Shop was surveyed because this area was identified in historical documentation as the location of the french drain. The survey was conducted in the area of a 3.0-in.-diameter steel pipe. A linear anomaly trending southwest from the pipe was identified (Weston, 2007). Once the drain was located during the utility survey, it was determined that this pipe was not associated with the french drain as there were no pipes feeding the drain.

\subsubsection{Visual Inspections}

The french drain was first located and marked during a utility survey that detected the drain approximately $10.0 \mathrm{ft}$ away from the southeast corner of the former Electricians Shop foundation. The drain was initially covered by several inches of soil before being uncovered. Inspection of the french drain revealed that it consisted of a bottomless 55-gal drum that was filled with leach rock mixed with some soil. The bed of leach rock extends to $7.0 \mathrm{ft}$ bgs to the native soil interface.

No additional biased samples were identified other than those proposed in the CAU 562 CAIP (NNSA/NSO, 2009).

\subsubsection{Sample Collection}

Sampling activities included the collection of three (including one FD) environmental subsurface soil samples from the one location shown in Figure A.11-1.

At the french drain (location I01), sample 562I001 was collected from the bottom 6.0 in. of the material inside the drain casing at a depth of 3.0 to $3.5 \mathrm{ft}$ bgs. This sample consisted of dark brown moist sand (leach rock removed from sample) with abundant plant organics, rust staining, and 
miscellaneous debris. Following removal of the drum casing, samples 562I002 and FD 562I003 were collected at 7.0 to $7.5 \mathrm{ft}$ bgs from the native soil interface within the bed of leach rock.

\subsubsection{Conceptual Site Model Validation}

A CSM was developed to represent the release mechanisms and potential migration pathways for contaminant releases at CAU 562 CASs. The CSM and associated discussion for this CAS are provided in the CAU 562 CAIP (NNSA/NSO, 2009).

The migration pathway and release mechanism information gathered during the CAI was consistent with the CSM, and all information gathered during the CAI supports and validates the CSM as presented in the CAIP.

\subsubsection{French Drain (CAS 02-60-07)}

Corrective Action Site 02-60-07 was identified in historical documentation as being located at the former Electrical Supply Building in the Area 2 Camp. The components of this CAS were not visible, so additional action was necessary to locate the french drain. Extensive vegetation removal was performed on all sides of the concrete pad that was the former foundation of the Electrical Supply Building. A utility survey was then performed; the survey extended $20.0 \mathrm{ft}$ in all directions from the concrete pad in order to identify underground utility lines and the location of the french drain. Several deactivated power lines, a communication line, a water line, and an “unknown” line (determined to be a surface electrical cable) were identified as a result of the survey; however, no french drain or pipe leading to a drain was identified. It is expected that if a drain was present, a strong metallic response would have been detected by the utility survey equipment similar to what was found at adjacent CAS 02-60-06.

Because the french drain was not identified during the utility survey, a backhoe was then used to excavate trenches on each side of the concrete pad to a depth of approximately $18.0 \mathrm{in}$. bgs. This depth is well beyond the expected depth of the top of the drain, based on findings at the other CAU 562 french drain CASs. The trenches on the east and west sides (long dimension) of the pad were approximately $12.0 \mathrm{ft}$ wide, and the trenches on the north and south sides of the pad were approximately $5.0 \mathrm{ft}$ wide. Only the wooden electrical board on the north side of the pad and the 
underground water line interfered with excavation; however, these areas were hand cleared and no french drains were identified.

The typical design of a french drain in Area 2 is a 55-gal drum that is installed in the ground with the top flush with the surrounding ground surface or covered with a few inches of soil (based on findings at adjacent CASs 02-60-02 and 02-60-06). Other drains included in this CAU were within $3.0 \mathrm{ft}$ of the associated concrete pads with the exception of CAS 02-60-06, where the drain was attached to a pipe approximately $10.0 \mathrm{ft}$ from the associated pad.

Because the french drain was not identified during the investigation effort, it is concluded that there was an error in the historical document that identified this area as an environmental concern and that there is no french drain associated with the Electrical Supply Building.

\subsubsection{Mud Trap Drain and Outfall (CAS 23-60-01)}

This CAS consists of the potential releases to the soil from a mud trap, grease rack, and outfall pipe that were part of the vehicle wash-down and maintenance area. The following sections summarize the field activities conducted at this CAS.

\subsubsection{Visual Inspections}

Mud Trap Drain - The concrete trench in the floor of the wash shed that drains to the mud trap was visually inspected to select a biased sample location. The trench had a concrete bottom and an outlet pipe at the midpoint of its length that drained to the mud trap located outside the south wall of the wash shed. The PSM in the drain consisted of fine dirt with well-sorted gravels that were covered with abundant windblown trash and vegetation debris. No staining was identified; therefore, sample location K01 was selected at the center of the trench adjacent to the outlet pipe. The mud trap drain was visually inspected to select a biased sample location. The mud trap consists of a concrete vault measuring 4.0 by 4.0 by $3.5 \mathrm{ft}$ with a metal grate cover. The contents included approximately $1.5 \mathrm{ft}$ of sediment with some miscellaneous debris.

Grease Rack - The soil below the grease rack was visually inspected to select biased sample locations. No surface staining was observed. 
Outfall - The subsurface outfall pipe that connects the mud trap to the outfall area was imaged with utility-surveying equipment and shown to terminate just beyond the barbed-wire fence into a wash. The pipe was cast iron and located at $2.0 \mathrm{ft}$ bgs. Additional sample locations were selected at the outfall and in the wash to gather additional characterization information.

\subsubsection{Sample Collection}

Sampling activities included the collection of 9 environmental surface and subsurface soil samples and 2 (including 1 FD) PSM samples from the 10 locations shown in Figure A.13-1. The sampling activities are discussed below.

Mud Trap Drain - Sample 562K001 was collected at a depth of 0.0 to $0.5 \mathrm{ft}$ bgs from the concrete trench in the floor of the wash shed (location K01). This sample consisted of a fine gray dirt mixed with well-sorted small gravel. Miscellaneous debris, including vegetation and plastics, was present. Samples 562K004 and FD 562K005 were collected from a depth of 3.0 to $3.5 \mathrm{ft}$ bgs from the center of the mud trap (location K04) because there were no other biasing factors (e.g., staining, chambers). The PSM consisted of moist brown sand with gravels and some miscellaneous debris (e.g., glass, paper, plastic).

Grease Rack - Two sample locations (K02 and K03) were selected at the expected ground surface locations where vehicle fluids may have leaked during routine maintenance operations. Sample 562K002 was collected from 0.0 to $0.5 \mathrm{ft}$ bgs at location K02 near the west end of the grease rack. This sample consisted of a well-sorted gravel with a thin horizon of dark-stained and slightly consolidated material observed at approximately $2.0 \mathrm{in.} \mathrm{bgs.} \mathrm{The} \mathrm{soil} \mathrm{underlying} \mathrm{this} \mathrm{layer} \mathrm{consisted}$ of fine soil mixed with well-sorted gravel. Sample 562K003 was collected from 0.0 to $0.5 \mathrm{ft}$ bgs at location K03 near the east end of the rack. This sample was nearly identical to sample 562K002, but with a slightly thicker horizon of dark-stained material.

Outfall - Sample 562K006 was collected at a depth of 1.0 to $1.5 \mathrm{ft}$ bgs at location K05, adjacent to the termination of the outfall pipe. The outfall area was very rocky, and most rocks had a dark coating or staining. The sample consisted of sandy soil mixed among the dark-stained rocks. Sample 562K007 was collected from within the mouth of the outfall pipe at a depth of 2.0 to $2.5 \mathrm{ft}$ bgs (location K06). The soil consisted of small consolidated pebbles mixed with some larger gravel and 
was gray in color. An additional sample (562K008) was collected directly below the outfall (location K07) at a depth of 3.0 to $3.5 \mathrm{ft}$ bgs. Sample location K08 was selected $8.0 \mathrm{ft}$ straight out from the outfall (opposite side of the wash), while sample locations K09 and K10 were selected downstream in the wash at a distance of 3.0 and $10.0 \mathrm{ft}$, respectively. These samples (562K009 through 562K011) were collected at a depth of 2.0 to $2.5 \mathrm{ft}$ bgs.

\subsubsection{Conceptual Site Model Validation}

A CSM was developed to represent the release mechanisms and potential migration pathways for contaminant releases at CAU 562 CASs. The CSM and associated discussion for this CAS are provided in the CAU 562 CAIP (NNSA/NSO, 2009).

The migration pathway and release mechanism information gathered during the CAI was consistent with the CSM, and all information gathered during the CAI supports and validates the CSM as presented in the CAIP.

\subsubsection{Grease Trap (CAS 23-99-06)}

This CAS consists of the potential releases to the soil from a grease trap located on the south side of Building 23-109. The following sections summarize the field activities conducted at this CAS.

\subsubsection{Visual Inspections}

The concrete grease trap was visually inspected to select biased sample locations. The trap consists of a concrete vault that is 3.5 by $2.0 \mathrm{ft}$ and approximately $4.0 \mathrm{ft}$ deep. The vault has two partitions, creating three separate sections (lower, middle, and upper weirs) designed to separate solid wastes from liquids. The upper and middle sections contain sediment up to the partition. The lower section also contains sediment but in a smaller quantity. Also visible in the lower section is the outlet pipe that originally drained to the septic system. Due to the design of the grease trap, additional biased sample locations were selected to gather characterization information from each section of the trap.

\subsubsection{Sample Collection}

Sampling activities included the collection of four (including one FD) PSM samples from the three locations shown in Figure A.14-1. The sampling activities are discussed below. 
Samples 562L001 and FD 562L002 were collected at the bottom of the lower weir (location L01) at a depth of 3.5 to $4.0 \mathrm{ft}$ bgs and consisted of dark brown sandy sediment with small pieces of paper and plastic. The sample appeared to be discolored in areas. Sample 562L003 was collected at the bottom of the middle weir (location L02) at the same depth (3.5 to $4.0 \mathrm{ft}$ bgs) and was nearly identical in composition to samples 562L001 and 562L002. Sample 562L004 was collected at the bottom of the upper weir (location L03) at the same depth and of the same composition of the other samples.

\subsubsection{Conceptual Site Model Validation}

A CSM was developed to represent the release mechanisms and potential migration pathways for contaminant releases at CAU 562 CASs. The CSM and associated discussion for this CAS are provided in the CAU 562 CAIP (NNSA/NSO, 2009).

The migration pathway and release mechanism information gathered during the CAI was consistent with the CSM, and all information gathered during the CAI supports and validates the CSM as presented in the CAIP.

\subsubsection{Building 3123 Outfalls (CAS 25-60-04)}

This CAS consists of the potential releases to the soil from two outfalls referred to as Drain A and Drain B. The following sections summarize the field activities conducted at this CAS.

\subsubsection{Visual Inspections}

Drain A - The outfall was previously removed during a renovation of a sewer line in the area. There were requirements for remaining $5.0 \mathrm{ft}$ away from the reconfigured active sewer line so the area sampled (location M01) was $5.0 \mathrm{ft}$ from the original opening of the outfall. The sampling interval was accessed by hand digging $5.0 \mathrm{ft}$ west of the active sewer line and then moving $2.0 \mathrm{ft}$ east toward the former location of the original outfall opening of Drain A. A second sample, location M02, was marked $100.00 \mathrm{ft}$ south of the original outfall opening. The sampling interval was accessed by hand digging $5.0 \mathrm{ft}$ south of this location because of the active sewer line. No biasing factors, such as staining, debris, and odor, were identified in the subsurface. 
Drain B - The Drain B outfall was uncovered at $1.0 \mathrm{ft}$ bgs by hand digging $47.0 \mathrm{ft}$ south of Building 3123. The drain consists of a 4.0-in. vitrified clay pipe with sludge contents and is underlain by 19.0 in. of pea gravel, some of which is stained. The native soil interface was approximately $3.0 \mathrm{ft}$ bgs.

Because of the presence of PSM in the outfall, an additional biased sample was collected to gather further characterization information.

\subsubsection{Sample Collection}

Sampling activities included the collection of 47 (including 3 FDs) environmental surface and subsurface samples and 1 PSM sample from 29 locations. All sample locations are shown in Figure A.15-1. The sampling activities are discussed below.

Drain A - At Drain A, sample 562M001 was collected $3.0 \mathrm{ft}$ away from the elbow (location M01), which was the original outfall opening (25.0 ft west of Building 3123). This sample was collected from 3.0 to $3.5 \mathrm{ft}$ bgs and consisted of native, well-sorted sand with moderate gravel. Samples 562M002 and FD 562M003 were collected at location M02, $5.0 \mathrm{ft}$ away from the reconfigured outfall opening (approximately $100.0 \mathrm{ft}$ south of location M01). These samples also consisted of native soil and were collected at a depth of 3.0 to $3.5 \mathrm{ft}$ bgs.

Drain B - At Drain B, sample 562M004 was collected directly below the outfall pipe (location M03) at 1.5 to $2.0 \mathrm{ft}$ bgs and consisted of moist sand mixed with pea gravel with a septic odor and dark staining. Sample 562M005 is a sample of the sludge contents inside the outfall pipe and was collected from within the pipe at a depth of 1.0 to $1.5 \mathrm{ft}$ bgs. This sample consisted of dark, mottled sludge with a strong septic odor and some miscellaneous debris. Sample 562M006 was collected at the native soil interface with the pea gravel, directly below the outfall pipe, at a depth of 3.0 to $3.5 \mathrm{ft}$ bgs. This sample consisted of well-sorted moist sand.

Based on the results of Decision I samples collected at Drain B, Decision II environmental samples (562M007 through 562M048) were collected from locations M04 through M29 using an iterative approach between November 4, 2009, and May 12, 2010. During sampling, broken pieces of vitrified clay pipe were identified near the end of the pipe. This, along with knowledge of the original 
termination point of the outfall, indicated that the outfall pipe had been cut. The disturbance of soil to reconfigure the outfall resulted in a distribution of contamination that was not consistent with what was expected (i.e., contaminants present at the surface interval). Surface and subsurface samples, to a depth of $3.5 \mathrm{ft}$ bgs, were collected in both areas most likely to be impacted by effluent flow from the pipe (in both the original and altered outfall locations) and beyond where the effluent would be expected in order to bound the contamination.

\subsubsection{Conceptual Site Model Validation}

A CSM was developed to represent the release mechanisms and potential migration pathways for contaminant releases at CAU 562 CASs. The CSM and associated discussion for this CAS are provided in the CAU 562 CAIP (NNSA/NSO, 2009).

The PCB contamination associated with Drain B is consistent with the CSM in that if discharge from the outfall resulted in a release of contaminants, the concentration of the contaminants would decrease from the area most likely to contain a COC. The Decision II soil samples show that the PCBs are limited to the 0.0- to 1.5-ft-deep interval where concentrations decrease to below the FALs within $25.0 \mathrm{ft}$ laterally of the outfall. The contaminant distribution is consistent with a release from an outfall. However, there appears to be some effect on the PCB distribution as a result of reworking the soil during the outfall reconfiguration. The information gathered during the CAI supports and validates the CSM as presented in the CAIP.

\subsection{Results}

The summary of data from the CAI provided in Section 2.2.1 defines the areas within the CAU 562 CASs where the contaminants of potential concern (COPCs) exceeded the FALs and extent of all identified COCs. Section 2.2.1.6 summarizes the assessment made in Appendix B, which demonstrates that the CAI results satisfy the DQO data requirements.

\subsubsection{Summary of Analytical Data}

Chemical and radiological results for environmental and PSM samples collected at each of the CASs are summarized in Sections 2.2.1.1 through 2.2.1.13. Environmental samples are evaluated against FALs to determine the presence of COCs and the extent of COC contamination, if present. The PSM 
sample results are compared to the PSM criteria and assumptions defined in Section 2.3 to determine whether a release of waste materials could result in the presence of a COC in the environmental media.

The PALs for the CAU 562 CAI were determined during the DQO process and are discussed in Section 3.3 of the CAU 562 CAIP (NNSA/NSO, 2009). The FALs used for determining the presence of COCs and for evaluating the need for corrective action are defined in Section 3.1. Details about the methods used during this CAI and a comparison of environmental sample results to the FALs are presented in Appendix A.

\subsubsection{Lead Shot (CAS 02-26-11)}

The environmental and PSM sample results are discussed in the sections below.

\subsection{Environmental Sample Results}

The concentration of total petroleum hydrocarbons (TPH)-diesel-range organics (DRO) in surface sample 562A012 was equal to the PAL of 100 milligrams per kilogram (mg/kg). The TPH-DRO was moved on to a Tier 2 evaluation, and FALs were established for the hazardous constituents of TPH-DRO. Concentrations of the hazardous constituents of TPH-DRO did not exceed FALs. Therefore, TPH-DRO is not considered a COC.

All concentrations of the other reported parameters at this site were less than the corresponding PALs. Therefore, the FALs were established at the corresponding PAL concentrations, and no COCs were identified in the soils at this site.

The maximum concentration of each detected contaminant in environmental samples collected at this CAS is listed in Table 2-1.

\subsection{Potential Source Material Sample Results}

With the exception of TPH-DRO, lead, antimony, arsenic, and chromium, all concentrations of the reported parameters were less than the PALs. 
Table 2-1

Maximum Concentration of Detected Contaminants for CAS 02-26-11, Lead Shot (Page 1 of 2)

\begin{tabular}{|c|c|c|c|c|c|c|}
\hline Contaminant & $\begin{array}{c}\text { Maximum } \\
\text { Result }\end{array}$ & $\begin{array}{l}\text { Sample } \\
\text { Number }\end{array}$ & $\begin{array}{c}\text { Depth } \\
\text { (ft bgs) }\end{array}$ & Location & FAL & Units \\
\hline Ac-228 & 2.18 & $562 \mathrm{~A} 013$ & $\begin{array}{l}4.0-6.0 \\
\text { (in. bgs) }\end{array}$ & A08 & 5 & $\mathrm{pCi} / \mathrm{g}$ \\
\hline Am-241 & $1.02(\mathrm{~J})$ & $562 \mathrm{~A} 004$ & $0.0-0.5$ & A03 & 12.7 & $\mathrm{pCi} / \mathrm{g}$ \\
\hline Antimony & 2.8 & $562 \mathrm{~A} 011$ & $\begin{array}{l}0.0-0.2 \\
\text { (in. bgs) }\end{array}$ & A08 & 410 & $\mathrm{mg} / \mathrm{kg}$ \\
\hline Aroclor 1260 & 0.075 & $562 A 003$ & $0.0-0.5$ & $\mathrm{~A} 02$ & 0.74 & $\mathrm{mg} / \mathrm{kg}$ \\
\hline Arsenic & 3.5 & $562 \mathrm{~A} 004$ & $0.0-0.5$ & A03 & 23 & $\mathrm{mg} / \mathrm{kg}$ \\
\hline Barium & $500(\mathrm{~J})$ & $562 \mathrm{~A} 011$ & $\begin{array}{l}0.0-0.2 \\
\text { (in. bgs) }\end{array}$ & A08 & 190,000 & $\mathrm{mg} / \mathrm{kg}$ \\
\hline Benzo(a)anthracene & $0.088(\mathrm{~J})$ & $562 A 004$ & $0.0-0.5$ & A03 & 2.1 & $\mathrm{mg} / \mathrm{kg}$ \\
\hline Benzo(a)pyrene & $0.11(\mathrm{~J})$ & $562 \mathrm{~A} 004$ & $0.0-0.5$ & A03 & 0.21 & $\mathrm{mg} / \mathrm{kg}$ \\
\hline Benzo(b)fluoranthene & $0.16(\mathrm{~J})$ & $562 A 004$ & $0.0-0.5$ & A03 & 2.1 & $\mathrm{mg} / \mathrm{kg}$ \\
\hline Benzo(g,h,i)perylene & $0.1(\mathrm{~J})$ & $562 \mathrm{~A} 004$ & $0.0-0.5$ & A03 & 17,000 & $\mathrm{mg} / \mathrm{kg}$ \\
\hline Benzo(k)fluoranthene & $0.073(\mathrm{~J})$ & 562A004 & $0.0-0.5$ & A03 & 21 & $\mathrm{mg} / \mathrm{kg}$ \\
\hline Bis(2-ethylhexyl)phthalate & 0.47 & $562 \mathrm{~A} 004$ & $0.0-0.5$ & $\mathrm{~A} 03$ & 120 & $\mathrm{mg} / \mathrm{kg}$ \\
\hline Cadmium & 7.3 & $562 \mathrm{~A} 003$ & $0.0-0.5$ & $\mathrm{~A} 02$ & 800 & $\mathrm{mg} / \mathrm{kg}$ \\
\hline Cs-137 & 1.34 & $562 \mathrm{~A} 007$ & $0-2.0$ & A06 & 12.2 & $\mathrm{pCi} / \mathrm{g}$ \\
\hline Chlordane & $0.096(\mathrm{~J})$ & $562 \mathrm{~A} 002$ & $0.0-0.5$ & $\mathrm{~A} 02$ & 6.5 & $\mathrm{mg} / \mathrm{kg}$ \\
\hline Chromium & 9 & $562 A 003$ & $0.0-0.5$ & $\mathrm{~A} 02$ & 450 & $\mathrm{mg} / \mathrm{kg}$ \\
\hline Chrysene & $0.1(\mathrm{~J})$ & $562 \mathrm{~A} 004$ & $0.0-0.5$ & A03 & 210 & $\mathrm{mg} / \mathrm{kg}$ \\
\hline Di-n-butyl phthalate & $0.3(\mathrm{~J})$ & $562 A 004$ & $0.0-0.5$ & A03 & 62,000 & $\mathrm{mg} / \mathrm{kg}$ \\
\hline DRO & 100 & $562 A 012$ & $\begin{array}{l}2.0-4.0 \\
\text { (in. bgs) }\end{array}$ & A08 & $\mathrm{N} / \mathrm{A}$ & $\mathrm{mg} / \mathrm{kg}$ \\
\hline Fluoranthene & $0.24(\mathrm{~J})$ & $562 A 004$ & $0.0-0.5$ & A03 & 22,000 & $\mathrm{mg} / \mathrm{kg}$ \\
\hline Indeno(1,2,3-cd)pyrene & $0.08(\mathrm{~J})$ & $562 \mathrm{~A} 004$ & $0.0-0.5$ & A03 & 2.1 & $\mathrm{mg} / \mathrm{kg}$ \\
\hline Lead & $54(\mathrm{~J}-)$ & $562 \mathrm{~A} 001$ & $0.0-0.5$ & A01 & 800 & $\mathrm{mg} / \mathrm{kg}$ \\
\hline Mercury & 0.051 & 562A001 & $0.0-0.5$ & $\mathrm{~A} 01$ & 34 & $\mathrm{mg} / \mathrm{kg}$ \\
\hline Methylene chloride & $0.0017(\mathrm{~J})$ & $562 A 007$ & $\begin{array}{l}0.0-2.0 \\
\text { (in. bgs) }\end{array}$ & A06 & 53 & $\mathrm{mg} / \mathrm{kg}$ \\
\hline Phenanthrene & $0.11(\mathrm{~J})$ & $562 A 004$ & $0.0-0.5$ & A03 & 170,000 & $\mathrm{mg} / \mathrm{kg}$ \\
\hline Pyrene & $0.33(\mathrm{~J})$ & $562 A 004$ & $0.0-0.5$ & A03 & 17,000 & $\mathrm{mg} / \mathrm{kg}$ \\
\hline
\end{tabular}


Table 2-1

Maximum Concentration of Detected Contaminants for CAS 02-26-11, Lead Shot (Page 2 of 2)

\begin{tabular}{|c|c|c|c|c|c|c|}
\hline Contaminant & $\begin{array}{c}\text { Maximum } \\
\text { Result }\end{array}$ & $\begin{array}{c}\text { Sample } \\
\text { Number }\end{array}$ & $\begin{array}{c}\text { Depth } \\
\text { (ft bgs) }\end{array}$ & Location & FAL Units \\
\hline \hline Selenium & 0.88 & $562 \mathrm{A005}$ & $0.0-0.5$ & $\mathrm{~A} 04$ & 5,100 & $\mathrm{mg} / \mathrm{kg}$ \\
\hline Th-234 & $2.01(\mathrm{~J})$ & $562 \mathrm{~A} 001$ & $0.0-0.5$ & $\mathrm{~A} 01$ & 105 & $\mathrm{pCi} / \mathrm{g}$ \\
\hline
\end{tabular}

Ac = Actinium

$\mathrm{Am}=$ Americium

$\mathrm{Cs}=$ Cesium

DRO = Diesel-range organics

$\mathrm{J}=$ Estimated value

$\mathrm{J}-=$ Result is an estimated quantity but may be biased low.
N/A = Not applicable

$\mathrm{pCi} / \mathrm{g}=$ Picocuries per gram

$\mathrm{Th}=$ Thorium

Lead, antimony, and arsenic were detected at concentrations exceeding PALs in sample 562A006 at location A05. This sample contained non-rusted shot. Lead was detected at a concentration of $120,000 \mathrm{mg} / \mathrm{kg}$, which exceeded the PAL of $800 \mathrm{mg} / \mathrm{kg}$. Antimony was detected at a concentration of $4,100 \mathrm{mg} / \mathrm{kg}$, which exceeded the PAL of $410 \mathrm{mg} / \mathrm{kg}$. Arsenic was detected at a concentration of $1,400 \mathrm{mg} / \mathrm{kg}$, which exceeded the PAL of $23 \mathrm{mg} / \mathrm{kg}$. Concentrations of arsenic and chromium were detected at concentrations exceeding PALs at location A07 in the surface soil sample (562A010) containing rusted shot. Arsenic was detected at a concentration of $31 \mathrm{mg} / \mathrm{kg}$, which exceeded the PAL of $23 \mathrm{mg} / \mathrm{kg}$. Chromium was detected at a concentration $450 \mathrm{mg} / \mathrm{kg}$, which is also the PAL. Because the PSM criteria for these contaminants were established as the PALs, they are considered PSM contaminants. Soil samples that did not contain shot were collected laterally (approximately 0.5 to $1.0 \mathrm{ft}$ distance) and vertically (at a depth of 1.0 to $1.5 \mathrm{ft}$ bgs) from the samples containing shot. No COCs were identified in these soil samples that did not contain shot. These results indicate that the PSM contaminants are present in both the rusted and non-rusted shot rather than in the soil itself. Therefore, the shot is considered PSM.

The maximum concentration of each detected contaminant at this CAS is listed in Table 2-2.

\subsubsection{Paint Spills and French Drain (CAS 02-44-02)}

The environmental and PSM sample results are discussed in the sections below. 
Table 2-2

Maximum Concentration of Detected Contaminants in PSM Samples from CAS 02-26-11, Lead Shot

\begin{tabular}{|c|c|c|c|c|c|c|}
\hline Contaminant & $\begin{array}{c}\text { Maximum } \\
\text { Result }\end{array}$ & $\begin{array}{l}\text { Sample } \\
\text { Number }\end{array}$ & $\begin{array}{l}\text { Depth } \\
\text { (ft bgs) }\end{array}$ & Location & $\begin{array}{c}\text { PSM } \\
\text { Criteria }\end{array}$ & Units \\
\hline Methylene chloride & $0.0017(\mathrm{~J})$ & $562 A 006$ & $0.0-0.5$ & A05 & 53 & $\mathrm{mg} / \mathrm{kg}$ \\
\hline Benzo(b)fluoranthene & $0.11(\mathrm{~J})$ & $562 A 006$ & $0.0-0.5$ & A05 & 2.1 & $\mathrm{mg} / \mathrm{kg}$ \\
\hline Di-n-butyl phthalate & $0.25(\mathrm{~J})$ & $562 \mathrm{~A} 006$ & $0.0-0.5$ & A05 & 62,000 & $\mathrm{mg} / \mathrm{kg}$ \\
\hline Fluoranthene & $0.16(\mathrm{~J})$ & $562 A 006$ & $0.0-0.5$ & A05 & 22,000 & $\mathrm{mg} / \mathrm{kg}$ \\
\hline Phenanthrene & $0.078(\mathrm{~J})$ & $562 \mathrm{~A} 010$ & $0.0-0.5$ & $\mathrm{~A} 07$ & 170,000 & $\mathrm{mg} / \mathrm{kg}$ \\
\hline Pyrene & $0.16(\mathrm{~J})$ & $562 A 006$ & $0.0-0.5$ & A05 & 17,000 & $\mathrm{mg} / \mathrm{kg}$ \\
\hline DRO & 29 & $562 \mathrm{~A} 010$ & $0.0-0.5$ & $\mathrm{~A} 07$ & N/A & $\mathrm{mg} / \mathrm{kg}$ \\
\hline Antimony & 4,100 & $562 A 006$ & $0.0-0.5$ & A05 & 410 & $\mathrm{mg} / \mathrm{kg}$ \\
\hline Arsenic & 1,400 & $562 A 006$ & $0.0-0.5$ & A05 & 23 & $\mathrm{mg} / \mathrm{kg}$ \\
\hline Barium & $4,300(\mathrm{~J})$ & $562 A 010$ & $0.0-0.5$ & $\mathrm{~A} 07$ & 190,000 & $\mathrm{mg} / \mathrm{kg}$ \\
\hline Cadmium & 0.65 & $562 \mathrm{~A} 010$ & $0.0-0.5$ & A07 & 800 & $\mathrm{mg} / \mathrm{kg}$ \\
\hline Chromium & $450(\mathrm{~J})$ & $562 A 010$ & $0.0-0.5$ & $\mathrm{~A} 07$ & 450 & $\mathrm{mg} / \mathrm{kg}$ \\
\hline Lead & 120,000 & $562 A 006$ & $0.0-0.5$ & A05 & 800 & $\mathrm{mg} / \mathrm{kg}$ \\
\hline Mercury & 0.034 & $562 A 010$ & $0.0-0.5$ & A07 & 34 & $\mathrm{mg} / \mathrm{kg}$ \\
\hline Selenium & 4.1 & $562 A 006$ & $0.0-0.5$ & A05 & 5,100 & $\mathrm{mg} / \mathrm{kg}$ \\
\hline Silver & 4.8 & 562A006 & $0.0-0.5$ & A05 & 5,100 & $\mathrm{mg} / \mathrm{kg}$ \\
\hline Aroclor 1254 & 0.079 & $562 \mathrm{~A} 010$ & $0.0-0.5$ & A07 & 0.74 & $\mathrm{mg} / \mathrm{kg}$ \\
\hline Ac-228 & 0.93 & $562 A 006$ & $0.0-0.5$ & A05 & 5 & $\mathrm{pCi} / \mathrm{g}$ \\
\hline Cs-137 & 0.54 & $562 A 006$ & $0.0-0.5$ & A05 & 12.2 & $\mathrm{pCi} / \mathrm{g}$ \\
\hline
\end{tabular}

$\mathrm{J}=$ Estimated value

Bold indicates the value equals or exceeds the PSM criteria.

\subsection{Environmental Sample Results}

With the exception of TPH-DRO and benzo(a)pyrene, all concentrations of the reported parameters were less than the PALs.

Surface soil sample 562B009 at location B08 contained benzo(a)pyrene at a concentration of $0.22 \mathrm{mg} / \mathrm{kg}$, which exceeds the PAL of $0.21 \mathrm{mg} / \mathrm{kg}$. Because the FAL was established at the PAL 
concentration, benzo(a)pyrene is considered a COC. Four Decision II samples (562B015 and 562B016 through 562B018) were collected laterally and vertically from this location. Sample 562B015 was collected at 1.0 to $1.5 \mathrm{ft}$ bgs at location B08, whereas the step-out surface samples were collected $3.0 \mathrm{ft}$ laterally in three directions from sample location B08. No COCs were identified in these bounding samples.

A concentration of $180 \mathrm{mg} / \mathrm{kg}$ of TPH-DRO was detected in subsurface sample 562B013, which exceeds the PAL of $100 \mathrm{mg} / \mathrm{kg}$. The TPH-DRO was moved on to a Tier 2 evaluation, and FALs were established for the hazardous constituents of TPH-DRO. Concentrations of the hazardous constituents of TPH-DRO did not exceed FALs.

The maximum concentration of each detected contaminant in environmental samples collected at this CAS is listed in Table 2-3.

\subsection{Potential Source Material Sample Results}

The analytical results for paint samples 562B006 and 562B010 indicate that chromium (530 and 5,800 mg/kg), benzo(a)pyrene (2.3 mg/kg), benzo(b)fluoranthene (5 mg/kg), lead (7,200 mg/kg), and bis(2-ethylhexyl)phthalate $(220 \mathrm{mg} / \mathrm{kg}$ ) are present at concentrations above the respective PSM criteria. These contaminants are, therefore, considered PSM contaminants.

Additionally, TPH-DRO was detected at concentrations of 1,100 and 3,000 mg/kg in the two PSM samples. The TPH-DRO was moved on to a Tier 2 evaluation, and PSM criteria were established for the hazardous constituents of TPH-DRO at their respective PAL concentrations.

Based on the analytical results, the paint is considered PSM. The maximum concentration of each detected contaminant in PSM samples collected at this CAS is listed in Table 2-4.

\subsubsection{Septic System (CAS 02-59-01)}

The environmental and PSM sample results are discussed in the sections below. 
Table 2-3

\section{Maximum Concentration of Detected Contaminants for Environmental Sample Results at CAS 02-44-02, Paint Spills and French Drain}

(Page 1 of 2)

\begin{tabular}{|c|c|c|c|c|c|c|}
\hline Contaminant & $\begin{array}{c}\text { Maximum } \\
\text { Result }\end{array}$ & $\begin{array}{l}\text { Sample } \\
\text { Number }\end{array}$ & $\begin{array}{c}\text { Depth } \\
\text { (ft bgs) }\end{array}$ & Location & FAL & Units \\
\hline Ac-228 & 2.83 & 562B020 & $3.0-3.5$ & B14 & 5 & $\mathrm{pCi} / \mathrm{g}$ \\
\hline Am-241 & $2.23(\mathrm{~J})$ & 562B008 & $0.0-0.5$ & B07 & 12.7 & $\mathrm{pCi} / \mathrm{g}$ \\
\hline Antimony & 4.4 & 562B001 & $0.0-0.5$ & B01 & 410 & $\mathrm{mg} / \mathrm{kg}$ \\
\hline Aroclor 1254 & 0.38 & 562B009 & $0.0-0.5$ & B08 & 0.74 & $\mathrm{mg} / \mathrm{kg}$ \\
\hline Aroclor 1260 & $0.53(\mathrm{~J})$ & 562B005 & $0.0-0.5$ & B04 & 0.74 & $\mathrm{mg} / \mathrm{kg}$ \\
\hline Arsenic & 4.3 & 562B008 & $0.0-0.5$ & B07 & 23 & $\mathrm{mg} / \mathrm{kg}$ \\
\hline Barium & 500 & 562B013 & $2.0-2.5$ & B10 & 190,000 & $\mathrm{mg} / \mathrm{kg}$ \\
\hline Benzo(a)anthracene & $0.21(\mathrm{~J})$ & 562B009 & $0.0-0.5$ & B08 & 2.1 & $\mathrm{mg} / \mathrm{kg}$ \\
\hline Benzo(a)pyrene & 0.22 & 562B009 & $0.0-0.5$ & B08 & 0.21 & $\mathrm{mg} / \mathrm{kg}$ \\
\hline Benzo(b)fluoranthene & 0.37 & 562B009 & $0.0-0.5$ & B08 & 2.1 & $\mathrm{mg} / \mathrm{kg}$ \\
\hline Benzo(g,h,i)perylene & $0.21(\mathrm{~J})$ & 562B016 & $0.0-0.5$ & B11 & 17,000 & $\mathrm{mg} / \mathrm{kg}$ \\
\hline Benzo(k)fluoranthene & $0.16(\mathrm{~J})$ & 562B009 & $0.0-0.5$ & B08 & 21 & $\mathrm{mg} / \mathrm{kg}$ \\
\hline Bis(2-ethylhexyl)phthalate & 8.5 & 562B013 & $2.0-2.5$ & B10 & 120 & $\mathrm{mg} / \mathrm{kg}$ \\
\hline Cadmium & 6.5 & 562B013 & $2.0-2.5$ & B10 & 800 & $\mathrm{mg} / \mathrm{kg}$ \\
\hline Cs-137 & 1.33 & 562B012 & $1.0-1.5$ & B01 & 12.2 & $\mathrm{pCi} / \mathrm{g}$ \\
\hline Chromium & 240 & 562B009 & $0.0-0.5$ & B08 & 450 & $\mathrm{mg} / \mathrm{kg}$ \\
\hline Chrysene & $0.25(\mathrm{~J})$ & 562B009 & $0.0-0.5$ & B08 & 210 & $\mathrm{mg} / \mathrm{kg}$ \\
\hline Di-n-butyl phthalate & 0.97 & 562B009 & $0.0-0.5$ & B08 & 62,000 & $\mathrm{mg} / \mathrm{kg}$ \\
\hline DRO & 180 & 562B013 & $2.0-2.5$ & B10 & $N / A$ & $\mathrm{mg} / \mathrm{kg}$ \\
\hline Fluoranthene & 0.62 & 562B009 & $0.0-0.5$ & B08 & 22,000 & $\mathrm{mg} / \mathrm{kg}$ \\
\hline Indeno(1,2,3-cd)pyrene & $0.11(\mathrm{~J})$ & 562B009 & $0.0-0.5$ & B08 & 2.1 & $\mathrm{mg} / \mathrm{kg}$ \\
\hline Lead & 600 & 562B009 & $0.0-0.5$ & B08 & 800 & $\mathrm{mg} / \mathrm{kg}$ \\
\hline Mercury & $12(\mathrm{~J}-)$ & 562B013 & $2.0-2.5$ & B10 & 34 & $\mathrm{mg} / \mathrm{kg}$ \\
\hline Methylene chloride & $0.0021(\mathrm{~J})$ & 562B001 & $0.0-0.5$ & B01 & 53 & $\mathrm{mg} / \mathrm{kg}$ \\
\hline Phenanthrene & 0.45 & 562B009 & $0.0-0.5$ & B08 & 170,000 & $\mathrm{mg} / \mathrm{kg}$ \\
\hline
\end{tabular}


Table 2-3

\section{Maximum Concentration of Detected Contaminants for Environmental Sample Results at CAS 02-44-02, Paint Spills and French Drain}

(Page 2 of 2)

\begin{tabular}{|c|c|c|c|c|c|c||}
\hline Contaminant & $\begin{array}{c}\text { Maximum } \\
\text { Result }\end{array}$ & $\begin{array}{c}\text { Sample } \\
\text { Number }\end{array}$ & $\begin{array}{c}\text { Depth } \\
\text { (ft bgs) }\end{array}$ & Location & FAL & Units \\
\hline \hline Pyrene & 0.65 & $562 \mathrm{~B} 009$ & $0.0-0.5$ & $\mathrm{~B} 08$ & 17,000 & $\mathrm{mg} / \mathrm{kg}$ \\
\hline Selenium & 1.1 & $562 \mathrm{~B} 005$ & $0.0-0.5$ & $\mathrm{~B} 04$ & 5,100 & $\mathrm{mg} / \mathrm{kg}$ \\
\hline Th-234 & $3.59(\mathrm{~J})$ & $562 \mathrm{~B} 002$ & $0.0-0.5$ & $\mathrm{~B} 02$ & 105 & $\mathrm{pCi} / \mathrm{g}$ \\
\hline
\end{tabular}

$\mathrm{J}=$ Estimated value

$\mathrm{J}$ - = Result is an estimated quantity but may be biased low.

Bold indicates the value equals or exceeds the FAL.

Table 2-4

Maximum Concentration of Detected Contaminants in PSM Samples from CAS 02-44-02, Paint Spills and French Drain

(Page 1 of 2)

\begin{tabular}{|c|c|c|c|c|c|c|}
\hline Contaminant & $\begin{array}{c}\text { Maximum } \\
\text { Result }\end{array}$ & $\begin{array}{l}\text { Sample } \\
\text { Number }\end{array}$ & $\begin{array}{l}\text { Depth } \\
\text { (ft bgs) }\end{array}$ & Location & $\begin{array}{c}\text { PSM } \\
\text { Criteria }\end{array}$ & Units \\
\hline DRO & 3,000 & 562B010 & N/A & B09 & N/A & $\mathrm{mg} / \mathrm{kg}$ \\
\hline Arsenic & 3.1 & 562B010 & N/A & B09 & 23 & $\mathrm{mg} / \mathrm{kg}$ \\
\hline Barium & 6,200 & 562B010 & N/A & B09 & 190,000 & $\mathrm{mg} / \mathrm{kg}$ \\
\hline Cadmium & 43 & 562B010 & N/A & B09 & 800 & $\mathrm{mg} / \mathrm{kg}$ \\
\hline Chromium & 5,800 & 562B010 & N/A & B09 & 450 & $\mathrm{mg} / \mathrm{kg}$ \\
\hline Lead & 7,200 & 562B010 & N/A & B09 & 800 & $\mathrm{mg} / \mathrm{kg}$ \\
\hline Mercury & 0.93 & 562B006 & N/A & B05 & 34 & $\mathrm{mg} / \mathrm{kg}$ \\
\hline Selenium & 5 & 562B010 & N/A & B09 & 5,100 & $\mathrm{mg} / \mathrm{kg}$ \\
\hline Silver & 0.25 & 562B010 & N/A & B09 & 5,100 & $\mathrm{mg} / \mathrm{kg}$ \\
\hline Aroclor 1260 & $0.66(\mathrm{~J})$ & 562B006 & N/A & B05 & 0.74 & $\mathrm{mg} / \mathrm{kg}$ \\
\hline Anthracene & $2.2(\mathrm{~J})$ & 562B010 & N/A & B09 & 170,000 & $\mathrm{mg} / \mathrm{kg}$ \\
\hline Benzo(a)pyrene & $2.3(\mathrm{~J})$ & 562B006 & N/A & B05 & 0.21 & $\mathrm{mg} / \mathrm{kg}$ \\
\hline Benzo(b)fluoranthene & $5(\mathrm{~J})$ & 562B006 & N/A & B05 & 2.1 & $\mathrm{mg} / \mathrm{kg}$ \\
\hline Benzoic acid & $17(\mathrm{~J})$ & 562B010 & N/A & B09 & 100,000 & $\mathrm{mg} / \mathrm{kg}$ \\
\hline Bis(2-ethylhexyl)phthalate & $220(J)$ & 562B010 & N/A & B09 & 120 & $\mathrm{mg} / \mathrm{kg}$ \\
\hline Butyl benzyl phthalate & $17(\mathrm{~J})$ & 562B010 & N/A & B09 & 910 & $\mathrm{mg} / \mathrm{kg}$ \\
\hline
\end{tabular}


Table 2-4

Maximum Concentration of Detected Contaminants in PSM Samples from CAS 02-44-02, Paint Spills and French Drain

(Page 2 of 2)

\begin{tabular}{|c|c|c|c|c|c|c||}
\hline Contaminant & $\begin{array}{c}\text { Maximum } \\
\text { Result }\end{array}$ & $\begin{array}{c}\text { Sample } \\
\text { Number }\end{array}$ & $\begin{array}{c}\text { Depth } \\
\text { (ft bgs) }\end{array}$ & Location & $\begin{array}{c}\text { PSM } \\
\text { Criteria }\end{array}$ & Units \\
\hline \hline Carbazole & $2.9(\mathrm{~J})$ & $562 \mathrm{~B} 006$ & $\mathrm{~N} / \mathrm{A}$ & $\mathrm{B} 05$ & 95.8 & $\mathrm{mg} / \mathrm{kg}$ \\
\hline Chrysene & $8.4(\mathrm{~J})$ & $562 \mathrm{~B} 006$ & $\mathrm{~N} / \mathrm{A}$ & $\mathrm{B} 05$ & 210 & $\mathrm{mg} / \mathrm{kg}$ \\
\hline Di-n-butyl phthalate & $16(\mathrm{~J})$ & $562 \mathrm{~B} 010$ & $\mathrm{~N} / \mathrm{A}$ & $\mathrm{B} 09$ & 62,000 & $\mathrm{mg} / \mathrm{kg}$ \\
\hline Di-n-octyl phthalate & $5.9(\mathrm{~J})$ & $562 \mathrm{~B} 010$ & $\mathrm{~N} / \mathrm{A}$ & $\mathrm{B} 09$ & 25,000 & $\mathrm{mg} / \mathrm{kg}$ \\
\hline Fluoranthene & 25 & $562 \mathrm{~B} 006$ & $\mathrm{~N} / \mathrm{A}$ & $\mathrm{B} 05$ & 22,000 & $\mathrm{mg} / \mathrm{kg}$ \\
\hline Phenanthrene & 15 & $562 \mathrm{~B} 006$ & $\mathrm{~N} / \mathrm{A}$ & $\mathrm{B} 05$ & 170,000 & $\mathrm{mg} / \mathrm{kg}$ \\
\hline Pyrene & 16 & $562 \mathrm{~B} 006$ & N/A & B05 & 17,000 & $\mathrm{mg} / \mathrm{kg}$ \\
\hline 2-butanone & 0.03 & $562 \mathrm{~B} 006$ & N/A & B05 & 110,000 & $\mathrm{mg} / \mathrm{kg}$ \\
\hline 2-hexanone & $0.018(\mathrm{~J})$ & $562 \mathrm{~B} 006$ & N/A & B05 & 110,000 & $\mathrm{mg} / \mathrm{kg}$ \\
\hline Acetone & 0.15 & $562 \mathrm{~B} 006$ & N/A & B05 & 54,000 & $\mathrm{mg} / \mathrm{kg}$ \\
\hline
\end{tabular}

$\mathrm{J}=$ Estimated value

$\mathrm{J}-=$ Result is an estimated quantity but may be biased low.

Bold indicates the value equals or exceeds the PSM criteria.

\subsection{Environmental Sample Results}

All concentrations of the reported parameters at this site were less than the corresponding PALs. Therefore, the FALs were established at the corresponding PAL concentrations, and no COCs were identified in the soil samples collected at this site.

The maximum concentration of each detected contaminant in environmental samples collected at this CAS is listed in Table 2-5.

\subsection{Potential Source Material Sample Results}

Two liquid and two sludge PSM samples were collected from the septic tank. Both sludge samples contained concentrations of TPH-DRO that exceeded the PAL concentration of $100 \mathrm{mg} / \mathrm{kg}$. The TPH-DRO was moved on to a Tier 2 evaluation, and PSM criteria were established for the hazardous constituents of TPH-DRO. Naphthalene and 1,4-dichlorobenzene are both hazardous constituents of 
Table 2-5

Maximum Concentration of Detected Contaminants for Environmental Samples Results at CAS 02-59-01, Septic System

\begin{tabular}{|c|c|c|c|c|c|c|}
\hline Contaminant & $\begin{array}{c}\text { Maximum } \\
\text { Result }\end{array}$ & $\begin{array}{c}\text { Sample } \\
\text { Number }\end{array}$ & $\begin{array}{c}\text { Depth } \\
\text { (ft bgs) }\end{array}$ & Location & FAL & Units \\
\hline \hline Ac-228 & 2.34 & $562 \mathrm{C006}$ & $11.5-12$ & $\mathrm{C} 05$ & $\mathrm{pCi} / \mathrm{g}$ \\
\hline Arsenic & 5.7 & $562 \mathrm{C002}$ & $13.0-13.5$ & $\mathrm{C} 02$ & 23 & $\mathrm{mg} / \mathrm{kg}$ \\
\hline Barium & 290 & $562 \mathrm{C005}$ & $13.0-13.5$ & $\mathrm{C} 04$ & 190,000 & $\mathrm{mg} / \mathrm{kg}$ \\
\hline Chromium & 6.1 & $562 \mathrm{C015}$ & $10.0-11.0$ & $\mathrm{C} 12$ & 450 & $\mathrm{mg} / \mathrm{kg}$ \\
\hline DRO & $2.9(\mathrm{~J})$ & $562 \mathrm{C002}$ & $13.0-13.5$ & $\mathrm{C} 02$ & $\mathrm{~N} / \mathrm{A}$ & $\mathrm{mg} / \mathrm{kg}$ \\
\hline Lead & 12 & $562 \mathrm{C015}$ & $10.0-11.0$ & $\mathrm{C} 12$ & 800 & $\mathrm{mg} / \mathrm{kg}$ \\
\hline Mercury & 0.1 & $562 \mathrm{C013}$ & $9.0-10.0$ & $\mathrm{C} 10$ & 34 & $\mathrm{mg} / \mathrm{kg}$ \\
\hline Selenium & 0.74 & $562 \mathrm{C002}$ & $13.0-13.5$ & $\mathrm{C} 02$ & 5,100 & $\mathrm{mg} / \mathrm{kg}$ \\
\hline
\end{tabular}

$\mathrm{J}=$ Estimated value

TPH-DRO, and their concentrations exceeded the PSM criteria in one sludge sample (562C011). Therefore, the sludge is considered PSM. The maximum concentration of each detected contaminant in sludge samples collected at this CAS are listed in Table 2-6.

Table 2-6

Maximum Concentration of Detected Contaminants in PSM Sludge Samples from CAS 02-59-01, Septic System

(Page 1 of 2)

\begin{tabular}{|c|c|c|c|c|c|c|}
\hline Contaminant & $\begin{array}{c}\text { Maximum } \\
\text { Result }\end{array}$ & $\begin{array}{l}\text { Sample } \\
\text { Number }\end{array}$ & $\begin{array}{l}\text { Depth } \\
\text { (ft bgs) }\end{array}$ & Location & $\begin{array}{c}\text { PSM } \\
\text { Criteria }\end{array}$ & Units \\
\hline DRO & 2,600 & $562 \mathrm{C} 011$ & $10.0-10.5$ & $\mathrm{C07}$ & N/A & $\mathrm{mg} / \mathrm{kg}$ \\
\hline Barium & 1,500 & $562 C 011$ & $10.0-10.5$ & $\mathrm{CO7}$ & 190,000 & $\mathrm{mg} / \mathrm{kg}$ \\
\hline Cadmium & 9.5 & $562 C 011$ & $10.0-10.5$ & $\mathrm{C} 07$ & 800 & $\mathrm{mg} / \mathrm{kg}$ \\
\hline Chromium & 330 & $562 \mathrm{C} 012$ & $10.0-10.5$ & C09 & 450 & $\mathrm{mg} / \mathrm{kg}$ \\
\hline Lead & 59 & $562 C 011$ & $10.0-10.5$ & $\mathrm{C} 07$ & 800 & $\mathrm{mg} / \mathrm{kg}$ \\
\hline Mercury & $2(\mathrm{~J}+)$ & $562 C 011$ & $10.0-10.5$ & $\mathrm{C} 07$ & 34 & $\mathrm{mg} / \mathrm{kg}$ \\
\hline Selenium & 4.1 & $562 C 011$ & $10.0-10.5$ & $\mathrm{C} 07$ & 5,100 & $\mathrm{mg} / \mathrm{kg}$ \\
\hline Silver & 290 & $562 C 011$ & $10.0-10.5$ & $\mathrm{C} 07$ & 5,100 & $\mathrm{mg} / \mathrm{kg}$ \\
\hline 4,4'-DDE & 0.075 & $562 \mathrm{C} 011$ & $10.0-10.5$ & $\mathrm{C07}$ & 5.1 & $\mathrm{mg} / \mathrm{kg}$ \\
\hline Dieldrin & $0.0091(\mathrm{~J})$ & $562 C 011$ & $10.0-10.5$ & $\mathrm{CO}$ & 0.11 & $\mathrm{mg} / \mathrm{kg}$ \\
\hline
\end{tabular}


Table 2-6

\section{Maximum Concentration of Detected Contaminants in PSM Sludge Samples from CAS 02-59-01, Septic System}

(Page 2 of 2)

\begin{tabular}{|c|c|c|c|c|c|c|}
\hline Contaminant & $\begin{array}{c}\text { Maximum } \\
\text { Result }\end{array}$ & $\begin{array}{l}\text { Sample } \\
\text { Number }\end{array}$ & $\begin{array}{l}\text { Depth } \\
\text { (ft bgs) }\end{array}$ & Location & $\begin{array}{c}\text { PSM } \\
\text { Criteria }\end{array}$ & Units \\
\hline 2,4,5-TP & $0.059(\mathrm{~J})$ & $562 C 012$ & $10.0-10.5$ & C09 & 4,900 & $\mathrm{mg} / \mathrm{kg}$ \\
\hline MCPP & 83 & $562 C 011$ & $10.0-10.5$ & $\mathrm{C} 07$ & 620 & $\mathrm{mg} / \mathrm{kg}$ \\
\hline Aroclor 1260 & 0.29 & $562 C 011$ & $10.0-10.5$ & $\mathrm{C} 07$ & 0.74 & $\mathrm{mg} / \mathrm{kg}$ \\
\hline Bis(2-ethylhexyl)phthalate & $3.6(\mathrm{~J})$ & $562 C 011$ & $10.0-10.5$ & $\mathrm{C} 07$ & 120 & $\mathrm{mg} / \mathrm{kg}$ \\
\hline Naphthalene & 45 & $562 C 011$ & $10.0-10.5$ & $\mathrm{C} 07$ & 18 & $\mathrm{mg} / \mathrm{kg}$ \\
\hline Pyrene & $1.5(\mathrm{~J})$ & $562 C 011$ & $10.0-10.5$ & $\mathrm{C07}$ & 17,000 & $\mathrm{mg} / \mathrm{kg}$ \\
\hline 1,1-dichloroethene & $0.037(\mathrm{~J})$ & $562 C 011$ & $10.0-10.5$ & C07 & 1,100 & $\mathrm{mg} / \mathrm{kg}$ \\
\hline 1,2-dichlorobenzene & $0.084(\mathrm{~J})$ & $562 C 011$ & $10.0-10.5$ & $\mathrm{C} 07$ & 9,800 & $\mathrm{mg} / \mathrm{kg}$ \\
\hline 1,2,4-trimethylbenzene & 0.025 & $562 C 012$ & $10.0-10.5$ & C09 & 260 & $\mathrm{mg} / \mathrm{kg}$ \\
\hline 1,3,5-trimethylbenzene & $0.0074(\mathrm{~J})$ & $562 C 012$ & $10.0-10.5$ & C09 & 10,000 & $\mathrm{mg} / \mathrm{kg}$ \\
\hline 1,4-dichlorobenzene & 250 & $562 C 011$ & $10.0-10.5$ & $\mathrm{C} 07$ & 12 & $\mathrm{mg} / \mathrm{L}$ \\
\hline 2-butanone & $0.36(\mathrm{~J})$ & $562 C 011$ & $10.0-10.5$ & $\mathrm{C} 07$ & 200,000 & $\mathrm{mg} / \mathrm{kg}$ \\
\hline Acetone & 1.4 & $562 C 011$ & $10.0-10.5$ & $\mathrm{C} 07$ & 630,000 & $\mathrm{mg} / \mathrm{kg}$ \\
\hline Carbon disulfide & $0.032(\mathrm{~J})$ & $562 C 011$ & $10.0-10.5$ & $\mathrm{C} 07$ & 3,700 & $\mathrm{mg} / \mathrm{kg}$ \\
\hline Cis-1,2-dichloroethene & 61 & $562 C 011$ & $10.0-10.5$ & $\mathrm{C07}$ & 10,000 & $\mathrm{mg} / \mathrm{kg}$ \\
\hline Ethylbenzene & $0.14(\mathrm{~J})$ & $562 C 011$ & $10.0-10.5$ & $\mathrm{C07}$ & 27 & $\mathrm{mg} / \mathrm{kg}$ \\
\hline Isopropylbenzene & 1.2 & $562 C 011$ & $10.0-10.5$ & $\mathrm{C07}$ & 11,000 & $\mathrm{mg} / \mathrm{kg}$ \\
\hline N-butylbenzene & 1.1 & $562 C 011$ & $10.0-10.5$ & $\mathrm{C} 07$ & 240 & $\mathrm{mg} / \mathrm{kg}$ \\
\hline N-propylbenzene & 3.9 & $562 C 011$ & $10.0-10.5$ & $\mathrm{C} 07$ & 21,000 & $\mathrm{mg} / \mathrm{kg}$ \\
\hline Sec-butylbenzene & 1.5 & $562 C 011$ & $10.0-10.5$ & $\mathrm{C} 07$ & 220 & $\mathrm{mg} / \mathrm{kg}$ \\
\hline Tert-butylbenzene & $0.11(\mathrm{~J})$ & $562 \mathrm{C} 011$ & $10.0-10.5$ & $\mathrm{C} 07$ & 390 & $\mathrm{mg} / \mathrm{kg}$ \\
\hline Toluene & 0.44 & 562C011 & $10.0-10.5$ & $\mathrm{C} 07$ & 45,000 & $\mathrm{mg} / \mathrm{kg}$ \\
\hline Vinyl chloride & $0.28(\mathrm{~J})$ & $562 C 011$ & $10.0-10.5$ & $\mathrm{C} 07$ & 1.7 & $\mathrm{mg} / \mathrm{kg}$ \\
\hline
\end{tabular}

$\mathrm{mg} / \mathrm{L}=$ Milligrams per liter

$\mathrm{J}=$ Estimated value

$\mathrm{J}+=$ Result is an estimated quantity but may be biased high.

Bold indicates the value equals or exceeds the PSM criteria. 
The calculation of PSM criteria for liquids in the septic tank was based on the PSM criteria specified in the CAIP (NNSA/NSO,2009):

For liquid wastes, the resulting concentration of contaminants in the surrounding soil will be calculated based on the concentration of contaminants in the waste and the liquid holding capacity of the soil. If the resulting soil concentration exceeds the FAL, then the liquid waste would be considered to be PSM.

The following formula was used to calculate the PSM criteria for liquids (in mg/L) using the FALs for soil, a soil density of 1.64 kilograms per liter $(\mathrm{kg} / \mathrm{L})$, and a conservative assumption that the liquid-holding capacity of these desert soils would be as high as 15 percent mass water content (0.15 kilogram per kilogram [kg/kg]). For CAS 02-59-01, the FALs were established at the PAL concentrations.

PSM criteria for liquids (mg/L) = FAL (mg/kg) / liquid-holding capacity $(0.15 \mathrm{~kg} / \mathrm{kg})$ x soil density $(1.64 \mathrm{~kg} / \mathrm{L})$

For barium, this calculation resulted in liquid PSM criteria that exceeded $1 \mathrm{~kg} / \mathrm{kg}$. Therefore, the PSM criterion for this contaminant was set at $1 \mathrm{~kg} / \mathrm{kg}$. As shown in Table 2-7, none of the results from the septic tank liquid exceeded PSM criteria for liquids, and the septic tank liquid is not considered PSM.

\subsubsection{Concrete Drain (CAS 02-60-01)}

With the exception of TPH-DRO and several SVOCs, all concentrations of the reported parameters were less than the PALs.

The TPH-DRO was detected in surface sample 562D001 at a concentration of $130 \mathrm{mg} / \mathrm{kg}$, which exceeds the PAL of $100 \mathrm{mg} / \mathrm{kg}$. The TPH-DRO was moved on to a Tier 2 evaluation, and FALs were established for the hazardous constituents of TPH-DRO at their respective PAL concentrations.

One or more SVOCs were detected in 11 samples at concentrations above their respective FALs. These SVOCs are benzo(a)anthracene, benzo(a)pyrene, benzo(b)fluoranthene, dibenzo(a,h)anthracene, and indeno(1,2,3-cd)pyrene. The constituents are PAHs, which are 
Table 2-7

Maximum Concentration of Detected Contaminants in PSM Liquid Samples from CAS 02-59-01, Septic System

\begin{tabular}{|c|c|c|c|c|c|c|}
\hline Contaminant & $\begin{array}{c}\text { Maximum } \\
\text { Result }\end{array}$ & $\begin{array}{l}\text { Sample } \\
\text { Number }\end{array}$ & $\begin{array}{l}\text { Depth } \\
\text { (ft bgs) }\end{array}$ & Location & $\begin{array}{c}\text { PSM } \\
\text { Criteria }\end{array}$ & Unit \\
\hline DRO & 5.6 & \multirow{14}{*}{$562 C 008$} & \multirow{14}{*}{$8.5-9.0$} & \multirow{14}{*}{$\mathrm{C} 07$} & N/A & $\mathrm{mg} / \mathrm{L}$ \\
\hline Barium & 0.37 & & & & $1,000,000$ & $\mathrm{mg} / \mathrm{L}$ \\
\hline Cadmium & 0.013 & & & & 8,747 & $\mathrm{mg} / \mathrm{L}$ \\
\hline Chromium & 0.16 & & & & 4,920 & $\mathrm{mg} / \mathrm{L}$ \\
\hline Lead & 0.21 & & & & 8,747 & $\mathrm{mg} / \mathrm{L}$ \\
\hline Mercury & 0.0049 & & & & 372 & $\mathrm{mg} / \mathrm{L}$ \\
\hline Selenium & 0.0082 & & & & 55,760 & $\mathrm{mg} / \mathrm{L}$ \\
\hline Silver & 0.55 & & & & 55,760 & $\mathrm{mg} / \mathrm{L}$ \\
\hline 4,4'-DDE & $0.000023(\mathrm{~J})$ & & & & 56 & $\mathrm{mg} / \mathrm{L}$ \\
\hline 1,4-dichlorobenzene & 0.004 & & & & 131 & $\mathrm{mg} / \mathrm{L}$ \\
\hline Cis-1,2-dichloroethene & 0.16 & & & & 109,333 & $\mathrm{mg} / \mathrm{L}$ \\
\hline Vinyl chloride & $0.0011(\mathrm{~J})$ & & & & 19 & $\mathrm{mg} / \mathrm{L}$ \\
\hline Carbon disulfide & $0.0014(\mathrm{~J})$ & & & & 40,453 & $\mathrm{mg} / \mathrm{L}$ \\
\hline 1,2,4-trimethylbenzene & $0.00084(\mathrm{~J})$ & & & & 2,843 & $\mathrm{mg} / \mathrm{L}$ \\
\hline
\end{tabular}

$\mathrm{J}=$ Estimated value

commonly associated with asphalt. It has been determined that the presence of PAHs in these samples is due to the presence of asphalt at this CAS; therefore, these PAHs are not COCs.

The maximum concentration of each detected contaminant at this CAS is listed in Table 2-8.

Table 2-8

Maximum Concentration of Detected Contaminants for CAS 02-60-01, Concrete Drain (Page 1 of 3)

\begin{tabular}{|c|c|c|c|c|c|c|}
\hline Contaminant & $\begin{array}{c}\text { Maximum } \\
\text { Result }\end{array}$ & $\begin{array}{c}\text { Sample } \\
\text { Number }\end{array}$ & $\begin{array}{c}\text { Depth } \\
\text { (ft bgs) }\end{array}$ & Location & FAL Units \\
\hline \hline 2-methylnaphthalene & $4.6(\mathrm{~J})$ & $562 \mathrm{D008}$ & $0.0-0.5$ & $\mathrm{D} 07$ & 4,100 & $\mathrm{mg} / \mathrm{kg}$ \\
\hline Acenaphthene & $20(\mathrm{~J})$ & $562 \mathrm{D008}$ & $0.0-0.5$ & $\mathrm{D} 07$ & 33,000 & $\mathrm{mg} / \mathrm{kg}$ \\
\hline Acenaphthylene & $0.18(\mathrm{~J})$ & $562 \mathrm{D008}$ & $0.0-0.5$ & $\mathrm{D} 07$ & 33,000 & $\mathrm{mg} / \mathrm{kg}$ \\
\hline Acetone & $0.0083(\mathrm{~J})$ & $562 \mathrm{D001}$ & $0.0-0.75$ & $\mathrm{D} 01$ & 630,000 & $\mathrm{mg} / \mathrm{kg}$ \\
\hline
\end{tabular}


Table 2-8

Maximum Concentration of Detected Contaminants for CAS 02-60-01, Concrete Drain (Page 2 of 3 )

\begin{tabular}{|c|c|c|c|c|c|c|}
\hline Contaminant & $\begin{array}{c}\text { Maximum } \\
\text { Result }\end{array}$ & $\begin{array}{l}\text { Sample } \\
\text { Number }\end{array}$ & $\begin{array}{l}\text { Depth } \\
\text { (ft bgs) }\end{array}$ & Location & FAL & Units \\
\hline Ac-228 & 2.17 & 562D002 & $1.5-2.0$ & D02 & 5 & $\mathrm{pCi} / \mathrm{g}$ \\
\hline Anthracene & $10(\mathrm{~J})$ & 562D008 & $0.0-0.5$ & D07 & 170,000 & $\mathrm{mg} / \mathrm{kg}$ \\
\hline Aroclor 1260 & 0.04 & 562D001 & $0.0-0.75$ & D01 & 0.74 & $\mathrm{mg} / \mathrm{kg}$ \\
\hline Arsenic & 4.7 & 562D001 & $0.0-0.75$ & D01 & 23 & $\mathrm{mg} / \mathrm{kg}$ \\
\hline Barium & 480 & 562D001 & $0.0-0.75$ & D01 & 190,000 & $\mathrm{mg} / \mathrm{kg}$ \\
\hline Benzo(a)anthracene & $18(\mathrm{~J})$ & 562D008 & $0.0-0.5$ & D07 & 2.1 & $\mathrm{mg} / \mathrm{kg}$ \\
\hline Benzo(a)pyrene & $16(\mathrm{~J})$ & 562D008 & $0.0-0.5$ & D07 & 0.21 & $\mathrm{mg} / \mathrm{kg}$ \\
\hline Benzo(b)fluoranthene & $21(\mathrm{~J})$ & 562D008 & $0.0-0.5$ & D07 & 2.1 & $\mathrm{mg} / \mathrm{kg}$ \\
\hline Benzo(g,h,i)perylene & $7.4(\mathrm{~J})$ & 562D008 & $0.0-0.5$ & D07 & 17,000 & $\mathrm{mg} / \mathrm{kg}$ \\
\hline Benzo(k)fluoranthene & $9.6(\mathrm{~J})$ & 562D008 & $0.0-0.5$ & D07 & 21 & $\mathrm{mg} / \mathrm{kg}$ \\
\hline Benzyl alcohol & 0.39 & 562D008 & $0.0-0.5$ & D07 & 62,000 & $\mathrm{mg} / \mathrm{kg}$ \\
\hline Bis(2-ethylhexyl)phthalate & 0.74 & 562D008 & $0.0-0.5$ & D07 & 120 & $\mathrm{mg} / \mathrm{kg}$ \\
\hline Butyl benzyl phthalate & 1.9 & 562D008 & $0.0-0.5$ & D07 & 910 & $\mathrm{mg} / \mathrm{kg}$ \\
\hline Cadmium & 9.7 & 562D001 & $0.0-0.75$ & D01 & 800 & $\mathrm{mg} / \mathrm{kg}$ \\
\hline Carbazole & 9.9 & 562D008 & $0.0-0.5$ & D07 & 95.8 & $\mathrm{mg} / \mathrm{kg}$ \\
\hline Cs-137 & 1.16 & 562D001 & $0.0-0.75$ & D01 & 12.2 & $\mathrm{pCi} / \mathrm{g}$ \\
\hline Chromium & $190(\mathrm{~J})$ & 562D001 & $0.0-0.75$ & D01 & 450 & $\mathrm{mg} / \mathrm{kg}$ \\
\hline Chrysene & $19(\mathrm{~J})$ & 562D008 & $0.0-0.5$ & D07 & 210 & $\mathrm{mg} / \mathrm{kg}$ \\
\hline Di-n-butyl phthalate & $100(\mathrm{~J})$ & 562D008 & $0.0-0.5$ & D07 & 62,000 & $\mathrm{mg} / \mathrm{kg}$ \\
\hline Dibenzo(a,h)anthracene & 1.5 & 562D008 & $0.0-0.5$ & D07 & 0.21 & $\mathrm{mg} / \mathrm{kg}$ \\
\hline Dibenzofuran & $15(\mathrm{~J})$ & 562D008 & $0.0-0.5$ & D07 & 1,000 & $\mathrm{mg} / \mathrm{kg}$ \\
\hline DRO & 130 & 562D001 & $0.0-0.75$ & D01 & $\mathrm{N} / \mathrm{A}$ & $\mathrm{mg} / \mathrm{kg}$ \\
\hline Fluoranthene & $61(\mathrm{~J})$ & 562D008 & $0.0-0.5$ & D07 & 22,000 & $\mathrm{mg} / \mathrm{kg}$ \\
\hline Fluorene & $15(\mathrm{~J})$ & 562D008 & $0.0-0.5$ & D07 & 22,000 & $\mathrm{mg} / \mathrm{kg}$ \\
\hline Indeno(1,2,3-cd)pyrene & $9(\mathrm{~J})$ & 562D008 & $0.0-0.5$ & D07 & 2.1 & $\mathrm{mg} / \mathrm{kg}$ \\
\hline Lead & 100 & 562D001 & $0.0-0.75$ & D01 & 800 & $\mathrm{mg} / \mathrm{kg}$ \\
\hline Mercury & $0.12(\mathrm{~J})$ & 562D001 & $0.0-0.75$ & D01 & 34 & $\mathrm{mg} / \mathrm{kg}$ \\
\hline Naphthalene & $3.2(\mathrm{~J})$ & 562D008 & $0.0-0.5$ & D07 & 18 & $\mathrm{mg} / \mathrm{kg}$ \\
\hline
\end{tabular}


Table 2-8

Maximum Concentration of Detected Contaminants for CAS 02-60-01, Concrete Drain (Page 3 of 3)

\begin{tabular}{|c|c|c|c|c|c|c|}
\hline Contaminant & $\begin{array}{c}\text { Maximum } \\
\text { Result }\end{array}$ & $\begin{array}{l}\text { Sample } \\
\text { Number }\end{array}$ & $\begin{array}{l}\text { Depth } \\
\text { (ft bgs) }\end{array}$ & Location & FAL & Units \\
\hline Phenanthrene & $73(\mathrm{~J})$ & 562D008 & $0.0-0.5$ & D07 & 170,000 & $\mathrm{mg} / \mathrm{kg}$ \\
\hline Pyrene & $50(\mathrm{~J})$ & 562D008 & $0.0-0.5$ & D07 & 17,000 & $\mathrm{mg} / \mathrm{kg}$ \\
\hline Selenium & 0.65 & 562D001 & $0.0-0.75$ & D01 & 5,100 & $\mathrm{mg} / \mathrm{kg}$ \\
\hline Trichloroethene & $0.0061(\mathrm{~J})$ & 562D001 & $0.0-0.75$ & D01 & 14 & $\mathrm{mg} / \mathrm{kg}$ \\
\hline
\end{tabular}

$\mathrm{J}=$ Estimated value

Bold indicates the value equals or exceeds the FAL.

\subsubsection{French Drain (CAS 02-60-02)}

With the exception of Aroclor 1260, all concentrations of the reported parameters were less than the PALs.

Concentrations of PCBs that exceeded the PALs were detected at location E03 at the base of the original french drain (2.5 to $3.0 \mathrm{ft}$ bgs). Sample 562E004 had a concentration of $5.8 \mathrm{mg} / \mathrm{kg}$, which exceeded the PAL of $0.74 \mathrm{mg} / \mathrm{kg}$ for Aroclor 1260. The FAL was established the PAL concentration, and, therefore, Aroclor 1260 is a COC. Subsurface soil sample 562E005, collected at 4.5 to $5.0 \mathrm{ft}$ bgs at location E03 did not contain any PCBs (particularly Aroclor 1260) at concentrations that exceed their respective PALs. Soil sample 562E008 was collected from location E05, and soil sample 562E009 was collected from location E06. These samples show that the PCBs are limited to the subsurface interval where concentrations decrease to below the FALs within $2.0 \mathrm{ft}$ laterally and $1.5 \mathrm{ft}$ vertically of the base of the french drain.

The maximum concentration of each detected contaminant at this CAS is listed in Table 2-9.

\subsubsection{Steam Cleaning Drain (CAS 02-60-03)}

With the exception of TPH-DRO, benzo(a)pyrene, and Aroclor 1260, all concentrations of the reported parameters were less than the PALs. 
Table 2-9

Maximum Concentration of Detected Contaminants for CAS 02-60-02, French Drain

\begin{tabular}{|c|c|c|c|c|c|c|}
\hline Contaminant & $\begin{array}{c}\text { Maximum } \\
\text { Result }\end{array}$ & $\begin{array}{l}\text { Sample } \\
\text { Number }\end{array}$ & $\begin{array}{l}\text { Depth } \\
\text { (ft bgs) }\end{array}$ & Location & FAL & Units \\
\hline AC-228 & 2.08 & 562E007 & $4.0-4.5$ & E04 & 5 & $\mathrm{pCi} / \mathrm{g}$ \\
\hline Aroclor 1260 & $5.8(J)$ & 562E004 & $2.5-3.0$ & E03 & 0.74 & $\mathrm{mg} / \mathrm{kg}$ \\
\hline Arsenic & 4.5 & 562E003 & $1.0-1.5$ & E02 & 23 & $\mathrm{mg} / \mathrm{kg}$ \\
\hline Barium & $170(\mathrm{~J})$ & 562E003 & $1.0-1.5$ & E02 & 190,000 & $\mathrm{mg} / \mathrm{kg}$ \\
\hline Benzo(a)anthracene & $0.18(\mathrm{~J})$ & 562E003 & $1.0-1.5$ & E02 & 2.1 & $\mathrm{mg} / \mathrm{kg}$ \\
\hline Benzo(a)pyrene & $0.18(\mathrm{~J})$ & 562E003 & $1.0-1.5$ & E02 & 0.21 & $\mathrm{mg} / \mathrm{kg}$ \\
\hline Benzo(b)fluoranthene & $0.32(\mathrm{~J})$ & 562E003 & $1.0-1.5$ & E02 & 2.1 & $\mathrm{mg} / \mathrm{kg}$ \\
\hline Benzo(k)fluoranthene & $0.13(\mathrm{~J})$ & 562E003 & $1.0-1.5$ & E02 & 21 & $\mathrm{mg} / \mathrm{kg}$ \\
\hline Bis(2-ethylhexyl)phthalate & 4.2 & 562E001 & $1.0-1.5$ & E01 & 120 & $\mathrm{mg} / \mathrm{kg}$ \\
\hline Cadmium & 12 & 562E006 & $2.5-3.0$ & E04 & 800 & $\mathrm{mg} / \mathrm{kg}$ \\
\hline Cs-137 & 0.4 & 562E004 & $2.5-3.0$ & E03 & 12.2 & $\mathrm{pCi} / \mathrm{g}$ \\
\hline Chromium & $92(\mathrm{~J})$ & 562E003 & $1.0-1.5$ & E02 & 450 & $\mathrm{mg} / \mathrm{kg}$ \\
\hline Chrysene & $0.21(\mathrm{~J})$ & 562E003 & $1.0-1.5$ & E02 & 210 & $\mathrm{mg} / \mathrm{kg}$ \\
\hline Di-n-butyl phthalate & 0.92 & 562E003 & $1.0-1.5$ & E02 & 62,000 & $\mathrm{mg} / \mathrm{kg}$ \\
\hline DRO & $55(\mathrm{~J})$ & 562E004 & $2.5-3.0$ & E03 & N/A & $\mathrm{mg} / \mathrm{kg}$ \\
\hline Diethyl phthalate & $0.089(\mathrm{~J})$ & 562E004 & $2.5-3.0$ & E03 & 490,000 & $\mathrm{mg} / \mathrm{kg}$ \\
\hline Fluoranthene & 0.59 & 562E001 & $1.0-1.5$ & E01 & 22,000 & $\mathrm{mg} / \mathrm{kg}$ \\
\hline Indeno(1,2,3-cd)pyrene & $0.084(\mathrm{~J})$ & 562E002 & $1.0-1.5$ & E02 & 2.1 & $\mathrm{mg} / \mathrm{kg}$ \\
\hline Lead & 320 & 562E004 & $2.5-3.0$ & E03 & 800 & $\mathrm{mg} / \mathrm{kg}$ \\
\hline Mercury & $0.034(\mathrm{~J}-)$ & 562E007 & $4.0-4.5$ & E04 & 34 & $\mathrm{mg} / \mathrm{kg}$ \\
\hline Phenanthrene & 0.42 & 562E003 & $1.0-1.5$ & E02 & 170,000 & $\mathrm{mg} / \mathrm{kg}$ \\
\hline Phenol & $0.093(\mathrm{~J})$ & 562E002 & $1.0-1.5$ & E02 & 180,000 & $\mathrm{mg} / \mathrm{kg}$ \\
\hline Pyrene & 0.43 & 562E003 & $1.0-1.5$ & E02 & 17,000 & $\mathrm{mg} / \mathrm{kg}$ \\
\hline Selenium & 3 & 562E002 & $1.0-1.5$ & E02 & 5,100 & $\mathrm{mg} / \mathrm{kg}$ \\
\hline Silver & 0.45 & 562E003 & $1.0-1.5$ & E02 & 5,100 & $\mathrm{mg} / \mathrm{kg}$ \\
\hline Th-234 & $4.6(\mathrm{~J})$ & 562E007 & $4.0-4.5$ & E04 & 105 & $\mathrm{pCi} / \mathrm{g}$ \\
\hline
\end{tabular}

$\mathrm{J}=$ Estimated value

$\mathrm{J}-=$ Result is an estimated quantity but may be biased low.

Bold indicates the value equals or exceeds the FAL. 
Surface sample 562F010 exceeded the PAL of $100 \mathrm{mg} / \mathrm{kg}$ for TPH-DRO. The TPH-DRO was moved on to a Tier 2 evaluation, and FALs were established for the hazardous constituents of TPH-DRO. Concentrations of the hazardous constituents of TPH-DRO for this sample did not exceed FALs.

Surface sample 562F011 collected at location F10 from within the sump contained benzo(a)pyrene at a concentration of $0.27 \mathrm{mg} / \mathrm{kg}$, which exceeds the PAL of $0.21 \mathrm{mg} / \mathrm{kg}$. Because the FAL for this contaminant was established as the PAL, it is considered a COC. Subsurface soil sample 562F012, collected at 3.0 to $3.5 \mathrm{ft}$ bgs at location F10, did not contain any SVOCs, particularly benzo(a)pyrene, at concentrations that exceed their respective PALs. The four samples collected from the surface soil outside of the sump (locations F06 through F09) did not contain any SVOCs above the PALs. Based on these results, the extent of benzo(a)pyrene contamination is limited to the interior of the sump and does not extend deeper than $3.5 \mathrm{ft}$ bgs.

Surface sample 562F008 collected on the southwest side of the sump (location F07) contained Aroclor 1260 at a concentration of $1.0 \mathrm{mg} / \mathrm{kg}$, which exceeded the PAL of $0.74 \mathrm{mg} / \mathrm{kg}$. The FAL was established at the PAL concentration; therefore, Aroclor 1260 is considered a COC. The soil samples collected from five locations (F07 [subsurface] and F11 through F14 [surface]) show that PCBs are limited to the surface interval. Concentrations decrease to below the FALs within $3.0 \mathrm{ft}$ laterally of the sump and $1.5 \mathrm{ft}$ vertically from sample location F07.

The maximum concentration of each detected contaminant at this CAS is listed in Table 2-10.

Table 2-10

Maximum Concentration of Detected Contaminants for CAS 02-60-03, Steam Cleaning Drain

(Page 1 of 2)

\begin{tabular}{||c|c|c|c|c|c|c||}
\hline Contaminant & $\begin{array}{c}\text { Maximum } \\
\text { Result }\end{array}$ & $\begin{array}{c}\text { Sample } \\
\text { Number }\end{array}$ & $\begin{array}{c}\text { Depth } \\
\text { (ft bgs) }\end{array}$ & Location & FAL & Units \\
\hline \hline Ac-228 & 1.92 & $562 \mathrm{F012}$ & $3.0-3.5$ & $\mathrm{~F} 10$ & 5 & $\mathrm{pCi} / \mathrm{g}$ \\
\hline Aroclor 1260 & $\mathbf{1}(\mathrm{J})$ & $562 \mathrm{~F} 008$ & $0.0-0.5$ & $\mathrm{~F} 07$ & 0.74 & $\mathrm{mg} / \mathrm{kg}$ \\
\hline Aroclor 1268 & $0.52(\mathrm{~J})$ & $562 \mathrm{~F} 010$ & $0.0-0.5$ & $\mathrm{~F} 09$ & 0.74 & $\mathrm{mg} / \mathrm{kg}$ \\
\hline Arsenic & 5.6 & $562 \mathrm{F004}$ & $0.0-0.5$ & $\mathrm{~F} 04$ & 23 & $\mathrm{mg} / \mathrm{kg}$ \\
\hline Barium & 760 & $562 \mathrm{F011}$ & $0.0-0.5$ & $\mathrm{~F} 10$ & 190,000 & $\mathrm{mg} / \mathrm{kg}$ \\
\hline Benzo(a)anthracene & $0.19(\mathrm{~J})$ & $562 \mathrm{~F} 011$ & $0.0-0.5$ & $\mathrm{~F} 10$ & 2.1 & $\mathrm{mg} / \mathrm{kg}$ \\
\hline
\end{tabular}


Table 2-10

\section{Maximum Concentration of Detected Contaminants for CAS 02-60-03, Steam Cleaning Drain} (Page 2 of 2)

\begin{tabular}{|c|c|c|c|c|c|c|}
\hline Contaminant & $\begin{array}{c}\text { Maximum } \\
\text { Result }\end{array}$ & $\begin{array}{l}\text { Sample } \\
\text { Number }\end{array}$ & $\begin{array}{l}\text { Depth } \\
\text { (ft bgs) }\end{array}$ & Location & FAL & Units \\
\hline Benzo(a)pyrene & 0.27 & $562 \mathrm{~F} 011$ & $0.0-0.5$ & $\mathrm{~F} 10$ & 0.21 & $\mathrm{mg} / \mathrm{kg}$ \\
\hline Benzo(b)fluoranthene & 0.56 & $562 F 011$ & $0.0-0.5$ & F10 & 2.1 & $\mathrm{mg} / \mathrm{kg}$ \\
\hline Benzo(g,h,i)perylene & $0.13(\mathrm{~J})$ & $562 F 010$ & $0.0-0.5$ & F09 & 17,000 & $\mathrm{mg} / \mathrm{kg}$ \\
\hline Benzo(k)fluoranthene & $0.26(\mathrm{~J})$ & $562 F 011$ & $0.0-0.5$ & $\mathrm{~F} 10$ & 21 & $\mathrm{mg} / \mathrm{kg}$ \\
\hline Bis(2-ethylhexyl)phthalate & $0.14(\mathrm{~J})$ & $562 F 005$ & $0.0-0.5$ & F05 & 120 & $\mathrm{mg} / \mathrm{kg}$ \\
\hline Butyl benzyl phthalate & $0.24(\mathrm{~J})$ & $562 F 008$ & $0.0-0.5$ & F07 & 910 & $\mathrm{mg} / \mathrm{kg}$ \\
\hline Cadmium & 26 & $562 F 008$ & $0.0-0.5$ & F07 & 800 & $\mathrm{mg} / \mathrm{kg}$ \\
\hline Cs-137 & 0.513 & $562 F 011$ & $0.0-0.5$ & F10 & 12.2 & $\mathrm{pCi} / \mathrm{g}$ \\
\hline Chromium & 9.4 & 562F008 & $0.0-0.5$ & F07 & 450 & $\mathrm{mg} / \mathrm{kg}$ \\
\hline Chrysene & $0.27(\mathrm{~J})$ & $562 F 011$ & $0.0-0.5$ & F10 & 210 & $\mathrm{mg} / \mathrm{kg}$ \\
\hline Di-n-butyl phthalate & 1 & $562 \mathrm{~F} 003$ & $0.0-0.5$ & F03 & 62,000 & $\mathrm{mg} / \mathrm{kg}$ \\
\hline DRO & 110 & $562 \mathrm{~F} 010$ & $0.0-0.5$ & F09 & N/A & $\mathrm{mg} / \mathrm{kg}$ \\
\hline Fluoranthene & 0.62 & $562 \mathrm{~F} 003$ & $0.0-0.5$ & $\mathrm{F03}$ & 22,000 & $\mathrm{mg} / \mathrm{kg}$ \\
\hline Indeno(1,2,3-cd)pyrene & $0.15(\mathrm{~J})$ & $562 F 011$ & $0.0-0.5$ & F10 & 2.1 & $\mathrm{mg} / \mathrm{kg}$ \\
\hline Lead & 50 & $562 F 008$ & $0.0-0.5$ & F07 & 800 & $\mathrm{mg} / \mathrm{kg}$ \\
\hline Mercury & 0.11 & $562 \mathrm{~F} 005$ & $0.0-0.5$ & F05 & 34 & $\mathrm{mg} / \mathrm{kg}$ \\
\hline Phenanthrene & 0.45 & $562 \mathrm{~F} 003$ & $0.0-0.5$ & F03 & 170,000 & $\mathrm{mg} / \mathrm{kg}$ \\
\hline Pyrene & 0.47 & 562F003 & $0.0-0.5$ & F03 & 17,000 & $\mathrm{mg} / \mathrm{kg}$ \\
\hline Selenium & 0.6 & $562 F 001$ & $0.0-0.5$ & F01 & 5,100 & $\mathrm{mg} / \mathrm{kg}$ \\
\hline Th-234 & $3.3(\mathrm{~J})$ & $562 F 011$ & $0.0-0.5$ & F10 & 105 & $\mathrm{pCi} / \mathrm{g}$ \\
\hline
\end{tabular}

$\mathrm{J}=$ Estimated value

Bold indicates the value equals or exceeds the FAL.

\subsubsection{French Drain (CAS 02-60-04)}

The environmental and PSM sample results are discussed in the sections below. 


\subsection{Environmental Sample Results}

All concentrations of the reported parameters at this site were less than the corresponding PALs. Therefore, the FALs were established at the corresponding PAL concentrations, and no COCs were identified in the soil samples collected at this site.

The maximum concentration of each detected contaminant in environmental samples collected at this CAS is listed in Table 2-11.

Table 2-11

Maximum Concentration of Detected Contaminants for CAS 02-60-04, French Drain

\begin{tabular}{||c|c|c|c|c|c|c|}
\hline Contaminant & $\begin{array}{c}\text { Maximum } \\
\text { Result }\end{array}$ & $\begin{array}{c}\text { Sample } \\
\text { Number }\end{array}$ & $\begin{array}{c}\text { Depth } \\
\text { (ft bgs) }\end{array}$ & Location & FAL Units \\
\hline \hline Ac-228 & 2.2 & $562 \mathrm{G} 007$ & $8.5-9.0$ & $\mathrm{G} 05$ & 5 & $\mathrm{pCi} / \mathrm{g}$ \\
\hline Aroclor 1260 & 0.044 & $562 \mathrm{G} 002$ & $10.0-11.0$ & $\mathrm{G} 02$ & 0.74 & $\mathrm{mg} / \mathrm{kg}$ \\
\hline Arsenic & 3.5 & $562 \mathrm{G} 002$ & $10.0-11.0$ & $\mathrm{G} 02$ & 23 & $\mathrm{mg} / \mathrm{kg}$ \\
\hline Barium & 110 & $562 \mathrm{G} 005$ & $8.5-9.0$ & $\mathrm{G} 04$ & 190,000 & $\mathrm{mg} / \mathrm{kg}$ \\
\hline Bis(2-ethylhexyl)phthalate & $0.1(\mathrm{~J})$ & $562 \mathrm{G} 006$ & $11.0-12.0$ & $\mathrm{G} 02$ & 120 & $\mathrm{mg} / \mathrm{kg}$ \\
\hline Cadmium & 0.086 & $562 \mathrm{G} 006$ & $11.0-12.0$ & $\mathrm{G} 02$ & 800 & $\mathrm{mg} / \mathrm{kg}$ \\
\hline Chromium & 4.3 & $562 \mathrm{G} 006$ & $11.0-12.0$ & $\mathrm{G} 02$ & 450 & $\mathrm{mg} / \mathrm{kg}$ \\
\hline DRO & 10 & $562 \mathrm{G} 002$ & $10.0-11.0$ & $\mathrm{G} 02$ & $\mathrm{~N} / \mathrm{A}$ & $\mathrm{mg} / \mathrm{kg}$ \\
\hline Lead & $9.5(\mathrm{~J})$ & $562 \mathrm{G} 005$ & $8.5-9.0$ & $\mathrm{G} 04$ & 800 & $\mathrm{mg} / \mathrm{kg}$ \\
\hline Mercury & $0.055(\mathrm{~J}-)$ & $562 \mathrm{G} 005$ & $8.5-9.0$ & $\mathrm{G} 04$ & 34 & $\mathrm{mg} / \mathrm{kg}$ \\
\hline Selenium & 0.39 & $562 \mathrm{G} 006$ & $11.0-12.0$ & $\mathrm{G} 02$ & 5,100 & $\mathrm{mg} / \mathrm{kg}$ \\
\hline
\end{tabular}

$\mathrm{J}=$ Estimated value

$\mathrm{J}-=$ Result is an estimated quantity but may be biased low.

\subsection{Potential Source Material Sample Results}

The analytical results for sediment sample 562G001 indicate that benzo(a)pyrene ( $0.26 \mathrm{mg} / \mathrm{kg})$, Aroclor 1260 (0.95 mg/kg), and Aroclor $1268(0.95 \mathrm{mg} / \mathrm{kg}$ ) are present at concentrations above the respective PALs. The PSM criteria were established at the PAL concentrations. These contaminants are considered PSM. 
Additionally, TPH-DRO was detected at a concentration of $530 \mathrm{mg} / \mathrm{kg}$, which exceeds the PAL of $100 \mathrm{mg} / \mathrm{kg}$. The TPH-DRO was moved on to a Tier 2 evaluation, and FALs were established for the hazardous constituents of TPH-DRO at their respective PAL concentrations. As benzo(a)pyrene exceeds the PSM criteria, the TPH-DRO is a PSM contaminant.

Based on the presence of PSM contaminants, the sediment in the casing is considered PSM. The maximum concentration of each detected contaminant in PSM samples collected at this CAS is listed in Table 2-12.

Table 2-12

Maximum Concentration of Detected Contaminants in PSM Samples from CAS 02-60-04, French Drain

(Page 1 of 2)

\begin{tabular}{|c|c|c|c|c|c|c|}
\hline Contaminant & $\begin{array}{c}\text { Maximum } \\
\text { Result }\end{array}$ & $\begin{array}{l}\text { Sample } \\
\text { Number }\end{array}$ & $\begin{array}{l}\text { Depth } \\
\text { (ft bgs) }\end{array}$ & Location & $\begin{array}{c}\text { PSM } \\
\text { Criteria }\end{array}$ & Units \\
\hline Ac-228 & 1.25 & $562 G 001$ & $8.5-9.0$ & G01 & 5 & $\mathrm{pCi} / \mathrm{g}$ \\
\hline Aroclor 1260 & $0.95(\mathrm{~J})$ & $562 \mathrm{G} 001$ & $8.5-9.0$ & G01 & 0.74 & $\mathrm{mg} / \mathrm{kg}$ \\
\hline Aroclor 1268 & $0.95(\mathrm{~J})$ & $562 \mathrm{G} 001$ & $8.5-9.0$ & G01 & 0.74 & $\mathrm{mg} / \mathrm{kg}$ \\
\hline Arsenic & $2.4(\mathrm{~J})$ & $562 \mathrm{G} 001$ & $8.5-9.0$ & G01 & 23 & $\mathrm{mg} / \mathrm{kg}$ \\
\hline Barium & $230(\mathrm{~J})$ & 562G001 & $8.5-9.0$ & G01 & 190,000 & $\mathrm{mg} / \mathrm{kg}$ \\
\hline Benzo(a)anthracene & $0.28(\mathrm{~J})$ & $562 \mathrm{G} 001$ & $8.5-9.0$ & G01 & 2.1 & $\mathrm{mg} / \mathrm{kg}$ \\
\hline Benzo(a)pyrene & $0.26(\mathrm{~J})$ & $562 \mathrm{G} 001$ & $8.5-9.0$ & G01 & 0.21 & $\mathrm{mg} / \mathrm{kg}$ \\
\hline Benzo(b)fluoranthene & $0.47(\mathrm{~J})$ & $562 \mathrm{G} 001$ & $8.5-9.0$ & G01 & 2.1 & $\mathrm{mg} / \mathrm{kg}$ \\
\hline Benzo(g,h,i)perylene & $0.32(\mathrm{~J})$ & $562 \mathrm{G} 001$ & $8.5-9.0$ & G01 & 17,000 & $\mathrm{mg} / \mathrm{kg}$ \\
\hline Benzo(k)fluoranthene & $0.13(\mathrm{~J})$ & $562 \mathrm{G} 001$ & $8.5-9.0$ & G01 & 21 & $\mathrm{mg} / \mathrm{kg}$ \\
\hline Bis(2-ethylhexyl)phthalate & 0.44 & $562 \mathrm{G} 001$ & $8.5-9.0$ & G01 & 120 & $\mathrm{mg} / \mathrm{kg}$ \\
\hline Cadmium & 32 & $562 \mathrm{G} 001$ & $8.5-9.0$ & G01 & 800 & $\mathrm{mg} / \mathrm{kg}$ \\
\hline Cs-137 & 0.78 & $562 \mathrm{G} 001$ & $8.5-9.0$ & G01 & 12.2 & $\mathrm{pCi} / \mathrm{g}$ \\
\hline Chromium & $47(\mathrm{~J})$ & $562 \mathrm{G} 001$ & $8.5-9.0$ & G01 & 450 & $\mathrm{mg} / \mathrm{kg}$ \\
\hline Chrysene & $0.26(\mathrm{~J})$ & $562 \mathrm{G} 001$ & $8.5-9.0$ & G01 & 210 & $\mathrm{mg} / \mathrm{kg}$ \\
\hline Di-n-butyl phthalate & $0.089(\mathrm{~J})$ & $562 \mathrm{G} 001$ & $8.5-9.0$ & G01 & 62,000 & $\mathrm{mg} / \mathrm{kg}$ \\
\hline Dibenzo(a,h)anthracene & $0.084(\mathrm{~J})$ & $562 \mathrm{G} 001$ & $8.5-9.0$ & G01 & 0.21 & $\mathrm{mg} / \mathrm{kg}$ \\
\hline DRO & 530 & $562 \mathrm{G} 001$ & $8.5-9.0$ & G01 & $\mathrm{N} / \mathrm{A}$ & $\mathrm{mg} / \mathrm{kg}$ \\
\hline Fluoranthene & 0.39 & $562 \mathrm{G} 001$ & $8.5-9.0$ & G01 & 22,000 & $\mathrm{mg} / \mathrm{kg}$ \\
\hline
\end{tabular}


Table 2-12

\section{Maximum Concentration of Detected Contaminants in PSM Samples from CAS 02-60-04, French Drain}

(Page 2 of 2)

\begin{tabular}{|c|c|c|c|c|c|c|}
\hline Contaminant & $\begin{array}{c}\text { Maximum } \\
\text { Result }\end{array}$ & $\begin{array}{l}\text { Sample } \\
\text { Number }\end{array}$ & $\begin{array}{l}\text { Depth } \\
\text { (ft bgs) }\end{array}$ & Location & $\begin{array}{c}\text { PSM } \\
\text { Criteria }\end{array}$ & Units \\
\hline Indeno(1,2,3-cd)pyrene & $0.3(\mathrm{~J})$ & $562 \mathrm{G} 001$ & $8.5-9.0$ & G01 & 2.1 & $\mathrm{mg} / \mathrm{kg}$ \\
\hline Lead & $200(\mathrm{~J})$ & $562 \mathrm{G} 001$ & $8.5-9.0$ & G01 & 800 & $\mathrm{mg} / \mathrm{kg}$ \\
\hline Mercury & $0.16(\mathrm{~J}-)$ & $562 \mathrm{G} 001$ & $8.5-9.0$ & G01 & 34 & $\mathrm{mg} / \mathrm{kg}$ \\
\hline Phenanthrene & $0.17(\mathrm{~J})$ & $562 \mathrm{G} 001$ & $8.5-9.0$ & G01 & 170,000 & $\mathrm{mg} / \mathrm{kg}$ \\
\hline Pyrene & 0.58 & $562 \mathrm{G} 001$ & $8.5-9.0$ & G01 & 17,000 & $\mathrm{mg} / \mathrm{kg}$ \\
\hline Silver & $6.1(\mathrm{~J})$ & $562 \mathrm{G} 001$ & $8.5-9.0$ & G01 & 5,100 & $\mathrm{mg} / \mathrm{kg}$ \\
\hline Tetrachloroethene & 0.013 & $562 \mathrm{G} 001$ & $8.5-9.0$ & G01 & 2.96 & $\mathrm{mg} / \mathrm{kg}$ \\
\hline
\end{tabular}

$\mathrm{J}=$ Estimated value

$\mathrm{J}$ - = Result is an estimated quantity but may be biased low

Bold indicates the value equals or exceeds the PSM criteria.

\subsubsection{French Drain (CAS 02-60-05)}

The environmental and PSM sample results are discussed in the sections below.

\subsection{Environmental Sample Results}

One or more of 6 SVOCs were detected in 16 surface and subsurface samples at concentrations above their respective FALs. These SVOCs are benzo(a)anthracene, benzo(a)pyrene, benzo(b)fluoranthene, benzo(k)fluoranthene, dibenzo(a,h)anthracene, and indeno(1,2,3-cd)pyrene, and are considered COCs. The SVOCs identified at locations H01, H02, H03, and H10 are associated with a release from the drain; however, it has been determined that the SVOCs reported in the remaining surface samples are attributed to the presence of the chip seal and are not considered COCs at those locations.

The maximum concentration of each detected contaminant at this CAS is listed in Table 2-13. 
Table 2-13

Maximum Concentration of Detected Contaminants for CAS 02-60-05, French Drain (Page 1 of 2)

\begin{tabular}{|c|c|c|c|c|c|c|}
\hline Contaminant & $\begin{array}{c}\text { Maximum } \\
\text { Result }\end{array}$ & $\begin{array}{l}\text { Sample } \\
\text { Number }\end{array}$ & $\begin{array}{l}\text { Depth } \\
\text { (ft bgs) }\end{array}$ & Location & FAL & Units \\
\hline 2-methylnaphthalene & 11 & $562 \mathrm{H} 005$ & $0.0-0.5$ & $\mathrm{H} 02$ & 4,100 & $\mathrm{mg} / \mathrm{kg}$ \\
\hline Acenaphthene & 19 & $562 \mathrm{H} 005$ & $0.0-0.5$ & $\mathrm{H} 02$ & 33,000 & $\mathrm{mg} / \mathrm{kg}$ \\
\hline Acenaphthylene & $0.18(\mathrm{~J})$ & $562 \mathrm{H} 005$ & $0.0-0.5$ & $\mathrm{H} 02$ & 33,000 & $\mathrm{mg} / \mathrm{kg}$ \\
\hline Ac-228 & 2.1 & $562 \mathrm{H} 004$ & $5.5-6.0$ & $\mathrm{H} 01$ & 5 & $\mathrm{pCi} / \mathrm{g}$ \\
\hline Anthracene & 23 & $562 \mathrm{H} 005$ & $0.0-0.5$ & $\mathrm{H} 02$ & 170,000 & $\mathrm{mg} / \mathrm{kg}$ \\
\hline Aroclor 1260 & 0.087 & $562 \mathrm{H} 002$ & $2.5-3.0$ & $\mathrm{H} 01$ & 0.74 & $\mathrm{mg} / \mathrm{kg}$ \\
\hline Arsenic & 3.3 & $562 \mathrm{H} 004$ & $5.5-6.0$ & $\mathrm{H} 01$ & 23 & $\mathrm{mg} / \mathrm{kg}$ \\
\hline Barium & 110 & $562 \mathrm{H} 001$ & $0.0-0.5$ & $\mathrm{H} 01$ & 190,000 & $\mathrm{mg} / \mathrm{kg}$ \\
\hline Benzo(a)anthracene & $33(\mathrm{~J})$ & $562 \mathrm{H} 005$ & $0.0-0.5$ & $\mathrm{H} 02$ & 2.1 & $\mathrm{mg} / \mathrm{kg}$ \\
\hline Benzo(b)fluoranthene & $41(\mathrm{~J})$ & $562 \mathrm{H} 005$ & $0.0-0.5$ & $\mathrm{HO2}$ & 2.1 & $\mathrm{mg} / \mathrm{kg}$ \\
\hline Benzo(g,h,i)perylene & $23(\mathrm{~J})$ & $562 \mathrm{H} 005$ & $0.0-0.5$ & $\mathrm{H} 02$ & 17,000 & $\mathrm{mg} / \mathrm{kg}$ \\
\hline Benzo(a)pyrene & $37(\mathrm{~J})$ & $562 \mathrm{H} 005$ & $0.0-0.5$ & $\mathrm{H} 02$ & 0.21 & $\mathrm{mg} / \mathrm{kg}$ \\
\hline Benzo(k)fluoranthene & $22(\mathrm{~J})$ & $562 \mathrm{H} 005$ & $0.0-0.5$ & $\mathrm{H} 02$ & 21 & $\mathrm{mg} / \mathrm{kg}$ \\
\hline Bis(2-ethylhexyl)phthalate & $2.7(\mathrm{~J})$ & $562 \mathrm{H} 005$ & $0.0-0.5$ & $\mathrm{H} 02$ & 120 & $\mathrm{mg} / \mathrm{kg}$ \\
\hline Butyl benzyl phthalate & $1.9(\mathrm{~J})$ & $562 \mathrm{H} 005$ & $0.0-0.5$ & $\mathrm{H} 02$ & 910 & $\mathrm{mg} / \mathrm{kg}$ \\
\hline Cadmium & 1.4 & $562 \mathrm{H} 001$ & $0.0-0.5$ & $\mathrm{H} 01$ & 800 & $\mathrm{mg} / \mathrm{kg}$ \\
\hline Carbazole & 9.5 & $562 \mathrm{H} 005$ & $0.0-0.5$ & $\mathrm{H} 02$ & 95.8 & $\mathrm{mg} / \mathrm{kg}$ \\
\hline Cs-137 & 0.57 & $562 \mathrm{H} 003$ & $2.5-3.0$ & $\mathrm{H} 01$ & 12.2 & $\mathrm{pCi} / \mathrm{g}$ \\
\hline Chromium & $5.9(\mathrm{~J})$ & $562 \mathrm{H} 001$ & $0.0-0.5$ & $\mathrm{H} 01$ & 450 & $\mathrm{mg} / \mathrm{kg}$ \\
\hline Chrysene & 35 & $562 \mathrm{H} 005$ & $0.0-0.5$ & $\mathrm{H} 02$ & 210 & $\mathrm{mg} / \mathrm{kg}$ \\
\hline Di-n-butyl phthalate & $100(\mathrm{~J})$ & $562 \mathrm{H} 005$ & $0.0-0.5$ & $\mathrm{H} 02$ & 62,000 & $\mathrm{mg} / \mathrm{kg}$ \\
\hline Dibenzo(a,h)anthracene & $7.7(\mathrm{~J})$ & $562 \mathrm{H} 005$ & $0.0-0.5$ & $\mathrm{H} 02$ & 0.21 & $\mathrm{mg} / \mathrm{kg}$ \\
\hline Dibenzofuran & 14 & $562 \mathrm{H} 005$ & $0.0-0.5$ & $\mathrm{H} 02$ & 1,000 & $\mathrm{mg} / \mathrm{kg}$ \\
\hline DRO & $62(\mathrm{~J})$ & $562 \mathrm{H} 001$ & $0.0-0.5$ & $\mathrm{HO1}$ & N/A & $\mathrm{mg} / \mathrm{kg}$ \\
\hline Fluoranthene & $92(\mathrm{~J})$ & $562 \mathrm{H} 005$ & $0.0-0.5$ & $\mathrm{HO2}$ & 22,000 & $\mathrm{mg} / \mathrm{kg}$ \\
\hline Fluorene & 17 & $562 \mathrm{H} 005$ & $0.0-0.5$ & $\mathrm{HO2}$ & 22,000 & $\mathrm{mg} / \mathrm{kg}$ \\
\hline Indeno(1,2,3-cd)pyrene & $24(\mathrm{~J})$ & $562 \mathrm{H} 005$ & $0.0-0.5$ & $\mathrm{HO} 2$ & 2.1 & $\mathrm{mg} / \mathrm{kg}$ \\
\hline
\end{tabular}


Table 2-13

Maximum Concentration of Detected Contaminants for CAS 02-60-05, French Drain (Page 2 of 2)

\begin{tabular}{|c|c|c|c|c|c|c|}
\hline Contaminant & $\begin{array}{c}\text { Maximum } \\
\text { Result }\end{array}$ & $\begin{array}{c}\text { Sample } \\
\text { Number }\end{array}$ & $\begin{array}{c}\text { Depth } \\
\text { (ft bgs) }\end{array}$ & Location & FAL Units \\
\hline \hline Lead & $31(\mathrm{~J})$ & $562 \mathrm{H001}$ & $0.0-0.5$ & $\mathrm{H} 01$ & 800 & $\mathrm{mg} / \mathrm{kg}$ \\
\hline Mercury & 0.05 & $562 \mathrm{H} 001$ & $0.0-0.5$ & $\mathrm{H} 01$ & 34 & $\mathrm{mg} / \mathrm{kg}$ \\
\hline Methylene chloride & $0.0046(\mathrm{~J})$ & $562 \mathrm{H003}$ & $2.5-3.0$ & $\mathrm{H} 01$ & 53 & $\mathrm{mg} / \mathrm{kg}$ \\
\hline Naphthalene & 1.9 & $562 \mathrm{H017}$ & $0.0-0.5$ & $\mathrm{H} 11$ & $\mathrm{mg} / \mathrm{kg}$ \\
\hline Phenanthrene & $90(\mathrm{~J})$ & $562 \mathrm{H005}$ & $0.0-0.5$ & $\mathrm{H} 02$ & 170,000 & $\mathrm{mg} / \mathrm{kg}$ \\
\hline Pyrene & $69(\mathrm{~J})$ & $562 \mathrm{H005}$ & $0.0-0.5$ & $\mathrm{H} 02$ & 17,000 & $\mathrm{mg} / \mathrm{kg}$ \\
\hline Selenium & 0.44 & $562 \mathrm{H002}$ & $2.5-3.0$ & $\mathrm{H} 01$ & 5,100 & $\mathrm{mg} / \mathrm{kg}$ \\
\hline Silver & 0.6 & $562 \mathrm{H001}$ & $0.0-0.5$ & $\mathrm{H} 01$ & 5,100 & $\mathrm{mg} / \mathrm{kg}$ \\
\hline Th-234 & $2.58(\mathrm{~J})$ & $562 \mathrm{H} 004$ & $5.5-6.0$ & $\mathrm{H} 01$ & 105 & $\mathrm{pCi} / \mathrm{g}$ \\
\hline
\end{tabular}

$\mathrm{J}=$ Estimated value

Bold indicates the value equals or exceeds the FAL.

\subsection{Potential Source Material Sample Results}

All concentrations of the reported parameters were less than the PSM criteria; therefore, there is no PSM at this CAS. The maximum concentration of each detected contaminant in potential source material samples collected at this CAS is listed in Table 2-14.

\subsubsection{French Drain (CAS 02-60-06)}

With the exception of TPH-DRO, all concentrations of the reported parameters were less than the PALs.

Two subsurface samples exceeded the PAL of $100 \mathrm{mg} / \mathrm{kg}$ for TPH-DRO. The TPH-DRO was moved on to a Tier 2 evaluation, and FALs were established for the hazardous constituents of TPH-DRO. Concentrations of the hazardous constituents of TPH-DRO did not exceed FALs. Therefore, TPH-DRO is not considered a COC.

The maximum concentration of each detected contaminant at this CAS is listed in Table 2-15. 
Table 2-14

Maximum Concentration of Detected Contaminants in PSM Samples from for CAS 02-60-05, French Drain

\begin{tabular}{|c|c|c|c|c|c|c|}
\hline Contaminant & $\begin{array}{c}\text { Maximum } \\
\text { Result }\end{array}$ & $\begin{array}{l}\text { Sample } \\
\text { Number }\end{array}$ & $\begin{array}{l}\text { Depth } \\
\text { (ft bgs) }\end{array}$ & Location & $\begin{array}{c}\text { PSM } \\
\text { Criteria }\end{array}$ & Units \\
\hline Benzo(a)anthracene & $0.095(\mathrm{~J})$ & \multirow{10}{*}{$562 \mathrm{H} 026$} & \multirow{10}{*}{$1.0-2.0$} & \multirow{10}{*}{$\mathrm{H} 12$} & 2.1 & $\mathrm{mg} / \mathrm{kg}$ \\
\hline Benzo(a)pyrene & $0.092(\mathrm{~J})$ & & & & 0.21 & $\mathrm{mg} / \mathrm{kg}$ \\
\hline Benzo(b)fluoranthene & $0.11(\mathrm{~J})$ & & & & 2.1 & $\mathrm{mg} / \mathrm{kg}$ \\
\hline Benzo(g,h,i)perylene & $0.086(\mathrm{~J})$ & & & & 17,000 & $\mathrm{mg} / \mathrm{kg}$ \\
\hline Bis(2-ethylhexyl)phthalate & $0.16(\mathrm{~J})$ & & & & 120 & $\mathrm{mg} / \mathrm{kg}$ \\
\hline Chrysene & $0.076(\mathrm{~J})$ & & & & 210 & $\mathrm{mg} / \mathrm{kg}$ \\
\hline Di-n-butyl phthalate & $0.29(\mathrm{~J})$ & & & & 62,000 & $\mathrm{mg} / \mathrm{kg}$ \\
\hline Fluoranthene & $0.15(\mathrm{~J})$ & & & & 22,000 & $\mathrm{mg} / \mathrm{kg}$ \\
\hline Phenanthrene & $0.21(\mathrm{~J})$ & & & & 170,000 & $\mathrm{mg} / \mathrm{kg}$ \\
\hline Pyrene & $0.43(\mathrm{~J})$ & & & & 17,000 & $\mathrm{mg} / \mathrm{kg}$ \\
\hline
\end{tabular}

$\mathrm{J}=$ Estimated value

\subsubsection{French Drain (CAS 02-60-07)}

Corrective Action Site 02-60-07 was determined not to exist; therefore, no sampling was completed.

\subsubsection{Mud Trap Drain and Outfall (CAS 23-60-01)}

The environmental and PSM sample results are discussed in the sections below.

\subsection{Environmental Sample Results}

With the exception of TPH-DRO and lead, all concentrations of the reported parameters were less than the PALs.

Six samples exceeded the PAL of $100 \mathrm{mg} / \mathrm{kg}$ for TPH-DRO. The TPH-DRO was moved on to a Tier 2 evaluation, and FALs were established for the hazardous constituents of TPH-DRO. Concentrations of the hazardous constituents of TPH-DRO did not exceed FALs. Therefore, TPH-DRO is not considered a COC. 
Table 2-15

Maximum Concentration of Detected Contaminants for CAS 02-60-06, French Drain

\begin{tabular}{|c|c|c|c|c|c|c||}
\hline Contaminant & $\begin{array}{c}\text { Maximum } \\
\text { Result }\end{array}$ & $\begin{array}{c}\text { Sample } \\
\text { Number }\end{array}$ & $\begin{array}{c}\text { Depth } \\
\text { (ft bgs) }\end{array}$ & Location & FAL & Units \\
\hline \hline Ac-228 & 2.22 & 5621003 & $7.0-7.5$ & 101 & 5 & $\mathrm{pCi} / \mathrm{g}$ \\
\hline Arcolor 1016 & $0.021(\mathrm{~J})$ & 5621001 & $3.0-3.5$ & 101 & 21 & $\mathrm{mg} / \mathrm{kg}$ \\
\hline Aroclor 1260 & $0.081(\mathrm{~J})$ & 5621001 & $3.0-3.5$ & 101 & 0.74 & $\mathrm{mg} / \mathrm{kg}$ \\
\hline Arsenic & $9(\mathrm{~J})$ & 5621001 & $3.0-3.5$ & 101 & 23 & $\mathrm{mg} / \mathrm{kg}$ \\
\hline Antimony & 7.6 & 5621001 & $3.0-3.5$ & 101 & 410 & $\mathrm{mg} / \mathrm{kg}$ \\
\hline Barium & 200 & 5621001 & $3.0-3.5$ & 101 & 190,000 & $\mathrm{mg} / \mathrm{kg}$ \\
\hline Bis(2-ethylhexyl)phthalate & 1.4 & 5621001 & $3.0-3.5$ & 101 & 120 & $\mathrm{mg} / \mathrm{kg}$ \\
\hline Cadmium & 44 & 5621001 & $3.0-3.5$ & 101 & 800 & $\mathrm{mg} / \mathrm{kg}$ \\
\hline Chromium & $120(\mathrm{~J})$ & 5621001 & $3.0-3.5$ & 101 & 450 & $\mathrm{mg} / \mathrm{kg}$ \\
\hline DRO & 850 & 5621001 & $3.0-3.5$ & 101 & $\mathrm{~N} / \mathrm{A}$ & $\mathrm{mg} / \mathrm{kg}$ \\
\hline Lead & 280 & 5621001 & $3.0-3.5$ & 101 & 800 & $\mathrm{mg} / \mathrm{kg}$ \\
\hline Mercury & $0.25(\mathrm{~J}-)$ & 5621001 & $3.0-3.5$ & 101 & 34 & $\mathrm{mg} / \mathrm{kg}$ \\
\hline Silver & $26(\mathrm{~J})$ & 5621001 & $3.0-3.5$ & 101 & 5,100 & $\mathrm{mg} / \mathrm{kg}$ \\
\hline
\end{tabular}

$\mathrm{J}=$ Estimated value

$\mathrm{J}-=$ Result is an estimated quantity but may be biased low.

Concentrations of lead that exceeded the PAL were detected at one location (K05) just above the outfall opening (1.0 to $1.5 \mathrm{ft}$ bgs). Sample 562K006 had a concentration of 1,000 mg/kg, which exceeded the PAL of $800 \mathrm{mg} / \mathrm{kg}$ for lead. A Tier 2 evaluation was performed for the lead concentration. This included the evaluation of risk presented by the lead through the use of the Adult Lead Methodology (ALM) developed by the U.S. Environmental Protection Agency (EPA) (EPA, 2009). The results showed that the lead does not pose an unacceptable risk to human health and is not considered a COC. The calculation of the FAL for lead is presented in Appendix D.

The maximum concentration of each detected contaminant in environmental samples collected at this CAS is listed in Table 2-16. 
Table 2-16

Maximum Concentration of Detected Contaminants for CAS 23-60-01, Mud Trap Drain and Outfall (Page 1 of 2)

\begin{tabular}{|c|c|c|c|c|c|c|}
\hline Contaminant & $\begin{array}{c}\text { Maximum } \\
\text { Result }\end{array}$ & $\begin{array}{l}\text { Sample } \\
\text { Number }\end{array}$ & $\begin{array}{c}\text { Depth } \\
\text { (ft bgs) }\end{array}$ & Location & FAL & Units \\
\hline 2-butanone & 0.022 & $562 \mathrm{~K} 003$ & $0.0-0.5$ & K03 & 200,000 & $\mathrm{mg} / \mathrm{kg}$ \\
\hline 2-methylnaphthalene & $0.093(\mathrm{~J})$ & $562 K 007$ & $2.0-2.5$ & K06 & 4,100 & $\mathrm{mg} / \mathrm{kg}$ \\
\hline 4,4'-DDE & $0.00037(\mathrm{~J})$ & $562 K 001$ & $0.0-0.5$ & K01 & 5.1 & $\mathrm{mg} / \mathrm{kg}$ \\
\hline 4,4'-DDT & $0.0057(\mathrm{~J})$ & $562 K 001$ & $0.0-0.5$ & K01 & 7 & $\mathrm{mg} / \mathrm{kg}$ \\
\hline Acetone & 0.077 & $562 K 003$ & $0.0-0.5$ & K03 & 630,000 & $\mathrm{mg} / \mathrm{kg}$ \\
\hline Ac-228 & 1.06 & $562 K 001$ & $0.0-0.5$ & K01 & 5 & $\mathrm{pCi} / \mathrm{g}$ \\
\hline Aroclor 1260 & $0.24(\mathrm{~J})$ & $562 K 007$ & $2.0-2.5$ & K06 & 0.74 & $\mathrm{mg} / \mathrm{kg}$ \\
\hline Arsenic & 12 & $562 K 006$ & $1.0-1.5$ & K05 & 23 & $\mathrm{mg} / \mathrm{kg}$ \\
\hline Barium & 190 & $562 K 001$ & $0.0-0.5$ & K01 & 190,000 & $\mathrm{mg} / \mathrm{kg}$ \\
\hline Benzo(a)anthracene & $0.12(\mathrm{~J})$ & $562 K 007$ & $2.0-2.5$ & K06 & 2.1 & $\mathrm{mg} / \mathrm{kg}$ \\
\hline Benzo(a)pyrene & $0.15(\mathrm{~J})$ & $562 K 007$ & $2.0-2.5$ & K06 & 0.21 & $\mathrm{mg} / \mathrm{kg}$ \\
\hline Benzo(b)fluoranthene & $0.17(\mathrm{~J})$ & $562 K 007$ & $2.0-2.5$ & K06 & 2.1 & $\mathrm{mg} / \mathrm{kg}$ \\
\hline Benzo(g,h,i)perylene & $0.093(\mathrm{~J})$ & $562 K 007$ & $2.0-2.5$ & K06 & 17,000 & $\mathrm{mg} / \mathrm{kg}$ \\
\hline Bis(2-ethylhexyl)phthalate & 1.6 & $562 K 001$ & $0.0-0.5$ & K01 & 120 & $\mathrm{mg} / \mathrm{kg}$ \\
\hline Cadmium & 2.5 & $562 K 007$ & $2.0-2.5$ & K06 & 800 & $\mathrm{mg} / \mathrm{kg}$ \\
\hline Cs-137 & 0.47 & $562 \mathrm{~K} 007$ & $2.0-2.5$ & K06 & 12.2 & $\mathrm{pCi} / \mathrm{g}$ \\
\hline Chlordane & $0.051(\mathrm{~J})$ & $562 K 001$ & $0.0-0.5$ & $\mathrm{~K} 01$ & 6.5 & $\mathrm{mg} / \mathrm{kg}$ \\
\hline Chromium & 26 & $562 K 001$ & $0.0-0.5$ & K01 & 450 & $\mathrm{mg} / \mathrm{kg}$ \\
\hline Chrysene & $0.14(\mathrm{~J})$ & $562 K 007$ & $2.0-2.5$ & K06 & 210 & $\mathrm{mg} / \mathrm{kg}$ \\
\hline Di-n-butyl phthalate & $0.17(\mathrm{~J})$ & $562 K 001$ & $0.0-0.5$ & K01 & 62,000 & $\mathrm{mg} / \mathrm{kg}$ \\
\hline Di-n-octyl phthalate & $0.1(\mathrm{~J})$ & $562 K 007$ & $2.0-2.5$ & K06 & 25,000 & $\mathrm{mg} / \mathrm{kg}$ \\
\hline DRO & 590 & $562 \mathrm{~K} 003$ & $0.0-0.5$ & K03 & $N / A$ & $\mathrm{mg} / \mathrm{kg}$ \\
\hline Endosulfan sulfate & $0.0019(\mathrm{~J})$ & $562 K 001$ & $0.0-0.5$ & $\mathrm{~K} 01$ & 3,700 & $\mathrm{mg} / \mathrm{kg}$ \\
\hline Fluoranthene & $0.11(\mathrm{~J})$ & $562 K 007$ & $2.0-2.5$ & K06 & 22,000 & $\mathrm{mg} / \mathrm{kg}$ \\
\hline Lead & 1,000 & $562 K 006$ & $1.0-1.5$ & K05 & 1,235 & $\mathrm{mg} / \mathrm{kg}$ \\
\hline Mercury & $0.34(\mathrm{~J})$ & $562 K 006$ & $1.0-1.5$ & K05 & 34 & $\mathrm{mg} / \mathrm{kg}$ \\
\hline Methylene chloride & $0.0049(\mathrm{~J})$ & $562 \mathrm{~K} 003$ & $0.0-0.5$ & K03 & 53 & $\mathrm{mg} / \mathrm{kg}$ \\
\hline Phenanthrene & $0.13(\mathrm{~J})$ & $562 \mathrm{~K} 007$ & $2.0-2.5$ & K06 & 170,000 & $\mathrm{mg} / \mathrm{kg}$ \\
\hline
\end{tabular}


Table 2-16

Maximum Concentration of Detected

Contaminants for CAS 23-60-01, Mud Trap Drain and Outfall

(Page 2 of 2 )

\begin{tabular}{|c|c|c|c|c|c|c|}
\hline Contaminant & $\begin{array}{c}\text { Maximum } \\
\text { Result }\end{array}$ & $\begin{array}{c}\text { Sample } \\
\text { Number }\end{array}$ & $\begin{array}{c}\text { Depth } \\
\text { (ft bgs) }\end{array}$ & Location & FAL & Units \\
\hline \hline Pyrene & $0.21(\mathrm{~J})$ & $562 \mathrm{~K} 007$ & $2.0-2.5$ & $\mathrm{~K} 06$ & 17,000 & $\mathrm{mg} / \mathrm{kg}$ \\
\hline Th-234 & $2.18(\mathrm{~J})$ & $562 \mathrm{~K} 003$ & $0.0-0.5$ & $\mathrm{~K} 03$ & 105 & $\mathrm{pCi} / \mathrm{g}$ \\
\hline
\end{tabular}

$\mathrm{J}=$ Estimated value

\subsection{Potential Source Material Sample Results}

The analytical results for sample 562K004 collected from within the mud trap indicate that lead was detected at $8,900 \mathrm{mg} / \mathrm{kg}$, which exceeds the PAL of $800 \mathrm{mg} / \mathrm{kg}$. The PSM criterion was established at the PAL concentration. Therefore, lead is considered a PSM contaminant. Additionally, TPH-DRO was detected at concentrations of 150 and $170 \mathrm{mg} / \mathrm{kg}$. Consequently, the TPH-DRO was moved on to a Tier 2 evaluation, and FALs were established for the hazardous constituents of TPH-DRO. No hazardous constituents of TPH-DRO exceeded their respective FAL concentrations. Therefore, TPH-DRO is not considered PSM.

Due to the presence of a PSM contaminant (lead), the sediment is considered PSM. The maximum concentration of each detected contaminant in environmental samples collected at this CAS is listed in Table 2-17.

Table 2-17

Maximum Concentrations of Detected Contaminants in PSM Samples from for CAS 23-60-01, Mud Trap Drain and Outfall

(Page 1 of 2)

\begin{tabular}{||c|c|c|c|c|c|c|}
\hline Contaminant & $\begin{array}{c}\text { Maximum } \\
\text { Result }\end{array}$ & $\begin{array}{c}\text { Sample } \\
\text { Number }\end{array}$ & $\begin{array}{c}\text { Depth } \\
\text { (ft bgs) }\end{array}$ & Location & $\begin{array}{c}\text { PSM } \\
\text { Criteria }\end{array}$ & Units \\
\hline \hline DRO & $170(\mathrm{~J})$ & $562 \mathrm{~K} 005$ & $3.0-3.5$ & $\mathrm{~K} 04$ & $\mathrm{~N} / \mathrm{A}$ & $\mathrm{mg} / \mathrm{kg}$ \\
\hline Arsenic & 9.4 & $562 \mathrm{~K} 004$ & $3.0-3.5$ & $\mathrm{~K} 04$ & 23 & $\mathrm{mg} / \mathrm{kg}$ \\
\hline Barium & $690(\mathrm{~J})$ & $562 \mathrm{K005}$ & $3.0-3.5$ & $\mathrm{~K} 04$ & 190,000 & $\mathrm{mg} / \mathrm{kg}$ \\
\hline Cadmium & 4 & $562 \mathrm{~K} 004$ & $3.0-3.5$ & $\mathrm{~K} 04$ & 800 & $\mathrm{mg} / \mathrm{kg}$ \\
\hline Chromium & $29(\mathrm{~J})$ & $562 \mathrm{~K} 004$ & $3.0-3.5$ & $\mathrm{~K} 04$ & 450 & $\mathrm{mg} / \mathrm{kg}$ \\
\hline Lead & $\mathbf{8 , 9 0 0}$ & $562 \mathrm{K004}$ & $3.0-3.5$ & $\mathrm{~K} 04$ & 800 & $\mathrm{mg} / \mathrm{kg}$ \\
\hline
\end{tabular}


Table 2-17

Maximum Concentrations of Detected Contaminants in PSM Samples from for CAS 23-60-01, Mud Trap Drain and Outfall (Page 2 of 2)

\begin{tabular}{|c|c|c|c|c|c|c|}
\hline Contaminant & $\begin{array}{c}\text { Maximum } \\
\text { Result }\end{array}$ & $\begin{array}{l}\text { Sample } \\
\text { Number }\end{array}$ & $\begin{array}{l}\text { Depth } \\
\text { (ft bgs) }\end{array}$ & Location & $\begin{array}{c}\text { PSM } \\
\text { Criteria }\end{array}$ & Units \\
\hline Mercury & $0.43(\mathrm{~J})$ & $562 K 004$ & $3.0-3.5$ & K04 & 34 & $\mathrm{mg} / \mathrm{kg}$ \\
\hline Selenium & 0.33 & $562 K 005$ & $3.0-3.5$ & K04 & 5,100 & $\mathrm{mg} / \mathrm{kg}$ \\
\hline Silver & 0.2 & $562 K 004$ & $3.0-3.5$ & K04 & 5,100 & $\mathrm{mg} / \mathrm{kg}$ \\
\hline Aroclor 1260 & $0.48(\mathrm{~J})$ & $562 K 004$ & $3.0-3.5$ & K04 & 0.74 & $\mathrm{mg} / \mathrm{kg}$ \\
\hline Benzo(b)fluoranthene & $0.14(\mathrm{~J})$ & $562 K 005$ & $3.0-3.5$ & K04 & 2.1 & $\mathrm{mg} / \mathrm{kg}$ \\
\hline Bis(2-ethylhexyl)phthalate & 8.3 & $562 K 004$ & $3.0-3.5$ & K04 & 120 & $\mathrm{mg} / \mathrm{kg}$ \\
\hline Chrysene & $0.16(\mathrm{~J})$ & $562 K 005$ & $3.0-3.5$ & K04 & 210 & $\mathrm{mg} / \mathrm{kg}$ \\
\hline Di-n-butyl phthalate & $0.11(\mathrm{~J})$ & $562 K 005$ & $3.0-3.5$ & K04 & 62,000 & $\mathrm{mg} / \mathrm{kg}$ \\
\hline Fluoranthene & 0.55 & $562 K 005$ & $3.0-3.5$ & K04 & 22,000 & $\mathrm{mg} / \mathrm{kg}$ \\
\hline Phenanthrene & $0.086(\mathrm{~J})$ & $562 K 005$ & $3.0-3.5$ & K04 & 170,000 & $\mathrm{mg} / \mathrm{kg}$ \\
\hline Pyrene & 0.52 & 562 K005 & $3.0-3.5$ & K04 & 17,000 & $\mathrm{mg} / \mathrm{kg}$ \\
\hline Ac-228 & 1.32 & 562 K005 & $3.0-3.5$ & K04 & 5 & $\mathrm{pCi} / \mathrm{g}$ \\
\hline Cs-137 & 0.67 & 562 K005 & $3.0-3.5$ & K04 & 12.2 & $\mathrm{pCi} / \mathrm{g}$ \\
\hline
\end{tabular}

$\mathrm{J}=$ Estimated value

Bold indicates the value equals or exceeds the PSM criteria.

\subsubsection{Grease Trap (CAS 23-99-06)}

No environmental samples were collected at this CAS. All samples collected were from inside the grease trap and were analyzed as PSM.

Arsenic, Aroclor 1260, chlordane, and TPH-DRO were detected at concentrations exceeding their respective PALs. All four PSM samples (including one FD) exceeded the PAL of $0.74 \mathrm{mg} / \mathrm{kg}$ for Aroclor 1260. Concentrations ranged from 1.1 to $1.4 \mathrm{mg} / \mathrm{kg}$. Four samples contained chlordane at concentrations ranging from 16 to $40 \mathrm{mg} / \mathrm{kg}$, which exceed the PAL of $6.5 \mathrm{mg} / \mathrm{kg}$. One sample contained arsenic at a concentration of $24 \mathrm{mg} / \mathrm{kg}$, which exceeded the PAL of $23 \mathrm{mg} / \mathrm{kg}$. Because the PSM criteria for these contaminants were established as the PALs, Aroclor 1260, chlordane, and arsenic are considered PSM contaminants. 
Additionally, one sample exceeded the PAL of $100 \mathrm{mg} / \mathrm{kg}$ for TPH-DRO. The TPH-DRO was moved on to a Tier 2 evaluation, and PSM criteria were established for the hazardous constituents of TPH-DRO. Concentrations of the hazardous constituents of TPH-DRO did not exceed PSM criteria. Therefore, TPH-DRO is not considered a PSM contaminant.

Because Aroclor 1260, chlordane, and arsenic are PSM contaminants, the sediment within the trap is considered PSM. The maximum concentration of each detected contaminant at this CAS is listed in Table 2-18.

Table 2-18

Maximum Concentration of Detected Contaminants for PSM at CAS 23-99-06, Grease Trap

(Page 1 of 2)

\begin{tabular}{|c|c|c|c|c|c|c|}
\hline Contaminant & $\begin{array}{l}\text { Maximum } \\
\text { Result }\end{array}$ & $\begin{array}{l}\text { Sample } \\
\text { Number }\end{array}$ & $\begin{array}{l}\text { Depth } \\
\text { (ft bgs) }\end{array}$ & Location & $\begin{array}{c}\text { PSM } \\
\text { Criteria }\end{array}$ & Units \\
\hline Ac-228 & 2 & 562L002 & $3.5-4.0$ & L01 & 5 & $\mathrm{pCi} / \mathrm{g}$ \\
\hline Aroclor 1260 & $1.4(\mathrm{~J})$ & 562L001 & $3.5-4.0$ & L01 & 0.74 & $\mathrm{mg} / \mathrm{kg}$ \\
\hline Arsenic & 24 & 562L004 & $3.5-4.0$ & L03 & 23 & $\mathrm{mg} / \mathrm{kg}$ \\
\hline Barium & 390 & 562L001 & $3.5-4.0$ & L01 & 190,000 & $\mathrm{mg} / \mathrm{kg}$ \\
\hline Benzo(a)pyrene & $0.078(\mathrm{~J})$ & 562L004 & $3.5-4.0$ & L03 & 0.21 & $\mathrm{mg} / \mathrm{kg}$ \\
\hline Benzo(b)fluoranthene & $0.21(\mathrm{~J})$ & 562L001 & $3.5-4.0$ & L01 & 2.1 & $\mathrm{mg} / \mathrm{kg}$ \\
\hline Benzo(g,h,i)perylene & $0.31(\mathrm{~J})$ & 562L004 & $3.5-4.0$ & L03 & 17,000 & $\mathrm{mg} / \mathrm{kg}$ \\
\hline Bis(2-ethylhexyl)phthalate & 0.63 & 562L003 & $3.5-4.0$ & L02 & 120 & $\mathrm{mg} / \mathrm{kg}$ \\
\hline Butyl benzyl phthalate & 0.48 & 562L004 & $3.5-4.0$ & L03 & 910 & $\mathrm{mg} / \mathrm{kg}$ \\
\hline Cadmium & 9.9 & 562L001 & $3.5-4.0$ & L01 & 800 & $\mathrm{mg} / \mathrm{kg}$ \\
\hline Cs-137 & 0.62 & 562L004 & $3.5-4.0$ & L03 & 12.2 & $\mathrm{pCi} / \mathrm{g}$ \\
\hline Chlordane & $40(J)$ & 562L003 & $3.5-4.0$ & L02 & 6.5 & $\mathrm{mg} / \mathrm{kg}$ \\
\hline Chromium & $60(\mathrm{~J})$ & 562L001 & $3.5-4.0$ & L01 & 450 & $\mathrm{mg} / \mathrm{kg}$ \\
\hline DRO & $150(\mathrm{~J})$ & 562L004 & $3.5-4.0$ & L03 & N/A & $\mathrm{mg} / \mathrm{kg}$ \\
\hline Indeno(1,2,3-cd)pyrene & $0.21(\mathrm{~J})$ & 562L004 & $3.5-4.0$ & L03 & 2.1 & $\mathrm{mg} / \mathrm{kg}$ \\
\hline Lead & 760 & 562L004 & $3.5-4.0$ & L03 & 800 & $\mathrm{mg} / \mathrm{kg}$ \\
\hline Mercury & 0.22 & 562L004 & $3.5-4.0$ & L03 & 34 & $\mathrm{mg} / \mathrm{kg}$ \\
\hline Pyrene & $0.095(\mathrm{~J})$ & 562L004 & $3.5-4.0$ & L03 & 17,000 & $\mathrm{mg} / \mathrm{kg}$ \\
\hline
\end{tabular}


Table 2-18

\section{Maximum Concentration of Detected Contaminants for PSM} at CAS 23-99-06, Grease Trap

(Page 2 of 2)

\begin{tabular}{|c|c|c|c|c|c|c|}
\hline Contaminant & $\begin{array}{c}\text { Maximum } \\
\text { Result }\end{array}$ & $\begin{array}{c}\text { Sample } \\
\text { Number }\end{array}$ & $\begin{array}{c}\text { Depth } \\
\text { (ft bgs) }\end{array}$ & Location & $\begin{array}{c}\text { PSM } \\
\text { Criteria }\end{array}$ & Units \\
\hline \hline Selenium & 0.57 & $562 \mathrm{LO01}$ & $3.5-4.0$ & $\mathrm{~L} 01$ & 5,100 & $\mathrm{mg} / \mathrm{kg}$ \\
\hline Silver & 0.34 & $562 \mathrm{LOO3}$ & $3.5-4.0$ & $\mathrm{~L} 02$ & 5,100 & $\mathrm{mg} / \mathrm{kg}$ \\
\hline
\end{tabular}

$\mathrm{J}=$ Estimated value

Bold indicates the value equals or exceeds the PSM criteria.

\subsubsection{Building 3123 Outfalls (CAS 25-60-04)}

The environmental and PSM sample results collected at this CAS are discussed in the sections below.

\subsection{Environmental Sample Results}

With the exception of Aroclor 1254, all concentrations of the reported parameters were less than the PALs.

Twelve samples (including one FD) exceeded the PAL of $0.74 \mathrm{mg} / \mathrm{kg}$ for Aroclor 1254 .

Concentrations ranged from 0.78 to $11.0 \mathrm{mg} / \mathrm{kg}$ at depth intervals ranging from 0.0 to $2.0 \mathrm{ft}$ bgs. The FAL was established at the PAL concentration; therefore, Aroclor 1254 is considered a COC.

Additional soil samples were collected at distances ranging from 2.0 to $30.0 \mathrm{ft}$ from the outfall at varying depth intervals (including the same depth interval as the location of the COC). These soil samples show that PCBs are limited to the interval of 0.0 to $2.0 \mathrm{ft}$ bgs and that concentrations decrease to below the FALs with distance from the outfall.

The maximum concentration of each detected contaminant in environmental samples collected at this CAS is listed in Table 2-19. 
Table 2-19

Maximum Concentration of Detected

Contaminants for CAS 25-60-04, Building 3123 Outfalls

\begin{tabular}{|c|c|c|c|c|c|c|}
\hline Contaminant & $\begin{array}{c}\text { Maximum } \\
\text { Result }\end{array}$ & $\begin{array}{l}\text { Sample } \\
\text { Number }\end{array}$ & $\begin{array}{c}\text { Depth } \\
\text { (ft bgs) }\end{array}$ & Location & FAL & Units \\
\hline Acetone & 0.024 & $562 \mathrm{M} 044$ & $0.0-0.5$ & M29 & 630,000 & $\mathrm{mg} / \mathrm{kg}$ \\
\hline Ac-228 & 2.08 & 562M001 & $3.0-3.5$ & M01 & 5 & $\mathrm{pCi} / \mathrm{g}$ \\
\hline Aroclor 1254 & 11 & 562M015 & $0.0-0.5$ & M11 & 0.74 & $\mathrm{mg} / \mathrm{kg}$ \\
\hline Aroclor 1260 & 0.16 & $562 \mathrm{M} 047$ & $0.0-0.5$ & M25 & 0.74 & $\mathrm{mg} / \mathrm{kg}$ \\
\hline Arsenic & 4 & $562 \mathrm{M} 042$ & $0.0-0.5$ & M27 & 23 & $\mathrm{mg} / \mathrm{kg}$ \\
\hline Barium & 130 & $562 \mathrm{M} 004$ & $1.5-2.0$ & M03 & 190,000 & $\mathrm{mg} / \mathrm{kg}$ \\
\hline Benzo(a)anthracene & $0.11(\mathrm{~J})$ & $562 \mathrm{M} 043$ & $0.0-0.5$ & M28 & 2.1 & $\mathrm{mg} / \mathrm{kg}$ \\
\hline Bis(2-ethylhexyl)phthalate & 1.1 & $562 \mathrm{M} 004$ & $1.5-2.0$ & M03 & 120 & $\mathrm{mg} / \mathrm{kg}$ \\
\hline Cadmium & 2.5 & $562 \mathrm{M} 006$ & $3.0-3.5$ & M03 & 800 & $\mathrm{mg} / \mathrm{kg}$ \\
\hline Carbon tetrachloride & $0.0027(\mathrm{~J})$ & $562 \mathrm{M} 044$ & $0.0-0.5$ & M29 & 1.2 & $\mathrm{mg} / \mathrm{kg}$ \\
\hline Chloroform & 0.0024 & $562 \mathrm{M} 044$ & $0.0-0.5$ & M29 & $0.0024(\mathrm{~J})$ & $\mathrm{mg} / \mathrm{kg}$ \\
\hline Chromium & 5.2 & $562 \mathrm{M} 044$ & $0.0-0.5$ & M29 & 450 & $\mathrm{mg} / \mathrm{kg}$ \\
\hline DRO & $28(\mathrm{~J})$ & 562M002 & $3.0-3.5$ & M02 & $\mathrm{N} / \mathrm{A}$ & $\mathrm{mg} / \mathrm{kg}$ \\
\hline Lead & $39(\mathrm{~J})$ & $562 \mathrm{M} 044$ & $0.0-0.5$ & M29 & 800 & $\mathrm{mg} / \mathrm{kg}$ \\
\hline Mercury & 0.064 & $562 \mathrm{M} 004$ & $1.5-2.0$ & M03 & 34 & $\mathrm{mg} / \mathrm{kg}$ \\
\hline Methylene chloride & $0.0042(\mathrm{~J})$ & $562 \mathrm{M} 004$ & $1.5-2.0$ & M03 & 53 & $\mathrm{mg} / \mathrm{kg}$ \\
\hline Pyrene & 0.088 & $562 \mathrm{M} 043$ & $0.0-0.5$ & M28 & $0.088(\mathrm{~J})$ & $\mathrm{mg} / \mathrm{kg}$ \\
\hline Selenium & 0.41 & $562 \mathrm{M} 043$ & $0.0-0.5$ & M28 & 0.41 & $\mathrm{mg} / \mathrm{kg}$ \\
\hline Silver & 0.37 & 562M006 & $3.0-3.5$ & M03 & 5,100 & $\mathrm{mg} / \mathrm{kg}$ \\
\hline Th-234 & $2.36(\mathrm{~J})$ & $562 \mathrm{M} 003$ & $3.0-3.5$ & M02 & 105 & $\mathrm{pCi} / \mathrm{g}$ \\
\hline
\end{tabular}

$\mathrm{J}=$ Estimated value

Bold indicates the value equals or exceeds the FAL. 


\subsection{Potential Source Material Sample Results}

Medium sampled consisted of sludge from the outfall piping. The sludge sample contained a concentration of $3,500 \mathrm{mg} / \mathrm{kg}$ of TPH-DRO, which exceeded the PAL of $100 \mathrm{mg} / \mathrm{kg}$. The TPH-DRO was moved on to a Tier 2 evaluation, and PSM criteria were established for the hazardous constituents of TPH-DRO. Concentrations of the hazardous constituents of TPH-DRO did not exceed PSM criteria. Therefore, TPH-DRO is not considered a PSM contaminant.

Lead and Aroclor 1254 were also found at concentrations exceeding their respective PSM criteria. Lead was detected at a concentration of $970 \mathrm{mg} / \mathrm{kg}$, and Aroclor 1254 was detected at a concentration of $8.7 \mathrm{mg} / \mathrm{kg}$. Lead and Aroclor 1254, therefore, are considered PSM contaminants.

Based on the presence of PSM contaminants, the sludge in the pipe is considered PSM. The maximum concentration of each detected contaminant in environmental samples collected at this CAS is listed in Table 2-20.

\subsubsection{Data Assessment Summary}

The DQA is presented in Appendix B and includes an evaluation of the DQIs to determine the degree of acceptability and usability of the reported data in the decision-making process. The DQO process ensures that the right type, quality, and quantity of data will be available to support the resolution of those decisions at an appropriate level of confidence. Using both the DQO and DQA processes helps ensure that DQO decisions are sound and defensible.

The DQA process as presented in Appendix B is composed of the following steps:

- Step 1: Review DQOs and Sampling Design

- Step 2: Conduct a Preliminary Data Review

- Step 3: Select the Test

- Step 4: Verify the Assumptions

- Step 5: Draw Conclusions from the Data

Sample locations that support the presence and/or extent of contamination at each CAS are shown in Appendix B. Based on the results of the DQA presented in Appendix B, the nature and extent of COCs at CAU 562 have been adequately identified to develop and evaluate CAAs. The DQA also 
Table 2-20

\section{Maximum Concentration of Detected Contaminants in PSM Samples from for CAS 25-60-04, Building 3123 Outfalls}

\begin{tabular}{|c|c|c|c|c|c|c|}
\hline Contaminant & $\begin{array}{c}\text { Maximum } \\
\text { Result }\end{array}$ & $\begin{array}{l}\text { Sample } \\
\text { Number }\end{array}$ & $\begin{array}{l}\text { Depth } \\
\text { (ft bgs) }\end{array}$ & Location & $\begin{array}{c}\text { PSM } \\
\text { Criteria }\end{array}$ & Units \\
\hline DRO & 3,500 & 562M005 & $1.0-1.5$ & M03 & $\mathrm{N} / \mathrm{A}$ & $\mathrm{mg} / \mathrm{kg}$ \\
\hline Arsenic & $2.8(\mathrm{~J}+)$ & 562M005 & $1.0-1.5$ & M03 & 23 & $\mathrm{mg} / \mathrm{kg}$ \\
\hline Barium & 150 & 562M005 & $1.0-1.5$ & M03 & 190,000 & $\mathrm{mg} / \mathrm{kg}$ \\
\hline Cadmium & 19 & 562M005 & $1.0-1.5$ & M03 & 800 & $\mathrm{mg} / \mathrm{kg}$ \\
\hline Chromium & 130 & 562M005 & $1.0-1.5$ & M03 & 450 & $\mathrm{mg} / \mathrm{kg}$ \\
\hline Lead & 970 & 562M005 & $1.0-1.5$ & M03 & 800 & $\mathrm{mg} / \mathrm{kg}$ \\
\hline Mercury & 0.74 & 562M005 & $1.0-1.5$ & M03 & 34 & $\mathrm{mg} / \mathrm{kg}$ \\
\hline Selenium & 0.84 & 562M005 & $1.0-1.5$ & M03 & 5,100 & $\mathrm{mg} / \mathrm{kg}$ \\
\hline Silver & 17 & 562M005 & $1.0-1.5$ & M03 & 5,100 & $\mathrm{mg} / \mathrm{kg}$ \\
\hline Aroclor 1254 & 8.7 & 562M005 & $1.0-1.5$ & M03 & 0.74 & $\mathrm{mg} / \mathrm{kg}$ \\
\hline 3-methylphenol & 15 & 562M005 & $1.0-1.5$ & M03 & 31,000 & $\mathrm{mg} / \mathrm{kg}$ \\
\hline Bis(2-ethylhexyl)phthalate & $6.8(\mathrm{~J})$ & 562M005 & $1.0-1.5$ & M03 & 120 & $\mathrm{mg} / \mathrm{kg}$ \\
\hline 1,4-dichlorobenzene & $0.019(\mathrm{~J})$ & 562M005 & $1.0-1.5$ & M03 & 12 & $\mathrm{mg} / \mathrm{kg}$ \\
\hline Carbon disulfide & $0.017(\mathrm{~J})$ & 562M005 & $1.0-1.5$ & M03 & 3,700 & $\mathrm{mg} / \mathrm{kg}$ \\
\hline Methylene chloride & $0.058(\mathrm{~J})$ & 562M005 & $1.0-1.5$ & M03 & 53 & $\mathrm{mg} / \mathrm{kg}$ \\
\hline Trichloroethene & $0.032(\mathrm{~J})$ & 562M005 & $1.0-1.5$ & M03 & 14 & $\mathrm{mg} / \mathrm{kg}$ \\
\hline
\end{tabular}

$\mathrm{J}=$ Estimated value

$\mathrm{J}+=$ Result is an estimated quantity but may be biased high.

Bold indicates the value equals or exceeds the PSM criteria.

determined that information generated during the CAI supports the CSM assumptions and that the data collected met the DQOs and support their intended use in the decision-making process.

\subsection{Need for Corrective Action}

Analytes detected during the CAI were evaluated against FALs to identify COCs. A corrective action may also be required if a tank or structure within a CAS contains contamination that, if released, could cause the surrounding environmental media to contain a COC (PSM). Table 2-21 is a summary of the PSM and COCs identified within the boundaries of CAU 562 CASs. 
Table 2-21

Summary of COCs and PSM by CAS

\begin{tabular}{|c|c|c|c|}
\hline CAS & Media & Contaminant(s) & PSM or COC \\
\hline \multirow[t]{2}{*}{ 02-26-11 } & Rusted and non-rusted shot & $\begin{array}{l}\text { Antimony } \\
\text { Arsenic } \\
\text { Lead } \\
\text { Chromium }\end{array}$ & PSM \\
\hline & Soil & None & N/A \\
\hline \multirow[t]{2}{*}{$02-44-02$} & Paint chips & $\begin{array}{c}\text { Chromium } \\
\text { Benzo(a)pyrene } \\
\text { Benzo(b)fluoranthene } \\
\text { Bis(2-ethylhexyl)phthalate } \\
\text { Lead }\end{array}$ & PSM \\
\hline & Soil & Benzo(a)pyrene & $\mathrm{COC}$ \\
\hline \multirow{3}{*}{ 02-59-01 } & Sludge & $\begin{array}{l}\text { 1,4-dichlorobenzene } \\
\text { Naphthalene }\end{array}$ & PSM \\
\hline & Liquid & None & N/A \\
\hline & Soil & None & N/A \\
\hline 02-60-01 & Soil & None & $\mathrm{N} / \mathrm{A}$ \\
\hline $02-60-02$ & Soil & Aroclor 1260 & $\mathrm{COC}$ \\
\hline $02-60-03$ & Soil & $\begin{array}{c}\text { Aroclor } 1260 \\
\text { Benzo(a)pyrene }\end{array}$ & $\mathrm{COC}$ \\
\hline \multirow[t]{2}{*}{$02-60-04$} & Sediment & $\begin{array}{c}\text { Aroclor } 1260 \\
\text { Aroclor } 1268 \\
\text { Benzo(a)pyrene }\end{array}$ & PSM \\
\hline & Soil & None & N/A \\
\hline \multirow[b]{2}{*}{$02-60-05$} & Asphalt & None & N/A \\
\hline & Soil & $\begin{array}{c}\text { Benzo(a)pyrene } \\
\text { Benzo(a)anthracene } \\
\text { Benzo(b)fluoranthene } \\
\text { Benzo(k)fluoranthene } \\
\text { Dibenzo(a,h)anthracene } \\
\text { Indeno(1,2,3-cd)pyrene }\end{array}$ & $\mathrm{COC}$ \\
\hline $02-60-06$ & Soil & None & N/A \\
\hline $02-60-07$ & $\mathrm{~N} / \mathrm{A}$ & None & $\mathrm{N} / \mathrm{A}$ \\
\hline \multirow{2}{*}{$23-60-01$} & Sediment & Lead & PSM \\
\hline & Soil & None & N/A \\
\hline 23-99-06 & Sediment & $\begin{array}{c}\text { Arsenic } \\
\text { Aroclor } 1260 \\
\text { Chlordane }\end{array}$ & PSM \\
\hline \multirow{2}{*}{$25-60-04$} & Sludge & $\begin{array}{l}\text { Aroclor } 1254 \\
\text { Lead }\end{array}$ & PSM \\
\hline & Soil & Aroclor 1254 & $\mathrm{COC}$ \\
\hline
\end{tabular}


To evaluate PSM for the potential to result in the introduction of a COC to the surrounding environmental media, the following conservative assumptions were made:

- Any physical waste containment would fail at some point and the contents would be released to the surrounding media.

- For liquid wastes, the resulting concentration of contaminants in the surrounding soil will be calculated based on the concentration of contaminants in the waste and the liquid-holding capacity of the soil. If the resulting soil concentration exceeds the FAL, then the liquid waste would be considered PSM.

- Any non-liquid waste containing a contaminant exceeding an equivalent FAL concentration would cause a COC to be present in the surrounding media.

Corrective action alternatives are identified and evaluated in Section 3.0. The impacted volume and characteristics are provided in each CAS-specific subsection below. Volume calculations for contaminated material to be removed from each area are shown in Appendix C. Corrective action alternatives are not evaluated for CASs that do not contain COCs or PSM.

The CAAs are identified in Section 3.0 and evaluated for their ability to ensure protection of the public and the environment in accordance with Nevada Administrative Code (NAC) 445A (NAC, 2006a), feasibility, and cost effectiveness.

\subsubsection{Lead Shot (CAS 02-26-11)}

Based on observations made and analytical results of soil samples collected at this CAS, no COCs were identified in the soil. Lead, antimony, arsenic, and chromium were detected in the shot scattered throughout the site boundary, but the soil samples show that the contaminants have not been released into the surrounding soil. The shot was identified as containing contaminants and is distributed throughout the surface of the CAS; however, the shot represents only 2.5 cubic yards $\left(\mathrm{yd}^{3}\right)$. Based on the presence of PSM, the CAAs of clean closure and closure in place with administrative controls will be evaluated for this CAS.

\subsubsection{Paint Spills and French Drain (CAS 02-44-02)}

Based on observations made and analytical results of soil samples collected at this CAS, benzo(a)pyrene is a COC in the surface soil adjacent to the former Painters Shed at sample location 
B08. The extent of COC contamination is limited to the surface from 0.0 to $0.5 \mathrm{ft}$ bgs and comprises approximately $2.0 \mathrm{yd}^{3}$. Samples of the paint collected from locations B05 and B09 showed the presence of various contaminants, but the adjacent soil samples show that the contaminants have not migrated into the surrounding soil. Because of the presence of contaminants in the paint samples, the paint is considered PSM. The volume of PSM to be removed is estimated not to exceed 55 gal. Based on the presence of a COC in the soil and PSM contaminants in paint, the CAAs of clean closure and closure in place with administrative controls will be evaluated for this CAS.

\subsubsection{Septic System (CAS 02-59-01)}

Based on observations made and analytical results for soil samples and septic tank contents collected at this CAS, no COCs were identified in the soil. However, PSM contaminants were identified in the sludge contents of the tank. Because of the presence of PSM contaminants in the sludge samples, the sludge is considered PSM. Based on the presence of PSM, the CAAs of clean closure and closure in place with administrative controls will be evaluated for this CAS.

\subsubsection{Concrete Drain (CAS 02-60-01)}

Based on observations made and analytical results of environmental samples collected at this CAS, no COCs are present at this CAS. Therefore, the selected CAA for this CAS is no further action.

\subsubsection{French Drain (CAS 02-60-02)}

Based on observations made and analytical results of soil samples collected at this CAS, Aroclor 1260 is a COC in the subsurface soil at the original french drain (location E03). The extent of COC contamination is limited to $4.5 \mathrm{ft}$ bgs and affects approximately $2.0 \mathrm{yd}^{3}$. Based on the presence of a COC in the soil, the CAAs of clean closure and closure in place with administrative controls will be evaluated for this CAS.

\subsubsection{Steam Cleaning Drain (CAS 02-60-03)}

Based on observations made and analytical results of soil samples collected at this CAS, benzo(a)pyrene and Aroclor 1260 are COCs. Benzo(a)pyrene was detected in the surface soil located in the sump (location F10), and Aroclor 1260 was detected in the surface soil at a location adjacent to 
the sump (location F07). The extent of benzo(a)pyrene contamination in the sump is limited to $3.0 \mathrm{ft}$ bgs and affects approximately $16.0 \mathrm{yd}^{3}$. The extent of Aroclor 1260 contamination adjacent to the sump is $1.5 \mathrm{ft}$ bgs and affects approximately $10.0 \mathrm{yd}^{3}$. There is a total of $26.0 \mathrm{yd}^{3}$ of COC contamination at this CAS. Based on the presence of COCs in the soil, the CAAs of clean closure and closure in place with administrative controls will be evaluated for this CAS.

\subsubsection{French Drain (CAS 02-60-04)}

Based on observations made and analytical results of soil samples collected at this CAS, no COCs were identified in the soil. Various contaminants were detected in the sediment sample collected at the base of the french drain, but the soil samples show that the contaminants have not migrated into the surrounding soil. Because of the presence of contaminants in the sediment, the sediment is considered PSM. The volume of PSM did not exceed 55 gal. The PSM was removed from the french drain during the sampling effort; therefore, the selected CAA for this CAS is clean closure.

\subsubsection{French Drain (CAS 02-60-05)}

Based on observations made and analytical results of soil samples collected at this CAS, benzo(a)pyrene, benzo(a)anthracene, benzo(b)fluoranthene, benzo(k)fluoranthene, dibenzo(a,h)anthracene, and indeno(1,2,3-cd)pyrene are COCs found at the surface to a depth of $8.0 \mathrm{ft}$ bgs at the french drain (location H01) and $3.0 \mathrm{ft}$ in the adjacent sample location H10. The volume of COC contamination is approximately $48.0 \mathrm{yd}^{3}$. Based on the presence of COCs in the soil, the CAAs of clean closure and closure in place with administrative controls will be evaluated for this CAS.

\subsubsection{French Drain (CAS 02-60-06)}

Based on observations made and analytical results of environmental samples collected at this CAS, no COCs are present at this CAS. Therefore, the selected CAA for this CAS is no further action.

\subsubsection{French Drain (CAS 02-60-07)}

There is no french drain or source of release associated with this CAS; therefore, the selected CAA for this CAS is no further action. 


\subsubsection{Mud Trap Drain and Outfall (CAS 23-60-01)}

Based on observations made and analytical results of soil samples collected at this CAS, no COCs were identified in the soil. Lead was detected in the sediment within the mud trap, but the soil samples show that lead has not resulted in the contamination of soil via the outfall. Because of the presence of lead in the sediment, the sediment is considered PSM and affects approximately $0.5 \mathrm{yd}^{3}$. Based on the presence of PSM, the CAAs of clean closure and closure in place with administrative controls will be evaluated for this CAS.

\subsubsection{Grease Trap (CAS 23-99-06)}

Based on observations made and analytical results of sediment samples collected at this CAS, PSM contaminants were identified. Aroclor 1260, chlordane, and arsenic were detected in the sediment within the grease trap. Because of the presence of these contaminants in the sediment, the sediment is considered PSM and affects approximately $0.5 \mathrm{yd}^{3}$. Based on the presence of PSM, the CAAs of clean closure and closure in place with administrative controls will be evaluated for this CAS.

\subsubsection{Building 3123 Outfalls (CAS 25-60-04)}

Based on observations made and analytical results of soil samples collected at this CAS, Aroclor 1254 is a COC in the surface soil adjacent to the outfall (location M03). The extent of COC contamination is limited to a depth of $3.0 \mathrm{ft}$ bgs and affects approximately $30.0 \mathrm{yd}^{3}$. Sludge samples collected from within the outfall show the presence of lead and Aroclor 1254 exceeding PSM criteria. Because of the presence of these PSM contaminants in the sludge, the sludge is considered PSM. Based on the presence of Aroclor 1254 in the soil (COC) and lead and arcolor 1254 in the sludge (PSM), the CAAs of clean closure and closure in place with administrative controls will be evaluated for this CAS. 


\subsection{Evaluation of Alternatives}

The purpose of this section is to present the corrective action objectives for CAU 562, describe the general standards and decision factors used to screen the various CAAs, and develop and evaluate a set of selected CAAs that will meet the corrective action objectives.

\subsection{Corrective Action Objectives}

The corrective action objective is to ensure that receptors are not subjected to an unacceptable risk from an exposure to a COC. A COC is defined as any contaminant exceeding a risk- or dose-based cleanup goal defined herein as a FAL. A COC may also be defined as a contaminant that, in combination with other like contaminants, is determined to jointly pose an unacceptable risk based on a multiple constituent analysis (NNSA/NSO, 2006). Implementation of the corrective action will ensure that each release site will not pose an unacceptable risk to human health and the environment and that conditions at each site are in compliance with all applicable laws and regulations.

The evaluation of the need for corrective action will include the potential for wastes that are present at a site to cause the future contamination of site environmental media if the wastes were released based on the PSM criteria and assumptions listed in Section 2.3.

The risk-based corrective action (RBCA) process used to establish FALs is described in the Industrial Sites Project Establishment of Final Action Levels (NNSA/NSO, 2006). This process conforms with NAC 445A.227 (NAC, 2006b), which lists the requirements for sites with soil contamination. For the evaluation of corrective actions, NAC 445A.22705 (NAC, 2006c) requires the use of American Society for Testing and Materials (ASTM) Method E1739 (ASTM, 1995) to “conduct an evaluation of the site, based on the risk it poses to public health and the environment, to determine the necessary remediation standards (i.e., FALs) or to establish that corrective action is not necessary.” 
This RBCA process defines three tiers (or levels) of evaluation involving increasingly sophisticated analyses:

- Tier 1 evaluation - Sample results from source areas (highest concentrations) are compared to action levels based on generic (non-site-specific) conditions (i.e., the PALs established in the CAIP [NNSA/NSO, 2009]). The FALs may then be established as the Tier 1 action levels or the FALs may be calculated using a Tier 2 evaluation.

- $\quad$ Tier 2 evaluation - Conducted by calculating Tier 2 site-specific target levels (SSTLs) using site-specific information as inputs to the same or similar methodology used to calculate Tier 1 action levels. The Tier 2 SSTLs are then compared to individual sample results from reasonable points of exposure (as opposed to the source areas as is done in Tier 1) on a point-by-point basis. Total petroleum hydrocarbon (TPH) concentrations will not be used for risk-based decisions under Tier 2 or Tier 3. Rather, the individual chemicals of concern will be compared to the SSTLs.

- Tier 3 evaluation - Conducted by calculating Tier 3 SSTLs on the basis of more sophisticated risk analyses using methodologies described in Method E1739 that consider site-, pathway-, and receptor-specific parameters.

A Tier 1 evaluation was conducted for all COPCs to determine whether contaminant levels satisfy the criteria for a quick regulatory closure or warrant a more site-specific assessment. This was accomplished by comparing individual source area contaminant concentration results to the Tier 1 action levels (the PALs established in the CAIP [NNSA/NSO, 2009]).

The constituents detected at the CAU 562 CASs that exceeded Tier 1 action levels are listed in Table 2-21. The concentrations of all constituents at CASs not listed in the table were below Tier 1 action levels and the corresponding FALs were established as the Tier 1 action levels. Of the constituents at CASs that exceeded Tier 1 action levels, only TPH-DRO and lead in the soil at CAS 23-60-01 were passed on to a Tier 2 evaluation. For the remaining constituents, the FALs were also established as the Tier 1 action levels.

The Tier 2 evaluation of TPH-DRO consisted of evaluating the hazardous constituents of TPH-DRO to the FALs. Because the individual hazardous constituents of TPH-DRO are reported and evaluated in the volatile organic compound (VOC) and SVOC results as potential COCs, TPH-DRO is not considered a COC. Additional details about the Tier 2 evaluation of TPH-DRO are provided in Appendix D. 
The Tier 2 evaluation of lead in the soil at CAS 23-60-01 used site-specific inputs to standard risk procedures contained in the EPA's ALM (EPA, 2009). A Tier 2 action level of 1,235 mg/kg was established as the FAL for lead at CAS 23-60-01.

The FALs for all CAU 562 COPCs are shown in Table 3-1.

Table 3-1

Definition of FALs for CAU 562 COPCs

\begin{tabular}{|c|c|c|c|}
\hline COPCs & Tier 1-Based FALs & Tier 2-Based FALs & Tier 3-Based FALs \\
\hline \hline VOCs & PALs & None & N/A \\
\hline SVOCs & PALs & None & N/A \\
\hline PCBs & PALs & None & N/A \\
\hline Pesticides & PALs & N/A \\
\hline Lead & PAL except for & NAS 23-60-01 & N/A \\
\hline Herbicides \\
(except lead)
\end{tabular}

\subsection{Screening Criteria}

The screening criteria used to evaluate and select the preferred CAAs are identified in the EPA Guidance on RCRA Corrective Action Decision Documents (EPA, 1991) and the Final RCRA Corrective Action Plan (EPA, 1994).

Corrective action alternatives are evaluated based on four general corrective action standards and five remedy selection decision factors. All CAAs must meet the four general standards to be selected for evaluation using the remedy selection decision factors.

The general corrective action standards are as follows:

- Protection of human health and the environment

- Compliance with media cleanup standards

- Control of the source(s) of the release

- Compliance with applicable federal, state, and local standards for waste management 
The remedy selection decision factors are as follows:

- Short-term reliability and effectiveness

- Reduction of toxicity, mobility, and/or volume

- Long-term reliability and effectiveness

- Feasibility

- Cost

\subsubsection{Corrective Action Standards}

The following text describes the corrective action standards used to evaluate the CAAs.

\section{Protection of Human Health and the Environment}

Protection of human health and the environment is a general mandate of the RCRA statute (EPA, 1994). This mandate requires that the corrective action include any necessary protective measures. These measures may or may not be directly related to media cleanup, source control, or management of wastes. The CAAs are evaluated for the ability to protect human health and the environment through an evaluation of risk as presented in Appendix D.

\section{Compliance with Media Cleanup Standards}

The CAAs are evaluated for the ability to meet the proposed media cleanup standards. The media cleanup standards are the FALs defined in Section 3.1.

\section{Control of the Source(s) of the Release}

The CAAs are evaluated for the ability to stop further environmental degradation by controlling or eliminating additional releases that may pose a threat to human health and the environment. Unless source control measures are taken, efforts to clean up releases may be ineffective or, at best, will essentially involve a perpetual cleanup. Therefore, each CAA must provide effective source control to ensure the long-term effectiveness and protectiveness of the corrective action.

\section{Compliance with Applicable Federal, State, and Local Standards for Waste Management}

The CAAs are evaluated for the ability to be conducted in accordance with applicable federal and state regulations (e.g., 40 Code of Federal Regulations [CFR] 260 to 282, “Hazardous Waste Management” [CFR, 2008a]; 40 CFR 761 “Polychlorinated Biphenyls,” [CFR, 2008b]; and NAC 444.842 to 444.980, “Facilities for Management of Hazardous Waste” [NAC, 2008]). 


\subsubsection{Remedy Selection Decision Factors}

The following text describes the remedy selection decision factors used to evaluate the CAAs.

\section{Short-Term Reliability and Effectiveness}

Each CAA must be evaluated with respect to its effects on human health and the environment during implementation of the selected corrective action. The following factors will be addressed for each alternative:

- Protection of the community from potential risks associated with implementation, such as fugitive dusts, transportation of hazardous materials, and explosion

- Protection of workers during implementation

- Environmental impacts that may result from implementation

- The amount of time until the corrective action objectives are achieved

\section{Reduction of Toxicity, Mobility, and/or Volume}

Each CAA must be evaluated for its ability to reduce the toxicity, mobility, and/or volume of the contaminated media. Reduction in toxicity, mobility, and/or volume refers to changes in one or more characteristics of the contaminated media by the use of corrective measures that decrease the inherent threats associated with that media.

\section{Long-Term Reliability and Effectiveness}

Each CAA must be evaluated in terms of risk remaining at the CAU after the CAA has been implemented. The primary focus of this evaluation is on the extent and effectiveness of the control that may be required to manage the risk posed by treatment of residuals and/or untreated wastes.

\section{Feasibility}

The feasibility criterion addresses the technical and administrative feasibility of implementing a CAA and the availability of services and materials needed during implementation. Each CAA must be evaluated for the following criteria:

- Construction and Operation - Refers to the feasibility of implementing a CAA given the existing set of waste and site-specific conditions. 
- Administrative Feasibility - Refers to the administrative activities needed to implement the CAA (e.g., permits, use restrictions [URs], public acceptance, rights of way, offsite approval).

- Availability of Services and Materials - Refers to the availability of adequate offsite and onsite treatment, storage capacity, disposal services, necessary technical services and materials, and prospective technologies for each CAA.

\section{Cost}

Costs for each alternative are estimated for comparison purposes only. The cost estimate for each CAA includes both capital, and operation and maintenance costs, as applicable, and are provided in Appendix C. The following is a brief description of each component:

- Capital Costs - These include direct costs that may consist of materials, labor, construction materials, equipment purchase and rental, excavation and backfilling, sampling and analysis, waste disposal, demobilization, and health and safety measures. Indirect costs are separate and not included in the estimates.

- Operation and Maintenance Costs - These costs are separate and include labor, training, sampling and analysis, maintenance materials, utilities, and health and safety measures. These costs are not included in the estimates.

\subsection{Development of Corrective Action Alternatives}

This section identifies and briefly describes the viable corrective action technologies and the CAAs considered for all of the CASs in CAU 562. Based on the review of existing data, future use, and current operations at the NTS, the following alternatives have been developed for consideration at CAU 562:

- Alternative 1 - No further action

- Alternative 2 - Clean closure

- Alternative 3 - Closure in place with administrative controls

\subsubsection{Alternative 1 - No Further Action}

Under the no further action alternative, no CAI activities will be implemented. This alternative is a baseline case with which to compare and assess the other CAAs and their ability to meet the corrective action standards. Although no further action is required, a best management practice (BMP) can be implemented that allows for the removal of debris and closure of components that have been shown not to contain PSM. All contents of the components will be removed and 
disposed of at an appropriate facility and the structures (e.g., septic tank, traps) will be filled with inert material or removed.

\subsubsection{Alternative 2 - Clean Closure}

For contaminated surface and subsurface soil, Alternative 2 includes excavating and disposing of all impacted soil and debris containing COCs. A visual inspection will be conducted to ensure that surface debris has been removed before the completion of the corrective action. Verification soil samples will also be collected and analyzed for the presence of COCs once the known volume of contaminated soil is removed.

Any contaminated material that is removed will be disposed of at an appropriate disposal facility. All excavated areas will be returned to surface conditions compatible with the intended future use of the site. Overburden soil (as feasible), along with additional clean fill, will be used to backfill excavations after removal of the contaminated soil. Clean borrow soil may be removed from a nearby location for placement in the excavation, as necessary.

This alternative also includes the BMP of removing debris and structures containing PSM. All contents of the CAS components will be removed and disposed of at an appropriate facility, and the structures will be filled with inert material or removed for disposal.

\subsubsection{Alternative 3 - Closure in Place with Administrative Controls}

For contaminated surface and subsurface soil, Alternative 3 includes the administrative activities and costs associated with UR for CASs where contamination is present at levels that exceed the FALs. Administrative controls will restrict inadvertent contact with contaminated media by prohibiting any activity that would cause significant exposure of site occupants to the identified COCs.

This alternative also includes the BMP of removing debris and structures containing PSM. All contents of the contaminated components will be removed and disposed of at an appropriate facility, and the structures will be filled with inert material or removed for disposal. 


\subsection{Evaluation and Comparison of Alternatives}

Each CAA presented in Section 3.3 will be evaluated based on the general corrective action standards described in Section 3.2. Evaluation and comparison of alternative for CASs 02-26-11, 02-44-02, 02-59-01, 02-60-02, 02-60-03, 02-60-04, 02-60-05, 23-60-01, 23-99-06, and 25-60-04 will be considered as a group because the contamination characteristics and the potential remediation alternatives at these sites are similar. This evaluation is presented in Table 3-2. Corrective action alternatives will also be evaluated for CASs 02-60-01, 02-60-06, and 02-60-07 as a group because no COCs were detected at these sites (Table 3-3). Any CAA that does not meet the general corrective action standards will be removed from consideration. The remaining CAAs will be further evaluated based on the remedy selection decision factors described in Section 3.2. As no COCs are present at CASs 02-60-01, 02-60-06, and 02-60-07, implementing the corrective actions of clean closure or closure in place with administrative controls would cause significant site disturbance without a corresponding reduction in risk to human health or the environment. Therefore, the group consisting of CASs 02-60-01, 02-60-06, and 02-60-07 will not be evaluated for the remedy selection decision factors as they did not meet the general corrective action standards. The selected CAA for these CASs is the corrective action of no further action.

The evaluation of the remedy selection decision factors is presented in Table 3-4. For each remedy selection decision factor, the CAAs are ranked relative to each other. The CAA with the least desirable impact on the remedy selection decision factor will be given a ranking of 1 . The CAAs with increasingly desirable impacts on the remedy selection decision factor will receive increasing ranking numbers. The CAAs that will have an equal impact on the remedy selection decision factor will receive an equal ranking number. The scoring listed in this table represents the sum of the remedy selection decision factor rankings for each CAA. 
Table 3-2

Evaluation of General Corrective Action Standards

\begin{tabular}{|c|c|c|}
\hline \multicolumn{3}{|c|}{$\begin{array}{c}\text { CASs 02-26-11, 02-44-02, 02-59-01, 02-60-02, 02-60-03, 02-60-04, } \\
\text { 02-60-05, 23-60-01, 23-99-06, and 25-60-04 }\end{array}$} \\
\hline Standard & Comply? & Explanation \\
\hline \multicolumn{3}{|c|}{ CAA 1, No Further Action } \\
\hline Protection of Human Health and the Environment & No & COCs are present. \\
\hline Compliance with Media Cleanup Standards & No & COCs are present. \\
\hline Control the Source(s) of the Release & Yes & Original source of the waste is no longer present. \\
\hline $\begin{array}{l}\text { Comply with Applicable Federal, State, and Local } \\
\text { Standards for Waste Management }\end{array}$ & Yes & This alternative will not generate waste. \\
\hline \multicolumn{3}{|c|}{ CAA 2, Clean Closure } \\
\hline Protection of Human Health and the Environment & Yes & $\begin{array}{l}\text { Contamination exceeding the risk-based action levels will } \\
\text { be removed. }\end{array}$ \\
\hline Compliance with Media Cleanup Standards & Yes & $\begin{array}{l}\text { Contamination exceeding the risk-based action levels will } \\
\text { be removed. }\end{array}$ \\
\hline Control the Source(s) of the Release & Yes & Original source of the waste is no longer present. \\
\hline $\begin{array}{l}\text { Comply with Applicable Federal, State, and Local } \\
\text { Standards for Waste Management }\end{array}$ & Yes & $\begin{array}{l}\text { Excavated waste would be managed in compliance with all } \\
\text { standards. }\end{array}$ \\
\hline \multicolumn{3}{|c|}{ CAA 3, Closure in Place with Administrative Controls } \\
\hline Protection of Human Health and the Environment & Yes & $\begin{array}{l}\text { Use restrictions will be implemented to protect site workers } \\
\text { from contamination exceeding the risk-based action levels. }\end{array}$ \\
\hline Compliance with Media Cleanup Standards & Yes & $\begin{array}{l}\text { Although COCs will not be removed, site workers will not be } \\
\text { exposed to COCs. }\end{array}$ \\
\hline Control the Source(s) of the Release & Yes & Original source of the waste is no longer present. \\
\hline $\begin{array}{l}\text { Comply with Applicable Federal, State, and Local } \\
\text { Standards for Waste Management }\end{array}$ & Yes & This alternative will not generate waste. \\
\hline
\end{tabular}


Table 3-3

Evaluation of General Corrective Action Standards

\begin{tabular}{|c|c|c|}
\hline \multicolumn{3}{|c|}{ CASs 02-60-01, 02-60-06, and 02-60-07 } \\
\hline Standard & Comply? & Explanation \\
\hline \multicolumn{3}{|c|}{ CAA 1, No Further Action } \\
\hline $\begin{array}{l}\text { Protection of Human Health and the } \\
\text { Environment }\end{array}$ & Yes & COCs are not present. \\
\hline $\begin{array}{l}\text { Compliance with Media Cleanup } \\
\text { Standards }\end{array}$ & Yes & COCs are not present. \\
\hline Control the Source(s) of the Release & Yes & Original source of the waste is no longer present. \\
\hline $\begin{array}{l}\text { Comply with Applicable Federal, State, and } \\
\text { Local Standards for Waste Management }\end{array}$ & Yes & This alternative will not generate waste. \\
\hline $\begin{array}{l}\text { Compliance with Media Cleanup } \\
\text { Standards }\end{array}$ & Yes & Site already complies with media cleanup standards. \\
\hline Control the Source(s) of the Release & Yes & Original source of the waste is no longer present. \\
\hline $\begin{array}{l}\text { Comply with Applicable Federal, State, and } \\
\text { Local Standards for Waste Management }\end{array}$ & Yes & Any removed media would already comply with waste standards. \\
\hline \multicolumn{3}{|c|}{ CAA 3, Closure in Place with Administrative Controls } \\
\hline $\begin{array}{l}\text { Comply with Applicable Federal, State, and } \\
\text { Local Standards for Waste Management }\end{array}$ & Yes & This alternative will not generate waste. \\
\hline
\end{tabular}


Table 3-4

Evaluation of Remedy Selection Decision Factors

\begin{tabular}{|c|c|c|}
\hline \multicolumn{3}{|c|}{$\begin{array}{c}\text { CASs } 02-26-11,02-44-02,02-59-01,02-60-02,02-60-03,02-60-04,02-60-05,23-60-01 \text {, } \\
23-99-06 \text {, and } 25-60-04\end{array}$} \\
\hline \multicolumn{3}{|c|}{ CAA 1, No Further Action } \\
\hline Factor & Rank & Explanation \\
\hline \multicolumn{3}{|c|}{ Not evaluated as this CAA did not meet the General Corrective Action Standards } \\
\hline \multicolumn{3}{|r|}{ CAA 2, Clean Closure } \\
\hline Standard & Rank & Explanation \\
\hline Short-Term Reliability and Effectiveness & 1 & $\begin{array}{l}\text { This alternative is reliable and effective but involves increased } \\
\text { short-term exposure of site workers to COCs. }\end{array}$ \\
\hline $\begin{array}{l}\text { Reduction of Toxicity, Mobility, and/or } \\
\text { Volume }\end{array}$ & 2 & $\begin{array}{l}\text { This alternative will result in a decrease of toxicity and mobility but will } \\
\text { generate moderate waste volumes. }\end{array}$ \\
\hline Long-Term Reliability and Effectiveness & 2 & $\begin{array}{l}\text { This alternative is reliable and effective at protecting human health } \\
\text { and the environment because removal of contaminated media will } \\
\text { prevent future exposure of site workers to COCs. }\end{array}$ \\
\hline Feasibility & 2 & $\begin{array}{l}\text { Removal of the contamination is easier than long-term maintenance } \\
\text { of a use restriction. }\end{array}$ \\
\hline Cost & 2 & $\begin{array}{l}\text { The excavation and waste disposal costs for this alternative are less } \\
\text { than the long-term maintenance costs (see Appendix C for details). }\end{array}$ \\
\hline Score & 9 & \\
\hline \multicolumn{3}{|c|}{ CAA 3, Closure in Place with Administrative Controls } \\
\hline Standard & Rank & Explanation \\
\hline Short-Term Reliability and Effectiveness & 2 & $\begin{array}{l}\text { This alternative is reliable and effective in providing increased } \\
\text { protection of human health by preventing contact with cOCs. }\end{array}$ \\
\hline $\begin{array}{l}\text { Reduction of Toxicity, Mobility, and/or } \\
\text { Volume }\end{array}$ & 1 & $\begin{array}{l}\text { This alternative will not reduce toxicity or mobility of the COCs that are } \\
\text { present but will not generate excavation waste volumes. }\end{array}$ \\
\hline Long-Term Reliability and Effectiveness & 1 & $\begin{array}{l}\text { This alternative is reliable in the long term with ongoing maintenance. } \\
\text { It is effective in providing increased protection of human health by } \\
\text { preventing contact with COCs. }\end{array}$ \\
\hline Feasibility & 1 & $\begin{array}{l}\text { This alternative is easily implemented but requires long-term } \\
\text { maintenance. }\end{array}$ \\
\hline Cost & 1 & $\begin{array}{l}\text { The installation and ongoing maintenance costs for this alternative are } \\
\text { more than the other CAA (see Appendix C for details). }\end{array}$ \\
\hline Score & 6 & \\
\hline
\end{tabular}




\subsection{Recommended Alternatives}

The two CAAs evaluated for CASs 02-26-11, 02-44-02, 02-59-01, 02-60-02, 02-60-03, 02-60-04, 02-60-05, 23-60-01, 23-99-06, and 25-60-04 were judged to meet all requirements for the general corrective action standards. As discussed in Section 2.3, the only CAA evaluated for CASs 02-60-01, 02-60-06, and 02-60-07 was no further action because COCs were not detected at these sites and the corrective actions of clean closure and closure in place with administrative controls did not meet the general corrective action standards. The recommended CAAs presented in this section meet all applicable federal and state regulations for closure of the sites and will minimize potential future exposure pathways to the contaminated media at CAU 562.

Alternative 1, no further action, is the preferred corrective action for CASs 02-60-01, 02-60-06, and 02-60-07. Selection of this CAA is consistent with past practices for CASs that do not contain COCs. For CAS features that were collection points for liquids, the following activities should be conducted as a BMP:

- CAS 02-60-01, Concrete Drain: Remove the concrete drain.

- CAS 02-60-06, French Drain: Dispose of the drain casing that was removed during the CAI.

Because no french drain or source of release was identified at CAS 02-60-07, no site-specific activity is recommended for this CAS. Alternative 2, clean closure, was the highest-scoring CAA in Table 3-4 and is selected as the preferred corrective action for CASs 02-26-11, 02-44-02, 02-59-01, 02-60-02, 02-60-03, 02-60-04, 02-60-05, 23-60-01, 23-99-06, and 25-60-04. Selection of this CAA is consistent with past practices for CASs that contain COCs where the removal of contaminated media is feasible, the alternative is cost-effective, the selected alternative can be safely completed, and future activity is expected. The CAS-specific activities recommended to meet the requirements of Alternative 2 include the following:

- CAS 02-26-11, Lead Shot: Remove the shot.

- CAS 02-44-02, Paint Spills and French Drain: Remove paint and contaminated soil near the former Painters Shed. Dispose of the drain casing and asbestos tile as a BMP.

- CAS 02-59-01, Septic System: Remove the septic tank contents as PSM. Remove the septic tank as a BMP. 
- CAS 02-60-02, French Drain: Remove the contaminated soil at the original french drain location. Dispose of the drain casings as a BMP.

- CAS 02-60-03, Steam Cleaning Drain: Remove contaminated soil from the sump and surrounding area. Remove the steam cleaning sump grate and outfall pipe as a BMP.

- CAS 02-60-04, French Drain: The PSM was removed during the CAI; however, the contaminated material needs to be properly disposed of. Dispose of the drain casing and concrete debris as a BMP.

- CAS 02-60-05, French Drain: Remove the contaminated soil from the french drain and surrounding area. Dispose of the drain casing as a BMP.

- CAS 23-60-01, Mud Trap and Outfall: Remove the PSM from the mud trap. Remove and dispose of the mud trap and outfall pipe as a BMP.

- CAS 23-99-06, Grease Trap: Remove the PSM from the grease trap. Backfill the grease trap with an inert material.

- CAS 25-60-04, Building 3123 Outfalls: Remove the contaminated soil from the outfall discharge area. Remove the outfall pipe containing PSM.

Alternative 3, closure in place with administrative controls, was not selected as the preferred corrective action for any CASs within CAU 562. 


\subsection{References}

ASTM, see American Society for Testing and Materials.

American Society for Testing and Materials. 1995 (reapproved 2002). Standard Guide for Risk-Based Corrective Action Applied at Petroleum Release Sites, ASTM E1739 - 95(2002). Philadelphia, PA.

CFR, see Code of Federal Regulations.

Code of Federal Regulations. 2008a. Title 40 CFR Parts 260 to 282, "Hazardous Waste Management.” Washington, DC: U.S. Government Printing Office.

Code of Federal Regulations. 2008b. Title 40 CFR 761, "Polychlorinated Biphenyls (PCBs) Manufacturing, Processing, Distribution in Commerce and Prohibitions.” Washington, DC: U.S. Government Printing Office.

EPA, see U.S. Environmental Protection Agency.

FFACO, see Federal Facility Agreement and Consent Order.

Federal Facility Agreement and Consent Order. 1996 (as amended March 2010). Agreed to by the State of Nevada; U.S. Department of Energy, Environmental Management; U.S. Department of Defense; and U.S. Department of Energy, Legacy Management.

NAC, see Nevada Administrative Code.

N-I GIS, see Navarro-Intera Geographic Information Systems.

NNSA/NSO, see U.S. Department of Energy, National Nuclear Security Administration Nevada Site Office.

NNSA/NV, see U.S. Department of Energy, National Nuclear Security Administration Nevada Operations Office.

Navarro-Intera Geographic Information Systems. 2010. ESRI ArcGIS Software.

Nevada Administrative Code. 2008. NAC 444, “Sanitation.” Carson City, NV. As accessed at http://www.leg.state.nv.us/nac on 4 December.

Nevada Administrative Code. 2006a. NAC 445A, “Water Controls.” Carson City, NV. As accessed at http://www.leg.state.nv.us/nac on 4 December 2008. 
Nevada Administrative Code. 2006b. NAC 445A.227, "Contamination of Soil: Order by Director for Corrective Action; Factors To Be Considered in Determining Whether Corrective Action Required.” Carson City, NV. As accessed at http://www.leg.state.nv.us/nac on 4 December 2008.

Nevada Administrative Code. 2006c. NAC 445A.22705, “Contamination of Soil: Evaluation of Site by Owner or Operator; Review of Evaluation by Division.” Carson City, NV. As accessed at http://www.leg.state.nv.us/nac on 4 December 2008.

REECo, see Reynolds Electrical \& Engineering Co., Inc.

Reynolds Electrical \& Engineering Co., Inc. 1995. Area 2 Base Camp Closure Demolition and Environmental Total Estimated Cost. August. U.S. Department of Energy, Project Development and Management Division.

U.S. Department of Energy, National Nuclear Security Administration Nevada Operations Office. 2002. Industrial Sites Quality Assurance Project Plan, Nevada Test Site, Nevada, Rev. 3, DOE/NV--372. Las Vegas, NV.

U.S. Department of Energy, National Nuclear Security Administration Nevada Site Office. 2009. Corrective Action Investigation Plan for Corrective Action Unit 562: Waste Systems, Nevada Test Site, Nevada, Rev. 0, DOE/NV--1317. Las Vegas, NV.

U.S. Department of Energy, National Nuclear Security Administration Nevada Site Office. 2006. Industrial Sites Project Establishment of Final Action Levels, Rev. 0, DOE/NV--1107. Las Vegas, NV.

U.S. Environmental Protection Agency. 1991. Guidance on RCRA Corrective Action Decision Documents: The Statement of Bases, Final Decision and Response to Comments, EPA/540/G-91/011. Washington, DC: Office of Waste Programs Enforcement.

U.S. Environmental Protection Agency. 1994. Final RCRA Corrective Action Plan, EPA/520-R-94-004. Washington, DC: Office of Solid Waste and Emergency Response.

U.S. Environmental Protection Agency. 2006. Guidance on Systematic Planning Using the Data Quality Objectives Process, EPA QA/G-4, EPA/240/B-06/001. Washington, DC: Office of Environmental Information.

U.S. Environmental Protection Agency. 2009. Update of the Adult Lead Methodology's Default Baseline Blood Lead Concentration and Geometric Standard Deviation Parameters, OSWER 9200.2-82. June. Prepared by the Lead Committee of the Technical Review Workgroup for Metals and Asbestos. Washington, DC: Office of Superfund Remediation and Technology Innovation. 
Weston, see Weston Solutions, Inc.

Weston Solutions, Inc. 2007. After Action Report: Technical Services for Preliminary Assessment Geophysical Investigations, Nevada Test Site Corrective Action Sites, Nye County, Nevada. September. Prepared for Stoller-Navarro Joint Venture. West Chester, PA. 


\section{Appendix A}

Corrective Action Investigation Results 
This appendix presents the CAI activities and analytical results for CAU 562. Corrective Action Unit 562 is located in Areas 2, 23, and 25 of the NTS (Figure 1-1) and includes the 13 CASs listed below:

- $\quad$ CAS 02-26-11, Lead Shot

- CAS 02-44-02, Paint Spills and French Drain

- CAS 02-59-01, Septic System

- CAS 02-60-01, Concrete Drain

- CAS 02-60-02, French Drain

- CAS 02-60-03, Steam Cleaning Drain

- CAS 02-60-04, French Drain

- CAS 02-60-05, French Drain

- CAS 02-60-06, French Drain

- CAS 02-60-07, French Drain

- CAS 23-60-01, Mud Trap Drain and Outfall

- CAS 23-99-06, Grease Trap

- CAS 25-60-04, Building 3123 Outfalls

All of the CASs in CAU 562 consist of site components or debris/spills that had the potential to release contaminants to the environment.

All of the Area 2 CASs in this CAU are located in the former Area 2 Camp, which supported LLNL drilling and construction activities from the mid-1950s to mid-1990s. The components identified in the CAS descriptions as french drains are more aptly constructed like dry wells. A true french drain is designed to remove liquid from the soil, whereas a dry well is designed for disposing of liquids into the soil. However, to be consistent with the FFACO nomenclature (FFACO, 1996; as amended March 2010), the CAS components constructed as dry wells are referred to as french drains in this document.

Corrective Action Site 02-26-11, Lead Shot, consists of potential releases to the soil from rusted and non-rusted shot located in the southwest corner of the former Laborers Storage Area. It is presumed that the shot was stored in this area and that either the shot was spilled or the packaging for the shot deteriorated (i.e., sandbags). 
Corrective Action Site 02-44-02, Paint Spills and French Drain, consists of potential releases to the soil from two french drains, a historical spill, and paint spills associated with activities at the former Painters Shed, Painters Shop, and Paint Storage Rack. It is suspected that fluids associated with the painters' activities were discarded in the french drains and that numerous spills that occurred over time were never cleaned up by personnel working at these three facilities.

Corrective Action Site 02-59-01, Septic System, consists of potential releases to the subsurface soil from a septic system that received sanitary waste from several facilities in the Area 2 Camp via toilets, sinks, service sinks, floor drains, and shower drains. The system consists of a septic tank (approximately 6,300 gal in capacity) and a leachfield that contains nine perforated leach lines.

Corrective Action Site 02-60-01, Concrete Drain, consists of potential releases to the soil from a shallow concrete drain located adjacent to the former Area 2 Tank Farm and Operations Warehouse. The drain was identified as being part of a hand-washing station.

Corrective Action Site 02-60-02, French Drain, consists of potential releases to the soil from two french drains and two elongated drains associated with the former Sheet Metal and Pipefitters Shop. It is suspected that effluent generated as a result of activities at this facility was discharged to both the french drain located on the southeast side of the facility and the french drain/elongated drain system that is present on the northwest side of the facility.

Corrective Action Site 02-60-03, Steam Cleaning Drain, consists of potential releases to the soil from a sump and an adjacent steam cleaning pad with associated outfall located near the former Linemans Shop. There were equipment parts, air conditioner exteriors, and tunnel and heavy construction equipment cleaned in various storage yards in the Area 2 Camp. The sump and pad were suspected to have been used to steam clean vehicles and equipment used in the Linemans Yard.

Corrective Action Site 02-60-04, French Drain, consists of potential releases to the soil from a french drain embedded in a concrete pad located adjacent to the former Refrigeration Shop. The french drain is suspected to have been used in conjunction with activities at the Refrigeration Shop (i.e., cleaning parts and equipment on the concrete pad, disposal of fluids from the shop). 
Corrective Action Site 02-60-05, French Drain, consists of potential releases to the soil from a french drain located adjacent to the Operators Office and the D-38 Storage Yard. The french drain was identified as being used as a hand-washing station, perhaps by personnel occupying the Operators Office or working in the storage yard.

Corrective Action Site 02-60-06, French Drain, consists of potential releases to the soil from a french drain associated with the former Electricians Shop. Documentation states this drain was used in conjunction with a hand washing station, presumably used by personnel working in the Electricians Shop.

Corrective Action Site 02-60-07, French Drain, was identified as a french drain associated with the former Electrical Supply Building. After conducting visual, geophysical, and utility surveys, it was determined that there was not a french drain present. It appears that the document identifying this site, which was used to add this CAS to the FFACO (1996, as amended March 2010), was in error and there is no french drain to address in CAS 02-60-07.

Corrective Action Site 23-60-01, Mud Trap Drain and Outfall, is located in Area 23, Mercury. The CAS consists of potential releases to the soil from a mud trap and outfall that received effluent from washing vehicles in a Wash Shed located in the former Defense Nuclear Agency (DNA) compound. Another component included in this CAS is a grease rack that was used for vehicle maintenance.

Corrective Action Site 23-99-06, Grease Trap, is located in Area 23, Mercury. The CAS consists of potential releases to the soil from a grease trap that received effluent via piping from Building 109, a former commercial gas station. The building is currently the Housing and Revenues office, and the commercial gas station components within the building have been grouted in place.

Corrective Action Site 25-60-04, Building 3123 Outfalls, is located near the RCP in Area 25. The CAS consists of potential releases to the soil from two outfalls associated with various activities in Building 3123. The building was formerly called the Technical Services building, which contained laboratories, shops, and service space.

Additional information regarding the history of each site, planning, and the scope of the investigation is presented in the CAU 562 CAIP (NNSA/NSO, 2009). 


\section{A.1.1 Project Objectives}

The primary objective of the investigation was to provide sufficient information to develop appropriate CAAs and to verify that closure objectives were met for each CAS in CAU 562. This objective was achieved by determining the presence of COCs and the vertical and lateral extent of the COCs, if present.

The selection of soil and/or waste characterization sample locations was based on site conditions and the strategy developed during the DQO process as presented in the CAU 562 CAIP. The sampling strategy was based on a judgmental approach.

\section{A.1.2 Contents}

This appendix contains information and data in sufficient detail to support the selection of preferred CAAs. The contents of this appendix are as follows:

- Section A.1.0 describes the investigation background, objectives, and content.

- $\quad$ Section A.2.0 provides an investigation overview.

- $\quad$ Sections A.3.0 through A.15.0 provide CAS-specific information regarding the field activities, sampling methods, and laboratory analytical results from investigation sampling.

- Section A.16.0 summarizes waste management activities.

- Section A.17.0 discusses the QA and QC procedures followed and results of the QA/QC activities.

- Section A.18.0 is a summary of the investigation results.

- $\quad$ Section A.19.0 lists the cited references.

The complete field documentation and laboratory data-including field activity daily logs (FADLs), sample collection logs (SCLs), analysis request/chain-of-custody forms, soil sample descriptions, laboratory certificates of analyses, analytical results, and surveillance results-are retained in project files as hard copy files or electronic media. 


\section{A.2.0 Investigation Overview}

Field investigation and sampling activities for the CAU 562 CAI were conducted from July 27, 2009, through May 12, 2010. Table A.2-1 lists the CAI activities that were conducted at each of the CASs.

The investigation and sampling program was managed in accordance with the requirements set forth in the CAU 562 CAIP (NNSA/NSO, 2009). Field activities were performed in compliance with safety documents that are consistent with the DOE Integrated Safety Management System. Samples were collected and documented following approved protocols and procedures. Quality control samples (e.g., field blanks, equipment rinsate blanks, trip blanks, and duplicate samples) were collected as required by the Industrial Sites QAPP (NNSA/NV, 2002) and the CAU 562 CAIP (NNSA/NSO, 2009). During field activities, waste minimization practices were followed in accordance with approved procedures, including segregation of waste by waste stream.

Because the field investigation spanned numerous months, the weather conditions at the site varied to include sun (moderate to low temperatures), above average rainfall, some snowfall, intermittent cloudiness, and light to strong winds. Rain and snow suspended site operations due to the inability to monitor for alpha radiation. Strong wind gusts delayed site operations due to the potential for airborne debris and alpha-emitting radioactive particles.

The CASs were investigated by conducting radiological surface screening and surveys, and sampling potential contaminant sources, and soils. Surface soil samples were collected by hand excavation. Subsurface soil samples were collected using hand augering or a backhoe. The soil samples were field screened at specific locations for alpha and beta/gamma radiation. The results were compared to screening levels to guide in the CAS-specific investigations. Samples of various media (e.g., paint, sediments) were collected to support both environmental and waste characterization.

Except as noted in the following CAS-specific sections, CAU 562 Decision I sampling locations were accessible and sampling activities at planned locations were not restricted. Decision II step-out sample locations were accessible and remained within anticipated spatial boundaries except where otherwise noted. 
Table A.2-1

CAI Activities Conducted at Each CAS

To Meet CAIP Requirements for CAU 562

\begin{tabular}{|c|c|c|c|c|c|c|c|c|c|c|c|c|c|}
\hline \multirow[b]{2}{*}{ CAl Activities } & \multicolumn{13}{|c|}{ CAS } \\
\hline & 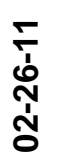 & 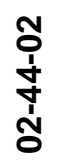 & 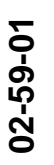 & 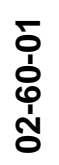 & 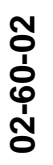 & 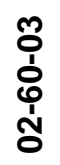 & 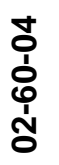 & 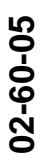 & 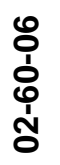 & $\begin{array}{l}\text { ㅇ } \\
\text { ò } \\
\text { ஸे } \\
\text { ஸे }\end{array}$ & $\begin{array}{l}\text { ㅇ } \\
\text { రీ } \\
\text { ஸे } \\
\text { ஸ் }\end{array}$ & 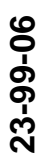 & 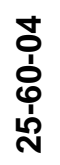 \\
\hline Inspected and verified the CAS components identified in the CAIP. & $\mathrm{X}$ & $\mathrm{X}$ & $\mathrm{X}$ & $x$ & $\mathrm{X}$ & $\mathrm{X}$ & $\mathrm{X}$ & $\mathrm{X}$ & $\mathrm{X}$ & -- & $\mathrm{X}$ & $\mathrm{x}$ & $\mathrm{X}$ \\
\hline Performed site walkovers to identified biased sampling locations. & $\mathrm{X}$ & $\mathrm{X}$ & $\mathrm{X}$ & $x$ & $\mathrm{X}$ & $\mathrm{X}$ & $\mathrm{X}$ & $\mathrm{X}$ & $x$ & -- & $\mathrm{X}$ & $\mathrm{x}$ & $\mathrm{X}$ \\
\hline $\begin{array}{l}\text { Conducted scanning radiological walkover surveys (i.e., soil, concrete surfaces, } \\
\text { debris) using a hand-held survey instrument. }\end{array}$ & $\mathrm{X}$ & $x$ & $x$ & $x$ & $x$ & $x$ & $x$ & $x$ & $x$ & -- & $x$ & $x$ & $x$ \\
\hline $\begin{array}{l}\text { Performed swipe sampling for removable radioactivity using a hand-held survey } \\
\text { instrument and/or a gamma scintillator. }\end{array}$ & -- & $x$ & -- & $x$ & $x$ & $x$ & $x$ & $x$ & $x$ & -- & -- & -- & -- \\
\hline Collected biased soil samples. & $x$ & $x$ & $x$ & $x$ & $x$ & $x$ & $x$ & $\mathrm{x}$ & $x$ & -- & $x$ & $x$ & $\mathrm{X}$ \\
\hline $\begin{array}{l}\text { Collected soil samples from step-out sample locations (Decision II) based on the outer } \\
\text { boundary sample locations where COCs were detected in Decision I soil samples. }\end{array}$ & -- & $x$ & -- & $x$ & $x$ & $x$ & $x$ & $x$ & -- & -- & -- & -- & $x$ \\
\hline $\begin{array}{l}\text { Field screened samples for alpha and beta/gamma radiation using a hand-held } \\
\text { survey instrument. }\end{array}$ & $\mathrm{X}$ & $x$ & $\mathrm{X}$ & $\mathrm{X}$ & $\mathrm{X}$ & $\mathrm{X}$ & $x$ & $\mathrm{X}$ & $x$ & -- & $\mathrm{X}$ & $\mathrm{x}$ & $\mathrm{X}$ \\
\hline $\begin{array}{l}\text { Conducted visual surveys to verify the features of a component, and identify pipe } \\
\text { contents or breaches in the associated piping. }\end{array}$ & $x$ & $\mathrm{x}$ & $\mathrm{x}$ & $\mathrm{X}$ & $x$ & $\mathrm{X}$ & $x$ & $\mathrm{X}$ & $\mathrm{X}$ & $x^{a}$ & $\mathrm{X}$ & $\mathrm{x}$ & $\mathrm{X}$ \\
\hline Submitted select samples for offsite laboratory analysis. & $x$ & $x$ & $\mathrm{x}$ & $x$ & $x$ & $x$ & $x$ & $x$ & $x$ & -- & $x$ & $\mathrm{x}$ & $x$ \\
\hline Collected GPS coordinates for sample locations and points of interest. & $\mathrm{X}$ & $\mathrm{X}$ & $\mathrm{x}$ & $\mathrm{X}$ & $x$ & $\mathrm{X}$ & $x$ & $\mathrm{X}$ & $x$ & -- & $\mathrm{X}$ & $x$ & $\mathrm{X}$ \\
\hline
\end{tabular}

${ }^{a}$ No CAS component or source of release was present

-- = Not applicable 
Sections A.2.1 through A.2.4 provide the investigation methodology, site geology and hydrology, and laboratory analytical information.

\section{A.2.1 Sample Locations}

Locations selected for sampling were based on interpretation of existing engineering drawings, aerial and land photographs, utility and geophysical survey results, information obtained during site visits, and site conditions as provided in the CAU 562 CAIP (NNSA/NSO, 2009). Sampling points for each site were selected based on the approach provided in the CAIP. The actual environmental sample locations are shown on the figures included in Sections A.3.0 through A.15.0. Some locations were modified slightly from planned positions due to field conditions and observations. In some cases, laboratory analytical results determined the need for step-out sampling locations. Sample locations were staked, labeled, and surveyed with a Trimble GeoXT GPS instrument to obtain geographic coordinates. Appendix F presents the geographic coordinates of sample locations in a tabular format.

\section{A.2.2 Investigation Activities}

The investigation activities performed at CAU 562 were based on field investigation activities discussed in the CAU 562 CAIP (NNSA/NSO, 2009). The technical approach consisted of the activities listed in Table A.2-1. The investigation strategy allowed the nature and extent of contamination associated with each CAS to be established. The following sections describe the specific investigation activities that took place at CAU 562.

\section{A.2.2.1 Radiological Surveys}

A radiological gamma walkover survey was conducted at each of the Area 2 CASs to identify the presence, nature, and extent of radiological contaminants at activities statistically distinguishable from background (more than twice background activity). The surveys were completed using a handheld TSA PRM470 scintillation radiation detector coupled with a Trimble GPS instrument. The results of the surveys did not show any readings significantly different from background. Therefore, no biasing sample locations were selected as a result of the radiological surveys. 


\section{A.2.2.2 Piping and Septic Tank Inspections}

For CAS 02-59-01, which consisted of a septic tank and leachfield, system component inspection of surface (access hatches and tie-ins) and subsurface (septic tank inlet and outlet pipes, tank integrity) features was conducted by exposing the component and performing a visual inspection. Details of investigation techniques that were used to verify the integrity of the tank and system components are listed below:

- The interior of the tank above the fluid level was not visually inspected due to the depth of the tank. It is speculated that the tank consists of two chambers because there are two access hatches and the depth of liquid and sludge varied from the two ends of the tank. The contents were measured using a composite liquid waste sampler (COLIWASA).

- Samples were collected of the individual phases of contents. Both liquid and sludge phases were present and collected from both access hatches of the tank.

- Integrity of the tank was evaluated by excavating to the base of the tank and verifying that there had been no release. Samples were collected from below the inlet and outlet pipes as well as from below each end of the tank.

\section{A.2.2.3 Surface and Subsurface Soil Sampling}

Surface soil samples were collected using hand sampling methods (scoop and trowel), and subsurface soil samples were collected by hand augering and backhoe excavation. All sample locations were initially field screened for alpha and beta/gamma radiation before the start of sampling. Additional screening was conducted during sample collection to guide the investigation and serve as a health and safety control to protect the sampling team. Labeled sample containers were filled according to the following sequence:

- Containers for VOC samples were filled with soil directly from the sample location.

- Additional soil was transferred into a stainless-steel bowl, homogenized, and field screened for alpha and beta/gamma radiation.

- Samples for the analysis of gamma radiation and TPH-DRO were collected from the homogenized soil.

- All remaining sample containers were filled with soil.

- Excess soil was returned to its original location. 
- Sample containers were appropriately disposed of (based on field-screening results [FSRs] and/or analytical results).

Surface soil samples were collected from 0.0 to $0.5 \mathrm{ft}$ bgs at biased locations (e.g., areas of suspected contamination based on the activities conducted at that site, location of stains or suspected spills, presence of paint on the ground). Shallow subsurface soil samples were collected from beneath surface locations where debris was present, there was a continuation of soil staining noted, and/or analytical results indicated contamination. Subsurface soil samples were collected from the soil horizon at the base of the french drains and at the base of the leach rock, at septic system components (i.e., tank and piping), at the base of outfall openings, and at the base of the sump.

\section{A.2.2.4 Waste Characterization Sampling}

Characterization of CAS-specific components, materials, and waste was performed to support recommendations for disposal of these items and determine whether the waste in question at these CASs could be acting as a source of potential soil contamination. Investigation methods included visual inspection, radiological surveys, and direct sampling of site components.

Samples were analyzed in accordance with the CAU 562 CAIP (NNSA/NSO, 2009). The specific analyses for each CAS are listed in CAS-specific sections, and the analytical results are compared to the federal limits for hazardous waste, NDEP hydrocarbon action levels, landfill acceptance criteria, and the limits in the NTS performance objective criteria (POC) (BN, 1995). The POC limits have been established for NTS hazardous waste generators to ensure that all hazardous waste being shipped off site contains no "added radioactivity."

Specific waste characterization sampling and analysis was conducted on the following potential waste streams:

- $\quad$ Lead shot at CAS 02-26-11

- Paint chips from the former Painters Shed foundation and Paint Storage Rack at CAS 02-44-02

- $\quad$ Sludge and liquid from the septic tank at CAS 02-59-01

- Sediment in the mud trap and outfall at CAS 23-60-01 and the outfall at CAS 25-60-04 
- Radiological swipe samples collected from drain casings at CASs 02-44-02, 02-60-02, 02-60-04, 02-60-05, and 02-60-06

- Soil containing COCs at CASs 02-60-02, 02-60-04, and 25-60-04

\section{A.2.3 Laboratory Analytical Information}

Chemical and radiological analyses were performed by ALS Laboratory Group, located in Fort Collins, Colorado. The analytical suites and laboratory analytical methods used to analyze investigation samples are listed in Table A.2-2. Analytical results are reported in this appendix if they were detected above the minimum detectable concentrations (MDCs). The complete laboratory data packages are available in the project files.

Validated analytical data for CAU 562 investigation samples have been compiled and evaluated to confirm the presence of contamination and define the extent of contamination, if present. The analytical results for each CAS are presented in Sections A.3.0 through A.15.0.

The analytical parameters are CAS specific and were selected through the application of site process knowledge according to the DQOs. Samples collected during step-out sampling were only analyzed for the COCs identified in the original samples.

\section{A.2.4 Comparison to Action Levels}

A COC is defined as any contaminant present in environmental media exceeding a FAL. A COC may also be defined as a contaminant that, in combination with other like contaminants, is determined to jointly pose an unacceptable risk based on a multiple constituent analysis (NNSA/NSO, 2006). Multiple constituent analyses are presented in Appendix D.

If COCs are present, corrective action must be considered for the CAS. The FALs for the CAU 562 investigation are defined for each CAS in Appendix D. Results that are equal to or greater than FALs are identified by bold text in the CAS-specific results tables presented in Sections A.3.0 through A.15.0. 
Table A.2-2

Laboratory Analyses and Methods, CAU 562 Investigation Samples ${ }^{a}$

\begin{tabular}{|c|c|}
\hline Analysis & Analytical Method ${ }^{b}$ \\
\hline VOCs & Aqueous/Non-aqueous - EPA SW- $846^{\mathrm{C}} 8260$ \\
\hline TCLP VOCs & EPA SW-846 $1311 / 8260$ \\
\hline SVOCs & Aqueous/Non-aqueous - EPA SW- $846^{\mathrm{C}} 8270$ \\
\hline TCLP SVOC & EPA SW-846 $1311 / 8270$ \\
\hline PCBs & Aqueous/Non-aqueous - EPA SW-846 8082 \\
\hline TPH-DRO & Aqueous/Non-aqueous - EPA SW- $846^{c} 8015$ Modified \\
\hline Pesticides & Aqueous/Non-aqueous - EPA SW-846 8081 \\
\hline TCLP Pesticides & EPA SW-846 $1311 / 8081$ \\
\hline Herbicides & Aqueous/Non-aqueous - EPA SW-846 8151 \\
\hline TCLP Herbicides & EPA SW-846 $1311 / 8151$ \\
\hline Metals & $\begin{array}{c}\text { Aqueous - EPA SW-846' 6010/6020/7470 } \\
\text { Non-aqueous - EPA SW-846 } 6010 / 6020 / 7471\end{array}$ \\
\hline TCLP Metals & EPA SW-846 $1311 / 6010 / 7470$ \\
\hline Gamma Spectroscopy & $\begin{array}{c}\text { Aqueous - EPA 901.1 }{ }^{\mathrm{d}} \\
\text { Non-aqueous - DOE EML HASL-300, Ga-01-R }\end{array}$ \\
\hline Gross Alpha/Beta & $\begin{array}{l}\text { Aqueous - EPA } 900.0^{d} \\
\text { Non-aqueous - SM } 7110 \text { Bi Modified }\end{array}$ \\
\hline Tritium & $\begin{array}{l}\text { Aqueous - EPA 906. } \\
\text { Non-aqueous }\end{array}$ \\
\hline
\end{tabular}

anvestigation samples include both environmental and waste characterization samples and associated QC samples.

${ }^{\mathrm{b}}$ The most current EPA, DOE, ASTM, NIOSH, or equivalent accepted analytical method may be used, including Laboratory Standard Operating Procedures approved by NNES in accordance with industry standards and the SNJV and NNES Statement of Work requirements (SNJV, 2006; NNES, 2009).

${ }^{\mathrm{c}}$ Test Methods for Evaluating Solid Waste, Physical/Chemical Methods (EPA, 2008).

${ }^{\mathrm{d}}$ The Procedures Manual of the Environmental Measurements Laboratory (DOE, 1997).

${ }^{\mathrm{e}}$ Prescribed Procedures for Measurement of Radioactivity in Drinking Water, (EPA, 1980).

Note: The term "modified" indicates modifications of approved methods. All modifications have been approved by the NNES Analytical Services Department.

ASTM = American Society for Testing and Materials EERF = Eastern Environmental Radiation Facility

$\mathrm{EML}=$ Environmental Measurements Laboratory

EPA = U.S. Environmental Protection Agency

HASL $=$ Health and Safety Laboratory
$\mathrm{NIOSH}=$ National Institute for Occupational Safety and Health NNES = Navarro Nevada Environmental Services, LLC

RESL = Radiological and Environmental Sciences Laboratory SNJV = Stoller-Navarro Joint Venture

TCLP $=$ Toxicity Characteristic Leaching Procedure 
The presence of a COC would require a corrective action. A corrective action may also be necessary if there is a potential for wastes that are present at a site to release COCs into site environmental media (i.e., PSM).

To evaluate wastes for the potential to result in the introduction of a COC to the surrounding environmental media, the following conservative assumptions were made:

- Any physical waste containment would fail at some point, and the contents would be released to the surrounding media.

- For liquid wastes, the resulting concentration of contaminants in the surrounding soil will be calculated based on the concentration of contaminants in the waste and the liquid-holding capacity of the soil. If the resulting soil concentration exceeds the FAL, then the liquid waste would be considered PSM.

- Any non-liquid waste containing a contaminant exceeding an equivalent FAL concentration would cause a COC to be present in the surrounding media and would be considered PSM. 


\section{A.3.0 CAS 02-26-11, Lead Shot, Investigation Results}

Corrective Action Site 02-26-11 is located in the Area 2 Camp in the southwest corner of the former Laborers Storage Area (Figure 1-2). Although no specific information has been identified for the use of the Laborers Storage Area, it is assumed that this area was used to store equipment, tools, and materials used by the laborers. Corrective Action Site 02-26-11 consists of the potential releases to the soil from shot pellets that have been abandoned in the area. Figure A.3-1 shows the sample locations and photographs of CAS 02-26-11.

\section{A.3.1 Corrective Action Investigation Activities}

A total of 13 environmental samples (including 1 FD) and 2 PSM samples were collected during investigation activities at CAS 02-26-11. The sample identifications (IDs), locations, types, and analyses are listed in Table A.3-1. The specific CAI activities conducted to satisfy the CAIP requirements at this CAS are described in the following sections.

\section{A.3.1.1 Radiological Surveys}

A radiological walkover survey was completed within the boundary of CAS 02-26-11. The results of the survey did not show radiological contaminants at activities statistically distinguishable from background activities (more than twice background levels). The survey results did not indicate the need for additional biased samples.

\section{A.3.1.2 Visual Inspections}

At CAS 02-26-11, both rusted and non-rusted shot is scattered throughout the area and is not uniformly distributed. Therefore, a visual survey was performed to identify one area with a high concentration of rusted shot and one area with a high concentration of non-rusted shot. As a result of this survey, two biased sample locations were selected at each area. A visual survey was also performed to determine the lateral extent in all directions of shot present on the ground surface. As a result of this survey, four biased sample locations were selected on the north, south, east, and west sides of the square-shaped area to confirm the lateral extent of the area potentially impacted by the shot. 


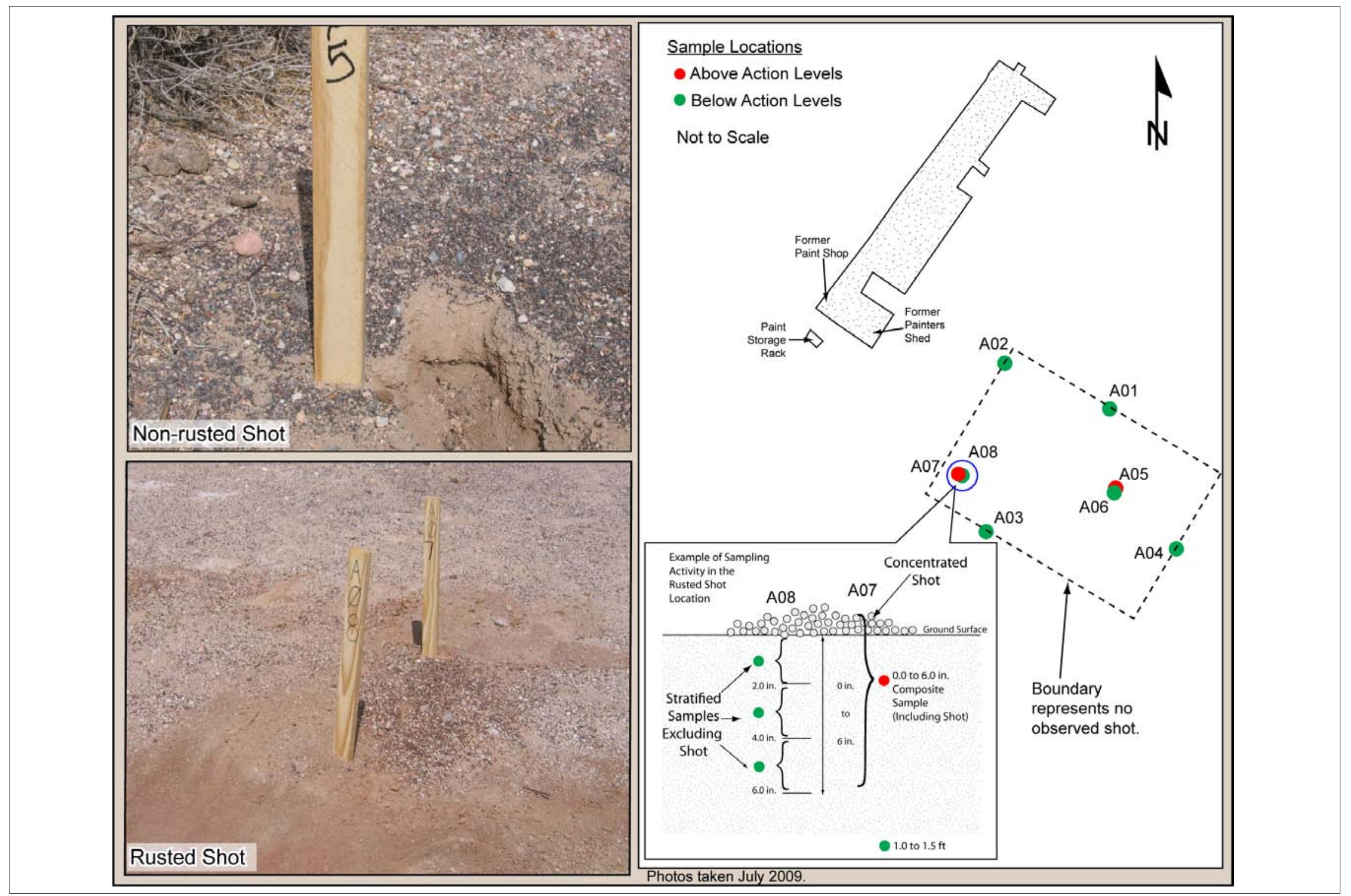

Figure A.3-1

Sample Locations at CAS 02-26-11, Lead Shot 
Table A.3-1

Samples Collected at CAS 02-26-11, Lead Shot

\begin{tabular}{|c|c|c|c|c|c|c|c|c|c|c|c|c|}
\hline $\begin{array}{l}\text { Sample } \\
\text { Location }\end{array}$ & $\begin{array}{l}\text { Sample } \\
\text { Number }\end{array}$ & $\begin{array}{l}\text { Depth } \\
\text { (ft bgs) }\end{array}$ & Matrix & Purpose & $\begin{array}{l}\text { 움 } \\
\text { 茄 }\end{array}$ & 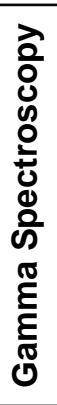 & $\begin{array}{l}\frac{0}{\pi} \\
\frac{\Phi}{\mathbb{2}} \\
\sum\end{array}$ & 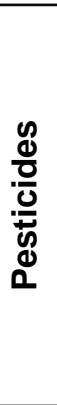 & 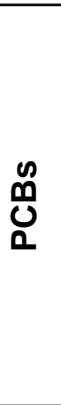 & 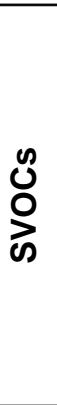 & 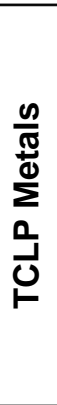 & $\begin{array}{l}0 \\
\text { O্ } \\
\end{array}$ \\
\hline A01 & 562A001 & $0.0-0.5$ & Soil & Environmental & $x$ & $\bar{x}$ & $\mathrm{x}$ & -- & $\mathrm{x}$ & $x$ & -- & $x$ \\
\hline \multirow[b]{2}{*}{ A02 } & $562 A 002$ & $0.0-0.5$ & Soil & Environmental & $x$ & $x$ & $x$ & $x$ & $x$ & $x$ & -- & $x$ \\
\hline & 562A003 & $0.0-0.5$ & Soil & $\begin{array}{c}\text { FD } \\
\text { of \#562A002 }\end{array}$ & $x$ & $x$ & $x$ & -- & $x$ & $x$ & -- & $x$ \\
\hline A03 & 562A004 & $0.0-0.5$ & Soil & Environmental & $x$ & $x$ & $x$ & -- & $x$ & $x$ & -- & $x$ \\
\hline A04 & 562A005 & $0.0-0.5$ & Soil & Environmental & $x$ & $x$ & $x$ & -- & $x$ & $x$ & -- & $x$ \\
\hline \multirow{2}{*}{ A05 } & 562A006 & $0.0-0.5$ & Solid & PSM & $x$ & $x$ & $x$ & -- & $x$ & $x$ & $x$ & $x$ \\
\hline & 562A015 & $1.0-1.5$ & Soil & Environmental & $x$ & $x$ & $x$ & -- & $x$ & $x$ & -- & $x$ \\
\hline \multirow{3}{*}{ A06 } & 562A007 & $\begin{array}{l}0.0-2.0 \\
\text { (in. bgs) }\end{array}$ & Soil & Environmental & $x$ & $x$ & $x$ & -- & $x$ & $x$ & $x$ & $x$ \\
\hline & 562A008 & $\begin{array}{l}2.0-4.0 \\
\text { (in. bgs) }\end{array}$ & Soil & Environmental & $x$ & $x$ & $x$ & -- & $x$ & $x$ & $x$ & $x$ \\
\hline & 562A009 & $\begin{array}{l}4.0-6.0 \\
\text { (in. bgs) }\end{array}$ & Soil & Environmental & $x$ & $x$ & $x$ & -- & $x$ & $x$ & $x$ & $x$ \\
\hline \multirow{2}{*}{ A07 } & $562 A 010$ & $0.0-0.5$ & Solid & PSM & $x$ & $x$ & $x$ & -- & $x$ & $x$ & $x$ & $x$ \\
\hline & 562A014 & $1.0-1.5$ & Soil & Environmental & $x$ & $x$ & $x$ & -- & $x$ & $x$ & -- & $x$ \\
\hline \multirow{3}{*}{ A08 } & 562A011 & $\begin{array}{l}0.0-2.0 \\
\text { (in. bgs) }\end{array}$ & Soil & Environmental & $x$ & $x$ & $x$ & -- & $x$ & $x$ & $x$ & $x$ \\
\hline & $562 A 012$ & $\begin{array}{l}2.0-4.0 \\
\text { (in. bgs) }\end{array}$ & Soil & Environmental & $x$ & $x$ & $x$ & -- & $x$ & $x$ & $x$ & $x$ \\
\hline & $562 A 013$ & $\begin{array}{l}4.0-6.0 \\
\text { (in. bgs) }\end{array}$ & Soil & Environmental & $x$ & $x$ & $x$ & -- & $x$ & $x$ & $x$ & $\mathrm{x}$ \\
\hline N/A & 562A301 & N/A & Water & Trip Blank & -- & -- & -- & -- & -- & -- & -- & $x$ \\
\hline N/A & $562 A 302$ & $N / A$ & Water & Trip Blank & -- & -- & -- & -- & -- & -- & -- & $x$ \\
\hline
\end{tabular}




\section{A.3.1.3 Sample Collection}

Sampling included the collection of 13 (including 1 FD) environmental surface and subsurface soil samples and 2 PSM samples from the 8 locations shown in Figure A.3-1. The sampling activities are discussed below.

Two sample locations, A05 and A06, were selected in an area of concentrated non-rusted shot. At sample location A05, one PSM sample (562A006) that included non-rusted shot was collected from 0.0 to $0.5 \mathrm{ft}$ bgs, and one soil sample (562A015) that did not contain shot was collected at a depth of 1.0 to $1.5 \mathrm{ft}$ bgs. At sample location A06, directly adjacent to A05, the shot was brushed away from the sample location and three samples excluding shot were collected at 2.0-in. intervals. Samples 562A007, 562A008, and 562A009 were collected at 0.0 to 2.0, 2.0 to 4.0, and 4.0 to 6.0 in. bgs, respectively.

Sample locations A07 and A08 were selected in an area of concentrated rusted shot. At sample location A07, one PSM sample (562A010) that included rusted shot was collected from 0.0 to $0.5 \mathrm{ft}$ bgs, and one soil sample (562A014) that did not include shot was collected at a depth of 1.0 to $1.5 \mathrm{ft}$ bgs. At sample location A08, directly adjacent to A07, the shot was brushed away from the sample location and three samples excluding shot were collected at 2.0-in. intervals. Samples 562A011, 562A012, and 562A013 were collected at 0.0 to 2.0, 2.0 to 4.0, and 4.0 to $6.0 \mathrm{in}$. bgs, respectively.

Samples 562A001 through 562A005 were collected from 0.0 to $0.5 \mathrm{ft}$ bgs at locations A01 through A04 in an attempt to define the lateral extent of the shot.

\section{A.3.1.4 Deviations}

There were no deviations to the CAU 562 CAIP (NNSA/NSO, 2009) associated with CAS 02-26-11. Investigation samples were collected as outlined in the CAU 562 CAIP and submitted for laboratory analysis. 


\section{A.3.2 Investigation Results}

The following sections provide analytical results from the samples collected to complete investigation activities as outlined in the CAIP (NNSA/NSO, 2009). The results from the analysis of PCBs included tentatively identified compounds with signatures similar to pesticides. Therefore, these samples were also analyzed for pesticides. The analytical parameters and laboratory methods used to analyze the investigation samples are listed in Table A.2-2. Table A.3-1 lists the sample-specific analytical suite for CAS 02-26-11.

Analytical results from the soil samples with concentrations exceeding MDCs are summarized in the following sections. An evaluation was conducted on all contaminants detected above MDCs by comparing individual concentration or activity results against the FALs. Establishment of the FALs is presented in Appendix D. The FALs were established as the corresponding PAL concentrations or activities if the contaminant concentrations were below their respective PALs.

\section{A.3.2.1 Volatile Organic Compounds}

Analytical results for VOCs in soil samples collected at this CAS that were detected above MDCs are presented in Table A.3-2. No VOCs were detected at concentrations exceeding their respective PALs. The FALs were established at the PAL concentrations.

Table A.3-2

Sample Results for Total VOCs Detected above MDCs at CAS 02-26-11, Lead Shot

\begin{tabular}{|c|c|c|c|}
\hline \multirow{2}{*}{$\begin{array}{c}\text { Sample } \\
\text { Location }\end{array}$} & \multirow{2}{*}{$\begin{array}{l}\text { Sample } \\
\text { Number }\end{array}$} & \multirow{2}{*}{$\begin{array}{l}\text { Depth } \\
\text { (ft bgs) }\end{array}$} & COPCs (mg/kg) \\
\hline & & & Methylene chloride \\
\hline \multicolumn{3}{|c|}{ FALs } & 53 \\
\hline A06 & $562 A 007$ & $\begin{array}{l}0.0-2.0 \\
\text { (in. bgs) }\end{array}$ & $0.0017(\mathrm{~J})$ \\
\hline
\end{tabular}

$\mathrm{J}=$ Estimated value 


\section{A.3.2.2 Semivolatile Organic Compounds}

Analytical results for SVOCs in soil samples collected at this CAS that were detected above MDCs are presented in Table A.3-3. No SVOCs were detected at concentrations exceeding the respective PALs. The FALs were established at the PAL concentrations.

\section{A.3.2.3 Total Petroleum Hydrocarbons}

Analytical results for TPH-DRO in soil samples collected at this CAS that were detected above MDCs are presented in Table A.3-4. The TPH-DRO concentration in surface sample (562A012) was equal to the PAL of $100 \mathrm{mg} / \mathrm{kg}$. The TPH-DRO was moved on to a Tier 2 evaluation, and FALs were established for the hazardous constituents of TPH-DRO. Concentrations of the hazardous constituents of TPH-DRO did not exceed FALs. Therefore, TPH-DRO is not considered a COC. The calculation of FALs for the hazardous constituents of TPH-DRO is presented in Appendix D.

\section{A.3.2.4 Resource Conservative and Recovery Act Metals (including Antimony)}

Analytical results for RCRA metals (including antimony) in soil samples collected at this CAS that were detected above MDCs are presented in Table A.3-5. No RCRA metals (including antimony) were detected at concentrations exceeding their respective PALs. The FALs were established at the PAL concentrations.

\section{A.3.2.5 Polychlorinated Biphenyls}

Analytical results for PCBs in soil samples collected at this CAS that were detected above MDCs are presented in Table A.3-6. No PCBs were detected at concentrations exceeding the respective PALs. The FALs were established at the PAL concentrations.

\section{A.3.2.6 Pesticides}

Analytical results for pesticides in soil samples collected at this CAS that were detected above MDCs are presented in Table A.3-7. No pesticides were detected at concentrations exceeding the respective PALs. The FALs were established at the PAL concentrations. 
Table A.3-3

Sample Results for Total SVOCs Detected above MDCs at CAS 02-26-11, Lead Shot

\begin{tabular}{|c|c|c|c|c|c|c|c|c|c|c|c|c|c|c|}
\hline \multirow[b]{2}{*}{$\begin{array}{l}\text { Sample } \\
\text { Location }\end{array}$} & \multirow[b]{2}{*}{$\begin{array}{l}\text { Sample } \\
\text { Number }\end{array}$} & \multirow[b]{2}{*}{$\begin{array}{c}\text { Depth } \\
\text { (ft bgs) }\end{array}$} & \multicolumn{12}{|c|}{ COPCs (mg/kg) } \\
\hline & & & 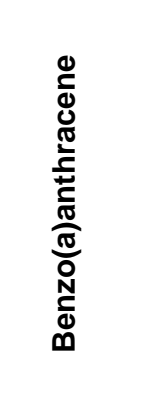 & 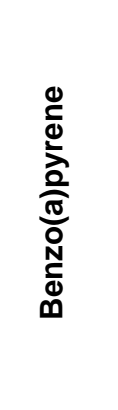 & 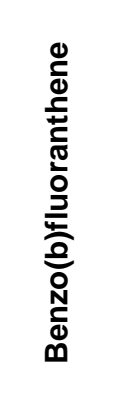 & 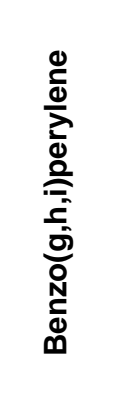 & 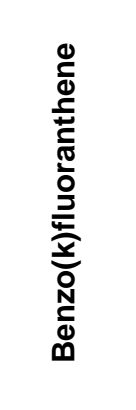 & 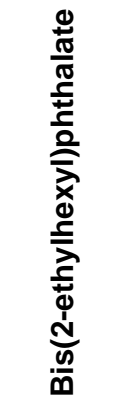 & 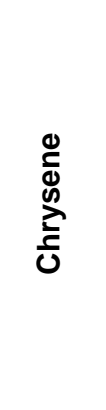 & 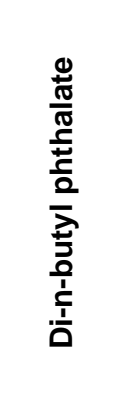 & 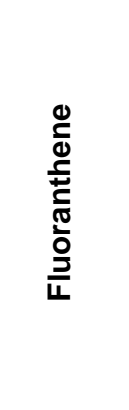 & 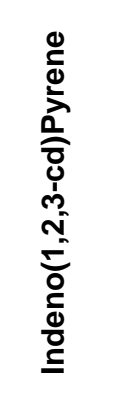 & 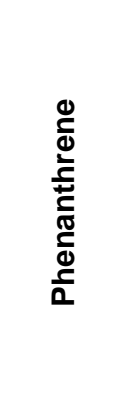 & 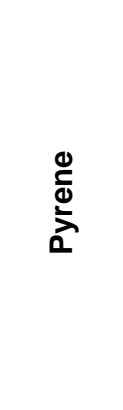 \\
\hline \multicolumn{3}{|c|}{ FALs } & 2.1 & 0.21 & 2.1 & 17,000 & 21 & 120 & 210 & 62,000 & 22,000 & 2.1 & 170,000 & 17,000 \\
\hline \multirow{2}{*}{$\mathrm{A} 02$} & $562 A 002$ & $0.0-0.5$ & -- & -- & -- & -- & -- & $0.14(\mathrm{~J})$ & -- & $0.15(\mathrm{~J})$ & $0.075(\mathrm{~J})$ & -- & -- & $0.071(\mathrm{~J})$ \\
\hline & 562A003 & $0.0-0.5$ & -- & -- & -- & -- & -- & $0.079(\mathrm{~J})$ & -- & $0.11(\mathrm{~J})$ & -- & -- & -- & -- \\
\hline $\mathrm{A} 03$ & $562 A 004$ & $0.0-0.5$ & $0.088(\mathrm{~J})$ & $0.11(\mathrm{~J})$ & $0.16(\mathrm{~J})$ & $0.1(\mathrm{~J})$ & $0.073(\mathrm{~J})$ & 0.47 & $0.1(\mathrm{~J})$ & $0.3(\mathrm{~J})$ & $0.24(\mathrm{~J})$ & $0.08(\mathrm{~J})$ & $0.11(\mathrm{~J})$ & $0.33(\mathrm{~J})$ \\
\hline A04 & $562 A 005$ & $0.0-0.5$ & -- & -- & -- & -- & -- & 0.41 & -- & $0.087(\mathrm{~J})$ & -- & -- & -- & -- \\
\hline
\end{tabular}

-- = Not detected above MDCs.

$\mathrm{J}=$ Estimated value 
Table A.3-4

Sample Results for TPH-DRO Detected above MDCs at CAS 02-26-11, Lead Shot

\begin{tabular}{|c|c|c|c|}
\hline \multirow{2}{*}{$\begin{array}{l}\text { Sample } \\
\text { Location }\end{array}$} & \multirow{2}{*}{$\begin{array}{l}\text { Sample } \\
\text { Number }\end{array}$} & \multirow{2}{*}{$\begin{array}{c}\text { Depth } \\
\text { (ft bgs) }\end{array}$} & COPCs (mg/kg) \\
\hline & & & DRO \\
\hline \multicolumn{3}{|c|}{ PALs } & 100 \\
\hline A01 & 562A001 & $0.0-0.5$ & 21 \\
\hline \multirow{2}{*}{ A02 } & 562A002 & $0.0-0.5$ & 35 \\
\hline & 562A003 & $0.0-0.5$ & 47 \\
\hline A03 & 562A004 & $0.0-0.5$ & 14 \\
\hline A04 & 562A005 & $0.0-0.5$ & $2(\mathrm{~J})$ \\
\hline \multirow{3}{*}{ A06 } & 562A007 & $\begin{array}{l}0.0-2.0 \\
\text { (in. bgs) }\end{array}$ & 24 \\
\hline & 562A008 & $\begin{array}{l}2.0-4.0 \\
\text { (in. bgs) }\end{array}$ & $3(\mathrm{~J})$ \\
\hline & 562A009 & $\begin{array}{l}4.0-6.0 \\
\text { (in. bgs) }\end{array}$ & $1.8(\mathrm{~J})$ \\
\hline \multirow{3}{*}{ A08 } & 562A011 & $\begin{array}{l}0.0-2.0 \\
\text { (in. bgs) }\end{array}$ & 14 \\
\hline & 562A012 & $\begin{array}{l}2.0-4.0 \\
\text { (in. bgs) }\end{array}$ & 100 \\
\hline & $562 A 013$ & $\begin{array}{l}4.0-6.0 \\
\text { (in. bgs) }\end{array}$ & $5.2(\mathrm{~J})$ \\
\hline
\end{tabular}

$\mathrm{J}=$ Estimated value

Bold indicates the value is equal to or exceeds the PAL. 
Table A.3-5

\section{Sample Results for Metals Detected above MDCs at CAS 02-26-11, Lead Shot}

\begin{tabular}{|c|c|c|c|c|c|c|c|c|c|c|}
\hline \multirow[b]{2}{*}{$\begin{array}{c}\text { Sample } \\
\text { Location }\end{array}$} & \multirow[b]{2}{*}{$\begin{array}{l}\text { Sample } \\
\text { Number }\end{array}$} & \multirow[b]{2}{*}{$\begin{array}{c}\text { Depth } \\
\text { (ft bgs) }\end{array}$} & \multicolumn{8}{|c|}{ COPCs (mg/kg) } \\
\hline & & & 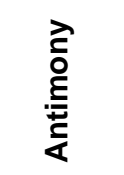 & 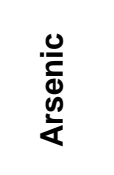 & 立 & 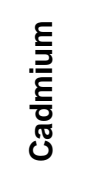 & 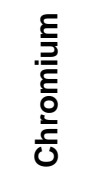 & ర్త & 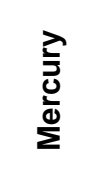 & $\frac{\Sigma}{D}$ \\
\hline \multicolumn{3}{|c|}{ FALs } & 410 & 23 & 190,000 & 800 & 450 & 800 & 34 & 5,100 \\
\hline $\mathrm{A} 01$ & 562A001 & $0.0-0.5$ & $0.57(\mathrm{~J})$ & 2.6 & 100 & -- & $3.8(\mathrm{~J})$ & $54(\mathrm{~J}-)$ & 0.051 & -- \\
\hline \multirow{2}{*}{$\mathrm{A} 02$} & 562A002 & $0.0-0.5$ & $1.1(\mathrm{~J})$ & 2.1 & 140 & 7 & $8.3(\mathrm{~J})$ & $20(\mathrm{~J}-)$ & 0.0082 & 0.57 \\
\hline & $562 \mathrm{~A} 003$ & $0.0-0.5$ & $0.92(\mathrm{~J})$ & 2.5 & 190 & 7.3 & $9(\mathrm{~J})$ & $30(\mathrm{~J}-)$ & 0.011 & 0.39 \\
\hline A03 & 562A004 & $0.0-0.5$ & $0.62(\mathrm{~J}-)$ & 3.5 & 200 & -- & $5.5(\mathrm{~J})$ & $37(\mathrm{~J}-)$ & 0.025 & -- \\
\hline $\mathrm{A} 04$ & 562A005 & $0.0-0.5$ & $1.2(\mathrm{~J}-)$ & $1.8(\mathrm{~J}-)$ & 200 & -- & $3.8(\mathrm{~J})$ & $17(\mathrm{~J}-)$ & 0.006 & 0.88 \\
\hline A05 & 562A015 & $1.0-1.5$ & -- & 2 & 72 & -- & 2 & 11 & $\begin{array}{c}0.0099 \\
(\mathrm{~J}-)\end{array}$ & -- \\
\hline \multirow{3}{*}{ A06 } & 562A007 & $\begin{array}{l}0.0-2.0 \\
\text { (in. bgs) }\end{array}$ & 1.9 & 3.5 & $110(\mathrm{~J})$ & 0.17 & $4(\mathrm{~J})$ & $40(\mathrm{~J})$ & 0.02 & 0.39 \\
\hline & 562A008 & $\begin{array}{l}2.0-4.0 \\
\text { (in. bgs) }\end{array}$ & 0.97 & 3.2 & $120(\mathrm{~J})$ & 0.13 & $4.3(\mathrm{~J})$ & $21(\mathrm{~J})$ & 0.014 & -- \\
\hline & 562A009 & $\begin{array}{l}4.0-6.0 \\
\text { (in. bgs) }\end{array}$ & 0.59 & 2.7 & $88(\mathrm{~J})$ & 0.11 & $3.6(\mathrm{~J})$ & $12(\mathrm{~J})$ & 0.014 & -- \\
\hline A07 & 562A014 & $1.0-1.5$ & 0.86 & 2.6 & 180 & 0.057 & 4.1 & 11 & $\begin{array}{c}0.018 \\
(\mathrm{~J}-)\end{array}$ & -- \\
\hline \multirow{3}{*}{ A08 } & $562 \mathrm{~A} 011$ & $\begin{array}{l}0.0-2.0 \\
\text { (in. bgs) }\end{array}$ & 2.8 & 2.5 & $500(\mathrm{~J})$ & 0.11 & $3(\mathrm{~J})$ & $8.5(\mathrm{~J})$ & 0.0055 & -- \\
\hline & 562A012 & $\begin{array}{l}2.0-4.0 \\
\text { (in. bgs) }\end{array}$ & 2.1 & 2.8 & $230(\mathrm{~J})$ & 0.12 & $3.4(\mathrm{~J})$ & $13(\mathrm{~J})$ & 0.015 & -- \\
\hline & $562 \mathrm{~A} 013$ & $\begin{array}{l}4.0-6.0 \\
\text { (in. bgs) }\end{array}$ & 1.3 & 2.9 & $96(\mathrm{~J})$ & 0.12 & $4.3(\mathrm{~J})$ & $9.4(\mathrm{~J})$ & 0.018 & -- \\
\hline
\end{tabular}

-- = Not detected above MDCs.

$\mathrm{J}=$ Estimated value

$\mathrm{J}-=$ Result is an estimated quantity but may be biased low. 
Table A.3-6

\section{Sample Results for PCBs Detected above \\ MDCs at CAS 02-26-11, Lead Shot}

\begin{tabular}{|c|c|c|c|}
\hline \multirow{2}{*}{$\begin{array}{l}\text { Sample } \\
\text { Location }\end{array}$} & \multirow{2}{*}{$\begin{array}{l}\text { Sample } \\
\text { Number }\end{array}$} & \multirow{2}{*}{$\begin{array}{l}\text { Depth } \\
\text { (ft bgs) }\end{array}$} & COPCs $(\mathrm{mg} / \mathrm{kg})$ \\
\hline & & & Aroclor 1260 \\
\hline \multicolumn{3}{|c|}{ FALs } & 0.74 \\
\hline \multirow{2}{*}{ A02 } & 562A002 & $0.0-0.5$ & 0.057 \\
\hline & $562 A 003$ & $0.0-0.5$ & 0.075 \\
\hline A03 & 562A004 & $0.0-0.5$ & $0.017(\mathrm{~J})$ \\
\hline A06 & 562A007 & $\begin{array}{l}0.0-2.0 \\
\text { (in. bgs) }\end{array}$ & $0.0077(\mathrm{~J})$ \\
\hline
\end{tabular}

$\mathrm{J}=$ Estimated value

Table A.3-7

Sample Results for Pesticides Detected above

MDCs at CAS 02-26-11, Lead Shot

\begin{tabular}{|c|c|c|c|}
\hline \multirow{2}{*}{$\begin{array}{c}\text { Sample } \\
\text { Location }\end{array}$} & $\begin{array}{c}\text { Sample } \\
\text { Number }\end{array}$ & $\begin{array}{c}\text { Depth } \\
\text { (ft bgs) }\end{array}$ & COPCs (mg/kg) \\
\cline { 4 - 4 } & & & Chlordane \\
\hline \multicolumn{3}{|c|}{ FALs } & 6.5 \\
\hline \hline $\mathrm{A} 02$ & $562 \mathrm{A002}$ & $0-0.5$ & $0.096(\mathrm{~J})$ \\
\hline
\end{tabular}

$\mathrm{J}=$ Estimated value

\section{A.3.2.7 Gamma-Emitting Radionuclides}

Analytical results for gamma-emitting radionuclides in soil samples collected at this CAS that were detected above MDCs are presented in Table A.3-8. No gamma-emitting radionuclides were detected at concentrations exceeding the respective PALs. The FALs were established at the PAL concentrations.

\section{A.3.3 Potential Source Material Sample Results}

Analytical results for the soil samples containing rusted and non-rusted shot detected above MDCs are presented in Table A.3-9. Concentrations of lead, antimony, and arsenic were detected at concentrations exceeding PALs in surface soil sample 562A006 collected at sample location A05. 
Table A.3-8

\section{Sample Results for Gamma-Emitting Radionuclides Detected above MDCs at CAS 02-26-11, Lead Shot}

\begin{tabular}{|c|c|c|c|c|c|c|}
\hline \multirow{2}{*}{$\begin{array}{l}\text { Sample } \\
\text { Location }\end{array}$} & \multirow{2}{*}{$\begin{array}{l}\text { Sample } \\
\text { Number }\end{array}$} & \multirow{2}{*}{$\begin{array}{l}\text { Depth } \\
\text { (ft bgs) }\end{array}$} & \multicolumn{4}{|c|}{ COPCs (pCi/g) } \\
\hline & & & \multirow{2}{*}{$\frac{A c-228}{5}$} & \multirow{2}{*}{$\frac{A m-241}{12.7}$} & \multirow{2}{*}{$\frac{\text { Cs-137 }}{12.2}$} & \multirow{2}{*}{$\begin{array}{c}\text { Th-234 } \\
105\end{array}$} \\
\hline \multicolumn{3}{|c|}{ FALs } & & & & \\
\hline $\mathrm{A} 01$ & 562A001 & $0.0-0.5$ & 2.16 & -- & 0.98 & $2.01(\mathrm{~J})$ \\
\hline \multirow{2}{*}{$\mathrm{A} 02$} & $562 A 002$ & $0.0-0.5$ & 1.32 & -- & -- & -- \\
\hline & 562A003 & $0.0-0.5$ & 1.7 & -- & -- & -- \\
\hline A03 & 562A004 & $0.0-0.5$ & 1.55 & $1.02(\mathrm{~J})$ & 1.22 & -- \\
\hline A04 & 562A005 & $0.0-0.5$ & 0.94 & -- & -- & -- \\
\hline A05 & $562 A 015$ & $1.0-1.5$ & 2.02 & -- & -- & -- \\
\hline \multirow{3}{*}{ A06 } & 562A007 & $\begin{array}{l}0.0-2.0 \\
\text { (in. bgs) }\end{array}$ & 1.86 & $0.72(\mathrm{~J})$ & 1.34 & -- \\
\hline & 562A008 & $\begin{array}{l}2.0-4.0 \\
\text { (in. bgs) }\end{array}$ & 1.99 & -- & 0.75 & -- \\
\hline & 562A009 & $\begin{array}{l}4.0-6.0 \\
\text { (in. bgs) }\end{array}$ & 1.83 & -- & -- & -- \\
\hline $\mathrm{A} 07$ & $562 \mathrm{~A} 014$ & $1.0-1.5$ & 2.08 & -- & -- & -- \\
\hline \multirow{3}{*}{ A08 } & $562 A 011$ & $\begin{array}{l}0.0-2.0 \\
\text { (in. bgs) }\end{array}$ & 0.87 & -- & -- & -- \\
\hline & $562 A 012$ & $\begin{array}{l}2.0-4.0 \\
\text { (in. bgs) }\end{array}$ & 1.38 & -- & 0.57 & -- \\
\hline & $562 A 013$ & $\begin{array}{l}4.0-6.0 \\
\text { (in. bgs) }\end{array}$ & 2.18 & -- & -- & -- \\
\hline
\end{tabular}

$--=$ Not detected above MDCs.

$\mathrm{J}=$ Estimated value

This sample contained non-rusted shot. Lead was detected at a concentration of 120,000 mg/kg, which exceeded the PAL of $800 \mathrm{mg} / \mathrm{kg}$. Antimony was detected at a concentration of 4,100 mg/kg, which exceeded the PAL of $410 \mathrm{mg} / \mathrm{kg}$. Arsenic was detected at a concentration of 1,400 mg/kg, which exceeded the PAL of $23 \mathrm{mg} / \mathrm{kg}$. Concentrations of arsenic and chromium were detected at concentrations exceeding the PALs at sample location A07 in surface soil sample 562A010, which contained rusted shot. Arsenic was detected at a concentration of $31 \mathrm{mg} / \mathrm{kg}$, which exceeded the PAL of $23 \mathrm{mg} / \mathrm{kg}$. Chromium was detected at a concentration $450 \mathrm{mg} / \mathrm{kg}$, which is equal to the PAL. The 
Table A.3-9

PSM Results Detected above MDCs for CAS 02-26-11, Lead Shot (Page 1 of 2)

\begin{tabular}{|c|c|c|c|c|c|c|}
\hline $\begin{array}{l}\text { Sample } \\
\text { Location }\end{array}$ & $\begin{array}{l}\text { Sample } \\
\text { Number }\end{array}$ & $\begin{array}{c}\text { Sample } \\
\text { Matrix }\end{array}$ & Parameter & Result & $\begin{array}{c}\text { PSM } \\
\text { Criteria }\end{array}$ & Unit \\
\hline \multirow{17}{*}{ A05 } & \multirow{17}{*}{ 562A006 } & \multirow{17}{*}{ Solid } & Methylene chloride & $0.0017(\mathrm{~J})$ & 53 & $\mathrm{mg} / \mathrm{kg}$ \\
\hline & & & Benzo(b)fluoranthene & $0.11(\mathrm{~J})$ & 2.1 & $\mathrm{mg} / \mathrm{kg}$ \\
\hline & & & Di-n-butyl phthalate & $0.25(\mathrm{~J})$ & 62,000 & $\mathrm{mg} / \mathrm{kg}$ \\
\hline & & & Fluoranthene & $0.16(\mathrm{~J})$ & 22,000 & $\mathrm{mg} / \mathrm{kg}$ \\
\hline & & & Phenanthrene & $0.072(\mathrm{~J})$ & 170,000 & $\mathrm{mg} / \mathrm{kg}$ \\
\hline & & & Pyrene & $0.16(\mathrm{~J})$ & 17,000 & $\mathrm{mg} / \mathrm{kg}$ \\
\hline & & & DRO & 16 & $N / A$ & $\mathrm{mg} / \mathrm{kg}$ \\
\hline & & & Antimony & 4,100 & 410 & $\mathrm{mg} / \mathrm{kg}$ \\
\hline & & & Arsenic & 1,400 & 23 & $\mathrm{mg} / \mathrm{kg}$ \\
\hline & & & Barium & 100 & 190,000 & $\mathrm{mg} / \mathrm{kg}$ \\
\hline & & & Cadmium & 0.52 & 800 & $\mathrm{mg} / \mathrm{kg}$ \\
\hline & & & Lead & 120,000 & 800 & $\mathrm{mg} / \mathrm{kg}$ \\
\hline & & & Mercury & 0.014 & 34 & $\mathrm{mg} / \mathrm{kg}$ \\
\hline & & & Selenium & 4.1 & 5,100 & $\mathrm{mg} / \mathrm{kg}$ \\
\hline & & & Silver & 4.8 & 5,100 & $\mathrm{mg} / \mathrm{kg}$ \\
\hline & & & Ac-228 & 0.93 & 5 & $\mathrm{pCi} / \mathrm{g}$ \\
\hline & & & Cs-137 & 0.54 & 12.2 & $\mathrm{pCi} / \mathrm{g}$ \\
\hline
\end{tabular}


Table A.3-9

PSM Results Detected above MDCs for CAS 02-26-11, Lead Shot

(Page 2 of 2)

\begin{tabular}{|c|c|c|c|c|c|c|}
\hline $\begin{array}{l}\text { Sample } \\
\text { Location }\end{array}$ & $\begin{array}{l}\text { Sample } \\
\text { Number }\end{array}$ & $\begin{array}{c}\text { Sample } \\
\text { Matrix }\end{array}$ & Parameter & Result & $\begin{array}{c}\text { PSM } \\
\text { Criteria }\end{array}$ & Unit \\
\hline \multirow{14}{*}{$\mathrm{A} 07$} & \multirow{14}{*}{$562 A 010$} & \multirow{14}{*}{ Solid } & Benzo(b)fluoranthene & $0.075(\mathrm{~J})$ & 2.1 & $\mathrm{mg} / \mathrm{kg}$ \\
\hline & & & Di-n-butyl phthalate & $0.24(\mathrm{~J})$ & 62,000 & $\mathrm{mg} / \mathrm{kg}$ \\
\hline & & & Fluoranthene & $0.13(\mathrm{~J})$ & 22,000 & $\mathrm{mg} / \mathrm{kg}$ \\
\hline & & & Phenanthrene & $0.078(\mathrm{~J})$ & 170,000 & $\mathrm{mg} / \mathrm{kg}$ \\
\hline & & & Pyrene & $0.11(\mathrm{~J})$ & 17,000 & $\mathrm{mg} / \mathrm{kg}$ \\
\hline & & & DRO & 29 & $\mathrm{~N} / \mathrm{A}$ & $\mathrm{mg} / \mathrm{kg}$ \\
\hline & & & Antimony & 38 & 410 & $\mathrm{mg} / \mathrm{kg}$ \\
\hline & & & Arsenic & 31 & 23 & $\mathrm{mg} / \mathrm{kg}$ \\
\hline & & & Barium & $4,300(\mathrm{~J})$ & 190,000 & $\mathrm{mg} / \mathrm{kg}$ \\
\hline & & & Cadmium & 0.65 & 800 & $\mathrm{mg} / \mathrm{kg}$ \\
\hline & & & Chromium & $450(\mathrm{~J})$ & 450 & $\mathrm{mg} / \mathrm{kg}$ \\
\hline & & & Mercury & 0.034 & 34 & $\mathrm{mg} / \mathrm{kg}$ \\
\hline & & & Aroclor 1254 & 0.079 & 0.74 & $\mathrm{mg} / \mathrm{kg}$ \\
\hline & & & Ac-228 & 0.78 & 5 & $\mathrm{pCi} / \mathrm{g}$ \\
\hline
\end{tabular}

$\mathrm{J}=$ Estimated value

Bold indicates the value is equal to or exceeds the PSM criteria.

PSM criteria for these contaminants were established as the PALs, and they are considered PSM contaminants. Therefore, the shot is considered PSM.

\section{A.3.4 Nature and Extent of Contamination}

Based on the analytical results for surface soil samples containing shot, RCRA metals (including antimony) were identified as exceeding PSM criteria. Soil samples that did not contain shot were collected laterally (approximately 0.5 to $1.0 \mathrm{ft}$ distance) and vertically (at a depth of 1.0 to $1.5 \mathrm{ft}$ bgs) from the samples that contained shot. No COCs were identified in the samples that did not contain shot. Additionally, the samples collected at the visible extent of the shot did not contain COCs. The data indicate that PSM contaminants are contained in the shot, and the contaminants have not migrated into the adjacent soil. 


\section{A.3.5 Revised Conceptual Site Model}

The CAIP requirements were met at this CAS, and no revisions were necessary to the CSM. 


\section{A.4.0 CAS 02-44-02, Paint Spills and French Drain, Investigation Results}

Corrective Action Site 02-44-02 is located in the Area 2 Camp at the Painters Shed, Painters Shop, and Paint Storage Rack (Figure 1-2). Although no specific information has been identified discussing the use of these buildings, it is assumed that this area was used to support the painters' activities and to store paint, tools, and other materials. Corrective Action Site 02-44-02 consists of the potential releases to the soil from two french drains, paint spills, and a historical spill of a resin-like substance. Figure A.4-1 shows the sample locations and photographs of CAS 02-44-02.

\section{A.4.1 Corrective Action Investigation Activities}

A total of 18 environmental samples (including 1 FD) and 2 PSM samples were collected during investigation activities at CAS 02-44-02. The sample IDs, locations, types, and analyses are listed in Table A.4-1. The specific CAI activities conducted to satisfy the CAIP requirements at this CAS are described in the following sections.

\section{A.4.1.1 Radiological Surveys}

A radiological walkover survey was completed within the boundary of CAS 02-44-02. The results of the survey did not show radiological contaminants at activities statistically distinguishable from background activities (more than twice background levels). The survey results did not indicate the need for additional biased samples.

\section{A.4.1.2 Visual Inspections}

The following features were visually inspected before and/or during sampling activities at CAS 02-44-02:

French Drains - Inspection of the original french drain discussed in the CAIP revealed that it consisted of a bottomless 55-gal drum with a removable lid and approximately $2.0 \mathrm{ft}$ of void space between the ground surface and the soil in the french drain. The bottom of the drum contained about 6.0 in. of soil with a thin layer of paint-like material on top. The drain was underlain by leach rock that extended to approximately $7.0 \mathrm{ft}$ bgs to the native soil interface. A small diameter pipe was 


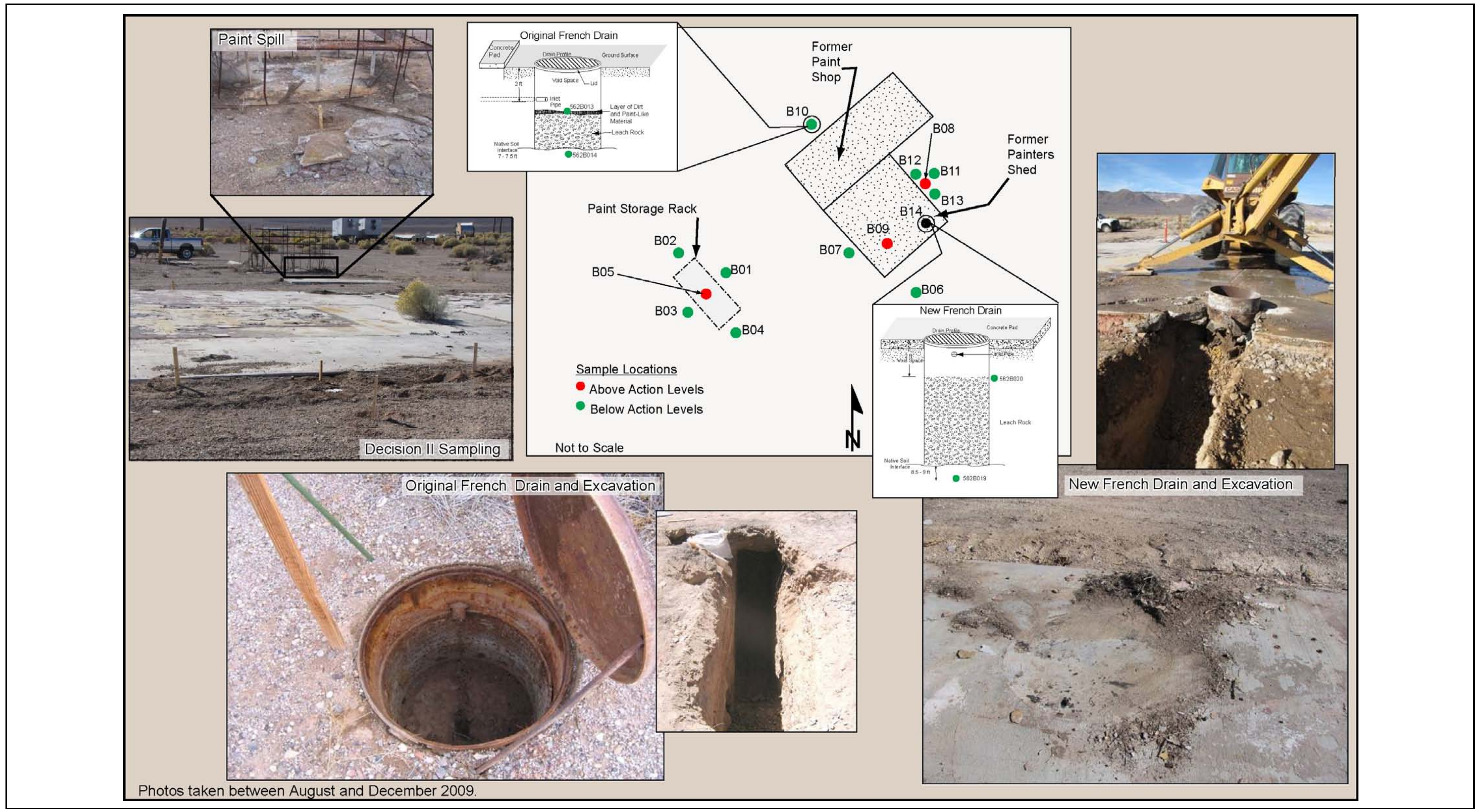

Figure A.4-1

Sample Locations at CAS 02-44-02, Paint Spills and French Drain 
Table A.4-1

Samples Collected at CAS 02-44-02, Paint Spills and French Drain

(Page 1 of 2)

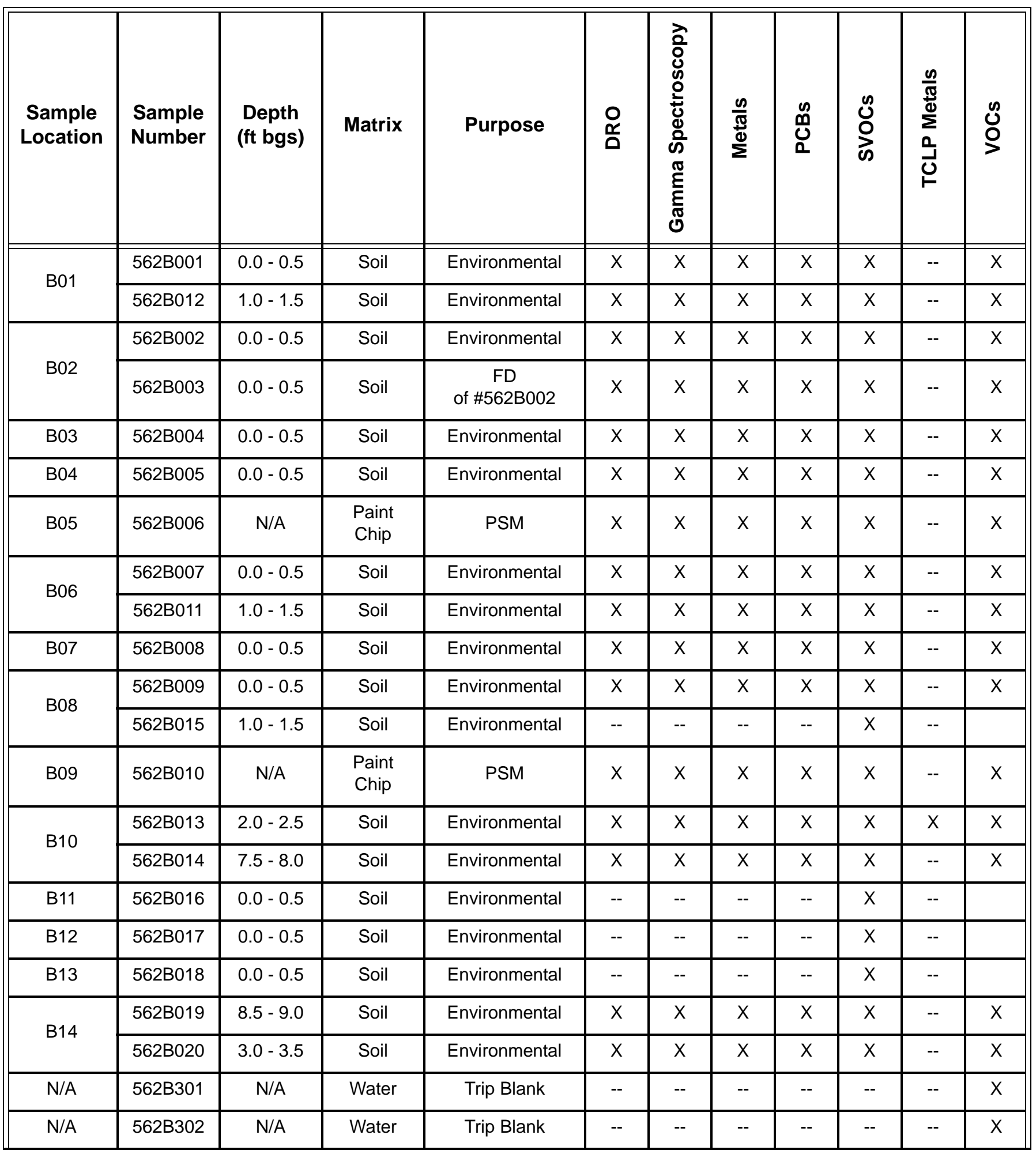


Table A.4-1

\section{Samples Collected at CAS 02-44-02, Paint Spills and French Drain}

(Page 2 of 2)

\begin{tabular}{|c|c|c|c|c|c|c|c|c|c|c|c|}
\hline $\begin{array}{l}\text { Sample } \\
\text { Location }\end{array}$ & $\begin{array}{l}\text { Sample } \\
\text { Number }\end{array}$ & $\begin{array}{c}\text { Depth } \\
\text { (ft bgs) }\end{array}$ & Matrix & Purpose & $\begin{array}{l}\text { 움 } \\
\text { 茄 }\end{array}$ & 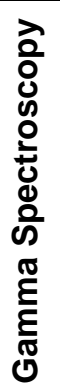 & $\begin{array}{l}\frac{\omega}{\pi} \\
\frac{\pi}{\tilde{e}}\end{array}$ & $\begin{array}{l}\mathscr{n} \\
\mathbf{0} \\
\text { Un }\end{array}$ & $\overbrace{n}^{0}$ & 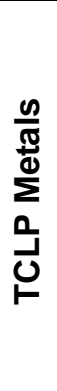 & $\begin{array}{l}\text { ç } \\
\text { o }\end{array}$ \\
\hline N/A & 562B304 & N/A & Water & Trip Blank & -- & -- & -- & -- & -- & -- & $x$ \\
\hline $\begin{array}{l}\text { Sample } \\
\text { Table }\end{array}$ & 562B303 & $N / A$ & Water & Field Blank & $x$ & $x$ & $x$ & $x$ & $x$ & -- & $x$ \\
\hline
\end{tabular}

$--=$ Not required

visible in the sidewall that was closest to the Painters Shop pad. It is believed that the pipe connected to the new french drain and the two french drains worked as an overflow system.

During the CAI, a new french drain was identified. This french drain consisted of a bottomless 55-gal drum with a lid that was embedded in the foundation of the former Painters Shed. There was approximately $2.0 \mathrm{ft}$ of void space above the leach rock that extends to a depth of approximately $8.5 \mathrm{ft}$ bgs. A small diameter pipe was also present in the sidewall that was closest to the Painters Shed pad. It is believed that this pipe connected the new french drain with the original french drain.

Paint Spills - Two areas consisting of multiple layers of dried paint were identified on the foundations of the former Paint Storage Rack and Painters Shed; these areas were selected as biased locations B05 and B09, respectively. A third paint spill was identified on the northeast side of the Paint Storage Rack foundation and was selected as biased location B01. The soil underlying the dried layers of paint at location B01 was mixed with pea gravel and slightly discolored.

Historical Spill - The area on the southeastern side of the former Painters Shed was inspected to identify the reported historical spill of a resin-like material; however, no soil discoloration or other visual evidence of a release was observed. The biased sample location (B06) representing the historical spill was, therefore, determined using GPS coordinates provided in the document that first identified the spill (REECo, 1995). 


\section{A.4.1.3 Sample Collection}

Sampling included the collection of 18 (including 1 FD) environmental surface and subsurface soil samples and 2 PSM samples from 14 locations. All sample locations are shown on Figure A.4-1. The sampling activities are discussed below.

French Drains - Sampling activities at the original french drain discussed in the CAIP included the collection of two environmental samples from location B10. Sample 562B013 was collected from a depth of 2.0 to $2.5 \mathrm{ft}$ bgs and consisted of soil mixed with possible paint chips and other miscellaneous debris. This sample was collected from the 6.0 in. of material on top of the leach rock. Leach rock extended from the base of the french drain to $7.0 \mathrm{ft}$ bgs. Sample 562B014 was collected at a depth of 7.5 to $8.0 \mathrm{ft}$ bgs and represents the native soil below the french drain and leach rock.

Sampling activities at the french drain identified in the Painters Shed foundation during the field investigation included the collection of two environmental samples from location B14. Sample 562B020 was collected from a depth of 3.0 to $3.5 \mathrm{ft}$ bgs, from the sidewall of the excavation directly below the base of the french drain. The french drain was emplaced in a bed of leach rock that extended $8.5 \mathrm{ft}$ bgs to the native soil interface. Sample 562B019 was collected from 8.5 to $9.0 \mathrm{ft}$ bgs and represents the native soil below the leach rock.

Paint Spills - Sampling activities at the Paint Storage Rack included the collection of one PSM sample and six environmental soil samples. Potential source material sample 562B006 (location B05) consisted of 1.0- to 3.0-mm-thick paint chips of various colors. Environmental samples 562B001 and 562B012 were collected from the paint spill location (B01) northeast of the Paint Storage Rack. Sample 562B001 was collected from 0.0 to $0.5 \mathrm{ft}$ bgs and consisted of soil and the surface layer of paint. Sample 562B012 was collected from 1.0 to $1.5 \mathrm{ft}$ bgs, directly below sample 562B001, and consisted of native soil. Environmental surface soil samples (562B002 through 562B005) were collected from each of the remaining sides of the Paint Storage Rack (location B02, northwest; location B03, southwest; and location B04, southeast).

Sampling activities at the Painters Shed foundation included the collection of one PSM sample and two environmental soil samples. Potential source material sample 562B010 was collected from the Painters Shed foundation (location B09) and consisted of 1.0- to 3.0-mm-thick paint chips. Surface 
samples 562B008 and 562B009 were collected from the southwestern and northeastern sides of the Painters Shed foundation at locations B07 and B08, respectively.

Because a COC was identified in sample 562B009, four Decision II environmental soil samples were collected to define the extent of contamination. One sample (562B015) was collected at 1.0 to $1.5 \mathrm{ft}$ bgs at sample location B08, which contained a COC. Three additional sample locations (B11 through B13) were selected approximately $3.0 \mathrm{ft}$ laterally in three directions from location B08. Sample location B12 was altered slightly because there was asphalt present in the area.

Historical Spill - Sampling activities at the historical spill included the collection of two environmental soil samples from location B06 on the southeastern side of the Painters Shed foundation. Sample 562B007 was collected from 0.0 to $0.5 \mathrm{ft}$ bgs and consisted of surface soil. Sample 562B011 was collected from 1.0 to $1.5 \mathrm{ft}$ bgs at the same location and consisted of native soil.

\section{A.4.1.4 Deviations}

An additional french drain was identified on the foundation of the former Painters Shed. The sampling design for the original french drain in this CAS was applied to the new french drain. Therefore, there were no deviations to the CAU 562 CAIP (NNSA/NSO, 2009) associated with CAS 02-44-02. Investigation samples were collected as outlined in the CAU 562 CAIP and submitted for laboratory analysis.

\section{A.4.2 Investigation Results}

The following sections provide analytical results from the samples collected to complete investigation activities as outlined in the CAIP (NNSA/NSO, 2009). Table A.4-1 lists the sample-specific analytical suite for CAS 02-44-02.

Analytical results from the soil samples with concentrations exceeding MDCs are summarized in the following sections. An evaluation was conducted on all contaminants detected above MDCs by comparing individual concentration or activity results against the FALs. Establishment of the FALs is presented in Appendix D. The FALs were established as the corresponding PAL concentrations or activities if the contaminant concentrations were below their respective PALs. 


\section{A.4.2.1 Volatile Organic Compounds}

Analytical results for VOCs in soil samples collected at this CAS that were detected above MDCs are presented in Table A.4-2. No VOCs were detected at concentrations exceeding their respective PALs. The FALs were established at the PAL concentrations.

Table A.4-2

Sample Results for Total VOCs Detected above MDCs at CAS 02-44-02, Paint Spills and French Drain

\begin{tabular}{|c|c|c|c|}
\hline \multirow{2}{*}{$\begin{array}{c}\text { Sample } \\
\text { Location }\end{array}$} & \multirow{2}{*}{$\begin{array}{c}\text { Sample } \\
\text { Number }\end{array}$} & \multirow{2}{*}{$\begin{array}{c}\text { Depth } \\
\text { (ft bgs) }\end{array}$} & COPCs (mg/kg) \\
\cline { 4 - 4 } & & & Methylene chloride \\
\hline \multicolumn{3}{|c|}{ FALs } & $0.0021(\mathrm{~J})$ \\
\hline B01 & $562 \mathrm{~B} 001$ & $0.0-0.5$ & $0.0017(\mathrm{~J})$ \\
\hline B03 & $562 \mathrm{~B} 004$ & $0.0-0.5$ & \\
\hline
\end{tabular}

$\mathrm{J}=$ Estimated value

\section{A.4.2.2 Semivolatile Organic Compounds}

Analytical results for SVOCs in soil samples collected at this CAS that were detected above MDCs are presented in Table A.4-3. Surface soil sample 562B009 at location B08 contained benzo(a)pyrene at a concentration of $0.22 \mathrm{mg} / \mathrm{kg}$, which exceeds the PAL of $0.21 \mathrm{mg} / \mathrm{kg}$. Because the FAL was established at the PAL concentration, benzo(a)pyrene is considered a COC. Four Decision II samples (562B015 through 562B018) were collected laterally and vertically from this soil sample location. Sample 562B015 was collected at 1.0 to $1.5 \mathrm{ft}$ bgs at location B08, whereas the step-out surface samples were collected $3.0 \mathrm{ft}$ laterally in three directions from sample location B08. No COCs were identified in these Decision II bounding samples.

\section{A.4.2.3 Total Petroleum Hydrocarbons}

Analytical results for TPH-DRO in soil samples collected at this CAS that were detected above MDCs are presented in Table A.4-4. A concentration of $180 \mathrm{mg} / \mathrm{kg}$ of TPH-DRO was detected at subsurface (2.0 to $2.5 \mathrm{ft}$ bgs) in sample 562B013, which exceeds the PAL of $100 \mathrm{mg} / \mathrm{kg}$. The TPH-DRO was moved on to a Tier 2 evaluation, and FALs were established for the hazardous constituents of TPH-DRO. Concentrations of the hazardous constituents of TPH-DRO did not 
Table A.4-3

Sample Results for Total SVOCs Detected above MDCs at CAS 02-44-02, Paint Spills and French Drain

(Page 1 of 2)

\begin{tabular}{|c|c|c|c|c|c|c|c|c|c|c|c|c|c|c|}
\hline \multirow[b]{2}{*}{$\begin{array}{l}\text { Sample } \\
\text { Location }\end{array}$} & \multirow[b]{2}{*}{$\begin{array}{l}\text { Sample } \\
\text { Number }\end{array}$} & \multirow[b]{2}{*}{$\begin{array}{c}\text { Depth } \\
\text { (ft bgs) }\end{array}$} & \multicolumn{12}{|c|}{ COPCs (mg/kg) } \\
\hline & & & 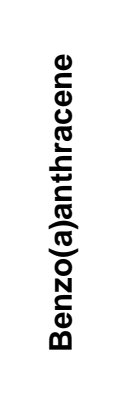 & 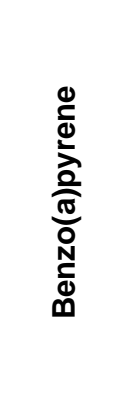 & 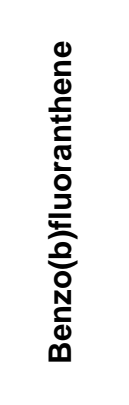 & 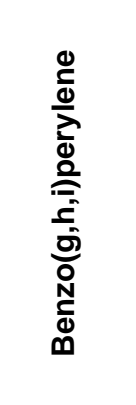 & 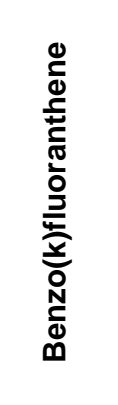 & 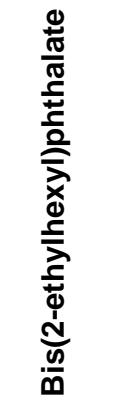 & 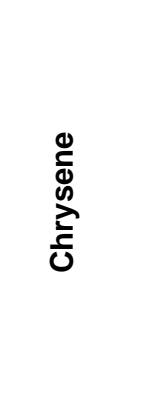 & 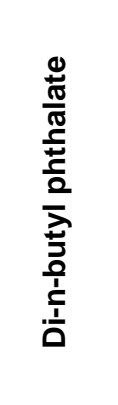 & 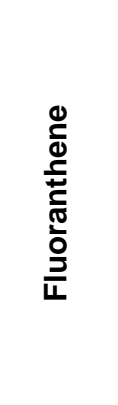 & 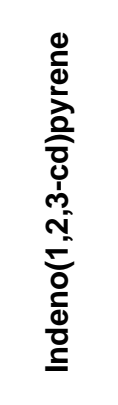 & 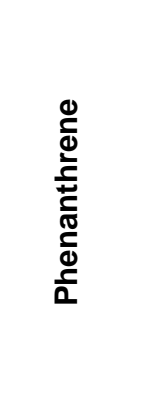 & 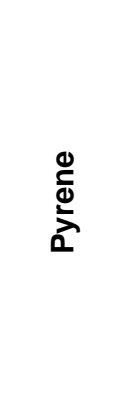 \\
\hline \multicolumn{3}{|c|}{ FALs } & 2.1 & 0.21 & 2.1 & 17,000 & 21 & 120 & 210 & 62,000 & 22,000 & 2.1 & 170,000 & 17,000 \\
\hline \multirow{2}{*}{ B01 } & 562B001 & $0.0-0.5$ & -- & -- & -- & -- & -- & 3 & -- & -- & -- & -- & -- & -- \\
\hline & 562B012 & $1.0-1.5$ & -- & -- & -- & -- & -- & 1.5 & -- & $0.21(\mathrm{~J})$ & $0.11(\mathrm{~J})$ & -- & $0.078(\mathrm{~J})$ & $0.081(\mathrm{~J})$ \\
\hline \multirow{2}{*}{ B02 } & 562B002 & $0.0-0.5$ & -- & -- & $0.088(\mathrm{~J})$ & -- & -- & -- & -- & $0.2(\mathrm{~J})$ & $0.14(\mathrm{~J})$ & -- & $0.083(\mathrm{~J})$ & $0.12(\mathrm{~J})$ \\
\hline & 562B003 & $0.0-0.5$ & $0.099(\mathrm{~J})$ & $0.095(\mathrm{~J})$ & $0.17(\mathrm{~J})$ & -- & -- & -- & $0.12(\mathrm{~J})$ & $0.2(\mathrm{~J})$ & $0.27(\mathrm{~J})$ & -- & $0.12(\mathrm{~J})$ & $0.22(\mathrm{~J})$ \\
\hline B03 & 562B004 & $0.0-0.5$ & $0.079(\mathrm{~J})$ & $0.081(\mathrm{~J})$ & $0.15(\mathrm{~J})$ & -- & -- & $0.1(\mathrm{~J})$ & $0.084(\mathrm{~J})$ & 0.44 & $0.26(\mathrm{~J})$ & -- & $0.15(\mathrm{~J})$ & $0.23(\mathrm{~J})$ \\
\hline B04 & 562B005 & $0.0-0.5$ & -- & -- & $0.076(\mathrm{~J})$ & -- & -- & -- & -- & $0.21(\mathrm{~J})$ & $0.15(\mathrm{~J})$ & -- & $0.097(\mathrm{~J})$ & $0.12(\mathrm{~J})$ \\
\hline \multirow{2}{*}{ B06 } & 562B007 & $0.0-0.5$ & -- & $0.075(\mathrm{~J})$ & $0.11(\mathrm{~J})$ & $0.076(\mathrm{~J})$ & -- & $0.11(\mathrm{~J})$ & $0.075(\mathrm{~J})$ & $0.29(\mathrm{~J})$ & $0.19(\mathrm{~J})$ & -- & $0.11(\mathrm{~J})$ & $0.31(\mathrm{~J})$ \\
\hline & 562B011 & $1.0-1.5$ & -- & -- & -- & -- & -- & $0.15(\mathrm{~J})$ & -- & $0.12(\mathrm{~J})$ & $0.09(\mathrm{~J})$ & -- & -- & $0.072(\mathrm{~J})$ \\
\hline B07 & 562B008 & $0.0-0.5$ & -- & -- & -- & -- & -- & $0.29(\mathrm{~J})$ & -- & -- & -- & -- & -- & -- \\
\hline \multirow{2}{*}{ B08 } & 562B009 & $0.0-0.5$ & $0.21(\mathrm{~J})$ & 0.22 & 0.37 & $0.096(\mathrm{~J})$ & $0.16(\mathrm{~J})$ & $2.4(\mathrm{~J})$ & $0.25(\mathrm{~J})$ & 0.97 & 0.62 & $0.11(\mathrm{~J})$ & 0.45 & 0.65 \\
\hline & 562B015 & $1.0-1.5$ & -- & -- & -- & -- & -- & $0.16(\mathrm{~J})$ & -- & -- & -- & -- & -- & -- \\
\hline B10 & 562B013 & $2.0-2.5$ & -- & -- & -- & -- & -- & 8.5 & -- & -- & -- & -- & -- & -- \\
\hline B11 & 562B016 & $0.0-0.5$ & -- & $0.078(\mathrm{~J})$ & $0.17(\mathrm{~J})$ & $0.21(\mathrm{~J})$ & -- & 3.2 & $0.088(\mathrm{~J})$ & $0.16(\mathrm{~J})$ & $0.17(\mathrm{~J})$ & $0.1(\mathrm{~J})$ & $0.09(\mathrm{~J})$ & $0.25(\mathrm{~J})$ \\
\hline
\end{tabular}


Table A.4-3

Sample Results for Total SVOCs Detected above MDCs at CAS 02-44-02, Paint Spills and French Drain

(Page 2 of 2)

\begin{tabular}{|c|c|c|c|c|c|c|c|c|c|c|c|c|c|c|}
\hline \multirow[b]{2}{*}{$\begin{array}{l}\text { Sample } \\
\text { Location }\end{array}$} & \multirow[b]{2}{*}{$\begin{array}{l}\text { Sample } \\
\text { Number }\end{array}$} & \multirow[b]{2}{*}{$\begin{array}{l}\text { Depth } \\
\text { (ft bgs) }\end{array}$} & \multicolumn{12}{|c|}{ COPCs (mg/kg) } \\
\hline & & & 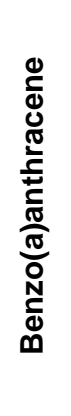 & 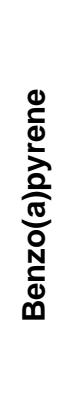 & 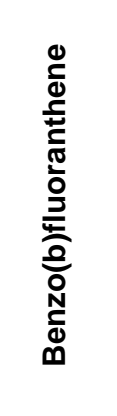 & 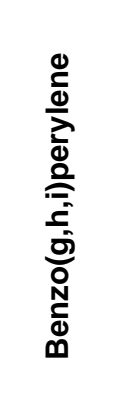 & 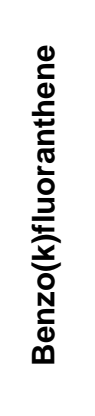 & 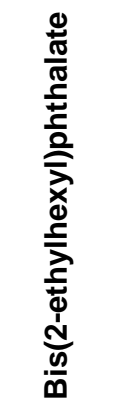 & 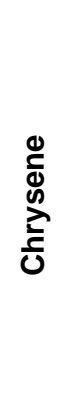 & 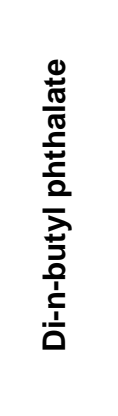 & 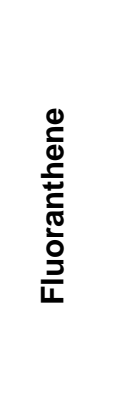 & 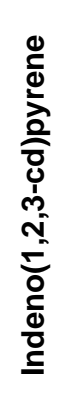 & 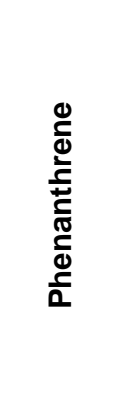 & 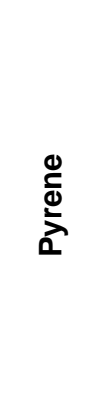 \\
\hline \multicolumn{3}{|c|}{ FALs } & 2.1 & 0.21 & 2.1 & 17,000 & 21 & 120 & 210 & 62,000 & 22,000 & 2.1 & 170,000 & 17,000 \\
\hline B12 & 562B017 & $0.0-0.5$ & -- & -- & $0.15(\mathrm{~J})$ & -- & $\begin{array}{c}0.069 \\
(\mathrm{~J})\end{array}$ & 0.72 & -- & $0.23(\mathrm{~J})$ & $0.17(\mathrm{~J})$ & -- & $0.096(\mathrm{~J})$ & $0.15(\mathrm{~J})$ \\
\hline B13 & 562B018 & $0.0-0.5$ & -- & -- & -- & -- & -- & 0.62 & -- & $\begin{array}{c}0.079 \\
(\mathrm{~J})\end{array}$ & -- & -- & -- & -- \\
\hline B14 & 562B020 & $3.0-3.5$ & -- & -- & -- & -- & -- & $0.28(\mathrm{~J})$ & -- & -- & -- & -- & -- & -- \\
\hline
\end{tabular}

$--=$ Not detected above MDCs.

$\mathrm{J}=$ Estimated value

Bold indicates the value is equal to or exceeds the FAL. 
Table A.4-4

\section{Sample Results for TPH-DRO Detected above MDCs at CAS 02-44-02, Paint Spills and French Drain}

\begin{tabular}{|c|c|c|c|}
\hline \multirow{2}{*}{$\begin{array}{c}\text { Sample } \\
\text { Location }\end{array}$} & \multirow{2}{*}{$\begin{array}{l}\text { Sample } \\
\text { Number }\end{array}$} & \multirow{2}{*}{$\begin{array}{c}\text { Depth } \\
\text { (ft bgs) }\end{array}$} & COPCs $(\mathrm{mg} / \mathrm{kg})$ \\
\hline & & & DRO \\
\hline \multicolumn{3}{|c|}{ PALs } & 100 \\
\hline \multirow{2}{*}{ B01 } & 562B001 & $0.0-0.5$ & 19 \\
\hline & 562B012 & $1.0-1.5$ & 18 \\
\hline \multirow{2}{*}{ B02 } & 562B002 & $0.0-0.5$ & 15 \\
\hline & 562B003 & $0.0-0.5$ & 13 \\
\hline B03 & 562B004 & $0.0-0.5$ & 56 \\
\hline B04 & 562B005 & $0.0-0.5$ & 8.7 \\
\hline \multirow{2}{*}{ B06 } & 562B007 & $0.0-0.5$ & 31 \\
\hline & 562B011 & $1.0-1.5$ & 20 \\
\hline B08 & 562B009 & $0.0-0.5$ & 42 \\
\hline \multirow{2}{*}{ B10 } & 562B013 & $2.0-2.5$ & 180 \\
\hline & 562B014 & $7.5-8.0$ & 10 \\
\hline \multirow{2}{*}{ B14 } & 562B019 & $8.5-9.0$ & $2.5(\mathrm{~J})$ \\
\hline & 562B020 & $3.0-3.5$ & $2.7(\mathrm{~J})$ \\
\hline
\end{tabular}

$\mathrm{J}=$ Estimated value

Bold indicates the value is equal to or exceeds the PAL.

exceed FALs. Therefore, TPH-DRO is not considered a COC. The calculation of FALs for the hazardous constituents of TPH-DRO is presented in Appendix D.

\section{A.4.2.4 Resource Conservation and Recovery Act Metals}

Analytical results for RCRA metals in soil samples collected at this CAS that were detected above MDCs are presented in Table A.4-5. No RCRA metals were detected at concentrations exceeding their PALs. The FALs were established at the PAL concentrations. 


\section{Table A.4-5 \\ Sample Results for Metals Detected above MDCs at CAS 02-44-02, Paint Spills and French Drain}

\begin{tabular}{|c|c|c|c|c|c|c|c|c|c|c|}
\hline \multirow[b]{2}{*}{$\begin{array}{l}\text { Sample } \\
\text { Location }\end{array}$} & \multirow[b]{2}{*}{$\begin{array}{l}\text { Sample } \\
\text { Number }\end{array}$} & \multirow[b]{2}{*}{$\begin{array}{c}\text { Depth } \\
\text { (ft bgs) }\end{array}$} & \multicolumn{8}{|c|}{ COPCs (mg/kg) } \\
\hline & & & 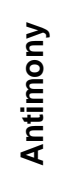 & 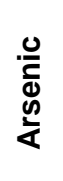 & 芷 & $\frac{\varepsilon}{\frac{\varepsilon}{\Sigma}}$ & 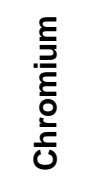 & ర్త్ర & $\begin{array}{l}\geqq \\
\frac{\lambda}{0} \\
\frac{0}{d} \\
\sum\end{array}$ & $\frac{\xi}{\frac{\varepsilon}{丂}}$ \\
\hline \multicolumn{3}{|c|}{ FALs } & 410 & 23 & 190,000 & 800 & 450 & 800 & 34 & 5,100 \\
\hline \multirow{2}{*}{ B01 } & 562B001 & $0.0-0.5$ & 4.4 & 1.9 & $140(\mathrm{~J})$ & 0.38 & $24(\mathrm{~J})$ & $130(\mathrm{~J})$ & 0.29 & -- \\
\hline & 562B012 & $1.0-1.5$ & -- & 2.4 & 200 & 0.6 & 32 & 140 & $0.099(\mathrm{~J}-)$ & -- \\
\hline \multirow{2}{*}{ B02 } & 562B002 & $0.0-0.5$ & -- & 2.5 & $110(\mathrm{~J})$ & 0.5 & $6(\mathrm{~J})$ & $24(J)$ & 0.035 & 0.35 \\
\hline & 562B003 & $0.0-0.5$ & -- & 2.3 & $110(\mathrm{~J})$ & 0.47 & $6.5(\mathrm{~J})$ & $27(\mathrm{~J})$ & 0.03 & -- \\
\hline B03 & 562B004 & $0.0-0.5$ & -- & 2 & $120(\mathrm{~J})$ & 0.39 & $18(\mathrm{~J})$ & $53(\mathrm{~J})$ & 0.15 & 0.58 \\
\hline B04 & 562B005 & $0.0-0.5$ & -- & 4 & $150(\mathrm{~J})$ & 3.2 & $17(\mathrm{~J})$ & $34(J)$ & 0.045 & 1.1 \\
\hline \multirow{2}{*}{ B06 } & 562B007 & $0.0-0.5$ & -- & 3.1 & 150 & 0.43 & 51 & 31 & -- & 0.67 \\
\hline & 562B011 & $1.0-1.5$ & -- & 2.6 & 120 & 0.32 & 10 & 28 & $0.029(\mathrm{~J}-)$ & -- \\
\hline B07 & 562B008 & $0.0-0.5$ & -- & 4.3 & 130 & 0.46 & 18 & 16 & 0.047 & 0.43 \\
\hline B08 & 562B009 & $0.0-0.5$ & -- & 2.4 & 220 & 3.4 & 240 & 600 & 0.26 & 0.54 \\
\hline \multirow{2}{*}{ B10 } & 562B013 & $2.0-2.5$ & -- & 1.3 & 500 & 6.5 & 44 & 180 & $12(\mathrm{~J}-)$ & -- \\
\hline & 562B014 & $7.5-8.0$ & -- & 2.5 & 170 & 0.14 & 4.1 & 8.7 & 0.67 (J-) & -- \\
\hline \multirow{2}{*}{ B14 } & 562B019 & $8.5-9.0$ & -- & 2.9 & 88 & -- & 3.5 & 9.5 & 0.029 & -- \\
\hline & 562B020 & $3.0-3.5$ & -- & 3.2 & 110 & -- & 7.7 & 12 & 0.035 & -- \\
\hline
\end{tabular}

$--=$ Not detected above MDCs.

$\mathrm{J}=$ Estimated value

$\mathrm{J}-=$ Result is an estimated quantity but may be biased low.

\section{A.4.2.5 Polychlorinated Biphenyls}

Analytical results for PCBs in soil samples collected at this CAS that were detected above MDCs are presented in Table A.4-6. No PCBs were detected at concentrations exceeding their PALs. The FALs were established at the PAL concentrations. 


\section{Table A.4-6 \\ Sample Results for PCBs Detected above MDCs at CAS 02-44-02, Paint Spills and French Drain}

\begin{tabular}{|c|c|c|c|c||}
\hline \multirow{2}{*}{$\begin{array}{c}\text { Sample } \\
\text { Location }\end{array}$} & \multirow{2}{*}{$\begin{array}{c}\text { Sample } \\
\text { Number }\end{array}$} & \multirow{2}{*}{$\begin{array}{c}\text { Depth } \\
\text { ft bgs) }\end{array}$} & Aroclor 1254 & Aroclor 1260 \\
\cline { 4 - 5 } & & & $\mathbf{0 . 7 4}$ & $\mathbf{0 . 7 4}$ \\
\hline \multirow{3}{*}{ FALs } & & -- & $0.1(\mathrm{~J})$ \\
\hline \hline \multirow{2}{*}{ B01 } & $562 \mathrm{~B} 001$ & $0.0-0.5$ & -- & 0.044 \\
\cline { 3 - 6 } & $562 \mathrm{~B} 012$ & $1.0-1.5$ & -- & 0.062 \\
\hline \multirow{2}{*}{ B02 } & $562 \mathrm{~B} 002$ & $0.0-0.5$ & -- & $0.056(\mathrm{~J})$ \\
\hline & $562 \mathrm{~B} 003$ & $0.0-0.5$ & -- & 0.042 \\
\hline B03 & $562 \mathrm{~B} 004$ & $0.0-0.5$ & -- & $0.53(\mathrm{~J})$ \\
\hline B04 & $562 \mathrm{~B} 005$ & $0.0-0.5$ & 0.068 & 0.091 \\
\hline \multirow{2}{*}{ B06 } & $562 \mathrm{~B} 007$ & $0.0-0.5$ & -- & 0.027 \\
\hline & $562 \mathrm{~B} 011$ & $1.0-1.5$ & 0.38 & 0.19 \\
\hline B08 & $562 \mathrm{~B} 009$ & $0.0-0.5$ & -- & $0.0092(\mathrm{~J})$ \\
\hline B10 & $562 \mathrm{~B} 013$ & $2.0-2.5$ & -- & $0.0048(\mathrm{~J})$ \\
\hline B14 & $562 \mathrm{~B} 020$ & $3.0-3.5$ & & \\
\hline
\end{tabular}

$--=$ Not detected above MDCs.

$\mathrm{J}=$ Estimated value

\section{A.4.2.6 Gamma-Emitting Radionuclides}

Analytical results for gamma-emitting radionuclides in soil samples collected at this CAS that were detected above MDCs are presented in Table A.4-7. No gamma-emitting radionuclides were detected at concentrations exceeding their PALs. The FALs were established at the PAL concentrations.

\section{A.4.3 Potential Source Material Sample Results}

Analytical results for paint samples (562B006 and 562B010) with concentrations exceeding MDCs are presented in Table A.4-8. The analytical results indicate that chromium (530 and 5,800 mg/kg), benzo(a)pyrene (2.3 mg/kg), benzo(b)floroanthene (5 mg/kg), lead (7,200 mg/kg), and bis(2-ethylhexyl)phthalate (220 mg/kg) are present at concentrations above the respective PALs. The PSM criteria were established at the PAL concentrations. Therefore, the contaminants are considered PSM. 
Table A.4-7

\section{Sample Results for Gamma-Emitting Radionuclides Detected above MDCs at CAS 02-44-02, Paint Spills and French Drain}

\begin{tabular}{|c|c|c|c|c|c|c|}
\hline \multirow{2}{*}{$\begin{array}{l}\text { Sample } \\
\text { Location }\end{array}$} & \multirow{2}{*}{$\begin{array}{l}\text { Sample } \\
\text { Number }\end{array}$} & \multirow{2}{*}{$\begin{array}{l}\text { Depth } \\
\text { (ft bgs) }\end{array}$} & \multicolumn{4}{|c|}{ COPCs (pCi/g) } \\
\hline & & & Ac-228 & Am-241 & Cs-137 & Th-234 \\
\hline \multicolumn{3}{|c|}{ FALs } & 5 & 12.7 & 12.2 & 105 \\
\hline \multirow{2}{*}{ B01 } & 562B001 & $0.0-0.5$ & 1.07 & -- & -- & -- \\
\hline & 562B012 & $1.0-1.5$ & 1.7 & $0.61(\mathrm{~J})$ & 1.33 & -- \\
\hline \multirow{2}{*}{ B02 } & 562B002 & $0.0-0.5$ & 2 & -- & 0.491 & $3.59(\mathrm{~J})$ \\
\hline & 562B003 & $0.0-0.5$ & 1.91 & -- & 0.27 & $2.45(\mathrm{~J})$ \\
\hline B03 & 562B004 & $0.0-0.5$ & 1.22 & -- & 0.42 & -- \\
\hline B04 & 562B005 & $0.0-0.5$ & 1.2 & -- & -- & -- \\
\hline B06 & 562B007 & $0.0-0.5$ & 1.13 & -- & 0.36 & -- \\
\hline B06 & 562B011 & $1.0-1.5$ & 1.6 & $0.89(\mathrm{~J})$ & 0.43 & -- \\
\hline B07 & 562B008 & $0.0-0.5$ & 1.09 & $2.23(\mathrm{~J})$ & 0.405 & -- \\
\hline B08 & 562B009 & $0.0-0.5$ & 1.44 & -- & 0.52 & -- \\
\hline \multirow{2}{*}{ B10 } & 562B013 & $2.0-2.5$ & -- & -- & -- & -- \\
\hline & 562B014 & $7.5-8.0$ & 2.05 & -- & -- & $2.31(\mathrm{~J})$ \\
\hline \multirow{2}{*}{ B14 } & 562B019 & $8.5-9.0$ & 2.82 & -- & -- & -- \\
\hline & 562B020 & $3.0-3.5$ & 2.83 & -- & -- & -- \\
\hline
\end{tabular}

-- = Not detected above MDCs.

$\mathrm{J}=$ Estimated value

Additionally, TPH-DRO was detected at concentrations of 1,100 and 3,000 mg/kg in the two PSM samples. The TPH-DRO was moved on to a Tier 2 evaluation, and PSM criteria were established for the hazardous constituents for TPH-DRO at their respective PAL concentrations. As benzo(a)pyrene and benzo(b)fluoranthene are hazardous constituents of TPH-DRO that exceeded the PSM criteria, they are considered PSM contaminants. Based on the presence of PSM contaminants, the paint is considered PSM.

\section{A.4.4 Nature and Extent of Contamination}

Based on the analytical results for soil samples collected within CAS 02-44-02, the only COC identified was benzo(a)pyrene in one surface sample collected adjacent to the former Painters Shed concrete foundation. The lateral and vertical extent of contamination was defined by the Decision II 
Table A.4-8

PSM Results Detected above MDCs for CAS 02-44-02, Paint Spills and French Drain (Page 1 of 2)

\begin{tabular}{|c|c|c|c|c|c|c|}
\hline $\begin{array}{l}\text { Sample } \\
\text { Location }\end{array}$ & $\begin{array}{l}\text { Sample } \\
\text { Number }\end{array}$ & $\begin{array}{c}\text { Sample } \\
\text { Matrix }\end{array}$ & Parameter & Result & $\begin{array}{c}\text { PSM } \\
\text { Criteria }\end{array}$ & Unit \\
\hline \multirow{22}{*}{ B05 } & \multirow{22}{*}{ 562B006 } & \multirow{22}{*}{ Paint } & DRO & 1,100 & N/A & $\mathrm{mg} / \mathrm{kg}$ \\
\hline & & & Arsenic & 1.7 & 23 & $\mathrm{mg} / \mathrm{kg}$ \\
\hline & & & Barium & 4,100 & 190,000 & $\mathrm{mg} / \mathrm{kg}$ \\
\hline & & & Cadmium & 4.4 & 800 & $\mathrm{mg} / \mathrm{kg}$ \\
\hline & & & Chromium & $530(\mathrm{~J})$ & 450 & $\mathrm{mg} / \mathrm{kg}$ \\
\hline & & & Lead & $580(\mathrm{~J})$ & 800 & $\mathrm{mg} / \mathrm{kg}$ \\
\hline & & & Mercury & 0.93 & 34 & $\mathrm{mg} / \mathrm{kg}$ \\
\hline & & & Selenium & 0.85 & 5,100 & $\mathrm{mg} / \mathrm{kg}$ \\
\hline & & & Aroclor 1260 & $0.66(\mathrm{~J})$ & 0.74 & $\mathrm{mg} / \mathrm{kg}$ \\
\hline & & & Benzo(a)pyrene & $2.3(\mathrm{~J})$ & 0.21 & $\mathrm{mg} / \mathrm{kg}$ \\
\hline & & & Benzo(b)fluoranthene & $5(J)$ & 2.1 & $\mathrm{mg} / \mathrm{kg}$ \\
\hline & & & Bis(2-ethylhexyl)phthalate & 84 & 120 & $\mathrm{mg} / \mathrm{kg}$ \\
\hline & & & Butyl benzyl phthalate & $6(\mathrm{~J})$ & 910 & $\mathrm{mg} / \mathrm{kg}$ \\
\hline & & & Carbazole & $2.9(\mathrm{~J})$ & 95.8 & $\mathrm{mg} / \mathrm{kg}$ \\
\hline & & & Chrysene & $8.4(\mathrm{~J})$ & 210 & $\mathrm{mg} / \mathrm{kg}$ \\
\hline & & & Di-n-butyl phthalate & $3.9(\mathrm{~J})$ & 62,000 & $\mathrm{mg} / \mathrm{kg}$ \\
\hline & & & Fluoranthene & 25 & 22,000 & $\mathrm{mg} / \mathrm{kg}$ \\
\hline & & & Phenanthrene & 15 & 170,000 & $\mathrm{mg} / \mathrm{kg}$ \\
\hline & & & Pyrene & 16 & 17,000 & $\mathrm{mg} / \mathrm{kg}$ \\
\hline & & & 2-butanone & 0.03 & 200,000 & $\mathrm{mg} / \mathrm{kg}$ \\
\hline & & & 2-hexanone & $0.018(\mathrm{~J})$ & 1,400 & $\mathrm{mg} / \mathrm{kg}$ \\
\hline & & & Acetone & 0.15 & 630,000 & $\mathrm{mg} / \mathrm{kg}$ \\
\hline \multirow{6}{*}{ B09 } & \multirow{6}{*}{ 562B010 } & \multirow{6}{*}{ Paint } & DRO & 3,000 & N/A & $\mathrm{mg} / \mathrm{kg}$ \\
\hline & & & Arsenic & 3.1 & 23 & $\mathrm{mg} / \mathrm{kg}$ \\
\hline & & & Barium & 6,200 & 190,000 & $\mathrm{mg} / \mathrm{kg}$ \\
\hline & & & Cadmium & 43 & 800 & $\mathrm{mg} / \mathrm{kg}$ \\
\hline & & & Chromium & 5,800 & 450 & $\mathrm{mg} / \mathrm{kg}$ \\
\hline & & & Lead & 7,200 & 800 & $\mathrm{mg} / \mathrm{kg}$ \\
\hline
\end{tabular}


Table A.4-8

PSM Results Detected above MDCs for CAS 02-44-02, Paint Spills and French Drain (Page 2 of 2)

\begin{tabular}{|c|c|c|c|c|c|c|}
\hline $\begin{array}{l}\text { Sample } \\
\text { Location }\end{array}$ & $\begin{array}{l}\text { Sample } \\
\text { Number }\end{array}$ & $\begin{array}{c}\text { Sample } \\
\text { Matrix }\end{array}$ & Parameter & Result & $\begin{array}{c}\text { PSM } \\
\text { Criteria }\end{array}$ & Unit \\
\hline \multirow{12}{*}{$\begin{array}{c}\text { B09 } \\
\text { (continued) }\end{array}$} & \multirow{12}{*}{ 562B010 } & \multirow{12}{*}{ Paint } & Mercury & $0.7(\mathrm{~J}+)$ & 34 & $\mathrm{mg} / \mathrm{kg}$ \\
\hline & & & Selenium & 5 & 5,100 & $\mathrm{mg} / \mathrm{kg}$ \\
\hline & & & Silver & 0.25 & 5,100 & $\mathrm{mg} / \mathrm{kg}$ \\
\hline & & & Anthracene & $2.2(\mathrm{~J})$ & 170,000 & $\mathrm{mg} / \mathrm{kg}$ \\
\hline & & & Benzo(b)fluoranthene & $1.9(\mathrm{~J})$ & 2.1 & $\mathrm{mg} / \mathrm{kg}$ \\
\hline & & & Benzoic Acid & $17(\mathrm{~J})$ & $2,500,000$ & $\mathrm{mg} / \mathrm{kg}$ \\
\hline & & & Bis(2-ethylhexyl)phthalate & $220(\mathrm{~J})$ & 120 & $\mathrm{mg} / \mathrm{kg}$ \\
\hline & & & Butyl benzyl phthalate & $17(\mathrm{~J})$ & 910 & $\mathrm{mg} / \mathrm{kg}$ \\
\hline & & & Di-n-butyl phthalate & $16(\mathrm{~J})$ & 62,000 & $\mathrm{mg} / \mathrm{kg}$ \\
\hline & & & Di-n-octyl phthalate & $5.9(\mathrm{~J})$ & 25,000 & $\mathrm{mg} / \mathrm{kg}$ \\
\hline & & & Fluoranthene & $3.2(\mathrm{~J})$ & 22,000 & $\mathrm{mg} / \mathrm{kg}$ \\
\hline & & & Acetone & 0.03 & 630,000 & $\mathrm{mg} / \mathrm{kg}$ \\
\hline
\end{tabular}

$\mathrm{J}=$ Estimated value

$\mathrm{J}+=$ Result is an estimated quantity but may be biased high.

Bold indicates the value is equal to or exceeds the PSM criteria.

samples with results less than the FAL. Asphalt was seen in the area of the sample location and was likely the source of the COC. No other COCs were identified at this CAS; however, paint present throughout the CAS was determined to be PSM. The environmental sample results showed that the contamination in the PSM has not been released to the underlying soil.

\section{A.4.5 Revised Conceptual Site Model}

The CAIP requirements were met at this CAS, and no revisions were necessary to the CSM. 


\section{A.5.0 CAS 02-59-01, Septic System, Investigation Results}

Corrective Action Site 02-59-01 is located at the Area 2 Camp adjacent to a cable storage yard on the south side of Rainier Mesa Road (Figure 1-2) and consists of the releases to the soil from a septic system. The former LLNL Warehouse, Field Operations Support Facility, Photo Skid Trailer, Conference Room Trailer, and Cable Fabrication Building discharged to the septic system. The buildings have been demolished, but the trailers remain on site. Figure A.5-1 shows the sample locations and photographs of CAS 02-59-01.

\section{A.5.1 Corrective Action Investigation Activities}

A total of 11 environmental samples (including 1 FD) and 4 PSM samples were collected during investigation activities at CAS 02-59-01. The sample IDs, locations, types, and analyses are listed in Table A.5-1. The specific CAI activities conducted to satisfy the CAIP requirements at this CAS are described in the following sections.

\section{A.5.1.1 Radiological Surveys}

A radiological walkover survey was completed within the site boundary of CAS 02-59-01. The results of the survey did not show radiological contaminants at activities statistically distinguishable from background activities (more than twice background levels). The survey results did not indicate the need for additional biased samples.

\section{A.5.1.2 Visual Inspections}

At CAS 02-59-01, the following features were visually inspected before and/or during sampling activities:

Septic Tank - The surface components of the septic tank include two access lids aligned in a northwest to southeast direction with a distribution box on each end. Each access lid sits $2.0 \mathrm{ft}$ above ground surface and is attached to a 3.0-ft-diameter steel pipe that extends $7.5 \mathrm{ft}$ to the top of the septic tank. Removal of the northwest and southeast access lids revealed a wire cable that is used to lift and remove a secondary lid on top of the septic tank. The septic tank is an approximately 30.0-ft-long, 6.0-ft-diameter concrete tank with a 6.0-in. PVC inlet pipe that enters the northwest side of the tank 


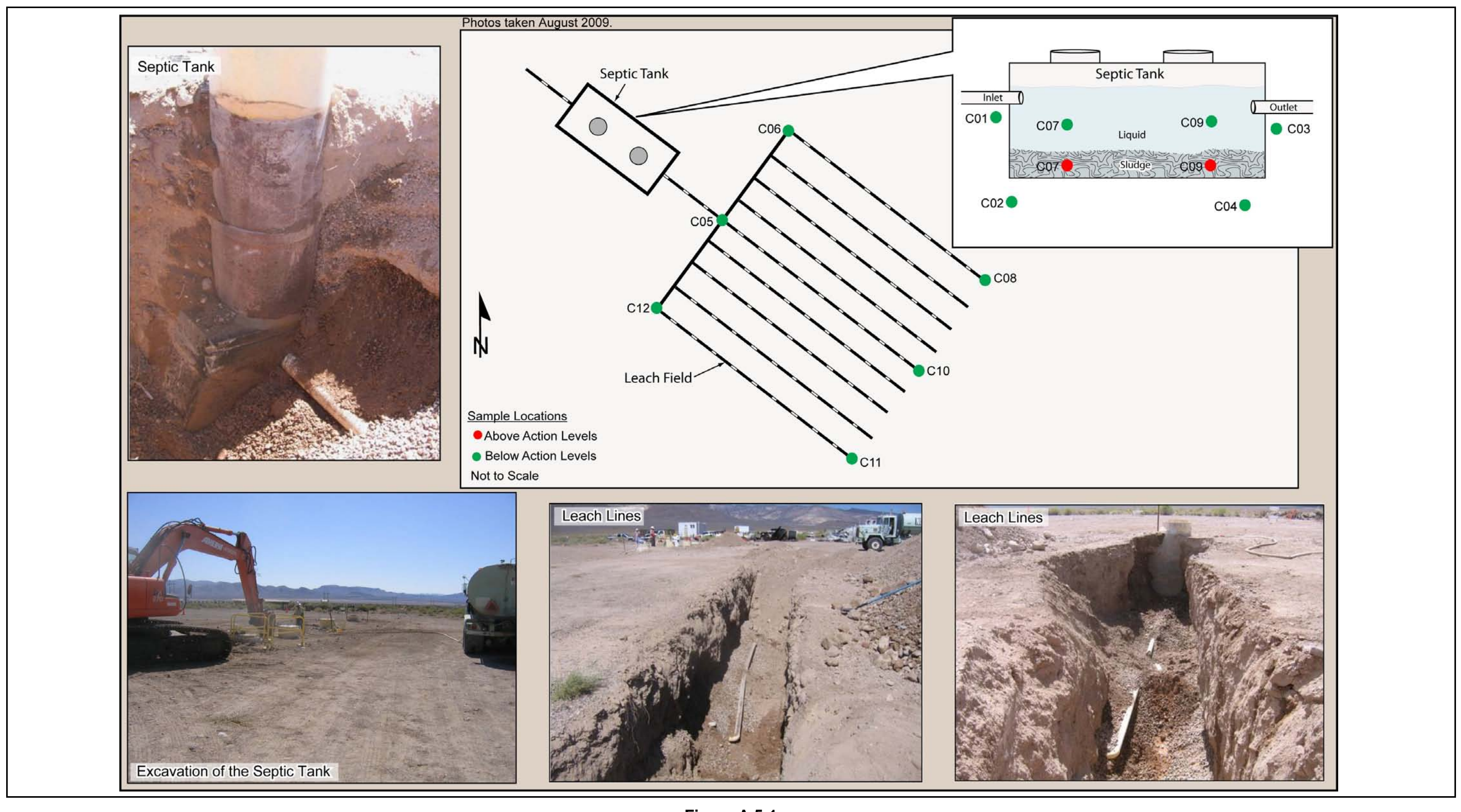

Sample Locations at CAS 02-59-01, Septic System 
Table A.5-1

Page A-44 of A-169

Samples Collected at CAS 02-59-01, Septic System

(Page 1 of 2)

\begin{tabular}{|c|c|c|c|c|c|c|c|c|c|c|c|c|c|c|c|c|c|c|c|}
\hline $\begin{array}{l}\text { Sample } \\
\text { Location }\end{array}$ & $\begin{array}{l}\text { Sample } \\
\text { Number }\end{array}$ & $\begin{array}{l}\text { Depth } \\
\text { (ft bgs) }\end{array}$ & Matrix & Purpose & $\begin{array}{l}\text { O } \\
\text { 号 }\end{array}$ & 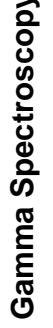 & 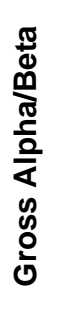 & $\begin{array}{l}\text { @) } \\
\frac{0}{0} \\
\frac{0}{0} \\
\frac{0}{1}\end{array}$ & $\frac{\frac{\infty}{\pi}}{\sum}$ & 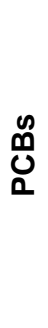 & 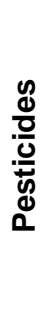 & 总 & 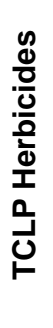 & 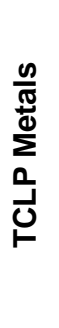 & 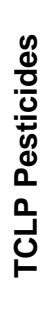 & 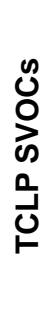 & 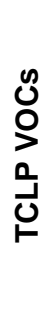 & 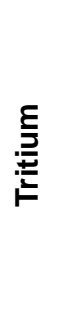 & 仓̊ \\
\hline $\mathrm{C} 01$ & $562 C 001$ & $7.5-8.0$ & Soil & Environmental & $x$ & $x$ & -- & $x$ & $x$ & $x$ & $x$ & $x$ & -- & -- & -- & -- & -- & -- & $x$ \\
\hline \multirow[b]{2}{*}{$\mathrm{C} 02$} & $562 \mathrm{C002}$ & $13.0-13.5$ & Soil & Environmental & $x$ & $x$ & -- & $x$ & $x$ & $x$ & $x$ & $x$ & -- & -- & -- & -- & -- & -- & $x$ \\
\hline & $562 C 003$ & $13.0-13.5$ & Soil & $\begin{array}{c}\text { FD } \\
\text { of } \# 562 \mathrm{C} 002\end{array}$ & $x$ & $x$ & -- & $x$ & $x$ & $x$ & $x$ & $x$ & -- & -- & -- & -- & -- & -- & $\mathrm{x}$ \\
\hline $\mathrm{C03}$ & $562 \mathrm{C004}$ & $8.0-8.5$ & Soil & Environmental & $x$ & $x$ & -- & $x$ & $x$ & $x$ & $x$ & $x$ & -- & -- & -- & -- & -- & -- & $x$ \\
\hline $\mathrm{CO4}$ & $562 C 005$ & $13.0-13.5$ & Soil & Environmental & $x$ & $x$ & -- & $x$ & $x$ & $x$ & $x$ & $x$ & -- & -- & -- & -- & -- & -- & $x$ \\
\hline $\mathrm{C} 05$ & $562 C 006$ & $11.5-12.0$ & Soil & Environmental & $x$ & $x$ & -- & $x$ & $x$ & $x$ & $x$ & $x$ & -- & -- & -- & -- & -- & -- & $x$ \\
\hline $\mathrm{C} 06$ & $562 C 007$ & $10.0-11.0$ & Soil & Environmental & $x$ & $x$ & -- & $x$ & $x$ & $x$ & $x$ & $x$ & -- & -- & -- & -- & -- & -- & $x$ \\
\hline \multirow{2}{*}{$\mathrm{C} 07$} & $562 C 008$ & $8.5-9.0$ & Liquid & PSM & $x$ & $x$ & $x$ & $x$ & $x$ & $x$ & $x$ & $x$ & -- & -- & -- & -- & -- & $x$ & $x$ \\
\hline & $562 C 011$ & $10.0-10.5$ & Sludge & PSM & $x$ & $x$ & $x$ & $x$ & $x$ & $x$ & $x$ & $x$ & $x$ & $x$ & $x$ & $x$ & $x$ & $x$ & $x$ \\
\hline $\mathrm{C} 08$ & $562 C 009$ & $10.5-11.0$ & Soil & Environmental & $x$ & $x$ & -- & $x$ & $x$ & $x$ & $x$ & $x$ & -- & -- & -- & -- & -- & -- & $x$ \\
\hline \multirow{2}{*}{ C09 } & $562 C 010$ & $8.5-9.0$ & Liquid & PSM & $x$ & $x$ & $x$ & $x$ & $x$ & $x$ & $x$ & $x$ & -- & -- & -- & -- & -- & $x$ & $x$ \\
\hline & $562 \mathrm{C} 012$ & $10.0-10.5$ & Sludge & PSM & $x$ & $x$ & $x$ & $x$ & $x$ & $x$ & $x$ & $x$ & $x$ & $x$ & $x$ & $x$ & $x$ & $x$ & $x$ \\
\hline C10 & $562 C 013$ & $9.0-10.0$ & Soil & Environmental & $x$ & $x$ & -- & $x$ & $x$ & $x$ & $x$ & $x$ & -- & -- & -- & -- & -- & -- & $x$ \\
\hline C11 & $562 C 014$ & $9.5-10.5$ & Soil & Environmental & $x$ & $x$ & -- & $x$ & $x$ & $x$ & $x$ & $x$ & -- & -- & -- & -- & -- & -- & $x$ \\
\hline $\mathrm{C} 12$ & $562 C 015$ & $10.0-11.0$ & Soil & Environmental & $x$ & $x$ & -- & $x$ & $x$ & $x$ & $x$ & $x$ & -- & -- & -- & -- & -- & -- & $x$ \\
\hline $\mathrm{N} / \mathrm{A}$ & $562 C 301$ & $N / A$ & Water & Trip Blank & -- & -- & -- & -- & -- & -- & -- & -- & -- & -- & -- & -- & -- & -- & $x$ \\
\hline
\end{tabular}


Table A.5-1

Samples Collected at CAS 02-59-01, Septic System

(Page 2 of 2)

\begin{tabular}{|c|c|c|c|c|c|c|c|c|c|c|c|c|c|c|c|c|c|c|c|}
\hline $\begin{array}{c}\text { Sample } \\
\text { Location }\end{array}$ & $\begin{array}{l}\text { Sample } \\
\text { Number }\end{array}$ & $\begin{array}{c}\text { Depth } \\
\text { (ft bgs) }\end{array}$ & Matrix & Purpose & $\begin{array}{l}\text { 우 } \\
\text { 号 }\end{array}$ & 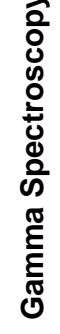 & 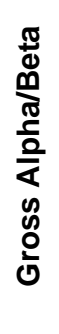 & 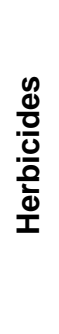 & $\begin{array}{l}\frac{\infty}{\pi} \\
\frac{\pi}{\Sigma}\end{array}$ & 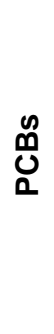 & 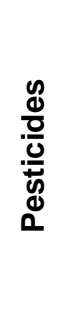 & 帒 & 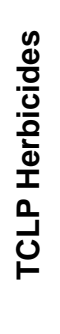 & 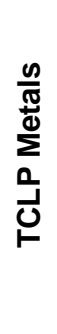 & 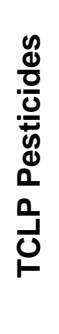 & 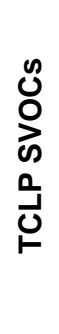 & 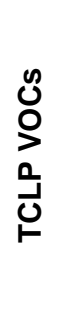 & 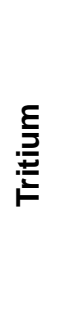 & ơ \\
\hline $\mathrm{N} / \mathrm{A}$ & $562 C 302$ & N/A & Water & Trip Blank & -- & -- & -- & -- & -- & -- & -- & -- & -- & -- & -- & -- & -- & -- & $x$ \\
\hline N/A & $562 C 303$ & N/A & Water & Trip Blank & -- & -- & -- & -- & -- & -- & -- & -- & -- & -- & -- & -- & -- & -- & $x$ \\
\hline $\mathrm{N} / \mathrm{A}$ & $562 C 304$ & N/A & Water & Trip Blank & -- & -- & -- & -- & -- & -- & -- & -- & -- & -- & -- & -- & -- & -- & $x$ \\
\hline N/A & $562 C 305$ & N/A & Water & Trip Blank & -- & -- & -- & -- & -- & -- & -- & -- & -- & -- & -- & -- & -- & -- & $\mathrm{x}$ \\
\hline
\end{tabular}

-- = Not required 
and a 6.0-in. PVC outlet pipe that exits the southeast side of the tank leading to the leachfield. The tank is situated in a gravel envelope and the leach lines are surrounded with leach rock. The tank contained approximately $1.5 \mathrm{ft}$ of air space, $4.0 \mathrm{ft}$ of liquid, and $0.5 \mathrm{ft}$ of sludge (based on measurements from the northwest tank access). It could not be determined if the tank design is a single or double chamber; however, the southeast end appeared to contain less sludge than the northwest end. Therefore, it is speculated that the tank has two chambers. Both the tank and the inlet and outlet pipes appeared to be in excellent condition.

Leachfield - The PVC outlet pipe of the septic tank leads to a distribution box accessed through a manhole cover. Removal of the manhole cover revealed three outlet distributions to the leachfield. The leachfield piping is 7.0 to $8.0 \mathrm{ft}$ bgs and consists of 9 leach pipes oriented in a northwest-southeast direction. The proximal and distal ends of each pipe tie-in to a north-south oriented pipe via T-joints, or 90-degree elbows. The leach pipe consists of a 4.0-in. PVC pipe with perforations set in a bed of leach rock that extends 9.0 to $10.0 \mathrm{ft}$ bgs to the native soil interface.

\section{A.5.1.3 Sample Collection}

Sampling activities included the collection of 11 (including 1 FD) environmental subsurface soil samples and 4 PSM samples from the 12 locations shown in Figure A.5-1. The sampling activities are discussed below.

Septic Tank - Four PSM samples were collected from inside the septic tank at locations C07 and C09. Because the tank was suspected to have two chambers, liquid and sludge samples were collected from each end of the tank (northwest and southeast). Samples 562C008 (liquid) and 562C011 (sludge) were collected from the northwest side of the tank (location C07). The liquid sample had a slight septic odor and consisted of clear fluid with some suspended black particles. An oil sheen was observed on the surface of the liquid in the tank. The sludge sample had a strong, septic-like odor, and consisted of black, muddy sludge with abundant miscellaneous debris. Samples 562C010 (liquid) and 562C012 (sludge) were collected from the southeast side of the tank (location C09) and resembled the samples from the northwest side, but less sludge was present at this location.

Environmental sampling outside the septic tank included the collection of subsurface soil samples 562C001 from directly below the inlet pipe connection (location C01) and 562C004 from below the 
outlet pipe connection (location C03). Samples 562C002 and FD 562C003 were collected directly below the base of the tank at the northwest end (location C02); and sample 562C005 was collected directly below the base of the tank at the southeast end (location C04). Samples were collected at depths ranging from 7.5 to $13.5 \mathrm{ft}$ bgs.

Leachfield - Sampling activities at the leachfield included the collection of six soil samples at the native soil interface below leach rock at the proximal and distal ends of the middle and outer leach pipes. The three leach pipes from which samples were collected are referred to as the middle, north, and south leach pipes. From the middle leach pipe, sample 562C006 was collected at the proximal end (location C05) and sample 562C013 was collected at the distal end (location C10). From the north leach pipe, sample 562C007 was collected at the proximal end (location C06) and sample 562C009 was collected at the distal end (location C08). From the south leach pipe, sample 562C015 was collected at the proximal end (location C12) and sample 562C014 was collected at the distal end (location C11). Samples were collected at depths ranging from 9.0 to $12.0 \mathrm{ft}$ bgs.

\section{A.5.1.4 Deviations}

There were no deviations to the CAU 562 CAIP (NNSA/NSO, 2009) associated with CAS 02-59-01. Investigation samples were collected as outlined in the CAU 562 CAIP and submitted for laboratory analysis.

\section{A.5.2 Investigation Results}

The following sections provide analytical results from the samples collected to complete investigation activities as outlined in the CAIP (NNSA/NSO, 2009). The analytical parameters and laboratory methods used to analyze the investigation samples are listed in Table A.2-2. Table A.5-1 lists the sample-specific analytical suite for CAS 02-59-01.

Analytical results from the soil samples with concentrations exceeding MDCs are summarized in the following sections. An evaluation was conducted on all contaminants detected above MDCs by comparing individual concentration or activity results against the FALs. Establishment of the FALs is presented in Appendix D. The FALs were established as the corresponding PAL concentrations or activities if the contaminant concentrations were below their respective PALs. 


\section{A.5.2.1 Volatile Organic Compounds}

No analytical results for VOCs in environmental samples collected at this CAS exceeded MDCs. Therefore, the FALs were established at the corresponding PAL concentrations.

\section{A.5.2.2 Semivolatile Organic Compounds}

No analytical results for SVOCs in environmental samples collected at this CAS exceeded MDCs. Therefore, the FALs were established at the corresponding PAL concentrations.

\section{A.5.2.3 Total Petroleum Hydrocarbons}

Analytical results for TPH-DRO in soil samples collected at this CAS that were detected above MDCs are presented in Table A.5-2. No TPH-DRO constituents were detected at concentrations exceeding their PALs. The FALs were established at the PAL concentrations.

Table A.5-2

Sample Results for TPH-DRO Detected above

MDCs at CAS 02-59-01, Septic System

\begin{tabular}{||c|c|c|c||}
\hline \multirow{2}{*}{$\begin{array}{c}\text { Sample } \\
\text { Location }\end{array}$} & \multirow{2}{*}{$\begin{array}{c}\text { Sample } \\
\text { Number }\end{array}$} & \multirow{2}{*}{$\begin{array}{c}\text { Depth } \\
\text { fft bgs) }\end{array}$} & COPCs (mg/kg) \\
\cline { 3 - 4 } & & & $\mathbf{1 0 0}$ \\
\hline \hline \multicolumn{3}{|c|}{ PALs } & $2.5(\mathrm{~J})$ \\
\hline $\mathrm{C} 01$ & $562 \mathrm{C001}$ & $7.5-8.0$ & $2.9(\mathrm{~J})$ \\
\hline $\mathrm{C} 02$ & $562 \mathrm{C} 002$ & $13-13.5$ & DRO \\
\hline
\end{tabular}

$\mathrm{J}=$ Estimated value

\section{A.5.2.4 Resource Conservation and Recovery Act Metals}

Analytical results for RCRA metals in soil samples collected at this CAS that were detected above MDCs are presented in Table A.5-3. No RCRA metals were detected at concentrations exceeding their PALs. The FALs were established at the PAL concentrations.

\section{A.5.2.5 Polychlorinated Biphenyls}

No analytical results for PCBs in environmental samples collected at this CAS exceeded MDCs. Therefore, the FALs were established at the corresponding PAL concentrations. 
Table A.5-3

Sample Results for Metals Detected above MDCs at CAS 02-59-01, Septic System

\begin{tabular}{|c|c|c|c|c|c|c|c|c|}
\hline \multirow[b]{2}{*}{$\begin{array}{l}\text { Sample } \\
\text { Location }\end{array}$} & \multirow[b]{2}{*}{$\begin{array}{l}\text { Sample } \\
\text { Number }\end{array}$} & \multirow[b]{2}{*}{$\begin{array}{l}\text { Depth } \\
\text { (ft bgs) }\end{array}$} & \multicolumn{6}{|c|}{ COPCs (mg/kg) } \\
\hline & & & 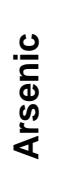 & 占 & 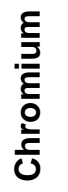 & శ్ర్తి & $\begin{array}{l}\frac{\lambda}{J} \\
\frac{0}{0} \\
\sum\end{array}$ & 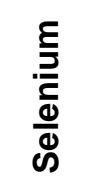 \\
\hline \multicolumn{3}{|c|}{ FALs } & 23 & 190,000 & 450 & 800 & 34 & 5,100 \\
\hline $\mathrm{C01}$ & $562 C 001$ & $7.5-8.0$ & 2.7 & 83 & 3.4 & 5.7 & -- & -- \\
\hline \multirow{2}{*}{$\mathrm{C} 02$} & $562 C 002$ & $13.0-13.5$ & 5.7 & 250 & 5.4 & 7.7 & -- & 0.74 \\
\hline & $562 C 003$ & $13.0-13.5$ & 5.4 & 220 & 5.6 & 11 & -- & -- \\
\hline $\mathrm{C03}$ & $562 \mathrm{C004}$ & $8.0-8.5$ & 2.4 & 71 & 2.5 & 7.9 & -- & -- \\
\hline $\mathrm{CO4}$ & $562 C 005$ & $13.0-13.5$ & 4.8 & 290 & 5.5 & 7.3 & -- & 0.63 \\
\hline $\mathrm{C} 05$ & $562 C 006$ & $11.5-12$ & -- & 88 & 4.7 & 6 & -- & -- \\
\hline $\mathrm{C} 06$ & $562 C 007$ & $10.0-11.0$ & 2.9 & 95 & 4.5 & 11 & -- & -- \\
\hline $\mathrm{C08}$ & $562 C 009$ & $10.5-11.0$ & 2.6 & 64 & 3.4 & 6.5 & -- & -- \\
\hline C10 & $562 C 013$ & $9.0-10.0$ & 3.6 & 82 & 5.6 & 11 & 0.1 & -- \\
\hline C11 & $562 C 014$ & $9.5-10.5$ & 2.6 & 110 & 2.6 & 5.3 & -- & -- \\
\hline C12 & $562 C 015$ & $10.0-11.0$ & 3.9 & 110 & 6.1 & 12 & 0.038 & -- \\
\hline
\end{tabular}

$--=$ Not detected above MDCs.

\section{A.5.2.6 Pesticides}

No analytical results for pesticides in environmental samples collected at this CAS exceeded MDCs. Therefore, the FALs were established at the corresponding PAL concentrations.

\section{A.5.2.7 Herbicides}

No analytical results for herbicides in environmental samples collected at this CAS exceeded MDCs. Therefore, the FALs were established at the corresponding PAL concentrations. 


\section{A.5.2.8 Gamma-Emitting Radionuclides}

Analytical results for gamma-emitting radionuclides in soil samples collected at this CAS that were detected above MDCs are presented in Table A.5-4. No gamma-emitting radionuclides were detected at concentrations exceeding their PALs. The FALs were established at the PAL concentrations.

Table A.5-4

Sample Results for Gamma-Emitting Radionuclides Detected above MDCs at CAS 02-59-01, Septic System

\begin{tabular}{|c|c|c|c|}
\hline \multirow{2}{*}{$\begin{array}{l}\text { Sample } \\
\text { Location }\end{array}$} & \multirow{2}{*}{$\begin{array}{l}\text { Sample } \\
\text { Number }\end{array}$} & \multirow{2}{*}{$\begin{array}{l}\text { Depth } \\
\text { (ft bgs) }\end{array}$} & COPCs (pCi/g) \\
\hline & & & Ac-228 \\
\hline \multicolumn{3}{|c|}{ FALs } & 5 \\
\hline $\mathrm{C} 01$ & 562C001 & $7.5-8.0$ & 2.3 \\
\hline \multirow{2}{*}{$\mathrm{C} 02$} & $562 \mathrm{C} 002$ & $13.0-13.5$ & 1.57 \\
\hline & $562 C 003$ & $13.0-13.5$ & 1.63 \\
\hline $\mathrm{C03}$ & $562 C 004$ & $8.0-8.5$ & 1.96 \\
\hline $\mathrm{CO4}$ & $562 C 005$ & $13.0-13.5$ & 1.72 \\
\hline $\mathrm{C} 05$ & $562 C 006$ & $11.5-12$ & 2.34 \\
\hline C06 & $562 \mathrm{C007}$ & $10.0-11.0$ & 2.15 \\
\hline C08 & $562 C 009$ & $10.5-11.0$ & 1.59 \\
\hline C10 & $562 C 013$ & $9.0-10.0$ & 1.99 \\
\hline C12 & $562 C 015$ & $10.0-11.0$ & 2.19 \\
\hline
\end{tabular}

\section{A.5.3 Potential Source Material Sample Results}

Analytical results for PSM samples collected at this CAS that were detected above MDCs are presented in Table A.5-5. Media sampled included liquid and sludge from the septic tank. Two sludge samples contained concentrations of TPH-DRO that exceeded the PAL concentration of $100 \mathrm{mg} / \mathrm{kg}$. The TPH-DRO was moved on to a Tier 2 evaluation, and FALs were established for the hazardous constituents of TPH-DRO. Naphthalene and 1,4-dichlorobenzene are both hazardous constituents of TPH-DRO, and their concentrations exceeded the PSM criteria in one sludge sample (562C011). Therefore, COCs are present, and the sludge is considered PSM. The calculation of FALs for the hazardous constituents of TPH-DRO is presented in Appendix D. 
Table A.5-5

PSM Results Detected above MDCs for CAS 02-59-01, Septic System (Page 1 of 3 )

\begin{tabular}{|c|c|c|c|c|c|c|}
\hline $\begin{array}{l}\text { Sample } \\
\text { Location }\end{array}$ & $\begin{array}{l}\text { Sample } \\
\text { Number }\end{array}$ & $\begin{array}{l}\text { Sample } \\
\text { Matrix }\end{array}$ & Parameter & Result & $\begin{array}{l}\text { PSM } \\
\text { Criteria }\end{array}$ & Unit \\
\hline \multirow{14}{*}{$\mathrm{C} 07$} & \multirow{14}{*}{$562 C 008$} & \multirow{14}{*}{ Liquid } & DRO & 5.6 & N/A & $\mathrm{mg} / \mathrm{L}$ \\
\hline & & & Barium & 0.37 & $1,000,000$ & $\mathrm{mg} / \mathrm{L}$ \\
\hline & & & Cadmium & 0.013 & 8,747 & $\mathrm{mg} / \mathrm{L}$ \\
\hline & & & Chromium & 0.16 & 4,920 & $\mathrm{mg} / \mathrm{L}$ \\
\hline & & & Lead & 0.21 & 8,747 & $\mathrm{mg} / \mathrm{L}$ \\
\hline & & & Mercury & 0.0049 & 372 & $\mathrm{mg} / \mathrm{L}$ \\
\hline & & & Selenium & 0.0082 & 55,760 & $\mathrm{mg} / \mathrm{L}$ \\
\hline & & & Silver & 0.55 & 55,760 & $\mathrm{mg} / \mathrm{L}$ \\
\hline & & & 4,4'-DDE & $0.000023(\mathrm{~J})$ & 56 & $\mathrm{mg} / \mathrm{L}$ \\
\hline & & & 1,4-dichlorobenzene & 0.004 & 131 & $\mathrm{mg} / \mathrm{L}$ \\
\hline & & & Cis-1,2-dichloroethene & 0.16 & 109,333 & $\mathrm{mg} / \mathrm{L}$ \\
\hline & & & Vinyl chloride & $0.0011(\mathrm{~J})$ & 19 & $\mathrm{mg} / \mathrm{L}$ \\
\hline & & & Carbon disulfide & $0.0014(\mathrm{~J})$ & 40,453 & $\mathrm{mg} / \mathrm{L}$ \\
\hline & & & 1,2,4-trimethylbenzene & $0.00084(\mathrm{~J})$ & 2,843 & $\mathrm{mg} / \mathrm{L}$ \\
\hline \multirow{12}{*}{$\mathrm{C} 07$} & \multirow{12}{*}{$562 C 011$} & \multirow{12}{*}{ Sludge } & DRO & 2,600 & $N / A$ & $\mathrm{mg} / \mathrm{kg}$ \\
\hline & & & Barium & 1,500 & 190,000 & $\mathrm{mg} / \mathrm{kg}$ \\
\hline & & & Cadmium & 9.5 & 800 & $\mathrm{mg} / \mathrm{kg}$ \\
\hline & & & Chromium & 240 & 450 & $\mathrm{mg} / \mathrm{kg}$ \\
\hline & & & Lead & 59 & 800 & $\mathrm{mg} / \mathrm{kg}$ \\
\hline & & & Mercury & $2(\mathrm{~J}+)$ & 34 & $\mathrm{mg} / \mathrm{kg}$ \\
\hline & & & Selenium & 4.1 & 5,100 & $\mathrm{mg} / \mathrm{kg}$ \\
\hline & & & Silver & 290 & 5,100 & $\mathrm{mg} / \mathrm{kg}$ \\
\hline & & & Dieldrin & $0.0091(\mathrm{~J})$ & 0.11 & $\mathrm{mg} / \mathrm{kg}$ \\
\hline & & & 4,4'-DDE & 0.075 & 5.1 & $\mathrm{mg} / \mathrm{kg}$ \\
\hline & & & Aroclor 1260 & 0.29 & 0.74 & $\mathrm{mg} / \mathrm{kg}$ \\
\hline & & & MCPP & 83 & 620 & $\mathrm{mg} / \mathrm{kg}$ \\
\hline
\end{tabular}


Table A.5-5

PSM Results Detected above MDCs for CAS 02-59-01, Septic System (Page 2 of 3 )

\begin{tabular}{|c|c|c|c|c|c|c|}
\hline $\begin{array}{c}\text { Sample } \\
\text { Location }\end{array}$ & $\begin{array}{l}\text { Sample } \\
\text { Number }\end{array}$ & $\begin{array}{l}\text { Sample } \\
\text { Matrix }\end{array}$ & Parameter & Result & $\begin{array}{c}\text { PSM } \\
\text { Criteria }\end{array}$ & Unit \\
\hline \multirow{19}{*}{$\begin{array}{c}\text { C07 } \\
\text { (continued) }\end{array}$} & \multirow{19}{*}{$562 C 011$} & \multirow{19}{*}{ Sludge } & Ethylbenzene & $0.14(\mathrm{~J})$ & 27 & $\mathrm{mg} / \mathrm{kg}$ \\
\hline & & & N-butylbenzene & 1.1 & 240 & $\mathrm{mg} / \mathrm{kg}$ \\
\hline & & & N-propylbenzene & 3.9 & 21,000 & $\mathrm{mg} / \mathrm{kg}$ \\
\hline & & & Toluene & 0.44 & 45,000 & $\mathrm{mg} / \mathrm{kg}$ \\
\hline & & & Sec-butylbenzene & 1.5 & 220 & $\mathrm{mg} / \mathrm{kg}$ \\
\hline & & & Chlorobenzene & 0.03 & 1,400 & $\mathrm{mg} / \mathrm{kg}$ \\
\hline & & & Cis-1,2-dichloroethene & 61 & 10,000 & $\mathrm{mg} / \mathrm{kg}$ \\
\hline & & & Acetone & 1.4 & 630,000 & $\mathrm{mg} / \mathrm{kg}$ \\
\hline & & & Vinyl chloride & $0.28(\mathrm{~J})$ & 1.7 & $\mathrm{mg} / \mathrm{kg}$ \\
\hline & & & Carbon disulfide & $0.032(\mathrm{~J})$ & 3,700 & $\mathrm{mg} / \mathrm{kg}$ \\
\hline & & & 1,1-dichloroethene & $0.037(\mathrm{~J})$ & 1,100 & $\mathrm{mg} / \mathrm{kg}$ \\
\hline & & & 2-butanone & $0.36(\mathrm{~J})$ & 200,000 & $\mathrm{mg} / \mathrm{kg}$ \\
\hline & & & 1,2-dichlorobenzene & $0.084(\mathrm{~J})$ & 9,800 & $\mathrm{mg} / \mathrm{kg}$ \\
\hline & & & Tert-butylbenzene & $0.11(\mathrm{~J})$ & 390 & $\mathrm{mg} / \mathrm{kg}$ \\
\hline & & & Isopropylbenzene & 1.2 & 11,000 & $\mathrm{mg} / \mathrm{kg}$ \\
\hline & & & 1,4-dichlorobenzene & 250 & 12 & $\mathrm{mg} / \mathrm{kg}$ \\
\hline & & & Naphthalene & 45 & 18 & $\mathrm{mg} / \mathrm{kg}$ \\
\hline & & & Bis(2-ethylhexyl)phthalate & $3.6(\mathrm{~J})$ & 120 & $\mathrm{mg} / \mathrm{kg}$ \\
\hline & & & Pyrene & $1.5(\mathrm{~J})$ & 17,000 & $\mathrm{mg} / \mathrm{kg}$ \\
\hline \multirow{6}{*}{ C09 } & \multirow{6}{*}{$562 C 010$} & \multirow{6}{*}{ Liquid } & DRO & $0.39(\mathrm{~J})$ & $\mathrm{N} / \mathrm{A}$ & $\mathrm{mg} / \mathrm{L}$ \\
\hline & & & 1,4-dichlorobenzene & 0.0011 & 131 & $\mathrm{mg} / \mathrm{L}$ \\
\hline & & & Cis-1,2-dichloroethene & 0.014 & 109,333 & $\mathrm{mg} / \mathrm{L}$ \\
\hline & & & Vinyl chloride & $0.0002(\mathrm{~J})$ & 19 & $\mathrm{mg} / \mathrm{L}$ \\
\hline & & & Carbon disulfide & $0.00017(\mathrm{~J})$ & 40,453 & $\mathrm{mg} / \mathrm{L}$ \\
\hline & & & 1,2,4-trimethylbenzene & $0.00017(\mathrm{~J})$ & 2,843 & $\mathrm{mg} / \mathrm{L}$ \\
\hline \multirow{3}{*}{ C09 } & \multirow{3}{*}{$562 \mathrm{C} 012$} & \multirow{3}{*}{ Sludge } & DRO & 190 & $\mathrm{~N} / \mathrm{A}$ & $\mathrm{mg} / \mathrm{kg}$ \\
\hline & & & Chromium & 330 & 450 & $\mathrm{mg} / \mathrm{kg}$ \\
\hline & & & Mercury & $0.13(\mathrm{~J}+)$ & 34 & $\mathrm{mg} / \mathrm{kg}$ \\
\hline
\end{tabular}


Table A.5-5

PSM Results Detected above MDCs for CAS 02-59-01, Septic System

(Page 3 of 3 )

\begin{tabular}{|c|c|c|c|c|c|c|}
\hline $\begin{array}{l}\text { Sample } \\
\text { Location }\end{array}$ & $\begin{array}{l}\text { Sample } \\
\text { Number }\end{array}$ & $\begin{array}{c}\text { Sample } \\
\text { Matrix }\end{array}$ & Parameter & Result & $\begin{array}{c}\text { PSM } \\
\text { Criteria }\end{array}$ & Unit \\
\hline \multirow{11}{*}{$\begin{array}{c}\text { C09 } \\
\text { (continued) }\end{array}$} & \multirow{11}{*}{$562 \mathrm{C} 012$} & \multirow{11}{*}{ Sludge } & Silver & 140 & 5,100 & $\mathrm{mg} / \mathrm{kg}$ \\
\hline & & & 4,4'-DDE & $0.0025(\mathrm{~J})$ & 5.1 & $\mathrm{mg} / \mathrm{kg}$ \\
\hline & & & 2,4,5-TP & $0.059(\mathrm{~J})$ & 62,000 & $\mathrm{mg} / \mathrm{kg}$ \\
\hline & & & Bis(2-ethylhexyl)phthalate & $0.46(\mathrm{~J})$ & 120 & $\mathrm{mg} / \mathrm{kg}$ \\
\hline & & & Ethylbenzene & $0.0073(\mathrm{~J})$ & 27 & $\mathrm{mg} / \mathrm{kg}$ \\
\hline & & & N-propylbenzene & $0.0034(\mathrm{~J})$ & 21,000 & $\mathrm{mg} / \mathrm{kg}$ \\
\hline & & & 1,4-dichlorobenzene & 0.033 & 12 & $\mathrm{mg} / \mathrm{kg}$ \\
\hline & & & 1,3,5-trimethylbenzene & $0.0074(\mathrm{~J})$ & 10,000 & $\mathrm{mg} / \mathrm{kg}$ \\
\hline & & & Cis-1,2-dichloroethene & $0.0037(\mathrm{~J})$ & 10,000 & $\mathrm{mg} / \mathrm{kg}$ \\
\hline & & & Acetone & 0.045 & 630,000 & $\mathrm{mg} / \mathrm{kg}$ \\
\hline & & & 1,2,4-trimethylbenzene & 0.025 & 260 & $\mathrm{mg} / \mathrm{kg}$ \\
\hline
\end{tabular}

$\mathrm{J}=$ Estimated value

$\mathrm{J}+=$ Result is an estimated quantity but may be biased high.

Bold indicates the value is equal to or exceeds the PSM criteria.

\section{A.5.4 Nature and Extent of Contamination}

Based on the analytical results of the environmental samples collected from around the septic tank and from within the leachfield, there has not been a release of contaminants to the environmental media. Additionally, during the visual inspection of the tank, it was determined that the integrity of the tank was sound. The analytical results from the liquid and sludge contents of the tank identified two constituents in the sludge that exceeded the PSM criteria; therefore, the sludge is considered PSM. The PSM is contained within the tank.

\section{A.5.5 Revised Conceptual Site Model}

The CAIP requirements were met at this CAS, and no revisions were necessary to the CSM. 


\section{A.6.0 CAS 02-60-01, Concrete Drain, Investigation Results}

Corrective Action Site 02-60-01 is located at the Area 2 Camp adjacent to the former Area 2 Tank Farm and Operation Warehouse, of which only a concrete foundation remains (Figure 1-2).

Corrective Action Site 02-60-01 consists of the potential releases to the soil from a concrete drain located on the south side of the building foundation. Figure A.6-1 shows the sample locations and photographs of CAS 02-60-01.

\section{A.6.1 Corrective Action Investigation Activities}

A total of 18 characterization samples (including 1 FD) were collected during investigation activities at CAS 02-60-01. The sample IDs, locations, types, and analyses are listed in Table A.6-1. The specific CAI activities conducted to satisfy the CAIP requirements at this CAS are described in the following sections.

\section{A.6.1.1 Radiological Surveys}

A radiological walkover survey was completed within the boundary of CAS 02-60-01. The results of the survey did not show radiological contaminants at activities statistically distinguishable from background activities (more than twice background levels). The survey results did not indicate the need for additional biased samples.

\section{A.6.1.2 Geophysical Surveys}

A geophysical survey was conducted to identify the location of the concrete drain. The geophysical survey results indicated that there were no linear anomalies representing possible inlets or outlets from the concrete drain; however, two anomalies were identified directly outside of the drain. It was noted that the anomalies were possibly a result of buried metal because the area had been previously disturbed (Weston, 2007).

\section{A.6.1.3 Visual Inspections}

Surface soils were removed from the area surrounding the concrete drain to fully uncover the drain and determine its configuration. The drain consists of a shallow concrete basin that is approximately 


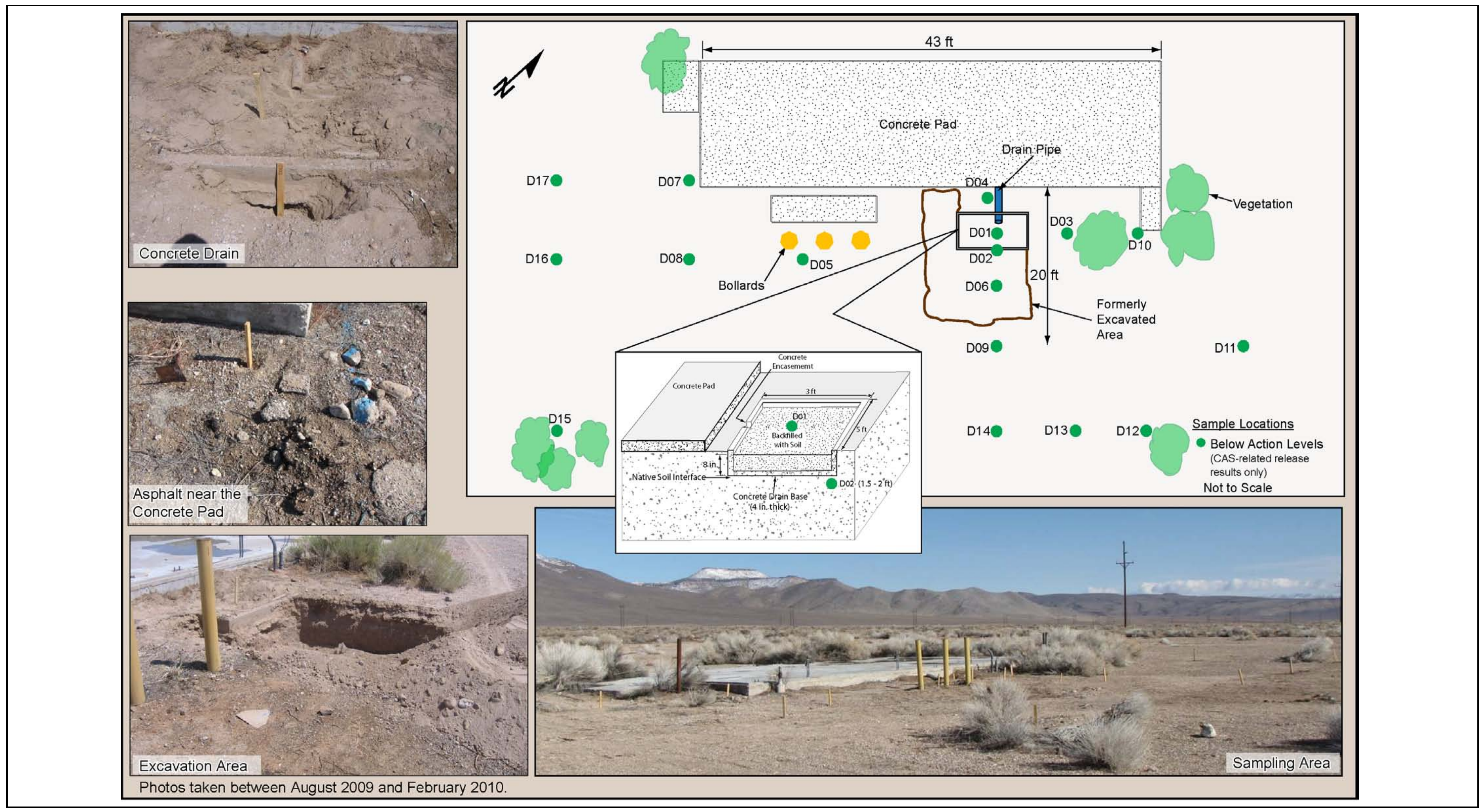

Figure A.6-1
Sample Locations at CAS 02-60-01, Concrete Drain 
Table A.6-1

Samples Collected at CAS 02-60-01, Concrete Drain

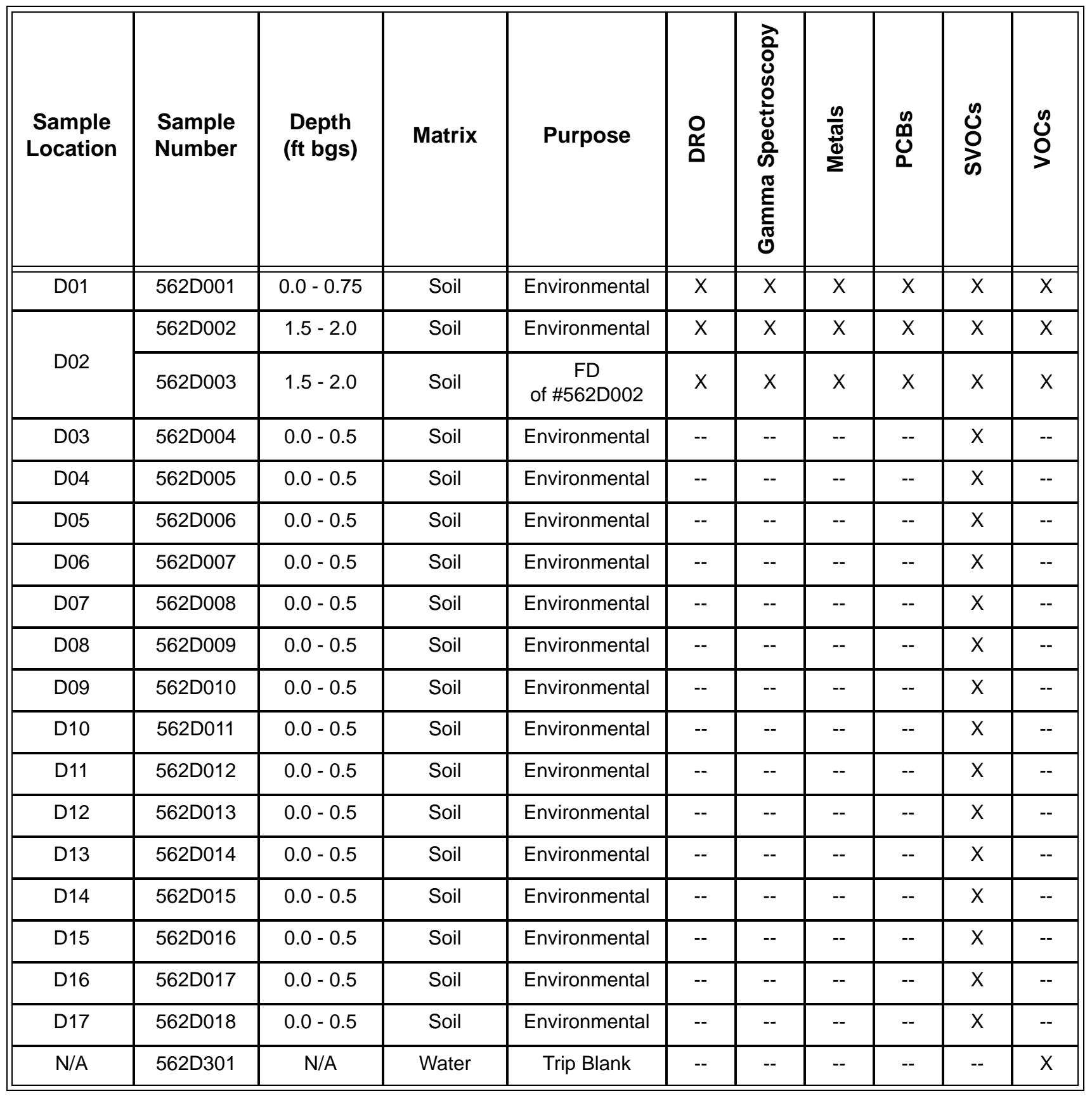

$--=$ Not required

$4.0 \mathrm{ft}$ long, $2.5 \mathrm{ft}$ wide, and $1.0 \mathrm{ft}$ deep. A 3.0-in.-diameter metal drain pipe that is no longer connected to the concrete foundation discharged to the drain. The drain contained $8.0 \mathrm{in}$. of soil that was likely backfill material. No staining or other biasing factors indicative of a release were 
observed. However, it should be noted that there is broken asphalt of various sizes and compositions surrounding the concrete drain, former building foundation, and throughout the storage yard. It appears that the storage yard was previously paved but the asphalt has deteriorated.

An area measuring 7.0 by $8.0 \mathrm{ft}$ adjacent to the southwest corner of the concrete drain was excavated to $2.0 \mathrm{ft}$ bgs to investigate the two anomalies identified in the geophysical survey. It was determined that the anomalies were associated with buried metal debris. The entire area surrounding CAS 02-60-01 was littered with other metal debris (e.g., pipe pieces, bolts, nuts, nails, scrap sheet metal). Because there was no evidence of a release associated with these anomalies, no samples were collected.

\section{A.6.1.4 Sample Collection}

Sampling activities included the collection of 18 (including 1 FD) environmental surface and subsurface soil samples from 17 sample locations. All sample locations are shown in Figure A.6-1. The sampling activities are discussed below.

Sample 562D001 was collected at location D01 from the bottom of the 8.0-in.-deep concrete drain directly adjacent to the opening of the drain pipe. This sample consisted of silty sand with miscellaneous debris (e.g., plastic, wood, paper); however, no staining was observed. Samples 562D002 and FD 562D003 were collected from 1.5 to $2.0 \mathrm{ft}$ bgs at the native soil interface directly below the concrete drain (location D02).

The Decision I analytical results showed that concentrations of various PAHs in sample 562D001 exceeded the PALs, and it was determined that Decision II sampling was necessary. Decision II sampling was conducted from November 3, 2009, to January 20, 2010. Samples (562D004 through 562D018) were collected at a depth of 0.0 to $0.5 \mathrm{ft}$ bgs from 15 sample locations (D03 through D17) ranging from approximately 1.0 to $35.0 \mathrm{ft}$ laterally from the concrete drain, the suspected source of contamination. These locations were positioned in a radial pattern moving outward from the concrete drain and adjacent former building foundation. Pieces of asphalt ranging in size from large chunks to small particles were observed throughout the storage yard. It was noted that much of the deteriorated asphalt was so small that it could not be distinguished from soil. Attempts were made to exclude 
visible pieces of asphalt from the samples, but it was impossible to know whether a sample contained grains of asphalt.

\section{A.6.1.5 Deviations}

There were no deviations to the CAU 562 CAIP (NNSA/NSO, 2009) associated with CAS 02-60-01. Investigation samples were collected as outlined in the CAU 562 CAIP and submitted for laboratory analysis.

\section{A.6.2 Investigation Results}

The following sections provide analytical results from the samples collected to complete investigation activities as outlined in the CAIP (NNSA/NSO, 2009). The analytical parameters and laboratory methods used to analyze the investigation samples are listed in Table A.2-2. Table A.6-1 lists the sample-specific analytical suite for CAS 02-60-01.

Analytical results from the soil samples with concentrations exceeding MDCs are summarized in the following sections. An evaluation was conducted on all contaminants detected above MDCs by comparing individual concentration or activity results against the FALs. Establishment of the FALs is presented in Appendix D. The FALs were established as the corresponding PAL concentrations or activities if the contaminant concentrations were below their respective PALs.

\section{A.6.2.1 Volatile Organic Compounds}

Analytical results for VOCs in soil samples collected at this CAS that were detected above MDCs are presented in Table A.6-2. No VOCs were detected at concentrations exceeding their respective PALs. The FALs were established at the PAL concentrations.

\section{A.6.2.2 Semivolatile Organic Compounds}

Analytical results for SVOCs in soil samples collected at this CAS that were detected above MDCs are presented in Table A.6-3. During the investigation of CAS 02-60-01, the only constituents found above action levels were PAHs that are commonly associated with asphalt. Additionally, the analytical results from the Decision II sampling showed the concentrations of PAHs generally increased with distance from the drain (e.g., sample locations D05, D06, D09, D11). Visual 
Table A.6-2

\section{Sample Results for Total VOCs Detected above MDCs at CAS 02-60-01, Concrete Drain}

\begin{tabular}{|c|c|c|c|c||}
\hline \multirow{2}{*}{$\begin{array}{c}\text { Sample } \\
\text { Location }\end{array}$} & \multirow{2}{*}{$\begin{array}{c}\text { Sample } \\
\text { Number }\end{array}$} & \multirow{2}{*}{$\begin{array}{c}\text { Depth } \\
\text { (ft bgs) }\end{array}$} & \multicolumn{2}{c|}{ COPCs (mg/kg) } \\
\cline { 4 - 5 } & & & Acetone & Trichloroethene \\
\hline \multicolumn{2}{|c|}{ FALs } & $\mathbf{6 3 0 , 0 0 0}$ & $\mathbf{1 4}$ \\
\hline \hline D01 & $562 \mathrm{D001}$ & $0.0-0.75$ & $0.0083(\mathrm{~J})$ & $0.0061(\mathrm{~J})$ \\
\hline
\end{tabular}

$\mathrm{J}=$ Estimated value

inspections showed that the sample locations with the highest concentrations of PAHs were in areas that contained the most visible asphalt. It has been determined that the presence of PAHs in 11 of the 16 surface samples is attributed to asphalt and not a release from the drain. Therefore, these SVOCs are not COCs at CAS 02-60-01.

\section{A.6.2.3 Total Petroleum Hydrocarbons}

Analytical results for TPH-DRO in soil samples collected at this CAS that were detected above MDCs are presented in Table A.6-4. Surface sample 562D001 was detected at a concentration of $130 \mathrm{mg} / \mathrm{kg}$, which exceeds the PAL of $100 \mathrm{mg} / \mathrm{kg}$. The TPH-DRO was moved on to a Tier 2 evaluation, and FALs were established for the hazardous constituents for TPH-DRO at their respective PAL concentrations. The hazardous constituents of TPH-DRO (Section A.6.2.2) that exceeded the PAL concentrations are attributed to asphalt rather than a release from the concrete drain.

\section{A.6.2.4 Resource Conservation and Recovery Act Metals}

Analytical results for RCRA metals in soil samples collected at this CAS that were detected above MDCs are presented in Table A.6-5. No RCRA metals were detected at concentrations exceeding their PALs. The FALs were established at the PAL concentrations. 
Table A.6-3

Sample Results for Total SVOCs Detected above MDCs at CAS 02-60-01, Concrete Drain

\begin{tabular}{|c|c|c|c|c|c|c|c|c|c|c|c|c|c|c|c|c|c|c|c|c|c|c|c|c|c|}
\hline \multirow[b]{2}{*}{ 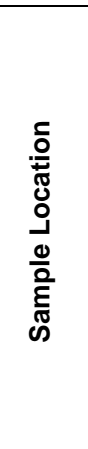 } & \multirow[b]{2}{*}{ 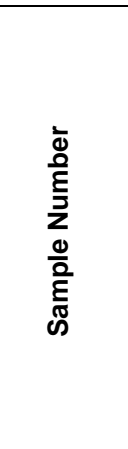 } & \multirow[b]{2}{*}{ 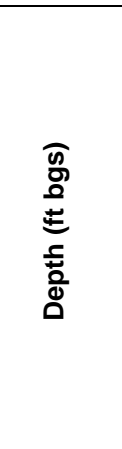 } & \multicolumn{23}{|c|}{ COPCs $(\mathrm{mg} / \mathrm{kg})$} \\
\hline & & & 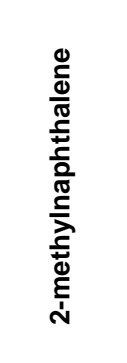 & 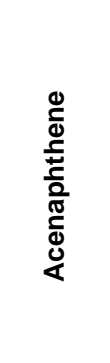 & 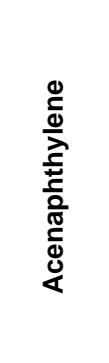 & 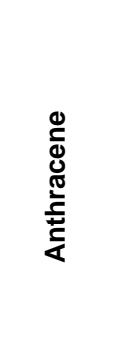 & 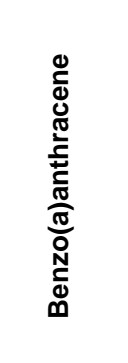 & 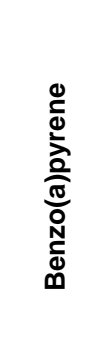 & 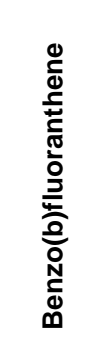 & 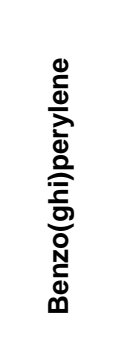 & 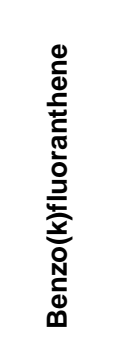 & 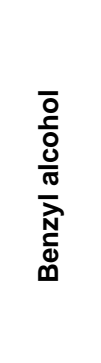 & 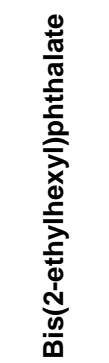 & 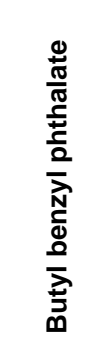 & 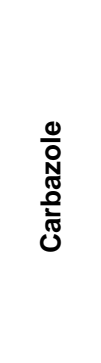 & 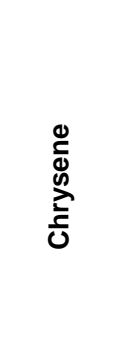 & 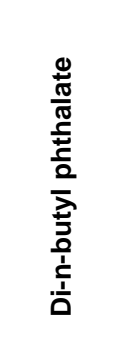 & 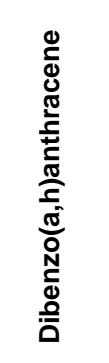 & 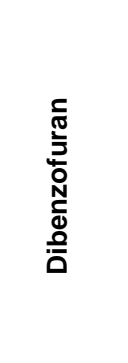 & 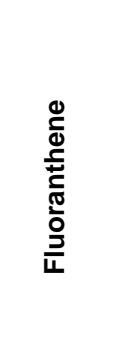 & 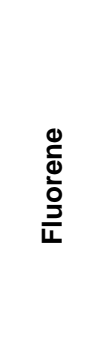 & 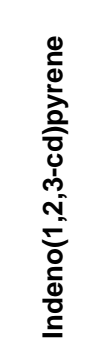 & 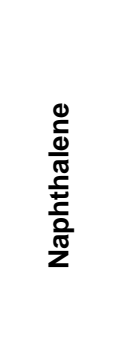 & 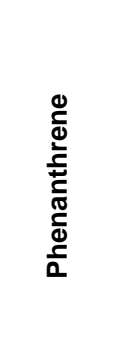 & 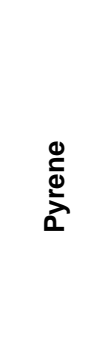 \\
\hline \multicolumn{3}{|c|}{ FALS } & 4,100 & 33,000 & 33,000 & 170,000 & 2.1 & 0.21 & 2.1 & 17,000 & 21 & 62,000 & 120 & 910 & 95.8 & 210 & 62,000 & 0.21 & 1,000 & 22,000 & 22,000 & 2.1 & 18 & 170,000 & 17,000 \\
\hline D01 & 562D001 & $0.0-0.75$ & -- & $0.17(\mathrm{~J})$ & -- & $0.34(\mathrm{~J})$ & 1.2 & $1.2(\mathrm{~J})$ & $2.5(\mathrm{~J})$ & $0.46(\mathrm{~J})$ & $0.71(\mathrm{~J})$ & -- & $0.58(\mathrm{~J})$ & -- & $0.28(\mathrm{~J})$ & 1.2 & 3.8 & $0.41(\mathrm{~J})$ & $0.19 \mathrm{~J})$ & 3.5 & $0.18(\mathrm{~J})$ & $0.65(\mathrm{~J})$ & -- & 2.9 & 2.9 \\
\hline \multirow{2}{*}{ D02 } & 562D002 & $1.5-2.0$ & -- & -- & -- & -- & -- & $0.072(J)$ & $0.11(\mathrm{~J})$ & -- & -- & -- & -- & -- & -- & -- & $0.099 \mathrm{~J}(\mathrm{~J})$ & -- & -- & $0.094(\mathrm{~J})$ & -- & -- & -- & -- & $0.086(\mathrm{~J})$ \\
\hline & $562 \mathrm{D003}$ & $1.5-2.0$ & -- & -- & -- & -- & $0.091(\mathrm{~J})$ & $0.12(\mathrm{~J})$ & $0.17(\mathrm{~J})$ & $0.1(\mathrm{~J})$ & $0.085(\mathrm{~J})$ & -- & $0.097(\mathrm{~J})$ & -- & -- & $0.094(\mathrm{~J})$ & $0.15(\mathrm{~J})$ & -- & -- & $0.17(\mathrm{~J})$ & -- & $0.08(J)$ & -- & -- & $0.15(\mathrm{~J})$ \\
\hline D03 & $562 \mathrm{D} 004$ & $0.0-0.5$ & -- & -- & -- & $0.082(\mathrm{~J})$ & 2 & 1.7 & 4 & 1.6 & 1.7 & -- & $0.13(\mathrm{~J})$ & -- & $0.1(\mathrm{~J})$ & 2.1 & 1.8 & 0.45 & 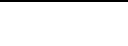 & 4.2 & -- & 1.7 & -- & 1.4 & 4 \\
\hline D04 & 5620005 & $0.0-0.5$ & - & - & -- & - & $0.29(\mathrm{~J})$ & $0.11(\mathrm{~J})$ & 0.5 & - & $0.21(\mathrm{~J})$ & - & $-\cdots$ & -- & - & $0.3(\mathrm{~J})$ & 0.98 & - & -- & 0.89 & - & - & -- & 0.62 & 0.65 \\
\hline D05 & 5620006 & $0.0-0.5$ & $0.18(\mathrm{~J})$ & $0.43(\mathrm{~J})$ & -- & $0.82(\mathrm{~J})$ & 2.6 & 2.2 & 4.2 & $1.9(\mathrm{~J})$ & $1.8(\mathrm{~J})$ & -- & $0.23(\mathrm{~J})$ & $0.092(J)$ & $0.63(\mathrm{~J})$ & 2.7 & 7.5 & $0.48(\mathrm{~J})$ & $0.27(\mathrm{~J})$ & 7 & $0.35(\mathrm{~J})$ & $2(\mathrm{~J})$ & $0.071(\mathrm{~J})$ & 4.6 & 6.2 \\
\hline D06 & 562D007 & $0.0-0.5$ & -- & $0.12(\mathrm{~J})$ & -- & $0.18(\mathrm{~J})$ & 1.7 & 1.8 & 3.7 & $1.1(\mathrm{~J})$ & 1.6 & -- & $0.084(\mathrm{~J})$ & -- & 0.15 (J) & 1.8 & 3.6 & $0.34(\mathrm{~J})$ & & 3.9 & 0.097 (J) & $1.2(\mathrm{~J})$ & -- & 1.7 & 3.5 \\
\hline D07 & 562D008 & $0.0-0.5$ & $4.6(\mathrm{~J})$ & 20 (J) & $0.18(\mathrm{~J})$ & $10(\mathrm{~J})$ & $18(\mathrm{~J})$ & $16(\mathrm{~J})$ & $21(\mathrm{~J})$ & $7.4(\mathrm{~J})$ & $9.6(\mathrm{~J})$ & 0.39 & 0.74 & 1.9 & $9.9(\mathrm{~J})$ & 19 (J) & $100(\mathrm{~J})$ & 1.5 & $15(\mathrm{~J})$ & $61(\mathrm{~J})$ & $15(\mathrm{~J})$ & $9(\mathrm{~J})$ & $3.2(\mathrm{~J})$ & $73(\mathrm{~J})$ & $50(\mathrm{~J})$ \\
\hline D08 & $562 \mathrm{D009}$ & $0.0-0.5$ & -- & -- & -- & $0.13(\mathrm{~J})$ & 0.46 & 0.42 & 0.66 & $0.22(\mathrm{~J})$ & $0.26(\mathrm{~J})$ & -- & -- & -- & $0.11(\mathrm{~J})$ & 0.46 & 1.8 & -- & -- & 1.3 & -- & $0.27(\mathrm{~J})$ & -- & 0.72 & 1 \\
\hline D09 & $562 \mathrm{D} 010$ & $0.0-0.5$ & $0.071(\mathrm{~J})$ & $0.2(\mathrm{~J})$ & -- & $0.74(\mathrm{~J})$ & 3.3 & 3.3 & 4.4 & $1.5 \mathrm{~J}(\mathrm{~J})$ & 1.9 &.- & $0.33(\mathrm{~J})$ & -- & 0.45 & 3.1 & 6.6 & $0.44(\mathrm{~J})$ & $0.12(\mathrm{~J})$ & 7.6 & $0.18(\mathrm{~J})$ & 1.8 & -- & 3.4 & 6.8 \\
\hline D10 & 5620011 & $0.0-0.5$ & -- & $0.11(\mathrm{~J})$ & -- & $0.1(\mathrm{~J})$ & $\begin{array}{l}.43 \\
\end{array}$ & 0.47 & 0.66 & $0.24(\mathrm{~J})$ & $0.3(\mathrm{~J})$ & -- & -- & -- & $0.1(\mathrm{~J})$ & 0.44 & 1.2 & -- & -- & 1.3 & 0.077 (J) & $0.29(\mathrm{~J})$ & -- & 0.81 & 0.99 \\
\hline D11 & $562 \mathrm{D} 012$ & $0.0-0.5$ & -- & $0.26(\mathrm{~J})$ & -- & 0.5 & 5.3 & $6.2(\mathrm{~J})$ & $9.1(\mathrm{~J})$ & $2.9(\mathrm{~J})$ & $5.3(\mathrm{~J})$ & -- & -- & -- & 0.44 & 4.7 & 3.2 & $1.5(\mathrm{~J})$ & $0.084(\mathrm{~J})$ & 10 & $0.16(\mathrm{~J})$ & $3.1(\mathrm{~J})$ & -- & 3.6 & 9.3 \\
\hline D12 & $562 \mathrm{D} 013$ & $0.0-0.5$ & -- & -- & -- & -- & $0.23(\mathrm{~J})$ & $0.25(\mathrm{~J})$ & 0.44 & $0.13(\mathrm{~J})$ & $0.2(\mathrm{~J})$ & -- & -- & -- & -- & $0.24(\mathrm{~J})$ & 0.55 & -- & -- & 0.77 & -- & $0.13(\mathrm{~J})$ & -- & $0.39(J)$ & 0.52 \\
\hline $\mathrm{D} 13$ & $562 D 014$ & $0.0-0.5$ & -- & -- & - & -- & $0.27(\mathrm{~J})$ & 0.26 & $0.34(\mathrm{~J})$ & $0.15(\mathrm{~J})$ & $0.22(\mathrm{~J})$ & - & -- & -- & -- & $0.28(\mathrm{~J})$ & 0.51 & -- & - & 0.81 & -- & $0.12(\mathrm{~J})$ & -- & $0.42(\mathrm{~J})$ & 0.53 \\
\hline D14 & $562 \mathrm{D} 015$ & $0.0-0.5$ & -- & -- & -- & - & -- & -- & $0.11(\mathrm{~J})$ & -- & -- & -- & -- & -- & -- & $0.085(\mathrm{~J})$ & $0.11(\mathrm{~J})$ & - & -- & $0.2(\mathrm{~J})$ & -- & -- & -- & -- & $0.13(\mathrm{~J})$ \\
\hline D15 & $562 \mathrm{D} 016$ & $0.0-0.5$ & -- & -- & -- & -- & 0.19 (J) & 0.19 (J) & $0.28(\mathrm{~J})$ & 0.085 (J) & $0.18(\mathrm{~J})$ & -- & -- & -- & - & $0.2(\mathrm{~J})$ & 0.53 & -- & -- & 0.54 & -- & 0.08 (J) & -- & 0.29 (J) & 0.39 \\
\hline D16 & $562 \mathrm{D} 017$ & $0.0-0.5$ & -- & -- & -- & -- & -- & -- & $0.11(\mathrm{~J})$ & -- & -- & -- & -- & -- & -- & -- & $0.31(\mathrm{~J})$ & -- & -- & $0.2(\mathrm{~J})$ & - & -- & -- & $0.11(\mathrm{~J})$ & $0.15(\mathrm{~J})$ \\
\hline D17 & 562D018 & $0.0-0.5$ & -- & -- & -- & -- & -- & - & -- & -- & -- &.- & -- & $\ldots$ & -- & -- & -- & - & -- & $0.12(\mathrm{~J})$ &.- & -- & -- & -- & $0.086(\mathrm{~J})$ \\
\hline
\end{tabular}

$j=$ Not detected above MDCs.
$j=$ Estimated value

Bold indicates the value equals or exceeds the FAL. 
Table A.6-4

\section{Sample Results for TPH-DRO Detected above MDCs at CAS 02-60-01, Concrete Drain}

\begin{tabular}{|c|c|c|c||}
\hline \multirow{2}{*}{$\begin{array}{c}\text { Sample } \\
\text { Location }\end{array}$} & \multirow{2}{*}{$\begin{array}{c}\text { Sample } \\
\text { Number }\end{array}$} & $\begin{array}{c}\text { Depth } \\
\text { (ft bgs) }\end{array}$ & COPCs (mg/kg) \\
\cline { 4 - 4 } & & & DRO \\
\hline \multicolumn{3}{|c|}{ PALs } \\
\hline \hline D01 & $562 \mathrm{D} 001$ & $0.0-0.75$ & $\mathbf{1 0 0}$ \\
\hline \multirow{2}{*}{ D02 } & $562 \mathrm{D} 002$ & $1.5-2.0$ & $\mathbf{1 3 0}$ \\
\cline { 2 - 5 } & $562 \mathrm{D} 003$ & $1.5-2.0$ & 6.4 \\
\hline
\end{tabular}

$\mathrm{J}=$ Estimated value

Table A.6-5

Sample Results for Metals Detected above MDCs at CAS 02-60-01, Concrete Drain

\begin{tabular}{|c|c|c|c|c|c|c|c|c|c|}
\hline \multirow[b]{2}{*}{$\begin{array}{c}\text { Sample } \\
\text { Location }\end{array}$} & \multirow[b]{2}{*}{$\begin{array}{l}\text { Sample } \\
\text { Number }\end{array}$} & \multirow[b]{2}{*}{$\begin{array}{l}\text { Depth } \\
\text { (ft bgs) }\end{array}$} & \multicolumn{7}{|c|}{ COPCs (mg/kg) } \\
\hline & & & 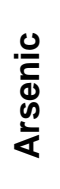 & 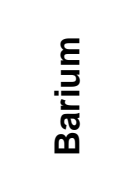 & 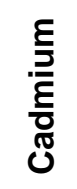 & 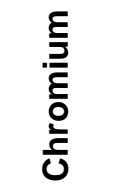 & $\begin{array}{l}\text { శ్ } \\
\text { త్ }\end{array}$ & 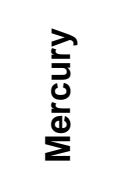 & 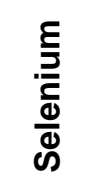 \\
\hline \multicolumn{3}{|c|}{ FALs } & 23 & 190,000 & 800 & 450 & 800 & 34 & 5,100 \\
\hline D01 & 562D001 & $0.0-0.75$ & 4.7 & 480 & 9.7 & $190(\mathrm{~J})$ & 100 & $0.12(\mathrm{~J})$ & 0.65 \\
\hline \multirow{2}{*}{ D02 } & 562D002 & $1.5-2.0$ & -- & 78 & 0.51 & $1.8(\mathrm{~J})$ & 5.9 & -- & -- \\
\hline & 562D003 & $1.5-2.0$ & -- & 74 & -- & $1.7(\mathrm{~J})$ & 5.9 & -- & -- \\
\hline
\end{tabular}

-- = Not detected above MDCs.

$\mathrm{J}=$ Estimated value

\section{A.6.2.5 Polychlorinated Biphenyls}

Analytical results for PCBs in soil samples collected at this CAS that were detected above MDCs are presented in Table A.6-6. No PCBs were detected at concentrations exceeding their PALs. The FALs were established at the PAL concentrations. 
Table A.6-6

Sample Results for PCBs Detected above MDCs at CAS 02-60-01, Concrete Drain

\begin{tabular}{|c|c|c|c||}
\hline \multirow{2}{*}{$\begin{array}{c}\text { Sample } \\
\text { Location }\end{array}$} & $\begin{array}{c}\text { Sample } \\
\text { Number }\end{array}$ & $\begin{array}{c}\text { Depth } \\
\text { (ft bgs) }\end{array}$ & COPCs (mg/kg) \\
\cline { 4 - 4 } & & Aroclor 1260 \\
\hline \multicolumn{3}{|c|}{ FALs } & $\mathbf{0 . 7 4}$ \\
\hline \hline D01 & $562 D 001$ & $0.0-0.75$ & 0.04 \\
\hline
\end{tabular}

\section{A.6.2.6 Gamma-Emitting Radionuclides}

Analytical results for gamma-emitting radionuclides in soil samples collected at this CAS that were detected above MDCs are presented in Table A.6-7. No gamma-emitting radionuclides were detected at concentrations exceeding their PALs. The FALs were established at the PAL concentrations.

Table A.6-7

Sample Results for Gamma-Emitting Radionuclides Detected above MDCs at CAS 02-60-01, Concrete Drain

\begin{tabular}{|c|c|c|c|c|}
\hline \multirow{2}{*}{$\begin{array}{c}\text { Sample } \\
\text { Location }\end{array}$} & \multirow{2}{*}{$\begin{array}{c}\text { Sample } \\
\text { Number }\end{array}$} & \multirow{2}{*}{$\begin{array}{c}\text { Depth } \\
\text { (ft bgs) }\end{array}$} & \multicolumn{2}{c|}{ COPCs (pCi/g) } \\
\cline { 4 - 5 } & & Ac-228 & Cs-137 \\
\hline \multicolumn{3}{|c|}{ FALs } & $\mathbf{5}$ & $\mathbf{1 2 . 2}$ \\
\hline \hline D01 & $562 \mathrm{D} 001$ & $0.0-0.75$ & 2.04 & 1.16 \\
\hline \multirow{2}{*}{ D02 } & $562 \mathrm{D} 002$ & $1.5-2.0$ & 2.17 & -- \\
\cline { 2 - 5 } & $562 \mathrm{D} 003$ & $1.5-2.0$ & 2.04 & -- \\
\hline
\end{tabular}

-- = Not detected above MDCs.

\section{A.6.3 Nature and Extent of Contamination}

The only analytes reported above FALs at CAS 02-60-01 were several PAHs (SVOCs) in 11 surface samples. These compounds are attributed to asphalt located throughout the yard in which the concrete drain is located and are not considered to originate from a release associated with the drain. There were no SVOCs reported at concentrations exceeding the FALs in the subsurface samples. Therefore, the PAHs are not considered COCs for the CAS, and no COCs were identified at CAS 02-60-01. 


\section{A.6.4 Revised Conceptual Site Model}

The CAIP requirements were met at this CAS, and no COCs were identified. Because the PAHs reported at this CAS were attributed to the presence of asphalt, no revisions to the CSM were necessary. 


\section{A.7.0 CAS 02-60-02, French Drain, Investigation Results}

Corrective Action Site 02-60-02 is located at the Area 2 Camp adjacent to the former Sheet Metal and Pipefitters Shop foundation (Figure 1-2). Although no specific information has been identified discussing the exact use of the Sheet Metal and Pipefitters Shop, it is assumed that effluent from activities at the building discharged to both the french drains and elongated drains. A second french drain was identified during investigation of the elongated drains along the edge of the concrete pad. Because of the discovery of an additional french drain, CAS 02-60-02 consists of the potential releases to the soil from two french drains and two elongated drains that serviced the former Sheet Metal and Pipefitters Shop foundation. Figure A.7-1 shows the sample locations and photographs of CAS 02-60-02.

\section{A.7.1 Corrective Action Investigation Activities}

A total of nine environmental samples (including one FD) were collected during investigation activities at CAS 02-60-02. The sample IDs, locations, types, and analyses are listed in Table A.7-1. The specific CAI activities conducted to satisfy the CAIP requirements at this CAS are described in the following sections.

\section{A.7.1.1 Geophysical Surveys}

A geophysical survey was conducted on the western side of the pad near the elongated drains to determine the presence of piping and a termination point for effluent. The geophysical survey results indicated that there were no linear anomalies originating from or terminating at the "drains on the west side” (Weston, 2007). Although the geophysical survey did not detect the presence of features associated with the elongated drains, piping and a french drain were identified during the utility survey.

\section{A.7.1.2 Radiological Surveys}

A radiological walkover survey was completed within the boundary of CAS 02-60-02. The results of the survey did not show radiological contaminants at activities statistically distinguishable from 


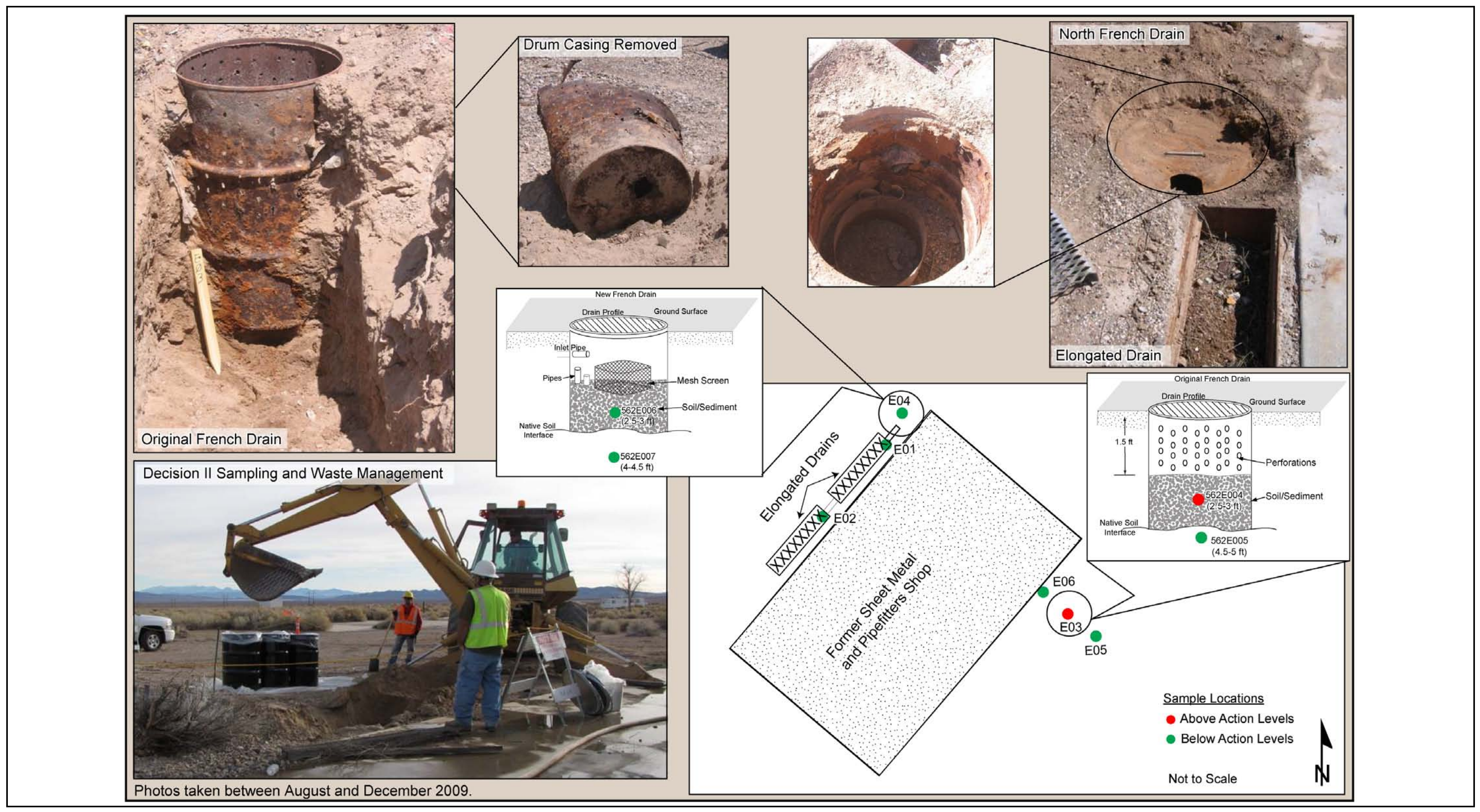

Figure A.7-1
Sample Locations at CAS 02-60-02, French Drain 
Table A.7-1

Samples Collected at CAS 02-60-02, French Drain

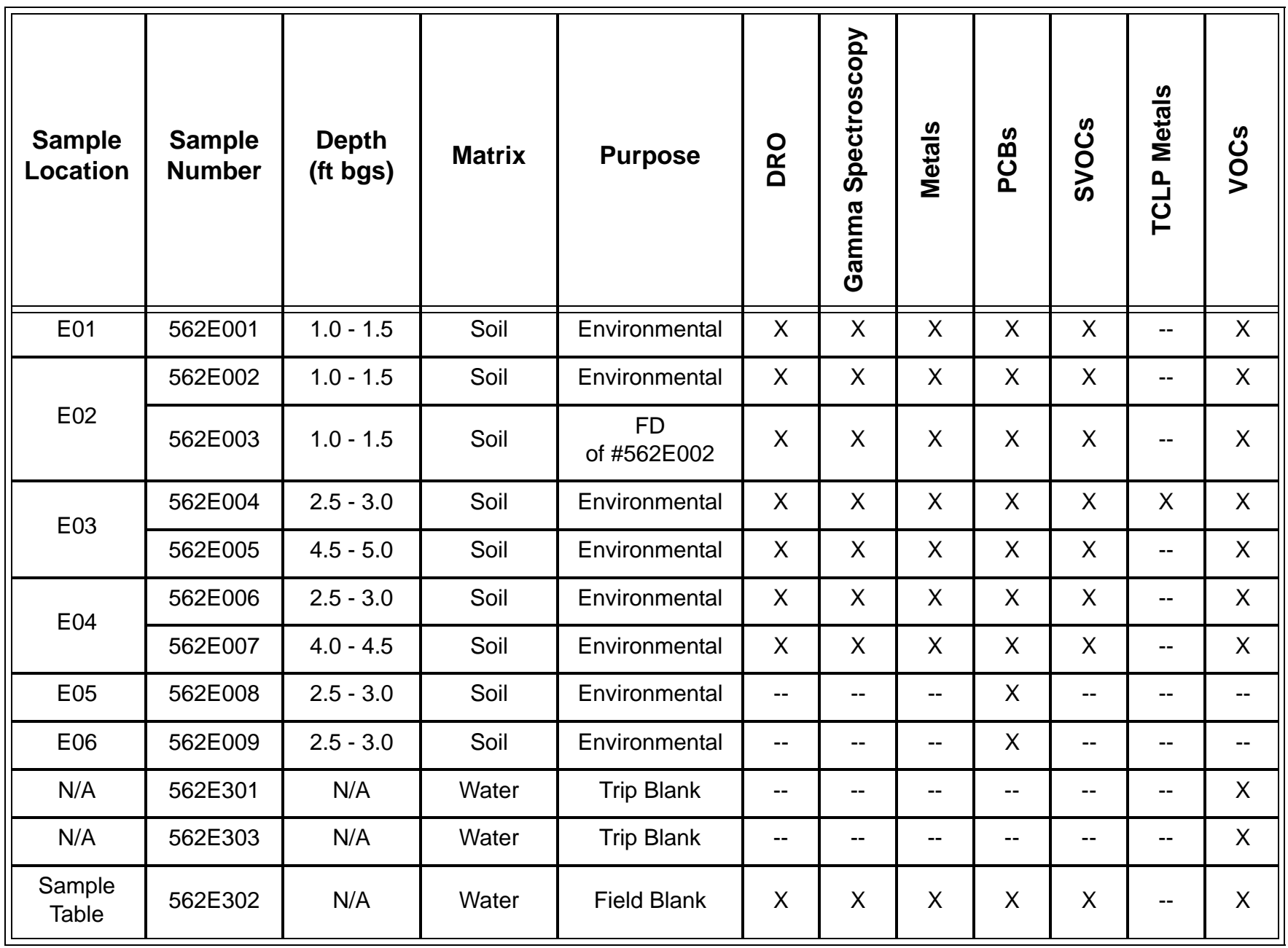

-- = Not required

background activities (more than twice background levels). The survey results did not indicate the need for additional biased samples.

\section{A.7.1.3 Visual Inspections}

At CAS 02-60-02, the following features were visually inspected before and/or during sampling activities:

French Drains - Visual inspection of the original french drain on the east side of the concrete foundation revealed that it consisted of a rusted 55-gal drum with holes drilled through the walls and 
bottom. The top of the drum was flush with the ground surface, and it was approximately half full of soil/sediment, which left a void space between the ground surface and the material in the bottom of the drain.

While investigating the north elongated drain, the inspection team identified a second french drain with a metal cover under several inches of soil. This drain, referred to as the north french drain, was approximately two-thirds full of soil/sediment, which left a void space between the ground surface and the material in the drain. The casing was a rusted and significantly corroded 55-gal drum with large holes punched though the bottom. No leach rock associated with this drain was identified. Instead, a metal screen was observed at the center, and two plastic vertical pipes, which were most likely installed to promote infiltration, were identified. The north french drain served as a discharge point for the two elongated drains.

Elongated Drains - Two elongated drains (north and south) consisting of a steel rectangular trough with a metal grate cover are located on the west side of the concrete foundation. Both drains were nearly full of soil/sediment and measured $7.0 \mathrm{ft}$ long by $11.0 \mathrm{in}$. wide and $15.0 \mathrm{in}$. deep. The south drain discharged to the north drain and ultimately to the adjacent north french drain via a small diameter metal drain pipe.

As a result of the visual inspection of the CAS, a new french drain was identified and additional samples were collected at this component.

\section{A.7.1.4 Sample Collection}

Sampling activities included the collection of nine (including one FD) environmental subsurface soil samples from six locations. All sample locations are shown on Figure A.7-1. The sampling activities are discussed below.

French Drains - At the original french drain (location E03), sample 562E004 was collected at 2.5 to $3.0 \mathrm{ft}$ bgs from the bottom interior of the 55-gal drum. This sample consisted of well-sorted sand with small miscellaneous debris and dark black (potentially organic-rich) material. Sample 562E005 was collected at 4.5 to $5.0 \mathrm{ft}$ bgs from the native soil interface directly below the original french drain. At the north french drain (location E04), sample 562E006 was collected from 2.5 to $3.0 \mathrm{ft}$ bgs from the 
bottom interior of the 55-gal drum. This sample consisted of moist, dark brown, silty sand with miscellaneous debris (e.g., metal, plastic, wood). Sample 562E007 was collected at 4.0 to $4.5 \mathrm{ft}$ bgs from the native soil interface directly below the north french drain.

Elongated Drains - A sample was collected from the contents of each of the two elongated drains. Sample 562E001 was collected from 1.0 to $1.5 \mathrm{ft}$ bgs inside the north elongated drain (location E01) directly adjacent to the drain pipe that discharges to the north french drain. Samples 562E002 and FD 562E003 were collected from 1.0 to $1.5 \mathrm{ft}$ bgs inside the south elongated drain (location E02) directly adjacent to the drain pipe that discharged to the north elongated drain. Each of these samples consisted of medium sand with miscellaneous debris (e.g., plant material, glass, possible paint chips). No staining was observed.

Decision I sampling results from the interior of the original french drain (sample 562E004) indicated the need for Decision II sampling because PCBs were detected at concentrations exceeding the FAL. Decision II sampling included collecting two soil samples (562E008 and 562E009) in two locations (E05 and E06) approximately $2.0 \mathrm{ft}$ laterally from the french drain at the same depth interval (2.5 to $3.0 \mathrm{ft}$ bgs) as the location of the PCBs.

\section{A.7.1.5 Deviations}

The CAIP stated that samples would be collected at the native soil interface below the elongated drains; however, the design of the drain was different than expected. Each drain had a metal bottom that was intact, and a drain pipe was present that connected the elongated drains and discharged to the newly identified french drain. Samples were, therefore, collected at the bottom of the north french drain and at the native soil interface below the french drain. It was determined unnecessary to sample the native soil below the elongated drains.

\section{A.7.2 Investigation Results}

The following sections provide analytical results from the samples collected to complete investigation activities as outlined in the CAIP (NNSA/NSO, 2009). The analytical parameters and laboratory methods used to analyze the investigation samples are listed in Table A.2-2. Table A.7-1 lists the sample-specific analytical suite for CAS 02-60-02. 
Analytical results from the soil samples with concentrations exceeding MDCs are summarized in the following sections. An evaluation was conducted on all contaminants detected above MDCs by comparing individual concentration or activity results against the FALs. Establishment of the FALs is presented in Appendix D. The FALs were established as the corresponding PAL concentrations or activities if the contaminant concentrations were below their respective PALs.

\section{A.7.2.1 Volatile Organic Compounds}

No analytical results for VOCs in environmental samples collected at this CAS exceeded MDCs. Therefore, the FALs were established at the corresponding PAL concentrations.

\section{A.7.2.2 Semivolatile Organic Compounds}

Analytical results for SVOCs in soil samples collected at this CAS that were detected above MDCs are presented in Table A.7-2. No SVOCs were detected at concentrations exceeding the respective PALs. The FALs were established at the PAL concentrations.

\section{A.7.2.3 Total Petroleum Hydrocarbons}

Analytical results for TPH-DRO in soil samples collected at this CAS that were detected above MDCs are presented in Table A.7-3. No TPH-DRO was detected at concentrations exceeding the PALs. The FALs were established at the PAL concentrations.

\section{A.7.2.4 Resource Conservation and Recovery Act Metals}

Analytical results for RCRA metals in soil samples collected at this CAS that were detected above MDCs are presented in Table A.7-4. No RCRA metals were detected at concentrations exceeding their PALs. The FALs were established at the PAL concentrations.

\section{A.7.2.5 Polychlorinated Biphenyls}

Analytical results for PCBs in soil samples collected at this CAS that were detected above MDCs are presented in Table A.7-5. Concentrations of PCBs that exceeded the PALs were detected at location E03 at the base of the original french drain (2.5 to $3.0 \mathrm{ft}$ bgs). Sample 562E004 contained Aroclor 1260 at concentration of $5.8 \mathrm{mg} / \mathrm{kg}$, which exceeded the PAL of $0.74 \mathrm{mg} / \mathrm{kg}$. The FAL was 
Table A.7-2

Sample Results for Total SVOCs Detected above MDCs at CAS 02-60-02, French Drain

\begin{tabular}{|c|c|c|c|c|c|c|c|c|c|c|c|c|c|c|c|}
\hline \multirow[b]{2}{*}{ 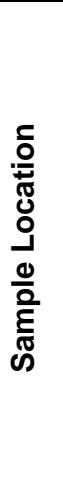 } & \multirow[b]{2}{*}{ 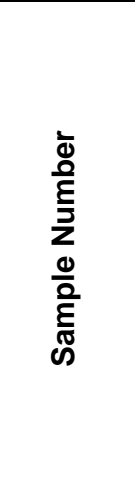 } & \multirow[b]{2}{*}{ 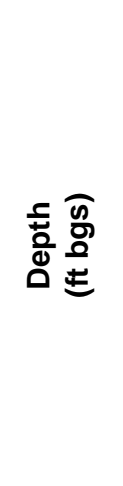 } & \multicolumn{13}{|c|}{ COPCs (mg/kg) } \\
\hline & & & 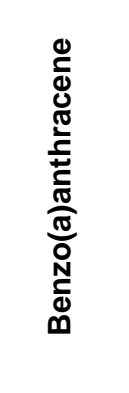 & 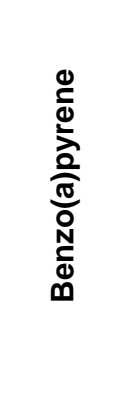 & 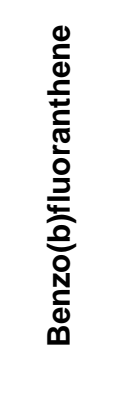 & 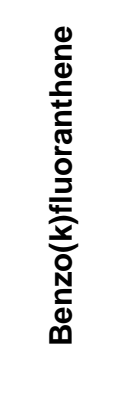 & 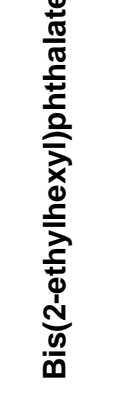 & 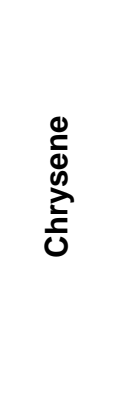 & 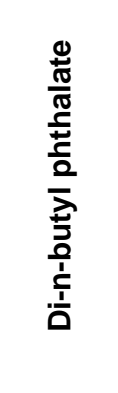 & 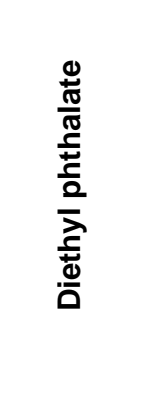 & 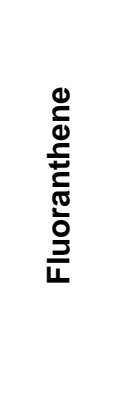 & 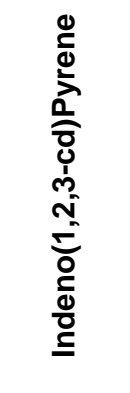 & 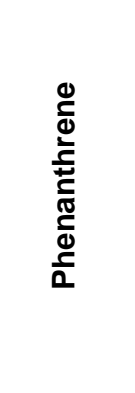 & $\begin{array}{l}\bar{o} \\
\frac{c}{d} \\
\frac{c}{\alpha}\end{array}$ & 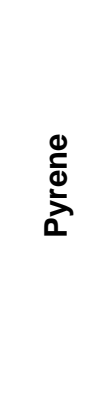 \\
\hline \multicolumn{3}{|c|}{ FALs } & 2.1 & 0.21 & 2.1 & 21 & 120 & 210 & 62,000 & 490,000 & 22,000 & 2.1 & 170,000 & 180,000 & 17,000 \\
\hline E01 & 562E001 & $1.0-1.5$ & $0.18(\mathrm{~J})$ & $0.17(\mathrm{~J})$ & $0.31(\mathrm{~J})$ & $0.11(\mathrm{~J})$ & 4.2 & $0.18(\mathrm{~J})$ & 0.58 & -- & 0.59 & -- & 0.4 & -- & 0.42 \\
\hline \multirow{2}{*}{ E02 } & 562E002 & $1.0-1.5$ & $0.16(\mathrm{~J})$ & $0.15(\mathrm{~J})$ & $0.29(\mathrm{~J})$ & $0.097(\mathrm{~J})$ & 1 & $0.19(\mathrm{~J})$ & 0.58 & -- & 0.51 & $0.084(\mathrm{~J})$ & $0.33(\mathrm{~J})$ & $0.093(\mathrm{~J})$ & 0.39 \\
\hline & 562E003 & $1.0-1.5$ & $0.18(\mathrm{~J})$ & $0.18(\mathrm{~J})$ & $0.32(\mathrm{~J})$ & $0.13(\mathrm{~J})$ & 0.71 & $0.21(\mathrm{~J})$ & 0.92 & -- & 0.58 & $0.077(\mathrm{~J})$ & 0.42 & -- & 0.43 \\
\hline E03 & 562E004 & $2.5-3.0$ & -- & -- & $0.1(\mathrm{~J})$ & -- & $0.27(\mathrm{~J})$ & -- & $0.12(\mathrm{~J})$ & $0.089(\mathrm{~J})$ & $0.11(\mathrm{~J})$ & -- & -- & -- & $0.11(\mathrm{~J})$ \\
\hline \multirow{2}{*}{ E04 } & 562E006 & $2.5-3.0$ & $0.088(\mathrm{~J})$ & $0.095(\mathrm{~J})$ & $0.17(\mathrm{~J})$ & -- & 1.8 & $0.11(\mathrm{~J})$ & $0.31(\mathrm{~J})$ & -- & $0.26(\mathrm{~J})$ & -- & $0.2(\mathrm{~J})$ & -- & $0.25(\mathrm{~J})$ \\
\hline & 562E007 & $4.0-4.5$ & -- & -- & -- & -- & 3 & -- & -- & -- & -- & -- & -- & -- & -- \\
\hline
\end{tabular}

$-=$ Not detected above MDCs.

$\mathrm{J}=$ Estimated value 
Table A.7-3

\section{Sample Results for TPH-DRO Detected above MDCs at CAS 02-60-02, French Drain}

\begin{tabular}{|c|c|c|c|}
\hline \multirow{2}{*}{$\begin{array}{c}\text { Sample } \\
\text { Location }\end{array}$} & \multirow{2}{*}{$\begin{array}{c}\text { Sample } \\
\text { Number }\end{array}$} & \multirow{2}{*}{$\begin{array}{c}\text { Depth } \\
\text { (ft bgs) }\end{array}$} & COPCs (mg/kg) \\
\cline { 4 - 5 } & & & DRO \\
\hline \multirow{3}{*}{ PALs } & $\mathbf{1 0 0}$ \\
\hline \hline E01 & $562 E 001$ & $1.0-1.5$ & $24(\mathrm{~J})$ \\
\hline \multirow{2}{*}{ E02 } & $562 E 002$ & $1.0-1.5$ & $41(\mathrm{~J})$ \\
\cline { 2 - 5 } & $562 E 003$ & $1.0-1.5$ & $42(\mathrm{~J})$ \\
\hline \multirow{2}{*}{ E03 } & $562 E 004$ & $2.5-3.0$ & $55(\mathrm{~J})$ \\
\hline \multirow{2}{*}{ E04 } & $562 E 006$ & $2.5-3.0$ & $30(\mathrm{~J})$ \\
\cline { 2 - 5 } & $562 E 007$ & $4.0-4.5$ & $4.4(\mathrm{~J})$ \\
\hline
\end{tabular}

$\mathrm{J}=$ Estimated value

Table A.7-4

Sample Results for Metals Detected above MDCs at CAS 02-60-02, French Drain

\begin{tabular}{|c|c|c|c|c|c|c|c|c|c|c|}
\hline \multirow[b]{2}{*}{$\begin{array}{l}\text { Sample } \\
\text { Location }\end{array}$} & \multirow[b]{2}{*}{$\begin{array}{l}\text { Sample } \\
\text { Number }\end{array}$} & \multirow[b]{2}{*}{$\begin{array}{l}\text { Depth } \\
\text { (ft bgs) }\end{array}$} & \multicolumn{8}{|c|}{ COPCs (mg/kg) } \\
\hline & & & 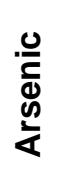 & 疍 & 点 & 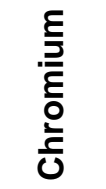 & 胥 & $\begin{array}{l}\stackrel{\lambda}{\bar{J}} \\
\frac{0}{d} \\
\sum\end{array}$ & 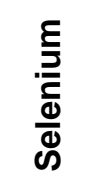 & $\frac{\sum_{\bar{j}}^{\bar{\omega}}}{\overline{\bar{n}}}$ \\
\hline \multicolumn{3}{|c|}{ FALs } & 23 & 190,000 & 800 & 450 & 800 & 34 & 5,100 & 5,100 \\
\hline E01 & 562E001 & $1.0-1.5$ & 3.6 & $150(\mathrm{~J})$ & 2.2 & $18(\mathrm{~J})$ & 58 & 0.022 (J-) & 0.83 & 0.25 \\
\hline \multirow{2}{*}{ E02 } & 562E002 & $1.0-1.5$ & 4.5 & $150(\mathrm{~J})$ & 5.9 & $83(\mathrm{~J})$ & 97 & $0.024(\mathrm{~J}-)$ & 3 & 0.41 \\
\hline & 562E003 & $1.0-1.5$ & 4.5 & $170(\mathrm{~J})$ & 5.3 & $92(\mathrm{~J})$ & 88 & 0.028 (J-) & 2.2 & 0.45 \\
\hline \multirow{2}{*}{ E03 } & 562E004 & $2.5-3.0$ & 3.5 & $170(\mathrm{~J})$ & 3.6 & $10(\mathrm{~J})$ & 320 & $0.031(\mathrm{~J}-)$ & 0.59 & 0.35 \\
\hline & 562E005 & $4.5-5.0$ & 2.3 & $72(\mathrm{~J})$ & -- & $1.8(\mathrm{~J})$ & 5.1 & $0.0093(\mathrm{~J}-)$ & -- & -- \\
\hline \multirow{2}{*}{ E04 } & 562E006 & $2.5-3.0$ & 4.1 & $160(\mathrm{~J})$ & 12 & $14(\mathrm{~J})$ & 88 & $0.032(\mathrm{~J}-)$ & -- & 0.17 \\
\hline & 562E007 & $4.0-4.5$ & 2.4 & $66(\mathrm{~J})$ & -- & $4.1(\mathrm{~J})$ & 59 & $0.034(\mathrm{~J}-)$ & -- & -- \\
\hline
\end{tabular}

$--=$ Not detected above MDCs.

$\mathrm{J}=$ Estimated value

$\mathrm{J}-=$ Result is an estimated quantity but may be biased low. 
Table A.7-5

Sample Results for PCBs Detected above MDCs at CAS 02-60-02, French Drain

\begin{tabular}{|c|c|c|c|}
\hline \multirow{2}{*}{$\begin{array}{c}\text { Sample } \\
\text { Location }\end{array}$} & \multirow{2}{*}{$\begin{array}{c}\text { Sample } \\
\text { Number }\end{array}$} & \multirow{2}{*}{$\begin{array}{c}\text { Depth } \\
\text { fft bgs) }\end{array}$} & COPCs (mg/kg) \\
\cline { 4 - 5 } & & & Aroclor 1260 \\
\hline \multicolumn{3}{|c|}{ FALs } & $\mathbf{0 . 7 4}$ \\
\hline \hline E01 & $562 E 001$ & $1.0-1.5$ & 0.056 \\
\hline \multirow{2}{*}{ E02 } & $562 E 002$ & $1.0-1.5$ & 0.072 \\
\cline { 2 - 5 } & $562 E 003$ & $1.0-1.5$ & 0.038 \\
\hline E03 & $562 E 004$ & $2.5-3.0$ & $\mathbf{5 . 8}(\mathbf{J})$ \\
\hline E04 & $562 E 006$ & $2.5-3.0$ & 0.093 \\
\hline E05 & $562 E 008$ & $2.5-3.0$ & 0.53 \\
\hline E06 & $562 E 009$ & $2.5-3.0$ & 0.2 \\
\hline
\end{tabular}

$\mathrm{J}=$ Estimated value

Bold indicates the value is equal to or exceeds the FAL.

established at the PAL concentration; therefore, Aroclor 1260 is considered a COC. Subsurface soil sample 562E005, collected at 4.5 to $5.0 \mathrm{ft}$ bgs at location E03, did not contain any PCBs, particularly Aroclor 1260, at concentrations that exceed their respective PALs. Two soil samples (562E008 and 562E009) were collected approximately $2.0 \mathrm{ft}$ laterally in two directions from the french drain at the same depth interval as the location of the COC. Soil samples 562E008 and 562E009 were collected from locations E05 and E06, respectively. These samples show that the PCBs are limited to the subsurface interval where concentrations decrease to below the FALs within $2.0 \mathrm{ft}$ laterally and $1.5 \mathrm{ft}$ vertically of the base of the french drain.

\section{A.7.2.6 Gamma-Emitting Radionuclides}

Analytical results for gamma-emitting radionuclides in soil samples collected at this CAS that were detected above MDCs are presented in Table A.7-6. No gamma-emitting radionuclides were detected at concentrations exceeding their PALs. The FALs were established at the PAL concentrations. 
Table A.7-6

\section{Sample Results for Gamma-Emitting Radionuclides Detected above MDCs at CAS 02-60-02, French Drain}

\begin{tabular}{|c|c|c|c|c|c|}
\hline \multirow{2}{*}{$\begin{array}{c}\text { Sample } \\
\text { Location }\end{array}$} & \multirow{2}{*}{$\begin{array}{c}\text { Sample } \\
\text { Number }\end{array}$} & \multirow{2}{*}{$\begin{array}{c}\text { Depth } \\
\text { (ft bgs) }\end{array}$} & \multicolumn{3}{|c|}{ COPCs (pCi/g) } \\
\cline { 4 - 6 } & & Ac-228 & Cs-137 & Th-234 \\
\hline \multirow{2}{*}{ FALs } & $\mathbf{5}$ & $\mathbf{1 2 . 2}$ & $\mathbf{1 0 5}$ \\
\hline \hline \multirow{2}{*}{ E01 } & $562 \mathrm{E} 001$ & $1.0-1.5$ & 1.12 & -- & -- \\
\hline \multirow{2}{*}{ E02 } & $562 \mathrm{E} 002$ & $1.0-1.5$ & 1.37 & -- & -- \\
\cline { 2 - 6 } & $562 \mathrm{E} 003$ & $1.0-1.5$ & 1.19 & -- & -- \\
\hline \multirow{2}{*}{ E03 } & $562 \mathrm{E} 004$ & $2.5-3.0$ & 1.76 & 0.4 & -- \\
\cline { 2 - 6 } & $562 \mathrm{E} 005$ & $4.5-5.0$ & 1.81 & -- & -- \\
\hline \multirow{2}{*}{ E04 } & $562 \mathrm{E} 006$ & $2.5-3.0$ & 1.49 & -- & $4.6(\mathrm{~J})$ \\
\cline { 2 - 6 } & $562 \mathrm{E} 007$ & $4.0-4.5$ & 2.08 & -- & \\
\hline
\end{tabular}

$--=$ Not detected above MDCs.

$\mathrm{J}=$ Estimated value

\section{A.7.3 Nature and Extent of Contamination}

Based on the analytical results for soil samples collected within CAS 02-60-02, the only COC identified was Aroclor 1260 in one subsurface sample collected from within the french drain. The Decision II soil samples show that the PCBs are limited vertically to the interval from the top of the material in the drain to a maximum depth of $4.5 \mathrm{ft}$ bgs and laterally a maximum distance of $2.0 \mathrm{ft}$ from the french drain.

\section{A.7.4 Revised Conceptual Site Model}

The CAIP requirements were met at this CAS, and no revisions were necessary to the CSM. 


\section{A.8.0 CAS 02-60-03, Steam Cleaning Drain, Investigation Results}

Corrective Action Site 02-60-03 is located at the Area 2 Camp adjacent to the former Linemans Shop (Figure 1-2). Corrective Action Site 02-60-03 consists of the potential releases to the soil from an earthen steam cleaning sump and an outfall pipe attached to an adjacent steam cleaning pad. Although no specific information has been identified discussing the use of the steam cleaning system, it is assumed that equipment and vehicles from the Area 2 Camp were washed, and potentially decontaminated, at this location. Figure A.8-1 shows the sample locations and photographs of CAS 02-60-03.

\section{A.8.1 Corrective Action Investigation Activities}

A total of 17 environmental samples (including 1 FD) were collected during investigation activities at CAS 02-60-03. The sample IDs, locations, types, and analyses are listed in Table A.8-1. The specific CAI activities conducted to satisfy the CAIP requirements at this CAS are described in the following sections.

\section{A.8.1.1 Radiological Surveys}

A radiological walkover survey was completed within the boundary of CAS 02-60-03. The results of the survey did not show radiological contaminants at activities statistically distinguishable from background activities (more than twice background levels). The survey results did not indicate the need for additional biased samples.

\section{A.8.1.2 Visual Inspections}

At CAS 02-60-03, the following components were visually inspected before and/or during sampling activities:

Steam Cleaning Sump - Visual inspection of the steam cleaning sump revealed that it consists of a shallow earthen pit with a fabricated steel grate cover designed to allow for vehicles to drive over it and waste water to drain to the subsurface soil. No liners or associated drain pipes were identified in the sump. The base of the sump consisted of a thin layer of silty sand underlain by leach rock. The 


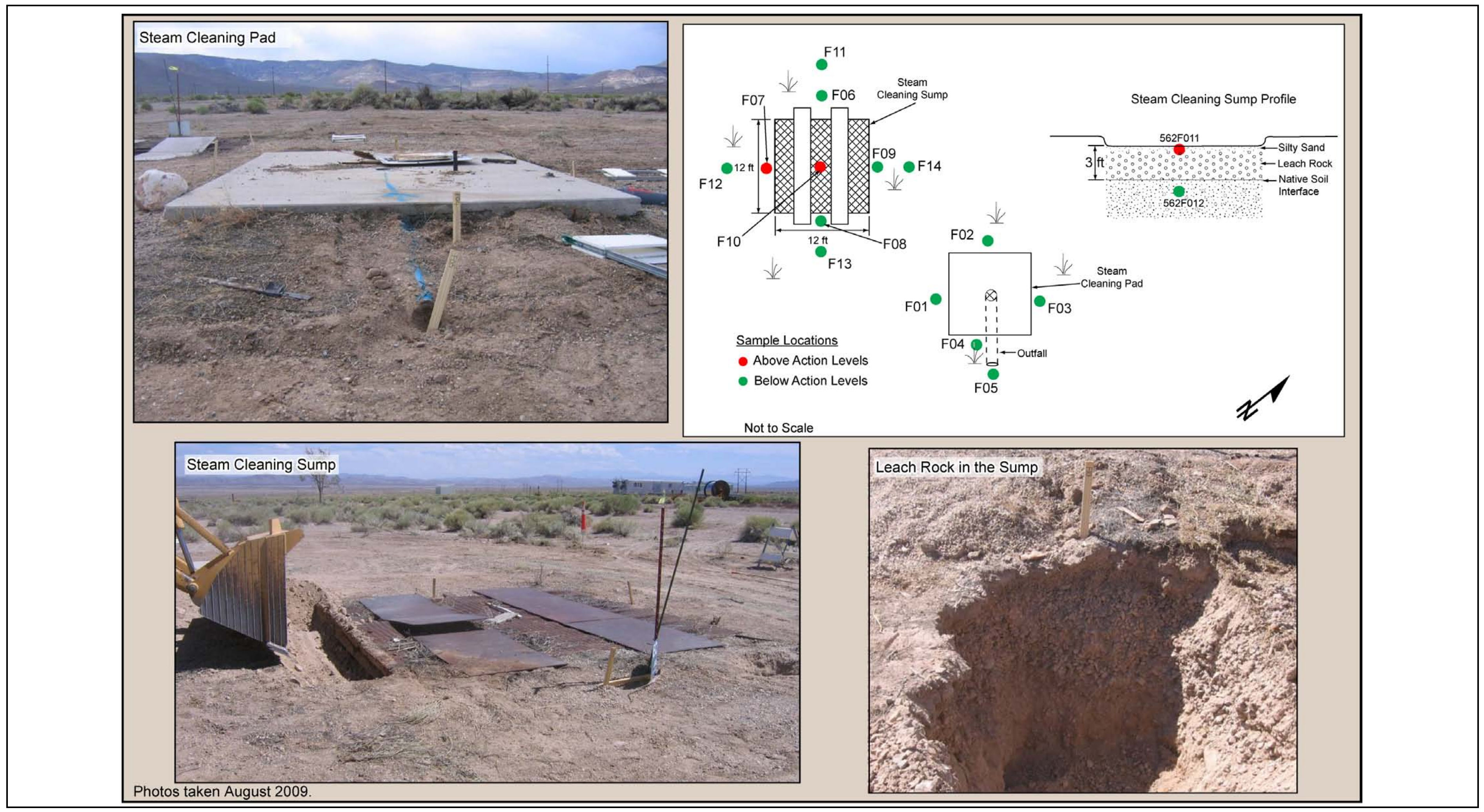

Sample Locations at CAS 02-60-03, Steam Cleaning Drain 
Table A.8-1

Samples Collected at CAS 02-60-03, Steam Cleaning Drain

\begin{tabular}{|c|c|c|c|c|c|c|c|c|c|c|c|}
\hline $\begin{array}{l}\text { Sample } \\
\text { Location }\end{array}$ & $\begin{array}{l}\text { Sample } \\
\text { Number }\end{array}$ & $\begin{array}{l}\text { Depth } \\
\text { (ft bgs) }\end{array}$ & Matrix & Purpose & $\begin{array}{l}\text { 옴 } \\
\text { 口 }\end{array}$ & 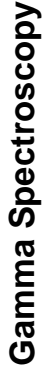 & $\frac{\frac{n}{\mathscr{T}}}{\stackrel{0}{\Sigma}}$ & $\begin{array}{l}0 \\
\frac{0}{0} \\
\frac{0}{0} \\
\frac{0}{0} \\
0 \\
0\end{array}$ & 品 & 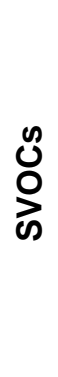 & $\begin{array}{l}\text { Uू } \\
\text { O̊ }\end{array}$ \\
\hline F01 & 562F001 & $0.0-0.5$ & Soil & Environmental & $\mathrm{X}$ & $X$ & $X$ & -- & 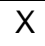 & $X$ & $\mathrm{x}$ \\
\hline F02 & 562F002 & $0.0-0.5$ & Soil & Environmental & 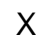 & $X$ & $\mathrm{X}$ & -- & $X$ & $x$ & $\mathrm{X}$ \\
\hline F03 & 562F003 & $0.0-0.5$ & Soil & Environmental & $\mathrm{X}$ & 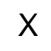 & $X$ & -- & $x$ & $X$ & $x$ \\
\hline F04 & 562F004 & $0.0-0.5$ & Soil & Environmental & $x$ & $\mathrm{X}$ & $\mathrm{X}$ & -- & $\mathrm{X}$ & $X$ & $\mathrm{X}$ \\
\hline F05 & 562F005 & $0.0-0.5$ & Soil & Environmental & $x$ & 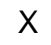 & $x$ & -- & 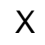 & $x$ & $X$ \\
\hline \multirow{2}{*}{ F06 } & 562F006 & $0.0-0.5$ & Soil & Environmental & $X$ & $X$ & $x$ & -- & $x$ & $X$ & $\mathrm{x}$ \\
\hline & 562F007 & $0.0-0.5$ & Soil & $\begin{array}{c}\text { FD } \\
\text { of } \# 562 F 006\end{array}$ & 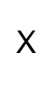 & 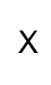 & $\mathrm{X}$ & -- & $X$ & $X$ & $x$ \\
\hline \multirow{2}{*}{ F07 } & 562F008 & $0.0-0.5$ & Soil & Environmental & $x$ & $x$ & $x$ & -- & $x$ & $x$ & $X$ \\
\hline & 562F013 & $1.0-1.5$ & Soil & Environmental & -- & -- & -- & -- & $X$ & -- & -- \\
\hline F08 & 562F009 & $0.0-0.5$ & Soil & Environmental & $X$ & $X$ & 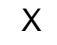 & -- & $X$ & $X$ & $\mathrm{x}$ \\
\hline F09 & 562F010 & $0.0-0.5$ & Soil & Environmental & $x$ & 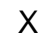 & $\mathrm{X}$ & -- & $x$ & $X$ & $x$ \\
\hline \multirow{2}{*}{ F10 } & 562F011 & $0.0-0.5$ & Soil & Environmental & $x$ & 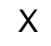 & $x$ & $X$ & $x$ & $x$ & $\mathrm{X}$ \\
\hline & 562F012 & $3.0-3.5$ & Soil & Environmental & $X$ & 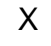 & $\mathrm{X}$ & -- & $X$ & $X$ & $x$ \\
\hline F11 & 562F014 & $0.0-0.5$ & Soil & Environmental & -- & -- & -- & -- & $X$ & -- & -- \\
\hline F12 & 562F015 & $0.0-0.5$ & Soil & Environmental & -- & -- & -- & -- & $x$ & -- & -- \\
\hline F13 & 562F016 & $0.0-0.5$ & Soil & Environmental & -- & -- & -- & -- & $x$ & -- & -- \\
\hline F14 & 562F017 & $0.0-0.5$ & Soil & Environmental & -- & -- & -- & -- & 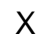 & -- & -- \\
\hline N/A & $562 F 302$ & N/A & Water & Trip Blank & -- & -- & -- & -- & -- & -- & $\mathrm{x}$ \\
\hline $\begin{array}{c}\text { Sample } \\
\text { Table }\end{array}$ & $562 F 301$ & N/A & Water & Field Blank & $\mathrm{X}$ & $X$ & $X$ & -- & $X$ & $X$ & $x$ \\
\hline
\end{tabular}


native soil interface with the leach rock was identified at approximately $3.0 \mathrm{ft}$ bgs. No soil staining was identified; therefore, sample locations F06 through F09 were selected at the midpoint of each side of the sump. Location F10 was selected at the lowest point in the middle of the sump.

Steam Cleaning Pad and Outfall - A metal outfall pipe extending from $3.0 \mathrm{ft}$ east from the steam cleaning pad was identified under several inches of soil as a result of an underground utility survey. The end of the outfall (3.0 in. diameter) was covered with a mesh screen and was mostly filled with soil. The location of the outfall was selected as biased sample location F05. Sample locations F01 through F04 were selected along the midpoint of each of the four sides of the steam cleaning pad.

\section{A.8.1.3 Sample Collection}

Sampling activities included the collection of 17 (including 1 FD) environmental surface and subsurface soil samples from 14 locations. All sample locations are shown in Figure A.8-1. The sampling activities are discussed below.

Steam Cleaning Sump - Because no biasing factors were identified, one environmental sample, including one FD (location F06), was collected from the midpoint of each side of the sump (locations F06 through F09). These samples (562F006 through 562F010) were collected at a depth of 0.0 to $0.5 \mathrm{ft}$ bgs. The steel grate was then removed and surface sample 562F011 was collected from the lowest point in the middle of the sump at location F10. This sample consisted of silty sand with some consolidated clumps, organics, and possible rusted metal debris. An additional sample (562F012) was collected at location F10. This sample was collected at the native soil interface directly below the leach rock from a depth of 3.0 to $3.5 \mathrm{ft}$ bgs.

Based on sample results from surface sample 562F008 at sample location F07, Decision II environmental samples were required at the steam cleaning sump. Sample 562F013 was collected at a depth of 1.0 to 1.5 bgs at sample location F07. A surface sample (562F015) was collected at location F12, approximately $2.0 \mathrm{ft}$ west from location F07. Three additional surface samples (562F014, 562F016, and 562F017) were collected from locations F11, F13, and F14, approximately $2.0 \mathrm{ft}$ laterally from the original sample locations (F06, F08, and F09) on the other three sides of the steam cleaning sump. 
Steam Cleaning Pad and Outfall - Because no biasing factors were identified, one sample was collected from the midpoint of each side of the concrete steam cleaning pad (locations F01 through F04). These samples (562F001 through 562F004) were collected at a depth of 0.0 to $0.5 \mathrm{ft}$ bgs. Surface sample 562F005 was collected directly adjacent to the open end of the outfall pipe at location F05.

\section{A.8.1.4 Deviations}

There were no deviations to the CAU 562 CAIP (NNSA/NSO, 2009) associated with CAS 02-60-03. Investigation samples were collected as outlined in the CAU 562 CAIP and submitted for laboratory analysis.

\section{A.8.2 Investigation Results}

The following sections provide analytical results from the samples collected to complete investigation activities as outlined in the CAIP (NNSA/NSO, 2009). The results from the analysis of PCBs included tentatively identified compounds with signatures similar to pesticides. Therefore, these samples were also analyzed for pesticides. The analytical parameters and laboratory methods used to analyze the investigation samples are listed in Table A.2-2. Table A.8-1 lists the sample-specific analytical suite for CAS 02-60-03.

Analytical results from the soil samples with concentrations exceeding MDCs are summarized in the following sections. An evaluation was conducted on all contaminants detected above MDCs by comparing individual concentration or activity results against the FALs. Establishment of the FALs is presented in Appendix D. The FALs were established as the corresponding PAL concentrations or activities if the contaminant concentrations were below their respective PALs.

\section{A.8.2.1 Volatile Organic Compounds}

No analytical results for VOCs in environmental samples collected at this CAS exceeded MDCs. Therefore, the FALs were established at the corresponding PAL concentrations. 


\section{A.8.2.2 Semivolatile Organic Compounds}

Analytical results for SVOCs in soil samples collected at this CAS that were detected above MDCs are presented in Table A.8-2. Surface (0.0 to $0.5 \mathrm{ft}$ bgs) sample 562F011 collected at location F10 from within the sump contained benzo(a)pyrene at a concentration of $0.27 \mathrm{mg} / \mathrm{kg}$, which exceeds the PAL of $0.21 \mathrm{mg} / \mathrm{kg}$. Because the FAL was established as the PAL for this contaminant, it is considered a COC.

\section{A.8.2.3 Total Petroleum Hydrocarbons}

Analytical results for TPH-DRO in soil samples collected at this CAS that were detected above MDCs are presented in Table A.8-3. Surface (0.0 to $0.5 \mathrm{ft}$ bgs) sample 562F010 exceeded the PAL of $100 \mathrm{mg} / \mathrm{kg}$ for TPH-DRO. The TPH-DRO was moved on to a Tier 2 evaluation, and FALs were established for the hazardous constituents of TPH-DRO. Concentrations of the hazardous constituents of TPH-DRO did not exceed FALs. Therefore, TPH-DRO is not considered a COC. The calculation of FALs for the hazardous constituents of TPH-DRO is presented in Appendix D.

\section{A.8.2.4 Resource Conservation and Recovery Act Metals}

Analytical results for RCRA metals in soil samples collected at this CAS that were detected above MDCs are presented in Table A.8-4. No RCRA metals were detected at concentrations exceeding their PALs. The FALs were established at the PAL concentrations.

\section{A.8.2.5 Polychlorinated Biphenyls}

Analytical results for PCBs in soil samples collected at this CAS that were detected above MDCs are presented in Table A.8-5. Surface sample 562F008 collected on the west side of the sump (location F07) had a concentration of $1.0 \mathrm{mg} / \mathrm{kg}$, which exceeded the PAL of $0.74 \mathrm{mg} / \mathrm{kg}$ for Aroclor 1260. The FAL was established at the PAL concentration for this contaminant, and, therefore, it is considered a COC. 
Table A.8-2

Sample Results for Total SVOCs Detected above MDCs at CAS 02-60-03, Steam Cleaning Drain

\begin{tabular}{|c|c|c|c|c|c|c|c|c|c|c|c|c|c|c|c|}
\hline \multirow[b]{2}{*}{ 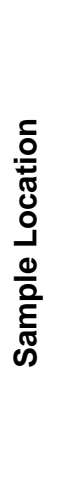 } & \multirow[b]{2}{*}{ 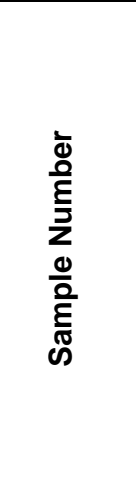 } & \multirow[b]{2}{*}{ 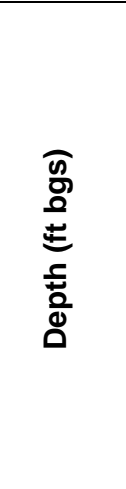 } & \multicolumn{13}{|c|}{ COPCs (mg/kg) } \\
\hline & & & 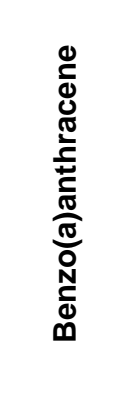 & 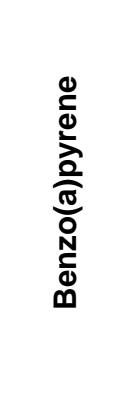 & 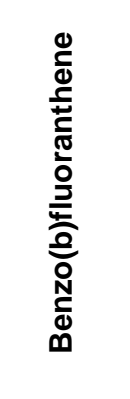 & 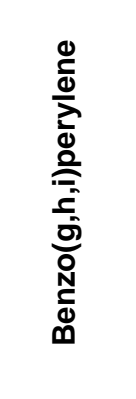 & 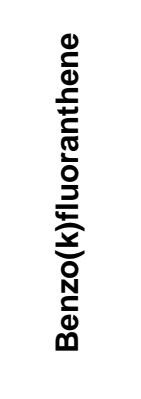 & 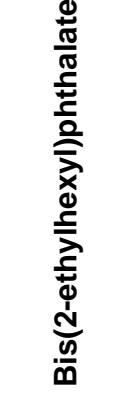 & 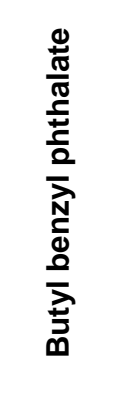 & 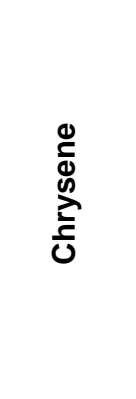 & 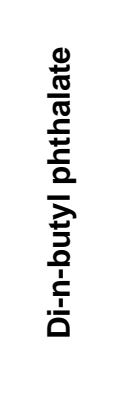 & 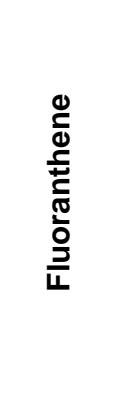 & 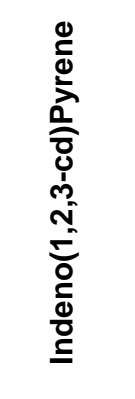 & 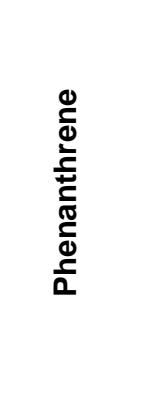 & 㐫 \\
\hline \multicolumn{3}{|c|}{ FALs } & 2.1 & 0.21 & 2.1 & 17,000 & 21 & 120 & 910 & 210 & 62,000 & 22,000 & 2.1 & 170,000 & 17,000 \\
\hline F02 & 562F002 & $0.0-0.5$ & $0.15(\mathrm{~J})$ & $0.15(\mathrm{~J})$ & $0.22(\mathrm{~J})$ & $0.084(\mathrm{~J})$ & $0.076(\mathrm{~J})$ & -- & -- & $0.14(\mathrm{~J})$ & 0.53 & 0.4 & $0.087(\mathrm{~J})$ & $0.25(\mathrm{~J})$ & $0.33(\mathrm{~J})$ \\
\hline F03 & $562 \mathrm{~F} 003$ & $0.0-0.5$ & $0.17(\mathrm{~J})$ & $0.19(\mathrm{~J})$ & $0.28(\mathrm{~J})$ & -- & $0.14(\mathrm{~J})$ & -- & -- & $0.21(\mathrm{~J})$ & 1 & 0.62 & $0.081(\mathrm{~J})$ & 0.45 & 0.47 \\
\hline F04 & 562F004 & $0.0-0.5$ & -- & -- & $0.12(\mathrm{~J})$ & -- & -- & -- & -- & $0.071(\mathrm{~J})$ & $0.24(\mathrm{~J})$ & $0.19(\mathrm{~J})$ & -- & $0.12(\mathrm{~J})$ & $0.23(\mathrm{~J})$ \\
\hline F05 & $562 F 005$ & $0.0-0.5$ & $0.08(\mathrm{~J})$ & $0.081(\mathrm{~J})$ & $0.14(\mathrm{~J})$ & -- & -- & $0.14(\mathrm{~J})$ & -- & $0.09(\mathrm{~J})$ & 0.54 & $0.27(\mathrm{~J})$ & -- & $0.2(\mathrm{~J})$ & $0.21(\mathrm{~J})$ \\
\hline \multirow{2}{*}{ F06 } & 562F006 & $0.0-0.5$ & $0.1(\mathrm{~J})$ & $0.12(\mathrm{~J})$ & $0.17(\mathrm{~J})$ & $0.086(\mathrm{~J})$ & $0.079(\mathrm{~J})$ & -- & -- & $0.11(\mathrm{~J})$ & 0.44 & $0.33(\mathrm{~J})$ & $0.1(\mathrm{~J})$ & $0.14(\mathrm{~J})$ & $0.27(\mathrm{~J})$ \\
\hline & 562F007 & $0.0-0.5$ & $0.097(\mathrm{~J})$ & $0.12(\mathrm{~J})$ & $0.19(\mathrm{~J})$ & $0.083(\mathrm{~J})$ & $0.08(\mathrm{~J})$ & $0.072(\mathrm{~J})$ & -- & $0.12(\mathrm{~J})$ & 0.4 & $0.32(\mathrm{~J})$ & $0.11(\mathrm{~J})$ & $0.17(\mathrm{~J})$ & $0.27(\mathrm{~J})$ \\
\hline F07 & $562 F 008$ & $0.0-0.5$ & $0.075(\mathrm{~J})$ & $0.096(\mathrm{~J})$ & $0.18(\mathrm{~J})$ & -- & -- & $0.095(\mathrm{~J})$ & $0.24(\mathrm{~J})$ & $0.095(\mathrm{~J})$ & $0.3(\mathrm{~J})$ & $0.23(\mathrm{~J})$ & $0.081(\mathrm{~J})$ & $0.11(\mathrm{~J})$ & $0.18(\mathrm{~J})$ \\
\hline F08 & 562F009 & $0.0-0.5$ & $0.076(\mathrm{~J})$ & $0.078(\mathrm{~J})$ & $0.16(\mathrm{~J})$ & $0.091(\mathrm{~J})$ & -- & $0.14(\mathrm{~J})$ & -- & $0.11(\mathrm{~J})$ & $0.25(\mathrm{~J})$ & $0.26(\mathrm{~J})$ & $0.093(\mathrm{~J})$ & $0.13(\mathrm{~J})$ & $0.23(\mathrm{~J})$ \\
\hline F09 & 562F010 & $0.0-0.5$ & $0.11(\mathrm{~J})$ & $0.15(\mathrm{~J})$ & $0.29(\mathrm{~J})$ & $0.13(\mathrm{~J})$ & $0.12(\mathrm{~J})$ & -- & -- & $0.16(\mathrm{~J})$ & $0.33(\mathrm{~J})$ & 0.34 & $0.11(\mathrm{~J})$ & $0.19(\mathrm{~J})$ & 0.37 \\
\hline F10 & 562F011 & $0.0-0.5$ & $0.19(\mathrm{~J})$ & 0.27 & 0.56 & $0.11(\mathrm{~J})$ & $0.26(\mathrm{~J})$ & -- & -- & $0.27(\mathrm{~J})$ & 0.52 & 0.57 & $0.15(\mathrm{~J})$ & $0.2(\mathrm{~J})$ & 0.45 \\
\hline
\end{tabular}

$-=$ Not detected above MDCs.

$\mathrm{J}=$ Estimated value

Bold indicates the value is equal to or exceeds the FAL. 
Table A.8-3

Sample Results for TPH-DRO Detected above MDCs at CAS 02-60-03, Steam Cleaning Drain

\begin{tabular}{|c|c|c|c|}
\hline \multirow{2}{*}{$\begin{array}{l}\text { Sample } \\
\text { Location }\end{array}$} & \multirow{2}{*}{$\begin{array}{l}\text { Sample } \\
\text { Number }\end{array}$} & \multirow{2}{*}{$\begin{array}{l}\text { Depth } \\
\text { (ft bgs) }\end{array}$} & COPCs $(\mathrm{mg} / \mathrm{kg})$ \\
\hline & & & DRO \\
\hline \multicolumn{3}{|c|}{ PALs } & 100 \\
\hline F02 & 562F002 & $0.0-0.5$ & 88 \\
\hline F03 & $562 F 003$ & $0.0-0.5$ & 29 \\
\hline F04 & 562F004 & $0.0-0.5$ & 31 \\
\hline F05 & 562F005 & $0.0-0.5$ & 41 \\
\hline \multirow{2}{*}{ F06 } & 562F006 & $0.0-0.5$ & 24 \\
\hline & 562F007 & $0.0-0.5$ & 39 \\
\hline F07 & 562F008 & $0.0-0.5$ & 95 \\
\hline F08 & 562F009 & $0.0-0.5$ & 43 \\
\hline F09 & 562F010 & $0.0-0.5$ & 110 \\
\hline \multirow{2}{*}{ F10 } & 562F011 & $0.0-0.5$ & $23(\mathrm{~J})$ \\
\hline & $562 \mathrm{~F} 012$ & $3.0-3.5$ & 16 \\
\hline
\end{tabular}

$\mathrm{J}=$ Estimated value

Bold indicates the value is equal to or exceeds the PAL.

Table A.8-4

Sample Results for Metals Detected above MDCs at CAS 02-60-03, Steam Cleaning Drain

(Page 1 of 2)

\begin{tabular}{|c|c|c|c|c|c|c|c|c|c|}
\hline \multirow[b]{2}{*}{$\begin{array}{c}\text { Sample } \\
\text { Location }\end{array}$} & \multirow[b]{2}{*}{$\begin{array}{l}\text { Sample } \\
\text { Number }\end{array}$} & \multirow[b]{2}{*}{$\begin{array}{l}\text { Depth } \\
\text { (ft bgs) }\end{array}$} & \multicolumn{7}{|c|}{ COPCs (mg/kg) } \\
\hline & & & 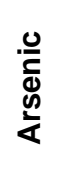 & 立 & 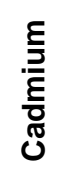 & 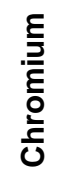 & శ్ర్తి & 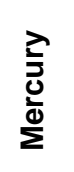 & $\frac{\underline{\Xi}}{\bar{D}}$ \\
\hline \multicolumn{3}{|c|}{ FALs } & 23 & 190,000 & 800 & 450 & 800 & 34 & 5,100 \\
\hline F01 & 562F001 & $0.0-0.5$ & 4.8 & 200 & 0.32 & 7.8 & 10 & -- & 0.6 \\
\hline F02 & $562 \mathrm{~F} 002$ & $0.0-0.5$ & 3.9 & 200 & 0.43 & 4.6 & 18 & -- & 0.34 \\
\hline F03 & 562F003 & $0.0-0.5$ & 2.3 & 210 & 0.85 & 6.9 & 21 & -- & -- \\
\hline F04 & $562 F 004$ & $0.0-0.5$ & 5.6 & 150 & 0.48 & 6.9 & 17 & -- & 0.41 \\
\hline F05 & 562F005 & $0.0-0.5$ & 2.6 & 130 & 0.89 & 4.9 & 17 & 0.11 & -- \\
\hline
\end{tabular}


Table A.8-4

Sample Results for Metals Detected above MDCs at CAS 02-60-03, Steam Cleaning Drain (Page 2 of 2)

\begin{tabular}{|c|c|c|c|c|c|c|c|c|c|}
\hline \multirow[b]{2}{*}{$\begin{array}{c}\text { Sample } \\
\text { Location }\end{array}$} & \multirow[b]{2}{*}{$\begin{array}{l}\text { Sample } \\
\text { Number }\end{array}$} & \multirow[b]{2}{*}{$\begin{array}{l}\text { Depth } \\
\text { (ft bgs) }\end{array}$} & \multicolumn{7}{|c|}{ COPCs (mg/kg) } \\
\hline & & & $\frac{0}{\frac{0}{d}}$ & 衣 & $\frac{\text { ह }}{\frac{D}{\varepsilon}}$ & 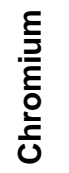 & ర్త్ర & 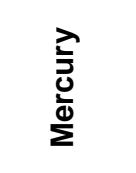 & 衣 \\
\hline \multicolumn{3}{|c|}{ FALs } & 23 & 190,000 & 800 & 450 & 800 & 34 & 5,100 \\
\hline \multirow{2}{*}{ F06 } & 562F006 & $0.0-0.5$ & 3.3 & 310 & 1.3 & 7.5 & 29 & -- & 0.46 \\
\hline & 562F007 & $0.0-0.5$ & 3.3 & 300 & 2.1 & 5.9 & 27 & -- & 0.52 \\
\hline F07 & 562F008 & $0.0-0.5$ & 3.4 & 250 & 26 & 9.4 & 50 & -- & 0.47 \\
\hline F08 & 562F009 & $0.0-0.5$ & 4 & 210 & 1.7 & 8.4 & 24 & -- & 0.35 \\
\hline F09 & $562 \mathrm{~F} 010$ & $0.0-0.5$ & 3.8 & 240 & 3.8 & 7.9 & 28 & -- & 0.44 \\
\hline \multirow{2}{*}{ F10 } & $562 F 011$ & $0.0-0.5$ & 3 & 760 & 0.84 & 7.2 & 22 & $0.022(\mathrm{~J}-)$ & -- \\
\hline & 562F012 & $3.0-3.5$ & 3.8 & 140 & 1.6 & 5 & 16 & $0.11(\mathrm{~J}-)$ & -- \\
\hline
\end{tabular}

$--=$ Not detected above MDCs.

$\mathrm{J}$ - = Result is an estimated quantity but may be biased low.

Table A.8-5

Sample Results for PCBs Detected above MDCs at CAS 02-60-03, Steam Cleaning Drain

(Page 1 of 2)

\begin{tabular}{|c|c|c|c|c|}
\hline \multirow{2}{*}{$\begin{array}{c}\text { Sample } \\
\text { Location }\end{array}$} & \multirow{2}{*}{$\begin{array}{c}\text { Sample } \\
\text { Number }\end{array}$} & \multirow{2}{*}{$\begin{array}{c}\text { Depth } \\
\text { (ft bgs) }\end{array}$} & Aroclor 1260 & Aroclor 1268 \\
\cline { 4 - 5 } & & & $\mathbf{0 . 7 4}$ & $\mathbf{0 . 7 4}$ \\
\hline \multirow{3}{*}{ FALs } & & 0.14 & -- \\
\hline \hline F02 & 562 F002 & $0.0-0.5$ & 0.11 & -- \\
\hline F03 & 562 F003 & $0.0-0.5$ & 0.057 & -- \\
\hline F05 & $562 F 005$ & $0.0-0.5$ & $0.045(\mathrm{~J})$ & 0.078 \\
\hline \multirow{2}{*}{ F06 } & $562 F 006$ & $0.0-0.5$ & $0.036(\mathrm{~J})$ & $0.12(\mathrm{~J})$ \\
\cline { 2 - 5 } & $562 F 007$ & $0.0-0.5$ & $\mathbf{1 ( J )}$ & -- \\
\hline \multirow{2}{*}{ F07 } & 562 F008 & $0.0-0.5$ & 0.054 & -- \\
\cline { 2 - 5 } & $562 F 013$ & $1.0-1.5$ & $0.021(\mathrm{~J})$ & 0.069 \\
\hline F08 & $562 F 009$ & $0.0-0.5$ & & \\
\hline
\end{tabular}


Table A.8-5

Sample Results for PCBs Detected above MDCs at CAS 02-60-03, Steam Cleaning Drain (Page 2 of 2)

\begin{tabular}{|c|c|c|c|c|}
\hline \multirow{2}{*}{$\begin{array}{c}\text { Sample } \\
\text { Location }\end{array}$} & \multirow{2}{*}{$\begin{array}{c}\text { Sample } \\
\text { Number }\end{array}$} & \multirow{2}{*}{$\begin{array}{c}\text { Depth } \\
\text { fft bgs) }\end{array}$} & Aroclor 1260 & Aroclor 1268 \\
\cline { 4 - 5 } & & & $\mathbf{0 . 7 4}$ & $\mathbf{0 . 7 4}$ \\
\hline \multirow{3}{*}{ FALs } & & -- & $0.52(\mathrm{~J})$ \\
\hline \hline F09 & $562 F 010$ & $0.0-0.5$ & $0.036(\mathrm{~J})$ & -- \\
\hline \multirow{2}{*}{ F10 } & $562 F 011$ & $0.0-0.5$ & 0.36 & -- \\
\cline { 3 - 5 } & $562 F 012$ & $3.0-3.5$ & 0.068 & -- \\
\hline F11 & $562 F 014$ & $0.0-0.5$ & $0.33(\mathrm{~J})$ & $0.2(\mathrm{~J})$ \\
\hline F12 & $562 F 015$ & $0.0-0.5$ & $0.052(\mathrm{~J})$ & -- \\
\hline F13 & $562 F 016$ & $0.0-0.5$ & 0.12 & \\
\hline F14 & $562 F 017$ & $0.0-0.5$ & & \\
\hline
\end{tabular}

$--=$ Not detected above MDCs.

$\mathrm{J}=$ Estimated value

Bold indicates the value is equal to or exceeds the FAL.

\section{A.8.2.6 Pesticides}

Analytical results for pesticides in soil samples collected at this CAS that were detected above MDCs are presented in Table A.8-6. No pesticides were detected at concentrations exceeding their PALs. The FALs were established at the PAL concentrations.

Table A.8-6

Sample Results for Pesticides Detected above MDCs at CAS 02-60-03, Steam Cleaning Drain

\begin{tabular}{|c|c|c|c|}
\hline \multirow{2}{*}{$\begin{array}{c}\text { Sample } \\
\text { Location }\end{array}$} & \multirow{2}{*}{$\begin{array}{c}\text { Sample } \\
\text { Number }\end{array}$} & $\begin{array}{c}\text { Depth } \\
\text { (ft bgs) }\end{array}$ & COPCs (mg/kg) \\
\cline { 4 - 4 } & & & Chlordane \\
\hline \multicolumn{3}{|c|}{ FALs } & 6.5 \\
\hline \hline F10 & 562 F011 & $0.0-0.5$ & $0.054(\mathrm{~J})$ \\
\hline
\end{tabular}

$\mathrm{J}=$ Estimated value 


\section{A.8.2.7 Gamma-Emitting Radionuclides}

Analytical results for gamma-emitting radionuclides in soil samples collected at this CAS that were detected above MDCs are presented in Table A.8-7. No gamma-emitting radionuclides were detected at concentrations exceeding their PALs. The FALs were established at the PAL concentrations.

Table A.8-7

\section{Sample Results for Gamma-Emitting Radionuclides Detected above MDCs at CAS 02-60-03, Steam Cleaning Drain}

\begin{tabular}{|c|c|c|c|c|c|}
\hline \multirow{2}{*}{$\begin{array}{l}\text { Sample } \\
\text { Location }\end{array}$} & \multirow{2}{*}{$\begin{array}{l}\text { Sample } \\
\text { Number }\end{array}$} & \multirow{2}{*}{$\begin{array}{c}\text { Depth } \\
\text { (ft bgs) }\end{array}$} & \multicolumn{3}{|c|}{ COPCs (pCi/g) } \\
\hline & & & \multirow{2}{*}{$\frac{A c-228}{5}$} & \multirow{2}{*}{$\begin{array}{c}\text { Cs-137 } \\
12.2\end{array}$} & \multirow{2}{*}{$\begin{array}{r}\text { Th-234 } \\
105\end{array}$} \\
\hline \multicolumn{3}{|c|}{ FALs } & & & \\
\hline F01 & 562F001 & $0.0-0.5$ & 1.42 & -- & -- \\
\hline F02 & 562F002 & $0.0-0.5$ & 1.06 & -- & -- \\
\hline F03 & $562 \mathrm{~F} 003$ & $0.0-0.5$ & 1.36 & 0.469 & $2.53(\mathrm{~J})$ \\
\hline F04 & $562 \mathrm{~F} 004$ & $0.0-0.5$ & 1.39 & 0.27 & -- \\
\hline F05 & 562F005 & $0.0-0.5$ & 1.41 & 0.42 & -- \\
\hline \multirow{2}{*}{ F06 } & $562 F 006$ & $0.0-0.5$ & 1.44 & -- & -- \\
\hline & 562F007 & $0.0-0.5$ & 1.26 & -- & -- \\
\hline F07 & 562F008 & $0.0-0.5$ & 1.6 & -- & -- \\
\hline F08 & 562F009 & $0.0-0.5$ & 1.33 & -- & $2(\mathrm{~J})$ \\
\hline F09 & $562 \mathrm{~F} 010$ & $0.0-0.5$ & 1.4 & 0.084 & $2.91(\mathrm{~J})$ \\
\hline \multirow{2}{*}{ F10 } & $562 F 011$ & $0.0-0.5$ & 1.77 & 0.513 & $3.3(\mathrm{~J})$ \\
\hline & $562 \mathrm{~F} 012$ & $3.0-3.5$ & 1.92 & -- & -- \\
\hline
\end{tabular}

$--=$ Not detected above MDCs.

$\mathrm{J}=$ Estimated value

\section{A.8.3 Nature and Extent of Contamination}

Based on the analytical results for soil samples collected within CAS 02-60-03, the only COCs identified were benzo(a)pyrene and Aroclor 1260.

Benzo(a)pyrene was detected in one surface sample collected from within the sump. The subsurface soil sample (3 to 3.5 bgs) collected below the contaminated location within the sump did not contain any SVOCs, particularly benzo(a)pyrene, at concentrations that exceed their respective PALs. The 
four subsurface soil samples collected outside the sump did not contain any SVOCs above the PALs. Therefore, the SVOC that exceeded the FAL was bounded vertically and laterally, and the contamination was limited to within the sump (12.0 by 12.0 by $3.0 \mathrm{ft})$.

Aroclor 1260 was detected in one sample collected adjacent to the southwest side of the sump. The

Decision II soil samples collected show that the concentration of Aroclor 1260 decreases to below the FAL vertically to a depth of $1.5 \mathrm{ft}$ and laterally to $3.0 \mathrm{ft}$ from the sump.

\section{A.8.4 Revised Conceptual Site Model}

The CAIP requirements were met at this CAS, and no revisions were necessary to the CSM. 


\section{A.9.0 CAS 02-60-04, French Drain, Investigation Results}

Corrective Action Site 02-60-04 is located at the Refrigeration Shop in the Area 2 Camp (Figure 1-2). Although no specific information has been identified discussing the use of the french drain, it is speculated that the french drain supported activities at the Refrigeration Shop (e.g., cleaning parts and equipment on the pad, disposal of fluids). Corrective Action Site 02-60-04 consists of the potential releases to the soil from the french drain installed in the concrete foundation. Figure A.9-1 shows the sample locations and photographs of CAS 02-60-04.

\section{A.9.1 Corrective Action Investigation Activities}

A total of six environmental samples (including one FD) and one PSM sample were collected during investigation activities at CAS 02-60-04. The sample IDs, locations, types, and analyses are listed in Table A.9-1. The specific CAI activities conducted to satisfy the CAIP requirements at this CAS are described in the following sections.

\section{A.9.1.1 Radiological Surveys}

A radiological walkover survey was completed within the boundary of CAS 02-60-04. The results of the survey did not show radiological contaminants at activities statistically distinguishable from background activities (more than twice background levels). The survey results did not indicate the need for additional biased samples.

\section{A.9.1.2 Visual Inspections}

Inspection of the french drain revealed that it consisted of a 10.0-in.-diameter, 9.0-ft-long perforated steel casing without an end cap. The casing, which was filled with pea gravel and PSM, was set in an 18.0-in.-diameter borehole. The drain was located in the center of an 18-in.-thick reinforced concrete foundation. An area of the concrete foundation approximately 22.0 by $20.0 \mathrm{ft}$ was removed to allow for access to the drain. The drain casing was full of material that consisted of mottled (dark brown, black, and orange stained) sediment with a mud-like consistency and abundant debris (e.g., plastic, wood, metal). Because of the presence of waste and the visual appearance of the sample, three more sample locations were identified to gather additional characterization information. 


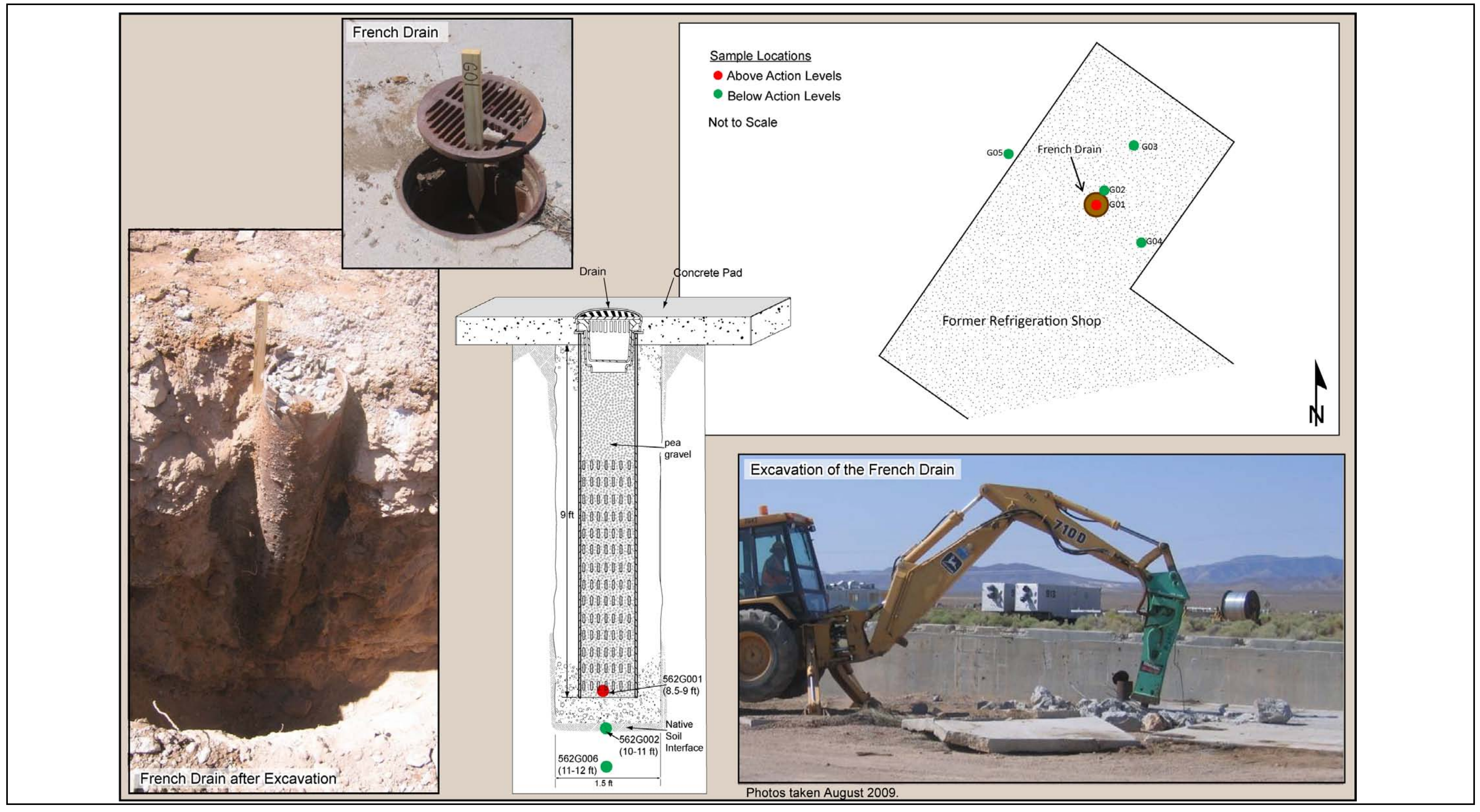

Figure A.9-1

Sample Locations at CAS 02-60-04, French Drain 
Table A.9-1

Samples Collected at CAS 02-60-04, French Drain

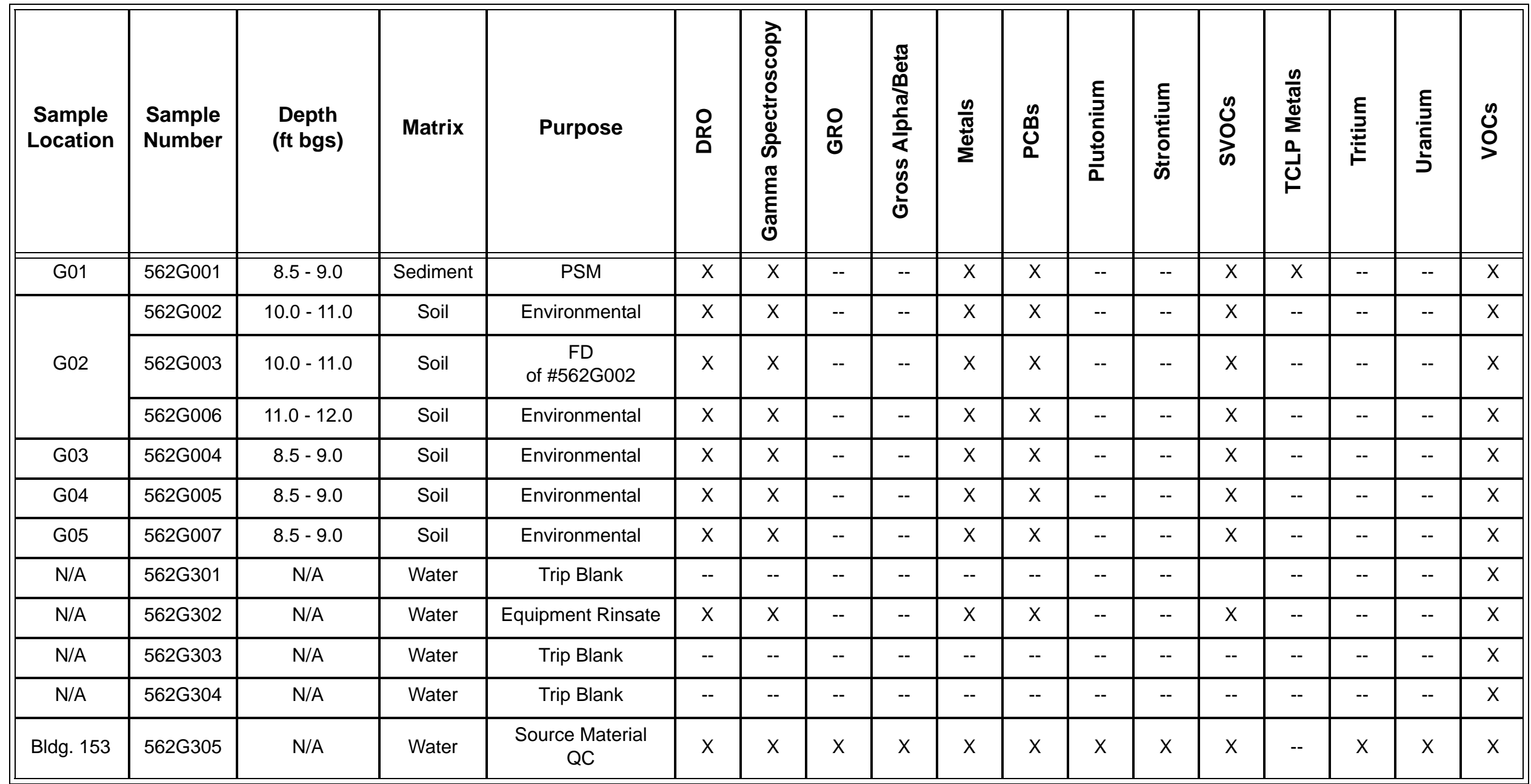

GRO = Gasoline-range organics

-- = Not required 


\section{A.9.1.3 Sample Collection}

Sampling activities included the collection of six (including one FD) environmental subsurface soil samples and one PSM sample from the five locations shown in Figure A.9-1. The sampling activities are discussed below.

At the french drain, sample 562G001 was collected from the bottom interior of the drain casing (location G01) at a depth of 8.5 to $9.0 \mathrm{ft}$ bgs. The sample consisted of a moist, mottled sediment with a mud-like consistency and was presumed to be PSM. Miscellaneous debris was present in the sample, and orange staining, possibly from rust, was visible. Samples 562G002 and FD 562G003 were collected from location G02 at 10.0 to $11.0 \mathrm{ft}$ bgs from the native soil interface directly below the french drain casing. An additional sample, 562G006, was collected at location G02 from 11.0 to $12.0 \mathrm{ft}$ bgs. The french drain casing was removed from the ground and the PSM was placed in a 55-gal drum staged on site at a satellite accumulation area.

Due to the presence of PSM in the french drain, additional sample locations G03, G04, and G05 were selected on the north, east, and west sides of the former french drain location, respectively. The locations could not be equally spaced around the drain due to the presence of the reinforced concrete pad that the drain was located in. Samples from each of these locations were collected from 8.5 to $9.0 \mathrm{ft}$ bgs, which represent the depth of the PSM collected from the interior of the french drain. Sample 562G004 was collected at location G03, $10.0 \mathrm{ft}$ north of the former french drain location (G01). Sample 562G005 was collected at location G04, $10.0 \mathrm{ft}$ east of location G01. Sample 562G007 was collected at location G05, $18.0 \mathrm{ft}$ west of location G01.

\section{A.9.1.4 Deviations}

Investigation samples were collected as outlined in the CAU 562 CAIP (NNSA/NSO, 2009) and submitted for laboratory analysis. However, additional samples were collected due to the presence of PSM in the french drain.

\section{A.9.2 Investigation Results}

The following sections provide analytical results from the samples collected to complete investigation activities as outlined in the CAIP (NNSA/NSO, 2009). The analytical parameters and 
laboratory methods used to analyze the investigation samples are listed in Table A.2-2. Table A.9-1 lists the sample-specific analytical suite for CAS 02-60-04.

Analytical results from the soil samples with concentrations exceeding MDCs are summarized in the following sections. An evaluation was conducted on all contaminants detected above MDCs by comparing individual concentration or activity results against the FALs. Establishment of the FALs is presented in Appendix D. The FALs were established as the corresponding PAL concentrations or activities if the contaminant concentrations were below their respective PALs.

\section{A.9.2.1 Volatile Organic Compounds}

No analytical results for VOCs in environmental samples collected at this CAS exceeded MDCs. Therefore, the FALs were established at the corresponding PAL concentrations.

\section{A.9.2.2 Semivolatile Organic Compounds}

Analytical results for SVOCs in soil samples collected at this CAS that were detected above MDCs are presented in Table A.9-2. No SVOCs were detected at concentrations exceeding their PALs. The FALs were established at the PAL concentrations.

Table A.9-2

Sample Results for Total SVOCs Detected above MDCs at CAS 02-60-04, French Drain

\begin{tabular}{|c|c|c|c|}
\hline \multirow{2}{*}{$\begin{array}{l}\text { Sample } \\
\text { Location }\end{array}$} & \multirow{2}{*}{$\begin{array}{l}\text { Sample } \\
\text { Number }\end{array}$} & \multirow{2}{*}{$\begin{array}{l}\text { Depth } \\
\text { (ft bgs) }\end{array}$} & COPCs (mg/kg) \\
\hline & & & Bis(2-ethylhexyl)phthalate \\
\hline \multicolumn{3}{|c|}{ FALs } & 120 \\
\hline G02 & $562 \mathrm{G} 006$ & $11.0-12.0$ & $0.1(\mathrm{~J})$ \\
\hline
\end{tabular}

$\mathrm{J}=$ Estimated value

\section{A.9.2.3 Total Petroleum Hydrocarbons}

Analytical results for TPH-DRO in soil samples collected at this CAS that were detected above MDCs are presented in Table A.9-3. No TPH-DRO was detected at concentrations exceeding their PALs. The FALs were established at the PAL concentrations. 
Table A.9-3

Sample Results for TPH-DRO Detected above MDCs at CAS 02-60-04, French Drain

\begin{tabular}{|c|c|c|c|}
\hline \multirow{2}{*}{$\begin{array}{l}\text { Sample } \\
\text { Location }\end{array}$} & \multirow{2}{*}{$\begin{array}{l}\text { Sample } \\
\text { Number }\end{array}$} & \multirow{2}{*}{$\begin{array}{l}\text { Depth } \\
\text { (ft bgs) }\end{array}$} & COPCs (mg/kg) \\
\hline & & & DRO \\
\hline \multicolumn{3}{|c|}{ PALs } & 100 \\
\hline \multirow{3}{*}{ G02 } & $562 \mathrm{G} 002$ & $10.0-11.0$ & 10 \\
\hline & $562 \mathrm{G} 003$ & $10.0-11.0$ & 10 \\
\hline & $562 \mathrm{G} 006$ & $11.0-12.0$ & 8 \\
\hline
\end{tabular}

\section{A.9.2.4 Resource Conservation and Recovery Act Metals}

Analytical results for RCRA metals in soil samples collected at this CAS that were detected above MDCs are presented in Table A.9-4. No RCRA metals were detected at concentrations exceeding their PALs. The FALs were established at the PAL concentrations.

Table A.9-4

Sample Results for Metals Detected above MDCs at CAS 02-60-04, French Drain

\begin{tabular}{|c|c|c|c|c|c|c|c|c|c|}
\hline \multirow[b]{2}{*}{$\begin{array}{l}\text { Sample } \\
\text { Location }\end{array}$} & \multirow[b]{2}{*}{$\begin{array}{l}\text { Sample } \\
\text { Number }\end{array}$} & \multirow[b]{2}{*}{$\begin{array}{l}\text { Depth } \\
\text { (ft bgs) }\end{array}$} & \multicolumn{7}{|c|}{ COPCs (mg/kg) } \\
\hline & & & 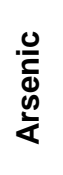 & 占 & 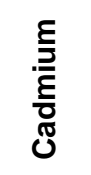 & 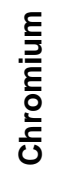 & ఫ్త్ర & $\begin{array}{l}\stackrel{\lambda}{J} \\
\frac{0}{0} \\
\sum\end{array}$ & $\frac{\xi}{\bar{D}}$ \\
\hline \multicolumn{3}{|c|}{ FALs } & 23 & 190,000 & 800 & 450 & 800 & 34 & 5,100 \\
\hline \multirow{3}{*}{ G02 } & $562 \mathrm{G} 002$ & $10.0-11.0$ & 3.5 & 78 & -- & 3.4 & 6.2 & $0.049(\mathrm{~J}-)$ & -- \\
\hline & $562 \mathrm{G} 003$ & $10.0-11.0$ & 2.8 & 73 & -- & 3.2 & 6 & $0.042(\mathrm{~J}-)$ & -- \\
\hline & $562 \mathrm{G} 006$ & $11.0-12.0$ & 2.9 & 80 & 0.086 & 4.3 & $7.2(\mathrm{~J})$ & -- & 0.39 \\
\hline G03 & 562G004 & $8.5-9.0$ & 2.7 & 100 & -- & 3.7 & $6.7(\mathrm{~J})$ & -- & 0.33 \\
\hline G04 & $562 \mathrm{G} 005$ & $8.5-9.0$ & 2.6 & 110 & 0.064 & 4 & $9.5(\mathrm{~J})$ & $0.055(\mathrm{~J}-)$ & -- \\
\hline G05 & $562 \mathrm{G} 007$ & $8.5-9.0$ & 2.8 & 100 & 0.05 & 3.5 & $7(\mathrm{~J})$ & -- & -- \\
\hline
\end{tabular}

$--=$ Not detected above MDCs.

$\mathrm{J}=$ Estimated value

$\mathrm{J}-=$ Result is an estimated quantity but may be biased low 


\section{A.9.2.5 Polychlorinated Biphenyls}

Analytical results for PCBs in soil samples collected at this CAS that were detected above MDCs are presented in Table A.9-5. No PCBs were detected at concentrations exceeding their PALs. The FALs were established at the PAL concentrations.

Table A.9-5

Sample Results for PCBs Detected above MDCs at CAS 02-60-04, French Drain

\begin{tabular}{||c|c|c|c|}
\hline \multirow{2}{*}{$\begin{array}{c}\text { Sample } \\
\text { Location }\end{array}$} & \multirow{2}{*}{$\begin{array}{c}\text { Sample } \\
\text { Number }\end{array}$} & $\begin{array}{c}\text { Depth } \\
\text { (ft bgs) }\end{array}$ & COPCs (mg/kg) \\
\cline { 4 - 5 } & & & Aroclor 1260 \\
\hline \multicolumn{3}{|c|}{ FALs } & $\mathbf{0 . 7 4}$ \\
\hline \hline \multirow{2}{*}{ G02 } & $562 \mathrm{G} 002$ & $10.0-11.0$ & 0.044 \\
\cline { 2 - 5 } & $562 \mathrm{G} 003$ & $10.0-11.0$ & 0.036 \\
\hline
\end{tabular}

\section{A.9.2.6 Gamma-Emitting Radionuclides}

Analytical results for gamma-emitting radionuclides in soil samples collected at this CAS that were detected above MDCs are presented in Table A.9-6. No gamma-emitting radionuclides were detected at concentrations exceeding their PALs. The FALs were established at the PAL concentrations.

Table A.9-6

Sample Results for Gamma-Emitting Radionuclides Detected above MDCs at CAS 02-60-04, French Drain

\begin{tabular}{|c|c|c|c|}
\hline \multirow{2}{*}{$\begin{array}{c}\text { Sample } \\
\text { Location }\end{array}$} & \multirow{2}{*}{$\begin{array}{c}\text { Sample } \\
\text { Number }\end{array}$} & \multirow{2}{*}{$\begin{array}{c}\text { Depth } \\
\text { (ft bgs) }\end{array}$} & COPCs (pCi/g) \\
\cline { 4 - 5 } & & & Ac-228 \\
\hline \multirow{3}{*}{ FALs } & $\mathbf{5}$ \\
\hline \hline \multirow{3}{*}{ G02 } & $562 \mathrm{G} 002$ & $10.0-11.0$ & 2.17 \\
\cline { 2 - 5 } & $562 \mathrm{G} 003$ & $10.0-11.0$ & 1.35 \\
\cline { 2 - 5 } & $562 \mathrm{G} 006$ & $11.0-12.0$ & 2.13 \\
\hline G03 & $562 \mathrm{G} 004$ & $8.5-9.0$ & 1.77 \\
\hline G04 & $562 \mathrm{G} 005$ & $8.5-9.0$ & 2.13 \\
\hline G05 & $562 \mathrm{G} 007$ & $8.5-9.0$ & 2.2 \\
\hline
\end{tabular}




\section{A.9.3 Potential Source Material Sample Results}

Analytical results for the sediment sample (562G001) with concentrations exceeding MDCs are presented in Table A.9-7. The analytical results indicate that benzo(a)pyrene $(0.26 \mathrm{mg} / \mathrm{kg})$, Aroclor 1260 (0.95 mg/kg), and Aroclor $1268(0.95 \mathrm{mg} / \mathrm{kg})$ are present at concentrations above the respective PSM criteria. Therefore, these contaminants are considered PSM.

Table A.9-7

PSM Results Detected above MDCs for CAS 02-60-04, French Drain (Page 1 of 2)

\begin{tabular}{|c|c|c|c|c|c|c|}
\hline $\begin{array}{l}\text { Sample } \\
\text { Location }\end{array}$ & $\begin{array}{l}\text { Sample } \\
\text { Number }\end{array}$ & $\begin{array}{c}\text { Sample } \\
\text { Matrix }\end{array}$ & Parameter & Result & $\begin{array}{c}\text { PSM } \\
\text { Criteria }\end{array}$ & Unit \\
\hline \multirow{21}{*}{ G01 } & \multirow{21}{*}{$562 G 001$} & \multirow{21}{*}{ Sediment } & DRO & 530 & N/A & $\mathrm{mg} / \mathrm{kg}$ \\
\hline & & & Ac-228 & 1.25 & 5 & $\mathrm{pCi} / \mathrm{g}$ \\
\hline & & & Cs-137 & 0.78 & 12.2 & $\mathrm{pCi} / \mathrm{g}$ \\
\hline & & & Arsenic & $2.4(\mathrm{~J})$ & 23 & $\mathrm{mg} / \mathrm{kg}$ \\
\hline & & & Barium & $230(\mathrm{~J})$ & 190,000 & $\mathrm{mg} / \mathrm{kg}$ \\
\hline & & & Cadmium & 32 & 800 & $\mathrm{mg} / \mathrm{kg}$ \\
\hline & & & Chromium & $47(\mathrm{~J})$ & 450 & $\mathrm{mg} / \mathrm{kg}$ \\
\hline & & & Lead & $200(\mathrm{~J})$ & 800 & $\mathrm{mg} / \mathrm{kg}$ \\
\hline & & & Mercury & $0.16(\mathrm{~J}-)$ & 34 & $\mathrm{mg} / \mathrm{kg}$ \\
\hline & & & Silver & $6.1(\mathrm{~J})$ & 5,100 & $\mathrm{mg} / \mathrm{kg}$ \\
\hline & & & Aroclor 1260 & $0.95(\mathrm{~J})$ & 0.74 & $\mathrm{mg} / \mathrm{kg}$ \\
\hline & & & Aroclor 1268 & $0.95(\mathrm{~J})$ & 0.74 & $\mathrm{mg} / \mathrm{kg}$ \\
\hline & & & Benzo(a)anthracene & $0.28(\mathrm{~J})$ & 2.1 & $\mathrm{mg} / \mathrm{kg}$ \\
\hline & & & Benzo(a)pyrene & $0.26(\mathrm{~J})$ & 0.21 & $\mathrm{mg} / \mathrm{kg}$ \\
\hline & & & Benzo(b)fluoranthene & $0.47(\mathrm{~J})$ & 2.1 & $\mathrm{mg} / \mathrm{kg}$ \\
\hline & & & Benzo(g,h,i)perylene & $0.32(\mathrm{~J})$ & 17,000 & $\mathrm{mg} / \mathrm{kg}$ \\
\hline & & & Benzo(k)fluoranthene & $0.13(\mathrm{~J})$ & 2.1 & $\mathrm{mg} / \mathrm{kg}$ \\
\hline & & & Bis(2-ethylhexyl)phthalate & 0.44 & 120 & $\mathrm{mg} / \mathrm{kg}$ \\
\hline & & & Chrysene & $0.26(\mathrm{~J})$ & 210 & $\mathrm{mg} / \mathrm{kg}$ \\
\hline & & & Di-n-butyl phthalate & $0.089(\mathrm{~J})$ & 62,000 & $\mathrm{mg} / \mathrm{kg}$ \\
\hline & & & Dibenzo(a,h)anthracene & $0.084(\mathrm{~J})$ & 0.21 & $\mathrm{mg} / \mathrm{kg}$ \\
\hline
\end{tabular}


Table A.9-7

\section{PSM Results Detected above MDCs for CAS 02-60-04, French Drain}

(Page 2 of 2)

\begin{tabular}{|c|c|c|c|c|c|c|}
\hline $\begin{array}{c}\text { Sample } \\
\text { Location }\end{array}$ & $\begin{array}{l}\text { Sample } \\
\text { Number }\end{array}$ & $\begin{array}{l}\text { Sample } \\
\text { Matrix }\end{array}$ & Parameter & Result & $\begin{array}{c}\text { PSM } \\
\text { Criteria }\end{array}$ & Unit \\
\hline \multirow{5}{*}{$\begin{array}{c}\text { G01 } \\
\text { (continued) }\end{array}$} & \multirow{5}{*}{$562 \mathrm{G} 001$} & \multirow{5}{*}{ Sediment } & Fluoranthene & 0.39 & 22,000 & $\mathrm{mg} / \mathrm{kg}$ \\
\hline & & & Indeno(1,2,3-cd)Pyrene & $0.3(\mathrm{~J})$ & 2.1 & $\mathrm{mg} / \mathrm{kg}$ \\
\hline & & & Phenanthrene & $0.17(\mathrm{~J})$ & 170,000 & $\mathrm{mg} / \mathrm{kg}$ \\
\hline & & & Pyrene & 0.58 & 17,000 & $\mathrm{mg} / \mathrm{kg}$ \\
\hline & & & Tetrachloroethene & 0.013 & 2.6 & $\mathrm{mg} / \mathrm{kg}$ \\
\hline
\end{tabular}

$\mathrm{J}=$ Estimated value

$\mathrm{J}-=$ Result is an estimated quantity but may be biased low.

Bold indicates the value is equal to or exceeds the PSM criteria.

Additionally, TPH-DRO was moved on to a Tier 2 evaluation, and PSM criteria were established for the hazardous constituents of TPH-DRO at their respective PAL concentrations. Benzo(a)pyrene is a hazardous constituent of TPH-DRO that exceeded PSM criteria and is considered to be a PSM contaminant.

Because PSM contaminants are present, the sediment in the casing is considered PSM.

\section{A.9.4 Nature and Extent of Contamination}

The sediment in the french drain has been determined to be PSM. Visual inspection of the soil surrounding the drain, as well as sample results of the native soil interface, indicates that the PSM was contained within the drain casing. The samples collected radially from the PSM did not contain contaminants that exceed their respective FALs; therefore, no COCs were identified. The PSM was removed at the time of characterization and placed in a 55-gal drum.

\section{A.9.5 Revised Conceptual Site Model}

The CAIP requirements were met at this CAS, and no revisions were necessary to the CSM. 


\section{A.10.0 CAS 02-60-05, French Drain, Investigation Results}

Corrective Action Site 02-60-05 is located at the former Operators Office and the D-38 Storage Yard in the Area 2 Camp and consists of the potential releases to the soil from a french drain. Historical documentation states that the french drain was used as a hand-washing station. No other information has been identified discussing the operational history of the french drain. Corrective Action Site 02-60-05 consists of the potential releases to the soil from the french drain.

Figure A.10-1 shows the sample locations and photographs of CAS 02-60-05.

\section{A.10.1 Corrective Action Investigation Activities}

A total of 32 characterization samples (including 2 FDs) and 2 PSM samples were collected during investigation activities at CAS 02-60-05. The sample IDs, locations, types, and analyses are listed in Table A.10-1. The specific CAI activities conducted to satisfy the CAIP requirements at this CAS are described in the following sections.

\section{A.10.1.1 Radiological Surveys}

A radiological walkover survey was completed within the boundary of CAS 02-60-05. The results of the survey did not show radiological contaminants at activities statistically distinguishable from background activities (more than twice background levels). The survey results did not indicate the need for additional biased samples.

\section{A.10.1.2 Visual Inspections}

Inspection of the french drain revealed that it consisted of a bottomless 55-gal drum that was rusted and corroded. The top 6.0 in. of the drum contained accumulated soil that was likely windblown or backfill material. The rest of the drum was filled with leach rock with very little soil and was set in a bed of leach rock that extended to $5.5 \mathrm{ft}$ bgs to the native soil interface. It was noted during surface sampling (with the exception of the surface sample collected at the french drain) that there was a layer of black material present throughout the area sampled. The thickness of the layer varied from barely visible to 1 in.; the depth of the layer was from less than 1 in. to $7.0 \mathrm{in.} \mathrm{bgs.} \mathrm{In} \mathrm{places,} \mathrm{the} \mathrm{material}$ 


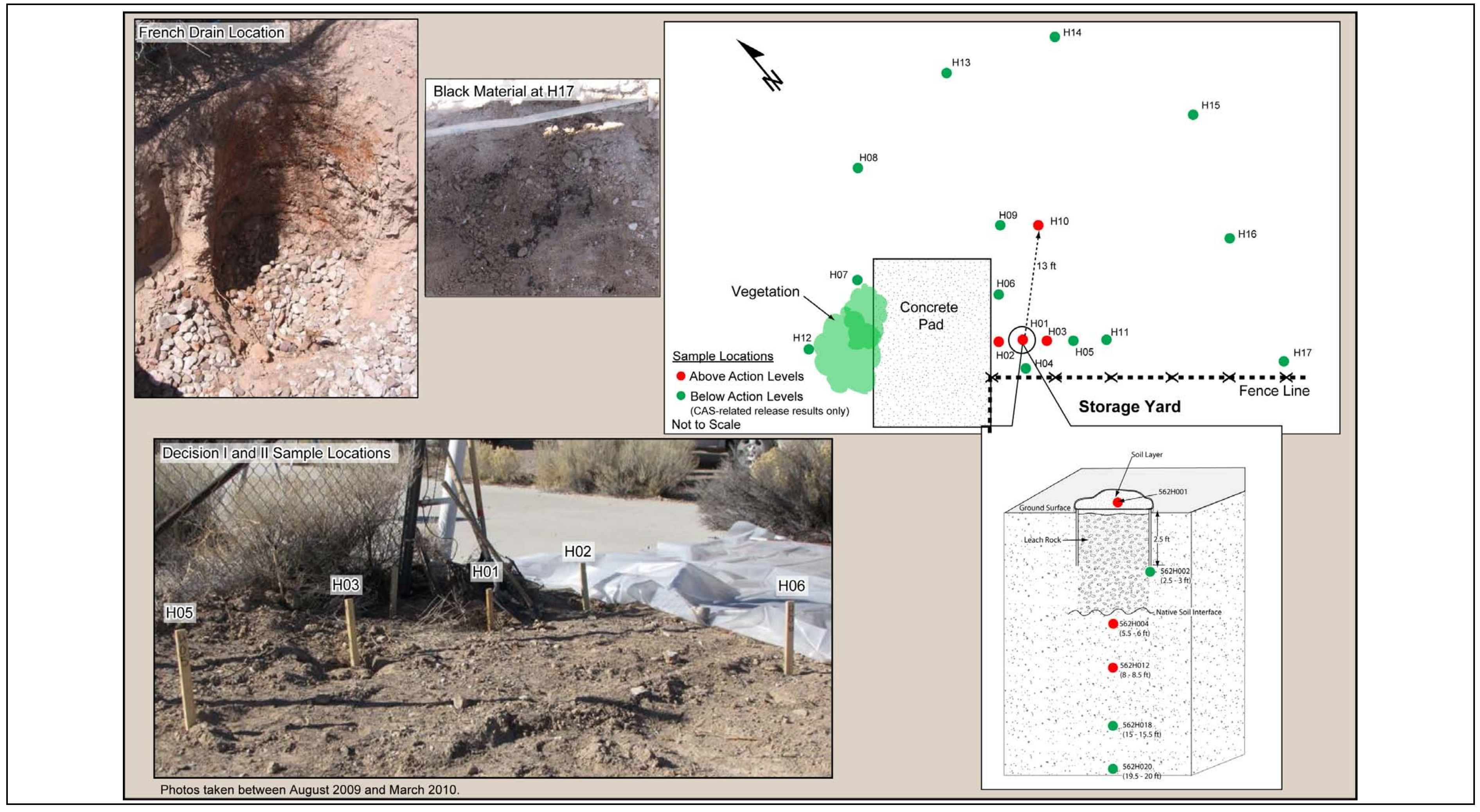

Figure A.10-1

Sample Locations at CAS 02-60-05, French Drain 
Table A.10-1

Samples Collected at CAS 02-60-05, French Drain

(Page 1 of 2)

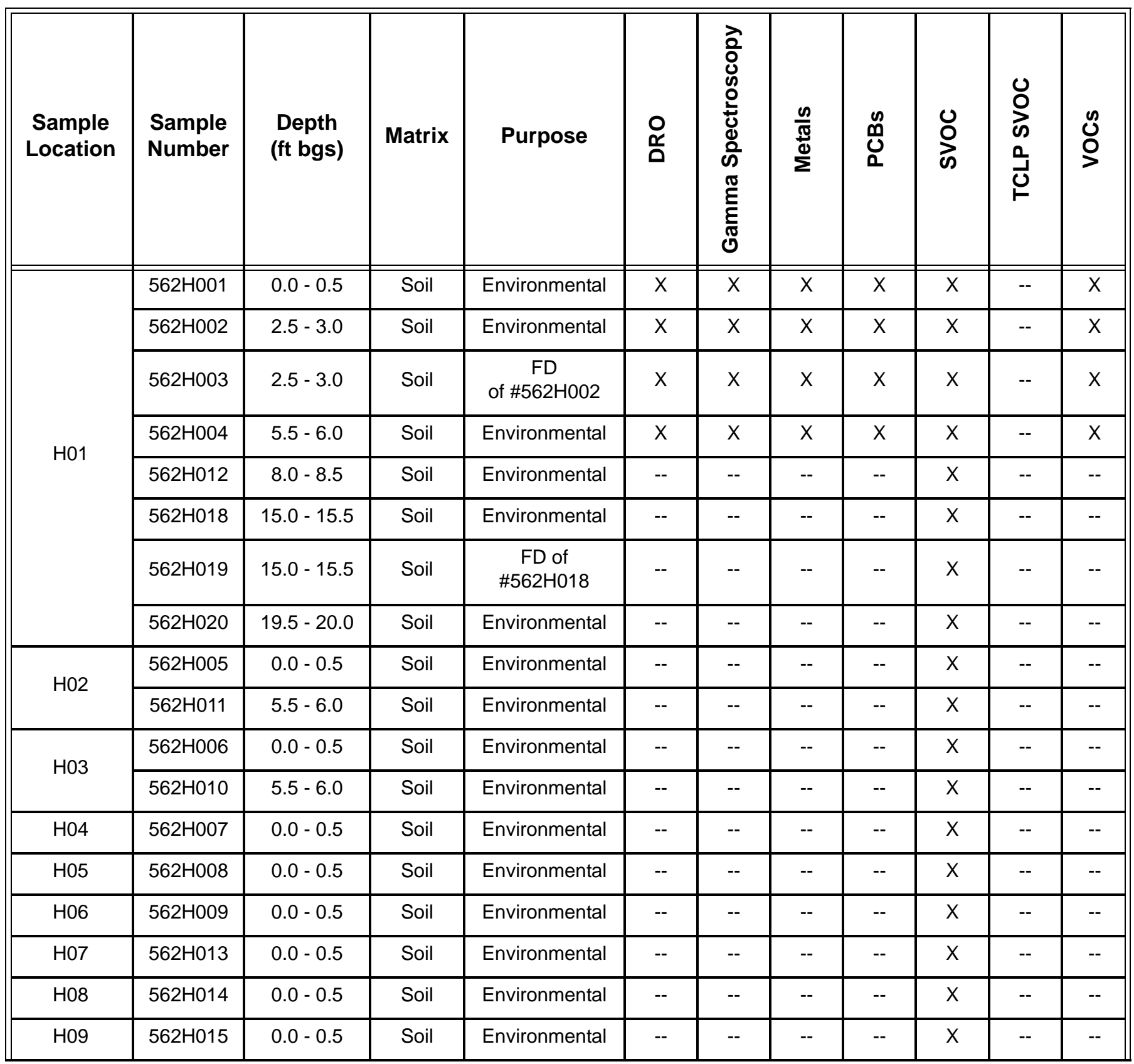


Table A.10-1

Samples Collected at CAS 02-60-05, French Drain

(Page 2 of 2)

\begin{tabular}{|c|c|c|c|c|c|c|c|c|c|c|c|}
\hline $\begin{array}{c}\text { Sample } \\
\text { Location }\end{array}$ & $\begin{array}{l}\text { Sample } \\
\text { Number }\end{array}$ & $\begin{array}{l}\text { Depth } \\
\text { (ft bgs) }\end{array}$ & Matrix & Purpose & $\begin{array}{l}\text { 옴 } \\
\text { 吕 }\end{array}$ & 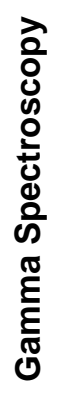 & 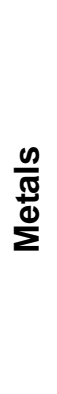 & $\begin{array}{l}\mathscr{n} \\
\stackrel{\leftrightarrow}{0} \\
\text { Un }\end{array}$ & $\sum_{\circlearrowleft}^{0}$ & $\begin{array}{l}0 \\
0 \\
\text { u } \\
0 \\
0 \\
0\end{array}$ & $\begin{array}{l}\text { Oٌ } \\
\text { O̊ }\end{array}$ \\
\hline \multirow{6}{*}{$\mathrm{H} 10$} & $562 \mathrm{H} 016$ & $0.0-0.5$ & Soil & Environmental & -- & -- & -- & -- & $x$ & -- & -- \\
\hline & $562 \mathrm{H} 021$ & $2.5-3.0$ & Soil & Environmental & -- & -- & -- & -- & $x$ & -- & -- \\
\hline & $562 \mathrm{H} 022$ & $5.5-6.0$ & Soil & Environmental & -- & -- & -- & -- & $x$ & -- & -- \\
\hline & $562 \mathrm{H} 023$ & $8.0-8.5$ & Soil & Environmental & -- & -- & -- & -- & $\mathrm{X}$ & -- & -- \\
\hline & $562 \mathrm{H} 024$ & $15.0-15.5$ & Soil & Environmental & -- & -- & -- & -- & $x$ & -- & -- \\
\hline & $562 \mathrm{H} 025$ & $19.5-20.0$ & Soil & Environmental & -- & -- & -- & -- & $x$ & -- & -- \\
\hline $\mathrm{H} 11$ & $562 \mathrm{H} 017$ & $0.0-0.5$ & Soil & Environmental & -- & -- & -- & -- & $x$ & -- & -- \\
\hline \multirow{3}{*}{$\mathrm{H} 12$} & $562 \mathrm{H} 026$ & $1.0-2.0$ & Solid & PSM & -- & -- & -- & -- & $x$ & $x$ & -- \\
\hline & $562 \mathrm{H} 027$ & $1.0-1.5$ & Soil & Environmental & -- & -- & -- & -- & $x$ & -- & -- \\
\hline & $562 \mathrm{H} 033$ & $2.0-2.5$ & Soil & Environmental & -- & -- & -- & -- & $x$ & -- & -- \\
\hline $\mathrm{H} 13$ & $562 \mathrm{H} 028$ & $2.5-3.0$ & Soil & Environmental & -- & -- & -- & -- & $x$ & -- & -- \\
\hline $\mathrm{H} 14$ & $562 \mathrm{H} 029$ & $2.5-3.0$ & Soil & Environmental & -- & -- & -- & -- & $x$ & -- & -- \\
\hline \multirow{2}{*}{$\mathrm{H} 15$} & $562 \mathrm{H} 030$ & $2.5-3.0$ & Soil & Environmental & -- & -- & -- & -- & $x$ & -- & -- \\
\hline & $562 \mathrm{H} 034$ & $0.0-0.5$ & Solid & PSM & -- & -- & -- & -- & $x$ & $x$ & -- \\
\hline $\mathrm{H} 16$ & $562 \mathrm{H} 031$ & $2.5-3.0$ & Soil & Environmental & -- & -- & -- & -- & $x$ & -- & -- \\
\hline $\mathrm{H} 17$ & $562 \mathrm{H} 032$ & $2.5-3.0$ & Soil & Environmental & -- & -- & -- & -- & $x$ & -- & -- \\
\hline N/A & $562 \mathrm{H} 301$ & N/A & Water & Trip Blank & -- & -- & -- & -- & -- & -- & $x$ \\
\hline
\end{tabular}

-- = Not required

appeared to be consolidated but was easily broken up and would become granular. This tar-like material was identified to be chip seal, which is a type of sprayed asphalt. 


\section{A.10.1.3 Sample Collection}

Sampling activities included the collection of 32 (including 2 FDs) environmental surface and subsurface soil samples and 2 PSM samples from the 17 locations shown in Figure A.10-1. The sampling activities are discussed below.

Sample 562H001 was collected from the top $6.0 \mathrm{in}$. of soil in the drum because the remainder of the drum was filled with leach rock. It is suspected that this sample represents an accumulation of windblown soil over the top of the drum. Subsequent to the removal of the drum, samples $562 \mathrm{H} 002$ and FD 562H003 were collected in the sidewall directly below the drum at a depth of 2.5 to $3.0 \mathrm{ft}$ bgs. The fourth Decision I sample was collected from location $\mathrm{H} 01$ at 5.5 to $6.0 \mathrm{ft}$ bgs from the native soil interface just below the leach rock. The analytical results from the Decision I sampling identified benzo(a)pyrene at concentrations exceeding the FALs extending from the surface to a depth of $6.0 \mathrm{ft}$ bgs, which necessitated Decision II sampling.

A total of 28 Decision II samples (including 1 FD) and 2 PSM samples were collected in a radial pattern at 16 locations ranging from 3.0 to $45.0 \mathrm{ft}$ laterally from the drain. Decision II subsurface samples were collected from the original location (H01) at three intervals below the deepest Decision I samples to a depth of $20.0 \mathrm{ft}$ bgs. Subsurface soil samples were also collected at various intervals at location H10 to a depth of $20.0 \mathrm{ft}$ bgs. Subsurface soil samples were also collected at intervals between 2.0 and $3.0 \mathrm{ft}$ bgs at eight locations and to a depth of $6.0 \mathrm{ft}$ bgs at two locations. Evaluation of the analytical results identified five additional PAHs [benzo(a)anthracene, benzo(b)fluoranthene, benzo(k)fluoranthene, dibenzo(a,h)anthracene, and indeno(1,2,3-cd)pyrene] that exceeded the FALs in various samples at various depths throughout the area sampled. Benzo(a)pyrene was the PAH that was detected most consistency and was the only PAH that exceeded the FALs within the Decision I samples. Based on the distribution and location of the PAHs identified beyond the immediate area of the drain, those contaminants could not have originated from CAS 02-60-05 (see Section 2.1.8.4). The additional PAHs identified beyond the immediate area of the french drain are not considered to result from a release from the drain but reflect the presence of an asphalt-like material identified as chip seal. 


\section{A.10.1.4 Deviations}

There were no deviations to the CAU 562 CAIP (NNSA/NSO, 2009) associated with CAS 02-60-05. Investigation samples were collected as outlined in the CAU 562 CAIP and submitted for laboratory analysis.

\section{A.10.2 Investigation Results}

The following sections provide analytical results from the samples collected to complete investigation activities as outlined in the CAIP (NNSA/NSO, 2009). The analytical parameters and laboratory methods used to analyze the investigation samples are listed in Table A.2-2. Table A.10-1 lists the sample-specific analytical suite for CAS 02-60-05.

Analytical results from the soil samples with concentrations exceeding MDCs are summarized in the following sections. An evaluation was conducted on all contaminants detected above MDCs by comparing individual concentration or activity results against the FALs. Establishment of the FALs is presented in Appendix D. The FALs were established as the corresponding PAL concentrations or activities if the contaminant concentrations were below their respective PALs.

\section{A.10.2.1 Volatile Organic Compounds}

Analytical results for VOCs in soil samples collected at this CAS that were detected above MDCs are presented in Table A.10-2. No VOCs were detected at concentrations exceeding their respective PALs. The FALs were established at the PAL concentrations.

\section{A.10.2.2 Semivolatile Organic Compounds}

Analytical results for SVOCs in soil samples collected at this CAS that were detected above MDCs are presented in Table A.10-3. One or more of 6 SVOCs were detected in 16 surface and subsurface samples at concentrations above their respective FALs. These SVOCs are benzo(a)anthracene, benzo(a)pyrene, benzo(b)fluoranthene, benzo(k)fluoranthene, dibenzo(a,h)anthracene, and indeno(1,2,3-cd)pyrene, and are considered COCs. The SVOCs identified at locations H01, H02, $\mathrm{H} 03$, and H10 are associated with a release from the drain; however, it has been determined that the 
Table A.10-2

Sample Results for Total VOCs Detected above MDCs at CAS 02-60-05, French Drain

\begin{tabular}{|c|c|c|c|}
\hline \multirow{2}{*}{$\begin{array}{c}\text { Sample } \\
\text { Location }\end{array}$} & $\begin{array}{c}\text { Sample } \\
\text { Number }\end{array}$ & \multirow{2}{*}{$\begin{array}{c}\text { Depth } \\
\text { (ft bgs) }\end{array}$} & COPCs (mg/kg) \\
\cline { 3 - 4 } & & & Methylene chloride \\
\hline \hline \multirow{3}{*}{$\mathrm{H} 01$} & $562 \mathrm{H} 001$ & $0.0-0.5$ & 53 \\
\cline { 2 - 4 } & $562 \mathrm{H} 002$ & $2.5-3.0$ & $0.0044(\mathrm{~J})$ \\
\cline { 2 - 4 } & $562 \mathrm{H} 003$ & $2.5-3.0$ & $0.004(\mathrm{~J})$ \\
\cline { 2 - 4 } & $562 \mathrm{H} 004$ & $5.5-6.0$ & $0.0046(\mathrm{~J})$ \\
\hline
\end{tabular}

$\mathrm{J}=$ Estimated value

SVOCs reported in the remaining surface samples are attributed to the presence of the asphalt-like chip seal and are not considered COCs.

\section{A.10.2.3 Total Petroleum Hydrocarbons}

Analytical results for TPH-DRO in soil samples collected at this CAS that were detected above MDCs are presented in Table A.10-4. No TPH-DRO was detected at concentrations exceeding the PALs. The FALs were established at the PAL concentrations.

\section{A.10.2.4 Resource Conservation and Recovery Act Metals}

Analytical results for RCRA metals in soil samples collected at this CAS that were detected above MDCs are presented in Table A.10-5. No RCRA metals were detected at concentrations exceeding their PALs. The FALs were established at the PAL concentrations.

\section{A.10.2.5 Polychlorinated Biphenyls}

Analytical results for PCBs in soil samples collected at this CAS that were detected above MDCs are presented in Table A.10-6. No PCBs were detected at concentrations exceeding their PALs. The FALs were established at the PAL concentrations. 
Table A.10-3

Sample Results for Total SVOCs Detected above MDCs at CAS 02-60-05, French Drain

\begin{tabular}{|c|c|c|c|c|c|c|c|c|c|c|c|c|c|c|c|c|c|c|c|c|c|c|c|c|}
\hline \multirow[b]{2}{*}{ 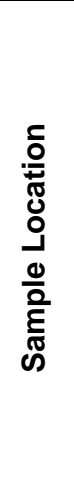 } & \multirow[b]{2}{*}{ 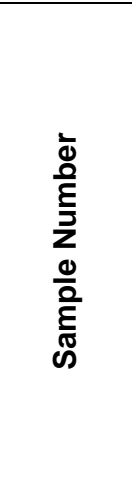 } & \multirow[b]{2}{*}{ 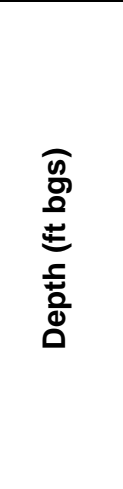 } & \multicolumn{22}{|c|}{ COPCs $(\mathrm{mg} / \mathrm{kg})$} \\
\hline & & & 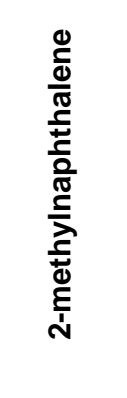 & 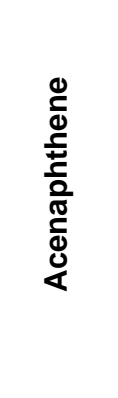 & 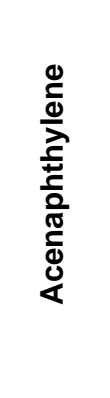 & 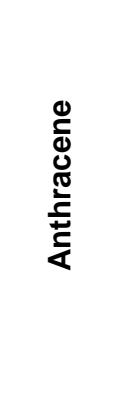 & 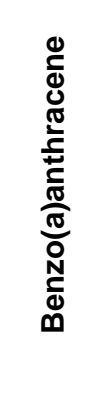 & 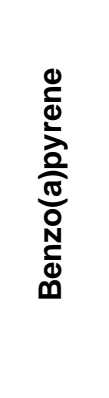 & 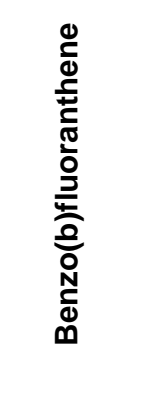 & 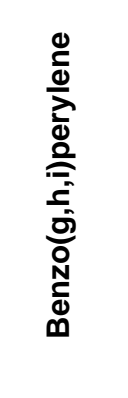 & 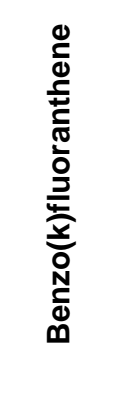 & 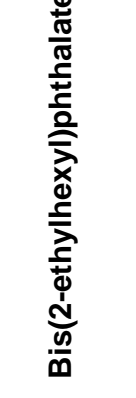 & 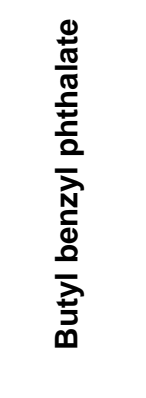 & 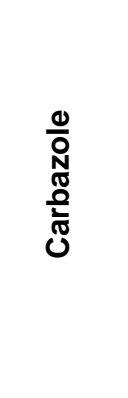 & 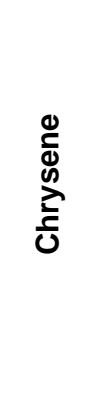 & 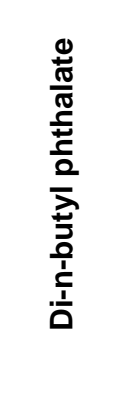 & 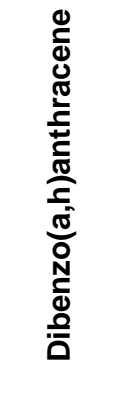 & 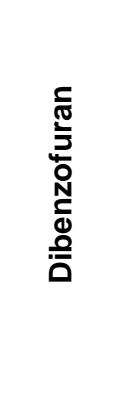 & 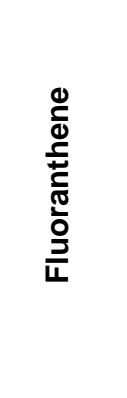 & 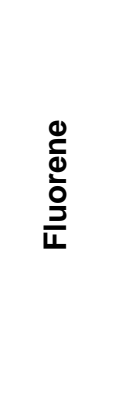 & 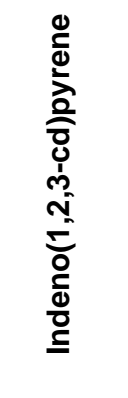 & 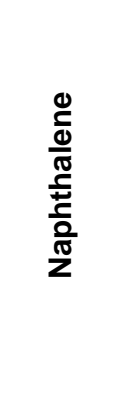 & 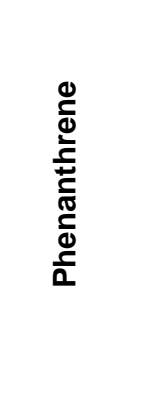 & 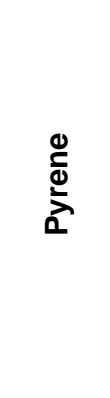 \\
\hline \multicolumn{3}{|c|}{ FALs } & 4,100 & 33,000 & 33,000 & 170,000 & 2.1 & 0.21 & 2.1 & 17,000 & 21 & 120 & 910 & 95.8 & 210 & 62,000 & 0.21 & 1,000 & 22,000 & 22,000 & 2.1 & 18 & 170,000 & 17,000 \\
\hline \multirow{5}{*}{ H01 } & $562 \mathrm{H} 001$ & $0.0-0.5$ & $0.22(\mathrm{~J})$ & $0.2(\mathrm{~J})$ & -- & $0.19(\mathrm{~J})$ & 0.4 & 0.36 & 0.58 & $0.11(\mathrm{~J})$ & $0.17(\mathrm{~J})$ & $0.34(\mathrm{~J})$ & -- & $0.12(\mathrm{~J})$ & 0.37 & 1.5 & -- & $0.16(\mathrm{~J})$ & 1.3 & $0.16(\mathrm{~J})$ & $0.14(\mathrm{~J})$ & -- & 1.2 & 0.82 \\
\hline & $562 \mathrm{H} 002$ & $2.5-3.0$ & -- & -- & -- & -- & -- & -- & -- & -- & -- & 0.53 & -- & -- & -- & $0.071(\mathrm{~J})$ & -- & -- & -- & -- & -- & -- & -- & -- \\
\hline & $562 \mathrm{H} 003$ & $2.5-3.0$ & -- & -- & -- & -- & -- & -- & $0.087(\mathrm{~J})$ & -- & -- & 0.5 & -- & -- & -- & $0.32(\mathrm{~J})$ & -- & -- & $0.18(\mathrm{~J})$ & -- & -- & -- & $0.16(\mathrm{~J})$ & $0.14(\mathrm{~J})$ \\
\hline & $562 \mathrm{H} 004$ & $5.5-6.0$ & $0.08(\mathrm{~J})$ & $0.19(\mathrm{~J})$ & -- & $0.25(\mathrm{~J})$ & 0.49 & 0.4 & 0.53 & $0.24(\mathrm{~J})$ & $0.17(\mathrm{~J})$ & $0.098(\mathrm{~J})$ & -- & $0.12(\mathrm{~J})$ & 0.42 & 1.8 & -- & $0.11(\mathrm{~J})$ & 1.3 & $0.14(\mathrm{~J})$ & $0.22(\mathrm{~J})$ & -- & 1.2 & 1.1 \\
\hline & $562 \mathrm{H} 012$ & $8.0-8.5$ & 0.4 & 0.6 & -- & 0.63 & 1.1 & 1.1 & 1.5 & $0.76(\mathrm{~J})$ & 0.64 & -- & -- & $0.28(\mathrm{~J})$ & 0.95 & 4.7 & $0.088(\mathrm{~J})$ & 0.37 & 3.6 & 0.47 & $0.58(\mathrm{~J})$ & -- & 3.3 & 2.3 \\
\hline \multirow{2}{*}{ HO2 } & $562 \mathrm{H} 005$ & $0.0-0.5$ & 11 & 19 & $0.18(\mathrm{~J})$ & 23 & $33(\mathrm{~J})$ & $37(\mathrm{~J})$ & $41(\mathrm{~J})$ & $23(\mathrm{~J})$ & $22(\mathrm{~J})$ & $2.7(\mathrm{~J})$ & $1.9(\mathrm{~J})$ & 9.5 & 35 & $100(\mathrm{~J})$ & $7.7(\mathrm{~J})$ & 14 & $92(\mathrm{~J})$ & 17 & $24(\mathrm{~J})$ & $1.6(\mathrm{~J})$ & $90(\mathrm{~J})$ & $69(\mathrm{~J})$ \\
\hline & $562 \mathrm{H} 011$ & $5.5-6.0$ & $0.21(\mathrm{~J})$ & 0.46 & -- & 0.51 & 1 & 0.99 & 1.4 & $0.26(\mathrm{~J})$ & 0.62 & -- & -- & $0.21(\mathrm{~J})$ & 0.8 & 4 & 0.079 (J) & $0.25(\mathrm{~J})$ & 3.1 & $0.35(\mathrm{~J})$ & $0.28(\mathrm{~J})$ & -- & 2.7 & 2 \\
\hline \multirow{2}{*}{ HO3 } & $562 \mathrm{H} 006$ & $0.0-0.5$ & $0.16(\mathrm{~J})$ & $0.32(\mathrm{~J})$ & -- & $0.36(\mathrm{~J})$ & 1 & $0.9(\mathrm{~J})$ & $1.6(\mathrm{~J})$ & $0.53(\mathrm{~J})$ & $0.64(\mathrm{~J})$ & 2.5 & -- & $0.17(\mathrm{~J})$ & 0.89 & 3.5 & -- & $0.19(\mathrm{~J})$ & 2.7 & $0.24(\mathrm{~J})$ & $0.45(\mathrm{~J})$ & -- & 2.2 & 2.1 \\
\hline & $562 \mathrm{H} 010$ & $5.5-6.0$ & 0.81 & 1.6 & -- & 1.7 & 3.3 & 2.9 & 4.1 & 1.1 & 1.5 & -- & $0.073(\mathrm{~J})$ & 0.67 & 2.6 & 12 & 0.37 & 0.98 & 9.5 & 1.3 & 1.3 & $0.09(\mathrm{~J})$ & 8.5 & 6.1 \\
\hline HO4 & $562 \mathrm{H} 007$ & $0.0-0.5$ & 0.45 & $0.88(\mathrm{~J})$ & -- & 0.93 & 2 & $1.6(\mathrm{~J})$ & 2.5 & $0.95(\mathrm{~J})$ & $1.2(\mathrm{~J})$ & $0.13(\mathrm{~J})$ & $0.085(\mathrm{~J})$ & 0.43 & 1.6 & 7.2 & $0.23(\mathrm{~J})$ & 0.58 & 5.3 & 0.74 & $0.91(\mathrm{~J})$ & -- & 5.2 & $4(\mathrm{~J})$ \\
\hline H05 & $562 \mathrm{H} 008$ & $0.0-0.5$ & $0.23(\mathrm{~J})$ & 0.37 & -- & 0.48 & 1.1 & 1 & 1.4 & 0.46 & 0.68 & -- & -- & $0.31(\mathrm{~J})$ & 1 & 4.6 & $0.14(\mathrm{~J})$ & $0.24(\mathrm{~J})$ & 3.8 & $0.28(\mathrm{~J})$ & 0.5 & -- & 2.9 & 2.4 \\
\hline H06 & $562 \mathrm{H} 009$ & $0.0-0.5$ & 0.65 & 1.2 & -- & 1.5 & 2.8 & 2.6 & 3.6 & 1.1 & 1.4 & -- & -- & 0.64 & 2.4 & 9.8 & 0.3 & 0.83 & 8 & 1 & 1.3 & $0.09(\mathrm{~J})$ & 6.9 & 5.4 \\
\hline H07 & $562 \mathrm{H} 013$ & $0.0-0.5$ & 2.1 & $3.8(\mathrm{~J})$ & -- & $5.3(\mathrm{~J})$ & $11(\mathrm{~J})$ & $9.5(\mathrm{~J})$ & $15(\mathrm{~J})$ & $3.8(\mathrm{~J})$ & $6.8(\mathrm{~J})$ & $0.18(\mathrm{~J})$ & $0.49(\mathrm{~J})$ & $3.2(\mathrm{~J})$ & 8.8 & $30 \mathrm{~J})$ & $1.5(\mathrm{~J})$ & $3.6(\mathrm{~J})$ & $27(\mathrm{~J})$ & $3(\mathrm{~J})$ & $3.5(\mathrm{~J})$ & 0.8 & $27(\mathrm{~J})$ & $19 \mathrm{(J}$ \\
\hline H08 & $562 \mathrm{H} 014$ & $0.0-0.5$ & 0.49 & 0.77 & -- & 1.1 & 2.5 & $2.1(\mathrm{~J})$ & $3.2(\mathrm{~J})$ & $1.6(\mathrm{~J})$ & $1.4(\mathrm{~J})$ & & $0.087(\mathrm{~J})$ & 0.61 & 2 & 6.8 & $0.32(\mathrm{~J})$ & 0.65 & 6.1 & 0.58 & $1.4(\mathrm{~J})$ & $0.15(\mathrm{~J})$ & 5.5 & 4.2 \\
\hline HO9 & $562 \mathrm{H} 015$ & $0.0-0.5$ & 1.1 & 2.1 & -- & 5.1 & 7.7 & $6.7(\mathrm{~J})$ & $9.7(\mathrm{~J})$ & $5.1(\mathrm{~J})$ & $5.1(\mathrm{~J})$ & $0.13(\mathrm{~J})$ & $0.26(\mathrm{~J})$ & 1.8 & 6.8 & 16 & $1.3(\mathrm{~J})$ & 1.3 & 20 & 1.7 & $4.5(\mathrm{~J})$ & $0.22(\mathrm{~J})$ & 18 & 21 \\
\hline \multirow{2}{*}{$\mathrm{H} 10$} & $562 \mathrm{H} 016$ & $0.0-0.5$ & $0.31(\mathrm{~J})$ & 0.66 & -- & 0.95 & $2.1(\mathrm{~J})$ & $1.8(\mathrm{~J})$ & $3.1(\mathrm{~J})$ & $1.6(\mathrm{~J})$ & $1.2(\mathrm{~J})$ & $0.2(\mathrm{~J})$ & -- & $0.57(\mathrm{~J})$ & $1.7(\mathrm{~J})$ & 7 & $0.35(\mathrm{~J})$ & 0.46 & 5.4 & 0.51 & $1.4(\mathrm{~J})$ & -- & 4.9 & 4.7 \\
\hline & $562 \mathrm{H} 021$ & $2.5-3.0$ & $0.097(\mathrm{~J})$ & $0.16(\mathrm{~J})$ & -- & $0.27(\mathrm{~J})$ & 0.58 & 0.5 & 0.7 & $0.17(\mathrm{~J})$ & $0.27(\mathrm{~J})$ & -- & -- & $0.13(\mathrm{~J})$ & 0.54 & 1.1 & -- & $0.11(\mathrm{~J})$ & 1.3 & $0.12(\mathrm{~J})$ & -- & -- & 0.92 & 1 \\
\hline H11 & $562 \mathrm{H} 017$ & $0.0-0.5$ & $7.8(\mathrm{~J})$ & $5.1(\mathrm{~J})$ & -- & $3.4(\mathrm{~J})$ & $7.3(\mathrm{~J})$ & $6.3(\mathrm{~J})$ & $11(\mathrm{~J})$ & $4.3(\mathrm{~J})$ & $4.1(\mathrm{~J})$ & $0.32(\mathrm{~J})$ & $0.38(\mathrm{~J})$ & $3.1(\mathrm{~J})$ & 7 (J) & $41(\mathrm{~J})$ & $1.1(\mathrm{~J})$ & $5.9(\mathrm{~J})$ & $24(\mathrm{~J})$ & 4.1 & $4(\mathrm{~J})$ & 1.9 & 31 (J) & 18 \\
\hline
\end{tabular}

$-=$ Not detected above MDCs.
$\mathrm{J}=$ Estimated value 
Table A.10-4

Sample Results for TPH-DRO Detected above MDCs at CAS 02-60-05, French Drain

\begin{tabular}{||c|c|c|c||}
\hline \multirow{2}{*}{$\begin{array}{c}\text { Sample } \\
\text { Location }\end{array}$} & \multirow{2}{*}{$\begin{array}{c}\text { Sample } \\
\text { Number }\end{array}$} & \multirow{2}{*}{$\begin{array}{c}\text { Depth } \\
\text { (ft bgs) }\end{array}$} & COPCs (mg/kg) \\
\cline { 4 - 5 } & & & DRO \\
\hline \multicolumn{3}{|c|}{ PALs } & $\mathbf{1 0 0}$ \\
\hline \hline \multirow{3}{*}{ H01 } & $562 \mathrm{HOO1}$ & $0.0-0.5$ & $62(\mathrm{~J})$ \\
\cline { 2 - 5 } & $562 \mathrm{H} 002$ & $2.5-3.0$ & $28(\mathrm{~J})$ \\
\cline { 2 - 5 } & $562 \mathrm{H} 003$ & $2.5-3.0$ & $25(\mathrm{~J})$ \\
\cline { 2 - 5 } & $562 \mathrm{H} 004$ & $5.5-6.0$ & $16(\mathrm{~J})$ \\
\hline
\end{tabular}

$\mathrm{J}=$ Estimated value

Table A.10-5

Sample Results for Metals Detected above MDCs at CAS 02-60-05, French Drain

\begin{tabular}{|c|c|c|c|c|c|c|c|c|c|c|}
\hline \multirow[b]{2}{*}{$\begin{array}{l}\text { Sample } \\
\text { Location }\end{array}$} & \multirow[b]{2}{*}{$\begin{array}{l}\text { Sample } \\
\text { Number }\end{array}$} & \multirow[b]{2}{*}{$\begin{array}{c}\text { Depth } \\
\text { (ft bgs) }\end{array}$} & \multicolumn{8}{|c|}{ COPCs (mg/kg) } \\
\hline & & & 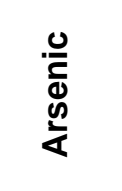 & 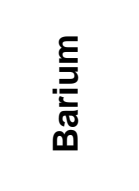 & 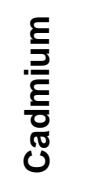 & 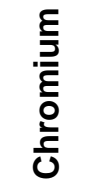 & ฮ్ّ & 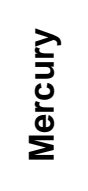 & 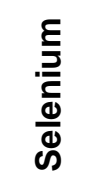 & $\frac{\bar{\Phi}}{\overline{\bar{\omega}}}$ \\
\hline \multicolumn{3}{|c|}{ FALs } & 23 & 190,000 & 800 & 450 & 800 & 34 & 5,100 & 5,100 \\
\hline \multirow{4}{*}{ H01 } & $562 \mathrm{H} 001$ & $0.0-0.5$ & $1.9(\mathrm{~J}+)$ & 110 & 1.4 & $5.9(\mathrm{~J})$ & $31(\mathrm{~J})$ & 0.05 & -- & 0.6 \\
\hline & $562 \mathrm{H} 002$ & $2.5-3.0$ & 3.1 & 110 & 0.33 & $5.1(\mathrm{~J})$ & $14(\mathrm{~J})$ & -- & 0.44 & -- \\
\hline & $562 \mathrm{H} 003$ & $2.5-3.0$ & 2.6 & 98 & 0.4 & $5.1(\mathrm{~J})$ & $22(\mathrm{~J})$ & -- & -- & -- \\
\hline & $562 \mathrm{H} 004$ & $5.5-6.0$ & 3.3 & 88 & 0.17 & $5(\mathrm{~J})$ & $9.6(\mathrm{~J})$ & 0.037 & -- & -- \\
\hline
\end{tabular}

-- = Not detected above MDCs.

$\mathrm{J}=$ Estimated value

$\mathrm{J}+=$ Result is an estimated quantity but may be biased high.

\section{A.10.2.6 Gamma-Emitting Radionuclides}

Analytical results for gamma-emitting radionuclides in soil samples collected at this CAS that were detected above MDCs are presented in Table A.10-7. No gamma-emitting radionuclides were detected at concentrations exceeding their PALs. The FALs were established at the PAL concentrations. 
Table A.10-6

Sample Results for PCBs Detected above MDCs at CAS 02-60-05, French Drain

\begin{tabular}{||c|c|c|c|}
\hline \multirow{2}{*}{$\begin{array}{c}\text { Sample } \\
\text { Location }\end{array}$} & \multirow{2}{*}{$\begin{array}{c}\text { Sample } \\
\text { Number }\end{array}$} & \multirow{2}{*}{$\begin{array}{c}\text { Depth } \\
\text { (ft bgs) }\end{array}$} & COPCs (mg/kg) \\
\cline { 4 - 5 } & & & Aroclor 1260 \\
\hline \multirow{3}{*}{ FALs } & $\mathbf{0 . 7 4}$ \\
\hline \hline \multirow{3}{*}{$\mathrm{H} 01$} & $562 \mathrm{H} 001$ & $0.0-0.5$ & 0.072 \\
\cline { 2 - 5 } & $562 \mathrm{H} 002$ & $2.5-3.0$ & 0.087 \\
\cline { 2 - 5 } & $562 \mathrm{H} 003$ & $2.5-3.0$ & 0.087 \\
\hline
\end{tabular}

Table A.10-7

Sample Results for Gamma-Emitting Radionuclides Detected above MDCs at CAS 02-60-05, French Drain

\begin{tabular}{||c|c|c|c|c|c|}
\hline \multirow{2}{*}{$\begin{array}{c}\text { Sample } \\
\text { Location }\end{array}$} & \multirow{2}{*}{$\begin{array}{c}\text { Sample } \\
\text { Number }\end{array}$} & \multirow{2}{*}{$\begin{array}{c}\text { Depth } \\
\text { (ft bgs) }\end{array}$} & \multicolumn{3}{|c|}{ COPCs (pCi/g) } \\
\cline { 4 - 6 } & & Ac-228 & Cs-137 & Th-234 \\
\hline \multirow{3}{*}{ FALs } & & $\mathbf{5}$ & $\mathbf{1 2 . 2}$ & $\mathbf{1 0 5}$ \\
\hline \hline \multirow{3}{*}{$\mathrm{H} 01$} & $562 \mathrm{H} 001$ & $0.0-0.5$ & 1.33 & 0.46 & -- \\
\cline { 2 - 6 } & $562 \mathrm{H} 002$ & $2.5-3.0$ & 1.91 & 0.55 & -- \\
\cline { 2 - 6 } & $562 \mathrm{H} 003$ & $2.5-3.0$ & 1.74 & 0.57 & -- \\
\cline { 2 - 6 } & $562 \mathrm{H} 004$ & $5.5-6.0$ & 2.1 & -- & $2.58(\mathrm{~J})$ \\
\hline
\end{tabular}

$--=$ Not detected above MDCs.

$\mathrm{J}=$ Estimated value

\section{A.10.2.7 Potential Source Material Sample Results}

Analytical results for the PSM samples detected above MDCs are presented in Table A.10-8. No constituents were identified at concentrations exceeding their respective PSM criteria; therefore, there is no PSM at CAS 02-60-05.

\section{A.10.3 Nature and Extent of Contamination}

The analytical results from the Decision I sampling identified benzo(a)pyrene at concentrations exceeding the PALs extending from the surface to a depth of $6.0 \mathrm{ft}$ bgs. Decision II sampling, designed to define the extent of the contamination, identified five additional PAHs, (benzo(a)anthracene, benzo(b)fluoranthene, benzo(k)fluoranthene, dibenzo(a,h)anthracene, and 
Table A.10-8

PSM Results Detected above MDCs for CAS 02-60-05, French Drain

\begin{tabular}{|c|c|c|c|c|c|c|}
\hline $\begin{array}{l}\text { Sample } \\
\text { Location }\end{array}$ & $\begin{array}{l}\text { Sample } \\
\text { Number }\end{array}$ & $\begin{array}{c}\text { Sample } \\
\text { Matrix }\end{array}$ & Parameter & Result & $\begin{array}{c}\text { PSM } \\
\text { Criteria }\end{array}$ & Unit \\
\hline \multirow{10}{*}{$\mathrm{H} 12$} & \multirow{10}{*}{$562 \mathrm{H} 026$} & \multirow{10}{*}{ Solid } & Benzo(a)anthracene & $0.095(\mathrm{~J})$ & 2.1 & $\mathrm{mg} / \mathrm{kg}$ \\
\hline & & & Benzo(a)pyrene & $0.092(\mathrm{~J})$ & 0.21 & $\mathrm{mg} / \mathrm{kg}$ \\
\hline & & & Benzo(b)fluoranthene & $0.11(\mathrm{~J})$ & 2.1 & $\mathrm{mg} / \mathrm{kg}$ \\
\hline & & & Benzo(g,h,i)perylene & $0.086(\mathrm{~J})$ & 17,000 & $\mathrm{mg} / \mathrm{kg}$ \\
\hline & & & Bis(2-ethylhexyl)phthalate & $0.16(\mathrm{~J})$ & 120 & $\mathrm{mg} / \mathrm{kg}$ \\
\hline & & & Chrysene & $0.076(\mathrm{~J})$ & 210 & $\mathrm{mg} / \mathrm{kg}$ \\
\hline & & & Di-n-butyl phthalate & $0.29(\mathrm{~J})$ & 62,000 & $\mathrm{mg} / \mathrm{kg}$ \\
\hline & & & Fluoranthene & $0.15(\mathrm{~J})$ & 22,000 & $\mathrm{mg} / \mathrm{kg}$ \\
\hline & & & Phenanthrene & $0.21(\mathrm{~J})$ & 170,000 & $\mathrm{mg} / \mathrm{kg}$ \\
\hline & & & Pyrene & $0.43(\mathrm{~J})$ & 17,000 & $\mathrm{mg} / \mathrm{kg}$ \\
\hline
\end{tabular}

$\mathrm{J}=$ Estimated value

indeno(1,2,3-cd)pyrene, that exceeded the PALs in various samples at various depths throughout the area sampled . Benzo(a)pyrene was the PAH that was detected most consistency and was the only PAH that exceeded the FAL in the Decision I sampling. Table A.10-3 and Figure A.10-1 show the analytical results and distribution of the samples.

Evaluation of the data showed that the vertical extent of the contamination at the french drain (locations H01, H02, and H03) extends to at least $8.5 \mathrm{ft}$ bgs but no deeper than $15.0 \mathrm{ft}$ bgs. Samples collected at deeper depths at this location did not show the presence of any SVOCs. Benzo(a)pyrene, benzo(a)anthracene, benzo(b)fluoranthene, and dibenzo(a,h)anthracene were reported at concentrations exceeding the PALs at one location (H10) in the surface interval (0.0 to $0.5 \mathrm{ft}$ bgs) but only benzo(a)pyrene was detected at a concentration exceeding the PAL in the subsurface (2.5 to $3.0 \mathrm{ft}$ bgs), approximately $13.0 \mathrm{ft}$ laterally from the drain. Samples collected at deeper depths did not identify any PAHs. As shown in Table A.10-3 and Figure A.10-1, the distribution of PAHs in the remaining sample locations, as well as the concentrations, is not consistent with what would be expected if the french drain were the only source of the release. The CSM suggests that the concentration of contamination should decrease as the distance from the source increases. Further evaluation of the data indicate that the concentrations and number of PAHs in the surface samples 
generally increase with distance from the drain. However, the concentrations do decrease with increasing depth. During the sampling, a layer of black tar-like material identified as chip seal was identified within the surface intervals that were sampled. This material ranged from 1.0 to $7.0 \mathrm{in}$. bgs and is considered the other source of the PAHs. The area around the CAS was once managed as an access road, and the chip seal was identified in the areas. The SVOC contamination in the outlying area is not considered to originate from a release associated with this CAS. The contamination associated with this CAS is limited to the area encompassed by sample locations H01, H02, H03, and H10. Location H10 has been included since a COC was identified in the 2.5- to 3.0-ft bgs depth interval. The other PAHs in the surface soil that are reported at concentrations exceeding the FALs are attributed to the presence of chip seal, and are not associated with CAS 02-60-05.

\section{A.10.4 Revised Conceptual Site Model}

The CAIP requirements were met at this CAS, and no revisions were necessary to the CSM. 


\section{A.11.0 CAS 02-60-06, French Drain, Investigation Results}

Corrective Action Site 02-60-06 is located at the former Electricians Shop in the Area 2 Camp (Figure 1-2). Historical documentation states that the french drain was used as a hand-washing station. No other information has been identified discussing the operational history of the french drain. Corrective Action Site 02-60-06 consists of the potential releases to the soil from a french drain. Figure A.11-1 shows the sample locations and photographs of CAS 02-60-06.

\section{A.11.1 Corrective Action Investigation Activities}

A total of three environmental samples (including one FD) were collected during investigation activities at CAS 02-60-06. The sample IDs, locations, types, and analyses are listed in Table A.11-1. The specific CAI activities conducted to satisfy the CAIP requirements at this CAS are described in the following sections.

\section{A.11.1.1 Geophysical Surveys}

A geophysical survey was conducted to identify the location of the french drain. The southwest corner of the former building foundation for the Electricians Shop was surveyed because this area was identified in historical documentation as the location of the french drain. The survey was conducted in the area of a 3.0-in.-diameter steel pipe. A linear anomaly trending southwest from the pipe was identified (Weston, 2007). Once the drain was located during the utility survey, it was determined that this pipe was not associated with the french drain as there were no pipes feeding the drain.

\section{A.11.1.2 Visual Inspections}

The french drain was first located and marked during a utility survey that detected the drain approximately $10.0 \mathrm{ft}$ away from the southeast corner of the former Electricians Shop foundation. The drain was initially covered by several inches of soil before being uncovered. Inspection of the french drain revealed that it consisted of a bottomless 55-gal drum that was filled with leach rock mixed with some soil. The bed of leach rock extends to $7.0 \mathrm{ft}$ bgs to the native soil interface. 


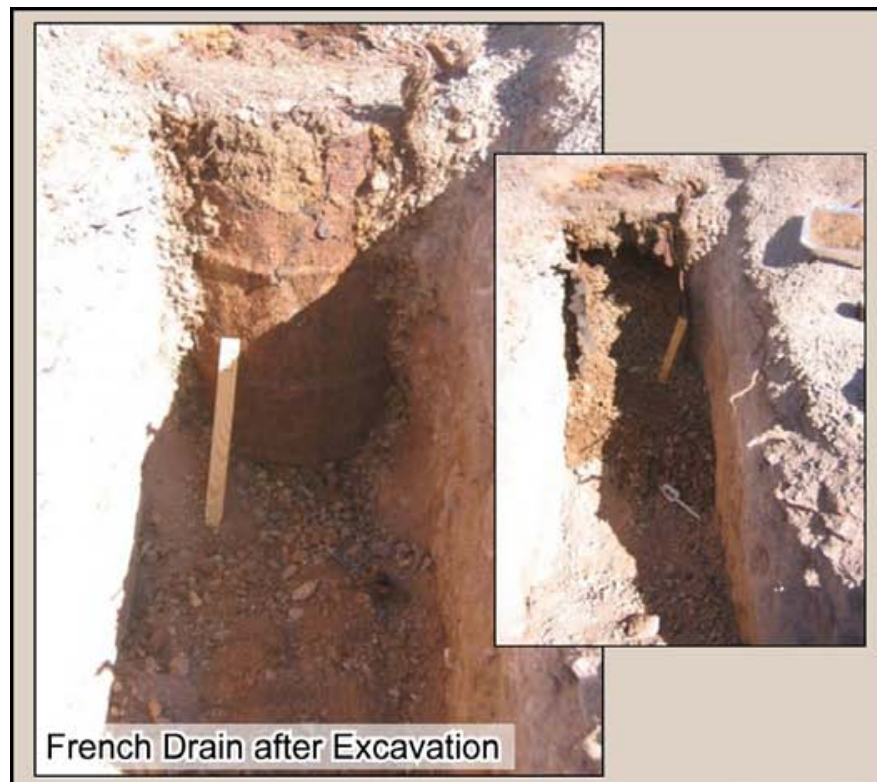

\section{Sample Locations \\ - Below Action Levels \\ Not to Scale}
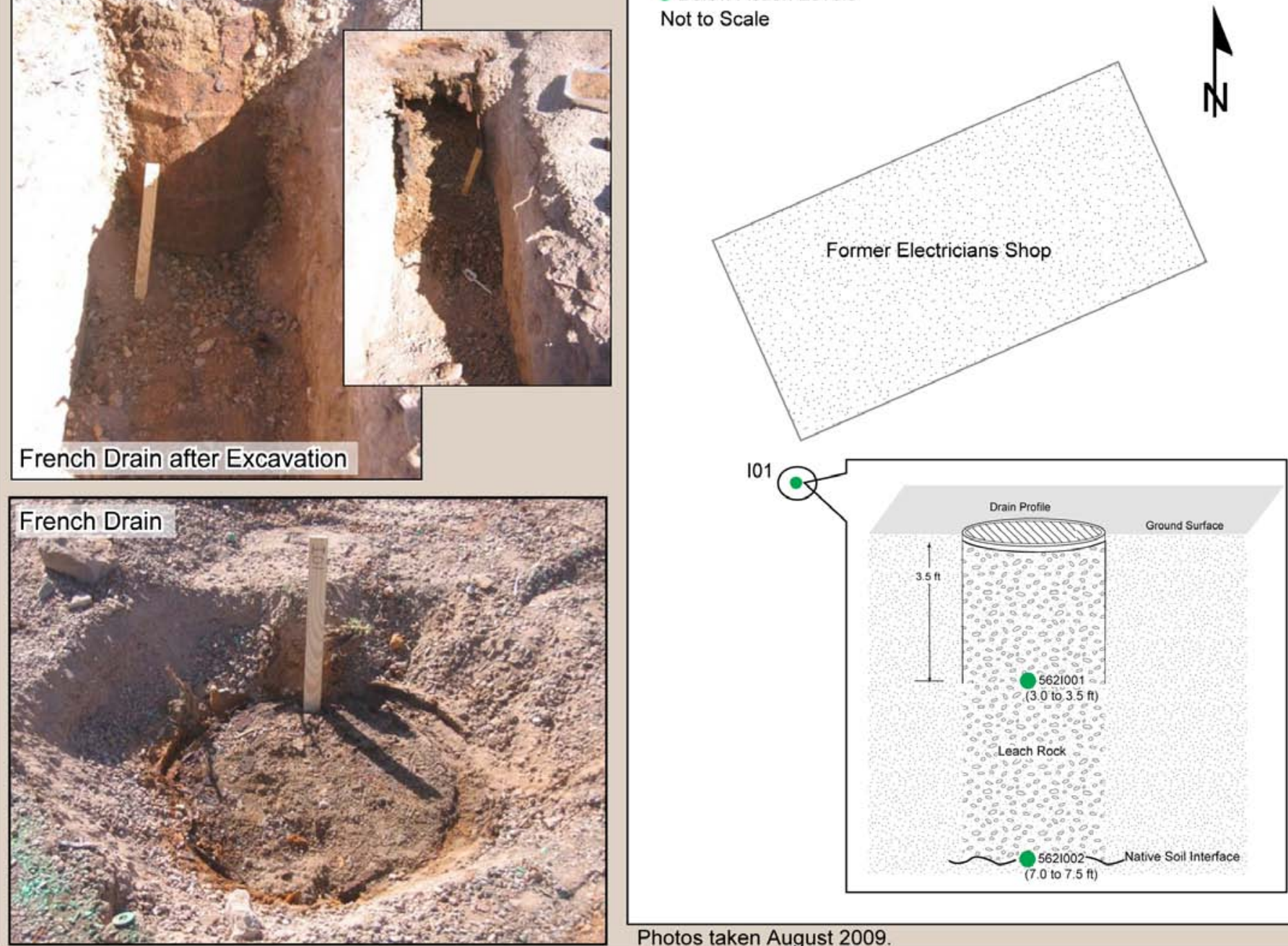

Photos taken August 2009

Figure A.11-1

Sample Locations at CAS 02-60-06, French Drain 
Table A.11-1

\section{Samples Collected at CAS 02-60-06, French Drain}

\begin{tabular}{|c|c|c|c|c|c|c|c|c|c|c|}
\hline $\begin{array}{l}\text { Sample } \\
\text { Location }\end{array}$ & $\begin{array}{l}\text { Sample } \\
\text { Number }\end{array}$ & $\begin{array}{c}\text { Depth } \\
\text { (ft bgs) }\end{array}$ & Matrix & Purpose & $\begin{array}{l}\text { 움 } \\
\text { 茄 }\end{array}$ & 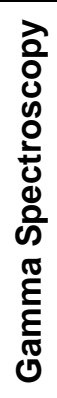 & $\begin{array}{l}\frac{n}{\pi} \\
\frac{\pi}{20}\end{array}$ & 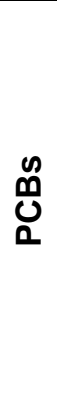 & 号 & $\begin{array}{l}\text { Uू } \\
\text { Oे }\end{array}$ \\
\hline \multirow{4}{*}{101} & 5621001 & $3.0-3.5$ & Soil & Environmental & $x$ & $x$ & $x$ & $x$ & $x$ & $x$ \\
\hline & 5621002 & $7.0-7.5$ & Soil & Environmental & $x$ & $x$ & $x$ & $x$ & $x$ & $x$ \\
\hline & 5621003 & $7.0-7.5$ & Soil & $\begin{array}{c}\text { FD } \\
\text { of } \# 5621002\end{array}$ & $x$ & $X$ & $x$ & $x$ & $x$ & $x$ \\
\hline & 5621301 & $N / A$ & Water & Trip Blank & -- & -- & -- & -- & -- & $x$ \\
\hline
\end{tabular}

$--=$ Not required

\section{A.11.1.3 Sample Collection}

Sampling activities included the collection of three (including one FD) environmental subsurface soil samples from the one location shown in Figure A.11-1.

At the french drain (location I01), sample 562I001 was collected from the bottom 6.0 in. of the material inside the drain casing at a depth of 3.0 to $3.5 \mathrm{ft}$ bgs. This sample consisted of dark brown moist sand (leach rock removed from sample) with abundant plant organics, rust staining, and miscellaneous debris. Following removal of the drum casing, samples 562I002 and FD 562I003 were collected at 7.0 to $7.5 \mathrm{ft}$ bgs from the native soil interface within the bed of leach rock.

\section{A.11.1.4 Deviations}

There were no deviations to the CAU 562 CAIP (NNSA/NSO, 2009) associated with CAS 02-60-06. Investigation samples were collected as outlined in the CAU 562 CAIP and submitted for laboratory analysis. 


\section{A.11.2 Investigation Results}

The following sections provide analytical results from the samples collected to complete investigation activities as outlined in the CAIP (NNSA/NSO, 2009). The analytical parameters and laboratory methods used to analyze the investigation samples are listed in Table A.2-2. Table A.11-1 lists the sample-specific analytical suite for CAS 02-60-06.

Analytical results from the soil samples with concentrations exceeding MDCs are summarized in the following sections. An evaluation was conducted on all contaminants detected above MDCs by comparing individual concentration or activity results against the FALs. Establishment of the FALs is presented in Appendix D. The FALs were established as the corresponding PAL concentrations or activities if the contaminant concentrations were below their respective PALs.

\section{A.11.2.1 Volatile Organic Compounds}

No analytical results for VOCs in environmental samples collected at this CAS exceeded MDCs. Therefore, the FALs were established at the corresponding PAL concentrations.

\section{A.11.2.2 Semivolatile Organic Compounds}

Analytical results for SVOCs in soil samples collected at this CAS that were detected above MDCs are presented in Table A.11-2. No SVOCs were detected at concentrations exceeding the respective PALs. The FALs were established at the PAL concentrations.

Table A.11-2

Sample Results for Total SVOCs Detected above MDCs at CAS 02-60-06, French Drain

\begin{tabular}{||c|c|c|c||}
\hline \multirow{2}{*}{$\begin{array}{c}\text { Sample } \\
\text { Location }\end{array}$} & \multirow{2}{*}{$\begin{array}{c}\text { Sample } \\
\text { Number }\end{array}$} & $\begin{array}{c}\text { Depth } \\
\text { (ft bgs) }\end{array}$ & COPCs (mg/kg) \\
\cline { 4 - 4 } & & & $\mathbf{1 2 0}$ \\
\hline \multicolumn{3}{|c|}{ FALs } & 1.4 \\
\hline \hline 101 & 5621001 & $3.0-3.5$ & Bis-ethylhexyl)phthalate \\
\hline
\end{tabular}




\section{A.11.2.3 Total Petroleum Hydrocarbons}

Analytical results for TPH-DRO in soil samples collected at this CAS that were detected above MDCs are presented in Table A.11-3. Two subsurface samples (562I001 and 562I002) exceeded the PAL of $100 \mathrm{mg} / \mathrm{kg}$ for TPH-DRO. The TPH-DRO was moved on to a Tier 2 evaluation, and FALs were established for the hazardous constituents of TPH-DRO. Concentrations of the hazardous constituents of TPH-DRO did not exceed FALs. Therefore, TPH-DRO is not considered a COC. The calculation of FALs for the hazardous constituents of TPH-DRO is presented in Appendix D.

Table A.11-3

Sample Results for TPH-DRO Detected above MDCs at CAS 02-60-06, French Drain

\begin{tabular}{|c|c|c|c|}
\hline \multirow{2}{*}{$\begin{array}{c}\text { Sample } \\
\text { Location }\end{array}$} & \multirow{2}{*}{$\begin{array}{c}\text { Sample } \\
\text { Number }\end{array}$} & \multirow{2}{*}{$\begin{array}{c}\text { Depth } \\
\text { ft bgs) }\end{array}$} & COPCs (mg/kg) \\
\cline { 4 - 5 } & & & $\mathbf{1 0 0}$ \\
\hline \multirow{3}{*}{101} & 5621001 & $3.0-3.5$ & $\mathbf{8 5 0}$ \\
\cline { 2 - 5 } & 5621002 & $7.0-7.5$ & $\mathbf{1 1 0}$ \\
\cline { 2 - 5 } & 5621003 & $7.0-7.5$ & 70 \\
\hline
\end{tabular}

Bold indicates the value is equal to or exceeds the PAL.

\section{A.11.2.4 Resource Conservation and Recovery Act Metals}

Analytical results for RCRA metals in soil samples collected at this CAS that were detected above MDCs are presented in Table A.11-4. No RCRA metals were detected at concentrations exceeding their PALs. The FALs were established at the PAL concentrations.

\section{A.11.2.5 Polychlorinated Biphenyls}

Analytical results for PCBs in soil samples collected at this CAS that were detected above MDCs are presented in Table A.11-5. No PCBs were detected at concentrations exceeding their PALs. The FALs were established at the PAL concentrations. 
Table A.11-4

Sample Results for Metals Detected above MDCs at CAS 02-60-06, French Drain

\begin{tabular}{|c|c|c|c|c|c|c|c|c|c|c|}
\hline \multirow[b]{2}{*}{$\begin{array}{l}\text { Sample } \\
\text { Location }\end{array}$} & \multirow[b]{2}{*}{$\begin{array}{l}\text { Sample } \\
\text { Number }\end{array}$} & \multirow[b]{2}{*}{$\begin{array}{l}\text { Depth } \\
\text { (ft bgs) }\end{array}$} & \multicolumn{8}{|c|}{ COPCs (mg/kg) } \\
\hline & & & 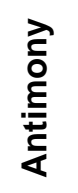 & 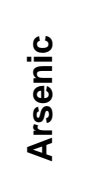 & 卢 & 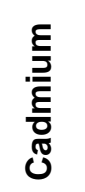 & 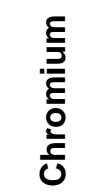 & 胥 & 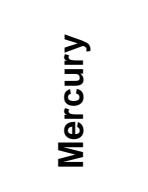 & $\frac{\sum_{\bar{j}}^{\bar{\omega}}}{\overline{\bar{s}}}$ \\
\hline \multicolumn{3}{|c|}{ FALs } & 410 & 23 & 190,000 & 800 & 450 & 800 & 34 & 5,100 \\
\hline \multirow{3}{*}{101} & 5621001 & $3.0-3.5$ & 7.6 & $9(\mathrm{~J})$ & 200 & 44 & $120(\mathrm{~J})$ & 280 & $0.25(\mathrm{~J}-)$ & $26(\mathrm{~J})$ \\
\hline & 5621002 & $7.0-7.5$ & -- & $2(\mathrm{~J})$ & 81 & 1.5 & $4(\mathrm{~J})$ & 18 & $0.041(\mathrm{~J}-)$ & -- \\
\hline & 5621003 & $7.0-7.5$ & -- & $2(\mathrm{~J})$ & 69 & 0.74 & $3.3(\mathrm{~J})$ & 9.6 & $0.021(\mathrm{~J}-)$ & -- \\
\hline
\end{tabular}

$--=$ Not detected above MDCs.

$\mathrm{J}=$ Estimated value

$\mathrm{J}-=$ Result is an estimated quantity but may be biased low.

Table A.11-5

Sample Results for PCBs Detected above MDCs at CAS 02-60-06, French Drain

\begin{tabular}{|c|c|c|c|c|}
\hline \multirow{2}{*}{$\begin{array}{c}\text { Sample } \\
\text { Location }\end{array}$} & \multirow{2}{*}{$\begin{array}{c}\text { Sample } \\
\text { Number }\end{array}$} & \multirow{2}{*}{$\begin{array}{c}\text { Depth } \\
\text { (ft bgs) }\end{array}$} & Aroclor 1260 & Aroclor 1016 \\
\cline { 4 - 5 } & & & $\mathbf{0 . 7 4}$ & $\mathbf{2 1}$ \\
\hline \multicolumn{3}{|c|}{ FALs } & $0.081(\mathrm{~J})$ & $0.021(\mathrm{~J})$ \\
\hline \hline 101 & 5621001 & $3.0-3.5$ & & \\
\hline
\end{tabular}

$\mathrm{J}=$ Estimated value

\section{A.11.2.6 Gamma-Emitting Radionuclides}

Analytical results for gamma-emitting radionuclides in soil samples collected this CAS that were detected above MDCs are presented in Table A.11-6. No gamma-emitting radionuclides were detected at concentrations exceeding their PALs. The FALs were established at the PAL concentrations.

\section{A.11.3 Nature and Extent of Contamination}

Based on the analytical results, no COCs were identified in the environmental soil samples collected within CAS 02-60-06. 
Table A.11-6

Sample Results for Gamma-Emitting Radionuclides Detected above MDCs at CAS 02-60-06, French Drain

\begin{tabular}{|c|c|c|c|}
\hline \multirow{2}{*}{$\begin{array}{c}\text { Sample } \\
\text { Location }\end{array}$} & \multirow{2}{*}{$\begin{array}{c}\text { Sample } \\
\text { Number }\end{array}$} & $\begin{array}{c}\text { Depth } \\
\text { (ft bgs) }\end{array}$ & COPCs (pCi/g) \\
\cline { 4 - 5 } & & Ac-228 \\
\hline \multicolumn{3}{|c|}{ FALs } & $\mathbf{5}$ \\
\hline \hline \multirow{2}{*}{101} & 5621002 & $7.0-7.5$ & 1.79 \\
\cline { 2 - 5 } & 5621003 & $7.0-7.5$ & 2.22 \\
\hline
\end{tabular}

\section{A.11.4 Revised Conceptual Site Model}

The CAIP requirements were met at this CAS, and no revisions were necessary to the CSM. 


\section{A.12.0 CAS 02-60-07, French Drain, Investigation Results}

Corrective Action Site 02-60-07 was identified in historical documentation as being located at the former Electrical Supply Building in the Area 2 Camp. The components of this CAS were not visible, so additional action was necessary to locate the french drain. Extensive vegetation removal was performed on all sides of the concrete pad that was the former foundation of the Electrical Supply Building. A utility survey was then performed; the survey extended $20.0 \mathrm{ft}$ in all directions from the concrete pad in order to identify underground utility lines and the location of the french drain. Several deactivated power lines, a communication line, a water line, and an “unknown” line (determined to be a surface electrical cable) were identified as a result of the survey; however, no french drain or pipe leading to a drain was identified. It is expected that if a drain was present, a strong metallic response would have been detected by the utility survey equipment similar to what was found at adjacent CAS 02-60-06.

Because the french drain was not identified during the utility survey, a backhoe was then used to excavate trenches on each side of the concrete pad to a depth of approximately $18.0 \mathrm{in}$. bgs. This depth is well beyond the expected depth of the top of the drain, based on findings at the other CAU 562 french drain CASs. The trenches on the east and west sides (long dimension) of the pad were approximately $12.0 \mathrm{ft}$ wide, and the trenches on the north and south sides of the pad were approximately $5.0 \mathrm{ft}$ wide. Only the wooden electrical board on the north side of the pad and the underground water line interfered with excavation; however, these areas were hand cleared and no french drains were identified.

The typical design of a french drain in Area 2 is a 55-gal drum that is installed in the ground with the top flush with the surrounding ground surface or covered with a few inches of soil (based on findings at adjacent CASs 02-60-02 and 02-60-06). Other drains included in this CAU were within $3.0 \mathrm{ft}$ of the associated concrete pads with the exception of CAS 02-60-06, where the drain was attached to a pipe approximately $10.0 \mathrm{ft}$ from the associated pad.

Because the french drain was not identified during the investigation effort, it is concluded that there was an error in the historical document that identified this area as an environmental concern and that there is no french drain associated with the Electrical Supply Building. 


\section{A.13.0 CAS 23-60-01, Mud Trap Drain and Outfall, Investigation Results}

Corrective Action Site 23-60-01 is located adjacent to a wash shed in the former DNA compound in Area 23 (Figure 1-2). A trench in the floor of the wash shed drained to the mud trap located on the south side of the shed. Overflow fluids from the mud trap discharged to an outfall pipe that released to a wash just beyond a barbed-wire fence. No specific documentation was identified regarding the grease rack located adjacent to the mud trap, although it is speculated that vehicles were serviced on the rack. Corrective Action Site 23-60-01 consists of the potential releases to the soil from a mud trap, grease rack, and outfall pipe that were part of the vehicle wash-down and maintenance area. Figure A.13-1 shows the sample locations and photographs of CAS 23-60-01.

\section{A.13.1 Corrective Action Investigation Activities}

A total of nine environmental samples and two PSM (including one FD) samples were collected during investigation activities at CAS 23-60-01. The sample IDs, locations, types, and analyses are listed in Table A.13-1. The specific CAI activities conducted to satisfy the CAIP requirements at this CAS are described in the following sections.

\section{A.13.1.1 Visual Inspections}

Mud Trap Drain - The concrete trench in the floor of the wash shed that drains to the mud trap was visually inspected to select a biased sample location. The trench had a concrete bottom and an outlet pipe at the midpoint of its length that drained to the mud trap located outside the south wall of the wash shed. The PSM in the drain consisted of fine dirt with well-sorted gravels that were covered with abundant windblown trash and vegetation debris. No staining was identified; therefore, sample location K01 was selected at the center of the trench adjacent to the outlet pipe. The mud trap drain was visually inspected to select a biased sample location. The mud trap consists of a concrete vault measuring 4.0 by 4.0 by $3.5 \mathrm{ft}$ with a metal grate cover. The contents included approximately $1.5 \mathrm{ft}$ of sediment with some miscellaneous debris.

Grease Rack - The soil below the grease rack was visually inspected to select biased sample locations. No surface staining was observed. 


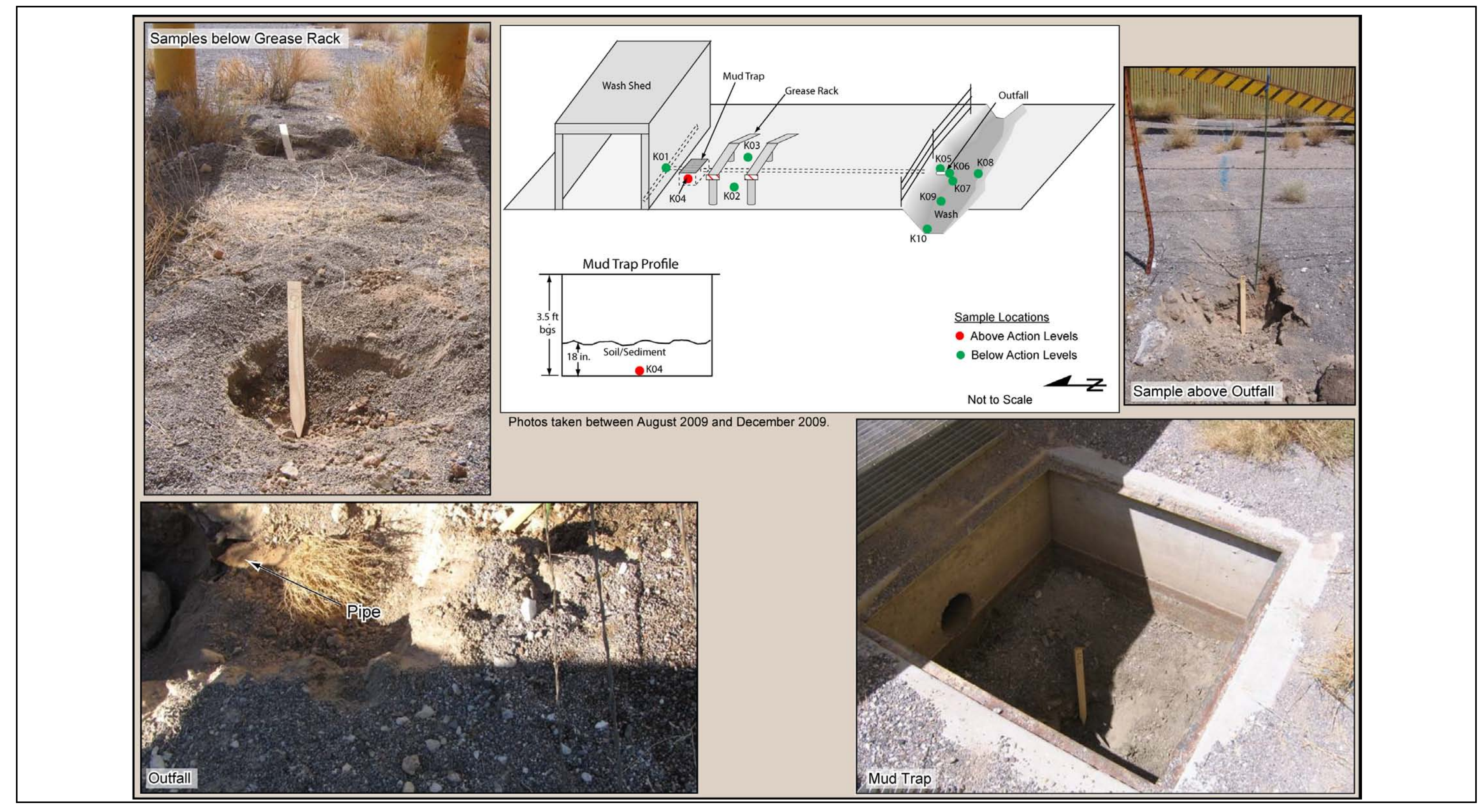

Figure A.13-1
Sample Locations at CAS 23-60-01, Mud Trap Drain and Outfall 
Table A.13-1

Samples Collected at CAS 23-60-01, Mud Trap Drain and Outfall

\begin{tabular}{|c|c|c|c|c|c|c|c|c|c|c|c|c|}
\hline $\begin{array}{l}\text { Sample } \\
\text { Location }\end{array}$ & $\begin{array}{l}\text { Sample } \\
\text { Number }\end{array}$ & $\begin{array}{c}\text { Depth } \\
\text { (ft bgs) }\end{array}$ & Matrix & Purpose & $\begin{array}{l}\text { 움 } \\
\text { م }\end{array}$ & 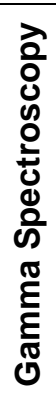 & 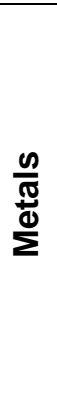 & 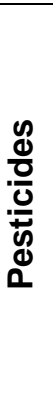 & $\begin{array}{l}\mathscr{m} \\
\text { Uñ } \\
\text { Un }\end{array}$ & 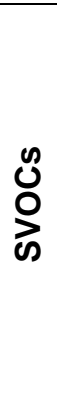 & 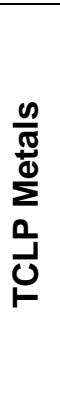 & $\begin{array}{l}\text { O্ } \\
\text { O্ }\end{array}$ \\
\hline K01 & $562 \mathrm{~K} 001$ & $0.0-0.5$ & Soil & Environmental & $x$ & $x$ & $x$ & $x$ & $x$ & $x$ & -- & $x$ \\
\hline K02 & $562 K 002$ & $0.0-0.5$ & Soil & Environmental & $x$ & $x$ & $x$ & -- & $x$ & $x$ & -- & $x$ \\
\hline K03 & $562 K 003$ & $0.0-0.5$ & Soil & Environmental & $x$ & $x$ & $x$ & -- & $x$ & $x$ & -- & $x$ \\
\hline \multirow[b]{2}{*}{ K04 } & $562 K 004$ & $3.0-3.5$ & Sediment & PSM & X & $x$ & $x$ & -- & $x$ & $x$ & $x$ & $x$ \\
\hline & $562 K 005$ & $3.0-3.5$ & Sediment & $\begin{array}{c}\text { FD } \\
\text { of \#562K004 }\end{array}$ & $x$ & $x$ & $x$ & -- & $x$ & $x$ & $x$ & $x$ \\
\hline K05 & $562 K 006$ & $1.0-1.5$ & Soil & Environmental & $x$ & $x$ & $x$ & -- & $x$ & $x$ & $x$ & $x$ \\
\hline K06 & $562 K 007$ & $2.0-2.5$ & Soil & Environmental & $x$ & $x$ & $x$ & -- & $x$ & $x$ & -- & $X$ \\
\hline K07 & $562 K 008$ & $3.0-3.5$ & Soil & Environmental & $x$ & $x$ & $x$ & -- & $X$ & $x$ & -- & $x$ \\
\hline K08 & $562 K 009$ & $2.0-2.5$ & Soil & Environmental & $x$ & $x$ & $x$ & -- & $X$ & $X$ & -- & $x$ \\
\hline K09 & $562 K 010$ & $2.0-2.5$ & Soil & Environmental & $x$ & $X$ & $x$ & -- & $x$ & $x$ & -- & $x$ \\
\hline K10 & $562 \mathrm{~K} 011$ & $2.0-2.5$ & Soil & Environmental & $x$ & $x$ & $x$ & -- & $x$ & $x$ & -- & $x$ \\
\hline $\mathrm{N} / \mathrm{A}$ & 562 K302 & $\mathrm{N} / \mathrm{A}$ & Water & Trip Blank & -- & -- & -- & -- & -- & -- & -- & $x$ \\
\hline $\begin{array}{c}\text { Sample } \\
\text { Table }\end{array}$ & 562 K301 & $\mathrm{N} / \mathrm{A}$ & Water & Field Blank & $x$ & $x$ & $x$ & -- & $x$ & $x$ & -- & $x$ \\
\hline
\end{tabular}

$--=$ Not required

Outfall - The subsurface outfall pipe that connects the mud trap to the outfall area was imaged with utility-surveying equipment and shown to terminate just beyond the barbed-wire fence into a wash. The pipe was cast iron and located at $2.0 \mathrm{ft}$ bgs. Additional sample locations were selected at the outfall and in the wash to gather additional characterization information. 


\section{A.13.1.2 Sample Collection}

Sampling activities included the collection of 9 environmental surface and subsurface soil samples and 2 (including 1 FD) PSM samples from the 10 locations shown in Figure A.13-1. The sampling activities are discussed below.

Mud Trap Drain - Sample 562K001 was collected at a depth of 0.0 to $0.5 \mathrm{ft}$ bgs from the concrete trench in the floor of the wash shed (location K01). This sample consisted of a fine gray dirt mixed with well-sorted small gravel. Miscellaneous debris, including vegetation and plastics, was present. Samples 562K004 and FD 562K005 were collected from a depth of 3.0 to $3.5 \mathrm{ft}$ bgs from the center of the mud trap (location K04) because there were no other biasing factors (e.g., staining, chambers). The PSM consisted of moist brown sand with gravels and some miscellaneous debris (e.g., glass, paper, plastic).

Grease Rack - Two sample locations (K02 and K03) were selected at the expected ground surface locations where vehicle fluids may have leaked during routine maintenance operations. Sample $562 \mathrm{~K} 002$ was collected from 0.0 to $0.5 \mathrm{ft}$ bgs at location K02 near the west end of the grease rack. This sample consisted of a well-sorted gravel with a thin horizon of dark-stained and slightly consolidated material observed at approximately 2.0 in. bgs. The soil underlying this layer consisted of fine soil mixed with well-sorted gravel. Sample 562K003 was collected from 0.0 to $0.5 \mathrm{ft}$ bgs at location K03 near the east end of the rack. This sample was nearly identical to sample 562K002, but with a slightly thicker horizon of dark-stained material.

Outfall - Sample 562K006 was collected at a depth of 1.0 to $1.5 \mathrm{ft}$ bgs at location K05, adjacent to the termination of the outfall pipe. The outfall area was very rocky, and most rocks had a dark coating or staining. The sample consisted of sandy soil mixed among the dark-stained rocks. Sample 562K007 was collected from within the mouth of the outfall pipe at a depth of 2.0 to $2.5 \mathrm{ft}$ bgs (location K06). The soil consisted of small consolidated pebbles mixed with some larger gravel and was gray in color. An additional sample (562K008) was collected directly below the outfall (location K07) at a depth of 3.0 to $3.5 \mathrm{ft}$ bgs. Sample location K08 was selected $8.0 \mathrm{ft}$ straight out from the outfall (opposite side of the wash), while sample locations K09 and K10 were selected downstream in the wash at a distance of 3.0 and $10.0 \mathrm{ft}$, respectively. These samples (562K009 through 562K011) were collected at a depth of 2.0 to $2.5 \mathrm{ft}$ bgs. 


\section{A.13.1.3 Deviations}

Investigation samples were collected as outlined in the CAU 562 CAIP and submitted for laboratory analysis. However, additional samples were collected at the outfall location and in the wash.

\section{A.13.2 Investigation Results}

The following sections provide analytical results from the samples collected to complete investigation activities as outlined in the CAIP (NNSA/NSO, 2009). The results from the analysis of PCBs included tentatively identified compounds with signatures similar to pesticides. Therefore, these samples were also analyzed for pesticides. The analytical parameters and laboratory methods used to analyze the investigation samples are listed in Table A.2-2. Table A.13-1 lists the sample-specific analytical suite for CAS 23-60-01.

Analytical results from the soil samples with concentrations exceeding MDCs are summarized in the following sections. An evaluation was conducted on all contaminants detected above MDCs by comparing individual concentrations or activity results against the FALs. Establishment of the FALs is presented in Appendix D. The FALs were established as the corresponding PAL concentrations or activities if the contaminant concentrations were below their respective PALs.

\section{A.13.2.1 Volatile Organic Compounds}

Analytical results for VOCs in soil samples collected at this CAS that were detected above MDCs are presented in Table A.13-2. No VOCs were detected at concentrations exceeding their respective PALs. The FALs were established at the PAL concentrations.

\section{A.13.2.2 Semivolatile Organic Compounds}

Analytical results for SVOCs in soil samples collected at this CAS that were detected above MDCs are presented in Table A.13-3. No SVOCs were detected at concentrations exceeding the respective PALs. The FALs were established at the PAL concentrations. 
Table A.13-2

Sample Results for Total VOCs Detected above MDCs at CAS 23-60-01, Mud Trap Drain and Outfall

\begin{tabular}{|c|c|c|c|c|c||}
\hline \multirow{2}{*}{$\begin{array}{c}\text { Sample } \\
\text { Location }\end{array}$} & \multirow{2}{*}{$\begin{array}{c}\text { Sample } \\
\text { Number }\end{array}$} & $\begin{array}{c}\text { Depth } \\
\text { (ft bgs) }\end{array}$ & 2-butanone & Acetone & $\begin{array}{c}\text { Methylene } \\
\text { Chloride }\end{array}$ \\
\cline { 5 - 6 } & & & 200,000 & $\mathbf{6 3 0 , 0 0 0}$ & 53 \\
\hline \hline $\mathrm{K} 01$ & $562 \mathrm{~K} 001$ & $0.0-0.5$ & $0.0071(\mathrm{~J})$ & 0.061 & $0.0044(\mathrm{~J})$ \\
\hline $\mathrm{K} 02$ & $562 \mathrm{~K} 002$ & $0.0-0.5$ & $0.0072(\mathrm{~J})$ & $0.018(\mathrm{~J})$ & $0.0046(\mathrm{~J})$ \\
\hline $\mathrm{K} 03$ & $562 \mathrm{~K} 003$ & $0.0-0.5$ & 0.022 & 0.077 & $0.0049(\mathrm{~J})$ \\
\hline
\end{tabular}

$\mathrm{J}=$ Estimated value

\section{A.13.2.3 Total Petroleum Hydrocarbons}

Analytical results for TPH-DRO in soil samples collected at this CAS that were detected above MDCs are presented in Table A.13-4. Six samples exceeded the PAL of $100 \mathrm{mg} / \mathrm{kg}$ for TPH-DRO. The TPH-DRO was moved on to a Tier 2 evaluation, and FALs were established for the hazardous constituents of TPH-DRO. Concentrations of the hazardous constituents of TPH-DRO did not exceed FALs. Therefore, TPH-DRO is not considered a COC. The calculation of FALs for the hazardous constituents of TPH-DRO is presented in Appendix D.

\section{A.13.2.4 Resource Conservation and Recovery Act Metals}

Analytical results for RCRA metals in soil samples collected at this CAS that were detected above MDCs are presented in Table A.13-5. Concentrations of lead that exceeded the PAL were detected at one location (K05) just above the outfall opening (1.0 to $1.5 \mathrm{ft}$ bgs). Sample 562K004 contained lead at a concentration of 1,000 mg/kg, which exceeded the PAL of $800 \mathrm{mg} / \mathrm{kg}$. A Tier 2 evaluation was performed for the lead concentration. This included the evaluation of risk presented by the lead through the use of the EPA ALM (EPA, 2009) (see Appendix D). The FAL for lead was established as $1,235 \mathrm{mg} / \mathrm{kg}$. The results showed that the lead does not pose an unacceptable risk to human health and is not considered a COC. 
Table A.13-3

Sample Results for Total SVOCs Detected above MDCs at CAS 23-60-01, Mud Trap Drain and Outfall

\begin{tabular}{|c|c|c|c|c|c|c|c|c|c|c|c|c|c|c|}
\hline \multirow[b]{2}{*}{$\begin{array}{l}\text { Sample } \\
\text { Location }\end{array}$} & \multirow[b]{2}{*}{$\begin{array}{l}\text { Sample } \\
\text { Number }\end{array}$} & \multirow[b]{2}{*}{$\begin{array}{l}\text { Depth } \\
\text { (ft bgs) }\end{array}$} & \multicolumn{12}{|c|}{ COPCs (mg/kg) } \\
\hline & & & 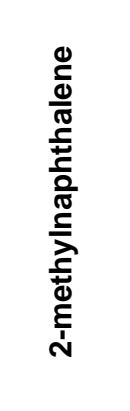 & 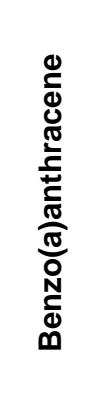 & 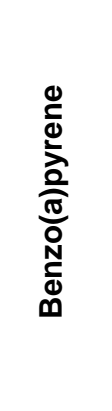 & 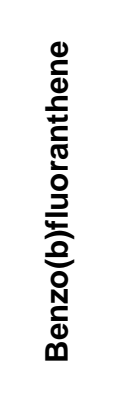 & 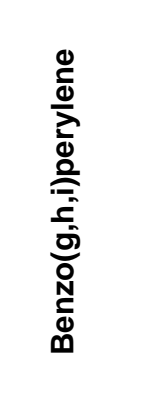 & 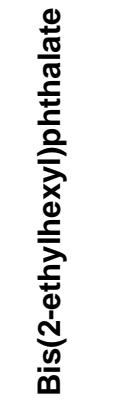 & 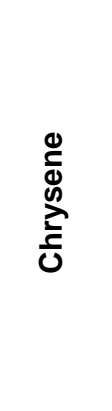 & 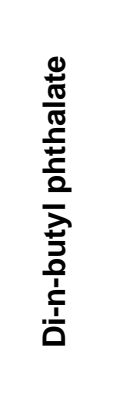 & 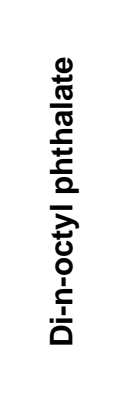 & 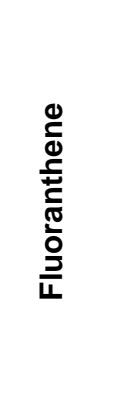 & 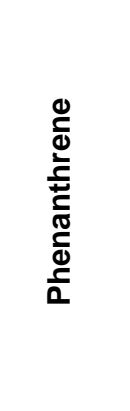 & 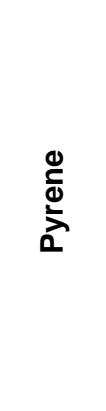 \\
\hline \multicolumn{3}{|c|}{ FALs } & 4,100 & 2.1 & 0.21 & 2.1 & 17,000 & 120 & 210 & 62,000 & 25,000 & 22,000 & 170,000 & 17,000 \\
\hline K01 & $562 K 001$ & $0.0-0.5$ & -- & -- & -- & -- & -- & 1.6 & -- & $0.17(\mathrm{~J})$ & -- & -- & -- & -- \\
\hline K02 & $562 K 002$ & $0.0-0.5$ & -- & -- & -- & -- & -- & 0.87 & -- & -- & -- & -- & -- & -- \\
\hline K03 & $562 \mathrm{~K} 003$ & $0.0-0.5$ & -- & -- & -- & -- & -- & $0.2(\mathrm{~J})$ & -- & -- & -- & -- & -- & -- \\
\hline K05 & $562 K 006$ & $1.0-1.5$ & -- & -- & -- & -- & -- & $0.16(\mathrm{~J})$ & -- & -- & -- & -- & -- & -- \\
\hline K06 & $562 K 007$ & $2.0-2.5$ & $0.093(\mathrm{~J})$ & $0.12(\mathrm{~J})$ & $0.15(\mathrm{~J})$ & $0.17(\mathrm{~J})$ & $0.093(\mathrm{~J})$ & 1.2 & $0.14(\mathrm{~J})$ & -- & $0.1(\mathrm{~J})$ & $0.11(\mathrm{~J})$ & $0.13(\mathrm{~J})$ & $0.21(\mathrm{~J})$ \\
\hline K09 & $562 \mathrm{~K} 010$ & $2.0-2.5$ & -- & -- & -- & -- & -- & -- & -- & -- & $0.073(\mathrm{~J})$ & -- & -- & -- \\
\hline
\end{tabular}

-- = Not detected above MDCs.

$\mathrm{J}=$ Estimated value 
Table A.13-4

Sample Results for TPH-DRO Detected above MDCs at CAS 23-60-01, Mud Trap Drain and Outfall

\begin{tabular}{|c|c|c|c||}
\hline \multirow{2}{*}{$\begin{array}{c}\text { Sample } \\
\text { Location }\end{array}$} & \multirow{2}{*}{$\begin{array}{c}\text { Sample } \\
\text { Number }\end{array}$} & \multirow{2}{*}{$\begin{array}{c}\text { Depth } \\
\text { (ft bgs) }\end{array}$} & COPCs (mg/kg) \\
\cline { 4 - 5 } & & & $\mathbf{1 0 0}$ \\
\hline \multicolumn{3}{|c|}{ PALs } & $\mathbf{1 1 0}(\mathrm{J})$ \\
\hline \hline K01 & $562 \mathrm{~K} 001$ & $0.0-0.5$ & $\mathbf{2 3 0}(\mathrm{J})$ \\
\hline K02 & $562 \mathrm{~K} 002$ & $0.0-0.5$ & $\mathbf{5 9 0}(\mathrm{J})$ \\
\hline K03 & $562 \mathrm{~K} 003$ & $0.0-0.5$ & $\mathbf{2 3 0}(\mathrm{J})$ \\
\hline K05 & $562 \mathrm{~K} 006$ & $1.0-1.5$ & $\mathbf{3 9 0}$ \\
\hline K06 & $562 \mathrm{~K} 007$ & $2.0-2.5$ & $\mathbf{1 6 0}$ \\
\hline K07 & $562 \mathrm{~K} 008$ & $3.0-3.5$ & $4.8(\mathrm{~J})$ \\
\hline K08 & $562 \mathrm{~K} 009$ & $2.0-2.5$ & 46 \\
\hline K09 & $562 \mathrm{~K} 010$ & $2.0-2.5$ & 10 \\
\hline K10 & $562 \mathrm{~K} 011$ & $2.0-2.5$ & \\
\hline
\end{tabular}

$\mathrm{J}=$ Estimated value

Bold indicates the value is equal to or exceeds the PAL.

Table A.13-5

Sample Results for Metals Detected above MDCs at CAS 23-60-01, Mud Trap Drain and Outfall

(Page 1 of 2)

\begin{tabular}{|c|c|c|c|c|c|c|c|c|}
\hline \multirow[b]{2}{*}{$\begin{array}{l}\text { Sample } \\
\text { Location }\end{array}$} & \multirow[b]{2}{*}{$\begin{array}{l}\text { Sample } \\
\text { Number }\end{array}$} & \multirow[b]{2}{*}{$\begin{array}{l}\text { Depth } \\
\text { (ft bgs) }\end{array}$} & \multicolumn{6}{|c|}{ COPCs (mg/kg) } \\
\hline & & & $\frac{0}{\frac{0}{c}}$ & 点 & 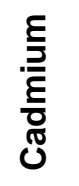 & 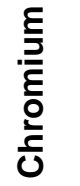 & శ్ర్తి & 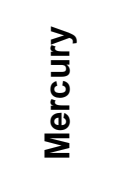 \\
\hline \multicolumn{3}{|c|}{ FALs } & 23 & 190,000 & 800 & 450 & 1,235 & 34 \\
\hline K01 & $562 \mathrm{~K} 001$ & $0.0-0.5$ & 6.6 & 190 & 2.1 & 26 & 320 & 0.059 \\
\hline K02 & $562 \mathrm{~K} 002$ & $0.0-0.5$ & 6.1 & 110 & 0.3 & 6.6 & 210 & -- \\
\hline K03 & $562 \mathrm{~K} 003$ & $0.0-0.5$ & 5.3 & 92 & 0.31 & 5.8 & 510 & -- \\
\hline K05 & $562 K 006$ & $1.0-1.5$ & 12 & $110(\mathrm{~J})$ & 0.96 & $7(\mathrm{~J})$ & 1,000 & $0.34(\mathrm{~J})$ \\
\hline K06 & $562 \mathrm{~K} 007$ & $2.0-2.5$ & 7.1 & 120 & 2.5 & 15 & 400 & 0.13 \\
\hline K07 & $562 \mathrm{~K} 008$ & $3.0-3.5$ & 4.2 & 78 & 1.8 & 4.4 & 120 & 0.038 \\
\hline
\end{tabular}


Table A.13-5

\section{Sample Results for Metals Detected above MDCs at CAS 23-60-01, Mud Trap Drain and Outfall}

(Page 2 of 2)

\begin{tabular}{|c|c|c|c|c|c|c|c|c|}
\hline \multirow[b]{2}{*}{$\begin{array}{l}\text { Sample } \\
\text { Location }\end{array}$} & \multirow[b]{2}{*}{$\begin{array}{l}\text { Sample } \\
\text { Number }\end{array}$} & \multirow[b]{2}{*}{$\begin{array}{c}\text { Depth } \\
\text { (ft bgs) }\end{array}$} & \multicolumn{6}{|c|}{ COPCs (mg/kg) } \\
\hline & & & $\begin{array}{l}\frac{0}{\bar{D}} \\
\frac{\omega}{0} \\
\frac{0}{\alpha}\end{array}$ & 思 & 立 & 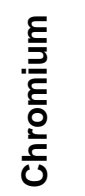 & శ్ర్త & 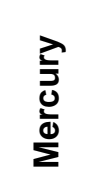 \\
\hline \multicolumn{3}{|c|}{ FALs } & 23 & 190,000 & 800 & 450 & 1,235 & 34 \\
\hline K08 & $562 K 009$ & $2.0-2.5$ & 3.2 & 47 & -- & 2.2 & 5.2 & 0.011 \\
\hline K09 & $562 \mathrm{~K} 010$ & $2.0-2.5$ & 3.6 & 58 & 1.5 & 3.7 & 38 & 0.037 \\
\hline K10 & 562K011 & $2.0-2.5$ & 3 & 41 & -- & 2.3 & 11 & 0.02 \\
\hline
\end{tabular}

-- = Not detected above MDCs.

$\mathrm{J}=$ Estimated value

$\mathrm{J}+=$ Result is an estimated quantity but may be biased high.

Bold indicates the value is equal to or exceeds the FAL.

\section{A.13.2.5 Polychlorinated Biphenyls}

Analytical results for PCBs in soil samples collected at this CAS that were detected above MDCs are presented in Table A.13-6. No PCBs were detected at concentrations exceeding their respective PALs. The FALs were established at the PAL concentrations.

\section{A.13.2.6 Pesticides}

Analytical results for pesticides in soil samples collected at this CAS that were detected above MDCs are presented in Table A.13-7. No pesticides were detected at concentrations exceeding the respective PALs. The FALs were established at the PAL concentrations.

\section{A.13.2.7 Gamma-Emitting Radionuclides}

Analytical results for gamma-emitting radionuclides in soil samples collected at this CAS that were detected above MDCs are presented in Table A.13-8. No gamma-emitting radionuclides were detected at concentrations exceeding their respective PALs. The FALs were established at the PAL concentrations. 
Table A.13-6

Sample Results for PCBs Detected above

MDCs at CAS 23-60-01, Mud Trap Drain and Outfall

\begin{tabular}{|c|c|c|c|}
\hline \multirow{2}{*}{$\begin{array}{c}\text { Sample } \\
\text { Location }\end{array}$} & \multirow{2}{*}{$\begin{array}{c}\text { Sample } \\
\text { Number }\end{array}$} & \multirow{2}{*}{$\begin{array}{c}\text { Depth } \\
\text { fft bgs) }\end{array}$} & COPCs (mg/kg) \\
\cline { 4 - 5 } & & Aroclor 1260 \\
\hline \multicolumn{3}{|c|}{ FALs } & $\mathbf{0 . 7 4}$ \\
\hline \hline K01 & $562 \mathrm{~K} 001$ & $0.0-0.5$ & $0.04(\mathrm{~J})$ \\
\hline K05 & $562 \mathrm{~K} 006$ & $1.0-1.5$ & $0.037(\mathrm{~J})$ \\
\hline K06 & $562 \mathrm{~K} 007$ & $2.0-2.5$ & $0.24(\mathrm{~J})$ \\
\hline K07 & $562 \mathrm{~K} 008$ & $3.0-3.5$ & 0.055 \\
\hline K09 & $562 \mathrm{~K} 010$ & $2.0-2.5$ & 0.075 \\
\hline K10 & $562 \mathrm{~K} 011$ & $2.0-2.5$ & 0.026 \\
\hline
\end{tabular}

$\mathrm{J}=$ Estimated value

Table A.13-7

Sample Results for Pesticides Detected above

MDCs at CAS 23-60-01, Mud Trap Drain and Outfall

\begin{tabular}{|c|c|c|c|c|c|c|}
\hline \multirow{2}{*}{$\begin{array}{c}\text { Sample } \\
\text { Location }\end{array}$} & \multirow{2}{*}{$\begin{array}{c}\text { Sample } \\
\text { Number }\end{array}$} & $\begin{array}{c}\text { Depth } \\
\text { (ft bgs) }\end{array}$ & \multicolumn{4}{c|}{ Contaminants of Potential (mg/kg) } \\
\cline { 4 - 7 } & & & $4,4 '-D D E$ & $4,4^{\prime}-\mathrm{DDT}$ & Chlordane & $\begin{array}{c}\text { Endosulfan } \\
\text { sulfate }\end{array}$ \\
\hline \multicolumn{3}{|c|}{ FALs } & $\mathbf{5 . 1}$ & $\mathbf{7}$ & $\mathbf{6 . 5}$ & $\mathbf{3 , 7 0 0}$ \\
\hline \hline $\mathrm{K} 01$ & $562 \mathrm{~K} 001$ & $0.0-0.5$ & $0.00037(\mathrm{~J})$ & $0.0057(\mathrm{~J})$ & $0.051(\mathrm{~J})$ & $0.0019(\mathrm{~J})$ \\
\hline
\end{tabular}

$\mathrm{J}=$ Estimated value

\section{A.13.3 Potential Source Material Sample Results}

Analytical results for sediment samples with concentrations exceeding MDCs (562K004 and FD 562K005) are presented in Table A.13-9. The analytical results show that lead was detected at a concentration of $8,900 \mathrm{mg} / \mathrm{kg}$, which exceeds the PAL of $800 \mathrm{mg} / \mathrm{kg}$. The PSM criteria were established at the PAL concentrations. Therefore, lead is considered a PSM contaminant.

Additionally, TPH-DRO was detected at a concentrations of 150 and $170 \mathrm{mg} / \mathrm{kg}$. The TPH-DRO was moved on to a Tier 2 evaluation, and PSM criteria were established for the hazardous constituents of 
Table A.13-8

Sample Results for Gamma-Emitting Radionuclides Detected above MDCs at CAS 23-60-01, Mud Trap Drain and Outfall

\begin{tabular}{|c|c|c|c|c|c|}
\hline \multirow{2}{*}{$\begin{array}{l}\text { Sample } \\
\text { Location }\end{array}$} & \multirow{2}{*}{$\begin{array}{l}\text { Sample } \\
\text { Number }\end{array}$} & \multirow{2}{*}{$\begin{array}{l}\text { Depth } \\
\text { (ft bgs) }\end{array}$} & \multicolumn{3}{|c|}{ COPCs (pCi/g) } \\
\hline & & & Ac-228 & Cs-137 & Th-234 \\
\hline \multicolumn{3}{|c|}{ FALs } & 5 & 12.2 & 105 \\
\hline K01 & $562 \mathrm{~K} 001$ & $0.0-0.5$ & 1.06 & 0.35 & -- \\
\hline K02 & $562 \mathrm{~K} 002$ & $0.0-0.5$ & 0.89 & -- & -- \\
\hline K03 & $562 \mathrm{~K} 003$ & $0.0-0.5$ & 0.96 & 0.119 & $2.18(\mathrm{~J})$ \\
\hline K05 & $562 \mathrm{~K} 006$ & $1.0-1.5$ & 0.82 & -- & -- \\
\hline K06 & 562K007 & $2.0-2.5$ & -- & 0.47 & -- \\
\hline
\end{tabular}

$--=$ Not detected above MDCs.

$\mathrm{J}=$ Estimated value

TPH-DRO at their respective PAL concentrations. No hazardous constituents of TPH-DRO exceeded their respective PSM criteria. Therefore, they are not considered PSM contaminants.

Due to the presence of lead exceeding the PSM criteria, the sediment is considered PSM.

\section{A.13.4 Nature and Extent of Contamination}

Although the sediment in the mud trap has been determined to be PSM, the sediment is contained within the trap and there were no COCs identified in the environment at any other features at this CAS.

\section{A.13.5 Revised Conceptual Site Model}

The CAIP requirements were met at this CAS, and no revisions were necessary to the CSM. 
Table A.13-9

PSM Results Detected above MDCs for CAS 23-60-01, Mud Trap Drain and Outfall (Page 1 of 2)

\begin{tabular}{|c|c|c|c|c|c|c|}
\hline $\begin{array}{l}\text { Sample } \\
\text { Location }\end{array}$ & $\begin{array}{l}\text { Sample } \\
\text { Number }\end{array}$ & $\begin{array}{c}\text { Sample } \\
\text { Matrix }\end{array}$ & Parameter & Result & $\begin{array}{c}\text { PSM } \\
\text { Criteria }\end{array}$ & Unit \\
\hline \multirow{23}{*}{ K04 } & \multirow{12}{*}{$562 \mathrm{~K} 004$} & \multirow{12}{*}{ Sediment } & DRO & $150(\mathrm{~J})$ & $\mathrm{N} / \mathrm{A}$ & $\mathrm{mg} / \mathrm{kg}$ \\
\hline & & & Arsenic & 9.4 & 23 & $\mathrm{mg} / \mathrm{kg}$ \\
\hline & & & Barium & $590(\mathrm{~J})$ & 190,000 & $\mathrm{mg} / \mathrm{kg}$ \\
\hline & & & Cadmium & 4 & 800 & $\mathrm{mg} / \mathrm{kg}$ \\
\hline & & & Chromium & $29(\mathrm{~J})$ & 450 & $\mathrm{mg} / \mathrm{kg}$ \\
\hline & & & Lead & 8,900 & 800 & $\mathrm{mg} / \mathrm{kg}$ \\
\hline & & & Mercury & $0.43(\mathrm{~J})$ & 34 & $\mathrm{mg} / \mathrm{kg}$ \\
\hline & & & Silver & 0.2 & 5,100 & $\mathrm{mg} / \mathrm{kg}$ \\
\hline & & & Aroclor 1260 & $0.48(\mathrm{~J})$ & .074 & $\mathrm{mg} / \mathrm{kg}$ \\
\hline & & & Bis(2-ethylhexyl)phthalate & 8.3 & 120 & $\mathrm{mg} / \mathrm{kg}$ \\
\hline & & & Ac-228 & 1.27 & 5 & $\mathrm{pCi} / \mathrm{g}$ \\
\hline & & & Cs-137 & 0.6 & 12.2 & $\mathrm{pCi} / \mathrm{g}$ \\
\hline & \multirow{11}{*}{$562 K 005$} & \multirow{11}{*}{ Sediment } & DRO & $170(\mathrm{~J})$ & $\mathrm{N} / \mathrm{A}$ & $\mathrm{mg} / \mathrm{kg}$ \\
\hline & & & Arsenic & 8 & 23 & $\mathrm{mg} / \mathrm{kg}$ \\
\hline & & & Barium & $690(\mathrm{~J})$ & 190,000 & $\mathrm{mg} / \mathrm{kg}$ \\
\hline & & & Cadmium & 4 & 800 & $\mathrm{mg} / \mathrm{kg}$ \\
\hline & & & Chromium & $21(\mathrm{~J})$ & 450 & $\mathrm{mg} / \mathrm{kg}$ \\
\hline & & & Lead & 400 & 800 & $\mathrm{mg} / \mathrm{kg}$ \\
\hline & & & Mercury & $0.18(\mathrm{~J})$ & 34 & $\mathrm{mg} / \mathrm{kg}$ \\
\hline & & & Selenium & 0.33 & 5,100 & $\mathrm{mg} / \mathrm{kg}$ \\
\hline & & & Silver & 0.14 & 5,100 & $\mathrm{mg} / \mathrm{kg}$ \\
\hline & & & Aroclor 1260 & $0.3(\mathrm{~J})$ & 0.74 & $\mathrm{mg} / \mathrm{kg}$ \\
\hline & & & Benzo(b)fluoranthene & $0.14(\mathrm{~J})$ & 2.1 & $\mathrm{mg} / \mathrm{kg}$ \\
\hline
\end{tabular}


Table A.13-9

PSM Results Detected above MDCs for CAS 23-60-01, Mud Trap Drain and Outfall (Page 2 of 2)

\begin{tabular}{|c|c|c|c|c|c|c|}
\hline $\begin{array}{l}\text { Sample } \\
\text { Location }\end{array}$ & $\begin{array}{l}\text { Sample } \\
\text { Number }\end{array}$ & $\begin{array}{l}\text { Sample } \\
\text { Matrix }\end{array}$ & Parameter & Result & $\begin{array}{c}\text { PSM } \\
\text { Criteria }\end{array}$ & Unit \\
\hline \multirow{8}{*}{ K04 } & \multirow{8}{*}{$\begin{array}{c}\text { 562K005 } \\
\text { (continued) }\end{array}$} & \multirow{8}{*}{ Sediment } & Bis(2-ethylhexyl)phthalate & 2.9 & 120 & $\mathrm{mg} / \mathrm{kg}$ \\
\hline & & & Chrysene & $0.16(\mathrm{~J})$ & 210 & $\mathrm{mg} / \mathrm{kg}$ \\
\hline & & & Di-n-butyl phthalate & $0.11(\mathrm{~J})$ & 62,000 & $\mathrm{mg} / \mathrm{kg}$ \\
\hline & & & Fluoranthene & 0.55 & 22,000 & $\mathrm{mg} / \mathrm{kg}$ \\
\hline & & & Phenanthrene & $0.086(\mathrm{~J})$ & 170,000 & $\mathrm{mg} / \mathrm{kg}$ \\
\hline & & & Pyrene & 0.52 & 17,000 & $\mathrm{mg} / \mathrm{kg}$ \\
\hline & & & Ac-228 & 1.32 & 5 & $\mathrm{pCi} / \mathrm{g}$ \\
\hline & & & Cs-137 & 0.67 & 12.2 & $\mathrm{pCi} / \mathrm{g}$ \\
\hline
\end{tabular}

$\mathrm{J}=$ Estimated value

Bold indicates the value is equal to or exceeds the PSM criteria. 


\section{A.14.0 CAS 23-99-06, Grease Trap, Investigation Results}

Corrective Action Site 23-99-06 is located adjacent to Building 109, a former fuel service station, currently the Housing and Revenues office in Area 23 (Figure 1-2). The grease trap originally drained to the active sewer system. The grease pit and dry well that originally discharged to the grease trap were deactivated and filled with concrete when the building was renovated. Therefore, the release of wastes to the grease trap ceased. Corrective Action Site 23-99-06 consists of the potential releases to the soil from a grease trap located on the south side of the building. Figure A.14-1 shows the sample locations and photographs of CAS 23-99-06.

\section{A.14.1 Corrective Action Investigation Activities}

A total of four PSM samples (including one FD) were collected during investigation activities at CAS 23-99-06. The sample IDs, locations, types, and analyses are listed in Table A.14-1. The specific CAI activities conducted to satisfy the CAIP requirements at this CAS are described in the following sections.

\section{A.14.1.1 Visual Inspections}

The concrete grease trap was visually inspected to select biased sample locations. The trap consists of a concrete vault that is 3.5 by $2.0 \mathrm{ft}$ and approximately $4.0 \mathrm{ft}$ deep. The vault has two partitions, creating three separate sections (lower, middle, and upper weirs) designed to separate solid wastes from liquids. The upper and middle sections contain sediment up to the partition. The lower section also contains sediment but in a smaller quantity. Also visible in the lower section is the outlet pipe that originally drained to the septic system. Due to the design of the grease trap, additional biased sample locations were selected to gather characterization information from each section of the trap.

\section{A.14.1.2 Sample Collection}

Sampling activities included the collection of four (including one FD) PSM samples from the three locations shown in Figure A.14-1. The sampling activities are discussed below.

Samples 562L001 and FD 562L002 were collected at the bottom of the lower weir (location L01) at a depth of 3.5 to $4.0 \mathrm{ft}$ bgs and consisted of dark brown sandy sediment with small pieces of paper and 


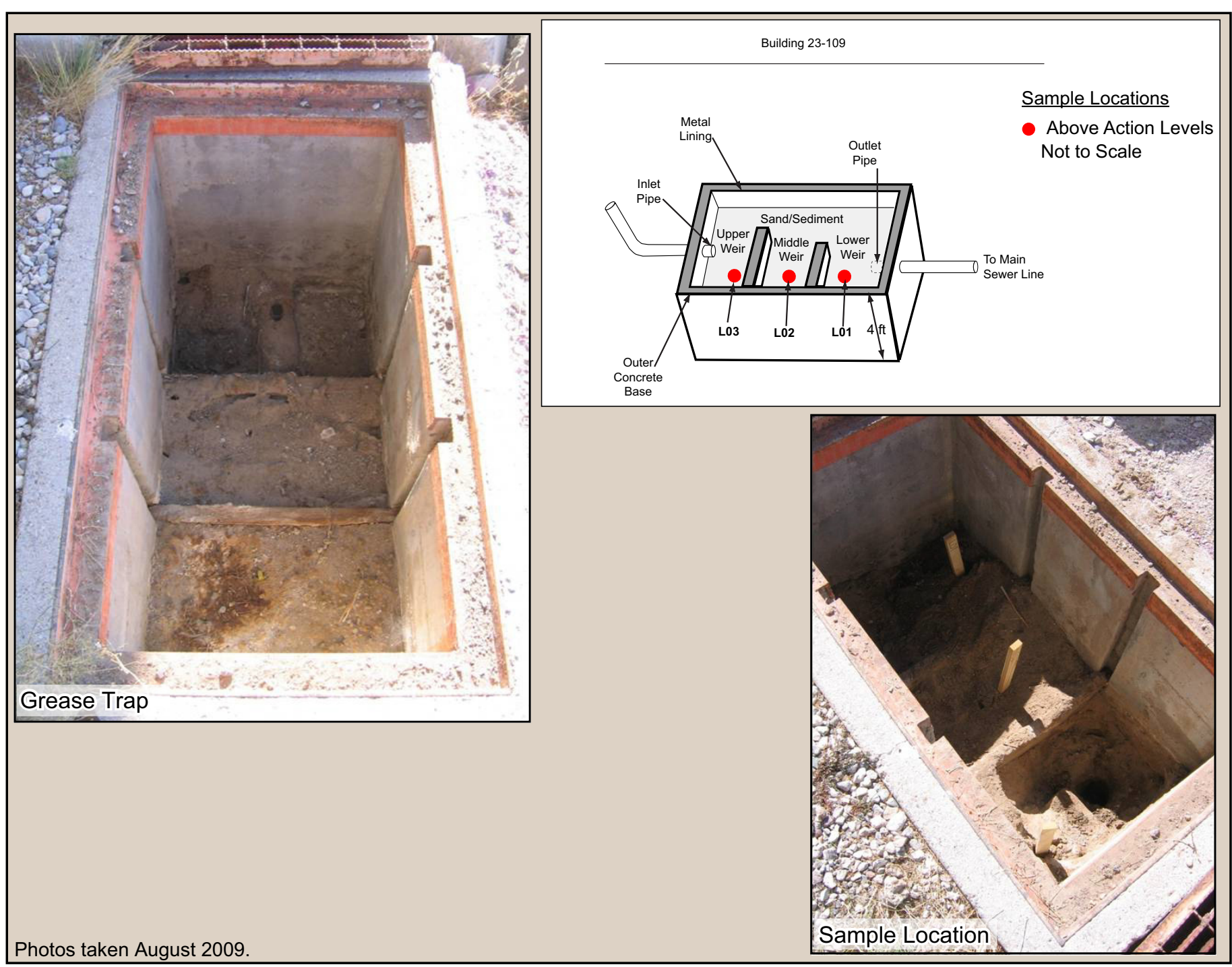

Figure A.14-1

Sample Locations at CAS 23-99-06, Grease Trap 
Table A.14-1

Samples Collected at CAS 23-99-06, Grease Trap

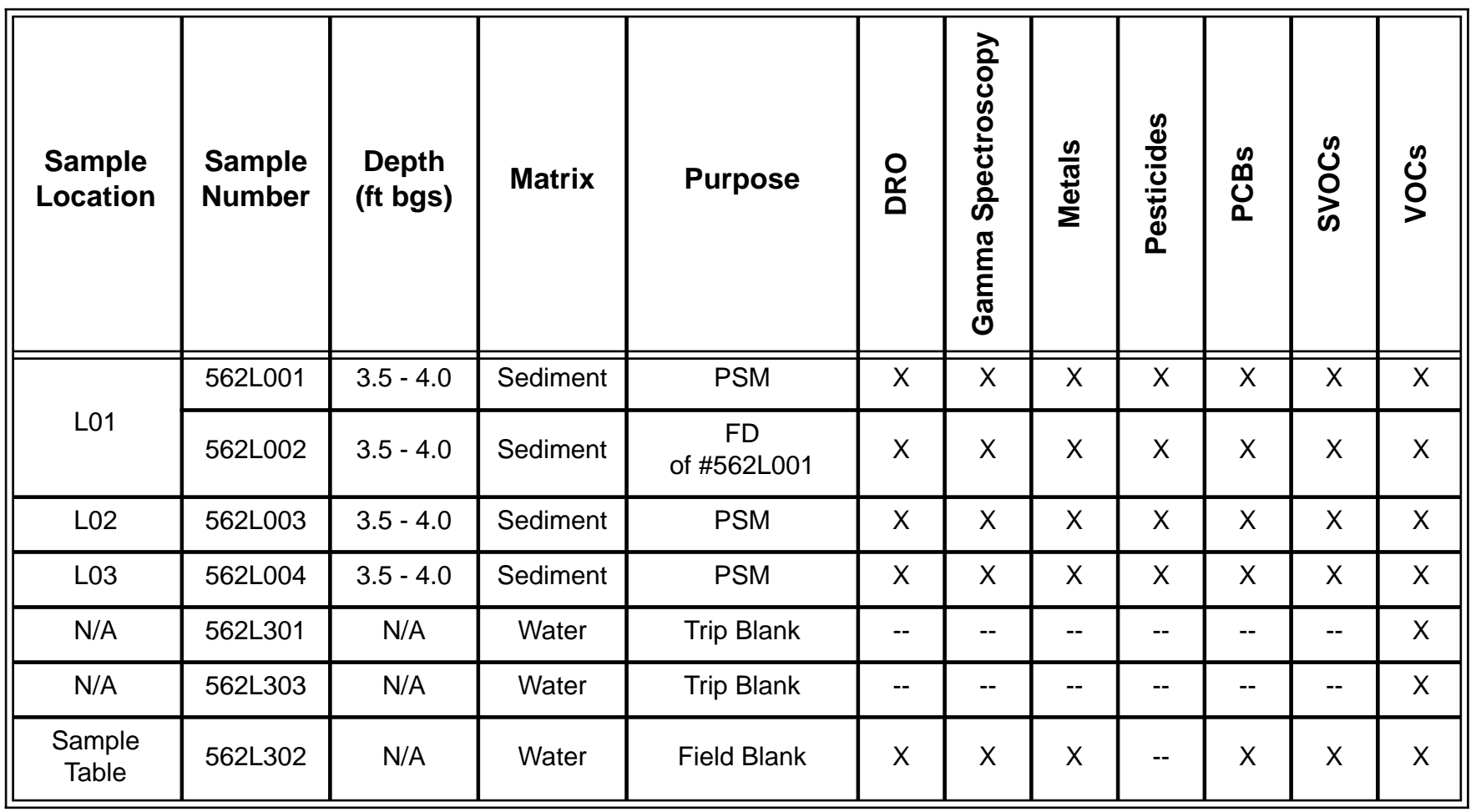

$--=$ Not required

plastic. The sample appeared to be discolored in areas. Sample 562L003 was collected at the bottom of the middle weir (location L02) at the same depth (3.5 to $4.0 \mathrm{ft}$ bgs) and was nearly identical in composition to samples 562L001 and 562L002. Sample 562L004 was collected at the bottom of the upper weir (location L03) at the same depth and of the same composition of the other samples.

\section{A.14.1.3 Deviations}

Investigation samples were collected as outlined in the CAU 562 CAIP and submitted for laboratory analysis (NNSA/NSO, 2009). Additional samples were collected because the sediment was segregated into three sections as a result of the weir.

\section{A.14.2 Investigation Results}

The following sections provide analytical results from the samples collected to complete investigation activities as outlined in the CAIP (NNSA/NSO, 2009). The results from the analysis of PCBs included tentatively identified compounds with signatures similar to pesticides. Therefore, 
these samples were also analyzed for pesticides. The analytical parameters and laboratory methods used to analyze the investigation samples are listed in Table A.2-2. Table A.14-1 lists the sample-specific analytical suite for CAS 23-99-06.

Analytical results from the PSM samples with concentrations exceeding MDCs are summarized in the following section. An evaluation was conducted on all contaminants detected above MDCs by comparing individual concentration or activity results against the PSM criteria. Establishment of the PSM criteria is presented in Appendix D. The PSM criteria were established as the corresponding PAL concentrations or activities.

\section{A.14.3 Potential Source Material Sample Results}

Analytical results for PSM samples collected at this CAS that were detected above MDCs are presented in Table A.14-2. Arsenic, Aroclor 1260, chlordane, and TPH-DRO were detected at concentrations exceeding their respective PALs. All four PSM samples (including one FD) exceeded the PAL of $0.74 \mathrm{mg} / \mathrm{kg}$ for Aroclor 1260 . Concentrations ranged from 1.1 to $1.4 \mathrm{mg} / \mathrm{kg}$. Four samples contained chlordane at concentrations ranging from 16 to $40 \mathrm{mg} / \mathrm{kg}$, which exceeded the PAL of $6.5 \mathrm{mg} / \mathrm{kg}$. One sample contained arsenic at a concentration of $24 \mathrm{mg} / \mathrm{kg}$, which exceeded the PAL of $23 \mathrm{mg} / \mathrm{kg}$. Because the PSM criteria for these contaminants were established as the PALs, Aroclor 1260, chlordane, and arsenic are considered PSM contaminants. Because Aroclor 1260, chlordane, and arsenic are PSM contaminants, the sediment within the trap is considered PSM.

Additionally, one sample exceeded the PAL of $100 \mathrm{mg} / \mathrm{kg}$ for TPH-DRO. The TPH-DRO was moved on to a Tier 2 evaluation, and PSM criteria were established for the hazardous constituents of TPH-DRO. Concentrations of the hazardous constituents of TPH-DRO did not exceed PSM criteria. Therefore, they are not considered PSM contaminants.

\section{A.14.4 Nature and Extent of Contamination}

The sediment in the grease trap has been determined to be PSM. Due to digging restrictions, no environmental samples were collected of the soil surrounding the grease trap. During PSM removal, the integrity of the trap will be addressed in the corrective action plan (CAP). 
Table A.14-2

PSM Results Detected above MDCs for CAS 23-99-06, Grease Trap (Page 1 of 3 )

\begin{tabular}{|c|c|c|c|c|c|c|}
\hline $\begin{array}{l}\text { Sample } \\
\text { Location }\end{array}$ & $\begin{array}{l}\text { Sample } \\
\text { Number }\end{array}$ & $\begin{array}{c}\text { Sample } \\
\text { Matrix }\end{array}$ & Parameter & Result & $\begin{array}{c}\text { PSM } \\
\text { Criteria }\end{array}$ & Unit \\
\hline \multirow{17}{*}{ L01 } & \multirow{17}{*}{ 562L001 } & \multirow{17}{*}{ Soil } & DRO & $83(\mathrm{~J})$ & N/A & $\mathrm{mg} / \mathrm{kg}$ \\
\hline & & & Arsenic & 15 & 23 & $\mathrm{mg} / \mathrm{kg}$ \\
\hline & & & Barium & 390 & 190,000 & $\mathrm{mg} / \mathrm{kg}$ \\
\hline & & & Cadmium & 9.9 & 800 & $\mathrm{mg} / \mathrm{kg}$ \\
\hline & & & Chromium & $60(\mathrm{~J})$ & 450 & $\mathrm{mg} / \mathrm{kg}$ \\
\hline & & & Lead & 650 & 800 & $\mathrm{mg} / \mathrm{kg}$ \\
\hline & & & Mercury & 0.18 & 34 & $\mathrm{mg} / \mathrm{kg}$ \\
\hline & & & Selenium & 0.57 & 5,100 & $\mathrm{mg} / \mathrm{kg}$ \\
\hline & & & Silver & 0.33 & 5,100 & $\mathrm{mg} / \mathrm{kg}$ \\
\hline & & & Ac-228 & 1.88 & 5 & $\mathrm{pCi} / \mathrm{g}$ \\
\hline & & & Cs-137 & 0.58 & 12.2 & $\mathrm{pCi} / \mathrm{g}$ \\
\hline & & & Aroclor 1260 & $1.4(\mathrm{~J})$ & 0.74 & $\mathrm{mg} / \mathrm{kg}$ \\
\hline & & & Chlordane & $16(\mathrm{~J})$ & 6.5 & $\mathrm{mg} / \mathrm{kg}$ \\
\hline & & & Benzo(b)fluoranthene & $0.21(\mathrm{~J})$ & 2.1 & $\mathrm{mg} / \mathrm{kg}$ \\
\hline & & & Bis(2-ethylhexyl)phthalate & $0.37(\mathrm{~J})$ & 120 & $\mathrm{mg} / \mathrm{kg}$ \\
\hline & & & Butyl Benzyl Phthalate & $0.23(\mathrm{~J})$ & 910 & $\mathrm{mg} / \mathrm{kg}$ \\
\hline & & & Indeno(1,2,3-cd)Pyrene & $0.1(\mathrm{~J})$ & 2.1 & $\mathrm{mg} / \mathrm{kg}$ \\
\hline
\end{tabular}


Table A.14-2

PSM Results Detected above MDCs for CAS 23-99-06, Grease Trap

(Page 2 of 3 )

\begin{tabular}{|c|c|c|c|c|c|c|}
\hline $\begin{array}{l}\text { Sample } \\
\text { Location }\end{array}$ & $\begin{array}{l}\text { Sample } \\
\text { Number }\end{array}$ & $\begin{array}{c}\text { Sample } \\
\text { Matrix }\end{array}$ & Parameter & Result & $\begin{array}{c}\text { PSM } \\
\text { Criteria }\end{array}$ & Unit \\
\hline \multirow{16}{*}{ L01 } & \multirow{16}{*}{ 562L002 } & \multirow{16}{*}{ Soil } & DRO & $90(\mathrm{~J})$ & N/A & $\mathrm{mg} / \mathrm{kg}$ \\
\hline & & & Arsenic & 16 & 23 & $\mathrm{mg} / \mathrm{kg}$ \\
\hline & & & Barium & 350 & 190,000 & $\mathrm{mg} / \mathrm{kg}$ \\
\hline & & & Cadmium & 9.9 & 800 & $\mathrm{mg} / \mathrm{kg}$ \\
\hline & & & Chromium & $25(\mathrm{~J})$ & 450 & $\mathrm{mg} / \mathrm{kg}$ \\
\hline & & & Lead & 650 & 800 & $\mathrm{mg} / \mathrm{kg}$ \\
\hline & & & Mercury & 0.17 & 34 & $\mathrm{mg} / \mathrm{kg}$ \\
\hline & & & Selenium & 0.5 & 5,100 & $\mathrm{mg} / \mathrm{kg}$ \\
\hline & & & Silver & 0.27 & 5,100 & $\mathrm{mg} / \mathrm{kg}$ \\
\hline & & & Ac-228 & 2 & 5 & $\mathrm{pCi} / \mathrm{g}$ \\
\hline & & & Cs-137 & 0.48 & 12.2 & $\mathrm{pCi} / \mathrm{g}$ \\
\hline & & & Aroclor 1260 & $1.4(\mathrm{~J})$ & 0.74 & $\mathrm{mg} / \mathrm{kg}$ \\
\hline & & & Chlordane & $25(\mathrm{~J})$ & 6.5 & $\mathrm{mg} / \mathrm{kg}$ \\
\hline & & & Benzo(b)fluoranthene & $0.2(\mathrm{~J})$ & 2.1 & $\mathrm{mg} / \mathrm{kg}$ \\
\hline & & & Bis(2-ethylhexyl)phthalate & $0.34(\mathrm{~J})$ & 120 & $\mathrm{mg} / \mathrm{kg}$ \\
\hline & & & Butly Benzyl Phthalate & $0.25(\mathrm{~J})$ & 910 & $\mathrm{mg} / \mathrm{kg}$ \\
\hline \multirow{11}{*}{ L02 } & \multirow{11}{*}{ 562L003 } & \multirow{11}{*}{ Soil } & DRO & $81(\mathrm{~J})$ & N/A & $\mathrm{mg} / \mathrm{kg}$ \\
\hline & & & Arsenic & 16 & 23 & $\mathrm{mg} / \mathrm{kg}$ \\
\hline & & & Barium & 280 & 190,000 & $\mathrm{mg} / \mathrm{kg}$ \\
\hline & & & Cadmium & 8.9 & 800 & $\mathrm{mg} / \mathrm{kg}$ \\
\hline & & & Chromium & $28(\mathrm{~J})$ & 450 & $\mathrm{mg} / \mathrm{kg}$ \\
\hline & & & Lead & 620 & 800 & $\mathrm{mg} / \mathrm{kg}$ \\
\hline & & & Mercury & 0.15 & 34 & $\mathrm{mg} / \mathrm{kg}$ \\
\hline & & & Silver & 0.34 & 5,100 & $\mathrm{mg} / \mathrm{kg}$ \\
\hline & & & Ac-228 & 1.66 & 5 & $\mathrm{pCi} / \mathrm{g}$ \\
\hline & & & Cs-137 & 0.56 & 12.2 & $\mathrm{pCi} / \mathrm{g}$ \\
\hline & & & Aroclor 1260 & $1.1(\mathrm{~J})$ & 0.74 & $\mathrm{mg} / \mathrm{kg}$ \\
\hline
\end{tabular}


Table A.14-2

PSM Results Detected above MDCs for CAS 23-99-06, Grease Trap (Page 3 of 3 )

\begin{tabular}{|c|c|c|c|c|c|c|}
\hline $\begin{array}{l}\text { Sample } \\
\text { Location }\end{array}$ & $\begin{array}{l}\text { Sample } \\
\text { Number }\end{array}$ & $\begin{array}{l}\text { Sample } \\
\text { Matrix }\end{array}$ & Parameter & Result & $\begin{array}{c}\text { PSM } \\
\text { Criteria }\end{array}$ & Unit \\
\hline \multirow{5}{*}{ L02 } & \multirow{5}{*}{$\begin{array}{c}\text { 562L003 } \\
\text { (continued) }\end{array}$} & \multirow{5}{*}{ Soil } & Chlordane & $40(\mathrm{~J})$ & 6.5 & $\mathrm{mg} / \mathrm{kg}$ \\
\hline & & & Benzo(b)fluoranthene & $0.095(\mathrm{~J})$ & 2.1 & $\mathrm{mg} / \mathrm{kg}$ \\
\hline & & & Benzo(g,h,i)perylene & $0.093(\mathrm{~J})$ & 17,000 & $\mathrm{mg} / \mathrm{kg}$ \\
\hline & & & Bis(2-ethylhexyl)phthalate & 0.63 & 120 & $\mathrm{mg} / \mathrm{kg}$ \\
\hline & & & Butyl Benzyl Phthalate & $0.29(\mathrm{~J})$ & 910 & $\mathrm{mg} / \mathrm{kg}$ \\
\hline \multirow{20}{*}{ L03 } & \multirow{20}{*}{ 562L004 } & \multirow{20}{*}{ Soil } & DRO & $150(\mathrm{~J})$ & $\mathrm{N} / \mathrm{A}$ & $\mathrm{mg} / \mathrm{kg}$ \\
\hline & & & Arsenic & 24 & 23 & $\mathrm{mg} / \mathrm{kg}$ \\
\hline & & & Barium & 240 & 190,000 & $\mathrm{mg} / \mathrm{kg}$ \\
\hline & & & Cadmium & 9.1 & 800 & $\mathrm{mg} / \mathrm{kg}$ \\
\hline & & & Chromium & $25(J)$ & 450 & $\mathrm{mg} / \mathrm{kg}$ \\
\hline & & & Lead & 760 & 800 & $\mathrm{mg} / \mathrm{kg}$ \\
\hline & & & Mercury & 0.22 & 34 & $\mathrm{mg} / \mathrm{kg}$ \\
\hline & & & Selenium & 0.48 & 5,100 & $\mathrm{mg} / \mathrm{kg}$ \\
\hline & & & Silver & 0.24 & 5,100 & $\mathrm{mg} / \mathrm{kg}$ \\
\hline & & & Ac-228 & 1.79 & 5 & $\mathrm{pCi} / \mathrm{g}$ \\
\hline & & & Cs-137 & 0.62 & 12.2 & $\mathrm{pCi} / \mathrm{g}$ \\
\hline & & & Aroclor 1260 & $1.3(\mathrm{~J})$ & 0.74 & $\mathrm{mg} / \mathrm{kg}$ \\
\hline & & & Chlordane & $18(\mathrm{~J})$ & 6.5 & $\mathrm{mg} / \mathrm{kg}$ \\
\hline & & & Benzo(a)pyrene & $0.078(\mathrm{~J})$ & 0.21 & $\mathrm{mg} / \mathrm{kg}$ \\
\hline & & & Benzo(b)fluoranthene & $0.16(\mathrm{~J})$ & 120 & $\mathrm{mg} / \mathrm{kg}$ \\
\hline & & & Benzo(g,h,i)perylene & $0.31(\mathrm{~J})$ & 17,000 & $\mathrm{mg} / \mathrm{kg}$ \\
\hline & & & Bis(2-ethylhexyl)phthalate & 0.53 & 120 & $\mathrm{mg} / \mathrm{kg}$ \\
\hline & & & Butyl Benzyl Phthalate & 0.48 & 910 & $\mathrm{mg} / \mathrm{kg}$ \\
\hline & & & Indeno(1,2,3-cd)Pyrene & $0.21(\mathrm{~J})$ & 2.1 & $\mathrm{mg} / \mathrm{kg}$ \\
\hline & & & Pyrene & $0.095(\mathrm{~J})$ & 17,000 & $\mathrm{mg} / \mathrm{kg}$ \\
\hline
\end{tabular}

$\mathrm{J}=$ Estimated value

Bold indicates the value is equal to or exceeds the PSM criteria. 


\section{A.14.5 Revised Conceptual Site Model}

The CAIP requirements were met at this CAS, and no revisions were necessary to the CSM. 


\section{A.15.0 CAS 25-60-04, Building 3123 Outfalls, Investigation Results}

Corrective Action Site 25-60-04 is located adjacent to Building 3123, Technical Services, which contained a laboratory, shop, and office space in Area 25 (Figure 1-2). The CAS consists of the potential releases to the soil from two outfalls referred to as Drain A and Drain B. Drain A initially received effluent from laboratories whereas Drain B received effluent from a floor drain from a room with unknown use. Both drains were designed to discharge to daylight. Recent activities in the building inadvertently discharged effluent to the outfalls. Drain A received effluent from the main kitchen, whereas Drain B received effluent from a smaller kitchen. Although the building remains active, all discharges to the outfalls have ceased and the outfalls are inactive. Figure A.15-1 shows the sample locations and photographs of CAS 25-60-04.

\section{A.15.1 Corrective Action Investigation Activities}

A total of 47 environmental samples (including 3 FDs) and 1 PSM sample were collected during investigation activities at CAS 25-60-04. The sample IDs, locations, types, and analyses are listed in Table A.15-1. The specific CAI activities conducted to satisfy the CAIP requirements at this CAS are described in the following sections.

\section{A.15.1.1 Visual Inspections}

Drain A - The outfall was previously removed during a renovation of a sewer line in the area. There were requirements for remaining $5.0 \mathrm{ft}$ away from the reconfigured active sewer line so the area sampled (location M01) was $5.0 \mathrm{ft}$ from the original opening of the outfall. The sampling interval was accessed by hand digging $5.0 \mathrm{ft}$ west of the active sewer line and then moving $2.0 \mathrm{ft}$ east toward the former location of the original outfall opening of Drain A. A second sample, location M02, was marked $100.00 \mathrm{ft}$ south of the original outfall opening. The sampling interval was accessed by hand digging $5.0 \mathrm{ft}$ south of this location because of the active sewer line. No biasing factors, such as staining, debris, and odor, were identified in the subsurface.

Drain B - The Drain B outfall was uncovered at $1.0 \mathrm{ft}$ bgs by hand digging $47.0 \mathrm{ft}$ south of Building 3123. The drain consists of a 4.0-in. vitrified clay pipe with sludge contents and is underlain 


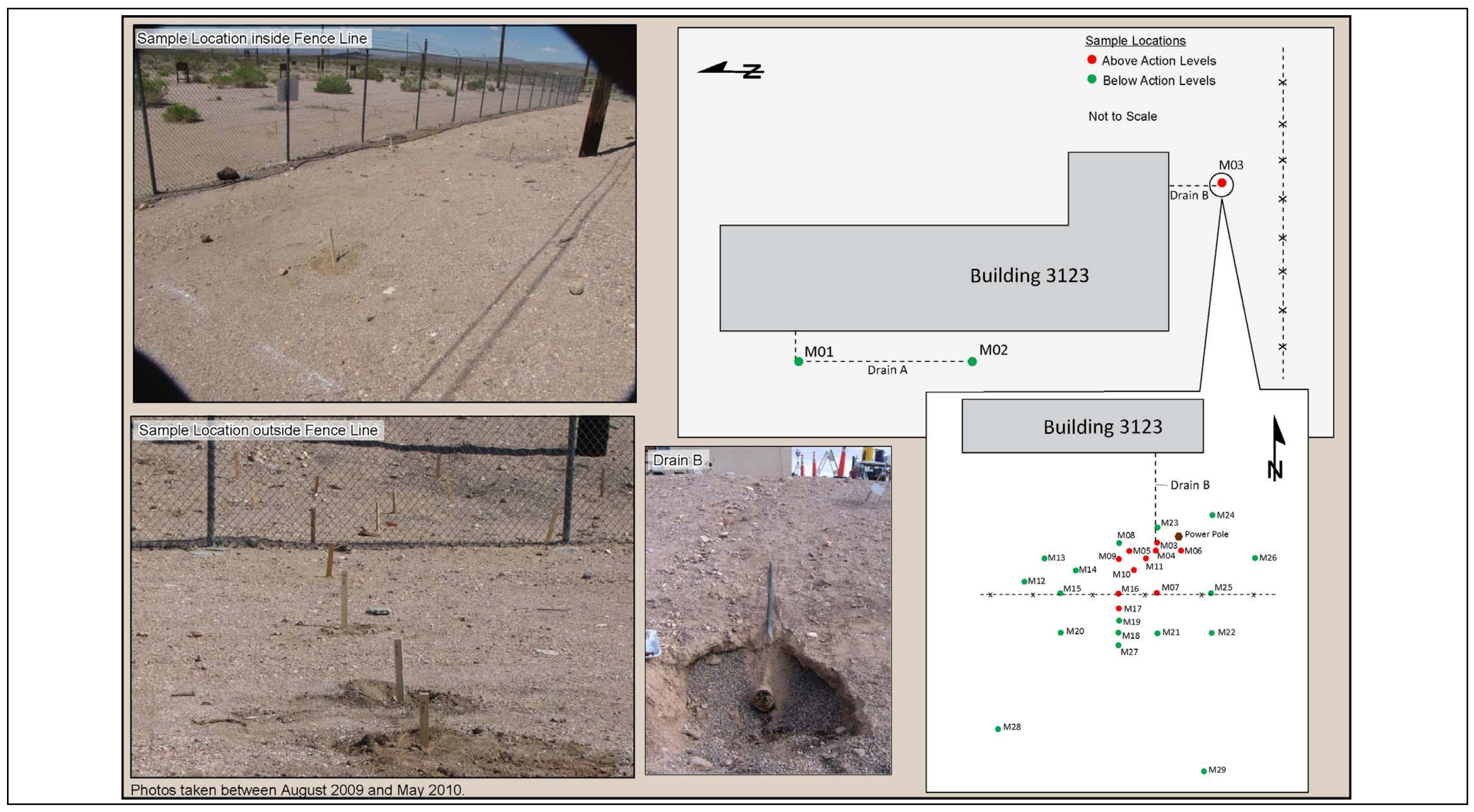

Sample Locations at CAS 25-60-04, Building 3123 Outfalls 
Table A.15-1

Samples Collected at CAS 25-60-04, Building 3123 Outfalls

(Page 1 of 3 )

\begin{tabular}{|c|c|c|c|c|c|c|c|c|c|c|c|c|c|}
\hline $\begin{array}{l}\text { Sample } \\
\text { Location }\end{array}$ & $\begin{array}{l}\text { Sample } \\
\text { Number }\end{array}$ & $\begin{array}{l}\text { Depth } \\
\text { (ft bgs) }\end{array}$ & Matrix & Purpose & $\begin{array}{l}\text { 우 } \\
\text { 吕 }\end{array}$ & 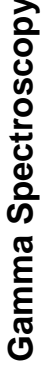 & $\frac{\frac{0}{\pi}}{\frac{\pi}{0}}$ & 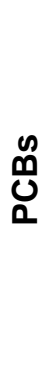 & $\begin{array}{l}\text { Uू } \\
\text { o }\end{array}$ & 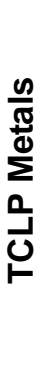 & 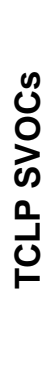 & 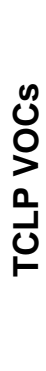 & $\begin{array}{l}\text { Uू } \\
\text { g }\end{array}$ \\
\hline M01 & 562M001 & $3.0-3.5$ & Soil & Environmental & $x$ & $x$ & $x$ & $X$ & $x$ & $X$ & $x$ & $x$ & $X$ \\
\hline \multirow[b]{2}{*}{ M02 } & 562M002 & $3.0-3.5$ & Soil & Environmental & $x$ & $x$ & $x$ & $X$ & $x$ & $x$ & $x$ & $x$ & $x$ \\
\hline & $562 \mathrm{M} 003$ & $3.0-3.5$ & Soil & $\begin{array}{c}\text { FD } \\
\text { of } \# 562 \mathrm{M002}\end{array}$ & $x$ & $X$ & $x$ & $x$ & $\mathrm{x}$ & -- & -- & -- & $X$ \\
\hline \multirow{3}{*}{ M03 } & 562M004 & $1.5-2.0$ & Soil & Environmental & $x$ & $x$ & $x$ & $x$ & $x$ & $x$ & $x$ & $x$ & $\mathrm{X}$ \\
\hline & 562M005 & $1.0-1.5$ & Sludge & PSM & $X$ & $X$ & $x$ & $X$ & $x$ & $X$ & -- & -- & 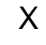 \\
\hline & 562M006 & $3.0-3.5$ & Soil & Environmental & $X$ & $X$ & $X$ & $x$ & $x$ & -- & -- & -- & $X$ \\
\hline \multirow{3}{*}{ M04 } & $562 \mathrm{M} 007$ & $0.5-1.0$ & Soil & Environmental & -- & -- & -- & $x$ & -- & -- & -- & -- & -- \\
\hline & $562 \mathrm{M} 012$ & $3.0-3.5$ & Soil & Environmental & -- & -- & -- & $x$ & -- & -- & -- & -- & -- \\
\hline & 562M029 & $0.0-0.5$ & Soil & Environmental & -- & -- & -- & $X$ & -- & -- & -- & -- & -- \\
\hline M05 & 562M008 & $0.5-1.0$ & Soil & Environmental & -- & -- & -- & $x$ & -- & -- & -- & -- & -- \\
\hline \multirow{3}{*}{ M06 } & 562M009 & $0.5-1.0$ & Soil & Environmental & -- & -- & -- & $X$ & -- & -- & -- & -- & -- \\
\hline & $562 \mathrm{M} 030$ & $0.0-0.5$ & Soil & Environmental & -- & -- & -- & $x$ & -- & -- & -- & -- & -- \\
\hline & $562 \mathrm{M} 031$ & $0.0-0.5$ & Soil & $\begin{array}{c}\text { FD } \\
\text { of \#562M030 }\end{array}$ & -- & -- & -- & $X$ & -- & -- & -- & -- & -- \\
\hline \multirow{2}{*}{ M07 } & $562 \mathrm{M} 010$ & $0.5-1.0$ & Soil & Environmental & -- & -- & -- & $x$ & -- & -- & -- & -- & -- \\
\hline & $562 \mathrm{M} 032$ & $0.0-0.5$ & Soil & Environmental & -- & -- & -- & $X$ & -- & -- & -- & -- & -- \\
\hline \multirow{2}{*}{ M08 } & 562M011 & $0.5-1.0$ & Soil & Environmental & -- & -- & -- & $x$ & -- & -- & -- & -- & -- \\
\hline & 562М033 & $0.0-0.5$ & Soil & Environmental & -- & -- & -- & $X$ & -- & -- & -- & -- & -- \\
\hline M09 & $562 \mathrm{M} 013$ & $0.5-1.0$ & Soil & Environmental & -- & -- & -- & $x$ & -- & -- & -- & -- & -- \\
\hline M10 & $562 \mathrm{M} 014$ & $0.5-1.0$ & Soil & Environmental & -- & -- & -- & $x$ & -- & -- & -- & -- & -- \\
\hline \multirow{3}{*}{ M11 } & 562M015 & $0.0-0.5$ & Soil & Environmental & -- & -- & -- & $x$ & -- & -- & -- & -- & -- \\
\hline & 562M016 & $0.5-1.0$ & Soil & Environmental & -- & -- & -- & $X$ & -- & -- & -- & -- & -- \\
\hline & 562M017 & $3.0-3.5$ & Soil & Environmental & -- & -- & -- & $X$ & -- & -- & -- & -- & -- \\
\hline
\end{tabular}


Table A.15-1

Samples Collected at CAS 25-60-04, Building 3123 Outfalls

(Page 2 of 3 )

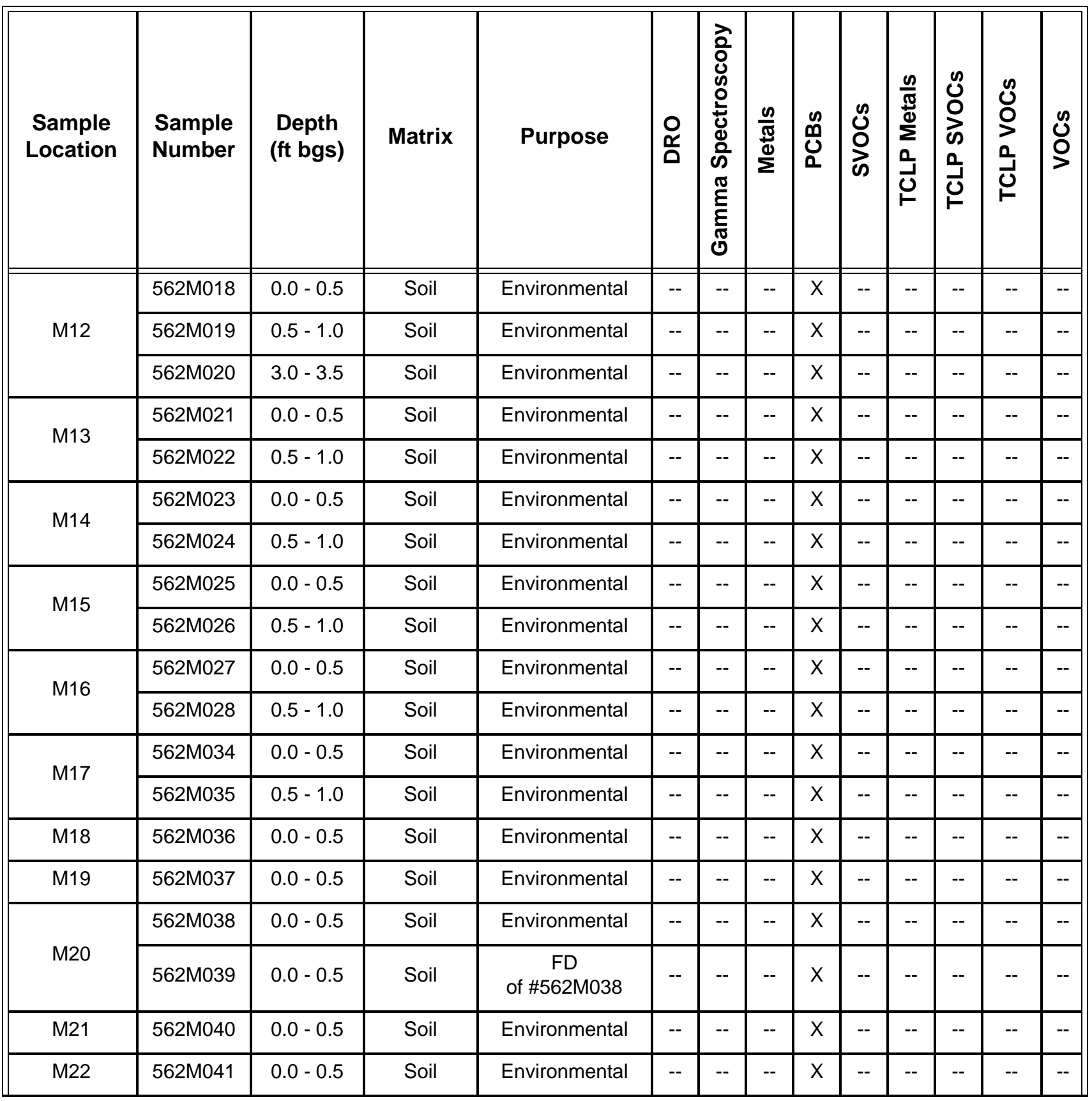


Table A.15-1

Samples Collected at CAS 25-60-04, Building 3123 Outfalls

(Page 3 of 3 )

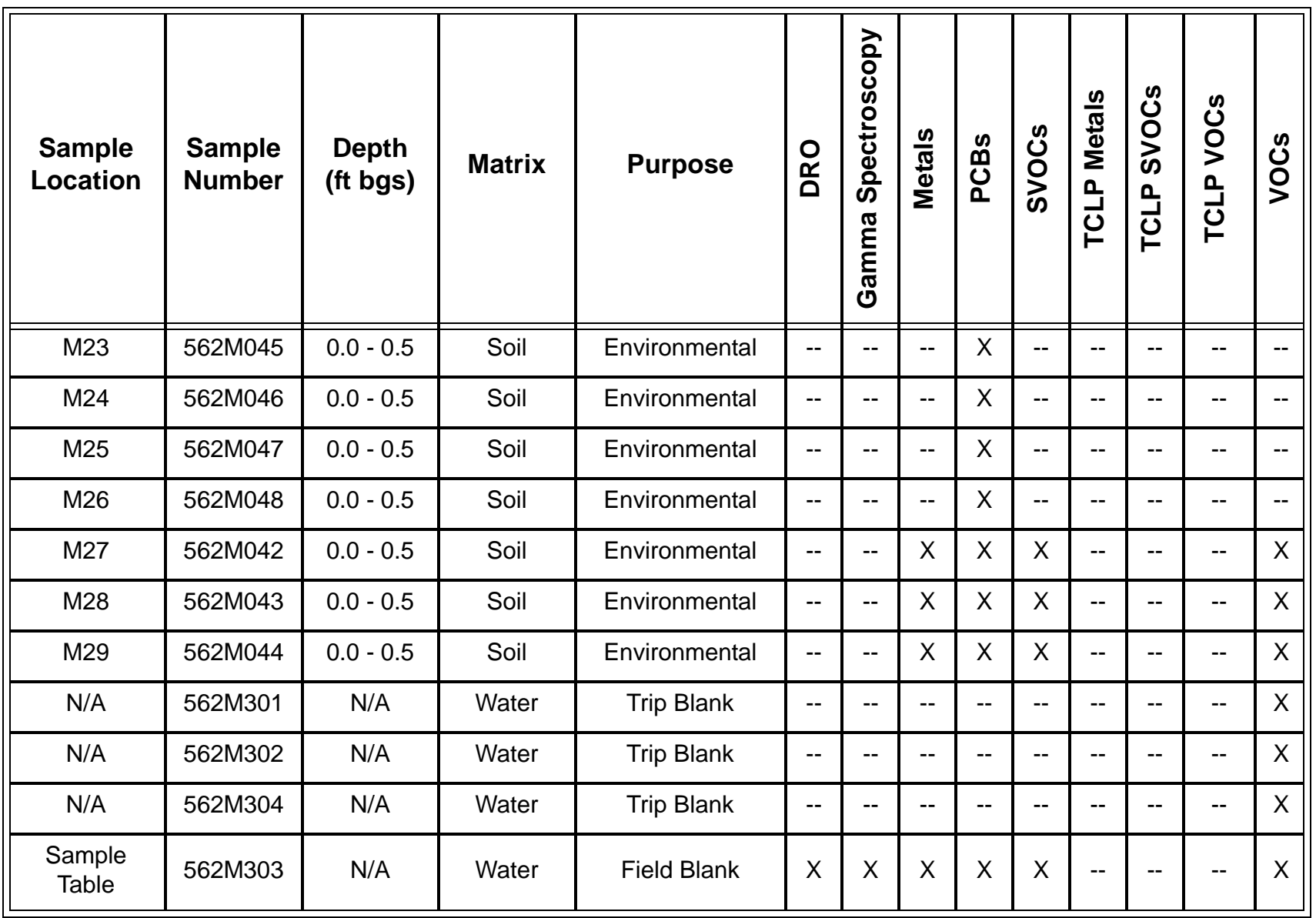

$--=$ Not required

by 19.0 in. of pea gravel, some of which is stained. The native soil interface was approximately $3.0 \mathrm{ft}$ bgs.

\section{A.15.1.2 Sample Collection}

Sampling activities included the collection of 47 (including 3 FDs) environmental surface and subsurface samples and 1 PSM sample from 29 locations. All sample locations are shown in Figure A.15-1. The sampling activities are discussed below.

Drain A - At Drain A, sample 562M001 was collected $3.0 \mathrm{ft}$ away from the elbow (location M01), which was the original outfall opening (25.0 ft west of Building 3123). This sample was collected 
from 3.0 to $3.5 \mathrm{ft}$ bgs and consisted of native, well-sorted sand with moderate gravel. Samples 562M002 and FD 562M003 were collected at location M02, $5.0 \mathrm{ft}$ away from the reconfigured outfall opening (approximately $100.0 \mathrm{ft}$ south of location M01). These samples also consisted of native soil and were collected at a depth of 3.0 to $3.5 \mathrm{ft}$ bgs.

Drain B - At Drain B, sample 562M004 was collected directly below the outfall pipe (location M03) at 1.5 to $2.0 \mathrm{ft}$ bgs and consisted of moist sand mixed with pea gravel with a septic odor and dark staining. Sample 562M005 is a sample of the sludge contents inside the outfall pipe and was collected from within the pipe at a depth of 1.0 to $1.5 \mathrm{ft}$ bgs. This sample consisted of dark, mottled sludge with a strong septic odor and some miscellaneous debris. Sample 562M006 was collected at the native soil interface with the pea gravel, directly below the outfall pipe, at a depth of 3.0 to $3.5 \mathrm{ft}$ bgs. This sample consisted of well-sorted moist sand.

Based on the results of Decision I samples collected at Drain B, Decision II environmental samples (562M007 through 562M048) were collected from locations M04 through M29 using an iterative approach between November 4, 2009, and May 12, 2010. During sampling, broken pieces of vitrified clay pipe were identified near the end of the pipe. This, along with knowledge of the original termination point of the outfall, indicated that the outfall pipe had been cut. The disturbance of soil to reconfigure the outfall resulted in a distribution of contamination that was not consistent with what was expected (i.e., contaminants present at the surface interval). Surface and subsurface samples, to a depth of $3.5 \mathrm{ft}$ bgs, were collected in both areas most likely to be impacted by effluent flow from the pipe (in both the original and altered outfall locations) and beyond where the effluent would be expected in order to bound the contamination.

\section{A.15.1.3 Deviations}

Investigation samples were collected as outlined in the CAU 562 CAIP and submitted for laboratory analysis. However, additional biased samples were collected at Drain B due to the presence of PSM.

\section{A.15.2 Investigation Results}

The following sections provide analytical results from the samples collected to complete investigation activities as outlined in the CAIP (NNSA/NSO, 2009). The analytical parameters and 
laboratory methods used to analyze the investigation samples are listed in Table A.2-2. Table A.15-1 lists the sample-specific analytical suite for CAS 25-60-04.

Analytical results from the soil samples with concentrations exceeding MDCs are summarized in the following sections. An evaluation was conducted on all contaminants detected above MDCs by comparing individual concentration or activity results against the FALs. Establishment of the FALs is presented in Appendix D. The FALs were established as the corresponding PAL concentrations or activities if the contaminant concentrations were below their respective PALs.

\section{A.15.2.1 Volatile Organic Compounds}

Analytical results for VOCs in soil samples collected at this CAS that were detected above MDCs are presented in Table A.15-2. No VOCs were detected at concentrations exceeding their respective PALs. The FALs were established at the PAL concentrations.

Table A.15-2

Sample Results for Total VOCs Detected above MDCs at CAS 25-60-04, Building 3123 Outfalls

\begin{tabular}{|c|c|c|c|c|c|c||}
\hline \multirow{2}{*}{$\begin{array}{c}\text { Sample } \\
\text { Location }\end{array}$} & \multirow{2}{*}{$\begin{array}{c}\text { Sample } \\
\text { Number }\end{array}$} & \multirow{2}{*}{$\begin{array}{c}\text { Depth } \\
\text { (ft bgs) }\end{array}$} & \multicolumn{5}{|c|}{ COPCs (mg/kg) } \\
\cline { 4 - 7 } & & & Acetone & $\begin{array}{c}\text { Carbon } \\
\text { Tetrachloride }\end{array}$ & Chloroform & $\begin{array}{c}\text { Methylene } \\
\text { chloride }\end{array}$ \\
\hline \multirow{2}{*}{ FALs } & & $\mathbf{6 3 0 , 0 0 0}$ & 1.2 & 1.5 & 53 \\
\hline \hline M01 & $562 \mathrm{M} 001$ & $3.0-3.5$ & -- & -- & -- & $0.0035(\mathrm{~J})$ \\
\hline \multirow{2}{*}{ M02 } & $562 \mathrm{M} 002$ & $3.0-3.5$ & -- & -- & -- & $0.0035(\mathrm{~J})$ \\
\cline { 2 - 8 } & $562 \mathrm{M} 003$ & $3.0-3.5$ & -- & -- & -- & $0.0037(\mathrm{~J})$ \\
\hline \multirow{2}{*}{ M03 } & $562 \mathrm{M} 004$ & $1.5-2.0$ & -- & -- & -- & $0.0042(\mathrm{~J})$ \\
\cline { 2 - 8 } & $562 \mathrm{M} 006$ & $3.0-3.5$ & -- & -- & -- & $0.0035(\mathrm{~J})$ \\
\hline M29 & $562 \mathrm{M} 044$ & $0.0-0.5$ & 0.024 & $0.0027(\mathrm{~J})$ & $0.0024(\mathrm{~J})$ & -- \\
\hline
\end{tabular}

$--=$ Not detected above MDCs.

$\mathrm{J}=$ Estimated value 


\section{A.15.2.2 Semivolatile Organic Compounds}

Analytical results for SVOCs in soil samples collected at this CAS that were detected above MDCs are presented in Table A.15-3. No SVOCs were detected at concentrations exceeding the respective PALs. The FALs were established at the PAL concentrations.

Table A.15-3

Sample Results for Total SVOCs Detected above MDCs at CAS 25-60-04, Building 3123 Outfalls

\begin{tabular}{|c|c|c|c|c|c|}
\hline \multirow[b]{2}{*}{$\begin{array}{l}\text { Sample } \\
\text { Location }\end{array}$} & \multirow[b]{2}{*}{$\begin{array}{l}\text { Sample } \\
\text { Number }\end{array}$} & \multirow[b]{2}{*}{$\begin{array}{c}\text { Depth } \\
\text { (ft bgs) }\end{array}$} & \multicolumn{3}{|c|}{ COPCs (mg/kg) } \\
\hline & & & 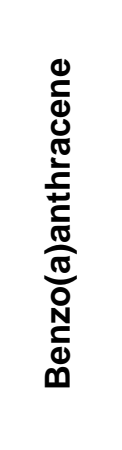 & 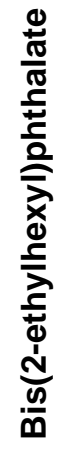 & \\
\hline \multicolumn{3}{|c|}{ FALs } & 2.1 & 120 & 17,000 \\
\hline M03 & 562M004 & $1.5-2.0$ & -- & 1.1 & -- \\
\hline M28 & $562 \mathrm{M} 043$ & $0.0-0.5$ & $0.11(\mathrm{~J})$ & -- & $0.088(\mathrm{~J})$ \\
\hline
\end{tabular}

$--=$ Not detected above MDCs.

$\mathrm{J}=$ Estimated value

\section{A.15.2.3 Total Petroleum Hydrocarbons}

Analytical results for TPH-DRO in soil samples collected at this CAS that were detected above MDCs are presented in Table A.15-4. No TPH-DRO was detected at concentrations exceeding the PALs. The FAL was established at the PAL concentrations for hazardous constituents of TPH-DRO.

\section{A.15.2.4 Resource Conservation and Recovery Act Metals}

Analytical results for RCRA metals in soil samples collected at this CAS that were detected above MDCs are presented in Table A.15-5. No RCRA metals were detected at concentrations exceeding their PALs. The FALs were established at the PAL concentrations. 
Table A.15-4

Sample Results for TPH-DRO Detected above MDCs at CAS 25-60-04, Building 3123 Outfalls

\begin{tabular}{|c|c|c|c||}
\hline \multirow{2}{*}{$\begin{array}{c}\text { Sample } \\
\text { Location }\end{array}$} & $\begin{array}{c}\text { Sample } \\
\text { Number }\end{array}$ & $\begin{array}{c}\text { Depth } \\
\text { (ft bgs) }\end{array}$ & COPCs (mg/kg) \\
\cline { 4 - 5 } & & & 100 \\
\hline \hline \multirow{2}{*}{ M02 } & $562 \mathrm{M} 002$ & $3.0-3.5$ & $28(\mathrm{~J})$ \\
\cline { 2 - 5 } & $562 \mathrm{M} 003$ & $3.0-3.5$ & $13(\mathrm{~J})$ \\
\hline \multirow{2}{*}{ M03 } & $562 \mathrm{M} 004$ & $1.5-2.0$ & $10(\mathrm{~J})$ \\
\cline { 2 - 5 } & $562 \mathrm{M} 006$ & $3.0-3.5$ & $6.2(\mathrm{~J})$ \\
\hline
\end{tabular}

$\mathrm{J}=$ Estimated value

Table A.15-5

Sample Results for Metals Detected above MDCs at CAS 25-60-04, Building 3123 Outfalls

\begin{tabular}{|c|c|c|c|c|c|c|c|c|c|c|}
\hline \multirow[b]{2}{*}{$\begin{array}{l}\text { Sample } \\
\text { Location }\end{array}$} & \multirow[b]{2}{*}{$\begin{array}{l}\text { Sample } \\
\text { Number }\end{array}$} & \multirow[b]{2}{*}{$\begin{array}{l}\text { Depth } \\
\text { (ft bgs) }\end{array}$} & \multicolumn{8}{|c|}{ COPCs (mg/kg) } \\
\hline & & & $\begin{array}{l}\frac{0}{c} \\
\frac{\tilde{d}}{2} \\
\frac{\omega}{\alpha}\end{array}$ & 立 & 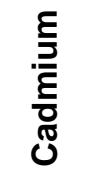 & 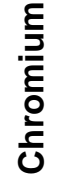 & ర్త్ర & 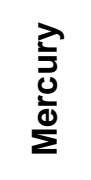 & 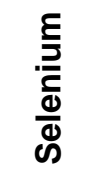 & 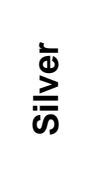 \\
\hline \multicolumn{3}{|c|}{ FALs } & 23 & 190,000 & 800 & 450 & 800 & 34 & 5,100 & 5,100 \\
\hline M01 & 562M001 & $3.0-3.5$ & 2.3 & 120 & 0.049 & 3.1 & 4.7 & 0.051 & -- & -- \\
\hline \multirow{2}{*}{ M02 } & 562M002 & $3.0-3.5$ & 3 & 98 & 0.057 & 3.4 & 5.4 & -- & -- & -- \\
\hline & $562 \mathrm{M} 003$ & $3.0-3.5$ & 2.9 & 88 & 0.062 & 3.3 & 5.5 & -- & -- & -- \\
\hline \multirow{2}{*}{ M03 } & 562M004 & $1.5-2.0$ & 2.4 & 130 & 2.1 & 4.1 & 20 & 0.064 & -- & 0.21 \\
\hline & 562M006 & $3.0-3.5$ & 2.3 & 84 & 2.5 & 3.4 & 13 & 0.051 & -- & 0.37 \\
\hline M27 & 562M042 & $0.0-0.5$ & 4 & 110 & 0.18 & 4.3 & 8.6 & -- & 0.36 & -- \\
\hline M28 & $562 \mathrm{M} 043$ & $0.0-0.5$ & 2.8 & 110 & 0.18 & 3.7 & 14 & -- & 0.41 & -- \\
\hline M29 & $562 \mathrm{M} 044$ & $0.0-0.5$ & 3.1 & 110 & 0.5 & 5.2 & 39 & -- & -- & -- \\
\hline
\end{tabular}

-- = Not detected above MDCs. 


\section{A.15.2.5 Polychlorinated Biphenyls}

Analytical results for PCBs in soil samples collected at this CAS that were detected above MDCs are presented in Table A.15-6. Twelve samples (including one FD) exceeded the PAL of $0.74 \mathrm{mg} / \mathrm{kg}$ for Aroclor 1254 . Concentrations ranged from 0.78 to $11.0 \mathrm{mg} / \mathrm{kg}$ at depth intervals ranging from 0.0 to $2.0 \mathrm{ft}$ bgs. The FAL was established at the PAL concentration; therefore, Aroclor 1254 is considered a COC. Additional soil samples were collected at distances ranging from 2.0 to $30.0 \mathrm{ft}$ from the outfall at varying depth intervals (including the same depth interval as the location of the COC). These soil samples show that the PCBs are limited to the 0.0- to 2.0-ft-bgs interval and that concentrations decrease to below the FALs with distance from the outfall.

Table A.15-6

Sample Results for PCBs Detected above MDCs at CAS 25-60-04, Building 3123 Outfalls (Page 1 of 2)

\begin{tabular}{|c|c|c|c|c|}
\hline \multirow{2}{*}{$\begin{array}{l}\text { Sample } \\
\text { Location }\end{array}$} & \multirow{2}{*}{$\begin{array}{l}\text { Sample } \\
\text { Number }\end{array}$} & \multirow{2}{*}{$\begin{array}{l}\text { Depth } \\
\text { (ft bgs) }\end{array}$} & \multicolumn{2}{|c|}{ COPCs (mg/kg) } \\
\hline & & & \multirow{2}{*}{$\begin{array}{c}\text { Aroclor } 1254 \\
0.74\end{array}$} & Aroclor 1260 \\
\hline \multicolumn{3}{|c|}{ FALs } & & 0.74 \\
\hline \multirow[t]{2}{*}{ M03 } & $562 \mathrm{M} 004$ & $1.5-2.0$ & $1.4(\mathrm{~J})$ & -- \\
\hline & 562M006 & $3.0-3.5$ & 0.29 & -- \\
\hline \multirow{3}{*}{ M04 } & $562 \mathrm{M} 007$ & $0.5-1.0$ & $5.9(\mathrm{~J})$ & -- \\
\hline & $562 \mathrm{M} 012$ & $3.0-3.5$ & 0.15 & -- \\
\hline & $562 \mathrm{M} 029$ & $0.0-0.5$ & $1.4(\mathrm{~J})$ & -- \\
\hline M05 & 562M008 & $0.5-1.0$ & $1.7(\mathrm{~J})$ & -- \\
\hline \multirow{3}{*}{ M06 } & 562M009 & $0.5-1.0$ & 0.11 & -- \\
\hline & $562 \mathrm{M} 030$ & $0.0-0.5$ & $1.5(\mathrm{~J})$ & -- \\
\hline & $562 \mathrm{M} 031$ & $0.0-0.5$ & $1.3(\mathrm{~J})$ & -- \\
\hline \multirow{2}{*}{ M07 } & $562 \mathrm{M} 010$ & $0.5-1.0$ & 0.28 & -- \\
\hline & $562 \mathrm{M} 032$ & $0.0-0.5$ & $0.78(\mathrm{~J})$ & -- \\
\hline \multirow{2}{*}{ M08 } & $562 \mathrm{M} 011$ & $0.5-1.0$ & 0.024 & -- \\
\hline & $562 \mathrm{M} 033$ & $0.0-0.5$ & 0.2 & -- \\
\hline M09 & 562M013 & $0.5-1.0$ & $2.6(\mathrm{~J})$ & -- \\
\hline M10 & 562M014 & $0.5-1.0$ & $2.8(\mathrm{~J})$ & -- \\
\hline
\end{tabular}


Table A.15-6

Sample Results for PCBs Detected above MDCs at CAS 25-60-04, Building 3123 Outfalls (Page 2 of 2)

\begin{tabular}{|c|c|c|c|c|}
\hline \multirow{2}{*}{$\begin{array}{l}\text { Sample } \\
\text { Location }\end{array}$} & \multirow{2}{*}{$\begin{array}{l}\text { Sample } \\
\text { Number }\end{array}$} & \multirow{2}{*}{$\begin{array}{l}\text { Depth } \\
\text { (ft bgs) }\end{array}$} & \multicolumn{2}{|c|}{ COPCs (mg/kg) } \\
\hline & & & Aroclor 1254 & Aroclor 1260 \\
\hline \multicolumn{3}{|c|}{ FALs } & 0.74 & 0.74 \\
\hline \multirow{3}{*}{ M11 } & 562M015 & $0.0-0.5$ & $11(\mathrm{~J})$ & -- \\
\hline & 562M016 & $0.5-1.0$ & 0.18 & -- \\
\hline & 562M017 & $3.0-3.5$ & 0.11 & -- \\
\hline M12 & 562M018 & $0.0-0.5$ & $0.01(\mathrm{~J})$ & -- \\
\hline M13 & $562 \mathrm{M} 021$ & $0.0-0.5$ & $0.12(\mathrm{~J})$ & -- \\
\hline \multirow{2}{*}{ M14 } & $562 \mathrm{M} 023$ & $0.0-0.5$ & $0.065(\mathrm{~J})$ & -- \\
\hline & $562 \mathrm{M} 024$ & $0.5-1.0$ & $0.6(\mathrm{~J})$ & -- \\
\hline M15 & $562 \mathrm{M} 025$ & $0.0-0.5$ & $0.69(\mathrm{~J})$ & -- \\
\hline \multirow{2}{*}{ M16 } & $562 \mathrm{M} 027$ & $0.0-0.5$ & $4(\mathrm{~J})$ & -- \\
\hline & 562M028 & $0.5-1.0$ & $0.18(\mathrm{~J})$ & -- \\
\hline \multirow{2}{*}{ M17 } & 562M034 & $0.0-0.5$ & $0.78(\mathrm{~J})$ & -- \\
\hline & 562M035 & $0.5-1.0$ & 0.027 & -- \\
\hline M19 & 562M037 & $0.0-0.5$ & 0.13 & 0.025 \\
\hline \multirow{2}{*}{ M20 } & 562M038 & $0.0-0.5$ & 0.12 & 0.023 \\
\hline & 562M039 & $0.0-0.5$ & 0.13 & $0.017(\mathrm{~J})$ \\
\hline M21 & $562 \mathrm{M} 040$ & $0.0-0.5$ & 0.3 & $0.026(\mathrm{~J})$ \\
\hline M22 & 562M041 & $0.0-0.5$ & 0.085 & $0.019(\mathrm{~J})$ \\
\hline M23 & $562 \mathrm{M} 045$ & $0.0-0.5$ & -- & 0.14 \\
\hline M24 & 562M046 & $0.0-0.5$ & -- & 0.035 \\
\hline M25 & $562 \mathrm{M} 047$ & $0.0-0.5$ & 0.3 & 0.16 \\
\hline M26 & 562M048 & $0.0-0.5$ & -- & 0.064 \\
\hline
\end{tabular}

$\mathrm{J}=$ Estimated value

Bold indicates the value is equal to or exceeds the FAL. 


\section{A.15.2.6 Gamma-Emitting Radionuclides}

Analytical results for gamma-emitting radionuclides in soil samples collected at this CAS that were detected above MDCs are presented in Table A.15-7. No gamma-emitting radionuclides were detected at concentrations exceeding their PALs. The FALs were established at the PAL concentrations.

Table A.15-7

Sample Results for Gamma-Emitting Radionuclides Detected above MDCs at CAS 25-60-04, Building 3123 Outfalls

\begin{tabular}{|c|c|c|c|c||}
\hline \multirow{2}{*}{$\begin{array}{c}\text { Sample } \\
\text { Location }\end{array}$} & \multirow{2}{*}{$\begin{array}{c}\text { Sample } \\
\text { Number }\end{array}$} & \multirow{2}{*}{$\begin{array}{c}\text { Depth } \\
\text { (ft bgs) }\end{array}$} & \multicolumn{2}{c|}{ COPCs (pCi/g) } \\
\cline { 4 - 5 } & & & Ac-228 & Th-234 \\
\hline \multirow{3}{*}{ FALs } & & $\mathbf{5}$ & $\mathbf{1 0 5}$ \\
\hline \hline M01 & $562 \mathrm{M} 001$ & $3.0-3.5$ & 2.08 & -- \\
\hline \multirow{2}{*}{ M02 } & $562 \mathrm{M} 002$ & $3.0-3.5$ & 1.68 & -- \\
\cline { 2 - 5 } & $562 \mathrm{M} 003$ & $3.0-3.5$ & 2.08 & $2.36(\mathrm{~J})$ \\
\hline \multirow{2}{*}{ M03 } & $562 \mathrm{M} 004$ & $1.5-2.0$ & 1.65 & -- \\
\cline { 2 - 5 } & $562 \mathrm{M} 006$ & $3.0-3.5$ & 1.76 & -- \\
\hline
\end{tabular}

-- = Not detected above MDCs.

$\mathrm{J}=$ Estimated value

\section{A.15.3 Potential Source Material Sample Results}

Analytical results for the PSM samples collected at this CAS that were detected above MDCs are presented in Table A.15-8. Medium sampled consisted of sludge from the outfall piping. The sludge sample contained TPH-DRO at a concentration of 3,500 mg/kg, which exceeded the PAL concentration of $100 \mathrm{mg} / \mathrm{kg}$. The TPH-DRO was moved on to a Tier 2 evaluation, and PSM criteria were established for the hazardous constituents of TPH-DRO. Concentrations of the hazardous constituents of TPH-DRO did not exceed PSM criteria. Therefore, they are not considered PSM contaminants.

Lead and Aroclor 1254 were also found at concentrations exceeding their respective PSM criteria. Lead was detected at a concentration of $970 \mathrm{mg} / \mathrm{kg}$, and Aroclor 1254 was detected at a concentration of $8.7 \mathrm{mg} / \mathrm{kg}$. Based on these results, the sludge in the pipe is considered PSM. 
Table A.15-8

PSM Results Detected above MDCs for CAS 25-60-04, Building 3123 Outfalls

\begin{tabular}{|c|c|c|c|c|c|c|}
\hline $\begin{array}{l}\text { Sample } \\
\text { Location }\end{array}$ & $\begin{array}{l}\text { Sample } \\
\text { Number }\end{array}$ & $\begin{array}{l}\text { Sample } \\
\text { Matrix }\end{array}$ & Parameter & Result & $\begin{array}{c}\text { PSM } \\
\text { Criteria }\end{array}$ & Unit \\
\hline \multirow{16}{*}{ M03 } & \multirow{16}{*}{ 562M005 } & \multirow{16}{*}{ Sludge } & DRO & $3,500(\mathrm{~J})$ & $\mathrm{N} / \mathrm{A}$ & $\mathrm{mg} / \mathrm{kg}$ \\
\hline & & & Arsenic & $2.8(\mathrm{~J}+)$ & 23 & $\mathrm{mg} / \mathrm{kg}$ \\
\hline & & & Barium & 150 & 190,000 & $\mathrm{mg} / \mathrm{kg}$ \\
\hline & & & Cadmium & 19 & 800 & $\mathrm{mg} / \mathrm{kg}$ \\
\hline & & & Chromium & 130 & 450 & $\mathrm{mg} / \mathrm{kg}$ \\
\hline & & & Lead & 970 & 800 & $\mathrm{mg} / \mathrm{kg}$ \\
\hline & & & Mercury & 0.74 & 34 & $\mathrm{mg} / \mathrm{kg}$ \\
\hline & & & Selenium & 0.84 & 5,100 & $\mathrm{mg} / \mathrm{kg}$ \\
\hline & & & Silver & 17 & 5,100 & $\mathrm{mg} / \mathrm{kg}$ \\
\hline & & & Aroclor 1254 & $8.7(\mathrm{~J})$ & 0.74 & $\mathrm{mg} / \mathrm{kg}$ \\
\hline & & & 3-methylphenol & 15 & 31,000 & $\mathrm{mg} / \mathrm{kg}$ \\
\hline & & & Bis(2-ethylhexyl)phthalate & $6.8(\mathrm{~J})$ & 120 & $\mathrm{mg} / \mathrm{kg}$ \\
\hline & & & 1,4-dichlorobenzene & $0.019(\mathrm{~J})$ & 12 & $\mathrm{mg} / \mathrm{kg}$ \\
\hline & & & Carbon disulfide & $0.017(\mathrm{~J})$ & 3,700 & $\mathrm{mg} / \mathrm{kg}$ \\
\hline & & & Methylene chloride & $0.058(\mathrm{~J})$ & 500 & $\mathrm{mg} / \mathrm{kg}$ \\
\hline & & & Trichloroethene & $0.032(\mathrm{~J})$ & 14 & $\mathrm{mg} / \mathrm{kg}$ \\
\hline
\end{tabular}

$\mathrm{J}=$ Estimated value

$\mathrm{J}+=$ Result is an estimated quantity but may be biased high.

Bold indicates the value is equal to or exceeds the PSM criteria.

\section{A.15.4 Nature and Extent of Contamination}

Based on analytical results for soil samples collected at CAS 25-60-04, the only COC identified was Aroclor 1254. The Decision II soil samples show that the PCBs are limited to the 0.0- to 2.0-ft-deep interval where concentrations decrease to below the FALs within $25.0 \mathrm{ft}$ laterally of the outfall. The contaminant distribution is consistent with a release from an outfall; however, there are some effects on the distribution of contamination due to the reworking of the area during the pipe reconfiguration. Additionally, lead and PCBs have been identified exceeding PSM criteria in the sludge contained within the outfall piping. According to analytical results of the soil in the discharge area, the lead has 
remained contained within the outfall piping, but it is presumed the PCBs present in the outfall have resulted in a release to the environment.

\section{A.15.5 Revised Conceptual Site Model}

The CSM was revised to include the reworking of soil around the outfall. 


\section{A.16.0 Waste Management}

Section A.16.1 addresses investigation-derived waste (IDW) management, and Section A.16.2 addresses the management of various remediation waste streams. The wastes generated, managed, and disposed of at CAU 562 are summarized in Tables A.16-1 through A.16-6.

\section{A.16.1 Investigation-Derived Waste}

\section{A.16.1.1 Waste Streams}

Waste generated during the investigation was segregated into the following waste streams:

- Disposable personal protective equipment (PPE) and sampling equipment, such as sampling scoops and aluminum tins

- French drain casings removed at CASs 02-44-02, 02-60-02, 02-60-04, 02-60-05, and 02-60-06 during sampling activities

- Concrete debris from accessing the french drain at CAS 02-60-04

\section{A.16.1.2 Waste Generated}

A total of four drums of IDW and bulk debris were generated during the investigation and are summarized in Table A.16-1:

- Three drums of IDW were generated at CAS 02-60-02. The IDW generated at CAS 02-60-02 was characterized as nonradioactive and nonhazardous sanitary waste, and are summarized in Table A.16-1. The disposal site for this waste was the U10c Industrial Waste Landfill located at the NTS.

- One drum of IDW was generated at CAS 02-60-04 and was characterized as hydrocarbon waste exceeding the regulatory threshold established by State of Nevada regulations (NDEP, 2006a and b). The disposal site for this waste was the U10c Industrial Waste Landfill located at the NTS.

- Approximately $10.0 \mathrm{yd}^{3}$ of bulk debris was generated at CAS 02-60-04. The debris consisted of metal and concrete, and was characterized as nonradioactive and nonhazardous sanitary waste. The disposal site for this waste was the U10c Industrial Waste Landfill located at the NTS. 
Table A.16-1

Waste Summary Table

\begin{tabular}{|c|c|c|c|c|c|c|c|c|c|}
\hline \multirow{2}{*}{ CAS } & \multirow{2}{*}{ Waste Items } & \multicolumn{4}{|c|}{ Waste Characterization } & \multicolumn{4}{|c|}{ Waste Disposition } \\
\hline & & Hazardous & Hydrocarbon & PCBs & Radioactive & $\begin{array}{l}\text { Disposal } \\
\text { Facility }\end{array}$ & $\begin{array}{l}\text { Waste } \\
\text { Volume }\end{array}$ & $\begin{array}{l}\text { Disposal } \\
\text { Date }\end{array}$ & $\begin{array}{c}\text { Disposal } \\
\text { Document }^{\mathrm{a}}\end{array}$ \\
\hline $02-60-02$ & Soil & No & Yes & No & No & Area 9 - U10C & $1.0 \mathrm{yd}^{3}$ & $06 / 30 / 2010$ & LVF \\
\hline \multirow[b]{2}{*}{$02-60-04$} & Soil & No & No & No & No & Area 9 - U10C & $0.3 \mathrm{yd}^{3}$ & $06 / 30 / 2010$ & LVF \\
\hline & $\begin{array}{l}\text { Bulk debris - } \\
\text { concrete, } \\
\text { plastic, metal }\end{array}$ & No & No & No & No & Area 9 - U10C & $10.0 \mathrm{yd}^{3}$ & 06/30/2010 & LVF \\
\hline
\end{tabular}

${ }^{\mathrm{a} C}$ Copies of waste disposal documents are located in Appendix $\mathrm{G}$ of this document.

LVF = Load Verification Form 
Sanitary industrial waste was inspected and disposed of in designated sanitary industrial waste bins located at Building 23-153 and allocated for disposal at the U10c Industrial Waste Landfill.

\section{A.16.2 Waste Characterization}

Samples of soil and PSM were collected from certain CASs for waste characterization purposes. The analytical suite was tailored to characterize the waste for disposal and to support recommended actions. Results were reviewed against federal regulations, state regulations, and DOE directives/policies/guidance, as well as waste disposal criteria for NTS facilities. Sections A.16.2.1 through A.16.2.7 describe the waste characterization samples collected during the CAI at CAU 562. Complete results (including nondetect [ND] results) for all samples are maintained in project files.

\section{A.16.2.1 CAS 02-26-11, Lead Shot}

Samples of shot were collected at CAS 02-26-11 and analyzed for the parameters listed in Table A.3-1. All analytical data were reviewed to determine a recommended waste disposal path for the waste streams generated. The waste stream anticipated at CAS 02-26-11 will be the shot. The shot is considered PSM, and because of the lead content, it will be managed as a RCRA-regulated hazardous waste. The volume of the PSM that will require disposal is estimated to be $2.5 \mathrm{yd}^{3}$. The results of the waste characterization sampling are presented in Table A.16-2.

\section{A.16.2.2 CAS 02-44-02, Paint Spills and French Drain}

Samples of the soil and PSM were collected during the CAI at CAS 02-44-02. These samples were collected and analyzed for the parameters listed in Table A.4-1. Additionally, a waste characterization sample was collected from the contents of the original french drain. Because the PSM criteria was not exceeded at this location, no waste characterization was necessary. The analytical data were reviewed to determine a recommended disposal path for the waste at this CAS. Two waste streams are identified at CAS 02-44-02. The first waste stream includes the removal and disposal of one 55-gal drum of the paint residue PSM. The PSM waste was characterized using paint chip sample numbers 562B006 and 562B010. The analytical data reported for the environmental soil samples indicated concentrations of barium, chromium, and lead exceeding the RCRA toxicity characteristic concentrations using the maximum theoretical leachate concentration. This evaluation resulted in a recommendation that the PSM be managed and disposed as a RCRA-regulated 
Table A.16-2

Waste Characterization Results Detected at CAS 02-26-11, Lead Shot

\begin{tabular}{|c|c|c|c|c|c|c|c|}
\hline $\begin{array}{l}\text { Sample } \\
\text { Location }\end{array}$ & $\begin{array}{l}\text { Sample } \\
\text { Number }\end{array}$ & $\begin{array}{l}\text { Depth } \\
\text { (ft bgs) }\end{array}$ & Matrix & Parameter & Result & $\begin{array}{c}\text { Criteria } \\
\text { (TC Levels) }\end{array}$ & Units \\
\hline \multirow{4}{*}{ A05 } & \multirow{4}{*}{$562 A 006$} & \multirow{4}{*}{$0.0-0.5$} & \multirow{4}{*}{ Soil } & Arsenic & 1.3 & 5 & $\mathrm{mg} / \mathrm{L}$ \\
\hline & & & & Cadmium & 0.011 & 1 & $\mathrm{mg} / \mathrm{L}$ \\
\hline & & & & Lead & 460 & 5 & $\mathrm{mg} / \mathrm{L}$ \\
\hline & & & & Selenium & 0.035 & 1 & $\mathrm{mg} / \mathrm{L}$ \\
\hline \multirow{6}{*}{ A06 } & \multirow{3}{*}{ 562A007 } & \multirow{3}{*}{$\begin{array}{l}0.0-2.0 \\
\text { (in. bgs) }\end{array}$} & \multirow{6}{*}{ Soil } & Antimony & 0.045 & N/A & $\mathrm{mg} / \mathrm{L}$ \\
\hline & & & & Cadmium & 0.0045 & 1 & $\mathrm{mg} / \mathrm{L}$ \\
\hline & & & & Lead & 0.026 & 5 & $\mathrm{mg} / \mathrm{L}$ \\
\hline & \multirow{2}{*}{$562 A 008$} & \multirow{2}{*}{$\begin{array}{l}2.0-4.0 \\
\text { (in. bgs) }\end{array}$} & & Antimony & 0.05 & $N / A$ & $\mathrm{mg} / \mathrm{L}$ \\
\hline & & & & Lead & 0.024 & 5 & $\mathrm{mg} / \mathrm{L}$ \\
\hline & 562A009 & $\begin{array}{l}4.0-6.0 \\
\text { (in. bgs) }\end{array}$ & & Antimony & 0.03 & N/A & $\mathrm{mg} / \mathrm{L}$ \\
\hline \multirow{2}{*}{ A07 } & \multirow{2}{*}{$562 A 010$} & \multirow{2}{*}{$0.0-0.5$} & \multirow{2}{*}{ Soil } & Barium & 2.8 & 100 & $\mathrm{mg} / \mathrm{L}$ \\
\hline & & & & Lead & 0.028 & 5 & $\mathrm{mg} / \mathrm{L}$ \\
\hline \multirow{4}{*}{ A08 } & \multirow{3}{*}{$562 A 011$} & \multirow{3}{*}{$\begin{array}{l}0.0-2.0 \\
\text { (in. bgs) }\end{array}$} & \multirow{4}{*}{ Soil } & Antimony & 0.07 & N/A & $\mathrm{mg} / \mathrm{L}$ \\
\hline & & & & Barium & 1.2 & 100 & $\mathrm{mg} / \mathrm{L}$ \\
\hline & & & & Lead & 0.019 & 5 & $\mathrm{mg} / \mathrm{L}$ \\
\hline & $562 A 013$ & $\begin{array}{l}4.0-6.0 \\
\text { (in. bgs) }\end{array}$ & & Selenium & 0.048 & 1 & $\mathrm{mg} / \mathrm{L}$ \\
\hline
\end{tabular}

$\mathrm{TC}=$ Toxicity characteristic

Bold indicates the value equals or exceeds the criteria (TC levels).

hazardous waste. However, this material should be evaluated through Toxicity Characteristic Leaching Procedure (TCLP) analysis before disposal to confirm the recommended disposal pathway.

The second waste stream includes approximately $2.0 \mathrm{yd}^{3}$ of soil that will be remediated at sample location B08. The remediated soil was characterized using environmental sample number 562B009. The analytical data reported a waste analysis of the environmental soil samples indicated concentrations of chromium and lead exceeding the RCRA toxicity characteristic concentrations using the maximum theoretical leachate concentration. Based on these results, the waste should be managed and disposed of as a RCRA-regulated hazardous waste. However, the waste should be 
reanalyzed during the remediation activities using the TCLP method and the results used to finalize the waste characterization for final disposal.

\section{A.16.2.3 CAS 02-59-01, Septic System}

Samples of liquid and sludge were collected at CAS 02-59-01 and analyzed for the parameters listed in Table A.5-1. All analytical data were reviewed to identify a disposal path for the waste streams anticipated at this CAS. The only waste stream anticipated at CAS 02-59-01 is approximately 4,200 gal of liquid and 550 gal of sludge that will be characterized as non-RCRA-regulated industrial waste. Once solidified, the waste will meet the permit requirements of the U10c Industrial Waste Landfill. The sample locations and analytical results are shown in Table A.16-3. The gross beta value reported in Table A.16-3 is conservative, i.e., the value shown is the gross beta measurement reported plus the two-sigma error associated with it. The resultant value is 51.2 picocuries per liter (pCi/L), which exceeds the water pollution control permit limit of $50.0 \mathrm{pCi} / \mathrm{L}$ for gross beta activity.

Table A.16-3

Waste Characterization Results Detected at CAS 02-59-01, Septic System

\begin{tabular}{|c|c|c|c|c|c|c|c|}
\hline $\begin{array}{l}\text { Sample } \\
\text { Location }\end{array}$ & $\begin{array}{l}\text { Sample } \\
\text { Number }\end{array}$ & $\begin{array}{c}\text { Depth } \\
\text { (ft bgs) }\end{array}$ & Matrix & Parameter & Result & $\begin{array}{c}\text { Criteria } \\
\text { (TC Levels) }\end{array}$ & Units \\
\hline \multirow{5}{*}{$\mathrm{C} 07$} & \multirow{2}{*}{$562 C 008$} & \multirow{2}{*}{$8.5-9.0$} & \multirow{2}{*}{ Liquid } & Gross Alpha & 30.3 & $15^{a}$ & $\mathrm{pCi} / \mathrm{L}$ \\
\hline & & & & Gross Beta & 51.2 & $50^{a}$ & $\mathrm{pCi} / \mathrm{L}$ \\
\hline & \multirow{3}{*}{$562 C 011$} & \multirow{3}{*}{$10.0-10.5$} & \multirow{3}{*}{ Sludge } & Vinyl chloride & 0.0012 & 0.2 & $\mathrm{mg} / \mathrm{L}$ \\
\hline & & & & 1,4-dichlorobenzene & 0.36 & 7.5 & $\mathrm{mg} / \mathrm{L}$ \\
\hline & & & & Gross Beta & $4.1(\mathrm{~J})$ & $50^{a}$ & $\mathrm{pCi} / \mathrm{g}$ \\
\hline \multirow{2}{*}{ C09 } & $562 C 010$ & $8.5-9.0$ & Liquid & Gross Beta & 9.5 & $50^{a}$ & $\mathrm{pCi} / \mathrm{L}$ \\
\hline & $562 C 012$ & $10.0-10.5$ & Sludge & 1,4-dichlorobenzene & 0.0015 & 7.5 & $\mathrm{mg} / \mathrm{L}$ \\
\hline
\end{tabular}

${ }^{a}$ Water Pollution Control Permit GNEV93001 (NDEP, 1999)

Bold indicates the value equals or exceeds the criteria (TC levels).

\section{A.16.2.4 CAS 02-60-01, Concrete Drain}

Soil samples were collected at CAS 02-60-01 and analyzed for the parameters listed in Table A.6-1. All analytical data were reviewed and no COCs were identified. Therefore, no waste will be generated at this CAS. 


\section{A.16.2.5 CAS 02-60-02, French Drain}

Soil samples were collected at CAS 02-60-02 and analyzed for the parameters listed in Table A.7-1. All analytical data were reviewed to determine a recommended disposal path for the waste generated at this CAS. The only waste stream anticipated at CAS 02-60-02 is approximately $2.0 \mathrm{yd}^{3}$ of soil that is contaminated with Aroclor 1260. Approximately $1.0 \mathrm{yd}^{3}$ of contaminated soil has already been removed from sample location E03 and disposed of at the U10c Industrial Waste Landfill, leaving approximately an additional $1.0 \mathrm{yd}^{3}$ to be disposed of during the corrective action. The remediated soil was characterized using the analytical results from environmental sample number 562F008. No analytical results for the soil exceeded the regulatory disposal criteria. Therefore, the remaining waste that will be generated at this CAS will be characterized as non-RCRA-regulated industrial waste and meets the permit requirements of the U10c Industrial Waste Landfill. The sample locations and analytical results are shown in Table A.16-4.

Table A.16-4

Waste Characterization Results Detected at CAS 02-60-02, French Drain

\begin{tabular}{|c|c|c|c|c|c|c|c||}
\hline $\begin{array}{c}\text { Sample } \\
\text { Location }\end{array}$ & $\begin{array}{c}\text { Sample } \\
\text { Number }\end{array}$ & $\begin{array}{c}\text { Depth } \\
\text { (ft bgs) }\end{array}$ & Matrix & Parameter & Result & $\begin{array}{c}\text { Criteria } \\
\text { (TC Levels) }\end{array}$ & Units \\
\hline \hline \multirow{2}{*}{ E03 } & $562 \mathrm{E} 004$ & $2.5-3.0$ & \multirow{2}{*}{ Soil } & Cadmium & 0.052 & 1 & $\mathrm{mg} / \mathrm{L}$ \\
\cline { 5 - 8 } & & & Lead & 0.13 & 5 & $\mathrm{mg} / \mathrm{L}$ \\
\hline
\end{tabular}

\section{A.16.2.6 CAS 02-60-03, Steam Cleaning Drain}

Soil samples were collected at CAS 02-60-03 and analyzed for the parameters listed in Table A.8-1. All analytical data were reviewed to determine a disposal path for the waste streams at this CAS. Based on the evaluation of the existing data, two waste streams have been identified. The first waste stream includes the remediation and disposal of approximately $16.0 \mathrm{yd}^{3}$ of soil contaminated with benzo(a)pyrene. The soil waste was characterized using the analytical results from environmental sample numbers 562F011 and 562F012. The results of the analysis did not identify any soil with concentrations that exceeded the regulatory disposal criteria. Therefore, the soil generated during the remediation will be characterized as non-RCRA-regulated industrial waste that meets the permit requirements of the U10c Industrial Waste Landfill. 
The second waste stream includes the remediation and disposal of approximately $10.0 \mathrm{yd}^{3}$ of soil that is contaminated with Aroclor 1254. During the corrective action, soil will be removed from the area around sample location F07. Initially, the remediated soil was characterized using the analytical results from environmental sample number 562F008. The analytical data reported from the environmental sample analysis indicated results for cadmium exceeding the RCRA toxicity characteristic concentrations using the maximum theoretical leachate concentration. Based on these data, the waste should be managed and disposed of as a RCRA-regulated hazardous waste. However, this characterization should be confirmed by collection and analysis of samples for waste characterization using TCLP during the excavation and closure of this CAS.

\section{A.16.2.7 CAS 02-60-04, French Drain}

No analytical results exceeded the regulatory disposal criteria at CAS 02-60-04. One 55-gal drum of waste has already been generated, and was disposed of at the U10c Industrial Waste Landfill. No further waste characterization is necessary. The sample locations and analytical results are shown in Table A.16-5.

Table A.16-5

Waste Characterization Results Detected at CAS 02-60-04, French Drain

\begin{tabular}{|c|c|c|c|c|c|c|c||}
\hline \hline $\begin{array}{c}\text { Sample } \\
\text { Location }\end{array}$ & $\begin{array}{c}\text { Sample } \\
\text { Number }\end{array}$ & $\begin{array}{c}\text { Depth } \\
\text { (ft bgs) }\end{array}$ & Matrix & Parameter & Result & $\begin{array}{c}\text { Criteria } \\
\text { (TC Levels) }\end{array}$ & Units \\
\hline \hline \multirow{2}{*}{ G01 } & $562 \mathrm{G} 001$ & $8.5-9.0$ & \multirow{2}{*}{ Soil } & Cadmium & 0.62 & 1 & $\mathrm{mg} / \mathrm{L}$ \\
\cline { 4 - 7 } & & & Lead & 0.049 & 5 & $\mathrm{mg} / \mathrm{L}$ \\
\hline
\end{tabular}

\section{A.16.2.8 CAS 02-60-05, French Drain}

Soil samples were collected at this CAS and analyzed for the parameters listed in Table A.10-1. Additionally, waste characterization samples were collected of the chip seal. Because the chip seal has been determined not to be associated with this and is not PSM, no waste characterization was necessary. Approximately $48.0 \mathrm{yd}^{3}$ of waste will be generated from the french drain and surrounding area during the corrective actions. None of the analytical results from the environmental soil samples exceeded the regulatory disposal criteria for the potential waste at this CAS. The waste has been characterized as non-RCRA-regulated industrial waste and will meet the permit requirements of the U10c Industrial Waste Landfill. 


\section{A.16.2.9 CAS 02-60-06, French Drain}

Soil samples were collected at CAS 02-60-06 and analyzed for the parameters listed in Table A.11-1. All analytical data were reviewed and no COCs were identified. Therefore, there are no recommended corrective actions and no waste will be generated at this CAS.

\section{A.16.2.10 CAS 23-60-01, Mud Trap Drain and Outfall}

Samples of sediment were collected at CAS 23-60-01 and analyzed for the parameters listed in Table A.13-1. All analytical data were reviewed to determine a recommended path for waste streams generated at this CAS. The only waste anticipated at this location is approximately $0.5 \mathrm{yd}^{3}$ of PSM within the mud trap. Analytical results for the sediment exceeded the regulatory disposal criteria for lead. Therefore, the waste generated at this CAS will be characterized as RCRA-regulated waste and will be shipped to the Area 5, RCRA-Permitted Storage Pad for treatment and disposal.

\section{A.16.2.11 CAS 23-99-06, Grease Trap}

Sediment samples were collected at CAS 23-99-06 and analyzed for the parameters listed in Table A.14-1. All analytical data were reviewed to determine a disposal path for the waste during the corrective actions at this CAS. The only waste stream anticipated at CAS 23-99-06 is approximately $0.5 \mathrm{yd}^{3}$ of PSM within the grease trap. No analytical results for the sediment exceeded the regulatory disposal criteria. Therefore, the waste generated at this CAS has been characterized as non-RCRA-regulated industrial waste, and the waste meets the permit requirements of the U10c Industrial Waste Landfill.

\section{A.16.2.12 CAS 25-60-04, Building 3123 Outfalls}

A sludge sample was collected at CAS 25-60-04 from within the pipe at Drain B and analyzed for the parameters listed in Table A.15-1. All analytical data were reviewed to determine a path for the disposal of the waste generated at this CAS. There are two waste streams anticipated at CAS 25-60-04. The first waste stream includes the removal and disposal of approximately $0.25 \mathrm{yd}^{3}$ of sludge (PSM) located within Drain B. The PSM waste was characterized using sample number 562M005. The analytical data reported from the environmental sample analysis indicated results for several RCRA metals and two SVOCs exceeding RCRA toxicity characteristic 
concentrations using the maximum theoretical leachate concentration. The waste also exceeds the TPH-DRO concentration for hydrocarbon contamination in soils and will be characterized as hydrocarbon-impacted waste. The analytical results also indicated PCB contamination at concentrations less than TSCA-regulated levels. Therefore, the PSM waste should be managed and disposed of as a RCRA-regulated hazardous waste. This characterization should be confirmed by collection and analysis of samples for waste characterization using TCLP during the excavation and closure of this CAS.

The second waste stream generated at this CAS includes approximately $30.0 \mathrm{yd}^{3}$ of remediated soil that contains PCB contamination that exceeds the FALs but is less than the TSCA-regulated concentration (i.e., less than $50 \mathrm{mg} / \mathrm{kg}$ ). Therefore, the waste has been characterized as non-RCRA regulated industrial waste that contains non-TSCA-regulated PCB contamination. The waste meets the permit requirements of the U10c Industrial Waste Landfill. The sample locations and analytical results are shown in Table A.16-6.

Table A.16-6

Waste Characterization Results Detected at CAS 25-60-04, Building 3123 Outfalls

\begin{tabular}{|c|c|c|c|c|c|c|c|}
\hline $\begin{array}{c}\text { Sample } \\
\text { Location }\end{array}$ & $\begin{array}{c}\text { Sample } \\
\text { Number }\end{array}$ & $\begin{array}{c}\text { Depth } \\
\text { (ft bgs) }\end{array}$ & Matrix & Parameter & Result & $\begin{array}{c}\text { Criteria } \\
\text { (TC Levels) }\end{array}$ & Units \\
\hline \hline M02 & $562 \mathrm{M002}$ & $3.0-3.5$ & Soil & Silver & 0.012 & 5 & $\mathrm{mg} / \mathrm{L}$ \\
\hline M03 & $562 \mathrm{M} 004$ & $1.5-2.0$ & Soil & Lead & $0.024(\mathrm{~J}-)$ & 5 & $\mathrm{mg} / \mathrm{L}$ \\
\hline
\end{tabular}

$\mathrm{J}$ - = Result is an estimated quantity but may be biased low. 


\section{A.17.0 Quality Assurance}

This section contains a summary of QA/QC measures implemented during the sampling and analysis activities conducted in support of the CAU 562 CAI. The following sections discuss the data validation process, QC samples, and nonconformances. A detailed evaluation of the DQIs is presented in Appendix B.

Laboratory analyses were conducted for samples used in the decision-making process to provide a quantitative measurement of any COPCs present. Rigorous QA/QC was implemented for all laboratory samples, including documentation, verification and validation of analytical results, and affirmation of DQI requirements related to laboratory analysis. Detailed information regarding the QA program is contained in the Industrial Sites QAPP (NNSA/NV, 2002).

\section{A.17.1 Data Validation}

Data validation was performed in accordance with the Industrial Sites QAPP and approved protocols and procedures. All laboratory data from samples collected and analyzed for CAU 562 were evaluated for data quality in a tiered process described in Sections A.17.1.1 through A.17.1.3. Data were reviewed to ensure that samples were appropriately processed and analyzed, and the results were evaluated using validation criteria. Documentation of the data qualifications resulting from these reviews is retained in project files as a hard copy and electronic media.

All of the data analyzed as part of this investigation were subjected to Tier I and Tier II evaluations. A Tier III evaluation was performed on approximately 5 percent of the data analyzed.

\section{A.17.1.1 Tier I Evaluation}

Tier I evaluation for chemical and radiochemical analysis examines, but is not limited to, the following:

- Sample count/type consistent with chain of custody

- Analysis count/type consistent with chain of custody

- Correct sample matrix

- Significant problems stated in cover letter or case narrative

- Completeness of certificates of analysis 
- Completeness of Contract Laboratory Program (CLP) or CLP-like packages

- Completeness of signatures, dates, and times on chain of custody

- Condition-upon-receipt variance form included

- Requested analyses performed on all samples

- Date received/analyzed given for each sample

- Correct concentration units indicated

- Electronic data transfer supplied

- Results reported for field and laboratory QC samples

- Whether or not the deliverable met the overall objectives of the project

\section{A.17.1.2 Tier II Evaluation}

Tier II evaluation for chemical analysis examines, but is not limited to, the following:

- Correct detection limits achieved

- Sample date, preparation date, and analysis date for each sample

- Holding-time criteria met

- Quality control batch association for each sample

- Cooler temperature upon receipt

- Sample pH for aqueous samples, as required

- Detection limits properly adjusted for dilution, as required

- Blank contamination evaluated and applied to sample results/qualifiers

- Matrix spike (MS)/matrix spike duplicate (MSD) percent recoveries (\%R) and relative percent differences (RPDs) evaluated and qualifiers applied to laboratory results, as necessary

- Field duplicate RPDs evaluated using professional judgment and qualifiers applied to laboratory results, as necessary

- Laboratory duplicate RPDs evaluated and qualifiers applied to laboratory results, as necessary

- Surrogate \%R evaluated and qualifiers applied to laboratory results, as necessary

- Laboratory control sample (LCS) \%R evaluated and qualifiers applied to laboratory results, as necessary

- Initial and continuing calibration evaluated and qualifiers applied to laboratory results, as necessary

- Internal standard evaluation

- Mass spectrometer tuning criteria

- Organic compound quantitation 
- Inductively coupled plasma interference check sample evaluation

- Graphite furnace atomic absorption QC

- Inductively coupled plasma serial dilution effects

- Recalculation of 10 percent of laboratory results from raw data

Tier II evaluation for radiochemical analysis examines, but is not limited to, the following:

- Correct detection limits achieved

- Blank contamination evaluated and, if significant, qualifiers applied to sample results

- Certificate of Analysis consistent with data package documentation

- Quality control sample results (duplicates, LCSs, laboratory blanks) evaluated and used to determine laboratory result qualifiers.

- Sample results, uncertainty, and MDC evaluated

- Detector system calibrated with National Institute of Standards and Technology (NIST)traceable sources

- Preparation of calibration sources documented, demonstrating proper preparation and appropriateness for sample matrix, emission energies, and concentrations.

- Detector system response to daily or weekly background and calibration checks for peak energy, peak centroid, peak full-width half-maximum, and peak efficiency, depending on the detection system

- Tracers NIST-traceable, appropriate for the analysis performed, and recoveries that met QC requirements

- Documentation of all QC sample preparation complete and properly performed

- Spectra lines, photon emissions, particle energies, peak areas, and background peak areas supporting the identified radionuclide and its concentration 


\section{A.17.1.3 Tier III Evaluation}

The Tier III review is an independent examination of the Tier II evaluation. A Tier III review of 5 percent of the sample analytical data was performed by Analytical Quality Associates in Albuquerque, New Mexico. Tier II and Tier III results were compared, and where differences are noted, data were reviewed and changes were made accordingly. This review included the following additional evaluations:

- Review:

- Case narrative, chain of custody, and sample receipt forms

- Lab qualifiers (applied appropriately)

- Method of analyses performed as dictated by the chain of custody

- Raw data, including chromatograms, instrument printouts, preparation logs, and analytical logs

- Manual integrations to determine whether the response is appropriate

- Data package for completeness

- Determine sample results qualifiers through the evaluation of (but not limited to):

- Tracers and QC sample results (e.g., duplicates, LCSs, blanks, MSs) evaluated and used to determine sample results qualifiers

- Sample preservation, sample preparation/extraction and run logs, sample storage, and holding time

- Instrument and detector tuning

- Initial and continuing calibrations

- Calibration verification (initial, continuing, second source)

- Retention times

- Second column and/or second detector confirmation

- Mass spectra interpretation 
- Interference check samples and serial dilutions

- Post-digestion spikes and method of standard additions

- Breakdown evaluations

- Perform calculation checks of:

- At least one analyte per QC sample and its recovery

- At least one analyte per initial calibration curve, continuing calibration verification, and second source recovery

- At least one analyte per sample that contains positive results (hits); radiochemical results only require calculation checks on activity concentrations (not error)

- Verify that target compound detects identified in the raw data are reported on the results form.

- Document any anomalies for the laboratory to clarify or rectify. The contractor should be notified of any anomalies.

\section{A.17.2 Field Quality Control Samples}

Field QC samples consisted of 25 trip blanks, 1 equipment rinsate blank, 6 field blanks, 1 source blank, 15 MS/MSDs, and 15 FDs. These samples were submitted to an analytical laboratory to be analyzed using the laboratory analytical methods shown in Table A.2-2. The QC samples were assigned individual sample numbers and sent to the laboratory "blind." Additional samples were selected by the laboratory to be analyzed as laboratory duplicates.

Field blanks, source blanks, and equipment rinsates were analyzed for the applicable parameters listed in Table A.2-2, and trip blanks were analyzed for VOCs only.

During the CAI, 15 FDs were sent as blind samples to the laboratory to be analyzed for the investigation parameters listed in Table A.2-2. For these samples, the RPDs between the environmental sample results and their corresponding FD sample results were analyzed to evaluate precision of sampling data. 


\section{A.17.2.1 Laboratory Quality Control Samples}

Analysis of method QC blanks was performed on each sample delivery group (SDG) for inorganics. Analysis of surrogate spikes and preparation blanks (PBs) was performed on each SDG for organics only. Analysis of initial and continuing calibration and LCSs was performed for each SDG. The results of these analyses were used to qualify associated environmental sample results.

Documentation of data qualifications resulting from the application of these guidelines is retained in project files as both hard copy and electronic media.

The laboratory included a PB, LCS, and a laboratory duplicate sample with each batch of field samples analyzed for radionuclides.

\section{A.17.3 Field Nonconformances}

There were no field nonconformances identified for the CAI.

\section{A.17.4 Laboratory Nonconformances}

Laboratory nonconformances are generally due to inconsistencies in the analytical instrumentation operation, sample preparations, extractions, missed holding times, and fluctuations in internal standards and calibration results. When laboratory nonconformances are encountered, they are accounted for and resolved during the data qualification process. 


\section{A.18.0 Summary}

Contaminants detected in environmental samples during the CAI were evaluated against FALs to determine the nature and extent of COCs for CAU 562. Assessment of the data generated from investigation activities indicates the FALs or PSM criteria were exceeded in 10 of the 13 CASs. The following summarizes the results for each CAS.

\section{CAS 02-26-11, Lead Shot}

Based on observations made and analytical results for soil samples collected at this CAS, no COCs were identified in the soil. Lead, antimony, arsenic, and chromium were detected in the shot scattered throughout the site boundary, but the soil samples show that the contaminants have not migrated into the surrounding soil. Because of the presence of contaminants in the shot, the shot is considered PSM. A CAA of clean closure is recommended for this CAS.

\section{CAS 02-44-02, Paint Spills and French Drain}

Based on observations made and analytical results for soil samples collected at this CAS, benzo(a)pyrene is a COC in the surface soil adjacent to the former Painters Shed at sample location B08. The extent of COC contamination is limited to the surface from 0.0 to $0.5 \mathrm{ft}$ bgs. Paint samples collected showed the presence of various contaminants, but the soil samples adjacent to the concrete pad showed that the contaminants have not migrated to the surrounding soil. Because of the presence of contaminants in the paint samples, the paint is considered PSM. A CAA of clean closure is recommended for this CAS.

\section{CAS 02-59-01, Septic System}

Based on observations made and analytical results for soil samples and septic tank contents collected at this CAS, no COCs were identified in the soil. However, COCs were identified in the sludge contents of the tank. Because of the presence of contaminants in the sludge samples, the sludge is considered PSM. A CAA of clean closure is recommended for this CAS. 


\section{CAS 02-60-01, Concrete Drain}

Based on observations made and analytical results for environmental samples collected at this CAS, no COCs are present at this CAS. Therefore, a CAA of no further action is recommended for this CAS.

\section{CAS 02-60-02, French Drain}

Based on observations made and analytical results for soil samples collected at this CAS, Aroclor 1260 is a COC in the subsurface soil at the original french drain (location E03). The extent of COC contamination is limited to $4.5 \mathrm{ft}$ bgs. A CAA of clean closure is recommended for this CAS.

\section{CAS 02-60-03, Steam Cleaning Drain}

Based on observations made and analytical results for soil samples collected at this CAS, benzo(a)pyrene and Aroclor 1260 are COCs. Benzo(a)pyrene was detected in the surface soil located in the sump (location F10), and Aroclor 1260 was detected in the surface soil at a location adjacent to the sump (location F07). The extent of COC contamination in the sump is limited to $3.0 \mathrm{ft}$ bgs, and the extent of COC contamination adjacent to the sump is $1.5 \mathrm{ft}$ bgs. A CAA of clean closure is recommended for this CAS.

\section{CAS 02-60-04, French Drain}

Based on observations made and analytical results for soil samples collected at this CAS, no COCs were identified in the soil. Various contaminants were detected in the sediment samples collected at the base of the french drain, but the soil samples show that the contaminants have not migrated into the surrounding soil. Because of the presence of contaminants in the sediment, the sediment is considered PSM. A CAA of clean closure is recommended for this CAS.

\section{CAS 02-60-05, French Drain}

Based on observations made and analytical results for soil samples collected at this CAS, benzo(a)pyrene, benzo(a)anthracene, benzo(b)fluoranthene, dibenzo(a,h)anthracene, and indeno(1,2,3-cd)pyrene are COCs found at the surface to a depth of $8.0 \mathrm{ft}$ bgs in the french drain (locations H01, H02, and H03) and $3.0 \mathrm{ft}$ bgs in the adjacent borehole (location H10). A CAA of clean closure is recommended for this CAS. 


\section{CAS 02-60-06, French Drain}

Based on observations made and analytical results for environmental samples collected at this CAS, no COCs are present at this CAS. Therefore, a CAA of no further action is recommended for this CAS.

\section{CAS 02-60-07, French Drain}

There is no french drain or source of release associated with this CAS; therefore, no CAAs will be evaluated for this CAS.

\section{CAS 23-60-01, Mud Trap Drain and Outfall}

Based on observations made and analytical results for soil samples collected at this CAS, no COCs were identified in the soil. Lead was detected in the sediment within the mud trap, but the soil samples show that the contaminant has not migrated into the surrounding soil via the outfall. Because of the presence of lead in the sediment, the sediment is considered PSM. A CAA of clean closure is recommended for this CAS.

\section{CAS 23-99-06, Grease Trap}

Based on observations made and analytical results for sediment samples collected at this CAS, COCs were identified in the trap. Aroclor 1260, chlordane, and arsenic were detected in the sediment within the grease trap. Because of the presence of contaminants in the sediment, the sediment is considered PSM. A CAA of clean closure is recommended for this CAS.

\section{CAS 25-60-04, Building 3123 Outfalls}

Based on observations made and analytical results for soil samples collected at this CAS, Aroclor 1254 is a COC in the surface soil adjacent to the outfall (location M03). The extent of COC contamination is limited to a depth of $3.0 \mathrm{ft}$ bgs. Sludge samples collected from within the outfall showed the presence of lead and Aroclor 1254. Because of the presence of contaminants in the sludge, the sludge is considered PSM. A CAA of clean closure is recommended for this CAS. 


\section{A.19.0 References}

BN, see Bechtel Nevada.

Bechtel Nevada. 1995. Nevada Test Site Performance Objective for Certification of Nonradioactive Hazardous Waste, Rev. 0, G-E11/96.01. Las Vegas, NV.

DOE, see U.S. Department of Energy.

EPA, see U.S. Environmental Protection Agency.

FFACO, see Federal Facility Agreement and Consent Order.

Federal Facility Agreement and Consent Order. 1996 (as amended March 2010). Agreed to by the

State of Nevada; U.S. Department of Energy, Environmental Management; U.S. Department of

Defense; and U.S. Department of Energy, Legacy Management.

NDEP, see Nevada Division of Environmental Protection.

NNES, see Navarro Nevada Environmental Services, LLC.

NNSA/NV, see U.S. Department of Energy, National Nuclear Security Administration Nevada Operations Office.

NNSA/NSO, see U.S. Department of Energy, National Nuclear Security Administration Nevada Site Office.

Navarro Nevada Environmental Services, LLC. 2009. Statement of Work for Analytical Laboratories, Section C. Las Vegas, NV.

Nevada Division of Environmental Protection. 1999. State of Nevada Water Pollution Control General Permit, No. GNEV93001. Carson City, NV.

Nevada Division of Environmental Protection. 2006a (as amended in August 2000). Class III Solid Waste Disposal Site for Hydrocarbon Burdened Soils, Area 6 of the NTS, Permit SW 13-097-02, Rev. 7. Carson City, NV.

Nevada Division of Environmental Protection. 2006b (as amended in August 2000). Class III Solid Waste Disposal Site; U10c, Area 9 of the NTS, Permit SW 13-097-03. Carson City, NV.

REECo, see Reynolds Electrical \& Engineering Co., Inc. 
Reynolds Electrical \& Engineering Co., Inc. 1995. Area 2 Base Camp Closure Demolition and Environmental Total Estimated Cost. August. U.S. Department of Energy, Project Development and Management Division.

SNJV, see Stoller-Navarro Joint Venture.

Stoller-Navarro Joint Venture. 2006. Model Statement of Work for Analytical Laboratories, Rev. 0. February. Las Vegas, NV.

U.S. Department of Energy. 1997. The Procedures Manual of the Environmental Measurements Laboratory, HASL-300. 28th Ed., Vol. I. February. New York, NY.

U.S. Department of Energy, National Nuclear Security Administration Nevada Operations Office. 2002. Industrial Sites Quality Assurance Project Plan, Nevada Test Site, Nevada, Rev. 3, DOE/NV--372. Las Vegas, NV.

U.S. Department of Energy, National Nuclear Security Administration Nevada Site Office. 2009. Streamlined Approach for Environmental Restoration for Corrective Action Unit 562: Waste Systems, Nevada Test Site, Nevada, Rev. 0, DOE/NV--1317. Las Vegas, NV.

U.S. Environmental Protection Agency. 1980. Prescribed Procedures for Measurement of Radioactivity in Drinking Water, EPA 600/4-80-032. Cincinnati, OH: Environmental Monitoring and Support Laboratory Office of Research and Development.

U.S. Environmental Protection Agency. 2008. Region 9: Superfund, Preliminary Remediation Goals, Screening Levels for Chemical Contaminants. As accessed at http://www.epa.gov/region09/waste/sfund/prg/index.html on 4 December. Prepared by EPA Office of Superfund and Oak Ridge National Laboratory.

U.S. Environmental Protection Agency. 2009. Update of the Adult Lead Methodology's Default Baseline Blood Lead Concentration and Geometric Standard Deviation Parameters, OSWER 9200.2-82. June. Prepared by the Lead Committee of the Technical Review Workgroup for Metals and Asbestos. Washington, DC: Office of Superfund Remediation and Technology Innovation.

Weston, see Weston Solutions, Inc.

Weston Solutions, Inc. 2007. After Action Report: Technical Services for Preliminary Assessment Geophysical Investigations, Nevada Test Site Corrective Action Sites, Nye County, Nevada. September. Prepared for Stoller-Navarro Joint Venture. West Chester, PA. 


\section{Appendix B}

\section{Data Assessment}




\section{B.1.0 Data Assessment}

The DQA process is the scientific evaluation of the actual CAI results to determine whether the DQO criteria established in the CAU 562 CAIP (NNSA/NSO, 2009) were met and whether DQO decisions can be resolved at the desired level of confidence. The DQO process ensures that the right type, quality, and quantity of data will be available to support the resolution of those decisions at an appropriate level of confidence. Using both the DQO and DQA processes help to ensure that DQO decisions are sound and defensible.

The DQA involves five steps that begin with a review of the DQOs and end with an answer to the DQO decisions. The five steps are briefly summarized as follows:

- Step 1: Review DQOs and Sampling Design - Review the DQO Process to provide context for analyzing the data. State the primary statistical hypotheses; confirm the limits on decision errors for committing false negative (Type I) or false positive (Type II) decision errors; and review any special features, potential problems, or deviations to the sampling design.

- $\quad$ Step 2: Conduct a Preliminary Data Review - Perform a preliminary data review by reviewing QA reports and inspecting the data both numerically and graphically, validating and verifying the data to ensure that the measurement systems performed in accordance with the criteria specified, and using the validated dataset to determine whether the quality of the data is satisfactory.

- Step 3: Select the Test - Select the test based on the population of interest, population parameter, and hypotheses. Identify the key underlying assumptions that could cause a change in one of the DQO decisions.

- Step 4: Verify the Assumptions - Perform tests of assumptions. If data are missing or are censored, determine the impact on DQO decision error.

- Step 5: Draw Conclusions from the Data - Perform the calculations required for the test.

\section{B.1.1 Review DQOs and Sampling Design}

This section contains a review of the DQO process presented in Appendix A of the CAU 562 CAIP (NNSA/NSO, 2009). The DQO decisions are presented with the DQO provisions to limit false negative or false positive decision errors. Special features, potential problems, or any deviations to the sampling design are also presented. 


\section{B.1.1.1 Decision I}

The Decision I statement as presented in the CAU 562 CAIP: “Is any COC present in environmental media within the CAS?” (NNSA/NSO, 2009).

Decision I Rules:

- If the population parameter of any COPC in the Decision I population of interest exceeds the corresponding FAL, then that contaminant is identified as a COC, and Decision II samples will be collected, else no further investigation is needed for that COPC in that population.

- If A COC exists at any CAS, then a corrective action will be determined, else no further action will be necessary.

- If a waste is present that, if released, has the potential to cause the future contamination of site environmental media, then a corrective action will be determined, else no further action will be necessary.

\section{B.1.1.1.1 DQO Provisions To Limit False Negative Decision Error}

A false negative decision error (where consequences are more severe) was controlled by meeting the following criteria:

1. Having a high degree of confidence that sample locations selected will identify COCs if present anywhere within the CAS.

2. Having a high degree of confidence that analyses conducted will be sufficient to detect any COCs present in the samples.

3. Having a high degree of confidence that the dataset is of sufficient quality and completeness.

\section{Criterion 1:}

The following methods (stipulated in the CAU 562 DQOs [NNSA/NSO, 2009]) were used in selecting sample locations.

1. Selection of sampling locations associated with surface and subsurface staining, odors, presence of debris, and other items was accomplished by visual field observations. 
2. Selection of sampling locations associated with french drains was accomplished by determining whether the contents were suspected PSM, locating the base of the drain, and identifying the native soil interface below the leach rock, if present.

3. Selection of sampling locations associated with outfalls was accomplished by identifying the following three areas:

- A: At the discharge point of the outfall

- B: Downgradient from the discharge (may be multiple locations based on COCs)

- C: Media samples from pipe contents, if available

4. Selection of sampling locations associated with professional judgment based on acceptable knowledge was accomplished by:

- Source and location of release

- Chemical nature and fate properties

- $\quad$ Physical transport pathways and properties

- Transport drivers

\section{Criterion 2:}

All samples were analyzed using the analytical methods listed in Table 3-1 of the CAU 562 CAIP and for the chemical and radiological parameters listed in Table 3-2 of the CAIP (NNSA/NSO, 2009). Table B.1-1 provides a reconciliation of samples analyzed to the planned analytical program.

Samples were submitted for all of the analytical methods specified in the analytical program shown in Table 3-1 of the CAU 562 CAIP (NNSA/NSO, 2009).

Sample results were assessed against the acceptance criterion for the DQI of sensitivity as defined in the Industrial Sites QAPP (NNSA/NV, 2002). The sensitivity acceptance criterion defined in the CAU 562 CAIP is that analytical detection limits will be less than the corresponding FAL (NNSA/NSO, 2009). This criterion was not achieved for the analytical results listed in Table B.1-2. Results not meeting the sensitivity acceptance criterion were not used to make DQO decisions as they are considered rejected data. The impact on DQO decisions is addressed in the assessment of completeness. 
Table B.1-1

CAU 562 Analyses Performed

\begin{tabular}{|c|c|c|c|c|c|c|c|c|c|c|}
\hline CAS & 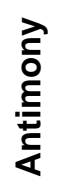 & 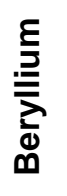 & $\begin{array}{l}\text { 우 } \\
\text { م }\end{array}$ & 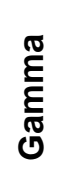 & 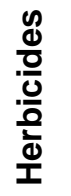 & $\begin{array}{l}\frac{0}{\pi} \\
\frac{\pi}{\infty} \\
\sum\end{array}$ & 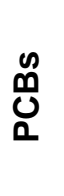 & 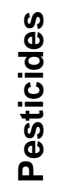 & 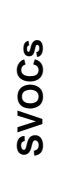 & $\begin{array}{l}\text { ơ } \\
\text { O }\end{array}$ \\
\hline $02-26-11$ & $\mathrm{RS}$ & -- & RS & RS & -- & RS & RS & $S$ & RS & RS \\
\hline $02-44-02$ & -- & -- & RS & RS & -- & RS & RS & -- & RS & RS \\
\hline 02-59-01 & -- & -- & RS & RS & RS & RS & RS & RS & RS & RS \\
\hline $02-60-01$ & -- & -- & RS & RS & -- & RS & RS & -- & RS & RS \\
\hline $02-60-02$ & -- & -- & RS & RS & -- & RS & RS & -- & RS & RS \\
\hline $02-60-03$ & -- & -- & RS & RS & -- & RS & RS & $S$ & RS & RS \\
\hline $02-60-04$ & -- & -- & RS & RS & -- & RS & RS & -- & RS & RS \\
\hline 02-60-05 & -- & -- & RS & RS & -- & RS & RS & -- & RS & RS \\
\hline $02-60-06$ & -- & -- & RS & RS & -- & RS & RS & -- & RS & RS \\
\hline 23-60-01 & -- & -- & RS & RS & -- & RS & RS & $S$ & RS & RS \\
\hline 23-99-06 & -- & -- & RS & RS & -- & RS & RS & $S$ & RS & RS \\
\hline $25-60-04$ & -- & RS & RS & RS & -- & RS & RS & -- & RS & RS \\
\hline
\end{tabular}

RS = Required and submitted

$\mathrm{S}=$ Submitted: (These analytes were not required, but were submitted in addition to the required analytical program)

-- = Not required and not submitted

Table B.1-2

Analytes Failing Sensitivity Criteria

\begin{tabular}{|c|c|c|c|c|}
\hline Sample & Constituent & CAS & $\begin{array}{c}\text { MDC } \\
(\mathrm{mg} / \mathrm{kg})\end{array}$ & $\begin{array}{c}\text { FAL } \\
(\mathrm{mg} / \mathrm{kg})\end{array}$ \\
\hline \multirow{3}{*}{ 562B013 } & N-nitroso di-n-propylamine & \multirow{3}{*}{$02-44-02$} & 0.37 & 0.25 \\
\hline & Benzo(a)pyrene & & 0.37 & 0.21 \\
\hline & Dibenzo(a,h)anthracene & & 0.37 & 0.21 \\
\hline
\end{tabular}




\section{Criterion 3:}

To satisfy the third criterion, the entire dataset, as well as individual sample results, were assessed against the acceptance criteria for the DQIs of precision, accuracy, representativeness, completeness, and comparability, as defined in the Industrial Sites QAPP (NNSA/NV, 2002). The DQI acceptance criteria are presented in Table 6-1 of the CAU 562 CAIP (NNSA/NSO, 2009). As presented in Tables B.1-2 and B.1-3, these criteria were met for each of the DQIs.

Table B.1-3

Precision Measurements

\begin{tabular}{|c|c|c|c|c|}
\hline Contaminant & Analyses & $\begin{array}{c}\text { Number of } \\
\text { Measurements } \\
\text { Qualified }\end{array}$ & $\begin{array}{c}\text { Number of } \\
\text { Measurements } \\
\text { Performed }\end{array}$ & $\begin{array}{c}\text { Percent within } \\
\text { Criteria }\end{array}$ \\
\hline \hline Mercury & Metals & 1 & 91 & 99 \\
\hline Silver & Metals & 3 & 91 & 96 \\
\hline Arsenic & Metals & 4 & 91 & 89 \\
\hline Am-241 & Gamma & 10 & 91 & 88 \\
\hline Barium & Metals & 11 & 91 & 81 \\
\hline Lead & Metals & 15 & 91 & 84 \\
\hline Chromium & Metals & 17 & 89 & 89 \\
\hline
\end{tabular}

\section{$\underline{\text { Precision }}$}

Precision was evaluated as described in Section 6.2 of the CAU 562 CAIP (NNSA/NSO, 2009) which stipulated a precision criterion of 80 percent. Table B.1-3 provides the chemical and radiological precision analysis results for all constituents that were qualified for precision. All precision rates exceeded the precision criteria. Therefore, the contaminant results that were qualified for reasons of precision can be confidently used to support DQO decisions and the dataset is determined to be acceptable for the DQI of precision.

\section{Accuracy}

Accuracy was evaluated as described in Section 6.2 of the CAU 562 CAIP (NNSA/NSO, 2009).

Table B.1-4 provides the chemical accuracy analysis results for all constituents qualified for accuracy. Accuracy rates are above the CAIP criterion of 80 percent, except for lead and antimony, which are 76.9 and 66.7 percent, respectively. There were no radiological data qualified for accuracy. 
Table B.1-4

Accuracy Measurements

\begin{tabular}{|c|c|c|c|}
\hline Contaminant & $\begin{array}{c}\text { Number of } \\
\text { Measurements } \\
\text { Qualified }\end{array}$ & $\begin{array}{l}\text { Number of } \\
\text { Measurements } \\
\text { Performed }\end{array}$ & $\begin{array}{c}\text { Percent } \\
\text { within } \\
\text { Criteria }\end{array}$ \\
\hline 2,3,4,6-tetrachlorophenol & 1 & 138 & 99.3 \\
\hline 2,4,5-trichlorophenol & 1 & 138 & 99.3 \\
\hline 2,4,6-trichlorophenol & 1 & 138 & 99.3 \\
\hline 2,4-dimethylphenol & 1 & 138 & 99.3 \\
\hline 2-chlorophenol & 1 & 138 & 99.3 \\
\hline 2-methylphenol & 1 & 138 & 99.3 \\
\hline 2-nitrophenol & 1 & 138 & 99.3 \\
\hline 3-methylphenol & 1 & 138 & 99.3 \\
\hline 4-nitrophenol & 1 & 138 & 99.3 \\
\hline Acenaphthene & 1 & 138 & 99.3 \\
\hline Benzoic acid & 1 & 138 & 99.3 \\
\hline Pentachlorophenol & 1 & 138 & 99.3 \\
\hline Phenol & 1 & 138 & 99.3 \\
\hline Pyrene & 1 & 138 & 99.3 \\
\hline Aroclor 1221 & 4 & 137 & 97.1 \\
\hline Aroclor 1232 & 4 & 137 & 97.1 \\
\hline Aroclor 1242 & 4 & 137 & 97.1 \\
\hline Aroclor 1248 & 4 & 137 & 97.1 \\
\hline Aroclor 1254 & 4 & 137 & 97.1 \\
\hline Chlorobenzene & 3 & 91 & 96.7 \\
\hline Trichloroethene & 3 & 91 & 96.7 \\
\hline Aroclor 1016 & 5 & 137 & 96.4 \\
\hline Aroclor 1268 & 6 & 137 & 95.6 \\
\hline Silver & 4 & 91 & 95.6 \\
\hline Aroclor 1260 & 9 & 137 & 93.4 \\
\hline Barium & 8 & 91 & 91.2 \\
\hline Chromium & 12 & 91 & 86.8 \\
\hline Lead & 21 & 91 & 76.9 \\
\hline Antimony & 5 & 15 & 66.7 \\
\hline
\end{tabular}


Of the 21 lead results qualified for accuracy, 11 were for failed MS recoveries contributed to matrix type interferences. All antimony results qualified for accuracy were a result of matrix interferences. Twenty-one lead and five antimony samples were qualified because of MS recoveries that were outside the control limits for accuracy. The highest estimated lead concentrations that were flagged for accuracy (200 mg/kg) were only 25 percent of the FAL (800 mg/kg). The highest estimated antimony concentrations $(19.5 \mathrm{mg} / \mathrm{kg}$ ) were only 0.3 percent of the FAL (410 $\mathrm{mg} / \mathrm{kg})$. Because these concentrations are significantly below the FALs, there is no reason to believe that these concentrations will result in a false negative decision. Therefore, the data are considered acceptable to support the DQO decision based on accuracy. Therefore, the lead and antimony results that were qualified for reasons of accuracy can be confidently used to support the DQO decisions. As the accuracy rate for all other constituents exceed the acceptance criteria for accuracy, the dataset is determined to be acceptable for the DQI of accuracy.

\section{$\underline{\text { Representativeness }}$}

The DQO process as identified in Appendix A of the CAU 562 CAIP (NNSA/NSO, 2009) was used to address sampling and analytical requirements for CAU 562. During this process, appropriate locations were selected that enabled the samples collected to be representative of the population parameters identified in the DQO (the most likely locations to contain contamination and locations that bound COCs). The sampling locations identified in the Criterion 1 discussion meet this criterion. Therefore, the analytical data acquired during the CAU 562 CAI are considered representative of the population parameters.

\section{Completeness}

The CAU 562 CAIP (NNSA/NSO, 2009) defines acceptable criteria for completeness to be that the dataset is sufficiently complete to be able to make the DQO decisions. This is initially evaluated as 80 percent of CAS-specific non-critical analytes identified in the CAIP having valid results and 100 percent of critical analytes (including Decision II samples) having valid results. Critical analytes for CAU 562 were identified in the CAIP as TPH-DRO and lead.

Rejected data (either qualified as rejected or data that failed the criterion of sensitivity) were not used in the resolution of DQO decisions and are not counted toward meeting the completeness acceptance criterion. The rejected data are proved in Table B.1-5. Benzo(a)pyrene, dibenzo(a,h)anthracene, and 
n-nitroso-di-n-propylamine failed the criterion for sensitivity in one sample at CAS 02-44-02. All critical analyte data met the completeness criteria of 100 percent. The completeness rate for all non-critical analytes exceeded the initial completeness criterion of 80 percent, and sufficient data are available to resolve the DQO decisions. Therefore, the dataset is determined to be acceptable for the DQI of completeness.

Table B.1-5

Rejected Measurements

(Page 1 of 2)

\begin{tabular}{|c|c|c|c|c|}
\hline Contaminant & Analyses & $\begin{array}{l}\text { Number of } \\
\text { Analytes } \\
\text { Qualified }\end{array}$ & $\begin{array}{c}\text { Number of } \\
\text { Measurements } \\
\text { Performed }\end{array}$ & $\begin{array}{l}\text { Percent within } \\
\text { Criteria }\end{array}$ \\
\hline Benzo(a)anthracene & SVOCS & 1 & 138 & 99.3 \\
\hline Pyrene & VOCs & 1 & 138 & 99.3 \\
\hline 1,1,2,2-tetrachloroethane & VOCs & 1 & 91 & 98.9 \\
\hline 1,2,4-trichlorobenzene & VOCs & 1 & 91 & 98.9 \\
\hline 1,2,4-trimethylbenzene & VOCs & 1 & 91 & 98.9 \\
\hline 1,2-dibromo-3-chloropropane & VOCs & 1 & 91 & 98.9 \\
\hline 1,2-dichlorobenzene & VOCs & 1 & 91 & 98.9 \\
\hline 1,3,5-trimethylbenzene & VOCs & 1 & 91 & 98.9 \\
\hline 1,3-dichlorobenzene & VOCs & 1 & 91 & 98.9 \\
\hline 1,4-dichlorobenzene & VOCs & 1 & 91 & 98.9 \\
\hline 2-chlorotoluene & VOCs & 1 & 91 & 98.9 \\
\hline N-butylbenzene & VOCs & 1 & 91 & 98.9 \\
\hline N-propylbenzene & VOCs & 1 & 91 & 98.9 \\
\hline P-isopropyltoluene & VOCs & 1 & 91 & 98.9 \\
\hline Sec-butylbenzene & VOCs & 1 & 91 & 98.9 \\
\hline Tert-butylbenzene & VOCs & 1 & 91 & 98.9 \\
\hline DRO & DRO & 1 & 88 & 98.9 \\
\hline Bis(2-ethylhexyl)phthalate & SVOCs & 2 & 138 & 98.6 \\
\hline Butyl benzyl phthalate & SVOCS & 2 & 138 & 98.6 \\
\hline Chrysene & SVOCS & 2 & 138 & 98.6 \\
\hline Di-n-octyl phthalate & SVOCS & 2 & 138 & 98.6 \\
\hline Benzo(a)pyrene & SVOCs & 3 & 138 & 97.8 \\
\hline Benzo(b)fluoranthene & SVOCs & 3 & 138 & 97.8 \\
\hline Benzo(g,h,i)perylene & SVOCS & 3 & 138 & 97.8 \\
\hline Benzo(k)fluoranthene & SVOCs & 4 & 138 & 97.1 \\
\hline
\end{tabular}


Table B.1-5

\section{Rejected Measurements}

(Page 2 of 2)

\begin{tabular}{|c|c|c|c|c|}
\hline Contaminant & Analyses & $\begin{array}{c}\text { Number of } \\
\text { Analytes } \\
\text { Qualified }\end{array}$ & $\begin{array}{c}\text { Number of } \\
\text { Measurements } \\
\text { Performed }\end{array}$ & $\begin{array}{c}\text { Percent within } \\
\text { Criteria }\end{array}$ \\
\hline \hline Dibenzo(a,h)anthracene & SVOCs & 4 & 138 & 97.1 \\
\hline Indeno(1,2,3-cd)pyrene & SVOCs & 4 & 138 & 97.1 \\
\hline Benzoic acid & SVOCs & 7 & 138 & 94.9 \\
\hline Pentachlorophenol & SVOCs & 7 & 138 & 94.9 \\
\hline
\end{tabular}

\section{Comparability}

Field sampling, as described in the CAU 562 CAIP (NNSA/NSO, 2009), was performed and documented in accordance with approved procedures that are comparable to standard industry practices. Approved analytical methods and procedures per DOE were used to analyze, report, and validate the data. These are comparable to other methods used not only in industry and government practices, but most importantly are comparable to other investigations conducted for the NTS. Therefore, project datasets are considered comparable to other datasets generated using these same standardized DOE procedures, thereby meeting DQO requirements.

Also, standard, approved field and analytical methods ensured that data were appropriate for comparison to the investigation action levels specified in the CAIP.

\section{B.1.1.1.2 DQO Provisions To Limit False Positive Decision Error}

The false positive decision error was controlled by assessing the potential for false positive analytical results. Quality assurance/QC samples such as field blanks, trip blanks, LCSs, and method blanks were used to determine whether a false positive analytical result may have occurred. This provision is evaluated during the validation process, and appropriate qualifications are applied to the data results when applicable.

Proper decontamination of sampling equipment and the use of certified clean sampling equipment and containers also minimized the potential for cross contamination that could lead to a false positive analytical result. 


\section{B.1.1.2 Decision II}

Decision II as presented in the CAU 562 CAIP: "If a COC is present, is sufficient information available to evaluate potential corrective action alternatives?” (NNSA/NSO, 2009). Sufficient information is defined to include:

- The lateral and vertical extent of COC contamination

- The information needed to determine potential remedial waste types.

- The information needed to evaluate the feasibility of remediation alternatives

\section{Decision Rules:}

- If the observed concentration of any COC in the Decision II population of interest exceeds the corresponding FAL in any bounding direction, then additional samples will be collected to complete the Decision II evaluation, else the extent of the COC contamination has been defined.

- If valid analytical results are available for the waste characterization samples, then the decision will be that sufficient information exists to determine potential remediation waste types and evaluate the feasibility of remediation alternatives, else collect additional waste characterization samples.

Population Parameters - The population parameters for Decision II data will be the observed concentration of each unbounded COC in any sample or the observed concentration of each sample used to characterize the potential waste streams.

\section{B.1.1.2.1 DQO Provisions To Limit False Negative Decision Error}

A false negative decision error (where consequences are more severe) is controlled by meeting the following criteria:

1. Having a high degree of confidence that the sample locations selected will identify the extent of the COCs.

2. Having a high degree of confidence that analyses conducted will be sufficient to detect any COCs present in the samples.

3. Having a high degree of confidence that the dataset is of sufficient quality and completeness.

4. Having a high degree of confidence that the potential waste streams are characterized. 


\section{Criterion 1:}

Soil sample results demonstrated that the vertical and lateral extent of COCs were defined. The extent sample locations and concentrations for the contaminants driving the extent of contamination are shown in Figures A.3-1 through A.15-1.

Six CASs were identified as requiring further delineation of COCs; therefore, Decision II samples were collected laterally and vertically to determine extent. Four CASs were identified as having PSM only, which was contained by a structure (e.g., tank, trap, drain).

\section{Criterion 2:}

All samples were analyzed for the COCs present at the corresponding CAS:

- CAS 02-26-11 - Lead, antimony, arsenic, and chromium

- CAS 02-44-02 - Benzo(a)pyrene, benzo(b)fluoranthene, bis(2-ethylhexyl)phthalate, lead, and chromium

- CAS 02-59-01 - Naphthalene and 1,4-dichlorobenzene

- CAS 02-60-02 - Aroclor 1260

- $\quad$ CAS 02-60-03 - Benzo(a)pyrene and Aroclor 1260

- CAS 02-60-04 - Benzo(a)pyrene, Aroclor 1260, and Aroclor 1268

- CAS 02-60-05 - Benzo(a)pyrene, benzo(a)anthracene, benzo(k)fluoranthene, benzo(b)fluoranthene, dibenzo(a,h)anthracene, and indeno(1,2,3-cd)pyrene

- CAS 23-60-01 - Lead

- CAS 23-99-06 - Aroclor 1260, arsenic, and chlordane

- CAS 25-60-04 - Aroclor 1254 and lead

All anayltes met the sensitivity criterion (as presented in Section B.1.1.1.1). 


\section{Criterion 3:}

To satisfy the third criterion for extent, the entire dataset, as well as individual sample results, were assessed against the DQIs of precision, accuracy, comparability, completeness, and representativeness, as defined in the Industrial Sites QAPP (NNSA/NV, 2002). The DQI discussion is presented under Criterion 3 for Decision I.

\section{B.1.1.2.2 DQO Provisions To Limit False Positive Decision Error}

The false positive decision error was controlled by assessing the potential for false positive analytical results. Quality assurance/QC samples such as field blanks, trip blanks, LCSs, and method blanks were used to determine whether a false positive analytical result may have occurred. Of 63 QA/QC samples submitted, no false positive analytical results were detected.

Proper decontamination of sampling equipment and the use of certified clean sampling equipment and containers also minimized the potential for cross contamination that could lead to a false positive analytical result.

\section{B.1.1.3 Sampling Design}

The CAU 562 CAIP (NNSA/NSO, 2009) made the following commitments for sampling:

1. Collect judgemental samples at locations specified in the CAIP.

Result: Judgemental samples were collected as determined in the DQOs.

2. Biased locations will have soil samples collected beneath and/or adjacent to collection and distribution systems to identify releases of contaminants and investigate the integrity of tanks, piping, and drains.

Result: The collection and distribution system components at the CASs identified in the DQOs were investigated by excavation and soil samples collected adjacent to and from beneath the required components, such as the base of tanks and outfall piping. 
All sampling was completed as planned, except for minor deviations discussed in Appendix A, and in some instances, additional sampling was completed if biasing factors were identified (e.g., a new french drain, presence of PSM) or to gather additional characterization information (e.g., further downstream in a wash).

\section{B.1.2 Conduct a Preliminary Data Review}

A preliminary data review was conducted by reviewing QA reports and inspecting the data. The contract analytical laboratories generate a QA non-conformance report when data quality does not meet contractual requirements. All data received from the analytical laboratories met contractual requirements, and a QA non-conformance report was not generated. Data were validated and verified to ensure that the measurement systems performed in accordance with the criteria specified. The validated dataset quality was found to be satisfactory.

\section{B.1.3 Select the Test and Identify Key Assumptions}

The test for resolving DQO Decision I was the comparison of the maximum analyte result from each CAS to the corresponding FAL. The test for making DQO Decision II was the comparison of all COC analyte results from each bounding sample to the corresponding FALs.

The key assumptions that could impact a DQO decision are listed in Table B.1-6.

\section{B.1.4 Verify the Assumptions}

The results of the CAI support the key assumptions identified in the CAU 562 DQOs and Table B.1-6.

All data collected during the CAI supported CSMs presented in the CAU 562 CAIP (NNSA/NSO, 2009).

\section{B.1.5 Draw Conclusions from the Data}

This section resolves the two DQO decisions for each of the CAU 562 CASs. 


\section{Key Assumptions}

\begin{tabular}{|c|c|}
\hline Exposure Scenario & $\begin{array}{l}\text { Site workers are only exposed to COCs through oral ingestion, inhalation, external } \\
\text { exposure to radiation, or dermal contact (by absorption) of COCs absorbed onto } \\
\text { the soils. } \\
\text { Exposure to contamination is limited to industrial site workers, } \\
\text { construction/remediation workers, and military personnel conducting training. }\end{array}$ \\
\hline Affected Media & $\begin{array}{l}\text { Surface soil, shallow subsurface soil, and potentially perched } \\
\text { (shallow) groundwater. } \\
\text { Deep groundwater contamination is not a concern. } \\
\text { Contaminants migrating to regional aquifers are not considered. }\end{array}$ \\
\hline $\begin{array}{l}\text { Location of } \\
\text { Contamination/Release Points }\end{array}$ & $\begin{array}{l}\text { The area of contamination is contiguous } \\
\text { The extent of COC concentration decreases away from the area of contamination. }\end{array}$ \\
\hline Transport Mechanisms & $\begin{array}{l}\text { Surface transport may occur as a result of a spill or storm water runoff. } \\
\text { Surface transport beyond shallow substrate is not a concern. }\end{array}$ \\
\hline Preferential Pathways & None. \\
\hline $\begin{array}{l}\text { Lateral and Vertical Extent } \\
\text { of Contamination }\end{array}$ & $\begin{array}{l}\text { Subsurface contamination, if present, is contiguous and decreases with distance } \\
\text { and depth from the source. } \\
\text { Surface contamination may occur laterally as a result of a spill or storm } \\
\text { water runoff. }\end{array}$ \\
\hline Groundwater Impacts & None. \\
\hline Future Land Use & Nonresidential. \\
\hline Other DQO Assumptions & $\begin{array}{l}\text { Buried material may exist at CAS 02-60-01. } \\
\text { Contamination may be present in the soils adjacent to a feature due to runoff or } \\
\text { intended use (e.g., steam cleaning sump). }\end{array}$ \\
\hline
\end{tabular}

\section{B.1.5.1 Decision Rules for Decision I}

Decision Rule: If the population parameter of any COPC in the Decision I population of interest exceeds the corresponding FAL pr PSM criteria, then that contaminant is identified as a COC , and Decision II samples will be collected, else no further investigation is needed for that COPC in that population.

Result: Decision II samples were collected for those CASs where a COC was identified. Those CASs where a COC was identified is shown on Table B.1-7. 
Table B.1-7

Summary of COCs and PSM by CAS

\begin{tabular}{|c|c|c|c|}
\hline CAS & Media & Contaminant(s) & PSM or COC \\
\hline \multirow[t]{2}{*}{ 02-26-11 } & Rusted and non-rusted shot & $\begin{array}{l}\text { Antimony } \\
\text { Arsenic } \\
\text { Lead } \\
\text { Chromium }\end{array}$ & PSM \\
\hline & Soil & None & N/A \\
\hline \multirow[t]{2}{*}{$02-44-02$} & Paint chips & $\begin{array}{c}\text { Chromium } \\
\text { Benzo(a)pyrene } \\
\text { Benzo(b)fluoranthene } \\
\text { Bis(2-ethylhexyl)phthalate } \\
\text { Lead }\end{array}$ & PSM \\
\hline & Soil & Benzo(a)pyrene & $\mathrm{COC}$ \\
\hline \multirow{3}{*}{ 02-59-01 } & Sludge & $\begin{array}{l}\text { 1,4-dichlorobenzene } \\
\text { Naphthalene }\end{array}$ & PSM \\
\hline & Liquid & None & N/A \\
\hline & Soil & None & N/A \\
\hline 02-60-01 & Soil & None & $\mathrm{N} / \mathrm{A}$ \\
\hline $02-60-02$ & Soil & Aroclor 1260 & $\mathrm{COC}$ \\
\hline $02-60-03$ & Soil & $\begin{array}{c}\text { Aroclor } 1260 \\
\text { Benzo(a)pyrene }\end{array}$ & $\mathrm{COC}$ \\
\hline \multirow[t]{2}{*}{$02-60-04$} & Sediment & $\begin{array}{c}\text { Aroclor } 1260 \\
\text { Aroclor } 1268 \\
\text { Benzo(a)pyrene }\end{array}$ & PSM \\
\hline & Soil & None & N/A \\
\hline \multirow[b]{2}{*}{$02-60-05$} & Asphalt & None & N/A \\
\hline & Soil & $\begin{array}{c}\text { Benzo(a)pyrene } \\
\text { Benzo(a)anthracene } \\
\text { Benzo(b)fluoranthene } \\
\text { Benzo(k)fluoranthene } \\
\text { Dibenzo(a,h)anthracene } \\
\text { Indeno(1,2,3-cd)pyrene }\end{array}$ & $\mathrm{COC}$ \\
\hline $02-60-06$ & Soil & None & N/A \\
\hline $02-60-07$ & $\mathrm{~N} / \mathrm{A}$ & None & $\mathrm{N} / \mathrm{A}$ \\
\hline \multirow{2}{*}{$23-60-01$} & Sediment & Lead & PSM \\
\hline & Soil & None & N/A \\
\hline 23-99-06 & Sediment & $\begin{array}{c}\text { Arsenic } \\
\text { Aroclor } 1260 \\
\text { Chlordane }\end{array}$ & PSM \\
\hline \multirow{2}{*}{$25-60-04$} & Sludge & $\begin{array}{l}\text { Aroclor } 1254 \\
\text { Lead }\end{array}$ & PSM \\
\hline & Soil & Aroclor 1254 & $\mathrm{COC}$ \\
\hline
\end{tabular}


Decision Rule: If a COC exists at any CAS, then a corrective action will be determined, else no further action will be necessary.

Result: A CAA of clean closure is recommended for all CASs containing a COC. No further action was identified as the corrective action for those CASs that do contain a COC. Table B.1-7 lists all CAU 562 CASs and whether or not there is an associated COC.

Decision Rule: If a waste is present that, if released, has the potential to cause future contamination of site environmental media, then a corrective action will be determined, else no further action will be necessary.

Result: There were CASs identified that contain waste, or PSM, and a CAA of clean closure is recommended for those CASs. Those CASs where PSM was identified is shown on Table B.1-7.

\section{B.1.5.2 Decision Rules for Decision II}

Decision Rule: If the observed concentration of any COC in the Decision II population of interest exceeds the corresponding FAL in any bounding direction, then additional samples will be collected.

Result: Samples to define extent were collected from CASs 02-26-11, 02-44-02, 02-60-02, 02-60-03, 02-60-05, and 25-60-04. Four of the remaining CASs had PSM and the extent was defined by the containment of the waste, while there were no COCs at the remaining three CASs.

Decision Rule: If all observed COC population parameters are less than the FALs, then the decision will be that the extent of contamination has been defined in the lateral and/or vertical direction.

Result: The vertical and lateral extent of contamination at all CASs containing a COC in the environment were defined through Decision II sampling. 


\section{B.2.0 References}

NNSA/NSO, see U.S. Department of Energy, National Nuclear Security Administration Nevada Site Office.

NNSA/NV, see U.S. Department of Energy, National Nuclear Security Administration Nevada Operations Office.

U.S. Department of Energy, National Nuclear Security Administration Nevada Operations Office. 2002. Industrial Sites Quality Assurance Project Plan, Nevada Test Site, Nevada, Rev. 3, DOE/NV--372. Las Vegas, NV.

U.S. Department of Energy, National Nuclear Security Administration Nevada Site Office. 2009. Corrective Action Investigation Plan for Corrective Action Unit 562: Waste Systems, Nevada Test Site, Nevada, Rev. 0, DOE/NV--1317. Las Vegas, NV. 


\section{Appendix C}

\section{Cost Estimates}

(38 Pages) 


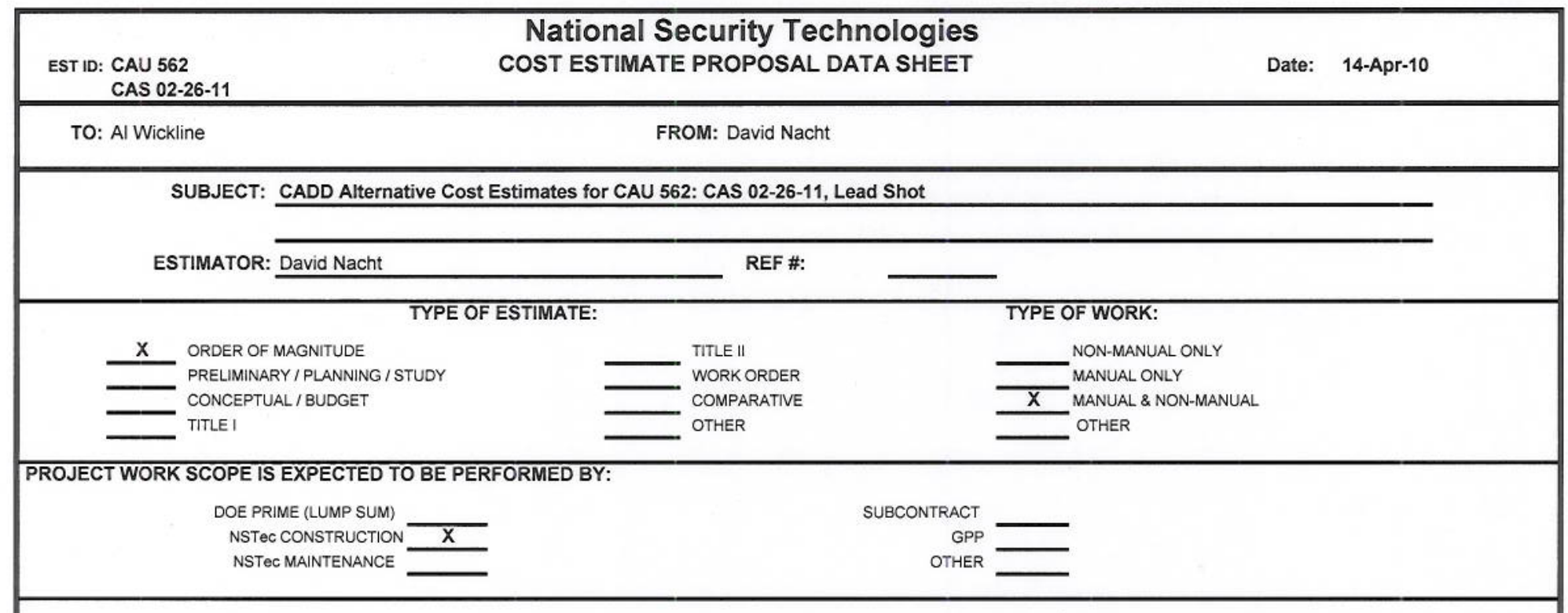

\section{STATEMENT OF WORK}

This estimate has been prepared to provide remedial alternative costs for the closure of Corrective Action Site (CAS) 02-26-11, which is included within Corrective Action Unit (CAU) 562. CAU 562 CAS 02-26-11 is an environmental restoration site listed in the Federal Facility Agreement and Consent Order (FFACO) and is specifically described within the FFACO as lead shot, located on the ground surface at the Area 2 Camp Laborer's Storage Area. Two alternatives have been evaluated for closure of the CAS: I. No Further Action and II. Clean Closure. These estimates will be used to identify the most cost effective alternative for closure of the site while remaining protective of human health and the environment. The total estimated costs are intended for comparative analysis of remedial fieldwork cost only. Cost for project management, plan preparation, project support, and/or other activities are not included herein.

\section{SCOPE:}

Provide site closure using one of the following alternatives:

I) NO FURTHER ACTION

II) CLEAN CLOSURE

\section{BASIS:}

The characterization contractor recently completed field investigations of CAS 02-26-11, that indicate the following: An area of approximately 0.6 acres is impacted with lead and steal shot. The underlying soil is not impacted with lead above the action level. This shot shall be removed from the surface. The site closure was estimated using historical data and Project Manager's experience with similar work. There is no estimate required for evaluation of the No Further Action alternative since no cost is incurred.

\section{ALTERNATIVE SPECIFIC BASIS OF ESTIMATE/ASSUMPTIONS}

Alternative I: No Further Action

Alternative II: Clean Closure

- Perform removal of lead and steel shot from within the 0.6 acres

- Review characterization contractor data packages for waste characterization and dispose shot 


\section{ASSUMPTIONS:}

- No corrective actions are required for the surrounding areas outside the CAS boundary

- All COCs at the site have been identified during the site investigation and analytical data accurately represent site conditions and waste characteristics

- The nature of contamination is limited to the lead shot and the underlying soil is not impacted above the action levels

- Radioactive contamination is not present

- Equipment will remain operational to support the planned/scheduled completion of each CADD alternative

- Waste volumes are based on field measurements collected during the corrective action investigation

- Work to be performed by NSTec during a "normal" workday (no provision for overtime has been provided). Shifts are based on 10-hour days / 4-days per week

- All Craft will be provided by EM and not by construction

- This estimate does not include the efficiencies which may be realized if work for similar activities at similar sites can be completed concurrently

- Dimensions, volumes, measurements, and analytical data provided by the characterization contractor accurately represent site conditions and waste characteristics

- This estimate does not include costs for preparation of required project plans, permits, reports, mobilization and demobilization, site preparations, or project management.

\section{ESCALATION:}

No escalation factors have been applied.

\section{CONTINGENCY:}

Contingency costs are not included in this estimate.

\section{RATES:}

Rates are based on Out Year Rates FY11-13 effective 4/19/10 and were applied using the NSTec FY10 cost model.

\section{COST ALTERNATIVES SUMMARY:}

Alternative I: No Further Action

Alternative ll: Clean Closure
a. Perform removal of lead and steel shot from within the 0.6 acre area.
b. Review characterization contractor data packages for waste characterization
c. Dispose of hazardous waste

\section{/s/ Thomas A. Thiele}

/s/ Yim Liu-Bacon

Business Manager

$$
\text { Is/ Peter E. Thornock } 4 / 14 / 10
$$

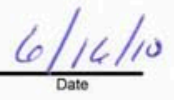


SUBJECT: CADD Alternative Cost Estimates for CAU 562: CAS 02-26-11, Lead Shot

ESTIMATOR: David Nacht REF \#:

\title{
TYPE OF ESTIMATE:
}

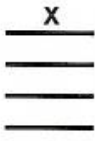
ORDER OF MAGNITUDE PRELIMINARY / PLANNING / STUDY CONCEPTUAL/BUDGET TITLE।

REF \#:
TYPE OF WORK:

\section{PROJECT WORK SCOPE IS EXPECTED TO BE PERFORMED BY:}

\author{
DOE PRIME (LUMP SUM) \\ NSTEC CONSTRUCTION \\ NSTEC MAINTENANCE
}

$\bar{x}$

SUBCONTRAC

GPP

TITLE ॥
WORK ORDER
COMPARATIVE
OTHER $\quad \begin{aligned} & \text { NON-MANUAL ONLY } \\ & \text { MANUAL ONLY } \\ & \text { MANUAL \& NON-MANUAL }\end{aligned}$

\section{STATEMENT OF WORK}

This is a supplemental estimate that has been prepared to evaluate the cost of Closure in Place with Administrative Controls. This estimate has been prepared to provide remedial alternative costs for the closure of Corrective Action Site (CAS) 02-26-11, which is included within Corrective Action Unit (CAU) 562. CAU 562 CAS 02-26-11 is an environmental restoration site listed in the Federal Facility Agreement and Consent Order (FFACO) and is specifically described within the FFACO as lead shot, located on the ground surface at the Area 2 Camp Laborer's Storage Area. Three alternatives have been evaluated for closure of the CAS: I. No Further Action Action, II. Clean Closure, and III. Closure in Place with Administrative Controls. Alternatives I and II were previously estimated, and these estimates are separate from the Alternative III estimate. These estimates will be used to identify the most cost effective alternative for closure of the site while remaining protective of human health and the environment. The total estimated costs are intended for comparative analysis of remedial fieldwork cost only. Cost for project management, plan preparation, project support, and/or other activities are not included herein.

\section{SCOPE:}

Provide site closure using one of the following alternatives:

III) CLOSURE IN PLACE WITH ADMINISTRATIVE CONTROLS

\section{BASIS:}

The characterization contractor recently completed field investigations of CAS $02-26-11$, that indicate the following: An area of approximately 0.6 acres is impacted with lead and steal shot. The underlying soil is not impacted with lead above the action level. Administrative controls (postings \& signs) will be installed. The site closure was estimated using historical data and Project Manager's There is no estimate required for evaluation of the No Further Action alternative since no cost is incurred.

\section{ALTERNATIVE SPECIFIC BASIS OF ESTIMATEIASSUMPTIONS}

Alternative III: Closure in Place with Administrative Controls

- Install administrative controls (postings and signs)

- Use restriction survey 


\section{ASSUMPTIONS:}

- No corrective actions are required for the surrounding areas outside the CAS boundary

- All COCs at the site have been identified during the site investigation and analytical data accurately represent site conditions and waste characteristics

- The nature of contamination is limited to the lead shot and the underlying soil is not impacted above the action levels

- Equipment will remain operational to support the planned/scheduled completion of each CADD alternative

- Work to be performed by NSTec during a "normal" workday (no provision for overtime has been provided). Shifts are based on 10-hour days / 4-days per
week

- All Craft will be provided by EM and not by construction

- This estimate does not include the efficiencies which may be realized if work for similar activities at similar sites can be completed concurrently

- Dimensions, volumes, measurements, and analytical data provided by the characterization contractor accurately represent site conditions and waste

characteristics

- This estimate does not include costs for preparation of required project plans, permits, reports, mobilization and demobilization, site preparations, or project management.

\section{ESCALATION:}

No escalation factors have been applied.

\section{CONTINGENCY:}

Contingency costs are not included in this estimate.

\section{RATES:}

Rates are based on Out Year Rates FY11-13 effective 4/19/10 and were applied using the NSTec FY10 cost model.

\section{COST ALTERNATIVES SUMMARY:}

Alternative III: Closure in Place with Administrative Controls

a. Install administrative controls (postings and 8 signs)

b. Use restriction survey

\section{REVIEW/ CONCURRENCE:}

Is/ Thomas A. Thiele

Program Manager

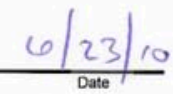

Is/ Yim Liu-Bacon

Businesy ylanager

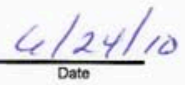

Is/Peter E, Thornock

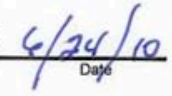


EST ID: CAU 562

National Security Technologies

CAS 02-44-02 COST ESTIMATE PROPOSAL DATA SHEET

Date: 14-Apr-10

TO: Al Wickline

FROM: David Nacht

SUBJECT: CADD Alternative Cost Estimates for CAU 562: CAS 02-44-02, Paint Spills and French Drain

ESTIMATOR: David Nacht

REF \#:

TYPE OF ESTIMATE:

$\mathrm{X}$ ORDER OF MAGNITUDE PRELIMINARY / PLANNING / STUDY CONCEPTUAL/BUDGET TITLEI

REF \#.

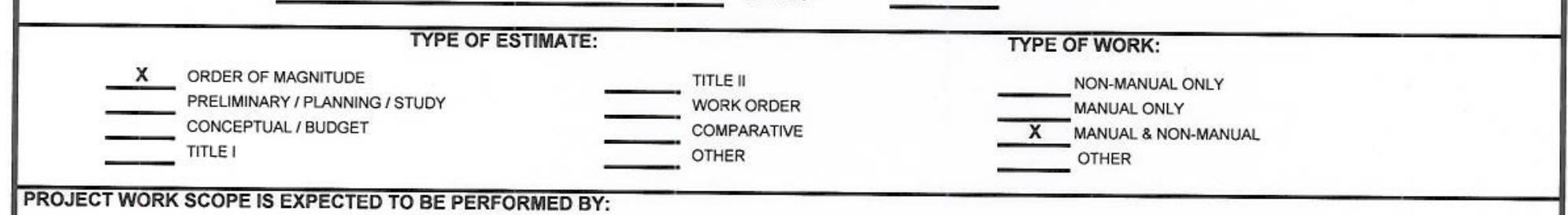

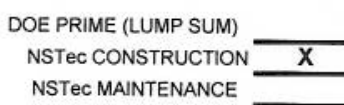

NSTEC MAINTENANCE

SUBCONTRACT

GPP

OTHER

\section{STATEMENT OF WORK}

This estimate has been prepared to provide remedial alternative costs for the closure of Corrective Action Site (CAS) 02-44-02, which is included within Corrective Action Unit (CAU) 562. CAU 562 CAS 02-44-02 is an environmental restoration site listed in the Federal Facility Agreement and Consent Order (FFACO) and is specifically described within the FFACO as paint spills and french drain, located in the vicinity of the Paint Shop and Painters' Shed located in Area 2 of the NTS. Two alternatives have been evaluated for closure of the CAS: I. No Further Action and II. Clean Closure. These estimates will be used to identify the most cost effective alternative for closure of the site while remaining protective of human health and the environment. The total estimated costs are intended for comparative analysis of remedial fieldwork cost only. Cost for project management, plan preparation, project support, and/or other
activities are not included herein.

\section{SCOPE:}

Provide site closure using one of the following alternatives:

I) NO FURTHER ACTION

ii) CLEAN CLOSURE

\section{BASIS:}

The characterization contractor recently completed field investigations of CAS 02-44-02, that indicate the following: Paint chips on the pad of the formers painter shed contains chromium, lead, benzo(a)pyrene, bis(2ethylhexyl)phthalate and 2 cy of soil contains benzo(a)pyrene. The paint will be scraped off the pad and packaged ashazardous waste and disposed off-site. The $2 \mathrm{cy}$ of impacted soil will be excavated and transported to U10C for disposal. Five SVOC verification samples will be collected and the excavation will be backfilled once the samples are below the action levels. In addition asbestos tiles ( $20 \mathrm{ft}$ by 20 $\mathrm{ft}$ ) will be removed from the building pad in the CAS boundary. The site closure was estimated using historical data and Project Manager's experience with similar work. There is no estimate required for evaluation of the No Further Action alternative since no cost is incurred.

\section{ALTERNATIVE SPECIFIC BASIS OF ESTIMATEIASSUMPTIONS}

\section{Alternative I: No Further Action}

Alternative II: Clean Closure

- Remove and package (hazardous waste) paint chips on the pad of the former Painters' Shed

- Excavate 2 cy of soil that contains benzo(a)pyrene, dispose in U10C, and collect SVOC verification samples

- Backfill excavation

- Review characterization contractor data packages for waste characterization and dispose of the paint chips

- Remove, package, and dispose asbestos tiles within a $20 \mathrm{ft}$ by $20 \mathrm{ft}$ area 


\section{ASSUMPTIONS:}

- No corrective actions are required for the surrounding areas outside the CAS boundary

- All COCs at the site have been identified during the site investigation and analytical data accurately represent site conditions and waste characteristics

- The nature of contamination is limited to the paint chips and the underlying concrete is not impacted and will not need to be removed

- The 2 cubic yards of soil impacted with benzo(a)pyren is not hazardous waste and can be disposed in U10C. Five SVOC verification samples will be

collected and the excavation will be backfilled once the samples are below the action levels

- Asbestos tiles ( $20 \mathrm{ft}$ by $20 \mathrm{ft}$ ) will be removed from the building pad in the CAS boundary

- Mixed, LLW, toxic, and hydrocarbon waste will not be generated

- Equipment will remain operational to support the planned/scheduled completion of each CADD alternative

- Waste volumes are based on field measurements collected during the corrective action investigation

- Work to be performed by NSTec during a "normal" workday (no provision for overtime has been provided). Shifts are based on 10-hour days / 4-days per week

- All Craft will be provided by EM and not by construction

- This estimate does not include the efficiencies which may be realized if work for similar activities at similar sites can be completed concurrently

- Dimensions, volumes, measurements, and analytical data provided by the characterization contractor accurately represent site conditions and waste characteristics

- This estimate does not include costs for preparation of required project plans, permits, reports, mobilization and demobilization, site preparations, or project management.

\section{ESCALATION:}

No escalation factors have been applied.

\section{CONTINGENCY:}

Contingency costs are not included in this estimate.

\section{RATES:}

Rates are based on Out Year Rates FY11-13 effective 4/19/10 and were applied using the NSTeC FY10 cost model.

\section{COST ALTERNATIVES SUMMARY:}

Alternative I: No Further Action

Alternative II: Clean Closure

a. Remove and package (hazardous waste) paint chips on the pad of the former Painters' Shed

b. Excavate $2 \mathrm{cy}$ of soil that contains benzo(a)pyrene and dispose in U10C. Collect verification samples and backfill excavation

c. Review characterization contractor data packages for waste characterization and dispose of hazardous waste

d. Remove, package, and dispose asbestos tiles within a $20 \mathrm{ft}$ by $20 \mathrm{ft}$ area

\section{REVIEW / CONCURRENCE:}

\section{Is/ Thomas A. Thiele}

Is/ Yim Liu-Bacon

Business Manager

Busin

/s/ Peter E. Thornock 
SUBJECT: CADD Alternative Cost Estimates for CAU 562: CAS 02-44-02, Paint Spills and French Drain

ESTIMATOR: David Nacht

SUBCONTRACT

GPP

OTHER

\section{STATEMENT OF WORK}

This is a supplemental estimate that has been prepared to evaluate the cost of Closure in Place with Administrative Controls. This estimate has been prepared to provide remedial alternative costs for the closure of Corrective Action Site (CAS) 02-44-02, which is included within Corrective Action Unit (CAU) 562. CAU 562 CAS 02-44-02 is an environmental restoration site listed in the Federal Facility Agreement and Consent Order (FFACO) and is specifically described within the FFACO as paint spills and french drain, located in the vicinity of the Paint Shop and Painters' Shed located in Area 2 of the NTSThree alternatives have been evaluated for closure of the CAS: I. No Further Action Action, II. Clean Closure, and III. Closure in Place with Administrative Controls. Alternatives I and II were previously estimated, and these estimates are separate from the Alternative III estimate. These estimates will be used to identify the most cost effective alternative for closure of the site while remaining protective of human health and the environment. The total estimated costs are intended for comparative analysis of remedial fieldwork cost only. Cost for project management, plan preparation, project support, and/or other activities are not included herein.

\section{SCOPE:}

Provide site closure using one of the following alternatives:

III) CLOSURE IN PLACE WITH ADMINISTRATIVE CONTROLS

\section{BASIS:}

The characterization contractor recently completed field investigations of CAS 02-44-02, that indicate the following: Paint chips on the pad of the formers painter shed contains chromium, lead, benzo(a)pyrene, bis(2ethylhexyl)phthalate and 2 cy of soil contains benzo(a)pyrene. Administrative controls (postings \& signs) will be installed. The site closure was estimated using historical data and Project Manager's experience with similar work.

\section{ALTERNATIVE SPECIFIC BASIS OF ESTIMATE/ASSUMPTIONS}

Alternative III: Closure in Place with Administrative Controls

- Install administrative controls (postings and signs)

- Use restriction survey 


\section{ASSUMPTIONS:}

- No corrective actions are required for the surrounding areas outside the CAS boundary

- All COCs at the site have been identified during the site investigation and analytical data accurately represent site conditions and waste characteristics

- The nature of contamination is limited to the paint chips and 2 cubic yards of soil impacted with benzo(a)pyren

- Equipment will remain operational to support the planned/scheduled completion of each CADD alternative

- Work to be performed by NSTec during a "normal" workday (no provision for overtime has been provided). Shifts are based on 10-hour days / 4-days per week

- All Craft will be provided by EM and not by construction

- This estimate does not include the efficiencies which may be realized if work for similar activities at similar sites can be completed concurrently

- Dimensions, volumes, measurements, and analytical data provided by the characterization contractor accurately represent site conditions and waste characteristics

- This estimate does not include costs for preparation of required project plans, permits, reports, mobilization and demobilization, site preparations, or project management.

\section{ESCALATION:}

No escalation factors have been applied.

\section{CONTINGENCY:}

Contingency costs are not included in this estimate.

\section{RATES:}

Rates are based on Out Year Rates FY11-13 effective 4/19/10 and were applied using the NSTec FY10 cost model.

\section{COST ALTERNATIVES SUMMARY:}

Alternative III: Closure in Place with Administrative Controls

a. Install administrative controls (postings and 4 signs)

b. Use restriction survey

\section{REVIEW / CONCURRENCE:}

\section{Is/ Thomas A. Thiele}

Program Manager

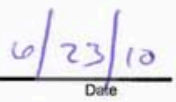

$\frac{\text { Is/ Yim Liu-Bacon }}{\text { Businessylanager }} \frac{6 / 24 / 10}{\text { Dato }}$

\section{/s/ Peter E. Thornock}

Project Controls

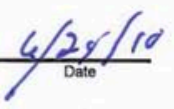




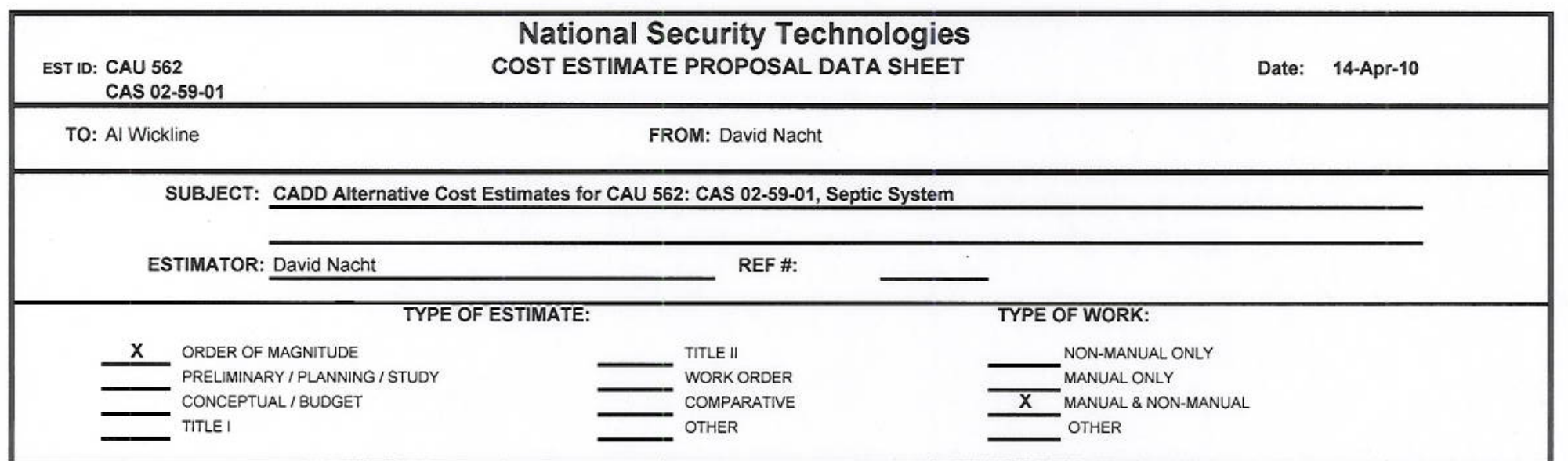

PROJECT WORK SCOPE IS EXPECTED TO BE PERFORMED BY:

$\begin{aligned} & \text { DOE PRIME (LUMP SUM) } \\ & \text { NSTec CONSTRUCTION } \\ & \text { NSTec MAINTENANCE }\end{aligned}-\quad$ SUBCONTRACT

\section{STATEMENT OF WORK}

This estimate has been prepared to provide remedial alternative costs for the closure of Corrective Action Site (CAS) 02-59-01, which is included within Corrective Action Unit (CAU) 562. CAU 562 CAS 02-59-01 is an environmental restoration site listed in the Federal Facility Agreement and Consent Order (FFACO) and is specifically described within the FFACO as a septic system, located in the Area 2 Camp in Area 2 of the NTS. Two alternatives have been evaluated for closure of the CAS: I. No Further Action and II Clean Closure. These estimates will be used to identify the most cost effective alternative for closure of the site while remaining protective of human health and the environment. The total estimated costs are intended for comparative analysis of remedial fieldwork cost only. Cost for project management, plan preparation, project support, and/or other activities are not included herein.

\section{SCOPE:}

Provide site closure using one of the following alternatives:

I) NO FURTHER ACTION

II) CLEAN CLOSURE

\section{BASIS:}

The characterization contractor recently completed field investigations of CAS 02-59-01, that indicate the following: The septic tank was found to be mostly full and contains 6,300 gallons of liquid and a small amount of hydrocarbon impacted sludge (up to $2,600 \mathrm{mg} / \mathrm{kg}$ ). The liquid cannot be disposed in the lagoon since it was found to contain slightly more than double the lagoon acceptance level of $15 \mathrm{pCi} / \mathrm{L}$ for gross alpha. It will be pumped from the septic tank and solidified in lined basins. After the majority of the liquid is removed, the remaining liquid and sludge will be solidified in the tank and removed for disposal and the tank will be removed and disposed. This waste will be disposed in U10C or the hydrocarbon landfill. The excavation will be backfilled to grade after hydrocarbon verification sample results come back below the action level. The site closure was estimated using historical data and Project Manager's experience with similar work. There is no estimate required for evaluation of the No Further Action alternative since no cost is incurred.

\section{ALTERNATIVE SPECIFIC BASIS OF ESTIMATE/ASSUMPTIONS}

\section{Alternative I: No Further Action}

Alternative II: Clean Closure

- Review characterization contractor data packages for waste characterization

- Deliver $\mathbf{4 4 0}$ cubic yards of NTS native soil for building solidification basins, solidifying waste, and backfilling tank excavation

- Build six solidification basins

- Pump 6,300 gallons of liquid from the septic tank into the solidification basins and solidify waste

- Open the top of the septic tank \& solidify remaining liquid and sludge

- Dispose of up to 320 cubic yards of solidified waste in U10C or the Hydrocarbon landfill using end-dumps

- Dispose the septic tank in U10C or the hydrocarbon landfill

- Collect TPH verification samples from the septic tank excavation

- Backfill septic tank excavation to grade 


\section{ASSUMPTIONS:}

- No corrective actions are required for the surrounding areas outside the CAS boundary

- All COCs at the site have been identified during the site investigation and analytical data accurately represent site conditions and waste characteristics

- The nature of contamination is limited to 6,300 gallons of liquid that is slightly more than double the lagoon acceptance level of 15 pCi/L for gross alpha and

a small amount of sludge that is impacted with hydrocarbons up to $2,600 \mathrm{mg} / \mathrm{kg}$

- Each solidification basin can be used to solidify up to 1,200 gallons and 6 basins will be required

- Soil under/around the septic tank is not impacted and will not be required to be removed

- Equipment will remain operational to support the planned/scheduled completion of each CADD alternative

- Waste volumes are based on field measurements collected during the corrective action investigation

- Work to be performed by NSTec during a "normal" workday (no provision for overtime has been provided). Shifts are based on 10-hour days / 4-days per week

- All Craft will be provided by EM and not by construction

- This estimate does not include the efficiencies which may be realized if work for similar activities at similar sites can be completed concurrently

- Dimensions, volumes, measurements, and analytical data provided by the characterization contractor accurately represent site conditions and waste characteristics

- This estimate does not include costs for preparation of required project plans, permits, reports, mobilization and demobilization, site preparations, or project management.

\section{ESCALATION:}

No escalation factors have been applied.

\section{CONTINGENCY:}

Contingency costs are not included in this estimate.

\section{RATES:}

Rates are based on Out Year Rates FY11-13 effective 4/19/10 and were applied using the NSTec FY10 cost model.

\section{COST ALTERNATIVES SUMMARY:}

Alternative I: No Further Action

Alternative II: Clean Closure

a. Deliver 440 cubic yards of NTS native soil for building solidification basins, solidifying waste, and backfilling tank excavation

b. Build six solidification basins, pump liquid from the septic tank, and solidify the liquid

c. Open septic tank, solidify and remove tank contents, and remove tank

d. Dispose of all waste in U10C or the hydrocarbon landfill

e. Collect TPH verification samples from the septic tank excavation

f. Backfill the septic tank excavation to grade

\section{/s/ Thomas A. Thiele}

/s/ Yim Liu-Bacon

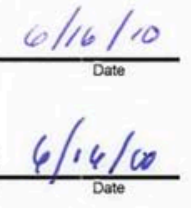




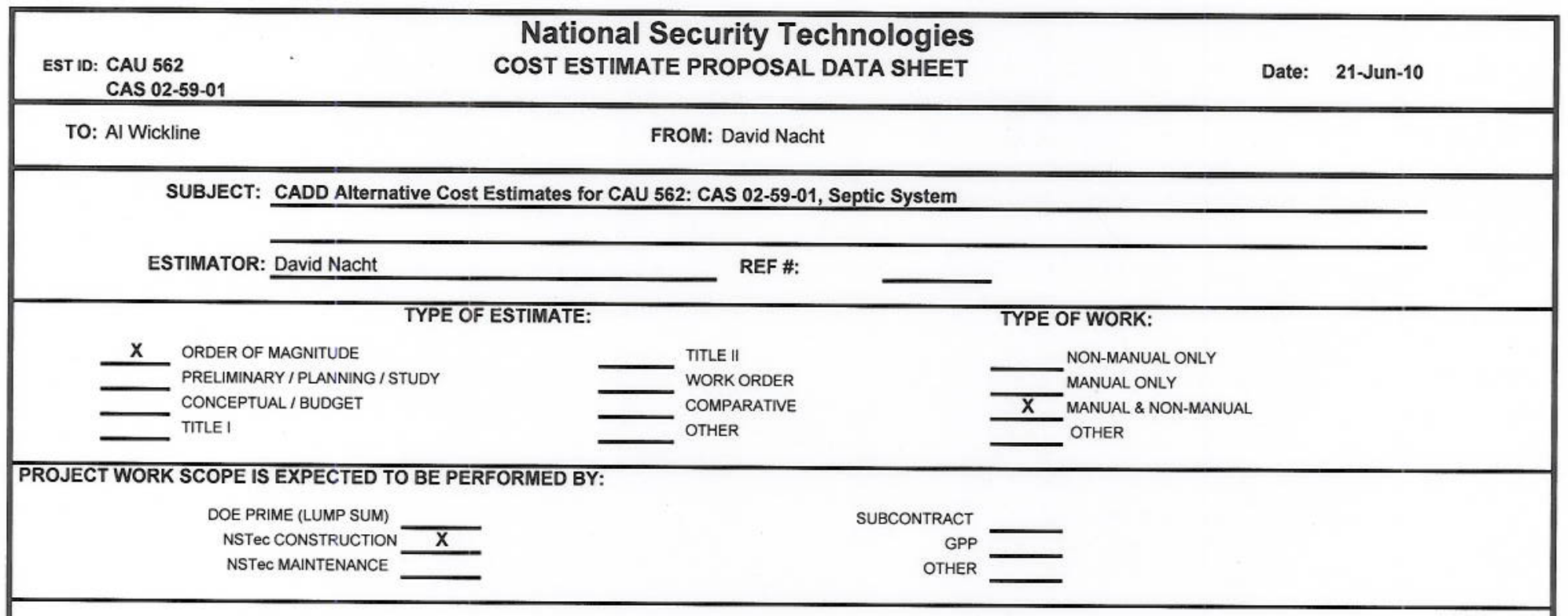

\section{STATEMENT OF WORK}

This is a supplemental estimate that has been prepared to evaluate the cost of Closure in Place with Administrative Controls. This estimate has been prepared to provide remedial alternative costs for the closure of Corrective Action Site (CAS) 02-59-01, which is included within Corrective Action Unit (CAU) 562. CAU 562 CAS 02-59-01 is an environmental restoration site listed in the Federal Facility Agreement and Consent Order (FFACO) and is specifically described within the FFACO as a septic system, located in the Area 2 Camp in Area 2 of the NTSThree alternatives have been evaluated for closure of the CAS: I. No Further Action Action, II. Clean Closure, and III. Closure in Place with Administrative Controls. Alternatives I and II were previously estimated, and these estimates are separate from the Alternative III estimate. These estimates will be used to identify the most cost effective alternative for closure of the site while remaining protective of human health and the environment. The total estimated costs are intended for comparative analysis of remedial fieldwork cost only. Cost for project management, plan preparation, project support, and/or other activities are not included herein.

\section{SCOPE:}

Provide site closure using one of the following alternatives:

III) CLOSURE IN PLACE WITH ADMINISTRATIVE CONTROLS

\section{BASIS:}

The characterization contractor recently completed field investigations of CAS 02-59-01, that indicate the following: The septic tank was found to be mostly full and contains 6,300 gallons of liquid and a small amount of hydrocarbon impacted sludge (up to $2,600 \mathrm{mg} / \mathrm{kg}$ ). Administrative controls (postings \& signs) will be installed. The site closure was estimated using historical data and Project Manager's experience with similar work

\section{ALTERNATIVE SPECIFIC BASIS OF ESTIMATE/ASSUMPTIONS}

Alternative III: Closure in Place with Administrative Controls

- Install administrative controls (postings and signs)

- Use restriction survey 


\section{ASSUMPTIONS:}

- No corrective actions are required for the surrounding areas outside the CAS boundary

- All COCs at the site have been identified during the site investigation and analytical data accurately represent site conditions and waste characteristics

- The nature of contamination is limited to the septic tank and consists of 6,300 gallons of liquid that is slightly more than double the lagoon acceptance level of

$15 \mathrm{pCi} / \mathrm{L}$ for gross alpha and a small amount of sludge that is impacted with hydrocarbons up to $2,600 \mathrm{mg} / \mathrm{kg}$

- Equipment will remain operational to support the planned/scheduled completion of each CADD alternative

- Work to be performed by NSTec during a "normal" workday (no provision for overtime has been provided). Shifts are based on 10-hour days / 4-days per

- All Craft will be provided by EM and not by construction

- This estimate does not include the efficiencies which may be realized if work for similar activities at similar sites can be completed concurrently

- Dimensions, volumes, measurements, and analytical data provided by the characterization contractor accurately represent site conditions and waste characteristics

- This estimate does not include costs for preparation of required project plans, permits, reports, mobilization and demobilization, site preparations, or project management.

\section{ESCALATION:}

No escalation factors have been applied.

\section{CONTINGENCY:}

Contingency costs are not included in this estimate.

\section{RATES:}

Rates are based on Out Year Rates FY11-13 effective 4/19/10 and were applied using the NSTec FY10 cost model.

\section{COST ALTERNATIVES SUMMARY:}

Alternative III: Closure in Place with Administrative Controls

a. Install administrative controls (postings and 4 signs)

b. Use restriction survey

\section{REVIEW/ CONCURRENCE:}

\section{Is/ Thomas A. Thiele}

Program Manager

\section{Is/ Yim Liu-Bacon}

Businers Manager

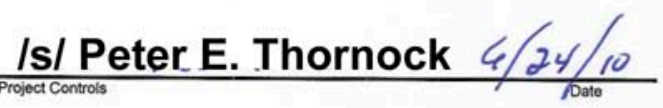




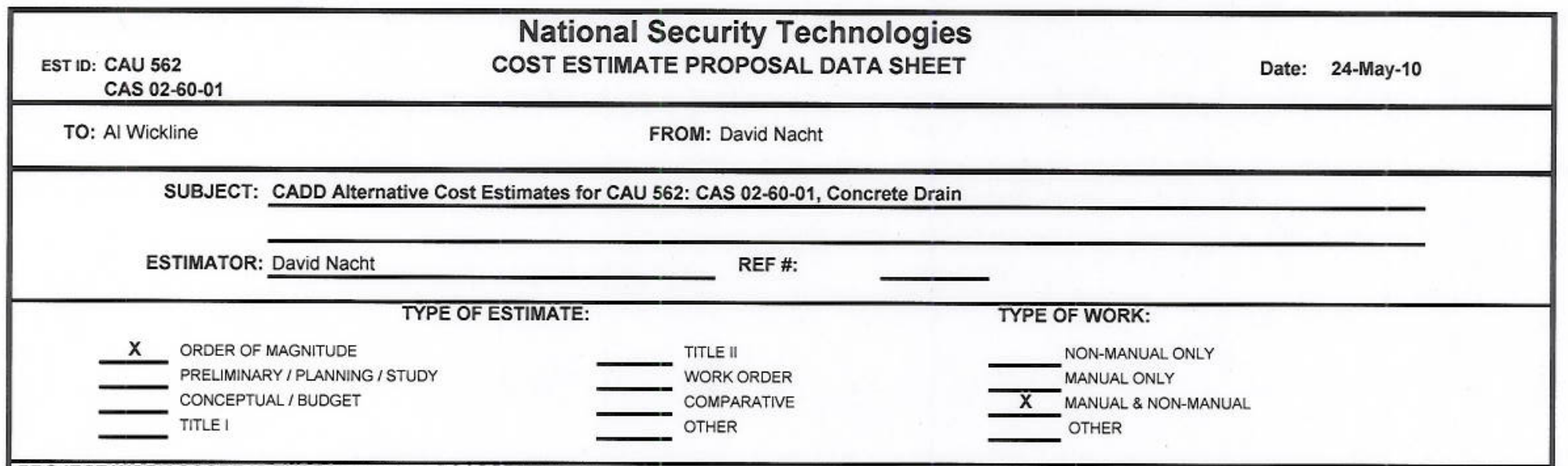

PROJECT WORK SCOPE IS EXPECTED TO BE PERFORMED BY:

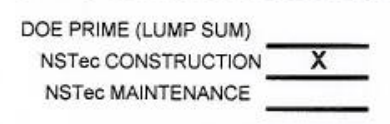

SUBCONTRACT

OTHER

\section{STATEMENT OF WORK}

This estimate has been prepared to provide remedial alternative costs for the closure of Corrective Action Site (CAS) 02-60-01, which is included within Corrective Action Unit (CAU) 562. CAU 562 CAS 02-60-01 is an environmental restoration site listed in the Federal Facility Agreement and Consent Order (FFACO) and is specifically described within the FFACO as a concrete drain, located adjacent to the concrete pad of Building $2 \mathrm{C}-56$ in the Area 2 Camp. Two alternatives have been evaluated for closure of the CAS: I. No Further Action and II. Clean Closure. These estimates will be used to identify the most cost effective alternative for closure of the site while remaining protective of human health and the environment. The total estimated costs are intended for comparative analysis of remedial fieldwork cost only. Cost for project management, plan preparation, project support, and/or other activities are not included herein.

\section{SCOPE:}

Provide site closure using one of the following alternatives:

I) NO FURTHER ACTION

II) CLEAN CLOSURE

\section{BASIS:}

The characterization contractor recently completed field investigations of CAS 02-60-01, that indicate the following: The concrete drain (up to 1cy of concrete) and $2 \mathrm{ft}$ of drain pipe will be removed and disposed as a best management practice since no contaminates of concern were identified. The excavation will be backfilled with soil. The site closure was estimated using historical data and Project Manager's experience with similar work. There is no estimate required for evaluation of the No Further Action alternative since no cost is incurred.

\section{ALTERNATIVE SPECIFIC BASIS OF ESTIMATE/ASSUMPTIONS}

\section{Alternative I: No Further Action}

Alternative II: Clean Closure

- Review characterization contractor data packages for waste characterization

- Remove the concrete drain and dispose up to $1 \mathrm{cy}$ of concrete and $2 \mathrm{ft}$ of piping in U10c

- Backfill the excavation with NTS native fill to the approximate natural contours 


\section{ASSUMPTIONS:}

- No corrective actions are required for the surrounding areas outside the CAS boundary

- No COCs at the site were identified during the site investigation

- Radiological, mixed, hazardous, hydrocarbon, or toxic waste will not be generated

- Verification samples will not be required

- Equipment will remain operational to support the planned/scheduled completion of each CADD alternative

-Waste volumes are based on field measurements collected during the corrective action investigation and all waste can go to U10C

- Work to be performed by NSTec during a "normal" workday (no provision for overtime has been provided). Shifts are based on 10-hour days / 4-days per wee.

- All Craft will be provided by EM and not by construction

- This estimate does not include the efficiencies which may be realized if work for similar activities at similar sites can be completed concurrently

- Dimensions, volumes, measurements, and analytical data provided by the characterization contractor accurately represent site conditions and waste characteristics

- This estimate does not include costs for preparation of required project plans, permits, reports, mobilization and demobilization, site preparations, or project management.

\section{ESCALATION:}

No escalation factors have been applied.

CONTINGENCY:

Contingency costs are not included in this estimate.

\section{RATES:}

Rates are based on Out Year Rates FY11-13 effective 4/19/10 and were applied using the NSTeC FY10 cost model.

\section{COST ALTERNATIVES SUMMARY:}

Alternative 1: No Further Action

Alternative II: Clean Closure

a. Remove the concrete drain and dispose up to $1 \mathrm{cy}$ of concrete and $2 \mathrm{ft}$ of piping in U10

b. Backfill the excavation with NTS native fill to the approximate natural contours

REVIEW/CONCURRENCE:

Is/ Thomas A. Thiele

Program Manager

/s/ Yim Liu-Bacon 


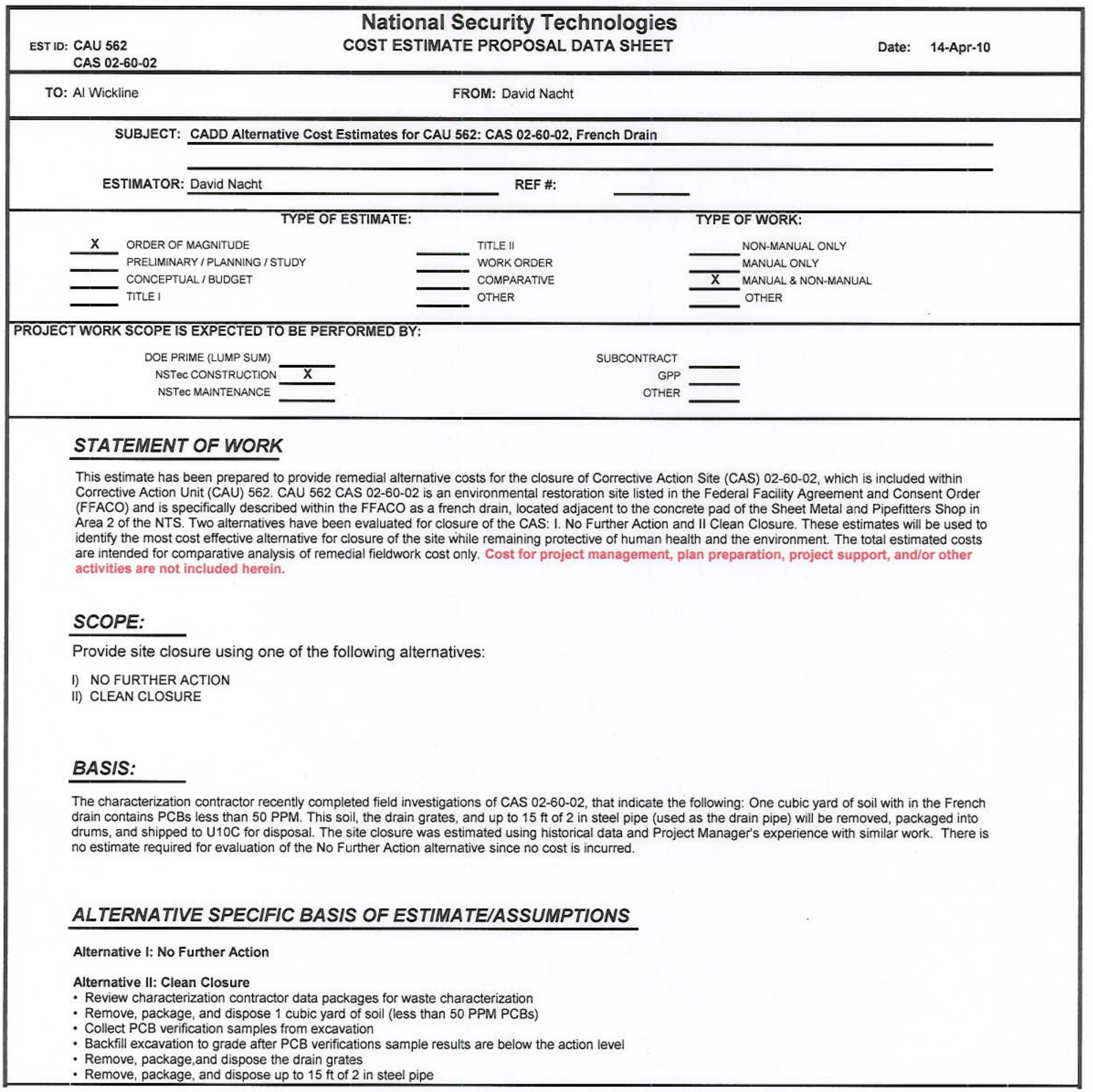




\section{ASSUMPTIONS:}

- No corrective actions are required for the surrounding areas outside the CAS boundary

- All COCs at the site have been identified during the site investigation and analytical data accurately represent site conditions and waste characteristics

- The nature of contamination is limited $1 \mathrm{cy}$ of PCB impacted soil (less than 50 PPM)

- Radiological, hazardous, or mixed waste will not be generated

- Equipment will remain operational to support the planned/scheduled completion of each CADD alternative

- Waste volumes are based on field measurements collected during the corrective action investigation

- Work to be performed by NSTec during a "normal" workday (no provision for overtime has been provided). Shifts are based on 10-hour days / 4-days per week

- All Craft will be provided by EM and not by construction

- This estimate does not include the efficiencies which may be realized if work for similar activities at similar sites can be completed concurrently

- Dimensions, volumes, measurements, and analytical data provided by the characterization contractor accurately represent site conditions and waste characteristics

- This estimate does not include costs for preparation of required project plans, permits, reports, mobilization and demobilization, site preparations, or project management.

\section{ESCALATION:}

No escalation factors have been applied.

\section{CONTINGENCY:}

Contingency costs are not included in this estimate.

\section{RATES:}

Rates are based on Out Year Rates FY11-13 effective 4/19/10 and were applied using the NSTec FY10 cost model.

\section{COST ALTERNATIVES SUMMARY:}

Alternative I: No Further Action

Alternative II: Clean Closure

a. Remove, package, and dispose 1 cubic yard of soil that contains less than 50 PPM PCBs

b. Collect PCB verification samples and backfill excavation

c. Remove, package, and dispose drain grates and $15 \mathrm{ft}$ of 2 inch drain piping

REVIEW/CONCURRENCE:

Is/ Thomas A. Thiele

Program Manager

Is/ Yim Liu-Bacon Business Matriger

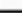

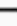

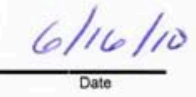

Is/ Peter E. Thornock 
SUBJECT: CADD Alternative Cost Estimates for CAU 562: CAS 02-60-02, French Drain

ESTIMATOR: David Nacht REF \#:

\title{
TYPE OF ESTIMATE:
}

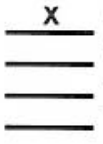

ORDER OF MAGNITUDE PRELIMINARY / PLANNING / STUDY CONCEPTUAL / BUDGET TITLE I

\section{PROJECT WORK SCOPE IS EXPECTED TO BE PERFORMED BY:}

\author{
DOE PRIME (LUMP SUM) \\ NSTEC CONSTRUCTION \\ NSTEC MAINTENANCE
}

$\mathrm{x}$

SUBCONTRACT

GPP

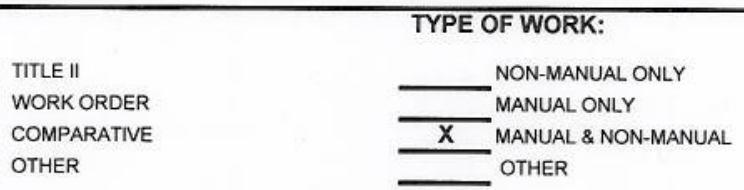

\section{STATEMENT OF WORK}

This is a supplemental estimate that has been prepared to evaluate the cost of Closure in Place with Administrative Controls. This estimate has been prepared to provide remedial alternative costs for the closure of Corrective Action Site (CAS) 02-60-02, which is included within Corrective Action Unit (CAU) 562. CAU 562 CAS 02-60-02 is an environmental restoration site listed in the Federal Facility Agreement and Consent Order (FFACO) and is specifically described within the FFACO as a french drain, located adjacent to the concrete pad of the Sheet Metal and Pipefitters Shop in Area 2 of the NTS. Three alternatives have been evaluated for closure of the CAS: I. No Further Action Action, II. Clean Closure, and III. Closure in Place with Administrative Controls. Alternatives I and II were previously estimated, and these estimates are separate from the Alternative III estimate. These estimates will be used to identify the most cost effective alternative for closure of the site while remaining protective of human health and the environment. The total estimated costs are intended for comparative analysis of remedial fieldwork cost only. Cost for project management, plan preparation, project support, and/or other activities are not included herein.

\section{SCOPE:}

Provide site closure using one of the following alternatives:

III) CLOSURE IN PLACE WITH ADMINISTRATIVE CONTROLS

\section{BASIS:}

The characterization contractor recently completed field investigations of CAS $02-60-02$, that indicate the following: One cubic yard of soil with in the French drain contains PCBs less than 50 PPM. Administrative controls (postings \& signs) will be installed. The site closure was estimated using historical data and Project Manager's experience with similar work

\section{ALTERNATIVE SPECIFIC BASIS OF ESTIMATE/ASSUMPTIONS}

Alternative III: Closure in Place with Administrative Controls

- Install administrative controls (postings and signs)

- Use restriction survey 


\section{ASSUMPTIONS:}

- No corrective actions are required for the surrounding areas outside the CAS boundary

- All COCs at the site have been identified during the site investigation and analytical data accurately represent site conditions and waste characteristics

- The nature of contamination is limited 1 cy of PCB impacted soil (less than 50 PPM)

- Radiological, hazardous, or mixed waste will not be generated

- Equipment will remain operational to support the planned/scheduled completion of each CADD alternative

- Waste volumes are based on field measurements collected during the corrective action investigation

- Work to be performed by NSTec during a "normal" workday (no provision for overtime has been provided). Shifts are based on 10-hour days / 4-days per week

- All Craft will be provided by EM and not by construction

- This estimate does not include the efficiencies which may be realized if work for similar activities at similar sites can be completed concurrently

- Dimensions, volumes, measurements, and analytical data provided by the characterization contractor accurately represent site conditions and waste characteristics

- This estimate does not include costs for preparation of required project plans, permits, reports, mobilization and demobilization, site preparations, or project management.

\section{ESCALATION:}

No escalation factors have been applied.

\section{CONTINGENCY:}

Contingency costs are not included in this estimate

\section{RATES:}

Rates are based on Out Year Rates FY11-13 effective 4/19/10 and were applied using the NSTec FY10 cost model.

\section{COST ALTERNATIVES SUMMARY:}

Alternative III: Closure in place with Administrative Controls

a. Install administrative controls (postings and 4 signs)

b. Use restriction survey

\section{Is/ Thomas A. Thiele}

Program Manager

\section{Is/ Yim Liu-Bacon \\ Business Manager}

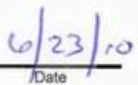

\section{Is/ Peter E. Thornock}

Project Controls
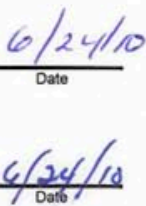


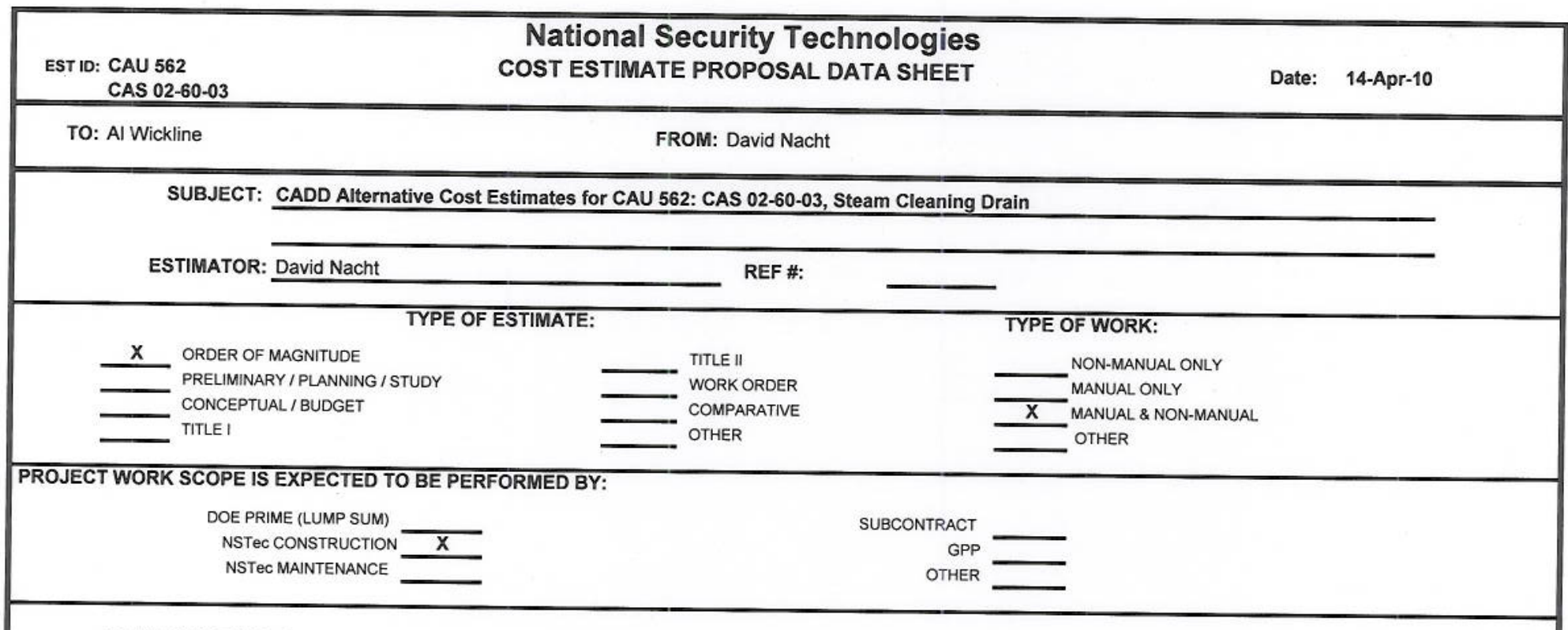

\section{STATEMENT OF WORK}

This estimate has been prepared to provide remedial alternative costs for the closure of Corrective Action Site (CAS) 02-60-03, which is included within Corrective Action Unit (CAU) 562. CAU 562 CAS 02-60-03 is an environmental restoration site listed in the Federal Facility Agreement and Consent Order (FFACO) and is specifically described within the FFACO as a steam cleaning drain, located near the Linemen Shop in the Area 2 Camp of the NTS. Two alternatives have been evaluated for closure of the CAS: I. No Further Action and II Clean Closure. These estimates will be used to identify the most cost effective alternative for closure of the site while remaining protective of human health and the environment. The total estimated costs are intended for comparative analysis of remedial fieldwork cost only. Cost for project management, plan preparation, project support, and/or other activities are not
included herein.

\section{SCOPE:}

Provide site closure using one of the following alternatives:

l) NO FURTHER ACTION

II) CLEAN CLOSURE

\section{BASIS:}

The characterization contractor recently completed field investigations of CAS 02-60-03, that indicate the following: The soil within the steam cleaning sump contains $16 \mathrm{cy}$ of soil impacted with $0.27 \mathrm{mg} / \mathrm{kg}$ benzo(a)pyrene and $10 \mathrm{cy}$ of soil around the sump contains PCBs at $1 \mathrm{mg} / \mathrm{kg}$. The soil in the sump and around the sump will be removed and disposed in U10C. The sump grate and outfall pipe ( $15 \mathrm{ft}$ ) will also be removed and disposed in U10C. The sump will be backfilled with soil and capped with a two foot layer of concrete and the excavation outside the sump will be backfilled with soil. The site closure was estimated using historical data and Project Manager's experience with similar work. There is no estimate required for evaluation of the No Further Action
alternative since no cost is incurred.

\section{ALTERNATIVE SPECIFIC BASIS OF ESTIMATEIASSUMPTIONS}

\section{Alternative I: No Further Action}

Alternative II: Clean Closure

- Review characterization contractor data packages for waste characterization

- Remove and dispose 16 cubic yards of soil impacted with $0.27 \mathrm{mg} / \mathrm{kg}$ benzo(a)pyrene to U10C in the sump

- Remove and dispose 10 cubic yards of soil to U10C around the sump

- Collect PCB verification samples from excavation

- Remove and dispose sump grate and $15 \mathrm{ft}$ of outfall pipe and dispose in U10C

- Backfill sump with soil and cap with concrete

- Backfill excavation outside of sump to grade once verifications sample results are below the action level 


\section{ASSUMPTIONS:}

- No corrective actions are required for the surrounding areas outside the CAS boundary

- All COCs at the site have been identified during the site investigation and analytical data accurately represent site conditions and waste characteristics

- The nature of contamination is limited $10 \mathrm{cy}$ of PCB impacted soll (less than 50 PPM) \& $16 \mathrm{cy}$ of soil impacted with $0.27 \mathrm{mg} / \mathrm{kg}$

- Radiological, hazardous, or mixed waste will not be generated

- Equipment will remain operational to support the planned/scheduled completion of each CADD alternative

- Waste volumes are based on field measurements collected during the corrective action investigation and are unexpanded. A 20\% expansion factor is estimate - Work to be performed by NSTec during a "normal" workday (no provision for overtime has been provided). Shifts are based on 10-hour days / 4-days per
week

- All Craft will be provided by EM and not by construction

- This estimate does not include the efficiencies which may be realized if work for similar activities at similar sites can be completed concurrently

- Dimensions, volumes, measurements, and analytical data provided by the characterization contractor accurately represent site conditions and waste

- This estimate does not include costs for preparation of required project plans, permits, reports, mobilization and demobilization, site preparations, or project management.

\section{ESCALATION:}

No escalation factors have been applied.

\section{CONTINGENCY:}

Contingency costs are not included in this estimate.

\section{RATES:}

Rates are based on Out Year Rates FY11-13 effective 4/19/10 and were applied using the NSTeC FY10 cost model.

\section{COST ALTERNATIVES SUMMARY:}

\section{Alternative 1: No Further Action}

Alternative II: Clean Closure
a. Remove and dispose 10 cubic yards of soil that contains less than 50 PPM PCBs in U10C
b. Remove and dispose 16 cubic yards of soil impacted with $0.27 \mathrm{mg} / \mathrm{kg}$ in U10C
c. Collect PCB verification samples from the excavation outside the sump
d. Remove and dispose sump grate and $15 \mathrm{ft}$ of outfall pipe and dispose in U10C
e. Backfill excavation outside sump with soil once $\mathrm{PCB}$ verification sample results are below action levels
f. Backfill sump with soil and cap with concrete

\section{REVIEW/ CONCURRENCE:}

\section{\begin{tabular}{l|l|l|l} 
Is/ Thomas A. Thiele $\quad 6$ & 16 & 10 \\
\hline Date &
\end{tabular}}

\section{/s/ Yim Liu-Bacon}

Business Qbanage

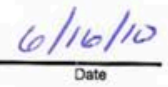

/s/ Peter E. Thornock 
SUBJECT: CADD Alternative Cost Estimates for CAU 562: CAS 02-60-03, Steam Cleaning Drain

ESTIMATOR: $\underline{\text { David Nacht }}$ REF \#: TYPE OF ESTIMATE:

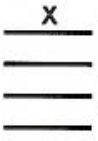
ORDER OF MAGNITUDE PRELIMINARY / PLANNING / STUDY CONCEPTUAL/BUDGET TITLE I

REF \#:

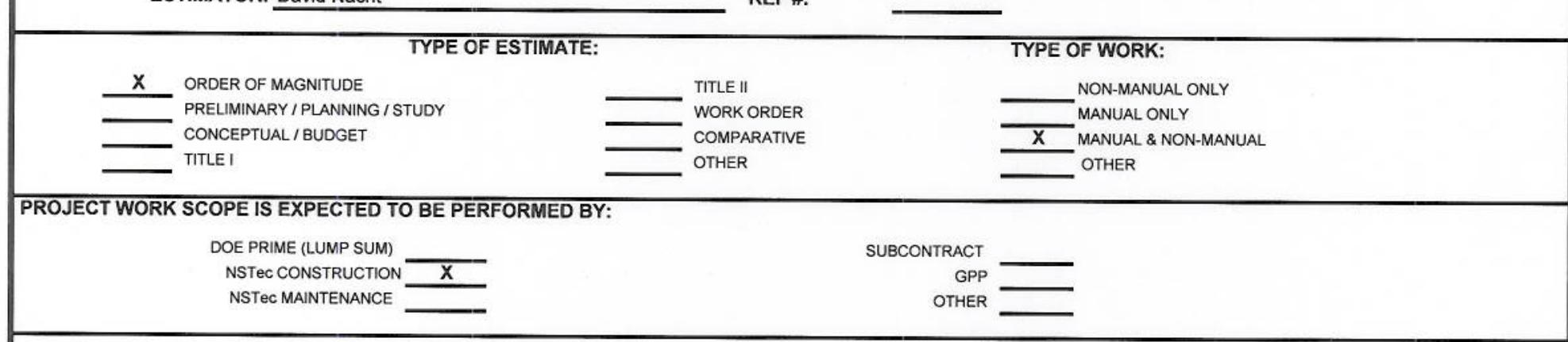

\section{STATEMENT OF WORK}

This is a supplemental estimate that has been prepared to evaluate the cost of Closure in Place with Administrative Controls. This estimate has been prepared to provide remedial alternative costs for the closure of Corrective Action Site (CAS) 02-60-03, which is included within Corrective Action Unit (CAU) 562. CAU 562 CAS 02-60-03 is an environmental restoration site listed in the Federal Facility Agreement and Consent Order (FFACO) and is specifically described within the FFACO as a steam cleaning drain, located near the Linemen Shop in the Area 2 Camp of the NTS. Three alternatives have been evaluated for closure of the CAS: I. No Further Action Action, II. Clean Closure, and III. Closure in Place with Administrative Controls. Alternatives I and II were previously estimated, and these estimates are separate from the Alternative III estimate. These estimates will be used to identify the most cost effective alternative for closure of the site while remaining protective of human health and the environment. The total estimated costs are intended for comparative analysis of remedial fieldwork cost only. Cost for project management, plan preparation, project support, and/or other activities are not included herein.

\section{SCOPE:}

Provide site closure using one of the following alternatives:

III) CLOSURE IN PLACE WITH ADMINISTRATIVE CONTROLS

\section{BASIS:}

The characterization contractor recently completed field investigations of CAS $02-60-03$, that indicate the following: The soil within the steam cleaning sump contains 16 cy of soil impacted with $0.27 \mathrm{mg} / \mathrm{kg}$ benzo(a)pyrene and $10 \mathrm{cy}$ of soil around the sump contains PCBs at $1 \mathrm{mg} / \mathrm{kg}$. Administrative controls (postings \& signs) will be installed. The site closure was estimated using historical data and Project Manager's experience with similar work.

\section{ALTERNATIVE SPECIFIC BASIS OF ESTIMATE/ASSUMPTIONS}

Alternative III: Closure in Place with Administrative Controls

- Install administrative controls (postings and signs)

- Use restriction survey 


\section{ASSUMPTIONS:}

- No corrective actions are required for the surrounding areas outside the CAS boundary

- All COCs at the site have been identified during the site investigation and analytical data accurately represent site conditions and waste characteristics

- The nature of contamination is limited to $10 \mathrm{cy}$ of PCB impacted soil (less than 50 PPM) \& $16 \mathrm{cy}$ of soil impacted with 0.27 mg/kg

- Equipment will remain operational to support the planned/scheduled completion of each CADD alternative

- Work to be performed by NSTec during a "normal" workday (no provision for overtime has been provided). Shifts are based on 10-hour days / 4-days per week

- All Craft will be provided by EM and not by construction

- This estimate does not include the efficiencies which may be realized if work for similar activities at similar sites can be completed concurrently

- Dimensions, volumes, measurements, and analytical data provided by the characterization contractor accurately represent site conditions and waste characteristics

- This estimate does not include costs for preparation of required project plans, permits, reports, mobilization and demobilization, site preparations, or project management.

\section{ESCALATION:}

No escalation factors have been applied.

\section{CONTINGENCY:}

Contingency costs are not included in this estimate.

\section{RATES:}

Rates are based on Out Year Rates FY11-13 effective 4/19/10 and were applied using the NSTec FY10 cost model.

\section{COST ALTERNATIVES SUMMARY:}

Alternative III: Closure in place with Administrative Controls

a. Install administrative controls (postings and 4 signs)

b. Use restriction survey

Is/ Thomas A. Thiele

Program Manager

$\frac{\text { Is/ Yim Liu-Bacon }}{\text { Busines/Manager }}$

Is/ Peter E. Thornock

project Controls
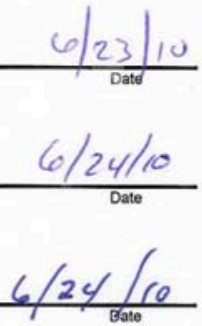


\begin{tabular}{|cc|c|c|c|c|c|c|}
\hline $\begin{array}{c}\text { National Security Technologies } \\
\text { EST ID: CAU } 562 \\
\text { CAS 02-60-05 }\end{array}$ & 26-May-10 ESTIMATE PROPOSAL DATA SHEET & Date: \\
\hline \hline
\end{tabular}

TO: Al Wickline

FROM: David Nacht

SUBJECT: CADD Alternative Cost Estimates for CAU 562: CAS 02-60-05, French Drain

ESTIMATOR: David Nacht

REF \#:

TYPE OF ESTIMATE:

$X$ ORDER OF MAGNITUDE PRELIMINARY / PLANNING / STUDY

$\longrightarrow$ PRELIMINARY / PLANNIN TITLEI

$\longrightarrow$ TITLE II
WORK ORDER
COMPARATIVE
OTHER
TYPE OF WORK: TITLE II
WORK ORDER
COMPARATIVE NON-MANUAL ONLY MANUAL ONLY

- TITEI

PROJECT WORK SCOPE IS EXPECTED TO BE PERFORMED BY:

DOE PRIME (LUMP SUM) NSTEC CONSTRUCTION NSTEC MAINTENANCE

$\bar{x}$

SUBCONTRACT

OTHER $=$

\section{STATEMENT OF WORK}

This estimate has been prepared to provide remedial alternative costs for the closure of Corrective Action Site (CAS) 02-60-05, which is included within Corrective Action Unit (CAU) 562. CAU 562 CAS 02-60-05 is an environmental restoration site listed in the Federal Facility Agreement and Consent Order (FFACO) and is specifically described within the FFACO as a French drain, located adjacent to the concrete pad of the Operators Office in the area 2 camp. Two alternatives have been evaluated for closure of the CAS: I. No Further Action and II. Clean Closure. These estimates will be used to identify the most cost effective alternative for closure of the site while remaining protective of human health and the environment. The total estimated costs are intended for comparative analysis of remedial fieldwork cost only. Cost for project management, plan preparation, project support, and/or other activities are not included herein.

\section{SCOPE:}

Provide site closure using one of the following alternatives:

I) NO FURTHER ACTION

II) CLEAN CLOSURE

\section{BASIS:}

The characterization contractor recently completed field investigations of CAS 02-60-05, that indicate the following: Benzo(a)Anthracene, Benzo(a)Pyrene, Benzo(b)Fluoranthene, Benzo(k)Fluoranthene, Dibenzo(a,h)Anthracene, and Indeno(1,2,3-cd)Pyrene were found above the final action levels in 44 cubic yards of soil around the drain. Based on the laboratory results and process knowledge this soil is not hazardous waste and can be disposed in U10C. The $44 \mathrm{cy}$ of impacted soil will be excavated and transported to U10C for disposal. Eight SVOC verification samples will be collected and the excavation will be backfilled once the samples are below the action levels. The site closure was estimated using historical data and Project Manager's experience with similar work. There is no estimate required for evaluation of the No Further Action alternative since no cost is incurred.

\section{ALTERNATIVE SPECIFIC BASIS OF ESTIMATEIASSUMPTIONS}

Alternative I: No Further Action

Alternative II: Clean Closure

- Review characterization contractor data packages for waste characterization

- Excavate up to $44 \mathrm{cy}$ of soil around the french drain and dispose in U10C dispose in U10C and collect SVOC verification samples

- Backfill the excavation with native fill to the approximate natural contours once verification samples are below action levels 


\section{ASSUMPTIONS:}

- No corrective actions are required for the surrounding areas outside the CAS boundary

- All COCs at the site have been identified during the site investigation and analytical data accurately represent site conditions and waste characteristics

- The nature of contamination is limited to $44 \mathrm{cy}$ of soil that meet the U10C disposal criteria. Eight SVOC verification samples will be collected and the

excavation will be backfilled once the samples are below the action levels

- Radiological, hazardous, hydrocarbon, toxic, or mixed waste will not be generated

- Equipment will remain operational to support the planned/scheduled completion of each CADD alternative

-Waste volumes are based on field measurements collected during the corrective action investigation

- Work to be performed by NSTec during a "normal" workday (no provision for overtime has been provided). Shifts are based on 10-hour days / 4-days per week

- All Craft will be provided by EM and not by construction

- This estimate does not include the efficiencies which may be realized if work for similar activities at similar sites can be completed concurrently

- Dimensions, volumes, measurements, and analytical data provided by the characterization contractor accurately represent site conditions and waste characteristics

- This estimate does not include costs for preparation of required project plans, permits, reports, mobilization and demobilization, site

preparations, or project management.

\section{ESCALATION:}

No escalation factors have been applied.

CONTINGENCY:

Contingency costs are not included in this estimate.

\section{RATES:}

Rates are based on Out Year Rates FY11-13 effective 4/19/10 and were applied using the NSTeC FY10 cost model.

\section{COST ALTERNATIVES SUMMARY:}

Alternative I: No Further Action

Alternative ll: Clean Closure

a. Excavate up to $44 \mathrm{cy}$ of soil around the french drain and dispose in U10C \& collect verification samples

b. Backfill the excavation with native fill to the approximate natural contours

\section{REVIEW/CONCURRENCE:}

\section{Is/ Thomas A. Thiele}

Program Manager

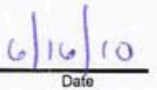

\section{/s/ Yim Liu-Bacon}

Busines/Manager

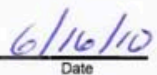

Is/ Peter E. Thornock 


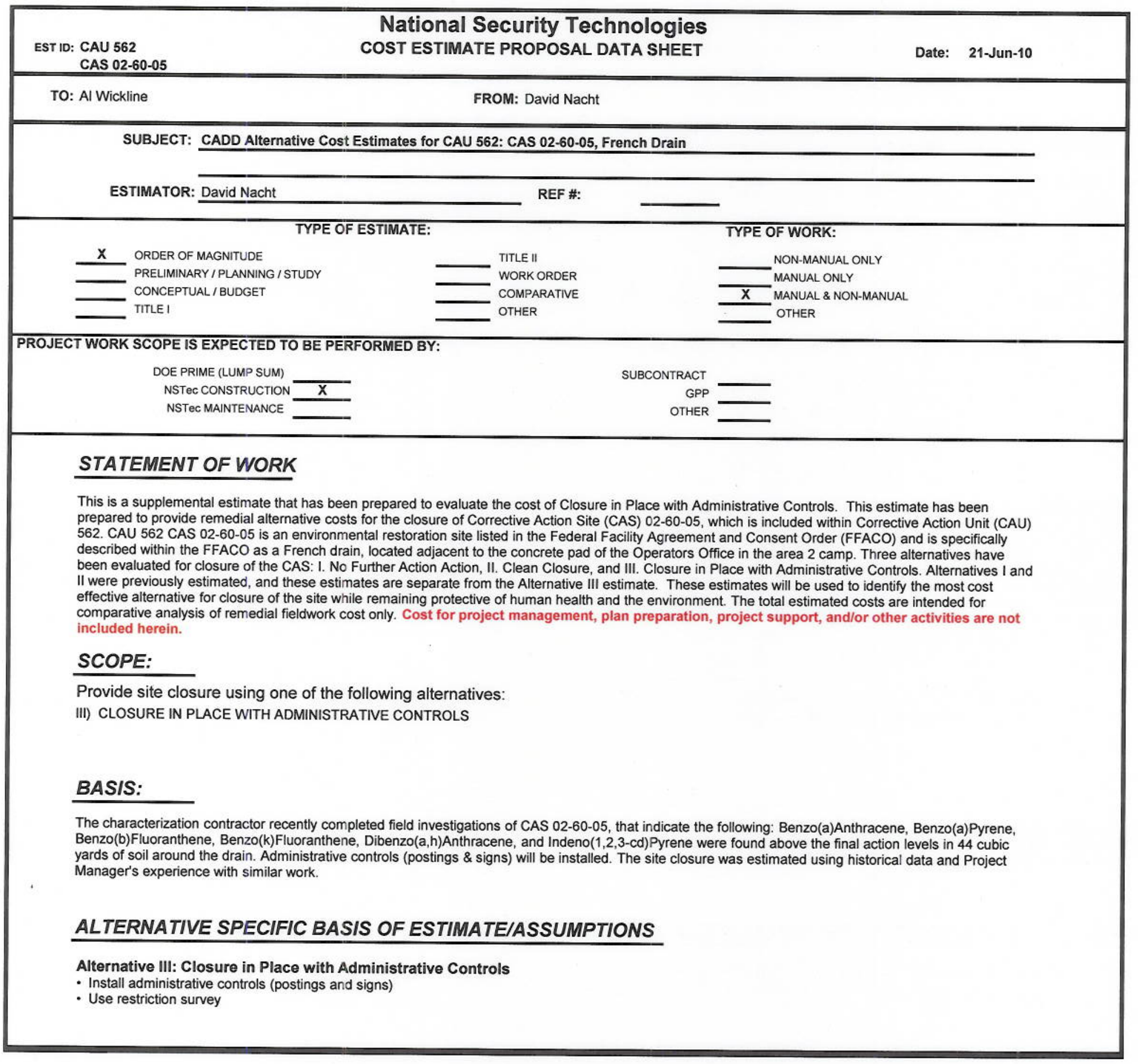

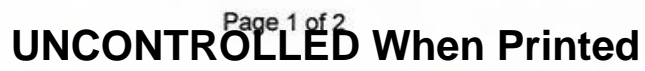




\section{ASSUMPTIONS:}

- No corrective actions are required for the surrounding areas outside the CAS boundary

- All COCs at the site have been identified during the site investigation and analytical data accurately represent site conditions and waste characteristics

- The nature of contamination is limited to $44 \mathrm{cy}$ of soil impacted with Benzo(a)Anthracene, Benzo(a)Pyrene, Benzo(b)Fluoranthene, Benzo(k)Fluoranthene,

Dibenzo(a,h)Anthracene, and Indeno(1,2,3-cd)Pyrene

- Equipment will remain operational to support the planned/scheduled completion of each CADD alternative

- Work to be performed by NSTec during a "normal" workday (no provision for overtime has been provided). Shifts are based on 10-hour days / 4-days per

- All Craft will be provided by EM and not by construction

- This estimate does not include the efficiencies which may be realized if work for similar activities at similar sites can be completed concurrently

- Dimensions, volumes, measurements, and analytical data provided by the characterization contractor accurately represent site conditions and waste characteristics

- This estimate does not include costs for preparation of required project plans, permits, reports, mobilization and demobilization, site preparations, or project management.

\section{ESCALATION:}

No escalation factors have been applied

\section{CONTINGENCY:}

Contingency costs are not included in this estimate.

\section{RATES:}

Rates are based on Out Year Rates FY11-13 effective 4/19/10 and were applied using the NSTec FY 10 cost model.

\section{COST ALTERNATIVES SUMMARY:}

Alternative III: Closure in place with Administrative Controls

a. Install administrative controls (postings and 4 signs)

b. Use restriction survey

\section{Is/ Thomas A. Thiele}

Program Manager
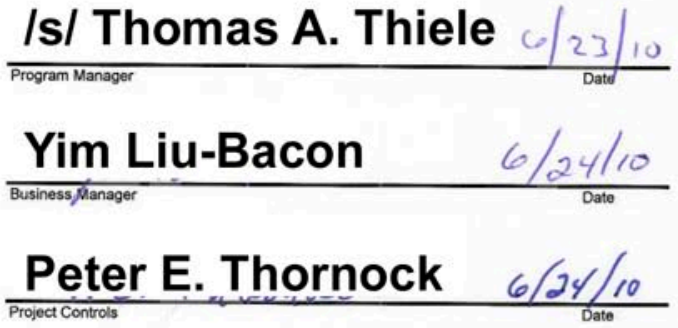


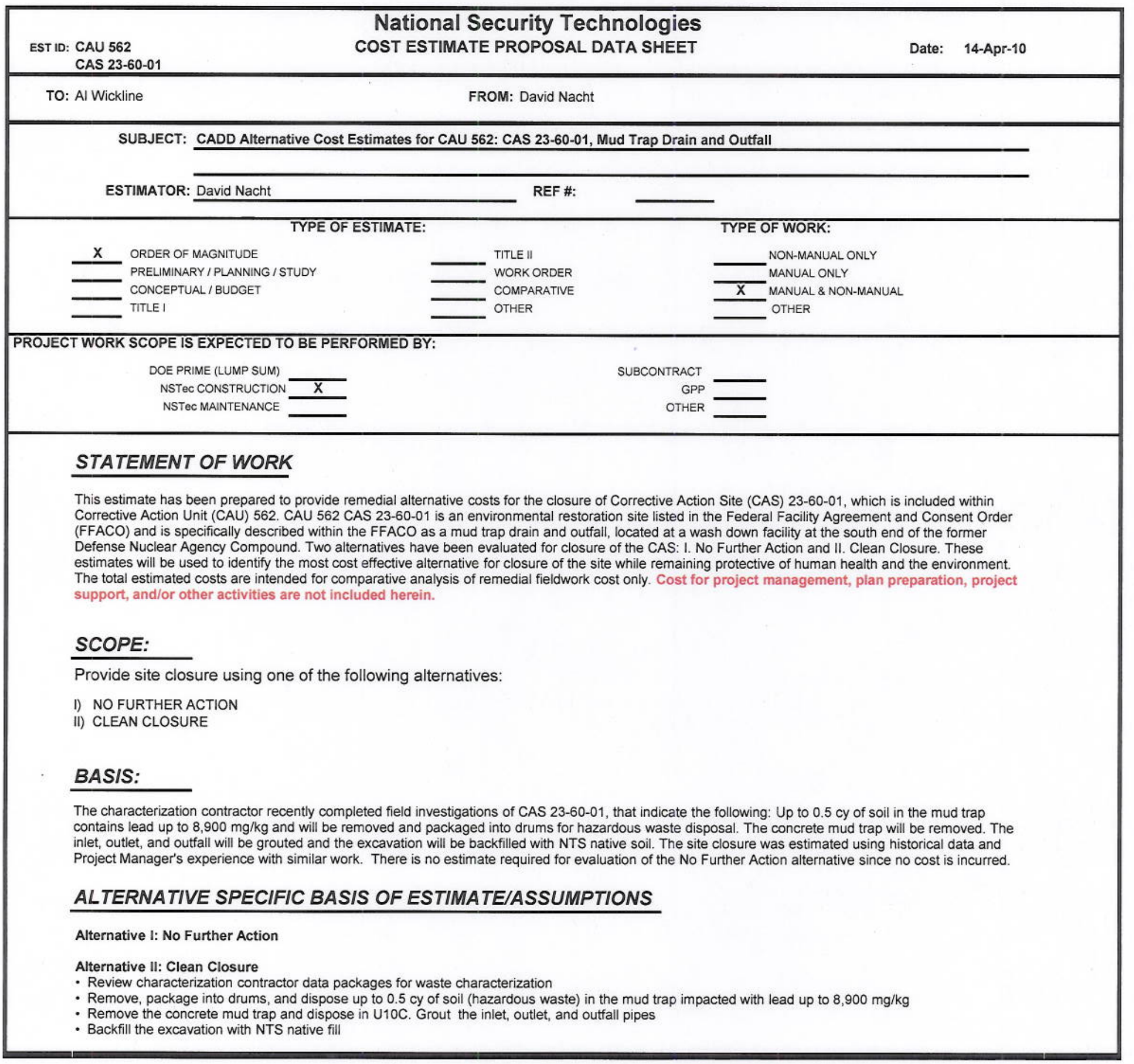




\section{ASSUMPTIONS:}

- No corrective actions are required for the surrounding areas outside the CAS boundary

- All COCs at the site have been identified during the site investigation and analytical data accurately represent site conditions and waste characteristics

- The nature of contamination is limited to $0.5 \mathrm{cy}$ of lead impacted soil (hazardous waste) in the mud trap

- Radiological, toxic, hydrocarbon, or mixed waste will not be generated

- Lead verification samples from the mud trap will not be required per RCRA since the mud trap was not found to be leaking during the investigation.

- Equipment will remain operational to support the planned/scheduled completion of each CADD alternative.

- Waste volumes are based on field measurements collected during the corrective action investigation.

- Work to be performed by NSTec during a "normal" workday (no provision for overtime has been provided). Shifts are based on 10-hour days / 4-days per week

- All Craft will be provided by EM and not by construction

- This estimate does not include the efficiencies which may be realized if work for similar activities at similar sites can be completed concurrently

- Dimensions, volumes, measurements, and analytical data provided by the characterization contractor accurately represent site conditions and waste

characteristics

- This estimate does not include costs for preparation of required project plans, permits, reports, mobilization and demobilization, site

preparations, or project management.

\section{ESCALATION:}

No escalation factors have been applied.

\section{CONTINGENCY:}

Contingency costs are not included in this estimate.

RATES:

Rates are based on Out Year Rates FY11-13 effective 4/19/10 and were applied using the NSTec FY10 cost model.

\section{COST ALTERNATIVES SUMMARY:}

Alternative 1: No Further Action

a. Remove, package into drums, and dispose up to $0.5 \mathrm{cy}$ of soil in the mud trap impacted with lead up to $8,900 \mathrm{mg} / \mathrm{kg}$ as hazardous waste

b. Remove the mud trap and dispose in U10C

c. Grout the inlet, outlet, and outfall pipes

d. Backfill the excavation with NTS native fill

\section{REVIEW / CONCURRENCE:}

\section{Is/ Thomas A. Thiele}

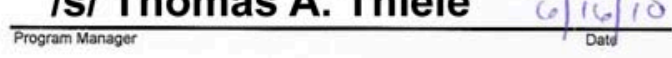

\section{Is/ Yim Liu-Bacon}

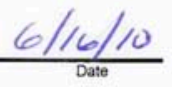

Is/ Peter E. Thornock 


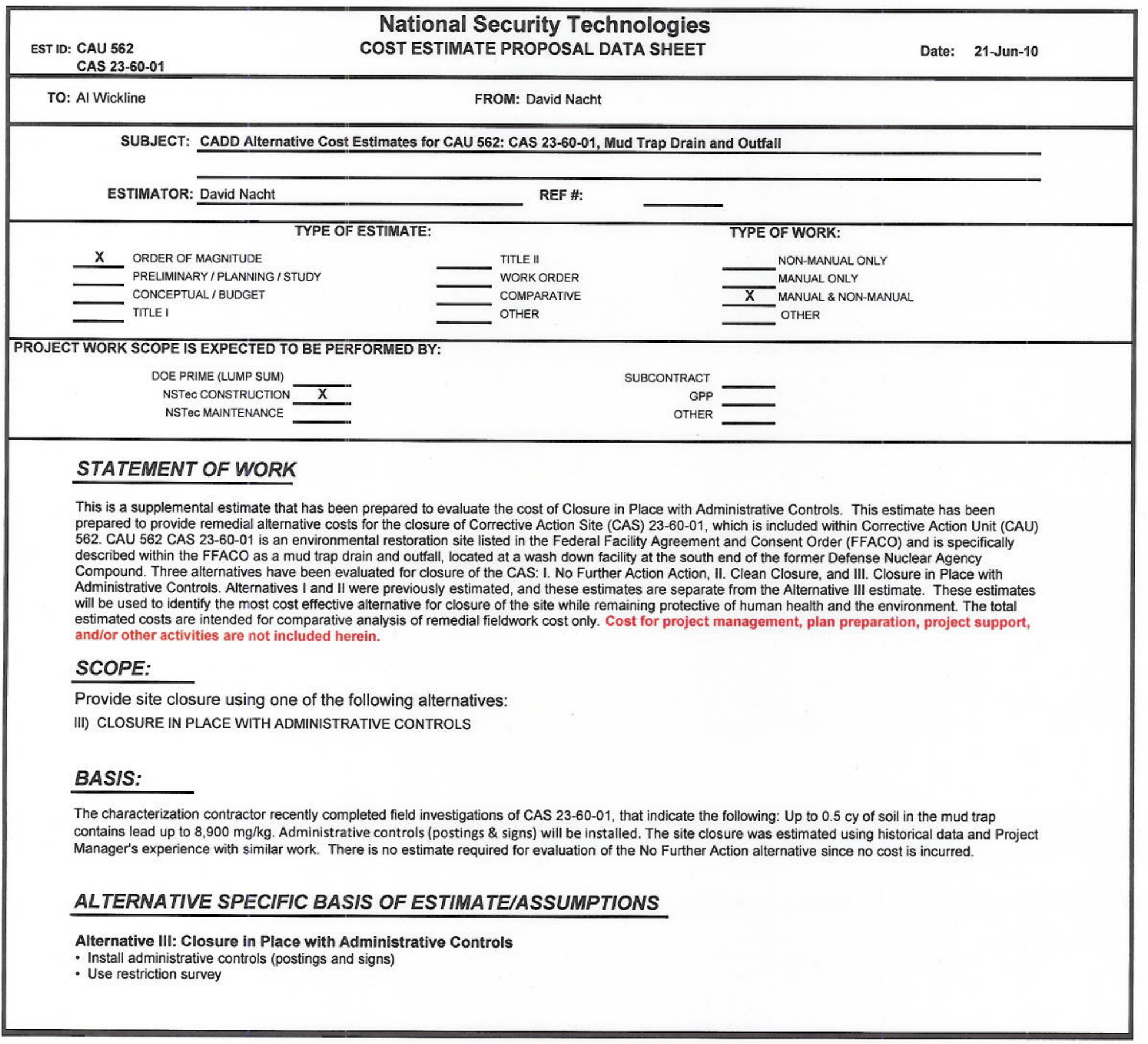


FROM: David Nacht

\section{ASSUMPTIONS:}

- No corrective actions are required for the surrounding areas outside the CAS boundary

- All COCs at the site have been identified during the site investigation and analytical data accurately represent site conditions and waste characteristics

- The nature of contamination is limited to 0.5 cy of lead impacted soil (hazardous waste) in the mud trap

- Equipment will remain operational to support the planned/scheduled completion of each CADD alternative.

- Work to be performed by NSTec during a "normal" workday (no provision for overtime has been provided). Shifts are based on 10-hour days / 4-days per week

- All Craft will be provided by EM and not by construction

- This estimate does not include the efficiencies which may be realized if work for similar activities at similar sites can be completed concurrently

- Dimensions, volumes, measurements, and analytical data provided by the characterization contractor accurately represent site conditions and waste characteristics

- This estimate does not include costs for preparation of required project plans, permits, reports, mobilization and demobilization, site preparations, or project management.

\section{ESCALATION:}

No escalation factors have been applied.

\section{CONTINGENCY:}

Contingency costs are not included in this estimate.

\section{RATES:}

Rates are based on Out Year Rates FY11-13 effective 4/19/10 and were applied using the NSTeC FY10 cost model.

\section{COST ALTERNATIVES SUMMARY:}

Alternative III: Closure in place with Administrative Controls

a. Install administrative controls (postings and 4 signs)

b. Use restriction survey

\section{REVIEW/CONCURRENCE:}

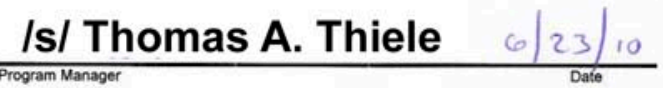

$\frac{\text { Is/ Yim Liu-Bacon }}{\text { Businessednangor }} \frac{6 / 24 / 10}{\text { Date }}$
/s/ Peter E. Thornock

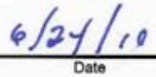




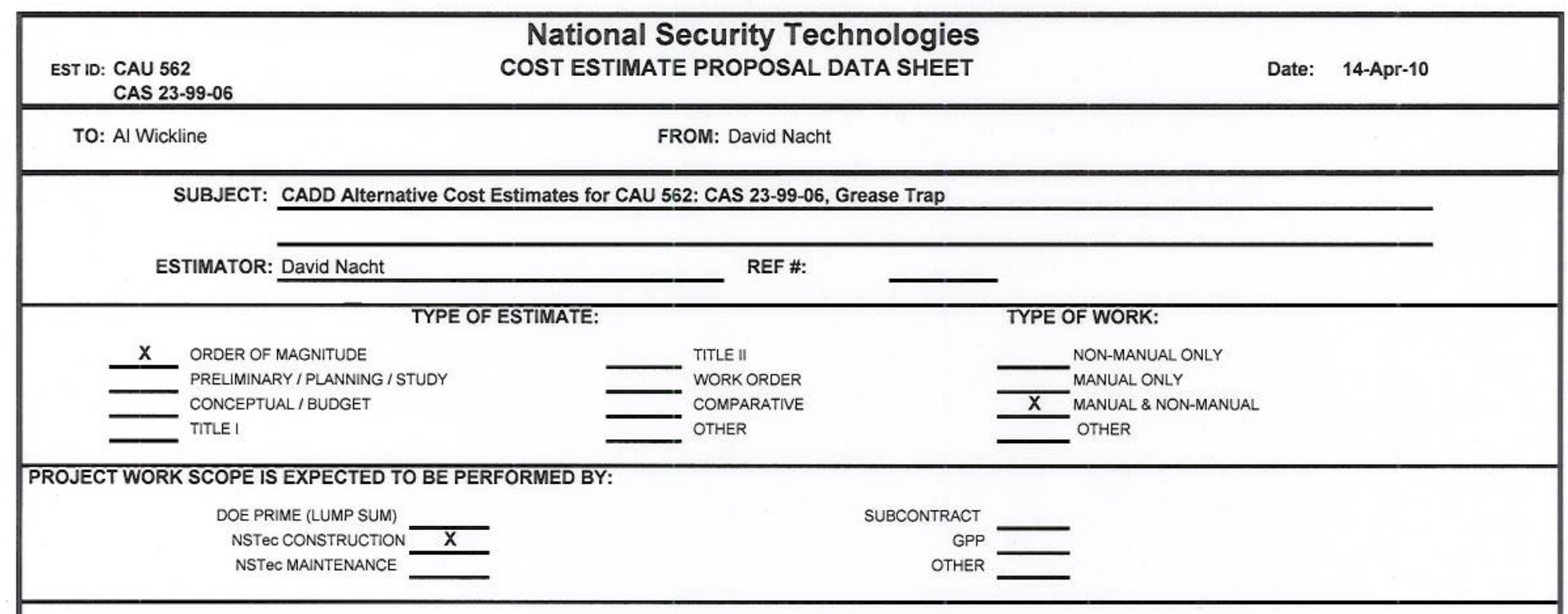

\section{STATEMENT OF WORK}

This estimate has been prepared to provide remedial alternative costs for the closure of Corrective Action Site (CAS) 23-99-06, which is included within Corrective Action Unit (CAU) 562. CAU 562 CAS 23-99-06 is an environmental restoration site listed in the Federal Facility Agreement and Consent Order (FFACO) and is specifically described within the FFACO as a grease trap adjacent to Building 109. Two alternatives have been evaluated for closure of the CAS: I. No Further Action and II. Clean Closure. These estimates will be used to identify the most cost effective alternative for closure of the site while remaining protective of human health and the environment. The total estimated costs are intended for comparative analysis of remedial fieldwork cost only. Cost for project management, plan preparation, project support, and/or other activities are not included herein.

\section{SCOPE:}

Provide site closure using one of the following alternatives:

I) NO FURTHER ACTION

II) CLEAN CLOSURE

\section{BASIS:}

The characterization contractor recently completed field investigations of CAS 23-99-06, that indicate the following: The material in the grease trap contains $\mathrm{PCBs}$ up to $1.4 \mathrm{mg} / \mathrm{kg}$ and will be removed by hand, packaged for disposal in the hydrocarbon landfill, and transported to the landfill. The grease trap will be filled with concrete and all pipes will be grouted. The site closure was estimated using historical data and Project Manager's experience with similar work.

There is no estimate required for evaluation of the No Further Action alternative since no cost is incurred.

\section{ALTERNATIVE SPECIFIC BASIS OF ESTIMATE/ASSUMPTIONS}

Alternative I: No Further Action

Alternative II: Clean Closure

- Review characterization contractor data packages for waste characterization

- Remove, package into drums, and dispose up to 0.5 cy of material in the grease trap impacted with PCBs up to $1.4 \mathrm{mg} / \mathrm{kg}$. This material will be disposed in the hydrocarbon landfill.

- Grout all pipes leading to the grease trap and fill the trap with concrete 


\section{ASSUMPTIONS:}

- No corrective actions are required for the surrounding areas outside the CAS boundary

- All COCs at the site have been identified during the site investigation and analytical data accurately represent site conditions and waste characteristics

- The nature of contamination is limited to $0.5 \mathrm{cy}$ of PCB impacted material (less than 50 PPM)

- Radiological, hazardous, or mixed waste will not be generated

- The grease trap does not need to be triple rinsed with diesel before it is closed since the PCB concentrations are not above 50 mg/kg

- PCB verification samples will not be required since the grease trap was not found to be leaking during the investigation and the grease trap will be filled with concrete and not removed

- Equipment will remain operational to support the planned/scheduled completion of each CADD alternative

- Waste volumes are based on field measurements collected during the corrective action investigation

- Work to be performed by NSTec during a "normal" workday (no provision for overtime has been provided). Shifts are based on 10-hour days / 4-days per week

- All Craft will be provided by EM and not by construction

- This estimate does not include the efficiencies which may be realized if work for similar activities at similar sites can be completed concurrently

- Dimensions, volumes, measurements, and analytical data provided by the characterization contractor accurately represent site conditions and waste characteristics

- This estimate does not include costs for preparation of required project plans, permits, reports, mobilization and demobilization, site preparations, or project management.

\section{ESCALATION:}

No escalation factors have been applied.

\section{CONTINGENCY:}

Contingency costs are not included in this estimate.

\section{RATES:}

Rates are based on Out Year Rates FY11-13 effective 4/19/10 and were applied using the NSTec FY10 cost model.

\section{COST ALTERNATIVES SUMMARY:}

Alternative I: No Further Action

Alternative II: Clean Closure

a. Remove, package, and dispose 0.5 cubic yards of material contains less than 50 PPM PCBs in the hydrocarbon landfill

b. Grout all pipes leading to the grease trap and fill the trap with concrete

\section{/s/ Thomas A. Thiele}

Program Manager

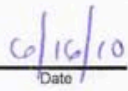

Is/ Yim Liu-Bacon 


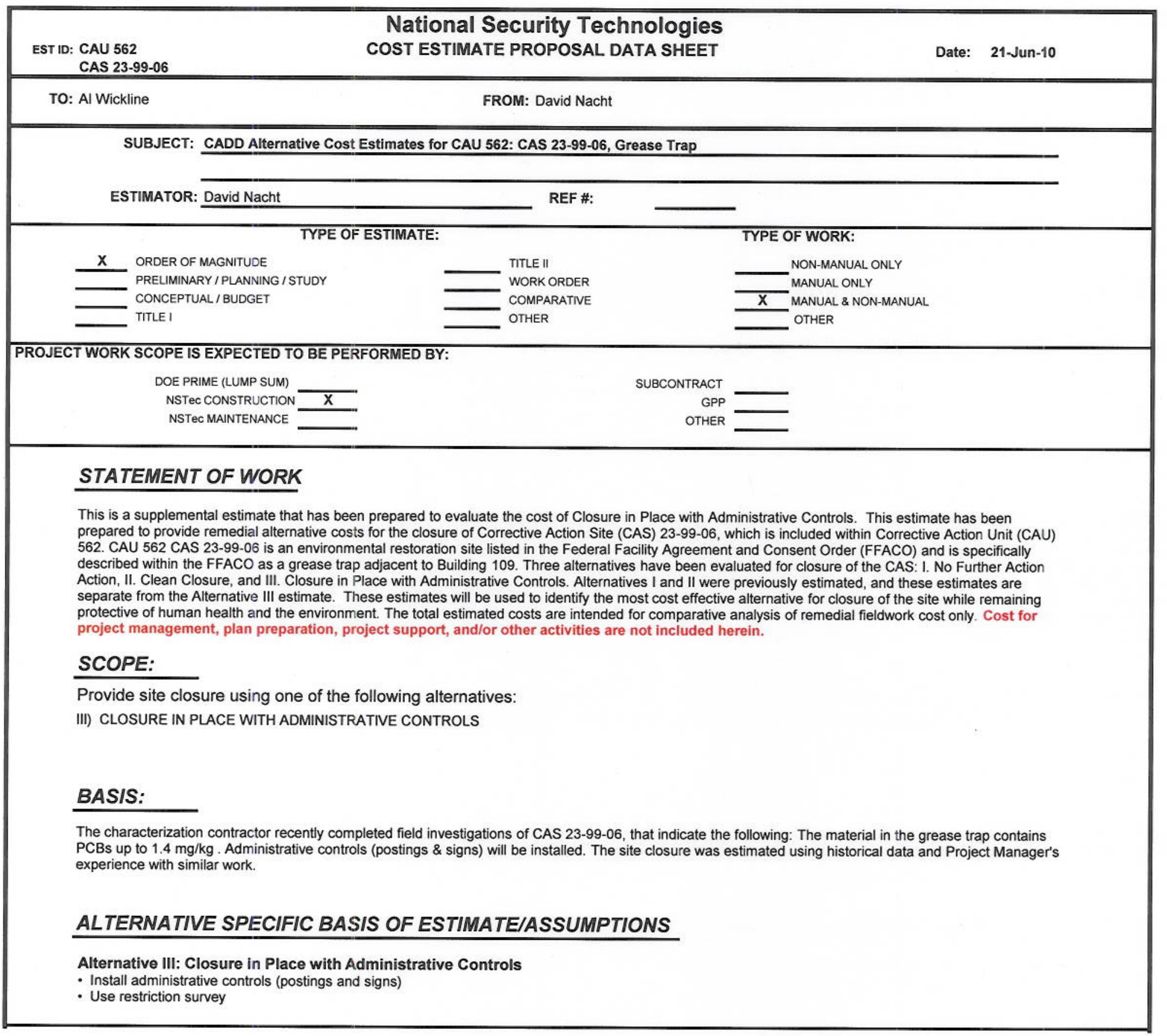




\section{ASSUMPTIONS:}

- No corrective actions are required for the surrounding areas outside the CAS boundary

- All COCs at the site have been identified during the site investigation and analytical data accurately represent site conditions and waste characteristics

- The nature of contamination is limited to $0.5 \mathrm{cy}$ of PCB impacted material (less than 50 PPM)

- Equipment will remain operational to support the planned/scheduled completion of each CADD alternative

- Waste volumes are based on field measurements collected during the corrective action investigation

- Work to be performed by NSTec during a "normal" workday (no provision for overtime has been provided). Shifts are based on 10-hour days / 4-days per week

- All Craft will be provided by EM and not by construction

- This estimate does not include the efficiencies which may be realized if work for similar activities at similar sites can be completed concurrently

- Dimensions, volumes, measurements, and analytical data provided by the characterization contractor accurately represent site conditions and waste characteristics

- This estimate does not include costs for preparation of required project plans, permits, reports, mobilization and demobilization, site preparations, or project management.

\section{ESCALATION:}

No escalation factors have been applied.

\section{CONTINGENCY:}

Contingency costs are not included in this estimate.

\section{RATES:}

Rates are based on Out Year Rates FY11-13 effective 4/19/10 and were applied using the NSTeC FY10 cost model

\section{COST ALTERNATIVES SUMMARY:}

Alternative III: Closure in place with Administrative Controls

a. Install administrative controls (postings and 4 signs)

b. Use restriction survey

REVIEW/CONCURRENCE:

Is/ Thomas A. Thiele

Program Manager

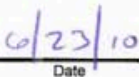

Is/ Yim Liu-Bacon

Business Manager

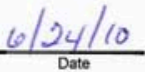

/s/ Peter E. Thornock

Project Controls

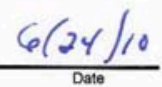


SUBJECT: CADD Alternative Cost Estimates for CAU 562: CAS 25-60-04, Building 3123 Outfalls

ESTIMATOR: David Nacht $\quad$ REF \#: TYPE OF ESTIMATE:

TITLE II

$\longrightarrow$ WORK ORDER
COMPARATIVE
OTHER

TYPE OF WORK:

NON-MANUAL ONLY

MANUAL ONLY

X MANUAL \& NON-MANUAL

OTHER

\section{STATEMENT OF WORK}

This estimate has been prepared to provide remedial alternative costs for the closure of Corrective Action Site (CAS) 25-60-04, which is included within Corrective Action Unit (CAU) 562. CAU 562 CAS 25-60-04 is an environmental restoration site listed in the Federal Facility Agreement and Consent Order (FFACO) and is specifically described within the FFACO as building 3123 outfalls. Two alternatives have been evaluated for closure of the CAS: I. No Further Action and II. Clean Closure. These estimates will be used to identify the most cost effective alternative for closure of the site while remaining protective of human health and the environment. The total estimated costs are intended for comparative analysis of remedial fieldwork cost only. Cost for project management, plan preparation, project support, and/or other activities are not included herein.

\section{SCOPE:}

Provide site closure using one of the following alternatives:

I) NO FURTHER ACTION

II) CLEAN CLOSURE

\section{BASIS:}

The characterization contractor recently completed field investigations of CAS 25-60-04, that indicate the following: Thirty cubic yards of soil in front of the drain B outfall contains PCBs less then 50 parts per million. Sludge in the drain B outfall was found to contain lead at $8.7 \mathrm{mg} / \mathrm{kg}$. A lead TCLP analysis of the sludge was below $5 \mathrm{mg} / \mathrm{l}$ but the holding time was not met. A lead TCLP waste characterization sample will be collected from the sludge before disposal. The 30 cy of PCB soil will be removed and disposed in U10C. Fifty feet of the drain B outfall pipe will also be removed and is expected to be able to be disposed based on the lead TCLP results that will be collected. The site closure was estimated using historical data and Project Manager's experience with similar work. There is no estimate required for evaluation of the No Further Action alternative since no cost is incurred.

\section{ALTERNATIVE SPECIFIC BASIS OF ESTIMATE/ASSUMPTIONS}

\section{Alternative I: No Further Action}

Alternative II: Clean Closure

- Review characterization contractor data packages for waste characterization

- Collect a lead TCLP waste characterization sample from the sludge in drain B outfall pipe

- Remove several sections of security fence to allow soil impacted with less then 50 PPM PCB to be excavated

- Excavate up to $30 \mathrm{cy}$ of soil (less then 50 PPM PCB) in front of the drain B outfall pipe \& dispose in U10C

- Excavate $50 \mathrm{ft}$ of the drain B outfall pipe and dispose in U10C \& grout pipe opening

- Collect PCB verification samples

- Backfill the excavations with native fill to the approximate natural contours

- Replace the several sections of security fencing that were removed for excavation operations 


\section{ASSUMPTIONS:}

- No corrective actions are required for the surrounding areas outside the CAS boundary

- All COCs at the site have been identified during the site investigation and analytical data accurately represent site conditions and waste characteristics

- The nature of contamination is limited to $30 \mathrm{cy}$ of soil (less then 50 PPM PCB) \& $50 \mathrm{ft}$ of the drain B outfall pipe impacted with lead less then 5 mg/L.

- The $30 \mathrm{cy}$ of soil is located around a live power pole. This pole is expected to only require bracing during excavation since only $2.5 \mathrm{ft}$ of

soil around the pole needs to be removed. The backfilled soil will be compacted around the pole to ensure stability after removing the bracing.

- Radiological, hazardous, hydrocarbon, toxic, or mixed waste will not be generated

- Equipment will remain operational to support the planned/scheduled completion of each CADD alternative

- Waste volumes are based on field measurements collected during the corrective action investigation

- Work to be performed by NSTec during a "normal" workday (no provision for overtime has been provided). Shifts are based on 10-hour days / 4-days per

- All Craft will be provided by EM and not by construction

- This estimate does not include the efficiencies which may be realized if work for similar activities at similar sites can be completed concurrently

- Dimensions, volumes, measurements, and analytical data provided by the characterization contractor accurately represent site conditions and waste characteristics

- This estimate does not include costs for preparation of required project plans, permits, reports, mobilization and demobilization, site preparations, or project management.

\section{ESCALATION:}

No escalation factors have been applied.

\section{CONTINGENCY:}

Contingency costs are not included in this estimate.

\section{RATES:}

Rates are based on Out Year Rates FY11-13 effective 4/19/10 and were applied using the NSTec FY10 cost model.

\section{COST ALTERNATIVES SUMMARY:}

Alternative 1: No Further Action
a. Collect a lead TCLP waste characterization sample from the sludge in drain B outfall pipe
b. Remove several sections of security fence to allow soil impacted with less then 50 PPM PCB to be excavated
c. Excavate up to $30 \mathrm{cy}$ of soil (less then 50 PPM PCB) in front of the drain B outfall pipe \& dispose in U10C \& brace the power pole
d. Excavate $50 \mathrm{ft}$ of the drain $\mathrm{B}$ outfall pipe and dispose in U10C
e. Collect $P C B$ verification samples
f. Backfill the excavations with native fill to the approximate natural contours
g. Replace the several sections of security fencing that were removed for excavation operations

REVIEW/CONCURRENCE:

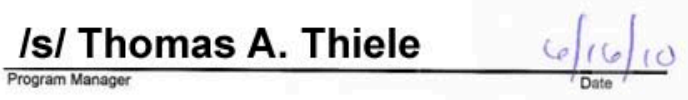

\section{/s/ Yim Liu-Bacon}

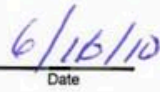

/s/ Peter E. Thornock 


\begin{tabular}{|ccc|}
\hline $\begin{array}{l}\text { EST ID: CAU } 562 \\
\text { CAS 25-60-04 }\end{array}$ & $\begin{array}{c}\text { National Security Technologies } \\
\text { COST ESTIMATE PROPOSAL DATA SHEET }\end{array}$ & 21-Jun-10 \\
\hline \hline
\end{tabular}

TO: Al Wickline

FROM: David Nacht

SUBJECT: CADD Alternative Cost Estimates for CAU 562: CAS 25-60-04, Building 3123 Outfalls

ESTIMATOR: David Nacht

REF \#:

TYPE OF ESTIMATE:

$\mathrm{X}$ ORDER OF MAGNITUDE TITLE ॥

PRELIMINARY / PLANNING / STUDY WORK ORDER

CONCEPTUAL/ BUDGET

COMPARATIVE

OTHER

TITLEI

PROJECT WORK SCOPE IS EXPECTED TO BE PERFORMED BY:

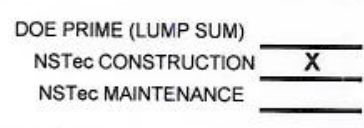

SUBCONTRACT

GPP

OTHER

\section{STATEMENT OF WORK}

This is a supplemental estimate that has been prepared to evaluate the cost of Closure in Place with Administrative Controls. This estimate has been prepared to provide remedial alternative costs for the closure of Corrective Action Site (CAS) 25-60-04, which is included within Corrective Action Unit (CAU) 562. CAU 562 CAS 25-60-04 is an environmental restoration site listed in the Federal Facility Agreement and Consent Order (FFACO) and is specifically described within the FFACO as Building 3123 Outfalls. Three alternatives have been evaluated for closure of the CAS: I. No Further Action Action, II. Clean Closure, and III. Closure in Place with Administrative Controls. Alternatives I and II were previously estimated, and these estimates are separate from the Alternative III estimate. These estimates will be used to identify the most cost effective alternative for closure of the site while remaining protective of human health and the environment. The total estimated costs are intended for comparative analysis of remedial fieldwork cost only. Cost for project management, plan preparation, project support, and/or other activities are not included herein.

\section{SCOPE:}

Provide site closure using one of the following alternatives:

III) CLOSURE IN PLACE WITH ADMINISTRATIVE CONTROLS

\section{BASIS:}

The characterization contractor recently completed field investigations of CAS 25-60-04, that indicate the following: Thirty cubic yards of soil in front of the drain B outfall contains PCBs less then 50 parts per million. Sludge in the drain B outfall was found to contain lead at $8.7 \mathrm{mg} / \mathrm{kg}$. Administrative controls (postings \& signs) will be installed. The site closure was estimated using historical data and Project Manager's experience with similar work.

\section{ALTERNATIVE SPECIFIC BASIS OF ESTIMATE/ASSUMPTIONS}

Alternative III: Closure in Place with Administrative Controls

- Install administrative controls (postings and signs)

- Use restriction survey 


\section{ASSUMPTIONS:}

- No corrective actions are required for the surrounding areas outside the CAS boundary

- All COCs at the site have been identified during the site investigation and analytical data accurately represent site conditions and waste characteristics

- The nature of contamination is limited to $30 \mathrm{cy}$ of soil (less then 50 PPM PCB) \& $50 \mathrm{ft}$ of the drain B outfall pipe impacted with lead less then 5 mg/L

- Equipment will remain operational to support the planned/scheduled completion of each CADD alternative

- Work to be performed by NSTec during a "normal" workday (no provision for overtime has been provided). Shifts are based on 10-hour days / 4-days per week

- All Craft will be provided by EM and not by construction

- This estimate does not include the efficiencies which may be realized if work for similar activities at similar sites can be completed concurrently

- Dimensions, volumes, measurements, and analytical data provided by the characterization contractor accurately represent site conditions and waste characteristics

- This estimate does not include costs for preparation of required project plans, permits, reports, mobilization and demobilization, site preparations, or project management.

\section{ESCALATION:}

No escalation factors have been applied.

\section{CONTINGENCY:}

Contingency costs are not included in this estimate.

\section{RATES:}

Rates are based on Out Year Rates FY11-13 effective 4/19/10 and were applied using the NSTeC FY10 cost model.

\section{COST ALTERNATIVES SUMMARY:}

Alternative III: Closure in place with Administrative Controls

a. Install administrative controls (postings and 8 signs)

b. Use restriction survey

REVIEW/CONCURRENCE:

Is/ Thomas A. Thiele

Program Manager

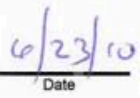

\section{Is/ Yim liu-Bacon}

Business Manager

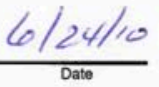

\section{/s/ Peter E. Thornock}

Project Controls

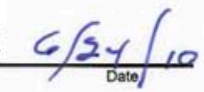


Appendix D

Evaluation of Risk 


\section{D.1.0 Evaluation of Risk}

The RBCA process used to establish FALs is described in the Industrial Sites Project Establishment of Final Action Levels (NNSA/NSO, 2006). This process conforms with NAC Section 445A.227 (NAC, 2006a), which lists the requirements for sites with soil contamination. For the evaluation of corrective actions, NAC Section 445A.22705 (NAC, 2006b) requires the use of ASTM Method E1739 (ASTM, 1995) to "conduct an evaluation of the site, based on the risk it poses to public health and the environment, to determine the necessary remediation standards (i.e., FALs) or to establish that corrective action is not necessary.”

The evaluation of the need for corrective action will include the potential for wastes that are present at a site to cause the future contamination of site environmental media if the wastes were to be released. To evaluate the potential for site waste to result in the introduction of a COC to the surrounding environmental media, the following conservative assumptions were made:

- Any current containment of wastes would fail at some point, and the contents would be released to the surrounding media.

- For non-liquid wastes, the resulting concentration of contaminants in the surrounding media would be equal to the concentration of contaminants in the waste.

- For liquid wastes, the resulting concentration of contaminants in the surrounding soil will be calculated based on the concentration of contaminants in the waste and the liquid holding capacity of the soil.

This section contains documentation of the RBCA process used to establish FALs described in the Industrial Sites Project Establishment of FALs (NNSA/NSO, 2006). This process defines three tiers (or levels) to establish FALs used to evaluate DQO decisions:

- $\quad$ Tier 1 - Sample results from source areas (highest concentrations) compared to risk-based screening levels (RBSLs) (i.e., PALs) based on generic (non-site-specific) conditions.

- $\quad$ Tier 2 - Sample results from exposure points compared to SSTLs calculated using site-specific inputs and Tier 1 formulas.

- Tier 3 - Sample results from exposure points compared to SSTLs and points of compliance calculated using chemical fate/transport and probabilistic modeling. 
The risk-based corrective action decision process stipulated in the Industrial Sites Project Establishment of FALs (NNSA/NSO, 2006) is summarized in Figure D.1-1.

\section{D.1.1 A. Scenario}

Corrective Action Unit 562, Waste Systems, comprises the following 13 inactive sites within Areas 2, 23, and 25 of the NTS:

- 02-26-11, Lead Shot

- 02-44-02, Paint Spills and French Drain

- 02-59-01, Septic System

- 02-60-01, Concrete Drain

- 02-60-02, French Drain

- 02-60-03, Steam Cleaning Drain

- 02-60-04, French Drain

- 02-60-05, French Drain

- 02-60-06, French Drain

- 02-60-07, French Drain

- 23-60-01, Mud Trap Drain and Outfall

- 23-99-06, Grease Trap

- 25-60-04, Building 3123 Outfalls

The Area 2 Camp operated between the mid-1950s and the mid-1990s. The camp was used by LLNL to support construction and drilling operations that took place in the Yucca Flat area. There were numerous facilities in the Area 2 Camp, such as linemen, refrigeration, painter, and electrician shops as well as various storage yards. There were french drains, a concrete drain, a septic system, and a steam cleaning sump in CAU 562 that supported activities associated with these type of shops and storage yards. There were also spills or releases of lead shot and paint as a result of the activities in the area.

The two CASs located in Mercury are associated with a former commercial gas service station and a wash-down facility. The former gas station discharged wastes generated during operations to a grease trap located outside of the building which ultimately released to the sanitary sewer system. The wash-down facility consisted of a wash shed and a grease rack. Waste from inside the wash shed flowed into a mud trap and then eventually to a wash via an outfall pipe. It is assumed that the grease rack was used for vehicle maintenance and that there could have been inadvertent releases to the environment. 


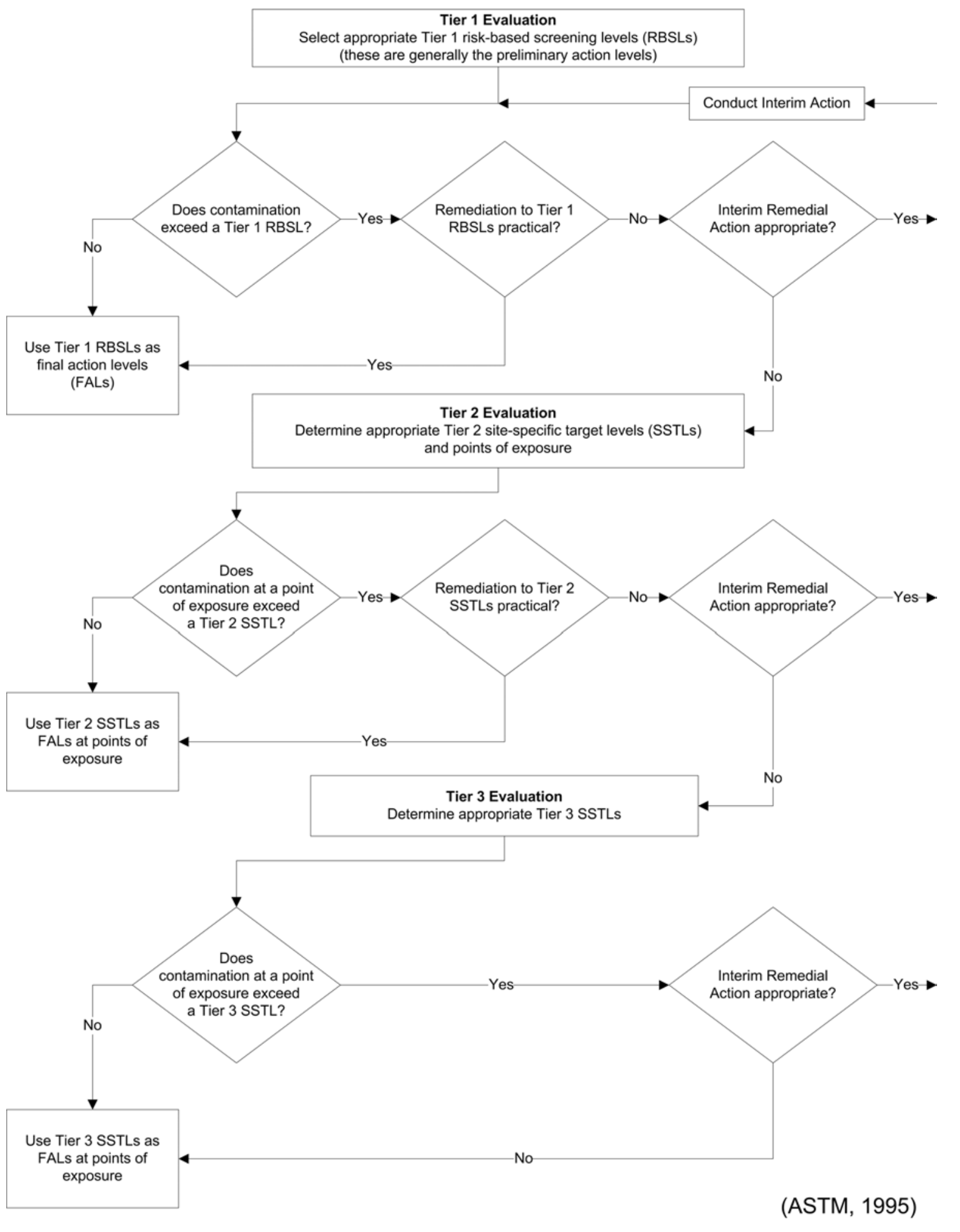

Figure D.1-1

Risk-Based Corrective Action Decision Process 
The remaining CAS is associated with Building 3123 located at the RCP in Area 25. The building originally housed a laboratory, shop, and office space. The two outfalls associated with this CAS originally discharged to daylight. The outfalls are no longer active.

\section{D.1.2 B. Site Assessment}

There are 10 CASs in CAU 562 that are located in Area 2, which is an abandoned work camp. The CAI at CAS 02-26-11, Lead Shot and CAS 02-60-01, Concrete Drain involved visual surveys and soil sampling within the abandoned storage yards that each CAS is located. There is shot present on the ground surface at CAS 02-26-11, which was also sampled. The concrete drain is still present at CAS 02-60-01; however, there is no source.

The CAI at CAS 02-59-01, Septic System included visual inspections through excavation and soil sampling adjacent to and beneath the inlet and outlet pipes, septic tank, and leach lines. Liquid and sludge still remains in the septic tank; however, the structural integrity of system components at this CAS is intact.

Corrective Action Sites 02-44-02, Paint Spill and French Drain; 02-60-02, French Drain; 02-60-04, French Drain; 02-60-05, French Drain; and 02-60-06, French Drain all include at least one french drain as part of the scope. The CAI at these CASs involved visual inspections through excavation and soil sampling adjacent to and/or below the french drains. In addition to the presence of french drains, there is paint at CAS 02-44-02 and elongated drains that connect to one french drain at CAS 02-60-02. The paint and soil in the elongated drains were sampled as well. The sources for the french drains, elongated drains, and paint are no longer present. Additionally, the french drain casings have been removed.

The CAI at CAS 02-60-03, Steam Cleaning Drain includes visual inspection and soil sampling adjacent to and/or below the sump, outfall, and steam cleaning pad. The CAS components are still present; however, there is no source of release.

During the CAI, it was determined that there was no source of release or components associated with CAS 02-60-07; therefore, CAS 02-60-07 was not investigated. 
The remaining three CASs in CAU 562 are located in Area 23 and 25, which are active work areas. The CAI at CAS 23-60-01, Mud Trap and Outfall; CAS 23-99-06, Grease Trap; and CAS 25-60-04, Building 3123 Outfalls included visual inspection and soil and/or PSM sampling adjacent to, within, and/or in the surrounding area of the components associated with each individual CAS. Corrective Action Site 23-60-01 includes a mud trap, outfall, and potential spill area under a grease rack;

CAS 23-99-06 consists of a grease trap; and CAS 25-60-04 consists of an outfall and discharge area. All of these components are still present; however, there is no associated source of release.

The COCs and PSM identified during the CAI are included in Table D.1-1. Tables D.1-2 and D.1-3 list the maximum concentrations of contaminants identified in soil and PSM samples collected from each CAS. 
Table D.1-1

Summary of COCs and PSM by CAS

\begin{tabular}{|c|c|c|c|}
\hline CAS & Media & Contaminant(s) & PSM or COC \\
\hline \multirow[t]{2}{*}{ 02-26-11 } & Rusted and non-rusted shot & $\begin{array}{l}\text { Antimony } \\
\text { Arsenic } \\
\text { Lead } \\
\text { Chromium }\end{array}$ & PSM \\
\hline & Soil & None & N/A \\
\hline \multirow[t]{2}{*}{$02-44-02$} & Paint chips & $\begin{array}{c}\text { Chromium } \\
\text { Benzo(a)pyrene } \\
\text { Benzo(b)fluoranthene } \\
\text { Bis(2-ethylhexyl)phthalate } \\
\text { Lead }\end{array}$ & PSM \\
\hline & Soil & Benzo(a)pyrene & $\mathrm{COC}$ \\
\hline \multirow{3}{*}{ 02-59-01 } & Sludge & $\begin{array}{l}\text { 1,4-dichlorobenzene } \\
\text { Naphthalene }\end{array}$ & PSM \\
\hline & Liquid & None & N/A \\
\hline & Soil & None & N/A \\
\hline 02-60-01 & Soil & None & $\mathrm{N} / \mathrm{A}$ \\
\hline $02-60-02$ & Soil & Aroclor 1260 & $\mathrm{COC}$ \\
\hline $02-60-03$ & Soil & $\begin{array}{c}\text { Aroclor } 1260 \\
\text { Benzo(a)pyrene }\end{array}$ & $\mathrm{COC}$ \\
\hline \multirow[t]{2}{*}{$02-60-04$} & Sediment & $\begin{array}{c}\text { Aroclor } 1260 \\
\text { Aroclor } 1268 \\
\text { Benzo(a)pyrene }\end{array}$ & PSM \\
\hline & Soil & None & N/A \\
\hline \multirow[b]{2}{*}{$02-60-05$} & Asphalt & None & N/A \\
\hline & Soil & $\begin{array}{c}\text { Benzo(a)pyrene } \\
\text { Benzo(a)anthracene } \\
\text { Benzo(b)fluoranthene } \\
\text { Benzo(k)fluoranthene } \\
\text { Dibenzo(a,h)anthracene } \\
\text { Indeno(1,2,3-cd)pyrene }\end{array}$ & $\mathrm{COC}$ \\
\hline $02-60-06$ & Soil & None & N/A \\
\hline $02-60-07$ & $\mathrm{~N} / \mathrm{A}$ & None & $\mathrm{N} / \mathrm{A}$ \\
\hline \multirow{2}{*}{$23-60-01$} & Sediment & Lead & PSM \\
\hline & Soil & None & N/A \\
\hline 23-99-06 & Sediment & $\begin{array}{c}\text { Arsenic } \\
\text { Aroclor } 1260 \\
\text { Chlordane }\end{array}$ & PSM \\
\hline \multirow{2}{*}{$25-60-04$} & Sludge & $\begin{array}{l}\text { Aroclor } 1254 \\
\text { Lead }\end{array}$ & PSM \\
\hline & Soil & Aroclor 1254 & $\mathrm{COC}$ \\
\hline
\end{tabular}


Table D.1-2

Maximum Reported Soil Sample Results for Tier I Comparison

(Page 1 of 3 )

\begin{tabular}{|c|c|c|c|c|c|c|c|c|c|c|c|c|c|}
\hline \multirow{2}{*}{ Parameter } & \multirow{2}{*}{ PAL } & \multirow{2}{*}{ Units } & \multicolumn{11}{|c|}{ Maximum Result } \\
\hline & & & $02-26-11$ & $02-44-02$ & $02-59-01$ & $02-60-01$ & $02-60-02$ & $02-60-03$ & $02-60-04$ & $02-60-05$ & $02-60-06$ & $23-60-01$ & $25-60-04$ \\
\hline 2-butanone & 200,000 & $\mathrm{mg} / \mathrm{kg}$ & -- & -- & -- & $\overline{--}$ & -- & -- & -- & -- & -- & 0.022 & -- \\
\hline 2-methylnaphthalene & 4,100 & $\mathrm{mg} / \mathrm{kg}$ & -- & -- & -- & $4.6(\mathrm{~J})$ & -- & -- & -- & 11 & -- & $0.093(\mathrm{~J})$ & -- \\
\hline 4,4'-DDE & 5.1 & $\mathrm{mg} / \mathrm{kg}$ & -- & -- & -- & $\begin{array}{l}- \\
-\end{array}$ & -- & -- & -- & -- & -- & $0.00037(\mathrm{~J})$ & -- \\
\hline 4,4'-DDT & 7 & $\mathrm{mg} / \mathrm{kg}$ & -- & -- & -- & -- & -- & -- & -- & -- & -- & $0.0057(\mathrm{~J})$ & -- \\
\hline Acenaphthene & 33,000 & $\mathrm{mg} / \mathrm{kg}$ & $\begin{array}{l}- \\
-\end{array}$ & -- & -- & $20(\mathrm{~J})$ & -- & -- & -- & 19 & -- & -- & -- \\
\hline Acenaphthylene & 33,000 & $\mathrm{mg} / \mathrm{kg}$ & -- & -- & -- & $0.18(\mathrm{~J})$ & -- & -- & -- & $0.18(\mathrm{~J})$ & -- & -- & -- \\
\hline Acetone & 630,000 & $\mathrm{mg} / \mathrm{kg}$ & -- & -- & -- & $0.0083(\mathrm{~J})$ & -- & -- & -- & -- & -- & 0.077 & 0.024 \\
\hline Ac-228 & 5 & $\mathrm{pCi} / \mathrm{g}$ & 2.18 & 2.83 & 2.34 & 2.17 & 2.08 & 1.92 & 2.2 & 2.1 & 2.22 & 1.06 & 2.08 \\
\hline Am-241 & 12.7 & $\mathrm{pCi} / \mathrm{g}$ & $1.02(\mathrm{~J})$ & $2.23(\mathrm{~J})$ & -- & -- & -- & -- & $\begin{array}{l}- \\
-\end{array}$ & -- & -- & -- & -- \\
\hline Anthracene & 170,000 & $\mathrm{mg} / \mathrm{kg}$ & -- & -- & $\overline{--}$ & $10(\mathrm{~J})$ & -- & $\overline{--}$ & $\overline{--}$ & 23 & $\overline{--}$ & $\overline{--}$ & $\overline{--}$ \\
\hline Antimony & 410 & $\mathrm{mg} / \mathrm{kg}$ & 2.8 & 4.4 & -- & -- & -- & -- & -- & -- & 7.6 & -- & -- \\
\hline Aroclor 1016 & 21 & $\mathrm{mg} / \mathrm{kg}$ & -- & -- & -- & -- & -- & -- & -- & -- & $0.021(\mathrm{~J})$ & -- & -- \\
\hline Aroclor 1254 & 0.74 & $\mathrm{mg} / \mathrm{kg}$ & -- & 0.38 & -- & -- & -- & -- & -- & -- & -- & -- & $11(\mathrm{~J})$ \\
\hline Aroclor 1260 & 0.74 & $\mathrm{mg} / \mathrm{kg}$ & 0.075 & $0.53(\mathrm{~J})$ & -- & 0.04 & $5.8(\mathrm{~J})$ & $1(\mathrm{~J})$ & 0.044 & 0.087 & $0.081(\mathrm{~J})$ & $0.24(\mathrm{~J})$ & 0.16 \\
\hline Aroclor 1268 & 0.74 & $\mathrm{mg} / \mathrm{kg}$ & -- & -- & -- & -- & -- & $0.52(\mathrm{~J})$ & -- & -- & -- & -- & -- \\
\hline Arsenic & 23 & $\mathrm{mg} / \mathrm{kg}$ & 3.5 & 4.3 & 5.7 & 4.7 & 4.5 & 5.6 & 3.5 & 3.3 & $9(\mathrm{~J})$ & 12 & 4 \\
\hline Barium & 190,000 & $\mathrm{mg} / \mathrm{kg}$ & $500(\mathrm{~J})$ & 500 & 290 & 480 & $170(\mathrm{~J})$ & 760 & 110 & 110 & 200 & 190 & 130 \\
\hline Benzo(a)anthracene & 2.1 & $\mathrm{mg} / \mathrm{kg}$ & $0.088(\mathrm{~J})$ & $0.21(\mathrm{~J})$ & -- & $18(\mathrm{~J})$ & $0.18(\mathrm{~J})$ & $0.19(\mathrm{~J})$ & -- & $33(\mathrm{~J})$ & -- & $0.12(\mathrm{~J})$ & $0.11(\mathrm{~J})$ \\
\hline Benzo(a)pyrene & 0.21 & $\mathrm{mg} / \mathrm{kg}$ & $0.11(\mathrm{~J})$ & 0.22 & -- & $16(\mathrm{~J})$ & $0.18(\mathrm{~J})$ & 0.27 & -- & $37(\mathrm{~J})$ & -- & $0.15(\mathrm{~J})$ & -- \\
\hline Benzo(b)fluoranthene & 2.1 & $\mathrm{mg} / \mathrm{kg}$ & $0.16(\mathrm{~J})$ & 0.37 & -- & $21(J)$ & $0.32(\mathrm{~J})$ & 0.56 & -- & $41(J)$ & -- & $0.17(\mathrm{~J})$ & -- \\
\hline Benzo(g,h,i)perylene & 17,000 & $\mathrm{mg} / \mathrm{kg}$ & $0.1(\mathrm{~J})$ & $0.21(\mathrm{~J})$ & -- & $7.4(\mathrm{~J})$ & -- & $0.13(\mathrm{~J})$ & -- & $23(\mathrm{~J})$ & -- & $0.093(\mathrm{~J})$ & -- \\
\hline Benzo(k)fluoranthene & 21 & $\mathrm{mg} / \mathrm{kg}$ & $0.073(\mathrm{~J})$ & $0.16(\mathrm{~J})$ & -- & $9.6(\mathrm{~J})$ & $0.13(\mathrm{~J})$ & $0.26(\mathrm{~J})$ & -- & $22(\mathrm{~J})$ & -- & -- & -- \\
\hline Benzyl alcohol & 62,000 & $\mathrm{mg} / \mathrm{kg}$ & - & -- & - & 0.39 & -- & -- & -- & -- & -- & - & - \\
\hline Bis(2-ethylhexyl)phthalate & 120 & $\mathrm{mg} / \mathrm{kg}$ & 0.47 & 8.5 & -- & 0.74 & 4.2 & $0.14(\mathrm{~J})$ & $0.1(\mathrm{~J})$ & $2.7(\mathrm{~J})$ & 1.4 & 1.6 & 1.1 \\
\hline
\end{tabular}


Table D.1-2

Maximum Reported Soil Sample Results for Tier I Comparison

(Page 2 of 3 )

\begin{tabular}{|c|c|c|c|c|c|c|c|c|c|c|c|c|c|}
\hline \multirow{2}{*}{ Parameter } & \multirow{2}{*}{ PAL } & \multirow{2}{*}{ Units } & \multicolumn{11}{|c|}{ Maximum Result } \\
\hline & & & $02-26-11$ & $02-44-02$ & $02-59-01$ & $02-60-01$ & $02-60-02$ & $02-60-03$ & $02-60-04$ & $02-60-05$ & $02-60-06$ & $23-60-01$ & $25-60-04$ \\
\hline Butyl benzyl phthalate & 910 & $\mathrm{mg} / \mathrm{kg}$ & -- & -- & -- & 1.9 & & $0.24(\mathrm{~J})$ & -- & $1.9(\mathrm{~J})$ & -- & -- & -- \\
\hline Cadmium & 800 & $\mathrm{mg} / \mathrm{kg}$ & 7.3 & 6.5 & -- & 9.7 & 12 & 26 & 0.086 & 1.4 & 44 & 2.5 & 2.5 \\
\hline Carbazole & 95.8 & $\mathrm{mg} / \mathrm{kg}$ & $\begin{array}{ll}- \\
-\end{array}$ & -- & -- & $9.9(\mathrm{~J})$ & $\begin{array}{ll}- \\
-\end{array}$ & -- & -- & 9.5 & -- & -- & -- \\
\hline Carbon tetrachloride & 1.2 & $\mathrm{mg} / \mathrm{kg}$ & -- & -- & -- & -- & -- & -- & -- & -- & -- & -- & $0.0027(\mathrm{~J})$ \\
\hline Cs-137 & 12.2 & $\mathrm{pCi} / \mathrm{g}$ & 1.34 & 1.33 & -- & 1.16 & 0.4 & 0.513 & -- & 0.57 & -- & 0.47 & -- \\
\hline Chlordane & 6.5 & $\mathrm{mg} / \mathrm{kg}$ & $0.096(\mathrm{~J})$ & -- & -- & -- & -- & $0.054(\mathrm{~J})$ & -- & -- & -- & $0.051(\mathrm{~J})$ & -- \\
\hline Chloroform & 1.5 & $\mathrm{mg} / \mathrm{kg}$ & -- & -- & -- & -- & -- & -- & -- & -- & -- & -- & $0.0024(\mathrm{~J})$ \\
\hline Chromium & 450 & $\mathrm{mg} / \mathrm{kg}$ & $9(\mathrm{~J})$ & 240 & 6.1 & $190(\mathrm{~J})$ & $92(\mathrm{~J})$ & 9.4 & 4.3 & $5.9(\mathrm{~J})$ & $120(\mathrm{~J})$ & 26 & 5.2 \\
\hline Chrysene & 210 & $\mathrm{mg} / \mathrm{kg}$ & $0.1(\mathrm{~J})$ & $0.25(\mathrm{~J})$ & -- & $19(\mathrm{~J})$ & $0.21(\mathrm{~J})$ & $0.27(\mathrm{~J})$ & $\begin{array}{l}- \\
-\end{array}$ & 35 & -- & $0.14(\mathrm{~J})$ & -- \\
\hline Dibenzo(a,h)anthracene & 0.21 & $\mathrm{mg} / \mathrm{kg}$ & -- & -- & -- & $1.5(\mathrm{~J})$ & -- & -- & -- & $7.7(\mathrm{~J})$ & -- & -- & $\overline{--}$ \\
\hline Dibenzofuran & 1,000 & $\mathrm{mg} / \mathrm{kg}$ & -- & $\begin{array}{ll}- \\
-\end{array}$ & -- & $15(\mathrm{~J})$ & -- & -- & -- & 14 & -- & -- & -- \\
\hline DRO & 100 & $\mathrm{mg} / \mathrm{kg}$ & 100 & 180 & $2.9(\mathrm{~J})$ & 130 & $55(\mathrm{~J})$ & 110 & 10 & $62(\mathrm{~J})$ & 850 & $590(\mathrm{~J})$ & $28(\mathrm{~J})$ \\
\hline Diethyl phthalate & 490,000 & $\mathrm{mg} / \mathrm{kg}$ & -- & -- & -- & -- & $0.089(\mathrm{~J})$ & -- & -- & -- & -- & -- & -- \\
\hline Di-n-butyl phthalate & 62,000 & $\mathrm{mg} / \mathrm{kg}$ & $0.3(\mathrm{~J})$ & 0.97 & -- & $100(\mathrm{~J})$ & 0.92 & 1 & -- & $100(\mathrm{~J})$ & & $0.17(\mathrm{~J})$ & -- \\
\hline Di-N-Octyl phthalate & 25,000 & $\mathrm{mg} / \mathrm{kg}$ & -- & -- & -- & -- & -- & -- & -- & -- & -- & $0.1(\mathrm{~J})$ & -- \\
\hline Endosulfan sulfate & 3,700 & $\mathrm{mg} / \mathrm{kg}$ & -- & -- & -- & -- & -- & -- & -- & -- & -- & $0.0019(\mathrm{~J})$ & -- \\
\hline Fluoranthene & 22,000 & $\mathrm{mg} / \mathrm{kg}$ & $0.24(\mathrm{~J})$ & 0.62 & -- & $61(\mathrm{~J})$ & 0.59 & 0.62 & -- & $92(\mathrm{~J})$ & -- & $0.11(\mathrm{~J})$ & -- \\
\hline Fluorene & 22,000 & $\mathrm{mg} / \mathrm{kg}$ & -- & -- & -- & $15(\mathrm{~J})$ & -- & -- & -- & 17 & -- & -- & -- \\
\hline Indeno(1,2,3-cd)pyrene & 2.1 & $\mathrm{mg} / \mathrm{kg}$ & $0.08(\mathrm{~J})$ & $0.11(\mathrm{~J})$ & -- & $9(\mathrm{~J})$ & $0.084(\mathrm{~J})$ & $0.15(\mathrm{~J})$ & -- & $24(J)$ & -- & -- & -- \\
\hline Lead & 800 & $\mathrm{mg} / \mathrm{kg}$ & $54(\mathrm{~J}-)$ & 600 & 12 & 100 & 320 & 50 & $9.5(\mathrm{~J})$ & $31(\mathrm{~J})$ & 280 & 1,000 & $39(\mathrm{~J})$ \\
\hline Mercury & 34 & $\mathrm{mg} / \mathrm{kg}$ & 0.051 & $12(\mathrm{~J}-)$ & 0.1 & $0.12(\mathrm{~J})$ & $0.034(\mathrm{~J}-)$ & $0.11(\mathrm{~J}-)$ & $0.055(\mathrm{~J}-)$ & 0.05 & $0.25(\mathrm{~J}-)$ & $0.34(\mathrm{~J})$ & 0.064 \\
\hline Methylene chloride & 53 & $\mathrm{mg} / \mathrm{kg}$ & $0.0017(\mathrm{~J})$ & $0.0021(\mathrm{~J})$ & -- & -- & -- & -- & -- & $0.0046(\mathrm{~J})$ & -- & $0.0049(\mathrm{~J})$ & $0.0042(\mathrm{~J})$ \\
\hline Naphthalene & 18 & $\mathrm{mg} / \mathrm{kg}$ & -- & -- & - & $3.2(\mathrm{~J})$ & - & -- & - & 1.9 & -- & -- & -- \\
\hline Phenanthrene & 170,000 & $\mathrm{mg} / \mathrm{kg}$ & $0.11(\mathrm{~J})$ & 0.45 & -- & $73(\mathrm{~J})$ & 0.42 & 0.45 & -- & $90(\mathrm{~J})$ & -- & $0.13(\mathrm{~J})$ & -- \\
\hline
\end{tabular}


Table D.1-2

Page D-9 of D-26

Maximum Reported Soil Sample Results for Tier I Comparison

(Page 3 of 3)

\begin{tabular}{|c|c|c|c|c|c|c|c|c|c|c|c|c|c|}
\hline \multirow{2}{*}{ Parameter } & \multirow{2}{*}{ PAL } & \multirow{2}{*}{ Units } & \multicolumn{11}{|c|}{ Maximum Result } \\
\hline & & & $02-26-11$ & $02-44-02$ & $02-59-01$ & $02-60-01$ & $02-60-02$ & $02-60-03$ & $02-60-04$ & $02-60-05$ & $02-60-06$ & $23-60-01$ & $25-60-04$ \\
\hline Phenol & 180,000 & $\mathrm{mg} / \mathrm{kg}$ & -- & -- & -- & -- & $0.093(\mathrm{~J})$ & -- & -- & -- & -- & -- & -- \\
\hline Pyrene & 17,000 & $\mathrm{mg} / \mathrm{kg}$ & $0.33(\mathrm{~J})$ & 0.65 & -- & $50(\mathrm{~J})$ & 0.43 & 0.47 & -- & $69(\mathrm{~J})$ & -- & $0.21(\mathrm{~J})$ & $0.088(\mathrm{~J})$ \\
\hline Selenium & 5,100 & $\mathrm{mg} / \mathrm{kg}$ & 0.88 & 1.1 & 0.74 & 0.65 & 3 & 0.6 & 0.39 & 0.44 & -- & -- & 0.41 \\
\hline Silver & 5,100 & $\mathrm{mg} / \mathrm{kg}$ & -- & -- & -- & -- & 0.45 & -- & -- & 0.6 & $26(\mathrm{~J})$ & -- & 0.37 \\
\hline Th-234 & 105 & $\mathrm{pCi} / \mathrm{g}$ & $2.01(\mathrm{~J})$ & $3.59(\mathrm{~J})$ & -- & -- & $4.6(\mathrm{~J})$ & $3.3(\mathrm{~J})$ & -- & $2.58(\mathrm{~J})$ & -- & $2.18(\mathrm{~J})$ & $2.36(\mathrm{~J})$ \\
\hline Trichloroethene & 14 & $\mathrm{mg} / \mathrm{kg}$ & -- & -- & -- & $0.0061(\mathrm{~J})$ & -- & -- & -- & -- & -- & -- & -- \\
\hline
\end{tabular}

$-=$ Not detected above MDCs.

$\mathrm{J}=$ Estimated value

$\mathrm{J}-\mathrm{=}$ Result is an estimated quantity but may be biased low.

Bold indicates the value is equal to or exceeds the PAL. 
Table D.1-3

Page D-10 of D-26

Maximum Reported PSM Sample Results for Tier I Comparison

(Page 1 of 3 )

\begin{tabular}{|c|c|c|c|c|c|c|c|c|c|c|}
\hline \multirow{2}{*}{ Parameter } & \multirow{2}{*}{ PAL } & \multirow{2}{*}{ Units } & \multicolumn{8}{|c|}{ Maximum Result } \\
\hline & & & $02-26-11$ & $02-44-02$ & $02-59-01$ & $02-60-04$ & 02-60-05 & 23-60-01 & 23-99-06 & $25-60-04$ \\
\hline 1,1-dichloroethene & 1,100 & $\mathrm{mg} / \mathrm{kg}$ & -- & -- & $0.037(\mathrm{~J})$ & -- & -- & -- & -- & -- \\
\hline 1,2,4-trimethylbenzene & 260 & $\mathrm{mg} / \mathrm{kg}$ & -- & -- & 0.025 & -- & -- & -- & -- & -- \\
\hline 1,2-dichlorobenzene & 9,800 & $\mathrm{mg} / \mathrm{kg}$ & -- & -- & $0.084(\mathrm{~J})$ & -- & -- & -- & -- & -- \\
\hline 1,3,5-trimethylbenzene & 10,000 & $\mathrm{mg} / \mathrm{kg}$ & -- & -- & $0.0074(\mathrm{~J})$ & -- & -- & -- & -- & -- \\
\hline 1,4-dichlorobenzene & 12 & $\mathrm{mg} / \mathrm{kg}$ & -- & -- & 250 & -- & -- & -- & -- & $0.019(\mathrm{~J})$ \\
\hline $2,4,5-\mathrm{TP}$ & 4,900 & $\mathrm{mg} / \mathrm{kg}$ & -- & -- & $0.059(\mathrm{~J})$ & -- & -- & -- & -- & -- \\
\hline 2-butanone & 200,000 & $\mathrm{mg} / \mathrm{kg}$ & -- & 0.03 & $0.36(\mathrm{~J})$ & -- & -- & -- & -- & -- \\
\hline 2-hexanone & 1,400 & $\mathrm{mg} / \mathrm{kg}$ & -- & $0.018(\mathrm{~J})$ & $\begin{array}{ll}- \\
-\end{array}$ & -- & -- & $\begin{array}{ll}- \\
-\end{array}$ & -- & -- \\
\hline 3-methylphenol (m-cresol) & 31,000 & $\mathrm{mg} / \mathrm{kg}$ & -- & -- & -- & -- & -- & -- & -- & 15 \\
\hline $4,4^{\prime}-\mathrm{DDE}$ & 5.1 & $\mathrm{mg} / \mathrm{kg}$ & -- & -- & 0.075 & -- & -- & -- & -- & -- \\
\hline Acetone & 630,000 & $\mathrm{mg} / \mathrm{kg}$ & -- & 0.15 & 1.4 & -- & -- & -- & -- & -- \\
\hline Ac-228 & 5 & $\mathrm{pCi} / \mathrm{g}$ & 0.93 & -- & -- & 1.25 & -- & 1.32 & 2.0 & -- \\
\hline Anthracene & 170,000 & $\mathrm{mg} / \mathrm{kg}$ & -- & $2.2(\mathrm{~J})$ & -- & -- & -- & -- & -- & -- \\
\hline Antimony & 410 & $\mathrm{mg} / \mathrm{kg}$ & 4,100 & -- & -- & -- & -- & -- & -- & -- \\
\hline Aroclor 1254 & 0.74 & $\mathrm{mg} / \mathrm{kg}$ & 0.079 & -- & -- & -- & -- & -- & -- & $8.7(\mathrm{~J})$ \\
\hline Aroclor 1260 & 0.74 & $\mathrm{mg} / \mathrm{kg}$ & -- & $0.66(\mathrm{~J})$ & 0.29 & $0.95(\mathrm{~J})$ & -- & $0.48(\mathrm{~J})$ & $1.4(\mathrm{~J})$ & -- \\
\hline Aroclor 1268 & 0.74 & $\mathrm{mg} / \mathrm{kg}$ & -- & -- & -- & $0.95(\mathrm{~J})$ & -- & -- & -- & -- \\
\hline Arsenic & 23 & $\mathrm{mg} / \mathrm{kg}$ & 1,400 & 3.1 & -- & $2.4(\mathrm{~J})$ & -- & 9.4 & 24 & $2.8(\mathrm{~J}+)$ \\
\hline Barium & 190,000 & $\mathrm{mg} / \mathrm{kg}$ & $4,300(\mathrm{~J})$ & 6,200 & 1,500 & $230(\mathrm{~J})$ & -- & $690(\mathrm{~J})$ & 390 & 150 \\
\hline Benzo(a)anthracene & 2.1 & $\mathrm{mg} / \mathrm{kg}$ & -- & -- & -- & $0.28(\mathrm{~J})$ & $0.095(\mathrm{~J})$ & -- & -- & -- \\
\hline Benzo(a)pyrene & 0.21 & $\mathrm{mg} / \mathrm{kg}$ & -- & $2.3(\mathrm{~J})$ & -- & $0.26(\mathrm{~J})$ & $0.092(\mathrm{~J})$ & -- & $0.078(\mathrm{~J})$ & -- \\
\hline Benzo(b)fluoranthene & 2.1 & $\mathrm{mg} / \mathrm{kg}$ & $0.11(\mathrm{~J})$ & $5(\mathrm{~J})$ & -- & $0.47(\mathrm{~J})$ & $0.11(\mathrm{~J})$ & $0.14(\mathrm{~J})$ & $0.21(\mathrm{~J})$ & -- \\
\hline Benzo(g,h,i)perylene & 17,000 & $\mathrm{mg} / \mathrm{kg}$ & -- & -- & -- & $0.32(\mathrm{~J})$ & $0.086(\mathrm{~J})$ & -- & $0.31(\mathrm{~J})$ & -- \\
\hline
\end{tabular}


Table D.1-3

Maximum Reported PSM Sample Results for Tier I Comparison

(Page 2 of 3 )

\begin{tabular}{|c|c|c|c|c|c|c|c|c|c|c|}
\hline \multirow{2}{*}{ Parameter } & \multirow{2}{*}{ PAL } & \multirow{2}{*}{ Units } & \multicolumn{8}{|c|}{ Maximum Result } \\
\hline & & & $02-26-11$ & $02-44-02$ & $02-59-01$ & $02-60-04$ & $02-60-05$ & 23-60-01 & 23-99-06 & $25-60-04$ \\
\hline Benzo(k)fluoranthene & 21 & $\mathrm{mg} / \mathrm{kg}$ & -- & -- & -- & $0.13(\mathrm{~J})$ & -- & -- & -- & -- \\
\hline Benzoic Acid & $2,500,000$ & $\mathrm{mg} / \mathrm{kg}$ & -- & $17(\mathrm{~J})$ & -- & -- & -- & -- & -- & -- \\
\hline Bis(2-ethylhexyl)phthalate & 120 & $\mathrm{mg} / \mathrm{kg}$ & -- & $220(\mathrm{~J})$ & $3.6(\mathrm{~J})$ & 0.44 & $0.16(\mathrm{~J})$ & 8.3 & 0.63 & $6.8(\mathrm{~J})$ \\
\hline Butyl benzyl phthalate & 910 & $\mathrm{mg} / \mathrm{kg}$ & -- & $17(\mathrm{~J})$ & -- & -- & -- & -- & 0.48 & -- \\
\hline Cadmium & 800 & $\mathrm{mg} / \mathrm{kg}$ & 0.65 & 43 & 9.5 & 32 & -- & 4 & 9.9 & 19 \\
\hline Carbazole & 96 & $\mathrm{mg} / \mathrm{kg}$ & -- & $2.9(\mathrm{~J})$ & -- & -- & -- & -- & -- & -- \\
\hline Carbon disulfide & 3,700 & $\mathrm{mg} / \mathrm{kg}$ & -- & -- & $0.032(\mathrm{~J})$ & -- & -- & -- & -- & $0.017(\mathrm{~J})$ \\
\hline Cs-137 & 12.2 & $\mathrm{pCi} / \mathrm{g}$ & 0.54 & $\begin{array}{ll}- \\
-\end{array}$ & $\begin{array}{ll}- \\
-\end{array}$ & 0.78 & $\begin{array}{ll}- \\
-\end{array}$ & 0.67 & 0.62 & $\begin{array}{l}-- \\
\end{array}$ \\
\hline Chlorobenzene & 1,400 & $\mathrm{mg} / \mathrm{kg}$ & -- & -- & $0.03(\mathrm{~J})$ & -- & -- & -- & -- & -- \\
\hline Chlordane & 7 & $\mathrm{mg} / \mathrm{kg}$ & -- & -- & -- & -- & -- & -- & $40(\mathrm{~J})$ & -- \\
\hline Chromium & 450 & $\mathrm{mg} / \mathrm{kg}$ & $450(\mathrm{~J})$ & 5,800 & 330 & $47(\mathrm{~J})$ & -- & $29(\mathrm{~J})$ & $60(\mathrm{~J})$ & 130 \\
\hline Chrysene & 210 & $\mathrm{mg} / \mathrm{kg}$ & -- & $8.4(\mathrm{~J})$ & -- & $0.26(\mathrm{~J})$ & $0.076(\mathrm{~J})$ & $0.16(\mathrm{~J})$ & -- & -- \\
\hline Cis-1,2-dichloroethene & 10,000 & $\mathrm{mg} / \mathrm{kg}$ & $\begin{array}{ll}-- \\
-1\end{array}$ & $\begin{array}{l}- \\
-\end{array}$ & 61 & -- & -- & -- & -- & $\begin{array}{l}-- \\
-1\end{array}$ \\
\hline Dieldrin & 0.11 & $\mathrm{mg} / \mathrm{kg}$ & -- & -- & $0.0091(\mathrm{~J})$ & -- & -- & -- & -- & -- \\
\hline Dibenzo(a,h)anthracene & 0.21 & $\mathrm{mg} / \mathrm{kg}$ & -- & -- & -- & $0.084(\mathrm{~J})$ & -- & -- & -- & -- \\
\hline DRO & 100 & $\mathrm{mg} / \mathrm{kg}$ & 29 & 3,000 & 2,600 & 530 & -- & $170(\mathrm{~J})$ & 150 & 3,500 \\
\hline Di-n-butyl phthalate & 62,000 & $\mathrm{mg} / \mathrm{kg}$ & $0.25(\mathrm{~J})$ & $16(\mathrm{~J})$ & -- & $0.089(\mathrm{~J})$ & $0.29(\mathrm{~J})$ & $0.11(\mathrm{~J})$ & -- & -- \\
\hline Di-n-octylphthalate & 25,000 & $\mathrm{mg} / \mathrm{kg}$ & -- & $5.9(\mathrm{~J})$ & -- & -- & -- & -- & -- & -- \\
\hline Ethylbenzene & 27 & $\mathrm{mg} / \mathrm{kg}$ & -- & -- & $0.14(\mathrm{~J})$ & -- & -- & -- & -- & -- \\
\hline Fluoranthene & 22,000 & $\mathrm{mg} / \mathrm{kg}$ & $0.16(\mathrm{~J})$ & 25 & -- & 0.39 & $0.15(\mathrm{~J})$ & 0.55 & -- & -- \\
\hline Indeno(1,2,3-cd)pyrene & 2.1 & $\mathrm{mg} / \mathrm{kg}$ & -- & -- & -- & $0.3(\mathrm{~J})$ & -- & -- & $0.21(\mathrm{~J})$ & -- \\
\hline Isopropylbenzene & 11,000 & $\mathrm{mg} / \mathrm{kg}$ & -- & -- & 1.2 & -- & -- & -- & -- & -- \\
\hline Lead & 800 & $\mathrm{mg} / \mathrm{kg}$ & 120,000 & 7,200 & 59 & $200(\mathrm{~J})$ & -- & 8,900 & 760 & 970 \\
\hline
\end{tabular}


Table D.1-3

Page D-12 of D-26

Maximum Reported PSM Sample Results for Tier I Comparison

(Page 3 of 3 )

\begin{tabular}{|c|c|c|c|c|c|c|c|c|c|c|}
\hline \multirow{2}{*}{ Parameter } & \multirow{2}{*}{ PAL } & \multirow{2}{*}{ Units } & \multicolumn{8}{|c|}{ Maximum Result } \\
\hline & & & $02-26-11$ & $02-44-02$ & $02-59-01$ & $02-60-04$ & $02-60-05$ & 23-60-01 & 23-99-06 & $25-60-04$ \\
\hline MCPP & 620 & $\mathrm{mg} / \mathrm{kg}$ & -- & -- & 83 & -- & -- & $\begin{array}{ll}- \\
-\end{array}$ & -- & $\begin{array}{ll}- \\
\end{array}$ \\
\hline Mercury & 34 & $\mathrm{mg} / \mathrm{kg}$ & 0.034 & 0.93 & $2(\mathrm{~J}+)$ & $0.16(\mathrm{~J}-)$ & -- & $0.43(\mathrm{~J})$ & 0.22 & 0.74 \\
\hline Methylene chloride & 500 & $\mathrm{mg} / \mathrm{kg}$ & $0.0017(\mathrm{~J})$ & -- & $\begin{array}{ll}- \\
-\end{array}$ & -- & -- & -- & -- & $0.058(\mathrm{~J})$ \\
\hline Naphthalene & 18 & $\mathrm{mg} / \mathrm{kg}$ & -- & -- & 45 & -- & $\overline{--}$ & -- & -- & -- \\
\hline N-butylbenzene & 240 & $\mathrm{mg} / \mathrm{kg}$ & -- & -- & 1.1 & $\begin{array}{ll}- \\
-\end{array}$ & -- & -- & -- & $\begin{array}{ll}-- \\
\end{array}$ \\
\hline N-propylbenzene & 21,000 & $\mathrm{mg} / \mathrm{kg}$ & -- & -- & 3.9 & -- & -- & -- & -- & -- \\
\hline Phenanthrene & 170,000 & $\mathrm{mg} / \mathrm{kg}$ & 0.078 & 15 & -- & $0.17(\mathrm{~J})$ & $0.21(\mathrm{~J})$ & $0.086(\mathrm{~J})$ & -- & -- \\
\hline Pyrene & 17,000 & $\mathrm{mg} / \mathrm{kg}$ & 0.16 & 16 & $1.5(\mathrm{~J})$ & 0.58 & $0.43(\mathrm{~J})$ & 0.52 & $0.095(\mathrm{~J})$ & -- \\
\hline Sec-bytylbenzene & 220 & $\mathrm{mg} / \mathrm{kg}$ & -- & -- & 1.5 & -- & -- & -- & -- & -- \\
\hline Selenium & 5,100 & $\mathrm{mg} / \mathrm{kg}$ & 4.1 & 5 & 4.1 & -- & -- & 0.33 & 0.57 & 0.84 \\
\hline Silver & 5,100 & $\mathrm{mg} / \mathrm{kg}$ & 4.8 & 0.25 & 290 & $6.1(\mathrm{~J})$ & -- & 0.2 & 0.34 & 17 \\
\hline Tert-butylbenzene & 390 & $\mathrm{mg} / \mathrm{kg}$ & -- & -- & $0.11(\mathrm{~J})$ & -- & -- & -- & -- & -- \\
\hline Tetrachloroethene & 2.6 & $\mathrm{mg} / \mathrm{kg}$ & -- & -- & -- & 0.013 & -- & -- & -- & -- \\
\hline Toluene & 45,000 & $\mathrm{mg} / \mathrm{kg}$ & -- & -- & 0.44 & -- & -- & -- & -- & -- \\
\hline Trichloroethene & 14 & $\mathrm{mg} / \mathrm{kg}$ & -- & -- & -- & -- & -- & -- & -- & $0.032(\mathrm{~J})$ \\
\hline Vinyl chloride & 2 & $\mathrm{mg} / \mathrm{kg}$ & -- & -- & $0.28(\mathrm{~J})$ & -- & -- & -- & -- & -- \\
\hline
\end{tabular}

-- = Not detected above MDCs.

$\mathrm{J}=$ Estimated value

$\mathrm{J}-=$ Result is an estimated quantity but may be biased low.

$\mathrm{J}+=$ Result is an estimated quantity but may be biased high

Bold indicates the value is equal to or exceeds the PAL. 


\section{D.1.3 C. Site Classification and Initial Response Action}

The four major site classifications listed in Table 3 of the ASTM Standard are: (1) immediate threat to human health, safety, and the environment; (2) short-term (0 to 2 years) threat to human health, safety, and the environment; (3) long-term (greater than 2 years) threat to human health, safety, or the environment; and (4) no demonstrated long-term threats.

Based on the CAI, none of the CASs present an immediate threat to human health, safety, and the environment as contaminants are not present at concentrations that would pose an immediate threat to human health and receptors are not present at these sites on a regular basis. Therefore, no interim response actions are necessary at these sites. Based on this information, CASs 02-60-01, 02-60-06, and 02-60-07 are determined to be Classification 4 sites as defined by ASTM Method E1739 and pose no demonstrated near- or long-term threats. The remaining CASs (listed in Table D.1-2) have COCs or PSM present that may pose long-term threats to human health, safety, or the environment and have been determined to be Classification 3 sites as defined by ASTM Method E1739.

\section{D.1.4 D. Development of Tier 1 Lookup Table of RBSLs}

Tier 1 action levels have been defined as the PALs established during the DQO process. The PALs are a tabulation of chemical-specific (but not site-specific) screening levels based on the type of media (soil) and potential exposure scenarios (industrial). These are very conservative estimates of risk, are preliminary in nature, and are used as action levels for site screening purposes. Although the PALs are not intended to be used as FALs, a FAL may be defined as the Tier 1 action level (i.e., PAL) value if individual contaminant analytical results are below the corresponding Tier 1 action level value. The FAL may also be established as the Tier 1 action level value if individual contaminant analytical results exceed the corresponding Tier 1 action level value and implementing a corrective action based on the FAL is practical. The PALs are defined as:

- EPA Region 9 Screening Levels for Chemical Contaminants in industrial soils (EPA, 2008), with the exception of chromium, where the 2006 Preliminary Remediation Goal (PRG) was used (EPA, 2006).

- Background concentrations for RCRA metals will be evaluated when natural background exceeds the PAL, as is often the case with arsenic. Background is considered the mean plus two times the standard deviation of the mean based on data published in Mineral and Energy Resource Assessment of the Nellis Air Force Range (NBMG, 1998; Moore, 1999). 
- TPH concentrations above the action level of $100 \mathrm{mg} / \mathrm{kg}$ per NAC 445A.2272 (NAC, 2006c).

- For COPCs without established PRGs, a protocol similar to that used by EPA Region 9 will be used to establish an action level; otherwise, an established PRG from another EPA region may be chosen.

- The PALs for radioactive contaminants are based on the National Council on Radiation Protection and Measurements (NCRP) Report No. 129 recommended screening limits for construction, commercial, industrial land-use scenarios (NCRP, 1999) scaled to 25-millirem-per-year (mrem/yr) dose constraint (Appenzeller-Wing, 2004) and the generic guidelines for residual concentration of radionuclides in DOE Order 5400.5 (DOE, 1993).

The PALs were developed based on an industrial scenario. As the CAU 562 CASs in Areas 2, 23, and 25 are not assigned work stations and are considered to be in remote or occasional use areas, the use of industrial reuse based PALs is conservative. The Tier 1 lookup table is defined as the PAL concentrations or activities defined in the CAIP (NNSA/NSO, 2009). For the evaluation of PSM samples, the following PSM assumptions listed in the CAIP were used:

- Any current containment of wastes would fail at some point, and the contents would be released to the surrounding media.

- For non-liquid wastes, the resulting concentration of contaminants in the surrounding media would be equal to the concentration of contaminants in the waste.

- For liquid wastes, the resulting concentration of contaminants in the surrounding soil will be calculated based on the concentration of contaminants in the waste and the liquid holding capacity of the soil.

The Tier 1 RBSL for PSM samples was established by comparing the resulting concentration in soil to the PAL concentrations as defined above for the soil samples.

\section{D.1.5 E. Exposure Pathway Evaluation}

The DQOs stated that site workers would only be exposed to COCs through oral ingestion, inhalation, or dermal contact (absorption) due to exposure to potentially contaminated media (i.e., soil) at the CASs. The results of the CAI showed that all COCs identified at CASs within CAU 562 are localized near the release point and have not migrated beyond the spatial boundaries defined in the DQOs. Therefore, the only potential exposure pathways would be through worker contact with the contaminated soil. The limited migration demonstrated by the analytical results, elapsed time since 
the suspected release, and depth to groundwater supports the selection and evaluation only surface and shallow subsurface contact as the complete exposure pathways. Groundwater is not considered to be a significant exposure pathway.

\section{D.1.6 F. Comparison of Site Conditions with Tier 1 RBSLS}

All analytical results from CAU 562 samples were less than corresponding Tier 1 action levels (i.e., PALs) except those listed in Table D.1-4. All CAU 562 waste sample (i.e., PSM sample) results indicate that, if released to the soil, the wastes would not result in the introduction of contamination exceeding Tier 1 action levels (i.e., PALs) except for TPH and those wastes listed as PSM in Table D.1-2.

\section{D.1.7 G. Evaluation of Tier 1 Results}

For all contaminants at all CASs not listed in Table D.1-4, the FALs were established as the Tier 1 RBSLs. It was determined that no further action is required for these contaminants at these CASs.

For all the contaminants listed in Table D.1-4 except TPH at all CASs and lead at CAS 23-60-01, the FALs were established as the Tier 1 RBSLs. For all the PSM listed in Table D.1-2, the FALs were established as the Tier 1 RBSLs.

\section{D.1.8 H. Tier 1 Remedial Action Evaluation}

It was determined that corrective action is practical and appropriate for all of the PSM listed in Table D.1-2 and contaminants listed in Table D.1-4, except TPH-DRO at all CASs. It was also determined that the lead in soil at CAS 23-60-01 required further risk evaluation to establish the Tier 2 RBSL.

\section{TPH-DRO Evaluation}

The TPH-DRO was not appropriate or practical to remediate to Tier 1 action levels as it is not appropriate to evaluate risk to receptors from TPH-DRO. The ASTM Method E1739 stipulates that risk evaluations for TPH-DRO contamination be calculated and evaluated based on the risk posed by the potentially hazardous constituents of TPH-DRO. Section 6.4.3 ("Use of Total Petroleum Hydrocarbon Measurements”) of ASTM Method E1739 states: “TPHs should not be used for risk 
Table D.1-4

Contaminants Exceeding PALs

\begin{tabular}{|c|c|c|c|c|c|c|c|c|c|c|c|c|c|c|c|c|c|c|}
\hline CAS & 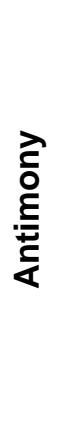 & 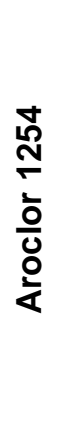 & $\begin{array}{l}\text { ¿ } \\
\text { ㄱ. } \\
\text { 흔 } \\
\frac{0}{0} \\
\frac{0}{4}\end{array}$ & 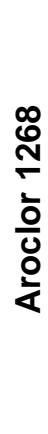 & 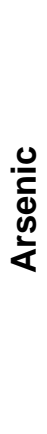 & 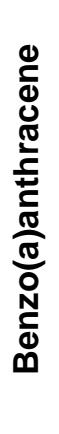 & 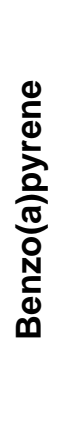 & 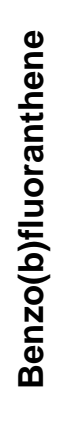 & 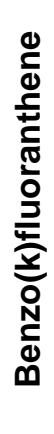 & 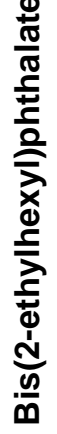 & $\frac{0}{\frac{0}{0}}$ & 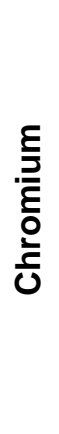 & 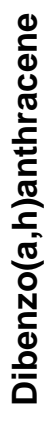 & 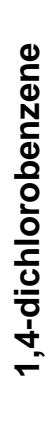 & 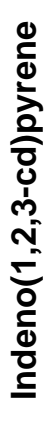 & ర్త & 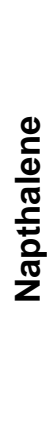 & 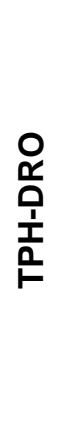 \\
\hline $02-26-11$ & $x$ & -- & -- & -- & $x$ & -- & -- & -- & -- & -- & -- & $\bar{x}$ & -- & -- & -- & $\bar{x}$ & -- & $X$ \\
\hline $02-44-02$ & -- & -- & -- & -- & -- & -- & $x$ & $x$ & -- & $x$ & -- & $x$ & -- & -- & -- & $x$ & -- & $x$ \\
\hline $02-59-01$ & -- & -- & -- & -- & -- & -- & -- & -- & -- & -- & -- & -- & -- & $x$ & -- & -- & $x$ & $x$ \\
\hline $02-60-01$ & -- & -- & -- & -- & -- & $x$ & $x$ & $x$ & -- & -- & -- & -- & $x$ & -- & $x$ & -- & -- & $x$ \\
\hline $02-60-03$ & -- & -- & $x$ & -- & -- & -- & $x$ & -- & -- & -- & -- & -- & -- & -- & -- & -- & -- & $x$ \\
\hline $02-60-04$ & -- & -- & $x$ & $x$ & -- & -- & $x$ & -- & -- & -- & -- & -- & -- & -- & -- & -- & -- & $x$ \\
\hline 02-60-05 & -- & -- & -- & -- & -- & $x$ & $x$ & $x$ & $x$ & -- & -- & -- & $x$ & -- & $X$ & -- & -- & -- \\
\hline $02-60-06$ & -- & -- & -- & -- & -- & -- & -- & -- & -- & -- & -- & -- & -- & -- & -- & -- & -- & $x$ \\
\hline 23-60-01 & -- & -- & -- & -- & -- & -- & -- & -- & -- & -- & -- & -- & -- & -- & -- & $x$ & -- & $x$ \\
\hline 23-99-06 & -- & -- & $x$ & -- & $X$ & -- & -- & -- & -- & -- & $x$ & -- & -- & -- & -- & -- & -- & $x$ \\
\hline $25-60-04$ & -- & $x$ & -- & -- & -- & -- & -- & -- & -- & -- & -- & -- & -- & -- & -- & $x$ & -- & $X$ \\
\hline
\end{tabular}

-- = Not detected 
assessment because the general measure of TPH-DRO provides insufficient information about the amounts of individual chemical(s) of concern present” (see also Sections X1.5.4 and X1.42 of Method E1739 in ASTM, 1995). Therefore, no actions to remediate any of the sites to Tier 1 action levels for TPH-DRO are proposed and TPH-DRO was moved to a Tier 2 evaluation which considers the risk posed by the hazardous constituents of diesel.

\section{Lead Evaluation}

As evidenced by the CAI results at CAS 23-60-01, lead contamination is present in soil at concentrations exceeding the Tier 1 RBSL. However, remediation to the Tier 1 RBSL was not considered appropriate or practical and the lead contamination in the soil at CAS 23-60-01 was passed on to a Tier 2 evaluation.

\section{D.1.9 I. Tier 2 Evaluation}

No additional data were needed to complete a Tier 2 evaluation.

\section{D.1.10 J. Development of Tier 2 SSTLS}

\section{Evaluation of TPH-DRO SSTLS}

The Tier 2 SSTLs for the hazardous constituents of TPH-DRO were established as the corresponding PAL concentrations of the individual constituents as defined in the CAIP. The individual potentially hazardous constituents in TPH-DRO were compared to corresponding Tier 2 SSTLs to evaluate the need for corrective action at each individual CAS at CAU 562. These SSTLs and the maximum reported level for each diesel constituent per CAS are presented in Table D.1-5. 
Table D.1-5

Page D-18 of D-26

Tier 2 SSTLs and CAU 562 Results for Hazardous Constituents of Diesel

(Page 1 of 2)

\begin{tabular}{|c|c|c|c|c|c|c|c|c|c|c|c|c|}
\hline \multirow[b]{2}{*}{ Constituent } & \multicolumn{12}{|c|}{ Maximum Reported Value (mg/kg) } \\
\hline & $\begin{array}{c}\text { SSTL } \\
\text { (mg/kg) }\end{array}$ & $02-26-11$ & $02-44-02$ & $02-59-01$ & $02-60-01$ & $02-60-02$ & $02-60-03$ & $02-60-04$ & $02-60-05$ & $23-60-01$ & $23-99-06$ & $25-60-04$ \\
\hline 1,3,5-trimethylbenzene & 10,000 & ND & ND & $0.0074(\mathrm{~J})$ & ND & ND & ND & ND & ND & ND & ND & ND \\
\hline 2-methylnaphthalene & 4,100 & ND & ND & ND & $4.6(\mathrm{~J})$ & ND & ND & ND & 11 & $0.093(\mathrm{~J})$ & ND & ND \\
\hline Anthracene & 170,000 & ND & $2.2(\mathrm{~J})$ & ND & $10(\mathrm{~J})$ & ND & ND & ND & 23 & ND & ND & ND \\
\hline Benzene & 5.4 & ND & ND & ND & ND & ND & ND & ND & ND & ND & ND & ND \\
\hline Benzo(a)anthracene & 2.1 & $0.088(\mathrm{~J})$ & $0.21(\mathrm{~J})$ & ND & $18(\mathrm{~J})$ & $0.18(\mathrm{~J})$ & $0.19(\mathrm{~J})$ & $0.28(\mathrm{~J})$ & $33(\mathrm{~J})$ & $0.12(\mathrm{~J})$ & ND & $0.11(\mathrm{~J})$ \\
\hline Benzo(a)pyrene & 0.21 & $0.11(\mathrm{~J})$ & $2.3(\mathrm{~J})$ & ND & $16(\mathrm{~J})$ & $0.18(\mathrm{~J})$ & 0.27 & $0.26(\mathrm{~J})$ & $37(\mathrm{~J})$ & $0.15(\mathrm{~J})$ & $0.078(\mathrm{~J})$ & ND \\
\hline Benzo(b)fluoranthene & 2.1 & $0.16(\mathrm{~J})$ & $5(\mathrm{~J})$ & ND & $21(\mathrm{~J})$ & $0.32(\mathrm{~J})$ & 0.56 & $0.47(\mathrm{~J})$ & $41(\mathrm{~J})$ & $0.17(\mathrm{~J})$ & $0.21(\mathrm{~J})$ & ND \\
\hline Benzo(g,h,i)perylene & 17,000 & $0.1(\mathrm{~J})$ & $0.21(\mathrm{~J})$ & ND & $7.4(\mathrm{~J})$ & ND & $0.13(\mathrm{~J})$ & $0.32(\mathrm{~J})$ & $23(\mathrm{~J})$ & $0.093(\mathrm{~J})$ & $0.31(\mathrm{~J})$ & ND \\
\hline Benzo(k)fluoranthene & 21 & $0.073(\mathrm{~J})$ & $0.16(\mathrm{~J})$ & ND & $9.6(\mathrm{~J})$ & $0.13(\mathrm{~J})$ & $0.26(\mathrm{~J})$ & $0.13(\mathrm{~J})$ & $22(\mathrm{~J})$ & ND & ND & ND \\
\hline Chrysene & 210 & $0.1(\mathrm{~J})$ & $8.4(\mathrm{~J})$ & ND & $19(\mathrm{~J})$ & $0.21(\mathrm{~J})$ & $0.27(\mathrm{~J})$ & $0.26(\mathrm{~J})$ & 35 & $0.16(\mathrm{~J})$ & ND & ND \\
\hline Ethylbenzene & 27 & ND & ND & $0.14(\mathrm{~J})$ & ND & ND & ND & ND & ND & ND & ND & ND \\
\hline Fluoranthene & 22,000 & $0.24(\mathrm{~J})$ & 25 & ND & $61(\mathrm{~J})$ & 0.59 & 0.62 & 0.39 & $92(\mathrm{~J})$ & 0.55 & ND & ND \\
\hline Fluorene & 26,000 & ND & ND & ND & $15(\mathrm{~J})$ & ND & ND & ND & 17 & ND & ND & ND \\
\hline N-propylbenzene & 21,000 & ND & ND & 3.9 & ND & ND & ND & ND & ND & ND & ND & ND \\
\hline N-butylbenzene & 240 & ND & ND & 1.1 & ND & ND & ND & $\mathrm{ND}$ & ND & ND & ND & ND \\
\hline Naphthalene & 18 & ND & ND & 45 & $3.2(\mathrm{~J})$ & ND & ND & ND & 1.9 & ND & ND & ND \\
\hline Phenanthrene & 170,000 & $0.11(\mathrm{~J})$ & 15 & ND & $73(\mathrm{~J})$ & 0.42 & 0.45 & $0.17(\mathrm{~J})$ & $90(\mathrm{~J})$ & $0.13(\mathrm{~J})$ & ND & ND \\
\hline Pyrene & 17,000 & $0.33(\mathrm{~J})$ & 16 & $1.5(\mathrm{~J})$ & $50(\mathrm{~J})$ & 0.43 & 0.47 & 0.58 & $69(\mathrm{~J})$ & 0.52 & $0.095(\mathrm{~J})$ & $0.088(\mathrm{~J})$ \\
\hline
\end{tabular}


Table D.1-5

Tier 2 SSTLs and CAU 562 Results for Hazardous Constituents of Diesel

(Page 2 of 2)

\begin{tabular}{|c|c|c|c|c|c|c|c|c|c|c|c|c|}
\hline \multirow{2}{*}{ Constituent } & \multicolumn{12}{|c|}{ Maximum Reported Value (mg/kg) } \\
\hline & $\begin{array}{c}\text { SSTL } \\
(\mathrm{mg} / \mathrm{kg})\end{array}$ & $02-26-11$ & $02-44-02$ & $02-59-01$ & $02-60-01$ & $02-60-02$ & $02-60-03$ & $02-60-04$ & $02-60-05$ & $23-60-01$ & $23-99-06$ & $25-60-04$ \\
\hline Total xylenes & 2,700 & $\mathrm{ND}$ & ND & $\mathrm{ND}$ & ND & ND & $\mathrm{ND}$ & ND & $\mathrm{ND}$ & $\mathrm{ND}$ & ND & ND \\
\hline Toluene & 45,000 & ND & ND & ND & ND & ND & ND & ND & ND & $\mathrm{ND}$ & ND & ND \\
\hline
\end{tabular}

$\mathrm{ND}=$ Nondetect

$\mathrm{J}=$ Estimated value

Bold indicates the value is equal to or exceeds the PAL. 


\section{Evaluation of Lead SSTLS}

An outdoor industrial soil Tier 2 SSTL was calculated for lead at CAS 23-60-01 using EPA's ALM (EPA, 2009) to estimate the concentration of lead in the blood of pregnant women and their developing fetuses who might be exposed to lead-contaminated soils. The ALM is a series of equations for calculation of fetal risks from adult exposures to specified levels of soil lead contamination. This approach supports EPA's goal of limiting the risk of elevated fetal blood lead concentrations due to lead exposures to women of child-bearing age. The ALM model is used to estimate blood lead concentrations which can then be correlated to estimate possible adverse health effects in persons who have been exposed.

The EPA recommends that default values for each of the ALM parameters not be replaced with other values unless the alternatives are supported by high quality site-specific data to which appropriate statistical analyses have been applied and that have undergone thorough scientific review. Therefore the default parameters were used in the ALM model for deriving a Tier 2 SSTL. The Tier 2 SSTL for lead using this methodology is $1,235 \mathrm{mg} / \mathrm{kg}$.

\section{D.1.11 K. Comparison of Site Conditions with Tier 2 SSTLS}

The Tier 2 action levels are typically compared to individual sample results from reasonable points of exposure (as opposed to the source areas as is done in Tier 1) on a point-by-point basis. Points of exposure are defined as those locations or areas at which an individual or population may come in contact with a COC originating from a CAS. For CAU 562, the Tier 2 action levels were compared to maximum contaminant concentrations from each sample location.

As shown in Table D.1-2, the maximum concentration for lead from CAS 23-60-01 (1,000 mg/kg) was less than corresponding Tier 2 action level of 1,235 mg/kg. The FAL for lead was established as the Tier 2 SSTL.

\section{D.1.12 L. Tier 2 Remedial Action Evaluation}

Based on the Tier 2 evaluation of the TPH-DRO hazardous constituents, benzo(a)pyrene and benzo(b)fluoranthene exceed the PSM criteria in paint samples at CAS 02-44-02. Therefore, the paint is considered PSM. Additionally, benzo(a)pyrene exceeds the PSM criteria in sediment samples 
at CAS 02-60-04. Therefore, the sediment at this CAS is PSM. It was determined that corrective action is practical and appropriate for these contaminants at these CASs.

Based on the Tier 2 evaluation of the lead, the lead in the soil at CAS 23-60-01 does not pose an unacceptable risk to human health and the environment. Therefore, no further action concerning lead in the soil is required at this CAS.

As all contaminant FALs were established as Tier 1 or Tier 2 action levels, a Tier 3 evaluation was not considered necessary. 


\section{D.2.0 Recommendations}

All of the site related contaminant concentrations identified in soils collected during the CAU 562 CAI were less than the corresponding FALs at CAS 02-60-01, Concrete Drain; CAS 02-60-06, French Drain; and CAS 02-60-07, French Drain (this site was determined not to exist). It was determined that there were no COCs or PSM at these CASs and that the CASs do not pose an unacceptable risk to human health or the environment and therefore, do not warrant corrective actions. However, this does not preclude the consideration of these sites for additional protective measures that may be implemented as BMPs (i.e., removal of the concrete drain at CAS 02-60-01 and the drain casing at CAS 02-60-06). The following sections discuss the remaining 10 CASs in CAU 562 that will require corrective action:

\section{CAS 02-26-11, Lead Shot}

As lead, antimony, arsenic, and chromium were detected in the shot at concentrations exceeding their corresponding PSM criteria (Tier 1 SSTL), it was determined that they are PSM contaminants. Therefore, the shot was identified as PSM and will require corrective action.

\section{CAS 02-44-02, Paint Spills and French Drain}

As benzo(a)pyrene was identified in soil above the corresponding FAL (Tier 1 SSTL), this constituent was identified as a COC. As various constituents were detected in the paint at concentrations exceeding their corresponding PSM criteria (Tier 1 SSTL), it was determined that they are PSM contaminants and the paint is PSM. As there are COCs present in the soil and the paint is considered PSM, a corrective action will be required for this CAS.

\section{CAS 02-59-01, Septic System}

As naphthalene and 1,4-dichlorobenzene were detected in the sludge at concentrations exceeding their corresponding PSM criteria (Tier 1 SSTL), it was determined that they are PSM contaminants. Therefore, the sludge was identified as PSM and will require corrective action. 


\section{CAS 02-60-02, French Drain}

As Aroclor 1260 was identified in soil above the corresponding FAL (Tier 1 SSTL), this constituent was identified as a COC. As there are COCs in the soil, a corrective action will be required for this CAS.

\section{CAS 02-60-03, Steam Cleaning Drain}

Aroclor 1260 and benzo(a)pyrene were identified in soil above the corresponding FAL (Tier 1 SSTL) and were identified as COCs. As there are COCs in the soil, a corrective action will be required for this CAS.

\section{CAS 02-60-04, French Drain}

As Aroclor 1260, Aroclor 1268, and benzo(a)pyrene were detected in the sediment at concentrations exceeding their corresponding PSM criteria (Tier 1 SSTL), it was determined that they are PSM contaminants. Therefore, the sediment was identified as PSM and will require corrective action.

\section{CAS 02-60-05, French Drain}

As benzo(a)pyrene, benzo(a)anthracene, benzo(b)fluoranthene, benzo(k)fluoranthene, dibenzo(a,h)anthracene, and indeno(1,2,3-cd)pyrene were identified in soil above the corresponding FAL (Tier 1 SSTL), they were identified as COCs. As there are COCs in the soil, a corrective action will be required for this CAS.

\section{CAS 23-60-01, Mud Trap and Outfall}

As lead was detected in the sediment within the mud trap at concentrations exceeding the corresponding PSM criteria (Tier 1 SSTL), lead is considered a PSM contaminant. Therefore, the sediment was identified as PSM and will require corrective action.

\section{CAS 23-99-06, Grease Trap}

As arsenic, Aroclor 1260, and chlordane were detected in the sediment at concentrations exceeding their corresponding PSM criteria (Tier 1 SSTL), it was determined that they are PSM contaminants. Therefore, the sediment was identified as PSM and will require corrective action. 


\section{CAS 25-60-04, Building 3123 Outfalls}

As Aroclor 1254 was identified in soil above the corresponding FAL (Tier 1 SSTL), this constituent was identified as a COC. As lead and Aroclor 1254 were detected in the sludge within the pipe at concentrations exceeding their corresponding PSM criteria (Tier 1 SSTL), it was determined that they are PSM contaminants and that the sludge is PSM. As there are COCs in the soil and the sludge is PSM, a corrective action will be required for this CAS. 


\section{D.3.0 References}

ASTM, see American Society for Testing and Materials.

American Society for Testing and Materials. 1995 (reapproved 2002). Standard Guide for Risk-Based Corrective Action Applied at Petroleum Release Sites, ASTM E1739 - 95(2002). Philadelphia, PA.

Appenzeller-Wing, J., U.S. Department of Energy, National Nuclear Security Administration Nevada Site Office. 2004. Letter to T.A. Maize (NDEP) entitled, "Submittal of Proposed Radiological Preliminary Action Levels (PALs) for the Industrial Sites Project,” 15 January. Las Vegas, NV.

DOE, see U.S. Department of Energy.

DOE/NV, see U.S. Department of Energy, Nevada Operations Office.

EPA, see U.S. Environmental Protection Agency.

Moore, J., Science Applications International Corporation. 1999. Memorandum to M. Todd (SAIC), “Background Concentrations for NTS and TTR Soil Samples,” 3 February. Las Vegas, NV.

NAC, see Nevada Administrative Code

NBMG, see Nevada Bureau of Mines and Geology.

NCRP, see National Council on Radiation Protection and Measurements.

National Council on Radiation Protection and Measurements. 1999. Recommended Screening Limits for Contaminated Surface Soil and Review of Factors Relevant to Site-Specific Studies, NCRP Report No. 129. Bethesda, MD.

Nevada Administrative Code. 2006a. NAC 445A.227, “Contamination of Soil: Order by Director for Corrective Action; Factors To Be Considered in Determining Whether Corrective Action Required.” Carson City, NV. As accessed at http://www.leg.state.nv.us/nac on 22 January 2009.

Nevada Administrative Code. 2006b. NAC 445A.22705, "Contamination of Soil: Evaluation of Site by Owner or Operator; Review of Evaluation by Division.” Carson City, NV. As accessed at http://www.leg.state.nv.us/nac on 22 January 2009.

Nevada Administrative Code. 2006c. NAC 445A.2272, “Contamination of Soil: Establishment of Action Levels.” Carson City, NV. As accessed at http://www.leg.state.nv.us/nac on 22 January 2009. 
Nevada Bureau of Mines and Geology. 1998. Mineral and Energy Resource Assessment of the Nellis Air Force Range, Open-File Report 98-1. Reno, NV.

U.S. Department of Energy. 1993. Radiation Protection of the Public and the Environment, DOE Order 5400.5, Change 2. Washington, DC: U.S. Government Printing Office.

U.S. Department of Energy, National Nuclear Security Administration Nevada Site Office. 2006. Industrial Sites Project Establishment of Final Action Levels, Rev. 0, DOE/NV--1107. Las Vegas, NV

U.S. Department of Energy, National Nuclear Security Administration Nevada Site Office. 2009. Corrective Action Investigation Plan for Corrective Action Unit 562: Waste Systems, Nevada Test Site, Nevada, Rev. 0, DOE/NV--1317. Las Vegas, NV.

U.S. Environmental Protection Agency. 2006. Region 9 Preliminary Remediation Goals (PRGs). As accessed at http://www.epa.gov/region09/waste/sfund/prg/index.htm on 4 December 2008. San Francisco, CA.

U.S. Environmental Protection Agency. 2008. Region 9: Superfund, Preliminary Remediation Goals, Screening Levels for Chemical Contaminants. As accessed at http://www.epa.gov/region09/waste/sfund/prg/index.html on 4 December. Prepared by EPA Office of Superfund and Oak Ridge National Laboratory.

U.S. Environmental Protection Agency. 2009. Update of the Adult Lead Methodology's Default Baseline Blood Lead Concentration and Geometric Standard Deviation Parameters, OSWER 9200.2-82. June. Prepared by the Lead Committee of the Technical Review Workgroup for Metals and Asbestos. Washington, DC: Office of Superfund Remediation and Technology Innovation. 


\section{Appendix E}

\section{Project Organization}


The NNSA/NSO Federal Sub-Project Director is Kevin Cabble. He can be contacted at (702) 295-5000. The NNSA/NSO Task Manager is Tiffany Lantow. She can be contacted at (702) 295-7645.

The identification of the project Health and Safety Officer and the Quality Assurance Officer can be found in the appropriate plan. However, personnel are subject to change, and it is suggested that the NNSA/NSO Federal Sub-Project Director be contacted for further information. 


\section{Appendix F}

\section{Sample Location Coordinates}




\section{F.1.0 Sample Location Coordinates}

Sample location coordinates were collected during the CAI using a Trimble GPS, Model TSCI. These coordinates identify the field sampling locations (e.g., latitude, longitude, elevation) at CAU 562.

Sample locations and pertinent locations of interest are shown on individual CAS figures located in Appendix A. The corresponding coordinates for sample locations associated with each CAS are listed in Table F.1-1.

Table F.1-1

Sample Location Coordinates and Locations of Interest for CAU 562 (Page 1 of 5)

\begin{tabular}{|c|c|c|}
\hline Location & Northing $^{a}$ & Easting $^{\mathrm{a}}$ \\
\hline \multicolumn{3}{|c|}{ CAS 02-26-11, Lead Shot } \\
\hline $\mathrm{A} 01$ & 4112763.7 & 580221.9 \\
\hline $\mathrm{A} 02$ & 4112774.5 & 580196.7 \\
\hline $\mathrm{A} 03$ & 4112734.4 & 580192.1 \\
\hline $\mathrm{A} 04$ & 4112730.4 & 580237.4 \\
\hline A05 & 4112743.8 & 580222.7 \\
\hline A06 & 4112744.8 & 580223.1 \\
\hline $\mathrm{A} 07$ & 4112748.8 & 580185.4 \\
\hline A08 & 4112748.2 & 580186.4 \\
\hline \multicolumn{3}{|c|}{ CAS 02-44-02, Paint Spills and French Drain } \\
\hline B01 & 4112775.5 & 580147.4 \\
\hline B02 & 4112774.5 & 580143.8 \\
\hline B03 & 4112771.9 & 580144.5 \\
\hline B04 & 4112772.4 & 580148.1 \\
\hline B05 & 4112773.5 & 580145.7 \\
\hline B06 & 4112777.7 & 580167.1 \\
\hline B07 & 4112783.4 & 580160.0 \\
\hline B08 & 4112789.1 & 580167.0 \\
\hline B09 & 4112783.3 & 580166.8 \\
\hline B10 & 4112795.8 & 580152.0 \\
\hline B11 & 4112791.1 & 580167.5 \\
\hline B12 & 4112789.9 & 580165.3 \\
\hline B13 & 4112788.4 & 580168.6 \\
\hline B14 & 4112782.5 & 580170.1 \\
\hline
\end{tabular}


Table F.1-1

Sample Location Coordinates and Locations of Interest for CAU 562

(Page 2 of 5 )

\begin{tabular}{|c|c|c|}
\hline Location & Northing $^{a}$ & Easting $^{\mathrm{a}}$ \\
\hline \multicolumn{3}{|c|}{ CAS 02-59-01, Septic System } \\
\hline $\mathrm{C01}$ & 4112446.5 & 579817.4 \\
\hline $\mathrm{CO} 2$ & 4112447.2 & 579819.0 \\
\hline $\mathrm{C03}$ & 4112442.0 & 579826.5 \\
\hline $\mathrm{CO4}$ & 4112438.9 & 579825.6 \\
\hline $\mathrm{C05}$ & 4112433.9 & 579832.7 \\
\hline $\mathrm{C06}$ & 4112442.2 & 579836.9 \\
\hline $\mathrm{C07}$ & 4112445.1 & 579819.7 \\
\hline $\mathrm{C08}$ & 4112428.0 & 579851.7 \\
\hline $\mathrm{C09}$ & 4112442.0 & 579824.1 \\
\hline C10 & 4112421.5 & 579847.9 \\
\hline C11 & 4112414.7 & 579844.5 \\
\hline C12 & 4112429.5 & 579829.3 \\
\hline \multicolumn{3}{|c|}{ CAS 02-60-01, Concrete Drain } \\
\hline D01 & 4113169.1 & 580246.3 \\
\hline D02 & 4113168.3 & 580246.7 \\
\hline D03 & 4113170.6 & 580249.1 \\
\hline D04 & 4113169.7 & 580246.0 \\
\hline D05 & 4113167.3 & 580244.6 \\
\hline D06 & 4113166.9 & 580247.3 \\
\hline D07 & 4113168.6 & 580240.3 \\
\hline D08 & 4113165.8 & 580241.6 \\
\hline D09 & 4113165.8 & 580247.8 \\
\hline D10 & 4113171.3 & 580251.4 \\
\hline D11 & 4113170.8 & 580256.5 \\
\hline D12 & 4113166.2 & 580256.9 \\
\hline D13 & 4113164.4 & 580252.5 \\
\hline D14 & 4113163.5 & 580249.7 \\
\hline D15 & 4113160.0 & 580241.6 \\
\hline D16 & 4113164.0 & 580238.9 \\
\hline D17 & 4113167.9 & 580237.6 \\
\hline
\end{tabular}


Table F.1-1

Sample Location Coordinates and Locations of Interest for CAU 562

(Page 3 of 5)

\begin{tabular}{|c|c|c|}
\hline Location & Northing $^{a}$ & Easting $^{\mathrm{a}}$ \\
\hline \multicolumn{3}{|c|}{ CAS 02-60-02, French Drain } \\
\hline E01 & 4112886.9 & 580134.1 \\
\hline E02 & 4112878.4 & 580126.5 \\
\hline E03 & 4112873.8 & 580142.5 \\
\hline E04 & 4112887.3 & 580134.1 \\
\hline E05 & 4112873.0 & 580143.6 \\
\hline E06 & 4112874.5 & 580141.3 \\
\hline \multicolumn{3}{|c|}{ CAS 02-60-03, Steam Cleaning Drain } \\
\hline F01 & 4112836.0 & 580053.0 \\
\hline $\mathrm{F} 02$ & 4112838.5 & 580052.2 \\
\hline F03 & 4112838.5 & 580054.9 \\
\hline F04 & 4112835.7 & 580055.6 \\
\hline F05 & 4112835.1 & 580056.2 \\
\hline F06 & 4112838.5 & 580045.5 \\
\hline F07 & 4112835.3 & 580046.1 \\
\hline F08 & 4112835.6 & 580049.4 \\
\hline F09 & 4112838.6 & 580048.6 \\
\hline F10 & 4112837.1 & 580047.4 \\
\hline F11 & 4112839.4 & 580044.5 \\
\hline $\mathrm{F} 12$ & 4112834.6 & 580045.6 \\
\hline F13 & 4112834.7 & 580050.3 \\
\hline $\mathrm{F} 14$ & 4112839.9 & 580049.6 \\
\hline \multicolumn{3}{|c|}{ CAS 02-60-04, French Drain } \\
\hline G01 & 4112852.1 & 580104.5 \\
\hline G02 & 4112852.4 & 580105.1 \\
\hline G03 & 4112854.1 & 580107.0 \\
\hline G04 & 4112850.3 & 580106.9 \\
\hline G05 & 4112852.7 & 580101.4 \\
\hline
\end{tabular}


Table F.1-1

Sample Location Coordinates and Locations of Interest for CAU 562

(Page 4 of 5)

\begin{tabular}{|c|c|c|}
\hline Location & Northing $^{a}$ & Easting $^{\mathrm{a}}$ \\
\hline \multicolumn{3}{|c|}{ CAS 02-60-05, French Drain } \\
\hline $\mathrm{H} 01$ & 4112897.9 & 580244.7 \\
\hline $\mathrm{H} 02$ & 4112899.0 & 580243.2 \\
\hline $\mathrm{H} 03$ & 4112897.0 & 580246.0 \\
\hline $\mathrm{HO4}$ & 4112896.6 & 580244.1 \\
\hline $\mathrm{H} 05$ & 4112895.9 & 580247.5 \\
\hline $\mathrm{H} 06$ & 4112901.0 & 580244.0 \\
\hline $\mathrm{H} 07$ & 4112902.5 & 580238.1 \\
\hline $\mathrm{H} 08$ & 4112905.4 & 580240.4 \\
\hline $\mathrm{H} 09$ & 4112905.1 & 580242.7 \\
\hline $\mathrm{H} 10$ & 4112901.0 & 580247.8 \\
\hline $\mathrm{H} 11$ & 4112896.3 & 580247.0 \\
\hline $\mathrm{H} 12$ & 4112905.1 & 580236.9 \\
\hline $\mathrm{H} 13$ & 4112908.9 & 580246.0 \\
\hline $\mathrm{H} 14$ & 4112909.1 & 580253.6 \\
\hline $\mathrm{H} 15$ & 4112902.0 & 580256.6 \\
\hline $\mathrm{H} 16$ & 4112895.9 & 580255.6 \\
\hline $\mathrm{H} 17$ & 4112891.1 & 580254.0 \\
\hline \multicolumn{3}{|c|}{ CAS 02-60-06, French Drain } \\
\hline 101 & 4112887.5 & 580097.9 \\
\hline \multicolumn{3}{|c|}{ CAS 23-60-01, Mud Trap Drain and Outfall } \\
\hline K01 & 4057148.7 & 590217.6 \\
\hline $\mathrm{K} 02$ & 4057147.2 & 590211.8 \\
\hline K03 & 4057146.7 & 590214.0 \\
\hline K04 & 4057146.3 & 590217.4 \\
\hline K05 & 4057138.9 & 590217.1 \\
\hline K06 & 4057138.0 & 590217.1 \\
\hline K07 & 4057137.7 & 590217.1 \\
\hline K08 & 4057135.5 & 590217.1 \\
\hline K09 & 4057138.0 & 590216.2 \\
\hline $\mathrm{K} 10$ & 4057138.0 & 590214.1 \\
\hline \multicolumn{3}{|c|}{ CAS 23-99-06, Grease Trap } \\
\hline L01 & 4057532.4 & 589797.3 \\
\hline L02 & 4057532.7 & 589796.9 \\
\hline L03 & 4057532.8 & 589796.3 \\
\hline
\end{tabular}


Table F.1-1

Sample Location Coordinates and Locations of Interest for CAU 562

(Page 5 of 5 )

\begin{tabular}{|c|c|c|}
\hline Location & Northing $^{a}$ & Easting $^{a}$ \\
\hline \multicolumn{3}{|c|}{ CAS 25-60-04, Building 3123 Outfalls } \\
\hline M01 & 4073322.5 & 564917.6 \\
\hline M02 & 4073292.6 & 564915.2 \\
\hline M03 & 4073233.7 & 564936.8 \\
\hline M04 & 4073232.9 & 564936.8 \\
\hline M05 & 4073233.1 & 564935.1 \\
\hline M06 & 4073232.7 & 564938.3 \\
\hline M07 & 4073228.5 & 564936.7 \\
\hline M08 & 4073234.0 & 564934.4 \\
\hline M09 & 4073232.4 & 564934.4 \\
\hline M10 & 4073231.1 & 564935.3 \\
\hline M11 & 4073232.2 & 564936.1 \\
\hline M12 & 4073230.7 & 564928.4 \\
\hline M13 & 4073233.0 & 564929.8 \\
\hline M14 & 4073231.6 & 564931.7 \\
\hline M15 & 4073229.3 & 564930.6 \\
\hline M16 & 4073228.8 & 564934.2 \\
\hline M17 & 4073227.2 & 564934.2 \\
\hline M18 & 4073224.6 & 564934.0 \\
\hline M19 & 4073226.0 & 564934.3 \\
\hline M20 & 4073225.1 & 564931.1 \\
\hline M21 & 4073224.2 & 564936.6 \\
\hline M22 & 4073224.3 & 564939.3 \\
\hline M23 & 4073236.1 & 564938.1 \\
\hline M24 & 4073235.9 & 564941.2 \\
\hline M25 & 4073228.1 & 564940.1 \\
\hline M26 & 4073230.7 & 564946.3 \\
\hline M27 & 4073222.3 & 564933.5 \\
\hline M28 & 4073205.3 & 564909.8 \\
\hline M29 & 4073195.6 & 564933.6 \\
\hline
\end{tabular}

aUniversal Transverse Mercator (UTM) Zone 11, North American Datum (NAD) 1927 (U.S. Western) 


\title{
Appendix G
}

\section{Waste Disposal Documentation}

\author{
(2 Pages)
}


Form

NTS LANDFILL LOAD VERIFICATION

SWO USE (Select One) AREA $\square 23 \quad \square 6 \quad$ D For waste characterization, aporoval, and/or assistance, contect Solid Waste Operation (SWO) at 5-7898. REQUIRED: WASTE GERERATOR INFORIAATION

(This torm is far rolloffs, dump truoks, and other onsite disposel of materials.) FAX $5-2241$

Waste Generator:

$$
\text { Mark Heser (NNES, WO) (M/S - NSF 176) (Fax 5-2241) }
$$
Phone Number: (0)5-2124; (c) 496-0150 Location / Origin CAU 582: CAS 02-60-04 \& CAS 02-60-02 - Bulk debris ID Phone Number. (o) $2-2124$; (c) $496-0150$ Waste Category: (check one) Waste Type: $\square$ NTS (check ono) ㅁ. Non-Putrescible $\square$ Commercial $\square$ Putresorible Industrial Pollution Prevention Cotegore (ched one) $\square$ Asbestos Containing Materia Q FFACO-onsite $\otimes$ Clean-Up $\square$ FFACO-offsite $\square$ Delense Projects 口WAC Excoption Prevention Cotegory: (check one) Mothod of Characterizution: (check one) $\otimes$ Sampling \& Analysis $\square$ Routine Prohibitod Wasto at all three Radioactive waste; RCRA waste; Hazardous waste; Freo kquids, PCBs above TSCA regulatory NTS landfills: Additional Prohibited Wasto at the Aroa 9 U1OC Landtill: levels, and Medical wastes (needies, sharps, bloody clothing).

Sewage Gludge, Animal carcaseres, Wet gartage (food waste); and Friable asbestos REQUIRED: WASTE CONTENTS ALLOWAELE WASTES

Check all alloweble wastes that are contained withln this load:

NOTE: Waste dispocal at the Area 6 Hydrocarbon Landfill must have come into contact with petroleum hydrocarbons or cookants, such as: gasolino (no berzern, head); jet fuel; diesel fuet: lubriconts and hydraulics; kerosene; asphaltic petroleum hydrocarbon; and ettrylene olycol.
Acceptable waste at any NTS landfill:
$\square$ Asphalt
Metal
$\square$ Wood
$\square$ Paper
Q Rocks / unaltered geologic materials
$\square$ Empty contsiners
$\triangle$ Soil
$\square$ Rubber (excluding tires)
$\otimes$ Plastic $\square$ Wire $\square$ Cable
$\square$ Cloth
$\square$ Inaulation (non-Asbestosfom)
$\square$ Demolition debris
凶 Cement 8 concrote

$\square$ Manufactured items: (swamp coolers, fumture, nugs, carpet, electronic components, PPE, etc) )

Additional waste accepted at the Area 23 Mercury Landfill: $\square$ Office Waste $\square$ Food Waste

$\square$ Asbestos $\square$ Friable $\square$ Nonf Fiable (contact SWO if regulated load) Quantity:

Additional wate accepted at tha Area 9 U100 Landfill:
$\square$ Non-friable asbestos
$\square$ Drained automobles and military vehictes
Lint ballacts (conteact swO)
$\square$ Drainad fual filters (gas \& diesel)
Solid fractions from sand/oilwater
$\square$ Hydrocarbons (contact SwO) $\otimes$ Other PCB below $50 \mathrm{ppm}$
$\square$ Deconned Underground and Above Ground Tanks

Additional wasto accepted at the Avea 6 Hydrocarbon Landfill:
$\square$ Sepic sludige $\square$ Rags
$\square$ Plants
$\square$ Drsined fuel filters (gas \& diesel)
$\square$ Sludge from sand/oilhrater separators REQUIRED: WASTE GENERATOR SIGNATURE
Crushed non-teme plated oil fiters PCBs below 50 parts per million

Initials: (If Inithaled, no radjological clearance is nocessary.)

The above mentioned waste was gencrated outside of a Contralled Waste Maragamo knowledge, does not contain radiological materials.

To the bost of my knowledge, the wasto deceribed above contains only those materis site. I hava verffied th/s through the wasto charactertation method Idontified above : prohibitad and allowable waste items, I have contectod Property Management and hs ia appereved for disposal in the handfill.

Print Narne: Mark Hegor

Signature: Is/ Mark Heser Dote: $6 / 29 / 10$

Note: -food wasto, office trash and must have eigned removal certication statament with Load Verificatlon."

SWO USE ONLY

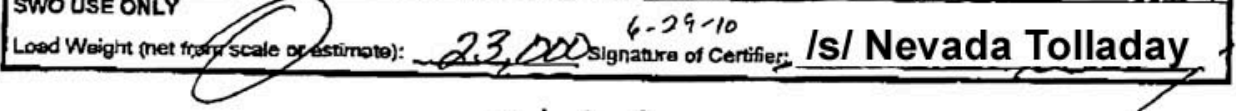
pg 1 of
2

Ltb-d $800^{\circ} d \mathrm{~B} \quad B z-1$

$8182-582-201$

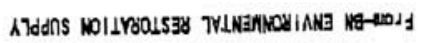

are25:80 0102-21-mat Rodiological Survay Ralenav for Wauta Dlapoinal RCT mathin This cont-inaenosed mnots tha criberla for no adided men-rnade radlerootive matertal

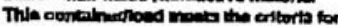

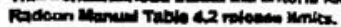

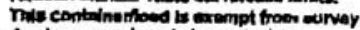
die to process knowlodge and orkin. BCacATURR: /s/ Harry Anagnostopoulos DATE: s/2 $/$ /C

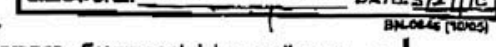


.

Form

NTS LANDFILL LOAD VERIFICATION

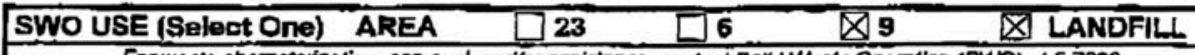
For waste characterization, approvgl, and or assistance, contact Sold Waste Operation (SWO) at 5-7898. REOUIRED: WASTE GERERATOR INFORMATION

This form is for rollofis, otump truoka, and other ansite disposal of materials.)

Waste Generator: Mark Heser (NNES, WO) MVS - NSF 176) (Fax 5-2241) Phone Number: (o) 5-2124: (c) $486-0150$ Location / Origin: CAL 5E2: CAS 02-60-04 \& CAS 02-60-02 - Bulk debris 10 562602. Drum \# 562601, E02, E03 \& 562 G01 Waste Catogory: (check one) Waste Type: (check one) $\square$ Non-Putrescible $\square$ Asbestos Containing Material $\triangle$ incustrial Pollution Provention Cotagory: (eneck one) $\triangle$ Environmental managament Pollution Prevention Category: (check one) Q Clesn-Up $\triangle$ FFACO-Onsite $\square$ WAC Excoption Method of Charaotarization: (check one) $\triangle$ Sampling \& Anslysis $\triangle$ Process Knowiedpe Contente Prohibited Waste an all three Radloective waste; RCRA waste; Hazardous warte; Free liquids, PCBs above TSCA regulatory NrS tandtitis:

Additlonal Prohibited Wasto at the Area 9 U10C Landfill: levets, and Medical wastes (needles, sharps, bloody clothing).

Sewage Sludge, Animal carcasses, Wet garbage (food waste); and Frable scbestos REOURED: WASTE CONTENTS ALLOWARIE WASTES

Check all alowable wastes that are contained within this load:

NOTE: Waste dieposal at the Area 8 Hydrocarbon Landill must have come into cormact with petroleum hydrocarbons or coolents, such as: gasoline (no benzena. lead); jet fuel; diesel fuel; lubricants and hydraulics: kerosene; asphalbic petroleum hydrocarion: and etnylene olvcol.
Acceptable waste at any NTS tandinil:
$\square$ Asphalt $\otimes \cdot$ Motal
$\square$ Wood
$\square$ Paper
Q Rocks / unaltered geologic msterials
$\square$ Empty containers
$凶$ Plastic $\square$ Wire
$\square$ Cable
区 Soĩ
$\square$ Rubber (emcluding tires)
$\square$ Dernaltion debris
Cemant 8 concreta

$\square$ Manufactured hems: (swamp coolers, furriture, ngs, carpet, electronic components, PPE. atc.)

Additional waete accepted at the Area 23 Merreury Landfill: $\square$ Office Waste $\square$ Food Waste $\square$ Animal Carcasses $\square$ Asbestos $\square$ Friable $\square$ Non-Friable (contact SWO if regulated load) Quantity:

Additional waste acceptod at the Area 9 U100 Landilit:

$\square$ Non-filable aebestos $\square$ Drained automobles and mitiary vehicles

$\square$ Light ballasts (contact swO) $\square$ Drained fual filters (gas \& dieeel

$\square$ Hychocarbons (eontact SWO) $\triangle$ Other PCB below $50 \mathrm{ppm}$

Solld fractions from sand/oil/water

$\square$ Decomned Undorground and Above

Addrional wasta acecpted at the Arva 6 Hydroceribon Landfill:

$\square$ Septic sludge $\square$ Rags
$\square$ Plants $\quad \square$ Soil

$\square$ Drained fuel filters (gas \& dlesel)

Sludge from sand/oll/water coparators

REQURED: WASTE GENERATOR SIGNATURE Ground Tanks

Inituals: (If initialed, no radlological clearance is necessary.)

The abova mantloned waste was generated curside of a Controlled Waste Manageme knowledge, does not oortain radiologicol matterials.

To the best of my knowiodge, the waste dorcribed above contains only those materil she. I have verified this through the waste charsectertzation mothod identified above I prohlbited and allowable waste ltems. L hrecontactod Properte wannegerent and is is approved for diegosal, in tha andFill.

Print Narne: Mark Heser

Signature: _ Is/ Mark Heser Dare: $6 / 29 / 10$

Crushed non-teme plated oil filters PCBs below 50 parts per milion

Note: "Food waste, office trash and anmal carcssses do not require a radlological clearance. Freon-containing appliances must have signed regrayal certifcation statement with Load Verification."

SWO USE ONLY

Load Weight (net fogl scalo or estimate): 21, 860 signature of Certifier:

Is/ Nevada Tolladay

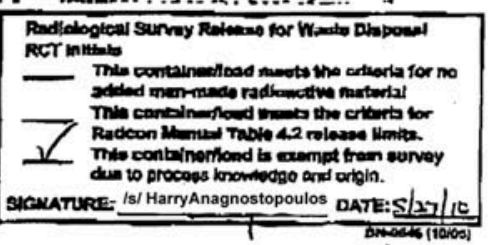
Con

$2 r p-d \quad \varepsilon 00 \cdot d \quad 6 E 2-1$

pg 2 of 2

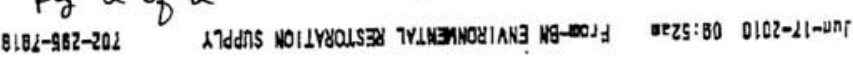




\title{
Appendix $\mathrm{H}$
}

\section{Nevada Division of Environmental Protection Comments}

\author{
(2 Pages)
}


July 22, 2010

Robert F. Boehlecke

Federal Project Director

Environmental Restoration Project

National Nuclear Security Administration

Nevada Site Office

P. O. Box 98518

Las Vegas, NV 89193-8518

RE: Review of the draft Corrective Action Decision Document (CADD) for Corrective Action Unit (CAU) 562: Waste Systems, Nevada Test Site, Nevada

Federal Facility Agreement and Consent Order

Dear Mr. Boehlecke:

The Nevada Division of Environmental Protection, Bureau of Federal Facilities (NDEP) staff has received and reviewed the draft Corrective Action Decision Document (CADD) for Corrective Action Unit (CAU) 562: Waste Systems, Nevada Test Site, Nevada. NDEP's review of this document did not indicate any deficiencies.

If you have any questions regarding this matter contact me at (702) 486-2850, ext. 233.

Sincerely,

\section{/s/ Jeff MacDougall}

Jeff MacDougall, Ph.D., C.P.M.

Supervisor

Bureau of Federal Facilities

$\mathrm{JJM} / \mathrm{JW} / \mathrm{DN} / \mathrm{KC}$ 
Robert F. Boehlecke

Page 2

July 22,2010

cc: K.J. Cabble, ERP, NNSA/NSO, Las Vegas, NV

N.Y. Carson. SNJV, Las Vegas, NV

E.F. DiSanza, WMP, NNSA/NSO

FFACO Group, PSG, NNSA/NSO, Las Vegas, NV

J.T. Fraher, DTRA/CXTS, Kirkland AFB, NM

M.J. Krauss, SNJV, Las Vegas, NV

A.L. Primrose, NSTec, Las Vegas, NV

T.D. Taylor, SNJV. Las Vegas, NV

T.A. Thiele, NSTec, Las Vegas, NV 


\section{Library Distribution List}

\begin{tabular}{|c|c|}
\hline & $\underline{\text { Copies }}$ \\
\hline $\begin{array}{l}\text { U.S. Department of Energy } \\
\text { National Nuclear Security Administration } \\
\text { Nevada Site Office } \\
\text { Technical Library } \\
\text { P.O. Box } 98518, \text { M/S } 505 \\
\text { Las Vegas, NV 89193-8518 }\end{array}$ & 1 (Uncontrolled, electronic copy) \\
\hline $\begin{array}{l}\text { U.S. Department of Energy } \\
\text { Office of Scientific and Technical Information } \\
\text { P.O. Box } 62 \\
\text { Oak Ridge, TN 37831-0062 }\end{array}$ & 1 (Uncontrolled, electronic copy) \\
\hline $\begin{array}{l}\text { Southern Nevada Public Reading Facility } \\
\text { c/o Nuclear Testing Archive } \\
\text { P.O. Box } 98521, \text { M/S } 400 \\
\text { Las Vegas, NV 89193-8521 }\end{array}$ & 2 (Uncontrolled, electronic copy) \\
\hline $\begin{array}{l}\text { Manager, Northern Nevada FFACO } \\
\text { Public Reading Facility } \\
\text { c/o Nevada State Library \& Archives } \\
\text { Carson City, NV 89701-4285 }\end{array}$ & 1 (Uncontrolled, electronic copy) \\
\hline
\end{tabular}

